
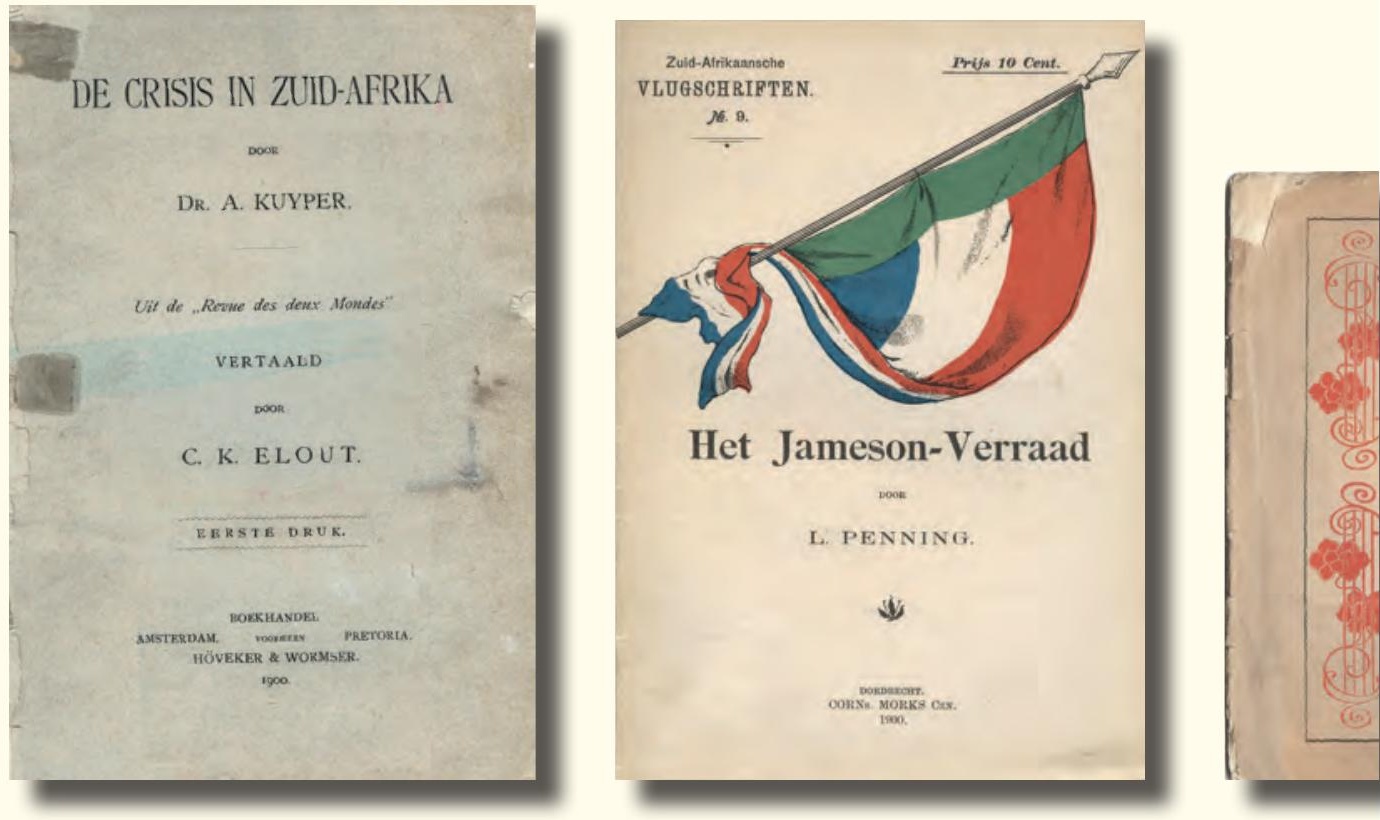

\title{
VINCENT KUITENBROUWER
}
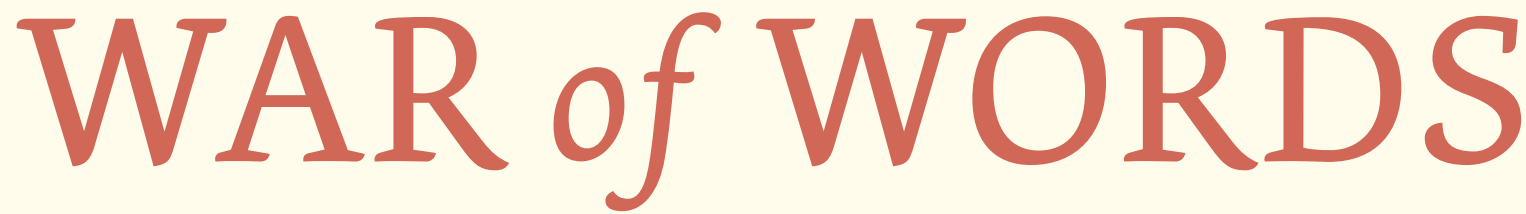

Dutch Pro-Boer Propaganda and the South African War (1899-1902)

A M S TERDAM UN IVERS I T Y PRES
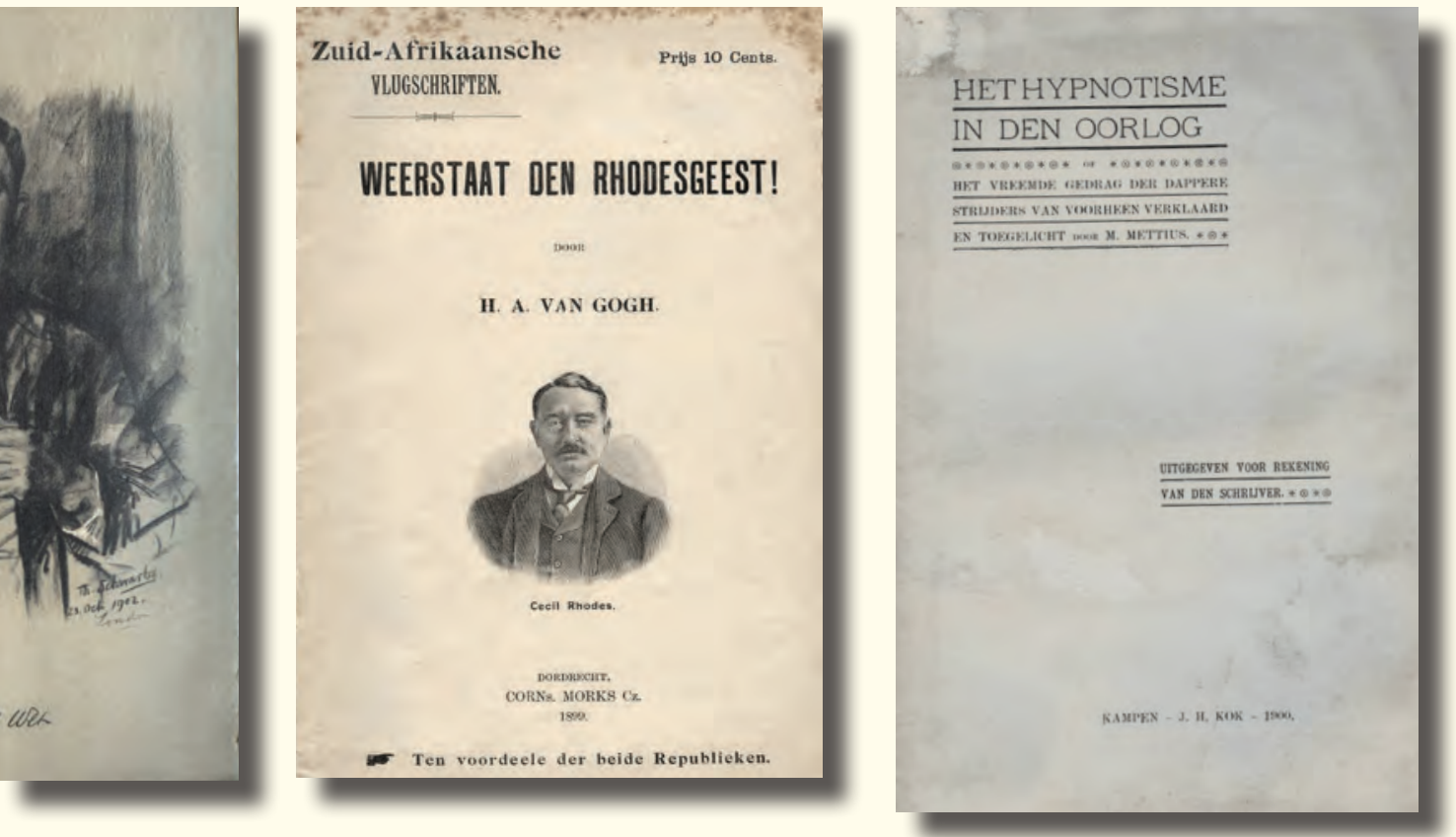

De Norist 
WAR OF WORDS 



\section{War of Words}

Dutch Pro-Boer Propaganda and

the South African War (I 899-I 902)

Vincent Kuitenbrouwer 
The publication of this book is made possible by a grant from OAPEN.nl, Stichting dr Hendrik Muller's Vaderlandsch Fonds, the ZASM Foundation, the M.A.O.C. Gravin van Bylandt Foundation, and the J.E. Jurriaanse Foundation.

This book is published in print and online through the online OAPEN library (www.oapen.org)

OAPEN (Open Access Publishing in European Networks) is a collaborative initiative to develop and implement a sustainable Open Access publication model for academic books in the Humanities and Social Sciences. The OAPEN Library aims to improve the visibility and usability of high quality academic research by aggregating peer reviewed Open Access publications from across Europe.

This publication is based on the $\mathrm{PhD}$ thesis by Vincent Kuitenbrouwer from $20 \mathrm{IO}$.

Cover illustrations: covers of pamphlets provided by the Zuid-Afrikahuis, Amsterdam.

Cover design: Studio Ron van Roon, Amsterdam

Lay-out: Adriaan de Jonge, Amsterdam

$\begin{array}{ll}\text { ISBN } & 9789089644 \text { I } 2 \text { I } \\ \text { e-ISBN } & 97890485 \text { I } 595 \text { O (pdf) } \\ \text { e-ISBN } & 97890485 \text { I } 5967 \text { (ePub) } \\ \text { NUR } & 697\end{array}$

(C) V. Kuitenbrouwer / Amsterdam University Press, Amsterdam 2012

All rights reserved. Without limiting the rights under copyright reserved above, no part of this book may be reproduced, stored in or introduced into a retrieval system, or transmitted, in any form or by any means (electronic, mechanical, photocopying, recording or otherwise) without the written permission of both the copyright owner and the author of the book.

Every effort has been made to obtain permission to use all copyrighted illustrations reproduced in this book. Nonetheless, whosoever believes to have rights to this material is advised to contact the publisher. 


\section{Table of contents}

\section{Introduction 9}

Historiography: Britain I 2

Historiography: the Netherlands I 8

Outline 25

Notes on vocabulary 29

PART I

PRINCIPLES OF PROPAGANDA（I 880-I 899) 33

Chapter I

'New Holland' in South Africa? Building a bridgehead between the Netherlands and the Boer republics 35

Pro-Boers in the Netherlands 38

Hollanders in South Africa 46

The Jameson Raid: a catalyst for pro-Boer propaganda 56

Conclusion 62

\section{Chapter 2}

'Blacks, Boers, and British': South Africa in Dutch literature 65

Adventurers and armchair scholars 69

The ambivalences of stamverwantschap 76

The language question 80

Dutch views on English Africana 86

The 'native' question 9I

The Uitlander question 95

Conclusion 99 
PART II

WAR OF WORDS (I 899-I9O2) IO3

Chapter 3

A 'factory of lies'? The lines of communication of the Boers and their supporters I05

Boer diplomats rog

Fraying at the edges: the Dutch policy of neutrality I I 6

Repatriates and refugees I I9

Evading censorship I 28

Letters from the front line I 35

Conclusion I39

Chapter 4

'A campaign of the pen': the Dutch pro-Boer organisations 143

The NZAV from within 146

Pro-Boers and pillarisation I $5 \mathrm{I}$

'A campaign of the pen': the ANV press office I 54

'Practical support' or 'impractical plans': emigration schemes I64

Fundraising 169

Conclusion 176

Chapter 5

'Dum-dums of public opinion': pro-Boer propaganda,

October I 899-June I900 I79

'We know so well how you drifted into this war' I 8 I

'Afrika voor den Afrikaner'? I 86

The Boer people's army 192

Britain's grave I99

From The Hague to Derdepoort: war atrocities 205

Conclusion 2 I 2

Chapter 6

'All will be well!' Pro-Boer propaganda,

June I900-June I902 2 I 5

After the British occupation 217

Bittereinders and Handsoppers 220

'Methods of barbarism' 226 
'The English have a red haze before their eyes': farm-burning 230

'That lethal idleness' of being locked up: the treatment of Pows 233

A 'policy of torturing women': concentration camps 238

The Peace of Vereeniging 245

Conclusion 249

PART III

THE AFTERMATH OF PRO-BOER PROPAGANDA (POST-I9O2) 253

Chapter 7

'Whoever wants to create a future for himself cannot lose sight of the past': Willem Leyds and Afrikaner nationalism 255

(Re)building Afrikaner nationalism 257

Willem Leyds and Afrikaner historiography 264

From Dordrecht to Pretoria: the collection of the Zuid-Afrikaansch

Museum 275

Conclusion 28I

Chapter 8

From stamverwantschap to anti-apartheid: the significance of the pro-Boer movement in the Netherlands 285

Pro-Boers and public opinion in the Netherlands 287

Dutch views on Afrikaner nationalism 288

The cultural ties between the Netherlands and South Africa 292

Dutch-South African relations after the Second World War 295

General concluding remarks 300

Abbreviations 307

Notes 309

Bibliography 377

Index of names 395

Index of subjects $40 \mathrm{I}$ 



\section{Introduction}

It was already clear to contemporaries that the Dutch enthusiasm for the Boers during the South African War (I899-I902) was to be seen in the context of the history of modern imperialism. In his book The Psychology of Jingoism, the journalist J. A. Hobson drew a parallel between the Dutch depiction of the conflict and the situation in Great Britain, where he argued that the public had been manipulated by a small group of South African capitalists and mining magnates. Sneering at jingo propagandists, he wrote that:

[they] must admit that it is likely that the Dutch nation in Holland, drawing nearly all their information from Dutch South African sources, are animated by a bias similar to, though not so strong as, ours [the British], have received a mass of evidence directly contradictory to ours, and that their intellectual judgement has been formed in a fashion similar to ours. ${ }^{\mathrm{I}}$

Despite Hobson's dislike of the jingoist views on the South African War, he was certainly not of the opinion that propagandists who supported the Boer republics were any better. In another book, he described Willem Leyds, the most important diplomatic representative of the Transvaal in Europe, as an 'evil genius' behind ' $[t]$ he notion of an unqualified Dutch political supremacy, with a complete dominance of Dutch language and ideas [in South Africa]'. ${ }^{2}$

Historians point out that Hobson's ideas about the capitalist conspiracy behind the prejudiced press coverage of the South African question were biased themselves, based on his own ideas about Britain's duty in the world and the role of the growing mass media. Still, his observations have shown their value for the historical study of the imperial press. ${ }^{3}$ If anything, Hobson's writings show that contemporaries not only considered imperialism to be a process that only took place outside Europe, they also saw a close connection with public opinion in the metropole. His comparative remarks about the coverage of the South African War suggest that this was not only the case in 
Britain but also in the Netherlands and that propaganda was seen as an important aspect of the struggle between the British Empire and the Boer republics. In later historiography about modern imperialism too, the South African War is considered to be an important topic. This book aims to examine contemporary notions about the concept of imperialism by taking the responses of Dutch propagandists to the South African question as a case study, comparing them with secondary literature about imperial culture in Britain.

Historical comparisons between the two countries on either side of the North Sea are nothing new. There is a series of conferences during which Dutch and British historians exchange views on different issues. The initiators of the first Anglo-Dutch historical conference emphasised that British history and Dutch history 'are closely related' and hoped that it would serve as a source of inspiration to scholars from both countries. ${ }^{4}$ In later years, the conferences focussed on specific topics such as Protestantism, Liberalism and mass society. The history of overseas expansion has been recognised as an important field too. In 1967, the editors of a volume of papers on Britain \& the Netherlands in Europe and Asia expressed the wish that 'English and Dutch historians will one day be able to confer on their cultural and institutional environments, so much akin as the world goes and yet so strangely and subtly diverse'. 5 The Anglo-Dutch historical conference in 2000 focussed on aspects of the two colonial empires between I 750 and I 850 . A broad comparison yielded that overseas ambitions of both countries focussed on Southeast Asia in that period, but that there were differences as well because of the fact that the Netherlands lost the dominant position that it had held in the seventeenth century, while Britain came to 'rule the waves' during that period. ${ }^{6}$ In the I 980 , another series of conferences held in Leiden, Cambridge, Delhi and Yogyakarta brought together scholars to discuss aspects of the colonial state in India and the Indonesian archipelago in the nineteenth and twentieth centuries. Many of the papers presented at these occasions explicitly aimed to draw comparisons between topics such as colonial administration, economic structures and the relationship with indigenous groups. ${ }^{7}$

Looking at these precedents, a comparison between the depictions of the British and Dutch empires in Asia might have been more straightforward, except that there are some differences that make such an exercise problematic. First of all, the Indian subcontinent is a single large landmass, while the Indonesian archipelago consists of a huge number of islands. Indian culture is therefore divided into much larger cultural groups than Indonesian culture, which made the colonial experience there inherently different. Another possi- 
bly more serious problem is the difference in chronology. British territorial expansion in India largely took place before I 860 while - except for Java - the extension of the Dutch sphere of influence in the Indonesian archipelago really took off in the I870s. ${ }^{8}$ This is a significant disparity, because the Western perspective on overseas expansion shifted considerably during the nineteenth century. After I 870, the universalistic belief in progress gave way to more rigid ideas about racial hierarchies, derived from Social Darwinism. ${ }^{9}$ These intellectual shifts make a comparison between the British and Dutch debates about colonial expansion in Asia problematic, which is not the case with the respective depictions of the South African War because these took shape in response to the same events and at times even interacted with one another.

Of course there were significant differences between the Netherlands' and Britain's relations with South Africa. The most obvious of these is that the whole region eventually became part of the British Empire, while at the end of the nineteenth century the Netherlands was not in any position to make territorial claims on that part of the world. Also, the economic significance of South Africa to the British was far greater than to the Dutch. It can therefore be maintained that these relations cannot be called imperial. ${ }^{\text {Io }}$ Nevertheless, it has been convincingly argued that the ties between the Netherlands and the Boer republics at the end of the nineteenth century were an 'informal' and 'cultural' form of imperialism because there was a structural attempt to gain influence in the region. ${ }^{\text {II }}$ The most tangible result of the Dutch sympathy for the Boers was the emigration of several thousand Dutch to the republics (mainly the Transvaal) at the end of the nineteenth century, contributing to the development of modern state institutions in Southern Africa.

In secondary literature, it has been shown that British contemporaries also considered such issues to be important because they believed their dominance in South Africa to be far from self-evident, even after the whole region had officially been incorporated into the British Empire. Throughout the first half of the twentieth century, colonial administrators considered the region a weak spot in the imperial system because of the presence of a distinctive group of colonial competitors - the Dutch-speaking Afrikaners. In order to improve their grip, they set out to 'Anglicise' the white population after I902, but these attempts failed. ${ }^{\mathrm{I} 2}$ In the light of this cultural struggle, the pro-Boer propaganda campaign in Europe can be characterised as nothing less than a war of words. The question is, however, how one should assess the historical significance of this phenomenon. The following review of historiography will explore how this complex question can be approached. 


\section{Historiography: Britain}

In recent decades, historians who study British imperialism have engaged in a debate about the extent to which the imperial experience shaped the ways in which people in Britain viewed the world and viewed themselves. In the I980s, John MacKenzie put forward that the empire had a great impact on popular culture on the British Isles, which from the I 870 os onwards led to the emergence of an 'ideological cluster of monarchism, militarism and Social Darwinism' that captured all social classes. ${ }^{\mathrm{I} 3}$ A different group of scholars, including Antoinette Burton and Catherine Hall, has mainly been influenced by the work of post-colonial authors. They argue that the imperial experience inspired specific views on gender and race, forging a set of hierarchies that shaped British society to a large extent. ${ }^{\mathrm{I}}$

There are academics like Bernard Porter who reject the claims of these socalled 'new imperial histories'. He argues that the British Empire only attracted the attention of a small elite that benefited directly from imperial expansion and were simply interested in firm control and effective exploitation of overseas dependencies. ${ }^{15}$ It has been pointed out, however, that this narrow definition fails to grasp the full complexity of the concept of 'Empire', which was already a hotly debated issue amongst contemporaries. ${ }^{16}$ Therefore, a number of historians, despite their critical stance towards claims that Britain itself was deeply influenced by the process of overseas expansion, have been attempting to put imperial culture into firm historical context in order to investigate the meaning (or meanings) of the concept of imperialism.

One of the most fruitful exercises in this sense has been a new approach to what can be called the 'geographies of the British Empire'. ${ }^{17}$ From the onset of the imperialism debate, concepts of space have played an important role, highlighting differences between the 'periphery' and the imperial 'core'. In their classic theory of expansion, which held sway between the I950s and I980s, Ronald Robinson and Jack Gallagher argued that, although the government in London preferred informal means of control, the British had no other option but to expand formal rule in response to crises taking place on the fringes of their sphere of influence. As such, imperialism can be seen as an 'excentric' process because the initiative for expansion came from the peripheries rather than from the centre. In this model, 'men on the spot' and local 'collaborators' were important intermediaries who influenced the 'official mind' of decision-makers in London. ${ }^{\mathrm{I}}$ In the early I 990s, another model for British imperialism was presented by P. J. Cain and A. G. Hopkins, who 
coined the concept of 'gentlemanly capitalism'. They argue that territorial expansion was driven by a group of aristocratic financiers in London who were in search of new opportunities for investments. In this view, the incentive for expansion was clearly 'metropolitan'. ${ }^{19}$

A few years before Cain and Hopkins presented their theory, David Fieldhouse already argued for a more middle-of-the-road approach. He emphasised the 'interactions' between the core and its peripheries, whereby Britain was affected in the fields of economy, foreign policy and armed forces, while the (former) colonies inherited, amongst other things, administrative systems, commodity structures and state boundaries. ${ }^{20}$ This premise was further elaborated on in an important article by John Darwin, in which he presents the concept of 'bridgeheads' to explain 'the dynamics of territorial expansion'. According to Darwin, earlier models tended to overlook the diversity of both British society and the regions where expansion took place as a result of the fixed focus on either the 'periphery' or the 'core'. Instead, he argues that it was the "bridgehead [...] the hinge or "interface" between the metrople and a local periphery' that determined ' $[w]$ hether British influence grew, or was transformed into formal or informal empire'. ${ }^{2 \mathrm{I}}$ Viewed in this way, the Victorian Empire was not a monolithic entity but a complex hotchpotch of different territories around the world, ranging from tropical dependencies to self-governing dominions in the temperate climate zones, all with their own relationship to the metropole. This 'webbed conception of imperial space', argues Alan Lester, narrows the gap between the 'traditional' empirical approach to imperialism as presented in the integrated models of expansion and the 'new imperial histories' that focus on the cultural aspects of empire. ${ }^{22}$ If anything, the idea of bridgeheads recognises the importance of domestic public opinion in addition to high politics and economics as a factor that played into the process of expansion. ${ }^{23}$

Following similar lines of argument, an ongoing series of international conferences under the heading of the 'British World' investigates issues concerning the imperial diaspora such as culture and identity. Mapping out this transnational space, the main focus has been on emigration to the so-called 'white' parts of the British Empire: the dominions. There, inhabitants recreated institutions of the motherland and retained a sense of belonging, which can be called 'Britishness'. ${ }^{24}$ Although it can be argued that the focus on the 'white' character of dominions ignores issues of exploitation and suppression of the indigenous populations, ${ }^{25}$ studies presented at these conferences have yielded important insights into identity formation in different parts of the 
British Empire. The swift process of decolonisation after the Second World War led to the commonly held view amongst academics that imperialism and nationalism were two opposite and contradictory concepts. As a result, the histories of the British nation-state and those of the countries that emerged out of its colonies were made into separate fields of study. ${ }^{26}$ Looking at the British world, however, a more complex picture emerges: despite obvious tensions, 'colonial nationalities' and 'imperial Britishness' did not rule each other out but complemented each other and at times even overlapped. ${ }^{27}$ Such feelings were supported by multiple overarching institutions and networks that survived two World Wars, although they were fatally weakened by the second, and have left a cultural legacy that survives even today in some parts of the world. ${ }^{28}$

One way in which historians have attempted to put notions of British identity into a global context is to investigate how information travelled around the empire. Lester shows how during the first half of the nineteenth century, different groups of British settlers in the Eastern Cape actively lobbied in the metropole to promote their particular views on colonial rule. ${ }^{29}$ Zoë Laidlaw argues that during the same period, patronage relations between local administrators and politicians in London greatly determined how policy took shape. ${ }^{3 \circ}$ In his study of the imperial press system, Simon Potter analyses how such networks developed during the late nineteenth and first half of the twentieth century. Great technological and social change such as the advent of intercontinental underwater telegraph cables and the rise of mass media increased the exchange between the metropolitan press and newspapers throughout the empire, particularly in the white settler colonies. Fleet Street in London became the undisputed centre of journalism in the British world from which news was distributed. At the same time, it provided a model for colonial editors, which led to a homogenisation of the imperial press. ${ }^{3 \mathrm{I}}$

More recently, Potter has published an interesting essay in which he warns against the pitfalls of anachronism in this 'webbed' notion of the British Empire as an interlinked set of networks. He takes issue with scholars who put the developments at the end of the nineteenth century on a par with the digital revolution a century later, for example by branding telegraph cables as a 'Victorian internet'. It should not be forgotten that contemporaries ran into technological and commercial problems that limited the flow of free information because institutions were needed to manage the infrastructure of the imperial mass media. Potter therefore distinguishes between 'networks' - which can be characterised as 'informal, open, multiple, competing and dynamic' - and 
'systems' that were 'dominated by a restricted number of powerful organisations, whose interest together dictate more formal, entrenched, and limited patterns of interconnection'. Throughout the history of the British Empire, Potter argues, informal networks continued to exist, but imperial connections must be interpreted in the light of their institutional framework - in other words as a system - in order to properly assess their historical meaning. ${ }^{32}$

What, then, was the impact of such imperial hardware on British society? Andrew Thompson has done thorough research in this field. In his study of imperial lobby groups, he shows that such organisations were able to put imperial issues on the political agenda by mobilising public opinion and as such contributed to metropolitan political culture. In line with the notion of the British World, he argues that the 'white' dominions, at that time known as 'Greater Britain', attracted most of the public's attention, more so than the tropical dependencies or even India. ${ }^{33}$ In more recent work, Thompson attempts to assess the wider impact of the empire on British culture. Although it is very difficult to gather a set of quantitative data in order to come up with a foolproof answer to this question, he investigates a range of social groups in Britain and comes to the conclusion that they all had some sort of interest in one part of the empire or another. Exactly because of this great diversity, both in the metropole and in the peripheries, the imperial experience was far from univocal: imperialism meant different things to different people. ${ }^{34}$ Following a similar line of argument, Potter argues against sweeping generalisations by both the 'new imperial histories' and their critics who claim that imperialism either completely formed British society or did not at all. In order to get a better understanding of the centripetal effects of imperialism, he calls for 'detailed research into particular examples' that are nonetheless 'part of a broader, collective endeavour'. He concludes that 'the work of different historians on different parts of the canvas can, when viewed at a distance, help us to see the outlines of what the painting might eventually look like'.35

In order to investigate the wider meaning of imperialism, much attention has been given to the South African question, which from the end of the nineteenth century has been an important topic in the debate about the British Empire. Some argue that the South African War - which was the largest of all colonial wars Britain ever fought and, indeed, the largest conflict the world had seen since the Franco-Prussian War (I870-I87I) - was the first sign that Britain's international dominance was waning. ${ }^{36}$ The costs to Britain were certainly high, both in human lives and in money, and several academics have argued that this was the reason that support for the empire amongst the pub- 
lic evaporated, if it had previously existed in the first place. In this view, the outbursts of public enthusiasm during the earlier stages of the conflict, such as the famous celebrations after the relief of Mafeking (May I900), were only superficial bouts of mass hysteria. ${ }^{37}$ In the light of the historiographical developments mentioned above, however, historians have come up with other ideas on the matter. One of the first to do so was MacKenzie, who asserts that the South African War did not break the imperial spirit. In his view, imperialism remained deeply entrenched in popular culture up until the I950s, which demonstrates its long 'shelf life'. ${ }^{8}$ Significantly, several studies that investigate the 'British World' adhere to a similar chronology and argue that the influence of imperialism reached far into the twentieth century. ${ }^{39}$ Although the South African War was a serious challenge, provoking many questions about how the British Empire functioned, it was certainly not the beginning of decolonisation. 'The old order had bent a little: it had not broken.'40

This, however, does not answer the question regarding the extent to which the South African War affected the British Empire as a whole. Although some advocates of imperial reform in Britain took the opportunity to put forward their plans, the tangible results of this campaign were rather limited. On the other hand, it can be argued that the wider effects of such lobby groups on public opinion and political culture were significant..$^{4 \mathrm{I}}$ Moreover, in some specific areas the conflict clearly did act as a catalyst. The coverage of events in South Africa, for example, raised fundamental issues concerning the functioning of the press, which were related to the rise of modern communication technology and mass media. ${ }^{42}$ In this sense, the South African War was a 'media war'. ${ }^{43}$ No less than two hundred correspondents working for British newspapers were present when the war started, and although media attention did decline after June I900, popular writers such as Rudyard Kipling and Arthur Conan Doyle continued to publish about the conflict. Jacqueline Beaumont shows that the war had an important influence on the careers of several journalists. ${ }^{4}$ Focussing on the authorities, she points out how the significant media attention was also noticed by prominent figures in the military high command and civil administration, who tried to enlarge their control over the coverage of events taking place in South Africa. The South African War was therefore an important phase in the development of modern censorship. ${ }^{45}$ Looking at the institutional aspects, Potter identifies the conflict as a watershed in the transference of information throughout the British Empire. Faced with the shortcomings of the existing institutions, reformers sought to improve the imperial press system - with considerable success, he argues. ${ }^{46}$ 
The South African question also had more diffuse effects like its effect on the thinking about British identity. Shortly after his appointment as high commissioner of the Cape in I 897, Alfred Milner lamented that South Africa was the 'weakest link in the imperial chain'. With this remark he did not refer to shortcomings in infrastructure but mainly to the presence of a group of colonial rivals that threatened British dominance in the region - the Dutch-speaking Afrikaners. In order to secure the region for the British Empire, the selfconfessed 'race patriot' and his supporters attempted to break down not only the political and military might of the Boer republics but also their cultural influence so that English would prevail as the dominant language used. ${ }^{47}$ In Britain, there was a group of outspoken critics of this onslaught who opposed the war because they thought that the Boers, as white settlers, were entitled to an independent existence. Paula Krebs points out that the fact that their views conflicted with the advocates of expansion did not mean that these Liberal authors challenged the ideological presumptions of their adversaries. Looking at the writings from both parties, she concludes that the public discourse about the South African War in Britain was greatly influenced by common notions of gender and race. ${ }^{48}$

One noticeable feature of the use of the term 'race' in this context was that it not only referred to differences between black and white people but also to differences between English-speaking and Dutch-speaking colonists. To contemporaries, language and heritage were the two most important markers that distinguished the two so-called 'white races' in South Africa. ${ }^{49}$ This polarisation was not absolute, Thompson argues, referring to the 'languages of loyalism' that were prevalent amongst certain groups of Afrikaners. ${ }^{\circ}$ Also on the British side, the divide was not experienced as sharply as might seem at first sight. Many British officers had genuine admiration for their adversaries, who they considered to be ideal soldiers. Others disliked the harsh methods that were used against the Boers. ${ }^{5}{ }^{\mathrm{I}}$ Even the Milner administration not only used sticks to ensure British sovereignty but also held out carrots to the Dutch-speaking population. One of the most significant compromises he made during the peace negotiation in 1902 was the suspension of the vote for black people, which was a demand of the Boers and which ensured white political supremacy in the region for decades to come. This shows that the 'race question' in all its facets was a central theme in the contemporary debate about South Africa and touched upon the fundamental question of how - using the terminology of the time - one might 'civilise' that part of the world. Bill Nasson has therefore argued that the South African War was in essence 'a 
European war fought in Africa over how best to get on with the colonial order, and what its dominant terms of reproduction should be'. ${ }^{22}$

In this sense, the conflict had a distinct international component too. Several groups in other parts of the British Empire expressed their sympathy for either one of the sides. For example, the authorities in Canada and Australia sent troops to a war outside their own region for the first time in their history, which should be seen as an important precedent for their support of Britain during the two World Wars. By contrast, dissident groups such as Frenchspeaking Quebecois in Canada and republicans in Ireland admired the Boers for their plucky fight for independence. Likewise, there was much sympathy for the Boer republics amongst the public on the European continent. ${ }^{53} \mathrm{Al}-$ though some of these sentiments were a source of concern for the British government - such as the proposal by several hotheads in Russia to invade northern India in retaliation - public agitation in favour of the Boers did not have serious diplomatic consequences because all the great powers remained neutral. 54 We must therefore ask ourselves whether the pro-Boer propaganda campaign had any effect. This is something that has occupied historians in the Netherlands, the country where sympathy for the Boers was most widespread because of feelings of racial kinship. The following section will describe how they have written about Dutch imperialism, the ties between the Netherlands and South Africa and how this work relates to British historiography.

\section{Historiography: the Netherlands}

The word 'imperialism' has only been introduced into the historical debate about Dutch overseas history relatively recently. ${ }^{55}$ One of the first to do so was Maarten Kuitenbrouwer in his 1985 thesis on colonial policy in the Netherlands. Comparing his findings to the work of R. F. Betts, he argues that despite its smaller size, Dutch territorial expansion (which mainly took place in the Indonesian archipelago) resembled British imperialism in several important ways. ${ }^{56}$ In his later work, he embraces the 'metropolitan' model of Cain and Hopkins and argues that the initiative for expansion came from wealthy financiers that belonged to the civic elites, the so-called 'regents' ${ }^{57}$ Other authors writing about the Dutch East Indies also refer to British models of expansion. Both Cees Fasseur and Hendrik Wesseling adopt the peripheral models of John Galbraith and Robinson and Gallagher respectively, emphasising that Dutch officials were even more reluctant than their British counterparts to expand the formal empire. ${ }^{8}$ Elsbeth Locher-Scholten explic- 
itly refers to Fieldhouse's work in her thorough case study on the annexation of a sultanate on Sumatra. ${ }^{59}$ Drawing from these examples, it is safe to say that there is a respectable tradition in historiography about Dutch imperialism which seeks to link in with the debate about British imperial history.

It is therefore quite remarkable that there has been no serious attempt by Dutch historians to join the debate about the cultural aspects of the British Empire. The most significant study of Dutch imperial culture, by Martin Bossenbroek, contains only a few references to the work of MacKenzie in some footnotes, even as he provides conclusions that merit comparison: he argues that events taking place in Indonesia and South Africa at the end of the nineteenth century were depicted in a wide range of genres, attracted attention from virtually all social classes and had a marked influence on Dutch national identity. ${ }^{60}$ Also studies about more detailed aspects of imperial culture in the Netherlands - such as colonial lobby groups and the work of ethnographers - contain no references to other countries. ${ }^{61}$ Others such as Susan Legêne and Marieke Bloembergen do consider the international context. They both discuss the work of Edward Said in their books about the cultural aspects of Dutch imperialism. ${ }^{62}$ But they, too, do not provide a profound reflection on the large body of secondary literature in Britain that is available on this topic and its possible relevance to the debate in the Netherlands.

Such an exercise can have significance for the historical understanding of imperialism - on both sides of the North Sea. The historical debate about the culture of the British Empire has brought up fundamental questions about the meaning of the concept of imperialism, which puts it into firm historical context by taking into account contemporary ideas on the matter. This book aims to contribute to this debate with a case study of Dutch-South African relations before, during and after the South African War, which will be compared with the historiography about the 'British World'. A further review of existing secondary literature on this topic shows that there are some interesting parallels that make such a comparison worthwhile.

It is widely acknowledged that the Transvaal War (I880-I88I) aroused much enthusiasm amongst the public in the Netherlands for the white Dutchspeaking population of South Africa, particularly those living in the two Boer republics - the South African Republic (SAR) also known as the Transvaal, and the Orange Free State (OFS). This was in sharp contrast to the decades before when there was hardly any attention for the Boers, after the British occupied the Cape Colony in I806, and after they formally annexed it in I8I4. But during the last two decades of the nineteenth century, with a climax dur- 
ing the South African War, the ties between the Boers and the Dutch were actually celebrated. The successful fight by the Transvaal burghers to regain their independence from the British Empire after the annexation of I 877 was for many people on a par with the revolt of the Dutch against the Spaniards in the sixteenth and seventeenth centuries. Also in other ways, the Boers were seen as worthy descendants of their ancestors, the pioneers of the Dutch East India Company who had settled in the Cape in I652. Memories of the socalled Golden Age of the seventeenth century were thought to give vitality to the Dutch race and so became a source of national inspiration. Another connection with the 'cousins in South Africa' was that High Dutch was the official written language in the republics, although the spoken dialect differed significantly. Such feelings of racial and cultural kinship were phrased by the term stamverwantschap - which, like 'Britishness', is virtually impossible to translate. ${ }^{63}$

Although historians do not question the existence of these sentiments, there are different views as to how they should be interpreted. Like the British debate, the concepts of nationalism and imperialism are essential in this respect. In general, it is acknowledged that the pro-Boer movement had a considerable effect on Dutch nationalism at the end of the nineteenth century, serving as a mirror for the nation. The heroic conduct of the Transvaalers reminded people of the prestige of the Netherlands during the Golden Age, which in the view of many had been lost over the course of the eighteenth century. Moreover, the Boers' victory over the mighty British Empire in I88I showed that there were still opportunities for small nations at a time when great power politics was at its height. Niek van Sas argues that in the early days of Dutch modern politics, which led to the formation of political parties and other social structures along ideological lines - the so-called process of pillarisation - sympathies for the Boers transcended the emerging divides and, together with symbols such as the monarchy, contributed to a unified Dutch national identity. ${ }^{64}$ Even amongst groups that initially criticised the Boers, there was a measure of sympathy for them, such as amongst Catholics (who objected to their strong Calvinism) and Socialists (some of whom thought the republics were still in a state of feudalism). ${ }^{65}$

Despite these outward signs of unity, however, there were more problematic aspects to the relationship between the Boer movement and the process of pillarisation, because some political groups claimed exclusive rights to the notion of stamverwantschap. This was especially the case with orthodox Protestants, who under the charismatic leadership of Abraham Kuyper be- 
came a significant force in Dutch politics. Chris van Koppen has written the most extensive account of his involvement in the pro-Boer movement to date. Because of his bravado, he soon came into conflict with other prominent members of the movement and alienated himself from the leadership of the Boer republics. Although he continued to reflect on South Africa in his personal writings throughout his life, after I 884 he was never again a member of an official pro-Boer organisation. ${ }^{66}$ Henk te Velde, in his study of Liberal nationalism, has noted that the feelings of sympathy for the republics amongst this group also were shrouded in ambivalence. There were great concerns amongst the Liberals about the rise of modern politics in the Netherlands, which they feared would divide the nation along party lines. The idealised image of the Boers served as a way of overcoming this fragmentation and drowning out doubts about the way in which modern society was developing. In this way, Te Velde argues, the pro-Boer movement in the Netherlands was detached from events in South Africa, projecting a set of constructed values on the outside world. He therefore concludes that the discourse should be seen in the light of domestic political culture only and not in terms of Dutch foreign policy. ${ }^{67}$

Others have put forward another view on this matter. Although they do not deny the impact of the pro-Boer movement on nationalism in the Netherlands, both Gerrit Schutte and Maarten Kuitenbrouwer argue that it was a form of imperialism too: in their view, nationalism and imperialism were two sides of the same coin. In the South African context, Dutch contemporaries used the word 'imperialism' exclusively to refer to the British Empire, but they pursued similar goals and structurally tried to extend their influence in the region. Some opinion makers even dreamed of a 'New Holland' in South Africa where the cream of the nation could go to in case of a German invasion of the Netherlands; but these territorial fantasies were exceptional. Rather, there were attempts to enlarge the cultural influence in the region by emigration to the republics and to help the Boers to develop themselves. This, it was hoped, would open up regional markets - which were growing rapidly because of the booming mining industry - to Dutch commerce. These ambitions became known under the guise of de Groot Nederlandse gedachte (the ideal of Greater Netherlands), which can be seen as an 'informal' and 'cultural' form of imperialism. ${ }^{68}$

Despite these ambitions, to what extent they actually had an effect remains an open question. One essential issue in this respect is public opinion, which is illustrated by the fact that pro-Boer organisations in the Netherlands priori- 
tised 'propaganda' from the very beginning. At the end of the nineteenth century, this word had a more neutral meaning than it has gained since the two World Wars: propagandists wanted to inform the public in order to mobilise support for their plans and to provide an alternative to the descriptions of the situation in South Africa by British authors. As such, it should be considered in the context of the emerging mass media at the end of the nineteenth century. As was the case in other Western countries, the press in the Netherlands grew due to technological developments and the abolition of taxes. Although there is widespread consensus on this point in secondary literature, virtually no studies have been devoted to the difficult question of the extent to which this had an impact on the reception and formation of opinions. ${ }^{69}$ This lacuna in historiography makes it hard to assess the impact of the pro-Boer movement on Dutch society, as there is little data available that gives insight into how public opinion in the Netherlands as a whole functioned at the turn of the twentieth century.

In historiography, however, it is suggested that there were several factors in the Netherlands that limited the influence of pro-Boers. The role of government was severely restricted due to the policy of neutrality, which was characteristic of 'the imperialism of a small power'.$^{70}$ As a result, official responses to the South African question were reserved. At the time of the Transvaal War, the boundaries between the Dutch East Indies and the British Empire in Southeast Asia were being demarcated. In government circles there were widespread fears that the British would decide to annex parts of the Indonesian archipelago in retaliation if the Netherlands were to officially become involved in South Africa. Although many prominent policymakers and even Queen Wilhelmina herself had strong personal sympathies for the Boers and on several occasions expressed these views, they prioritised the vested interests in Asia. Even when the emotions of the public at home ran high during the South African War, the government continued to adhere to the principle of neutrality and was careful to avoid open involvement in the pro-Boer propaganda campaign. Another limiting factor that seems to have been connected with the international position of the Netherlands was the underdeveloped state of its global lines of communication. In contrast with the British, there was no independent Dutch network of undersea telegraph cables, which made the press dependent on information from foreign agencies. ${ }^{71}$

These restrictions were apparent to contemporaries, who actively discussed them, raising questions about the relationship between pro-Boer organisations and the general public. The South African War, during which 
sympathy for the Boers was widespread, can be seen as the climax of the proBoer movement. It is therefore remarkable that Dutch historians have paid relatively little attention to the people and organisations involved in the propaganda campaign between I 899 and I902. Significantly, two foreign studies that address the international impact of the pro-Boer agitation, written by Ulrich Kröll and Lynette van Niekerk, emphasise the central role of Dutch in the international network that distributed propagandistic material in support of the embattled republics' cause. ${ }^{72}$ In the assessment of the proBoer propaganda campaign, the nature of this network will be taken into consideration. If anything, the source material indicates that, at the dawn of the age of mass media, Boer supporters actively reflected on the importance of public opinion, which makes this study relevant for Dutch historiography.

A second topic to consider in the light of the overall effect of the pro-Boer movement is Dutch-South African relations, and in particular the possible influence that Dutch have had on Afrikaner nationalism. Schutte shows that from the beginning of the pro-Boer movement there was a 'love-hate relationship' between Dutch and their 'cousins' in South Africa. In the I 880 os and I 890 s, some 6,500 people from the Netherlands went to South Africa (particularly the Transvaal) to offer their services to the Boers there. Considering the total white population in the region (at the time approximately one million), this was not an overwhelming number. Moreover, these so-called Hollanders were not always appreciated by their new compatriots and there were distinct anti-Dutch sentiments amongst certain groups of Boers. Likewise, many of the emigrants, who originated from modern Western society, considered the inhabitants of the republics to be rather underdeveloped and were disillusioned by their experiences. ${ }^{73}$

Despite these limitations, Schutte and others note that Dutch emigrants, many of whom were well educated, occupied important positions in the Transvaal under the patronage of Paul Kruger, who was the president of the republic from I 88 I to I900. They played a significant role in the development of state institutions such as the railways and the education system, and they contributed to the modernisation of Southern Africa. ${ }^{74}$ Moreover, the Hollanders promoted the formation of a national identity in the Transvaal, writing books about the history of South Africa that defended the independence of the Boer republics against propagandists who argued that they should be incorporated into the British Empire. ${ }^{75}$ Such examples would suggest that imperial dreams of stamverwantschap and the emphasis on Boer independence did not necessarily cancel each other out and that pro-Boer propaganda 
was mainly about the colonial future of South Africa. In historiography to date, there is no overview of these sources and their contents, which shed light on the relationship between the pro-Boer movement in the Netherlands and Afrikaner nationalism. This too will be a topic of discussion in the following chapters.

A final point of consideration is chronology. Historians who argue that the pro-Boer movement had a limited impact on Dutch history point out a great discontinuity after the absolute climax of public enthusiasm for the Boers during the South African War. They maintain that the Dutch public was greatly disappointed by the end of the conflict in June 1902 and the peace treaty, which formalised the annexation of the republics by the British Empire. All dreams of a viable Dutch bridgehead in South Africa were shattered, and several historians argue that sympathy for the Boers thus disappeared as suddenly as it had emerged two decades previously. ${ }^{76}$ In his study of Dutch-South African relations after 1902, Bart de Graaff writes that, in addition to these frustrated ambitions, there were also developments in South Africa that widened the gap between the Dutch and the Afrikaners. With the rise of modern Afrikaner nationalism and the second Taalbeweging (Language movement), which sought to make Afrikaans an independent language, there was a growing dislike of meddling from the Netherlands, he argues. In his view, notions of stamverwantschap were no more than a 'myth'. This would suggest that the Netherlands were detached from the rise of modern Afrikaner nationalism, which ultimately resulted in the system of apartheid after 1948.77

This is a sensitive topic in historiography, especially given the political situation in South Africa during the second half of the twentieth century, when the apartheid regime was ostracised by the international community. Dunbar Moodie argues that Kuyper's Dutch orthodox Protestant movement served as a model for radical Afrikaners, who after the South African War forged a 'civil religion' of Christian nationalism that formed the intellectual basis of the apartheid system..$^{7}$ Schutte opposes this view and states that there were fundamental differences between the nature of Calvinism in the Netherlands and that in South Africa, which made the relationship more complex. ${ }^{79} \mathrm{He}$ does not deny, however, that there was a lingering sympathy for the Afrikaners amongst the Dutch public, which only ended in the I960s when the Netherlands became one of the forerunners in the protests against the apartheid regime. Schutte argues that this complete swing in public perception of the Afrikaners should not obscure the fact that there was an ongoing feeling of involvement with events taking place in South Africa, and he even 
calls the Dutch anti-apartheid policy of the 1980 s a form of cultural imperialism that showed a strong continuity with the ideal of stamverwantschap. ${ }^{80}$

Literary scholars also argue that the shelf life of Dutch Africana stretched beyond I902. These ideas were already apparent in the works of G. Besselaar and Elizabeth Conradie, two Afrikaner academics working in the Low Countries who wrote books on this subject in the I9 Ios and I930s. Although they noted differences between literary circles in the Netherlands and in South Africa, it was clear to them that there was a significant overlap too, and they argued that the nascent Afrikaner Taalbeweging did benefit from the ties with the cultural motherland. ${ }^{81}$ More recently, new generations of academics have also pointed out that this relationship continued after I902. Siegfried Huigen argues that Afrikaans only became a separate language in 1925 and that the ongoing interaction had a marked influence on the development of Afrikaner nationalism. ${ }^{82}$ Wilfred Jonckheere shows that the view of nineteenth-century writers on South Africa was reproduced in popular novels and poetry in the Netherlands up until the $1960{ }^{8}{ }^{83}$

These three issues - the organisation of the pro-Boer movement in the Netherlands, its relationship with the Afrikaners and the question of whether I 902 really marked such a great discontinuity - will be leading themes in this book. In this way, it provides an analysis of the pro-Boer movement in the Netherlands before, during and after the South African War. A comparison with related themes in the secondary literature about the British World will deepen our understanding of the subject. This is all the more significant because, as will appear in the following chapters, Dutch contemporaries themselves thought it important that the British coverage of events in South Africa be countered. At times, the tone of such publications was quite agitated, but there continued to be a genuine admiration for the Liberal tradition on the other side of the North Sea. Although contemporaries did signal the existence of 'anti-British' sentiments, these should be seen in the context of the South African question and not as feelings of outright contempt. ${ }^{84}$

\section{Outline}

The question of the impact of the Dutch pro-Boer movement will be approached from two angles, assessing both its institutional framework and the contents of the propaganda it produced. First of all, the organisations and institutions that were connected with the interface between the Netherlands and South Africa will be analysed. Which groups were involved in the trans- 
fer of information from South Africa to the Netherlands? What was the nature of the institutions that constituted this channel of communication? How did it develop during and after the South African War? Significantly, such questions were actively discussed by contemporaries, which says something about their importance and the need to include a description of this network in a conceptual history of imperialism. A second issue is the contents of publications that came forth from this transfer of information. How did Dutch authors depict the nineteenth-century history of South Africa and the relations between the British and the Boers? In what ways did these views play a role in the coverage of the South African War? How did these publications relate to what was written by English-speaking authors? And last but not least, how did they affect views on the war after it had ended? Here too, the sources reveal that contemporaries themselves attached much importance to this sort of material in order to provide an alternative to the British coverage of events and to show the injustice that had been inflicted on the Boer republics by the British Empire.

This approach resembles the historiography of the British World and imperial culture. First of all, it feeds into notions of space. What were the relations between the metropole (in this case the Netherlands) and the peripheries (in this case South Africa, and in particular the Boer republics)? As with the British debate, nationalism and imperialism are fundamental concepts to this debate. Were the notions of national identity in the Netherlands and the rise of Afrikaner nationalism separated? Or was there some sort of interaction along the lines of communication that facilitated an exchange of certain ideas on the South African question? This would suggest that notions of stamverwantschap existed side by side with more narrow feelings of belonging restricted by national borders, and that there was possibly even some measure of overlap. To properly assess the historical meaning of such networks, it is important to take into account, as Simon Potter reminds us, the structure of the institutions along with the contents of the debate.

A second fundamental issue that is central to the rethinking of British imperialism is chronology and the idea that the South African War was not the beginning of the end for the empire. Although there was a marked discontinuity in the relations between the Netherlands and South Africa after I902, a comparison with the British Empire opens up interesting perspectives. One of the most important features of the work of MacKenzie is his assessment that popular imperial culture had a long shelf life that lasted up until the I950s. In the Netherlands there has been little research on this matter. In the most substan- 
tial study of this subject to date, Bossenbroek draws the line at I902, using the rather peculiar metaphor of the 'hop-skip-jump': the run-up to the enthusiasm of the Dutch public started in the I870s and I 880 , the jump took place in the 1890 and first two years of the new century, after which there was an inevitable 'landing'. ${ }^{85}$ But several literary scholars show that certain views on South Africa were more persistent in Dutch literature than this rudimentary chronology suggests. Another important question is whether there was an ongoing interaction between Dutch pro-Boer organisations and Afrikaner nationalists. During the I970s and I980s, this was a sensitive issue because it raises the question of whether the Netherlands was in any way associated with the rise of the ideology that led to the system of apartheid. Now that white minority rule in South Africa is assigned to history itself, this might be a good time to revisit this issue.

On the following pages, these questions will be dealt with in three clusters. The first part will discuss the beginnings of the interface between the Netherlands and South Africa - what can be called the 'principles of propaganda'. Chapter one will describe how the pro-Boer institutions came into being in the years after I 880 and the role that Dutch emigrants played in South Africa in the period up until s 899. Chapter two will describe how Dutch authors wrote about South Africa at the time and in what ways their work related to the writings of Afrikaner and English authors. The second, and largest, part will look at the propaganda campaign during the South African War. Chapters three and four will focus on the development of the institutions of the pro-Boers during the conflict. Chapter three looks at how information was transferred from South Africa to the Netherlands and which groups were involved in this. The next chapter will describe how pro-Boer organisations in the Netherlands related to this supply of information and how they were involved in the propaganda campaign. Chapters five and six deal with the contents of the propagandistic material: the former deals with the period between the outbreak of war (October I 899) and the occupation of Pretoria (June I900); the latter looks at the coverage of the guerrilla phase, which lasted two years, up until June I902. Finally, part three is about the aftermath of the pro-Boer propaganda campaign. Chapters seven and eight explore the effects in South Africa and the Netherlands respectively.

The research for this book was conducted both in the Netherlands and South Africa, which in itself is an illustration of the reciprocal nature of the ties of stamverwantschap. One important source has been the archive of Willem Leyds, the Dutch-born state secretary of the Transvaal between I 890 
and I 898, who subsequently served as minister plenipotentiary of that republic in Europe until I902. In the latter function, he played a central role in the pro-Boer propaganda campaign during the South African War. Apart from several books on the history of South Africa, his paper legacy includes a personal archive that is kept in the Dutch national archives in The Hague and a much larger official archive that is kept in Pretoria. Leyds published four volumes of documents from the latter one, but the archive still holds many files that have barely been researched, including the correspondence of one of the most important pro-Boer institutions - the press office of the Algemeen $\mathrm{Ne}$ derlandsch Verbond (General Dutch Alliance, hereafter ANV). Before the cultural boycott of South Africa in the I980s, Kröll used this archive in his study of Leyds's propagandistic work, and Schutte has also looked at files from his days as state secretary in the Transvaal. Moreover, the collection has been used as a source by several South African historians. The author who has most extensively studied the collection is Van Niekerk, who wrote a biography of Leyds that appeared in 1985 . Since the cultural boycott ended in the early I990s, no European researchers have visited this rich archive, which contains much information about the organisation of the propaganda campaign, which has been used in chapters three and four. Moreover, the collection contains a large amount of material on the period after I902, which has not been described by historians at all. In fact, the reason why Leyds sent his official archive to South Africa was to provide the Afrikaners with cultural ammunition for their political struggle against British domination. In this way, the archive itself was part of the ongoing war of words that will be assessed on the following pages. This issue will be discussed extensively in chapter seven.

The Zuid-Afrikahuis (South Africa House) in Amsterdam contains the archives of the most important pro-Boer organisations in the Netherlands and of several individuals who were involved in them. These documents have mainly been used in chapters one, three and four. In addition to these papers, the library also contains an extensive collection of publications from the period I880-1902, ranging from books to pamphlets and photos. In order to get an overview of these publications about South Africa, I resorted to secondary literature. For the period up to I 899, the books by Besselaar and Conradie were particularly useful. These findings will be presented in chapter two. In order to get an idea of the amount of publications about the South African War - the topic of chapters five and six - I have looked at the catalogues of the Zuid-Afrikahuis and a collection of printed material that Leyds donated 
to the University of Stellenbosch in the 1930 s. ${ }^{86} \mathrm{I}$ am also very grateful to Henriette Latsky from the University of Witwatersrand for allowing me to use her unpublished bibliography of Dutch publications about the South African War. ${ }^{87}$ From these sources I have distilled a list that counts 358 titles that appeared between I 899 and I902, many of which can be found in the Zuid-Afrikahuis.

Another interesting find in that library was the A. Welcker collection, a series of scrapbooks with complete coverage of the South African War between October I899 and June 1902 from the Nieuwe Rotterdamsche Courant $(N R C)$, an important national newspaper in the Netherlands. Originally this collection was kept in the library of E. G. A. ten Siethoff, a medical doctor in Scheveningen. He - together with Welcker, a student at Leiden University wanted to write a history of the war, but this plan was never executed. After the library was moved to a storage in Amsterdam, the newspaper collection ended up in the Zuid-Afrikabuis. ${ }^{88}$ The NRC was a prominent Liberal newspaper at that time and does not provide a representative section of public opinion in the Netherlands, because the press was also segmented during the process of pillarisation. Nevertheless, it is an important source because many of the articles contain letters from South Africa - either excerpts or complete texts - that show that the pro-Boer network extended into the national press. The Welcker collection has been extensively used in chapters five and six, which focus on the coverage of the South African War in the Netherlands.

\section{Notes on vocabulary}

Some comments are due about translations. This study has been written in English but mainly draws on primary sources in the Dutch language as it existed a century ago. To improve the readability I have translated quotations in the text, with the original excerpts in the footnotes. A few terms such as stamverwantschap and Hollander could not be translated and have been used in their original form, as are the names and abbreviations of Dutch organisations and periodicals.

Another difficulty was to phrase the words that were used to refer to the different groups of Dutch-speaking people. Contemporaries were certainly aware that people in South Africa spoke, and sometimes wrote, a dialect that was different from the official language in the Netherlands, but this was not formalised until I925. Authors were therefore not consistent in the ways in which they described these differences. For the sake of clarity, I have intro- 
duced some terms that are meant to provide a better categorisation. In reference to the local Dutch dialects in South Africa, the word 'Afrikaans' is used; for the official language in the Netherlands, the term 'Hoog-Hollandsch' or 'High Dutch' is used. The term 'Dutch' is used in two ways: referring to someone from the Netherlands or, in the South African context, to people who either spoke Afrikaans or High Dutch, or both. About the words 'Boers' and 'Afrikaners': the former has been used to refer to white Dutch-speaking inhabitants of the Transvaal and the ofs between the I 840 S and I902, the latter to the white Dutch-speaking population in the Cape Colony and, more generally, to the white Dutch-speaking population all across South Africa.

Finally, some remarks on other aspects of semantics. As the title of this book suggests, the war of I899-1902 between the British Empire and the Boer republics has always been a hotly debated issue, which is reflected in the variety of names that have been used to refer to the conflict. For a long time it was known amongst Afrikaners as die Tweede Vryheidsoorlog (the Second War for Freedom), whereas British authors used more neutral terms such as the Second Transvaal War. Eventually the term Boer War, or Anglo-Boer War, came to be used. This name, which suggests that the war only affected the white population, has received much criticism in recent decades. Several studies, including books by Peter Warwick and Bill Nasson, have shown that black people were also involved, which led to the introduction of the more inclusive name 'South African War'. ${ }^{89}$ Despite the historical evidence of black involvement, one should take care not to overemphasise the multicultural nature of the war. In his later work, Nasson argues that it was essentially a conflict between groups of white settlers about which colonial model was best suited for South Africa. In this sense, black people were the great losers because the peace between the British and the Boers in 1902 effectively put an end to their political franchise for nine decades. $9^{90}$ Nevertheless, I have chosen to use the name South African War, which allows it to link in with the imperialism debate in Britain, where this term is commonly used.

This books deals with the ways in which the events that were unfolding in South Africa were depicted in contemporary Dutch sources and thus does not reflect my own views. The authors who wrote about these issues at the end of the nineteenth and beginning of the twentieth century had outspoken opinions on South Africa, largely coloured by racism, which was common in their day. I will mainly focus on their ideas about the relations between the "white races' and the way this fitted into a European literary tradition. Depictions of black people are only dealt with indirectly, and it goes beyond the scope of 
this study to unravel their voices. In citations, derogatory words such as ' $k a f$ fer' have been left in, in order to give a sense of the tone of contemporary sources. Having grown up in the Netherlands at a time when the antiapartheid movement was at its height, it was sometimes difficult for me to grasp that such views were in vogue just a century ago. And also the contemporary sympathy for Afrikaans as a poetical language was intriguing to me, as that was absent from my own education.

At the time I write this, roughly two decades after the birth of the 'rainbow nation', the relationship between the Netherlands and South Africa has once again shifted significantly. In I996, Queen Beatrix signed a new cultural treaty, replacing the old one that was unilaterally terminated by the Dutch government in I98 I after it had been suspended in response to the Soweto riots (I976) and the death of Steve Biko (I977). Since the end of the boycotts, tourism has grown enormously and many Dutch travellers are intrigued by the flowery names of Cape vineyards that sound familiar yet exotic. This leads to new ideas about their relationship with the white Dutch-speaking population of South Africa; a topic of reflection in many weblogs. In addition, several artists such as Stef Bos and Herman van Veen have performed in South Africa and have written songs in Afrikaans. On television, the position of the Afrikaners is being reinvestigated - whether in the documentary by Adriaan van Dis or in the drama series Stellenbosch, both filmed in South Africa. These developments make it interesting to revisit the historical ties between the Netherlands and South Africa and to critically assess both the (in our perception) positive and the negative sides of this history. The aim is not to provide sweeping statements about their impact but rather to fill a small corner of the canvas that depicts Dutch identity in a global context, and so to contribute to the international debate about modern imperialism. 

PART I

Principles of propaganda (I 880-I 899) 



\section{'New Holland' in South Africa? Building a bridgehead between the Netherlands and the Boer republics}

Historians agree that several groups in the Netherlands suddenly (re-)discovered the Boers after the Transvaal War (I880-I88I). Drawing on ideas of racial kinship, or stamverwantschap, there was much sympathy and enthusiasm for the so-called 'cousins in South Africa', which were expressed in many ways. The meaning of the pro-Boer movement, however, is subject to discussion, which is a reflection of its complex nature. On the one hand it can be argued that the Boers served as an example to people in the Netherlands, who took pride in their heroic struggle and saw it as a sign that the Dutch race had found new élan. As such, the ideology of stamverwantschap played a marked role in society at the end of the nineteenth century, which can be characterised as the 'climax of civil culture' in the Netherlands. ${ }^{\mathrm{I}}$ But there were also overseas aspects to the pro-Boer movement. The main goal of the organisations that were established was to recruit emigrants for South Africa in order to assist in the development of the Boer republics and to strengthen their position against the British Empire. On the other hand, as many hoped, the existence of an independent state in South Africa where Dutch was spoken would mean that the influence of the Netherlands in that region would grow and lead to lucrative economic ties. Such sentiments were clearly reflected in a public letter written in I 886 by a number of intellectuals who asserted that the ties between the people in the Netherlands and the Boers were mutually beneficial. ${ }^{2}$ Looking at the pro-Boer movement as a whole, its domestic and international aspects prompt the question how it was related to ideas of imperialism and nationalism.

Some historians put much emphasis on the domestic aspects of the proBoer movement. Henk te Velde holds that the idealised image of the Boers had little to do with the principles of Dutch foreign policy but was instead a sign of the transformations taking place in domestic society and the changing political culture. In his study of Liberal nationalism, he argues that protagonists from this group were in search of unity and stabilisation at the dawn of 
the age of modern politics in the Netherlands, which was associated with increasing rivalry amongst the emerging parties. ${ }^{3}$ According to this view, the enthusiasm for the Transvaal was mainly a way to strengthen the self-image of certain groups within the Dutch nation-state.

It cannot be denied that this domestic dynamism was present and that the pro-Boer movement was linked to the formation of political parties. Certain groups of Liberals hoped that the archaic Boers could inspire the Dutch people to return to seventeenth-century values, which would result in a second Golden Age in the nation's history. Driven by this desire, many conservatives embraced a modern form of nationalism that drew on ideas about national self-determination and international law. ${ }^{4}$ Other political groups also embraced the South African issue. The orthodox Protestants, under the leadership of jack-of-all-trades Abraham Kuyper (who aside from being a political leader was also a professor and a journalist), saw the Boers with their fervent Calvinism as a shining example and hoped that he could forge an exclusive bond between his party and the Boer republics. 5 Support for the Boers from these two political currents was the most unambiguous, but others also joined in, which indicates that these sympathies also contributed to a national sense of belonging. The Catholics, who at first sight had no religious ties with the 'cousins' in South Africa, supported their battle for independence wholeheartedly. ${ }^{6}$ And even a number of Socialists openly showed their sympathy for the Boers. Their support was the most ambivalent though, as they had to navigate between the Scylla of Boer conservatism and the Charibdys of British high finance. Moreover, domestic issues such as the improvement of working conditions for labourers were of greater priority to the Socialist movement at the time. ${ }^{7}$

Nonetheless, it can be argued that there was more to the pro-Boer movement than domestic politics. Initially, the feelings of sympathy for the republics were seen by scholars in terms of the development of international law, which was associated with the tradition of neutrality. ${ }^{8}$ Several historians consider the South African question to be a part of the history of Dutch imperialism. Gerrit Schutte and Maarten Kuitenbrouwer both describe the pro-Boer movement as a structural attempt to expand Dutch influence in South Africa, something that can be considered an 'informal' and 'cultural' form of imperialism. ${ }^{9}$ It should be remembered that the Netherlands was a small nation and that its size had limiting effects on these ambitions in the context of international power relations. In addition, the measure of influence that Dutch emigrants could yield in South Africa - particularly in the 
Transvaal, which was the most popular destination - also needs to be critically assessed.

Such views resemble the way in which historians have been writing about the British World. As has emerged from this literature, concepts of imperialism and nationalism did not always cancel each other out but could in fact coexist and at times even overlapped. Kuitenbrouwer and Schutte have shown that both in the Netherlands and in South Africa, different groups emerged that considered it to be in their interest that there was a form of independence for the white, Dutch-speaking population in South Africa. Despite the tensions that surrounded these feelings, this shows that nationalism and imperialism were two sides of the same coin. It can be argued that a bridgehead emerged between the Netherlands and South Africa consisting of people who had the ambition of strengthening the ties of stamverwantschap between these two parts of the world. This chapter aims to describe this interface and its nature. As Simon Potter has argued, it is important to examine in what way such a transnational space was organised and to place it in its historical context. Therefore, the following questions will be addressed. What institutions made up this network and how did they function? Which groups of people were connected to these institutions and what were their interests? In this respect it is important to look at not only the situation in the Netherlands but to take into account the situation in South Africa too.

Another striking feature of the Dutch pro-Boer movement was that it focussed not only on the political and economic ties between the Netherlands and South Africa but also on the cultural ties, which were arguably the most important priority. In this way, the bridgehead acted as an information channel. Dutch publishers and journalists helped the Boers to propagate their views on the future of South Africa and to legitimise the existence of their republics. At the other end of the lines of communication, pro-Boer organisations tried to inform public opinion in the Netherlands in order to mobilise support for their efforts to strengthen the ties of stamverwantschap. As tensions mounted between the British and the Boers during the I 890 os, such activities were increasingly considered to be of importance. The dominance of the British Empire was typified by its monopoly of undersea cables, which allowed British coverage of colonial affairs to dominate. Dutch-speaking institutions, whether in the Netherlands or South Africa, did not have the means to set up an alternative network of global telegraph lines. Still, people in these circles started to think about ways to counter British propaganda and to provide the European public with an alternative view on the situation in South 
Africa. The pro-Boer movement in the Netherlands should therefore be seen not only in terms of domestic politics but also in terms of its strong connection with modern imperialism and the emergence of mass media.

\section{Pro-Boers in the Netherlands}

The bonds between the Netherlands and South Africa were established in I652, when Jan van Riebeeck set foot on the coast of the Cape of Good Hope. He founded a permanent settlement with a refreshment station for Dutch ships on their way to the East Indies. With the British occupation of the Cape Colony in $\mathrm{I} 806$ and the formal takeover in $\mathrm{I} 8 \mathrm{I} 4$, the ties were largely broken off. In the I 83 os and I 840 os several thousands of descendants of the former Dutch East India Company employees - the Boers - migrated into the interior during the Great Trek, but this was virtually unknown in the Netherlands at the time. Similarly, the formal establishment of two republics, the South African Republic (SAR) - also known as the Transvaal - and the Orange Free State (OFS) in I 852 and I 854 , did not arouse much public attention. South Africa was far away, communication was slow and in the Netherlands there was not enough willingness to invest in improvements. Although many travellers to the East Indies passed by the Cape along the way, almost none of them visited the Boer republics. Up to I 880 an average of four publications about South Africa appeared annually in the Netherlands, and no figures are known about emigration in this period. Some individual philanthropists, missionaries and businessmen took initiatives to persuade people to settle in South Africa, but because the journey was long and expensive, not many emigrants chose it as a destination. The few that did go sent back negative accounts of the laziness and backwardness of the Boers. Another common complaint was their harsh attitude towards the black population. Such criticism in print contributed to the perception that the Boers blocked the advent of Christianity and civilisation amongst the peoples of Africa. ${ }^{10}$

The annexation of the Transvaal by Britain in I 877 did not initially rouse any interest outside the small groups of people who were interested in South Africa. There were some protests, but these were largely ignored. ${ }^{\text {II }}$ During the two years that followed, unease about the annexation grew slowly. The Anglo-Zulu War of I 879 raised doubts with regard to the British policy towards black Africans, especially amongst Protestants. ${ }^{\mathrm{I} 2}$ There was also a great deal of disappointment about the failure of the British Liberal government to come to an agreement about self-government. ${ }^{\mathrm{I}}{ }^{3}$ The big turnaround 
came, however, when the Boers in the Transvaal took up arms to regain their independence in $\mathrm{I} 880$. This led to an enthusiastic response from many groups in Dutch society. The most successful initiative to mobilise the public was taken by a number of professors from Utrecht, headed by the biologist Pieter Harting. On 23 December 1880 , he published an open letter in a local newspaper that called upon the British people and their sense of justice to end the war and return independence to the Transvaal. Unlike previous protests, this address to the British nation received much attention, was reproduced in the national press and even published by some foreign papers. In the following weeks, 6,082 people, including many influential individuals, signed the document. Subsequently, a committee was founded in Utrecht, chaired by Harting, which aimed to co-ordinate the campaign for the Transvaal in the whole country. In the meantime, committees had been set up in other towns and cities, of which the one from Amsterdam was the most prominent. The most radical group came into being in Purmerend, collecting I I, ০০o autographs for a petition to Queen Victoria. Some members even suggested that they establish contact with Irish nationalists and form a militia that could go and fight in South Africa. Although this extreme plan was not realised, it caused great anxiety amongst some of the more conservative groups that supported the Boers. ${ }^{\text {I4 }}$

In order to ensure more solid and lasting support for the Boer republics, the leaders of the Amsterdam and Utrecht committees decided to join forces in a central body, the Nederlandsch Zuid-Afrikaansche Vereeniging (Dutch South African Society, hereafter NZAV). A broad alliance of prominent Liberals and Protestants took up positions in the executive committee of the new society that was founded on I2 May I 88I, with Harting as honorary president. ${ }^{\mathrm{I}} 5$ According to the statutes, its main purpose was to strengthen the ties between the Netherlands and the Boer republics in South Africa. This was envisaged in two ways: firstly to establish closer ties with the Boers and, with their consent, to create and develop institutions to stimulate agriculture, trade, industry and other material interests and secondly to inform the public in the Netherlands and in other European countries about the situation in South Africa - which shows that the NZAV considered propaganda a priority from the very beginning. ${ }^{16}$ The organisation started off with 300 members, a number that rapidly grew to I,000 in I 886, a fact that can be accounted for by the NZAV's appointment of correspondents for the first time in that year, who then became active recruiters. Until I 899 , the membership steadily rose to about I, 600 members, with a temporary peak of I,800 in I 896 as a result of the Jameson Raid. ${ }^{\mathrm{I}}$ 
Despite the article in the constitution of the NZAV that stated that it was a non-political organisation, the harmony between the Liberals and the Protestants in the executive committee did not last for long. Harting and the Utrecht professor in international law, J. de Louter, two prominent Liberals, thought that the Protestant faction headed by Abraham Kuyper had too much influence. They tried to bypass their rivals by appointing a commissioner who was to go to South Africa and take charge of affairs there. The candidate they had in mind, H. F. Jonkman, was a close ally of theirs. They staged their coup during a meeting when many Protestant members of the executive committee were absent. Afterwards, Kuyper protested vehemently and eventually cancelled his membership of the NZAv, together with other Calvinist members of the executive committee. ${ }^{18}$ Although the NZAV was generally seen as a Liberal bulwark after this incident, several Protestants remained active in the organisation. ${ }^{19}$ This raises the question whether the pro-Boer movement should be seen in the context of the so-called process of pillarisation, during which public life in the Netherlands was divided along ideological lines. Although domestic political tensions clearly did have an effect on the early years of the NZAV, such considerations were certainly not the only interests at stake, something that will be further discussed in this section.

The broad sympathy for the Boers in the Netherlands was seen by many people within the NZAV as an opportunity to strengthen the ties with them, and in its early years many plans were formulated to achieve this. Some even dreamed of a 'New Holland' (Nieuw Holland) that could serve as a colonial refuge for the Dutch population in case of a German invasion of the motherland. Moreover, it was hoped that the new élan would push the Netherlands back up amongst the great powers of the world and restore the prominent place it had once held in the days of the seventeenth-century republic. ${ }^{20}$ Historians have rightfully questioned the realism behind these grand ideas. In fact, the NZAV was a heterogeneous organisation and it should rather be seen as a platform where different visions on Dutch-South African relations were discussed. ${ }^{21}$ Aside from the tensions between people of different political persuasions within the organisation, there were also other problems. Many members, for example, had different interests due to their professional background. The NZAV could boast that it drew members from several influential sectors of Dutch society such as politics, business, academia and the press. At first sight it would seem that this variation was its strength, because it meant that the pro-Boer network was broadly spread. But there were also disadvantages to this. Although many people sympathised with the idea of a closer 
stamverwantschap, their responsibilities in daily life did not always allow them to promote it to the fullest. The effectiveness of the pro-Boer movement therefore was a central concern to its adherents, and the reason why the NZAV prioritised propaganda was to mobilise public opinion, which could lend more weight to its plans. But this was no easy task. The diversity of interests represented in the NZAV made it difficult to communicate a single agenda.

The biggest clash between the ideal of stamverwantschap and harsh reality was in the field of foreign policy. Many prominent politicians were closely involved in the founding of the NZAV. Several leading figures from the Liberal movement such as the future Foreign Minister W. H. de Beaufort and the future President of the Upper House of Parliament (Eerste Kamer) A. van Naamen van Eemnes were active members in the early years (the latter even combined his high function in Parliament with a place in the executive committee of the society). Kuyper, who after his fallout with the NZAV in I 884 remained interested in the fate of the Boers, became first minister in I90I. These people, however, kept their personal sympathies strictly separate from their responsibilities as statesmen. The NZAV, for instance, did not receive any support from the government. ${ }^{22}$ Anglo-Boer rivalry was a delicate matter for Dutch statesmen. On the one hand, sympathy for the Boers was a domestic force to be reckoned with, especially because the issue was brought up in Parliament on several occasions and, as such, influenced the electorate. On the other hand, the international situation would not allow overt support for the Boer republics. In the light of the territorial safety of the colonial possessions in the Dutch East Indies, the Netherlands simply could not afford a confrontation with Great Britain. Especially during the Borneo crisis of the I 88 os, Dutch statesmen became aware of their country's relative vulnerability and feared that the British would annex parts of the Indonesian archipelago if they lost their temper over other issues. In this equation, Dutch interests in South Africa were far less important than those in the East Indies. ${ }^{23}$

This reluctance on the part of the government became apparent as early as February I 88I, when a proposal from G. J. T. Beelaerts van Blokland - the future consul-general of the SAR in the Netherlands - for mediation between Great Britain and the Boers was refused because it might have damaged diplomatic relations. ${ }^{24}$ The NZAV also received aloof responses from state officials on several occasions. In the I 88 os, it campaigned for the establishment of Dutch consulates in both the SAR and the Cape Colony, which only succeeded after much lobbying. ${ }^{25}$ At times, the reserved attitude of the government was criticised in the press and in Parliament. However, many figureheads of 
the pro-Boer movement, such as academics who were closely linked to the political elites, recognised the difficult diplomatic situation of the government and accepted its cautious policy of neutrality. ${ }^{26}$

A sector that at first glance seemed to have significant interests in the Boer republics was the business community. Bossenbroek has shown that of the I, 300 directors of colonial companies, no less than I 50 were members of the NZAV. This meant that the society drew more people from that sector than the two largest lobby groups promoting commercial interests in the Dutch East Indies together. ${ }^{27}$ On paper, the prospects in South Africa looked very promising indeed. Trade with white settler communities was lucrative, and it was believed that the Boer population would prefer Dutch produce over British goods. ${ }^{28}$ Moreover, the expanding economies of the Boer republics, particularly the SAR after the gold rush of I 886 , were in dire need of investment. Demands for more infrastructure also opened up opportunities. Contemporary pro-Boers hoped that such considerations would provide an extra incentive for investors, but in practice this was not the case. By I 900 around fl. 25 million had been invested in the whole of South Africa by the Dutch business community. This looks meagre compared to the capital raised for enterprise in the Dutch East Indies, which amounted to fl. 390 million. ${ }^{29}$ And that sum is dwarfed by the $£ 75$ million (at the time about fl. 900 million) that had been invested in the Transvaal gold mines up until 1899 , mainly by British capitalists. ${ }^{\circ}$

The Dutch business community's reluctance to actually provide money for projects that would promote the cause of stamverwantschap is well illustrated by the tedious process to raise money for the only successful Dutch company in South Africa in that period, the Nederlandsche Zuid-Afrikaansche Spoorweg Maatschappij (Dutch South-African Railway Company, hereafter NZASM). In I 884, a Transvaal deputation visited the Netherlands after negotiations in London. In Amsterdam, they granted the directors of the NZASM a preliminary concession to build a railway line between Pretoria and Delagoa Bay. Apart from the business opportunities, this railway was also important to the strategic position of the SAR. Dutch financiers, however, reacted reluctantly. It would take three long years to raise the required fl. I4 million, the majority of which came from Germany. ${ }^{\text {I }}$ Other plans such as the attempt to gain access to the port of Delagoa Bay and establish a shipping service between Amsterdam and South East Africa in I 889 were even more problematic. Although Boer supporters stressed the strategic advantages of a route to Southern Africa that did not depend on British ports, not enough money 
could be found for the initiative for the time being. ${ }^{32}$

Another distinctive social group that was represented in the NZAV were members of Dutch academia. Of the I 80 professors in the Netherlands, no less than $8 \mathrm{I}$ had signed Harting's address to the British nation in the early weeks of I 88I. ${ }^{33}$ Many scholars remained active in the NZAV afterwards, including R. Fruin, C. B. Spruyt, J. de Louter, J. P. Moltzer and J. W. Gunning, who became members of the executive committee. Because neither of the Boer republics had a university, these men wanted, amongst other things, to improve the opportunities for South Africans to study in the Netherlands. In I 885 , the NZAV founded the studiefonds (study fund) that provided scholarships for this purpose. ${ }^{34}$ Moreover, it successfully protested against several requirements that the education law set for exchange students, which were abolished in I 887 . This did not immediately lead to a great number of South Africans coming to the Netherlands: until I 902 only 45 students participated in the programme. ${ }^{35}$ Furthermore, the matter led to further tensions between Liberals and Protestants. In general, the established universities were Liberal institutions, but in I 880 Abraham Kuyper had founded the Free University, which was explicitly Protestant. When plans were formulated for the exchange programme, Kuyper tried to persuade the SAR government to allow its citizens to attend his university only, because it would be the place where they, as Calvinists, would feel most at home. This plea was ignored by the Boers, however, much to the chagrin of the Protestant leader. Other universities in the Netherlands, especially the one in Utrecht, became more popular destinations for Afrikaner students than the Free University. ${ }^{36}$

Higher education was not the only concern of the NZAV. To ensure a more intensive relation between the Netherlands and the Boer republics, language was seen as an absolute requirement. High Dutch, or Hoog-Hollandsch, was the official language of the Boer republics and later one of the official languages of the Union of South Africa until I925. It was also noted, however, that Afrikaans as a vernacular, which differed significantly from $\mathrm{Hoog}-\mathrm{Hol}$ landsch on several points, was on the rise from the late nineteenth century. Moreover, it was argued that the complicated grammatical rules made Dutch far less popular at schools in the Cape than English, which students considered to be easier to learn. Many pro-Boers were therefore involved in an organisation that advocated the simplification of the Dutch language - the Vereeniging tot vereenvoudiging van onze schrifftal. It was argued that a simpler form of High Dutch would benefit the ties with the 'kinsmen' in South Africa. The professor of law Moltzer, who was also a member of the 
Raad van State (Privy Council) and the executive committee of the NZAV, was one of the main protagonists of this organisation. ${ }^{37}$

Apart from scholars, many teachers were interested in this issue as well. $\mathrm{H}$. J. Emous (I848-I933), who was the headmaster of a Protestant school in Amsterdam, was one of the most diligent activists in this field. In the I 890 , he was a member of the school fund (schoolfonds) and the language fund (taalfonds), two subcommittees of the NZAV. In this capacity, he was in close contact with Moltzer, although politically they were linked to opposing parties. ${ }^{38}$ In addition, he was the editor of the periodical of the Vereeniging tot vereenvoudiging van onze schriftaal, which shows that the schemes for language reform and the improvement of primary education in the Transvaal were related, although it should be noted that there were different views on the matter of spelling reforms. ${ }^{39}$ From the early days onwards, these subcommittees of the NZAV organised shipments of Dutch books to schools and libraries throughout South Africa. $4^{\circ}$ Another priority of these committees was the recruitment of capable teachers for Dutch-speaking schools in the republics. ${ }^{4 \mathrm{I}}$ As a member of the schoolfonds, which was mainly devoted to this latter activity, and as the editor of the pedagogic periodical Christelijk Schoolblad, Emous kept in contact with many of these teachers, and from I 897 he published their letters from the Transvaal in this magazine..$^{2}$

Another important sector of society for the pro-Boer movement in the Netherlands was the press. Between I 880 and I902, a vast amount of material was published on the South African question. It is difficult, however, to get a good overall picture of the available material because few papers or individual journalists in the Netherlands have left archives. Another complicating factor is that most authors at that time published anonymously or under a pseudonym. These combined factors make it difficult to say something about the organisation of the press coverage of South African affairs. Nonetheless, there are indications that journalists played an important role in the early period of the NZAV. One of the founders of the Amsterdam Transvaal Committee in I 880 was A. G. C. van Duyl, editor-in-chief of Het Algemeen Handelsblad, an influential newspaper. He has been described as one of the 'hotheads' of the movement who actively tried to mobilise public opinion in order to put pressure on the government. ${ }^{43}$ His successor at Het Algemeen Handelsblad, Charles Boissevain, also became deeply involved in the pro-Boer movement and was a member of the executive committee of the NZAV in I9OI and I9O2. Generally, Boissevain is considered to be one of the greatest propagandists of Dutch interests in South Africa, and many of his famous editorials contained 
passionate diatribes on this subject. In addition, during the South African War he wrote several important pamphlets that reached an international audience. ${ }^{44}$ Abraham Kuyper, apart from being the political leader of the Protestants and a professor at the Free University, was also the editor-in-chief of the daily newspaper De Standaard until he was elected as first minister in I90I. He wrote the majority of the editorials and had a personal column in which the South African situation frequently featured. In addition, much attention was given to the fate of the Boer republics in the regular articles of De Standaard. Between February and April I88 I, for instance, a special section was reserved for the events in the Transvaal, placed in between domestic and foreign news. 45

This last example shows that the attention of the Dutch press for South Africa grew exponentially after the battle of Majuba Hill (I88I). In subsequent years, events like the I 884 visit by the SAR deputation to the Netherlands and the Jameson Raid continued to receive much coverage in newspapers. In the weeks before and after the outbreak of the South African War in October I899, news from South Africa even dominated the press in the Netherlands. ${ }^{46}$ In general, the NZAV was satisfied with the attitude of Dutch journalists, although there were some doubts about certain correspondents. In the annual report of I 888-I 889, it was mentioned that an increasing number of newspapers had contacts in South Africa who provided them with news. ' $[\mathrm{N}]$ ot everything that we get to see about this subject appears to us to have been based on correct observations. In many cases, however, we can be well satisfied about the light that is spread in this manner'. ${ }^{47}$

Although this remark shows that Dutch editors at the time were interested in letters from South Africa (and particularly from the Transvaal), it is hard to get an overview of the correspondents that contributed to their papers. It must be kept in mind that, certainly when compared to other countries, the Dutch press was rather unprofessional at the end of the nineteenth century. There were no independent national news agencies nor international telegraph lines, so that Dutch newspapers had to depend on foreign press offices such as Reuters (British), Havas (French) and Wolff (German) for the latest reports about developments around the world..$^{8}$ The establishment of professional reporters in foreign countries was rare. In many cases the term 'correspondent' referred to nothing more than an expatriate who wrote letters about the developments in the country where he lived. 49 This also seems to have been the case in South Africa. Articles that appeared in the Netherlands about the NZASM were generally written by the Dutch staff of that company 
such as M. E. de Wildt, who regularly contributed to the Nieuwe Rotterdamsche Courant $(\mathrm{NRC})$. Usually these articles tried to persuade Dutch to join the railway company in the SAR..$^{\circ}$ The Dutch emigrant F. V. Engelenburg, proprietor of the newspaper De Volksstem, was also active as a correspondent for European media. From I896, he supplied the Havas news agency with cables from the Transvaal, which he sent to the office of the company in The Hague..$^{\text {I }}$ This company was a major supplier of news, and it is therefore likely that Dutch journalists had access to these reports. Moreover, papers in the Netherlands received South African periodicals by mail and published reviews of these magazines. ${ }^{52}$

To summarise the previous paragraphs, it can safely be said that the South African question did receive increasing attention after 1880 , given the large variety of social groups that supported the Boers in the Netherlands. The tensions between the Liberals and the Protestants do show that domestic politics played a role in this debate, but it should not be forgotten that there were other considerations as well. In the realms of foreign policy and business, the ideal of stamverwantschap had limited leverage due to the neutrality of the Netherlands and the reluctance to invest in South African enterprises. There were, however, also small successes for the pro-Boers such as the establishment of diplomatic representations in the Boer republics and the Delagoa railway line. An exchange programme for Afrikaner students was started in higher education. These projects were co-ordinated by the NZAV, which acted as a platform from which protagonists of such plans could propagate them. In other words, propaganda was the core business of the society, and relations with the press were considered to be of vital importance. In this respect there were severe problems too. The underdeveloped state of the press in the Netherlands made it hard to establish independent lines of communication with South Africa, and much of the news was supplied by foreign agencies. Still, a growing amount of information reached the Netherlands during the last decades of the nineteenth century, which was not least the result of the growing number of Dutch in the Boer republics. These distinctive groups of emigrants will be dealt with in the next section.

\section{Hollanders in South Africa}

The most important goal of the NZAV propaganda campaign in the I $880 \mathrm{os}$ and 1890 s, was to recruit emigrants to go to South Africa and so help to develop the Boer republics. Aside from support to existing emigration organisa- 
tions, the NZAV founded her own informatiebureau voor emigranten (information bureau for emigrants) in I 888.53 This bureau tried to persuade potential migrants to choose South Africa above other destinations, of which the United States of America was the most popular. It was argued that Dutch could more easily retain their identity amongst the Boers, would feel more at home in a Calvinistic society and would support the ideal of stamverwantschap. ${ }^{54}$ In addition, a voorschotbank (lending bank) was established that provided financial advances to people who wanted to settle in South Africa. ${ }^{55}$ A central concern was to select suitable emigrants that could contribute to the Boer cause. One group the recruiters tried to target were farmers. But, although the Dutch agricultural sector was in dire straits and unemployment had recently risen, not many farmers were keen on leaving because of the limited prospects in Southern Africa for unskilled labour. This could explain why most Dutch emigrants to the region were educated people, with roots in the higher social classes and an urban environment. ${ }^{56}$

Their main destination was the Transvaal, where the gold boom of the I880s and the benevolent attitude of the Kruger government towards socalled Hollanders (the term used to describe people from the Netherlands) provided the most opportunities. It should be kept in mind, however, that they did not swamp the country. There is no official census material available from the SAR, but decades later one former administrator estimated that there were approximately 226,000 white inhabitants in the republic, of which I 50,000 were born in South Africa. ${ }^{57}$ Others have established that 5,000 to 6,500 people from the Netherlands settled in the Transvaal between I 884 and I 899, which, given the size of the white population - let alone the total population - was not an overwhelming number. ${ }^{8}$ Nor is it significant when compared to the stream of other European immigrants to the mines of the Witwatersrand, drawn by the enormous quantities of gold that were extracted there - the so-called Uitlanders. It is probable that of the 75,000 Uitlanders in I 896, no less than 4I,000 were British. 59

The small numbers of Dutch emigrants, however, should not obscure the relatively important position they had in the SAR between I 884 and I899. Contrary to many Uitlanders, who worked mainly as unskilled labourers, Hollanders were often well educated and held high offices. Moreover, the Transvaal government actively tried to keep the Uitlanders marginalised so that the SAR would remain under Boer control. Uitlanders mainly lived in Johannesburg, near the mines. There they could yield only limited political power because they were denied full citizen rights, including the right to vote, 
which led to dissatisfaction amongst some of their leaders. Judging by the lukewarm reactions of the majority of the Uitlanders, however, it does not seem likely that many of them were interested in anything other than making their fortune as quickly as possible. ${ }^{60}$ In contrast, many Hollanders lived in the capital, Pretoria, and performed important government duties that, because of the limited opportunities for higher education in the SAR, could not be done by the Boers themselves. Even though President Kruger preferred administrators who were born in the Transvaal, he chose people from the Netherlands because he trusted them more than British immigrants or even Afrikaners from the Cape, who he considered to have been spoiled by English influences. ${ }^{6 \mathrm{~T}}$ This led to the establishment of so-called Hollander bolwerken (Hollander bulwarks). ${ }^{62}$

The privileged position of the Dutch was not uncontested. Many groups in Transvaal society carried a strong Hollanderhaat (hate directed against Hollanders). Much of this resentment was a result of the differing backgrounds of many emigrants from the Netherlands and the Boers. Most of the newcomers were born in an urban and cosmopolitan environment, while SAR society was predominantly rural, with conservative and patriarchal values. Moreover, many Dutch had adopted more moderate views on faith, if not having completely abandoned it, while Boers were unshaken in their Calvinism. ${ }^{63}$ This explains why people from the Netherlands were at times appalled by the rudeness and xenophobic attitude of the Boers, a complaint that can be found in many letters home. ${ }^{64}$ The distrust was mutual. Most inhabitants of the SAR did not like any foreign influences whatsoever, even if they came from a nation that claimed to be closely related to them. In their eyes, many Dutch were badly behaved, drinking too much and cursing in public. Finally, the Boers accused immigrants of arrogance and contempt for the simple life led in the republics. ${ }^{65}$ As will appear from the following pages, Hollanderhaat manifested itself on specific issues that contemporaries associated with the presence of influential Dutch emigrants. Apparently, the idea of stamverwantschap, although it was embedded in certain institutions in the Transvaal, was not as popular in South Africa as many people in the Netherlands believed it to be. This is a reminder that this concept meant different things to different people.

The most noticeable bulwark of the Hollanders in the SAR was the bureaucracy. Already during the British occupation of the SAR (I877-I88I), 2I of the 88 state officials came from the Netherlands. When national institutions expanded rapidly in I 886 as a result of the gold rush, the number of Dutch of- 
ficials rose too, although their relative share declined. During the I 890 , on average approximately I $8 \%$ of all SAR officials were born in the Netherlands. In I 897, their number was 306 , compared to 682 of their colleagues who were born in the Transvaal and 478 who came from the Cape colony. ${ }^{66}$ Many Hollander officials still had quite influential positions: in 1897 , thirteen of the twenty-three highest functions in the executive and judiciary branches of government were occupied by people from the Netherlands. Some important departments even had an almost entirely Dutch staff such as the state office (which combined the prime minister's office and the foreign office), the department of education and the departments involved with infrastructure. ${ }^{67}$

The most famous of the Hollander statesmen in the Transvaal was Willem Johannes Leyds (I 859-I940). In I 884, just after he had obtained a doctoral degree at the University of Amsterdam, his tutors, one of whom was Moltzer, introduced him to the SAR deputation that visited the Netherlands. Leyds was persuaded by his professors and Kruger to accept the post of state attorney and left for the Transvaal with his young bride. In I 888 , he was elected as state secretary but only took up the position a year later because he had not yet reached the required age of 30 . He was re-elected twice and resigned in I 898, when he became the most important diplomatic representative of the Transvaal in Europe. Although Leyds, who in his student days had been a well-known figure in cultural circles in Amsterdam, had a totally different background from the boorish Kruger, who had been born during the Great Trek, the two worked closely for more than a decade, an indication of how well their personalities complemented each other. ${ }^{68}$ During his career in the Transvaal, Leyds lived through dynamic times due to the transformation that took place after the gold rush of I 886 . Although he had both strengths (his intellect and charm) and weaknesses (his vanity and stubbornness), his biographer Lynette van Niekerk is of the opinion that his work made an important contribution to the development of modern South Africa. ${ }^{69}$

Two particular groups in SAR society reacted against the political influence of Hollanders and Leyds in particular. First, there were the Uitlanders, who associated the Dutch immigrants with the Kruger regime that kept them marginalised and disenfranchised. Despite their demands for more political rights, the influence of this group remained limited because they were effectively barred from both the government and the most important assembly, the Volksraad. $7^{\circ}$ A second group were the so-called 'progressives' who supported closer union with the Cape and the newly founded Afrikaner Bond, which argued for a South African federation. This idea stood in sharp con- 
trast to Kruger's policy of keeping the SAR independent. Moreover, the president had an innate distrust of Cape politicians like Jan Hofmeyr, whom he thought to be too conciliatory towards British statesmen like Cecil Rhodes. ${ }^{7 \mathrm{I}}$ The party of the 'progressives' in the Transvaal, under the leadership of General Piet Joubert, was politically active because it consisted of people who had been born in the SAR and thus had the vote. In the election campaign of I 893, they put the recruitment policy of Kruger high on the agenda, openly attacking Leyds, who was seen as the most important exponent of Hollander influence. ${ }^{72}$ This campaign stirred up a lot of controversy, and the election results were close. Kruger nevertheless managed to secure victory, and the impact of Hollanderhaat on the political landscape of the SAR should therefore not be overestimated. 73

Another (in)famous Hollander bulwark was the NZasm. Although Dutch investors did not provide much of the finances, most of the directors and over half the skilled employees were of Dutch origin. In total, I,700 people from the Netherlands were employed by the company in the Transvaal. ${ }^{74}$ The main project was the railway between Pretoria and Delagoa Bay, which was finished in I 895. Afterwards, the NZASM became responsible for running it. Up until the South African War, which marked the end of the Dutch company, the line was rather profitable under the management of Gerard Middelberg (I 846-I9I6), who was its director in Pretoria from I89I to the beginning of I 899. Moreover, the railway opened up a window to the rest of the world for the SAR. In this way, as Robert de Jong has argued, the NZASM contributed to the development of the Transvaal as a modern state. 75 In addition, the Delagoa Bay line was an important strategic asset, making the SAR less dependent on trade routes that went via the Cape. There was therefore much political controversy in 1888 , when the concession (which had been granted in I 884 by the SAR deputation in Amsterdam) was put to the Volksraad for ratification. The opposition in the SAR preferred closer federation with the Cape and therefore proposed an alternative, a line to Kimberley, which would tap into the railway network of the colony. British companies were interested in this project too and tried to influence the decision. Nevertheless, Kruger stood his ground and eventually the NZASM concession was approved. ${ }^{76}$ As a result, the company was seen by many critics as an important symbol of what in their eyes was the nefarious Hollander influence and nepotistic nature of the Kruger regime. ${ }^{77}$

Another controversial aspect of Kruger's policy was his habit of granting monopolies on certain products to befriended businessmen, which fed allega- 
tions of corruption. One of the most infamous examples was the dynamite monopoly, which was attacked by the Rand miners because they claimed that it seriously impeded their work. ${ }^{7}$ Here too, Hollanders were associated with this practice, and Leyds, as a representative of the Kruger government, was often accused of taking bribes. Van Niekerk has argued that the state secretary, who personally believed in laissez-faire economics, was against the establishment of monopolies in principle and certainly did not accept illicit money in the dynamite case. Nonetheless, he thought that this policy served a political purpose by keeping the power of the Uitlander mining magnates at bay and thereby protecting the national integrity of the SAR. ${ }^{79}$ Leyds was also involved in the Selati affair, which arose over a controversial concession for a railway line to gold mines in the north-eastern Transvaal. In this case too, Van Niekerk exempts Leyds from wrongdoing but thinks his personal interest was due to his vanity, because a town was named after him in the region. When it appeared that some of the people involved in this project had committed fraud, Leyds himself initiated a trial in Pretoria. ${ }^{80}$

Other Hollanders seemed to have fewer qualms about the existence of monopolies. D. H. Schmüll, an entrepreneur from Amsterdam who was involved in the establishment of the NZAV, settled in the Transvaal in I 885 . There, he tried to get hold of concessions for copper and iron mining but ended up with the exclusive rights for the production of matches. ${ }^{8 \mathrm{I}}$ Schmüll's broad business interests were surpassed by his colleague G. R. Ockerse, who was not satisfied with applying for concessions such as for pottery and mining only but came up with more creative ideas, such as a scheme to extract oil from groundnuts. Eventually he got his hands on a health spa on the Transvaal Highveldt. ${ }^{82}$ The work of the historian P.J. van Winter, from the I930s, provides the best overview of these entrepreneurial adventures, which more often than not ended in bitter disappointment. Many businessmen were blinded by the pro-Boer atmosphere in the Netherlands during the $\mathrm{I} 88 \mathrm{os}$ and I 890 s and thought that Dutch enterprise would be welcomed with open arms. On arrival in the Transvaal, however, these hopes turned out to be false because the Dutch were relatively inexperienced in vital sectors such as mining. Moreover, the commercial demands of the Boers were rather different from those of the public in the Netherlands. ${ }^{8} 3$ In addition, Van Winter argued that these initiatives failed to contribute to closer bonds between South Africa and the Netherlands because the Dutch businessmen did not co-operate with each other. '[Concerning trade and industry] the Dutch volksgeist found its expression in personal development, rather than the creation of important national power centres' ${ }^{8}{ }^{8}$ 
People with more spiritual inclinations went to the SAR as clergymen. Missionary work in the region had been a longstanding tradition, and the majority of Dutch travellers that went to the Boer republics before $\mathrm{I} 880$ had a religious background. Orthodox Protestants (Gereformeerden) in particular thought they could get a strong foothold in the Transvaal. Likewise their religious competitors, the reformed Protestants (Hervormden), developed plans to enlarge their influence amongst the Boers. The tensions between these denominations already surfaced in I 859, when the Dutch minister D. Postma forced a schism in the Transvaal religious community by leaving the Nederduitsch Hervormde Kerk, which was the most common denomination amongst Afrikaners. His new Vrije Gereformeerde Kerk was the rallying point for the so-called Doppers, people with ultra-orthodox persuasions. ${ }^{85}$ This schism probably contributed to the growing mutual distrust between Kruger, who was a prominent Dopper, and the Afrikaner Bond in the Cape, which was dominated by people who remained loyal to the Reformed Church. ${ }^{86}$

Although the impact of Hollanders on the religious landscape in South Africa was substantial, whether it had any wider consequences for the politics of the Transvaal is open to debate. Not all Hollanders had an unfaltering faith, and particularly Leyds's religious beliefs were openly questioned by his critics, who on separate occasions accused him of being an atheist, a Jew and a Catholic. ${ }^{87}$ Even though he repeatedly proclaimed that he believed in God and considered himself to be Protestant, these speculations indicate that religion did not receive his unconditional devotion. Leyds himself, however, claimed that this did not obstruct his good working relationship with Kruger, who was famous for his deep religious conviction. ${ }^{88}$ It seems that the president did not allow faith to interfere much with matters of state. As has been mentioned, Kuyper hoped that the shared tradition of Calvinism would mean that he and his followers could build up a special alliance with the Transvaal. But his hopes turned out to be false when it became apparent that the Boer leaders, even the most devout, chose to base the relationship with the Netherlands on raison d'état rather than on religious sympathies. ${ }^{89}$

Another important sector of society where Hollanders had a marked impact was education. The old system in the Transvaal, which mainly focussed on spelling out the Bible and singing hymns, became redundant with the quick social transformations that took place after i 886. The Hollander Nicolaas Mansvelt (I 852 -I933), who had arrived in South Africa in I 874 to teach modern languages at Victoria College in Stellenbosch, was recruited to initi- 
ate the necessary reforms. In I 890, he was appointed superintendent of education in the SAR. He professionalised the school system by introducing inspection and improved secondary education. Mansvelt was shocked by the poor quality of the teachers, many of whom were barely literate themselves. Together with Leyds, he set out to raise the standards by recruiting capable people from the Netherlands. As a result, in I 898 more than 300 out of 836 teachers in the SAR were of Dutch origin. $9^{\circ}$

In their personal lives, several teachers experienced Hollanderhaat from the Boer population, who often treated them with hostile mistrust, and many letters home were filled with complaints about this behaviour.9I Nevertheless, most of these men and women clung to their ideals and did not abandon their work. As has been mentioned, many people who supported the ideal of stamverwantschap agreed with the SAR government, considering education to be of vital importance for the future independence of the republic. If the curriculum retained its Dutch character, it was argued, the schools could serve as a bulwark against the growing influence of English. In this context the teachers' influence on the youth was crucial, and as such they played an important role in strengthening national identity in the Transvaal. ${ }^{92}$ Kruger's opponents were also aware of this, and it became one of the grievances of the Uitlanders, who demanded that English also become an official language and part of the programme at state schools. ${ }^{93}$

Another institution that was vital to the Kruger government was the press. The Uitlander agitators had taken over several newspapers in the SAR with the help of mining capitalists, particularly in the Johannesburg area. British journalists with jingoist inclinations were recruited to work for these papers and chastise the SAR government. ${ }^{94}$ Although they denounced these practices, the Krugerites on their part also tried to influence newspapers. In I897, a press law was passed that gave the SAR government the power to suppress any paper that was 'in conflict with public morals or dangerous to the order and peace of the Republic'.95 In addition, the government spent $£$ 6,0007,000 a year on advertisements, which served as a covert subsidy. The lion's share of that sum went to pro-government newspapers such as The Standard \& Diggers News and De Volksstem. ${ }^{96}$

The latter, a steadfastly loyal newspaper, was run by Hollanders from I 888. Its most famous editor was F. V. Engelenburg (I863-I938), who came to the SAR in I 889 and started to work as a journalist in the same year. In the I 890 s, he acquired the majority of shares in De Volksstem and ran the paper until I924, with a short break between I900 and I902. Despite some reserva- 
tions against certain aspects of Krugerism, such as the practices surrounding the monopolies, De Volksstem often took a stance against critics from the 'progressive' party and the Uitlanders on issues like state bureaucracy, the NZASM and education. This led to several polemics, most notably with the periodical Land en Volk, in which the regular contributor 'Afrikanus' scolded Hollander influence in his articles. ${ }^{97}$ In this way the Hollander press in the Transvaal was caught up in the political turmoil of the I 890 and Engelenburg became a prominent opinion maker and a well-known public figure in Pretoria.

Publishers were another group in Dutch society with a keen interest in the South African market. In the late I890s, at least four different companies became active in the export of books and magazines to the region. The Hollandsch-Afrikaansche Uitgevers-Maatschappij (Dutch-African Publishing Company, hereafter HAUM) was established in I 897 and had offices in Cape Town and Amsterdam. ${ }^{8}$ It focussed mainly on the publication of Afrikaner authors. One of their most successful writers was J. F. van Oordt, whose historical novels sold well both in South Africa and the Netherlands. ${ }^{99}$ P. A. Nierstrasz, a former artillery officer in the German army who travelled around South Africa in I896, set up a publishing house called „Nederland” based in The Hague and Pretoria. This company focussed on patriotic publications such as the weekly Hollandia, which was a magazine for Dutch overseas. During the South African War, Nierstrasz became involved in the proBoer propaganda campaign in Europe and was in close contact with the diplomatic representatives of the SAR, even years after the war. ${ }^{100}$

Established publishing houses were also involved in the pro-Boer movement. J. H. de Bussy went to Pretoria at the end of I 896 and opened a Dutch bookshop there. Although the NZAV warned against a surplus of such enterprises, which could have led to a saturation of the market, the society approved this project, and a year later even provided the financial means to help open Dutch kiosks at train stations so that travellers would not have to depend on English reading matter on their journeys. ${ }^{\text {IOI }}$ In addition, the firm got much work from the NZAV, printing their annual reports and most of the circulars. It also published many other pro-Boer publications of various kinds.

Another publisher with warm sympathies for the Boers was J. A. Wormser, a prominent member of Kuyper's orthodox Protestant movement. He also travelled around South Africa in I 896 and opened two shops in the Transvaal: one in Pretoria - which was run by his son - and one in Potchefstroom, the intellectual centre of the Doppers. Wormser expressed his sympathies for 
Afrikaners in a book about his trip and a series of lectures. ${ }^{102}$ These activities made him a well-known figure amongst pro-Boers in the Netherlands. The fact that he was closely linked to Kuyper, both as a publisher and an important figure in the Anti-Revolutionary Party, did not prevent him from being an active member of the NZAV; he even served on the executive committee between 1900 and $1907 .{ }^{103}$ His enthusiasm for the Boer cause might have obscured his assessment of the potential risks for his company as he made large sums of money available for his South African activities. In I 898, he invested substantially in the Pretoria branch in order to boost the Transvaal market for books. Less than a decade later he had to conclude, however, that the 'fateful' war of I 899-1902 had put an end to these plans because supply routes were disrupted and demand plummeted. According to him, the economic depression in post-war South Africa and the attitude of Afrikaner leaders, who were reluctant to spent money on Dutch education, effectively meant the end of his business there. Because he had invested so much money in South Africa, Wormser's whole company went bankrupt in I907, which led to a personal crisis later that year, after which he retreated from public life. ${ }^{\text {I04 }}$

It cannot be denied that the Hollanders were a noticeable group in South Africa during the $\mathrm{I} 88 \mathrm{O}$ S and I890s. Especially in the SAR, which rapidly underwent enormous changes after the gold boom of I 886 , they contributed significantly to the development of modern state institutions. Politically, the Hollanders were allied with the Kruger government, but this should be seen as a marriage of convenience, because there remained a great deal of mistrust of the Boers towards influences from the Netherlands. Several of the emigrants were aware of this Hollanderhaat, which influenced their actions. On the one hand they were convinced of their duty to help the rough Boers enter the modern age; on the other hand they were aware of the limitations of the influence they could yield in the republic. Van Winter has argued that such realistic people, for example the NZASm director Middelberg, were the most successful. ${ }^{\text {I05 }}$ This shows that the interests of Hollanders and Boers at the time were perceived to be mutually beneficial by certain individuals, and the relation between the two communities became increasingly intense after I 880 .

The Dutch bridgehead in the Transvaal that came into being at the end of the nineteenth century was directly linked to the question of colonial rule in South Africa and which group of settlers was to become dominant in the region: the white Dutch-speaking population or the white English-speaking population. Despite the tensions that existed between certain groups within the Boer community, most Hollanders thought that the Dutch race should 
take the lead in the process of 'civilising' the region and that it was at least entitled to an independent state outside the British Empire where this dream could take shape. Such ideas corresponded with the views of Kruger, who wanted to ensure Transvaal independence as a guarantee against British interference. In this way, his narrow form of nationalism overlapped with the imperialist dreams of the proponents of stamverwantschap in the Netherlands, and they became allies. One result was that Hollanders ran certain institutions that had a marked effect on developments in the region. At the other end of the line, the public in the Netherlands was mainly informed about the situation in South Africa via the bodies that supported the Krugerite fraction, and as such saw the independence of the Transvaal as a key issue. Events taking place in the 1890 s reinforced these views and the need to make them public, but at the same time posed questions about the reliability of these lines of communication in case of an emergency.

\section{The Jameson Raid: a catalyst for pro-Boer propaganda}

The mounting tensions between the Boer republics and the British Empire during the I 890 os did not go unnoticed in the Netherlands. The Jameson Raid on New Year's Day I 896 in particular led to much commotion amongst the Dutch public, which condemned the so-called 'buccaneers' of the mounted column of the British South Africa Company and celebrated the Boer commandos that stopped and captured them. ${ }^{106}$ In many ways, the reactions to this incident foreshadowed what was to come during the war that started in I899. In this respect, the situation in South Africa was connected to wider questions about the position of the Netherlands amongst the colonial powers. At the end of the nineteenth century, rapid territorial expansion - not only in Africa, but also in Southeast Asia - aroused fears that (parts of) the Dutch colonial possessions in the Indonesian archipelago could be taken by rivals. In the I 880 os, treaties were concluded with Britain and Germany on the demarcation of the spheres of influence on Borneo (I 884) and New Guinea (I 885 ) respectively. Still, the issue remained a predicament because the Netherlands lacked the military strength to defend these islands had one of their powerful neighbours decided to take them. ${ }^{107}$ There were even persistent fears that the Germans would try to annex the Netherlands if given the chance. ${ }^{\text {108 }}$

The delicate balance in the East was the reason that the Dutch government could not afford to provoke the British, and so a strict policy of neutrality remained in force with regard to events taking place in South Africa around the 
New Year of 1896 . In contrast with the emotional reaction of the German emperor, who immediately sent a controversial telegram to Kruger in which he pledged his support to the Boers, The Hague only sent a discreet message to Pretoria a week after the raid. ${ }^{109}$ This prudent attitude did not change over time, which became clear in I 899 during preparations for the Hague Peace Conference that took place between May and July of that year. After a British threat that it would boycott the meeting if the Boer republics were represented, both the ofs and the SAR did not receive an invitation. In Parliament, Abraham Kuyper attacked the Liberal Foreign Minister, W. H. de Beaufort on this issue whom he accused of having no sympathy for the Boers - a rather bold statement considering that both men had been closely involved in the founding of the NZAV. It therefore has been suggested that the motives of the Protestant leader for this remarkable performance was electoral gain. Although several Dutch diplomats condemned Kuyper's rash action, it had no serious repercussions, and the invitation list of the peace conference was approved by Parliament. ${ }^{\text {I }} \mathrm{O}$

It would be wrong, however, to see the Dutch response to the growing crisis between the British Empire and the Boer republics in terms of domestic politics only. There were wider considerations that touched upon the role of public opinion in the context of international affairs. In this respect too, the South African question was linked to the debate about colonial possessions in the East. The fact that the British had far better access to the lines of communication with South Africa and thus controlled the coverage of events there was a stark reminder that the Dutch did not possess independent undersea cables to the Dutch East Indies and that they depended on the British network. ${ }^{\text {II }}$ As a result, the Dutch were not in a position to influence the coverage of events taking place in the archipelago in the foreign media, something that was considered harmful to national prestige by government officials. ${ }^{I I 2}$

Groups that wanted to improve the relationship between the Netherlands and the Boers in South Africa also paid attention to such issues. They did not consider the ties of stamverwantschap to be solely a question of politics or economics but also emphasised the importance of other issues such as the improvement of infrastructure, education and the press. The growing pressure on the Boer republics provoked discussion as to how these institutions could be improved in order to protect Boer independence and thus keep the dream of a Greater Netherlands alive. Public opinion was considered to be of vital importance in this respect, and the focus was placed on the existing institutions that were connected to the lines of communication between South 
Africa and the Netherlands and how they functioned. Just as the emergence of pro-Boer feelings in the Netherlands during the Transvaal War of i 880 had been a complex process, the public reactions to later crises in South Africa varied as well.

The Jameson Raid caused a great public outcry, and at first sight the NZAV did seem to benefit from this greater attention. Although the society made it clear that it did not try to capitalise on the public dismay about the careful response of government to the events in South Africa, membership jumped from I, 300 to I, 800 within a short period after the Jameson Raid. ${ }^{113}$ This had a direct impact on the organisation, because for the first time the NZAV was in a position to rent an office where the increased amount of paperwork could be handled. ${ }^{\text {II }} 4$ Moreover, the raid led to several new initiatives within the society to once more strengthen the ties with South Africa. The most noticeable of these was the foundation of the taalfonds (language fund) by several prominent members such as Robert Fruin, the famous professor of history from Leiden, as well as Moltzer and Emous. This fund collected fl. 60,000 in its first year, which was spent on prizes for schoolchildren in the SAR who excelled in the Dutch language and on subsidies to schools. There was also more money available for grants to emigrating teachers and financial support for the publishing house De Bussy to open bookshops in the SAR. ${ }^{\text {II } 5}$

Despite these successes, the executive committee complained that only a small proportion of the public with an interest in South Africa were members of the NZAV. This was illustrated by the fact that the media were flooded with letters from people outside the society who had great plans for the development of bonds between the Dutch and Boers. Many of these ideas, concerning emigration, the establishment of a shipping line to Delagoa Bay or increasing the number of exchange students from South Africa, also circulated amongst members of the NZAV themselves. The executive committee thought it would be a good idea to discuss these plans collectively and argued that the society could serve as a platform. This was considered necessary with an eye to the future of the Dutch presence in South Africa. 'We Dutch can only do so little, even when we are united. What, then, can be expected of divided efforts?' ${ }^{\text {II6 }}$ Although the complaints about fragmentation continued to exist, the NZAV also found likeminded spirits in other organisations, which resulted in close co-operation.

One of the most substantial initiatives after the Jameson Raid was the foundation of the Algemeen Nederlandsch Verbond (General Dutch Alliance, hereafter ANV). This organisation aimed to promote the idea of a Greater 
Netherlands with a special focus on the Dutch language. This initiative can therefore be seen as a clear manifestation of the concept of stamverwantschap. ${ }^{\mathrm{II} 7}$ Historians give several accounts of the exact origins of the ANV, which in the beginning had a Flemish branch under the leadership of $\mathrm{H}$. van Meert from Ghent and a counterpart in the Netherlands led by H. J. Kiewiet de Jonge (I847-I935), a headmaster from Dordrecht. After the two branches merged, the ANV in Dordrecht dominated and the headquarters were moved there. ${ }^{\text {II } 8}$ This new organisation attracted wide attention within Dutch society, which is illustrated by the fact that it was actively supported by N. G. Pierson, Abraham Kuyper and H. J. A. M. Schaepman, political leaders of the Liberals, Protestants and Catholics respectively. Only the Socialists remained outsiders. ${ }^{\text {I } 99}$

The situation in South Africa was one of the most important driving forces behind the foundation of the ANV, which immediately established a Transvaal branch and asked Kruger to become its honorary president. ${ }^{\text {I20 }}$ In I 898 and I 899, the ANV branches in South Africa had the largest increase of new members. ${ }^{\mathrm{I} I \mathrm{I}}$ This international success is remarkable when compared to the NZAV, which mainly drew its members from the Netherlands. By the start of the South African War, the number of members in both organisations were comparable. ${ }^{\mathrm{I} 22}$ Bossenbroek has suggested that the ANV was much more radical than the established body of pro-Boerism in the Netherlands, the NZAV. ${ }^{\mathrm{I}} 3$ This is, however, not supported by historical evidence. Two important individuals in the early ANV - professor H. Kern from Leiden, who became the first president and Kiewiet de Jonge, the first secretary - were active members of the NZAV. ${ }^{\mathrm{I}} 4$ The latter even joined the executive committee of the association in I900. ${ }^{\mathrm{I}} 5$ Moreover, despite some dissonant notes in the annual report of the NZAV that argued that two organisations propagating stamverwantschap would clash in such a small country as the Netherlands, the ANV was seen as a useful ally rather than a competitor. Soon it was announced that the executive committees of the two organisations were in correspondence with each other and that the ANV had announced that it fully supported the goals of the NZAV. In addition, NZAV members were encouraged to join the ANV. ${ }^{\text {I26 }}$

As shall be shown in later chapters, co-operation between the NZAV and the ANV increased during the South African War, especially in the field of propaganda. By then, as a result of overwhelming public enthusiasm, the organisations were dealing with several problems that made it hard to control the distribution of information. ${ }^{\mathrm{I}} 27$ In addition, another aspect of the propa- 
ganda campaign became more urgent, namely that of getting information from alternative sources to counter the British coverage of events in South Africa. Already before 1899 , however, the influence of the jingo press was a concern for people associated with the network that extended between the Netherlands and the Boer republics. In this context too, the Jameson Raid was a signal for them to take action and prepare for what was to come.

When visiting Europe in I895-I896, Willem Leyds was shocked by the negative light in which the Boers were depicted in German and particularly French newspapers. In his view, this was due to the fact that the British press had a monopoly on the coverage of South African affairs and propagated views that were harmful to the Boer cause. ${ }^{\mathrm{I} 28}$ When he returned to the SAR, he offered to resign as state secretary and go to Europe as a minister plenipotentiary to try and change the public mood and to consolidate the diplomatic ties between the SAR and the continental powers. The plan was initially met with much scepticism because of the high costs involved and because Leyds had been re-elected in I 897 . When the consul-general in the Netherlands and Belgium - G. J. T. Beelaerts van Blokland - died, however, Leyds was allowed to go and set up a legation in Brussels, from where he would co-ordinate his activities in Europe. ${ }^{\mathrm{I} 29}$ Most governments on the continent received him well and accepted his letters of credence. By contrast, British diplomats received strict orders not to meet Leyds officially, because London viewed this as being a violation of the London convention of I884, on the basis of which Britain claimed 'suzerainty' over the Transvaal. ${ }^{130}$

Public opinion in France, where Rhodes' press conglomerate owned several papers, was one of Leyds's primary concerns. Therefore, a press office was set up in Paris which, under the leadership of the French journalist Edgar Roëls, offered material to newspapers that provided an alternative vision on the situation in South Africa. In the following year, the image of the Boers improved considerably, and when war broke out in October I 899, most journalists supported the republics. It is, however, debatable to what extent Roëls' press office was responsible for this. ${ }^{\text {I3I }}$ Public opinion in the Netherlands was less of a problem for Leyds, as the Boer cause was already very popular there. When he visited Amsterdam in February i 896, he was enthusiastically welcomed at the train station by a delegation from the NZAV, and during a reception that was attended by hundreds of people, he was warmly addressed by several well-known speakers such as his former professor, Moltzer. ${ }^{\mathrm{I} 32}$ This clearly shows that Leyds was well acquainted with Dutch opinion makers and, because of the growing interest of the press in the SAR, 
Willem Leyds. Portrait by Jan Veth, I 896. Source: NZAV-fotoarchief, Amsterdam.

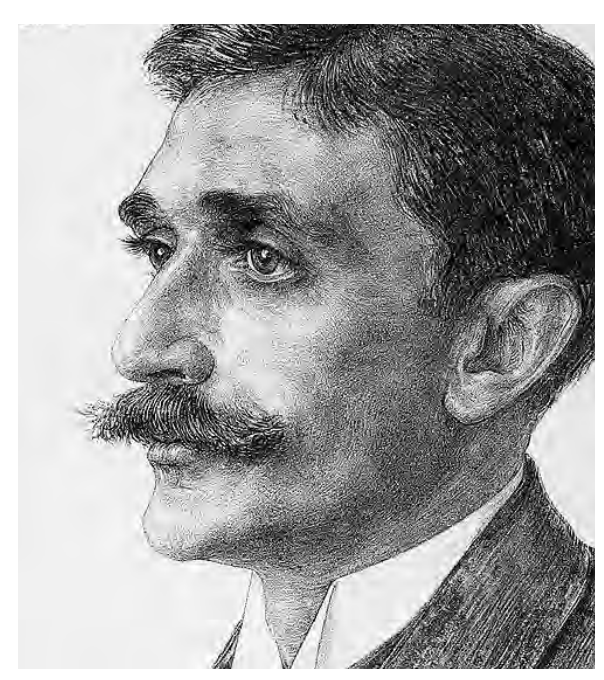

he even became a public figure. As will be discussed in later chapters, these Dutch contacts would prove to be essential in the pro-Boer propaganda campaign.

The ofs did not pursue such an active policy of public relations but did have a diplomatic representative in the Netherlands. The Rotterdam merchant Hendrik Muller (I859-I94I) had become acquainted with Africa as the director of the Oost-Afrikaansche Compagnie (East Africa Company), which focussed on trade with Mozambique. In that capacity he travelled throughout south-eastern Africa extensively in I 889. Muller published his travelogue and several ethnological articles about that region, which earned him a doctorate at the University of Leipzig in I 894. ${ }^{\mathrm{I}} 33$ Apart from his knowledge of the situation in Southern Africa, Muller was also an active Boer supporter and affiliated with the NZAV from the beginning. ${ }^{\mathrm{I}} 34$ These qualifications made him the most suitable candidate to succeed H. A. L. Hamelberg, who died in September I 896, as consul-general for the of S.

The government of the ofs was careful not to provoke Great Britain by conducting an all-out diplomatic campaign on the European continent, because President Steyn feared that it could work like 'the red flag to the British bull'. ${ }^{135}$ In practice, this meant that Muller did not get full diplomatic status, so that his authority was limited. Moreover, the annual budget for the post was just $£ 50$. Some contemporary commentators thought that the SAR was far more popular in Europe than the oFs as a result of this cautious policy. ${ }^{\mathrm{I}} 6$ This did not seem to temper Muller's enthusiasm for the Boer cause, and he 
was more than prepared to supplement the meager stipend from the ofS with his own money. In addition, he was a prolific author defending the Boer cause against the British, which resulted in several books and many articles in the domestic and foreign press. ${ }^{\mathrm{I} 37}$ His outspoken ideas and the confusion that existed around his precise diplomatic status were a source of controversy, however. In addition, Leyds greatly distrusted him and the two representatives of the Boer republics could not stand each other personally, which was already apparent the first time they met in I 898, when Muller visited South Africa. ${ }^{\mathrm{I} 38}$ Tensions continued to mount between the two, which led to open hostility in later years. ${ }^{139}$

The examples mentioned above show that the Jameson Raid and its aftermath were in many ways forebodings of the responses to events between I 899 and I902. Both after the failed coup and during the South African War, fundamental questions were raised about the organisation of the pro-Boer movement in the Netherlands and how it could support the Boer republics in their efforts to defend their independence. The attempt by British imperialists to topple the Transvaal government caused an outcry in the Netherlands because it was seen as a confirmation of the fears that these men would settle for nothing less than complete dominance over South Africa. This was perceived as a threat to Dutch national interests because the bridgehead in the region would be lost, and also because it could serve as a dangerous precedent for great powers to bully small nations, which raised concerns about the territorial integrity of the Netherlands and its colonial possessions. But the concerns were not limited to the political or economical situation: public opinion was also seen as an important issue in the context of modern imperialism. The British dominance of the lines of communication between Europe and South Africa bothered Dutch pro-Boer organisations and representatives of the republics, who tried to provide alternatives for the coverage of South African events. Their attempts, however, had limited success because of the fragmented nature of the pro-Boer movement in the Netherlands, which was a continual source of frustration.

\section{Conclusion}

The issues discussed in this chapter show that the pro-Boer movement in the Netherlands was not simply an expression of a narrow form of nationalism that was detached from international relations. Although contemporaries were aware of domestic restraints, their main focus was on ties with the Boer 
republics in South Africa (and particularly the Transvaal) in the light of the rivalry for colonial dominance with the British Empire. Several groups in the Netherlands thought they could benefit from closer ties with their 'kinsmen' in South Africa. In addition, despite the strained relations with different groups of Afrikaner nationalists, Hollanders were seen by the Kruger government, albeit reluctantly, as important allies, and at times their interests clearly overlapped. It has been argued that in this way a Dutch bridgehead was established in South Africa that was an informal form of imperialism, which contemporaries phrased in terms of stamverwantschap. These ideals, however, were heterogeneous, and it should be remembered that this concept of Dutch racial kinship in an international sense meant different things to different people. Seen from this perspective, the network of stamverwantschap showed similarities to the webbed space of imperial Britishness. Both cases show that the assumption that concepts of nationalism and imperialism were separate by definition is fundamentally incorrect and that historians today need to reassess such terms in order to grasp their historical meaning.

Despite this important similarity, there were also differences between the British and Dutch bridgeheads in South Africa. The main one seems to have been the size and strength of the institutions that bolstered these relations. Much to the disappointment of contemporaries, Dutch trade and emigration figures remained relatively low. To this should be added that the organisations that propagated the ideal of stamverwantschap had severe flaws compared to those of British imperialists, which again led to much frustration in the Netherlands. Bearing in mind Simon Potter's remarks about the structure of the global lines of communication, this says something about the nature of these institutions. He has characterised the infrastructure of the British Empire as a solid 'system' of information: a distinctive community of journalists and other authors travelling easily throughout the dominions and keeping in contact via a grid of intercontinental telegraph lines. ${ }^{\mathrm{I}}{ }^{\circ} \mathrm{By}$ contrast, the Dutch counterpart in South Africa can probably best be characterised as a 'network', mainly because it lacked such hardware and thus depended on British communication lines for the latest news. The Dutch pro-Boers certainly did try to bolster their institutions, but this proved to be difficult because of the reluctance of the government and the business community to support such initiatives. Notwithstanding these severe limitations, it shows that for people in the Netherlands too, the phenomenon of modern imperialism was connected with both public opinion in the metropole and global lines of communication. 
Importantly, many contemporary authors reflected on such issues, and the difficulties that have been mentioned in this chapter are evident from the primary sources. Such remarks serve as a means of getting a deeper sense of the ambivalences that characterised the movement. But there was more to it than that. The next chapter will argue that the Krugerite views, which reached the Netherlands via the network that was set up at the end of the nineteenth century, greatly influenced the depiction of South Africa in Dutch literature. In these publications, both good and bad aspects of the Boers were mentioned, as were their tensions with Hollanders. Such nuances to a large extent seemed to fall away, however, when looking at the bigger picture and the question of which group of white colonists should dominate South Africa: English-speaking or Dutch-speaking. Publications in the Netherlands about this issue provided a particular interpretation of the recent history of South Africa, which was intended to show that the Boer republics were equally, if not better, equipped to 'civilise' that part of the world, as contemporaries liked to call it. This clearly shows that pro-Boer propaganda was firmly connected to events taking place in South Africa in the context of the struggle for colonial dominance. As such, this corpus was the most significant result of the network between the Netherlands and the Boer republics that came into being during the last two decades of the nineteenth century. 


\section{'Blacks, Boers and British': South Africa in Dutch literature}

The (re-)discovery of the Boers by the Dutch public at the end of the nineteenth century was accompanied by a great increase in the number of publications about South Africa that appeared in the Netherlands. ${ }^{\mathrm{I}}$ Many authors from that time were well aware that they stood in a long literary tradition dating back to the journal that Jan van Riebeeck kept after landing at the Cape of Good Hope in I 652. ${ }^{2}$ But this had been quite different during the greatest part of the century. After the handover of the Cape Colony to the British in I 806, the production of books about South Africa dwindled, and in general those that were published were quite negative about the Boers. The interest in the Boer republics after the Transvaal War brought about a radical change: not only did the number of publications about South Africa grow but the tone about the 'cousins' in that part of the world became far more positive. Dutch Africana included many genres such as travelogues, memoirs, ethnographic studies, novels, children's books, poetry, history and journalism. In addition, the authors had many different backgrounds, which affected their views on the situation. People who had lived in South Africa were often influenced by their personal experiences and their political allegiances. But not all authors were familiar with the local situation. There were even writers who had never set foot in the region and took their information from what they read about the country and its inhabitants.

Literary scholars, both in the Netherlands and South Africa, have written interesting studies about Dutch Africana. These books have been used as guides for this chapter, which does not aim to give a complete overview of this corpus but rather provide an outline of some of the themes that it featured. Before the Second World War, academics such as G. Besselaar and Elizabeth Conradie pioneered the field, describing the literature up until the early twentieth century. Both of them were of Afrikaner descent and their work should be considered in the light of the development of Afrikaans as a separate language, which they saw as a desirable and logical development. ${ }^{3}$ More 
recently, some authors have argued along similar lines, describing language as an important feature of Afrikaner nationalism and a means to preserve its identity against foreign (English) influences. ${ }^{4}$ Other literary scholars such as Siegfried Huigen, Wilfred Jonckheere and Ena Jansen critically re-appraised earlier work, describing a more complex and less univocal process that shaped Afrikaans. ${ }^{5}$

One central theme in Dutch publications about South Africa at the end of the nineteenth century was the dynamic relation between Dutch as it was written and spoken in the Netherlands and the development of Afrikaans. Some authors emphasise the differences, but Huigen points out that the literary circles of the Netherlands and the Afrikaners in South Africa were closely intertwined at least until I925, when Afrikaans became an official language. ${ }^{6}$ The primary sources I have used for this chapter, which is about the period between the Transvaal War and the South African War, support that view. There was certainly awareness of the tensions between the emerging Afrikaner movement and the literary establishment in the Netherlands, but it was often hard for contemporaries to categorise them and distinguish between these groups, particularly in the context of the rivalry with the English language in South Africa. This indicates that, although the contents were highly biased and there was a variety of different views in the Netherlands about this subject, the debate about South Africa was linked to the political situation there and was fed by the channels of information that were being set up in the period between I 880 and I 899 .

As a result, another important topic in Dutch-South African literature from that period was the so-called 'race question': the relationship between different ethnic and cultural groups in that part of the world. During the nineteenth century the region that is now South Africa was an intricate battleground where conflicts took place between several ethnic groups, both black and white. At the beginning of the century, the Zulus under King Shaka and the Matabele under King Moselekatse pushed down from the north into present-day Kwazulu-Natal, Mpumalanga and Gauteng during the Mfecane. From the I830s, Boer pioneers left the Cape Colony during the Great Trek and waged many wars with African 'tribes' in those regions before establishing their own republics there. Then from the I 870 , the British began expanding their colonial territory northwards from the Cape during the Scramble for Africa, clashing both with the Boers and black Africans.

Although it was certainly no fixed outcome, by the end of the nineteenth century it became clear that colonists of either British or Dutch descent 
would dominate the region. It can therefore be argued that the South African War, which was the largest of the conflicts, was fundamentally about the question of which of these two groups of white settlers would prevail and shape the colonial order. ${ }^{7}$ It should be borne in mind, however, that many of the views that were put forward in pro-Boer propaganda during the South African War were already evident in Dutch publications about South Africa before I 899. To contemporaries, such issues did not only have to do with the 'hard' tools of power such as military force and capital but also with less tangible aspects such as national identity, cultural heritage and, last but not least, language. At the time, the British and the Boers were commonly referred to as two 'white races', ${ }^{8}$ which indicates that the meaning of race in South Africa was not only tied up with skin colour but also had a strong cultural component.

Nonetheless, relations between black and white played a large role in the debate about which form of colonial rule was best for South Africa. Although black people were increasingly marginalised throughout the nineteenth century, the rise of white settler supremacy did not lead to a great demographical decrease of the non-Western population, as happened in other areas that many Europeans emigrated to, such as Australia, Canada and the United States of America; in fact, at the beginning of the twentieth century the black majority outnumbered the white minority by approximately four to one. ${ }^{9}$ Contemporaries were aware of these figures, and there was a constant fear amongst the white colonists that the black majority would seriously imperil social order and was even capable of destroying it. Therefore, at the time the attitude towards 'natives' or 'kaffers', as black people were referred to in English and Dutch sources respectively, was perceived as one of the most important rupture points between the British and the Boers.

The following pages will not be so much about the historical realities of these complex processes but rather the way in which they were depicted in Dutch literature about South Africa between I 880 and I 899. It was argued in the previous chapter that the Dutch emigrants who went to South Africa, and particularly to the Transvaal, served as mediators between the Boer republics and the public in Europe during the last two decades of the nineteenth century. This chapter will analyse the writings that were disseminated via this network. Many of these publications were available both in the Netherlands and South Africa, where several Dutch publishers set up branches. In this way, accounts of South African history written by Dutch authors became part of the Afrikaner canon, ${ }^{\text {IO }}$ while literary critics in the Netherlands be- 
came acquainted with early texts written in Afrikaans. Because of the complex interaction, the contents of this literature were not monolithic. Authors did not shy away from mentioning the differences between people from the Netherlands and their 'cousins' in the republics, and although their opinions about the Boers were far more positive than in the decades before, there was certainly still a lot of ambivalence.

To complicate matters, there was also a direct link between Dutch Africana and publications about South Africa written in English. Propagandists who supported the expansion of the British Empire in that region wrote several notorious accounts about the Boers in which they were portrayed as backward and cruel oppressors who were not capable of responsible government. These views were reflected in the coverage of South African affairs by the British press during the I 890 os, which was increasingly influenced by reports from correspondents who were associated with pro-expansionist pressure groups such as the South African League (SAL) and the Imperial South Africa Association (ISAA). ${ }^{\text {II }}$ Dutch authors saw such writings as an imminent threat to the existence of the Boer republics and therefore thought it important to publish alternative accounts of South African history, in order to lend legitimacy to Boer claims to independence. There were also English-speaking publicists who criticised the propagandistic onslaught on the republics, however. These works were occasionally translated and were quite popular with Dutch authors. This shows that, aside from the complex relations between people from the Netherlands and the Afrikaners, there was also interaction with the English cultural sphere, which was rather ambiguous too.

This survey of South Africa in Dutch literature at the end of the nineteenth century is intended to place this diverse corpus in its historical context. To a large extent the contents were shaped by the channels of information between the Netherlands and South Africa as described in the previous chapter. The very existence of this network was the result of an alliance between different groups that supported independence of the Boer republics for a variety of reasons. Although their views on specific topics differed significantly, their publications generally supported the existence of an independent Dutch entity in South Africa and reflected on the relations between the different ethnic groups in that region: in short, the racial triangle of 'Blacks, Boers and British'. ${ }^{\mathrm{I} 2}$ This highlights the fact that this kind of literature did not stand by itself but was clearly related to the development of colonial rule in that part of the world. On the following pages, this relationship will be further explored. 


\section{Adventurers and armchair scholars}

In many ways, the Transvaal War of I 880-I $88 \mathrm{I}$ was a turning point in public perception of the Afrikaners in the Netherlands. Before that period, there had only been limited interest in the fate of the Boers. Only a few publications a year appeared on South Africa, mostly by travellers or other people who had been there. In general, their opinions of the Boers were quite negative. Several of the few settlers who went to South Africa before I 880 wrote home to complain that their dreams had fallen into pieces: apart from practical problems they encountered such as high prices and low wages, they considered the Boers to be backward, hostile to outsiders and abusive towards black people. More criticism was expressed in the writings of British missionaries, who also accused the Boers of mistreating black Africans in addition to allegations that they inhibited the spread of Christianity. These English texts became available in the Netherlands, where several were translated into Dutch and used as a source for pamphlets. ${ }^{\text {I } 3}$

In the I870s, some of the Hollander administrators who had come to the SAR still published negative accounts of the Boers. These men had been recruited by President François Burgers (1872-1877), who was an outspoken reformer. This Afrikaner, who had been born in the Cape and who studied in the Netherlands at the University of Utrecht, had far-reaching plans for the future of the republic. Many people in the Transvaal were distrustful of these schemes, much to the chagrin of the progressive Hollanders. In I 879, two years after the temporary annexation of the sAR by the British, Burgers's secretary T. M. Tromp published his memoirs in which he described the Boer character as follows, thereby probably summing up the general opinion in the Netherlands before I 880 : 'In addition to being cowardly, they are false, hypocritical, prone to perjury, unreasonable, inhospitable, lazy, dirty and ungrateful.' '4 However, public opinion changed rapidly after Tromp's work appeared. Burgers's image was tarnished following allegations that he had made a deal with the British; he had allegedly resigned as president and promised not to return to the Transvaal in exchange for a pension and a large farm in the Cape Colony. ${ }^{\mathrm{I}} 5$ Meanwhile, others in the Transvaal became increasingly dissatisfied with the situation, which resulted in the war that made them so popular in the Netherlands and that led to a reappraisal of the Boer character by the Dutch.

After I 88 I, several publications appeared, written by Dutch authors who had lived in South Africa before the annexation, that indicated this shift. Al- 
though they were far less dismissive than Tromp's account, they did vary in tone, which can be explained by the personal experiences of the authors with the Boers. One of the most influential of these books was by Frans Lion Cachet, a Calvinist minister who arrived in the region in 1858 and worked in Natal and the SAR. Throughout his career he was known as a polemist, and during a stay in the Netherlands in the I 870 os he established contacts with the Protestant leader Abraham Kuyper whose newspaper, De Standaard, he used as a platform. ${ }^{16}$ His most famous work, a bulky history of the Afrikaner people up till the end of annexation called De worstelstrijd der Transvalers, was widely read outside Calvinist circles and played a large role in the shift in public opinion in the Netherlands in favour of the Boers. ${ }^{17}$ Lion Cachet did acknowledge that he wrote from a personal point of view; to give a negative description of the Boers was impossible for him, 'by the nature of the matter'. ${ }^{18}$ Some aspects of the book were not uncontroversial, such as his open praise for orthodox Boer leaders and an all-out attack on Burgers, who had been quite popular amongst Liberals. ${ }^{19}$

This points to there being a direct link between Lion Cachet's opinions about South Africa and his Calvinist principles, a point that has been argued by Chris van Koppen. ${ }^{20}$ Also the alliance with Kuyper, who was one of the few to praise De worstelstrijd as an 'objective' account, suggests this. ${ }^{2 \mathrm{I}} \mathrm{How}$ ever, the idea that Calvinism had a large impact on the Boer character was certainly not a prerogative of the Anti-Revolutionary Party, and the idea was generally shared by writers of the day. Moreover, Lion Cachet seems to have derived much authority from the fact that he had lived in Africa for so long. This can clearly be detected in his description of the Boers. Apart from his belief that divine providence had favoured the Afrikaners, he also praised their racial qualities such as their 'stubbornness' which had enabled them to hold out against British tyranny, secure dominance over the black population and establish civilisation in the wilderness of the African interior. ${ }^{22}$ This shows that Lion Cachet not only made propaganda for the Boer cause out of religious conviction but that he was also genuinely interested in the 'race question' in South Africa. And so, while Kuyper lost touch with the Boers in the I 88 os, Lion Cachet continued his influential propaganda campaign with articles in De Standaard and sermons throughout the country. He died while on the job, preparing to lead a prayer meeting against the South African War in the town of Bergen-op-Zoom in November I899. The following year the third edition of his famous book appeared posthumously. ${ }^{23}$

Several Liberal writers were less outspoken in their praise for the Boers 
than Lion Cachet. A good example of this are the memoirs of E. J. P. Jorissen, one of the Hollanders who were recruited by Burgers but who remained in service of the SAR after his previous employer had left the political arena. His book, which appeared after his return to the Netherlands in I 897, was considered to be an authoritative source on the events before, during and after the Transvaal War in which he acted as a negotiator. Jorissen, who had a background as a philosopher and liberal minister, became the state attorney without any previous experience in that field. ${ }^{24}$ In his somewhat conceited memoirs, Jorissen hinted that his lack of political experience was no problem and that his capacities had been much appreciated by both Burgers and the orthodox Boers. In fact, he was asked by Kruger and Joubert to help them formulate their protests against the annexation, and he was also a member of several deputations that negotiated with the British during the turbulent period up to I 88I. Contemporaries were therefore most interested in his description of the negotiations because they considered it to be a valuable account of an insider. ${ }^{25}$

Jorissen was not modest about his accomplishments, which points to the controversy that surrounded his career in the SAR. His apparent arrogance was often mentioned as one of the reasons why he was not popular with the Transvalers. ${ }^{26}$ In several passages in his monograph he claimed to have been the mastermind behind the restoration of independence, which, so he complained, was not always fully recognised by his new compatriots. ${ }^{27}$ Moreover, Jorissen's outward support for the Krugerite fraction in the SAR was ambivalent, to say the least, considering his opinions on the president. Jorissen himself emphasised that, despite the fact that they had fundamentally different views, there was a mutual respect between him and Kruger that ensured a good working relationship. This did not stop him, however, from writing a somewhat disdainful passage in which he described the old Boer as a simple and unworldly man with the outlook on life of a Calvinist from the sixteenth century. 'In his eyes, the sun revolves around the earth. ${ }^{28}$ In addition to these taunts, Jorissen was known for his involvement in various political controversies in the Transvaal, which caused contemporaries to question his dedication to the Boer cause. This view appeared to be supported by the fact that after his return to the Netherlands, he spent his days in obscurity and, unlike many other Hollanders who had returned from the republics, did not join the propaganda campaign against the South African War. ${ }^{29}$

Another genre of Dutch publications were travelogues about South Africa, and these also contained varied accounts of the Boers. One of the most noto- 
rious of these was by the explorer Daniël Veth, who in I 884 went to Umpata in South-West Africa to examine the possibility of founding a Dutch colony there. The expedition was a complete failure and Veth died of fever. Before his death, he wrote an account of his findings, which were extremely negative, particularly about the Boer pioneers in the region, whom he bitterly described as 'idle, greedy, rude and coarse'. ${ }^{30}$

Visitors who suffered less during their journeys produced more positive views of the Boers. The businessman Hendrik Muller, the future consul-general of the ofs in the Netherlands, travelled from Mozambique to the Cape in the late I880s, and his travelogue appeared in I889. Muller was also known for his work as an ethnographer, and the volume contains many extensive yet vivid descriptions of the various people he encountered: Boers, British and blacks. ${ }^{3}$ Although he was far better disposed towards the Dutch element in South Africa than Veth, his descriptions of the Afrikaners he encountered did vary in tone. With patriotic pride Muller emphasised the influence of the Dutch East India Company on the institutions in the Cape and the Boer republics in areas such as language, law and architecture. ${ }^{32}$ Passages about less developed parts of the Transvaal, however, contain amusing observations of Boers living on the Highveldt, whom he thought rather peculiar, with a childlike sweet tooth and bad table manners. ${ }^{33}$

The publisher J. A. Wormser also wrote down his impressions after an eightmonth business trip throughout South Africa in I896 and I897. He was more explicitly positive about the Boer lifestyle, which undoubtedly had to do with his Protestant background. He praised them for possessing a perfect mix of fear of God and love for freedom, which in his eyes made them an example to Christians in the Netherlands. ${ }^{34}$ However, Wormser's elated views on the Afrikaners probably also had much to do with the political situation in South Africa, because he travelled there during the aftermath of the turbulent Jameson Raid. The author made no secret of his admiration for the men who stopped the British invasion, praising their patriotism and excellent skills on the battlefield. 35

Not every Dutch author who wrote about South Africa had actually been there, but such people were nonetheless influential in the dissemination of knowledge about the region. An important figure in this respect was C. B. Spruyt, a professor of philosophy in Amsterdam, who was the secretary of the NZAV between I 884 and I 897 , in which capacity he wrote many articles on South Africa. Henk te Velde regards Spruyt as a clear example of an arm- 
chair scholar, who projected his views on South Africa and the Boers in order to cope with the domestic political situation in the Netherlands at that time. ${ }^{36}$ It is true that Spruyt never set foot in Southern Africa, and in some ways he seems to have idealised the Boers in an attempt to cure the ills of modern society, which becomes apparent in his introduction to a collection of his essays on South Africa from I897. He explicitly hailed the calm and steadfast character of the Boers in the Transvaal as an antidote to the apparent 'fevered excitement' in Europe during the confusing days of the fin-desiècle. ${ }^{37}$

But this view on Spruyt's work disregards the fact that he was well positioned in the network between the Netherlands and the Boer republics and as such was an important propagandist for the ideal of stamverwantschap. He was well informed about the publications that appeared about South Africa at that time, and his articles - several of which appeared in the prestigious literary magazine De Gids - cited them extensively. In I 89I, for example, he published a long review of Muller's travelogue in which he praised the book as an important contribution to knowledge about South Africa in the Netherlands..$^{8}$ Moreover, as a member of the executive committee of the NZAv, he corresponded regularly with prominent figures in the SAR such as Nicolaas Mansvelt, whom he greatly admired. 39 The respect was mutual, as is shown in an obituary by Mansvelt after Spruyt died in I90I. The deceased was praised as a relentless activist for the dissemination of the Dutch language in South Africa and also for his thorough knowledge of the region, even though Mansvelt did not agree with all of Spruyt's views..$^{\circ}$

Not all the publications on South Africa by Dutch authors were as highbrow as Spruyt's. Martin Bossenbroek has rightly pointed out that it is hard to draw distinctions between high and low culture in the depiction of South Africa. ${ }^{4 \mathrm{I}}$ Several people that were connected to the network surrounding the NZAV and the Hollanders in the SAR actively tried to make a link with popular culture. One of them was the geographer H. Blink, a member of the NZAV in The Hague..$^{2}$ In I 889 , he published a short overview of South Africa in which he sketched the region's history from Van Riebeeck onwards and gave a description of the situation in the Transvaal. In the introduction, he mentioned that he drew most of his information from well-known authors like George McCall Theal, Spruyt and Lion Cachet. ${ }^{43}$ The executive committee of the NZAV welcomed it as a useful booklet and recommended it to future emigrants, who did not have access to these sources. ${ }^{44}$ Blink was also the editor of the popular magazine Vragen van den Dag that regularly contained ar- 


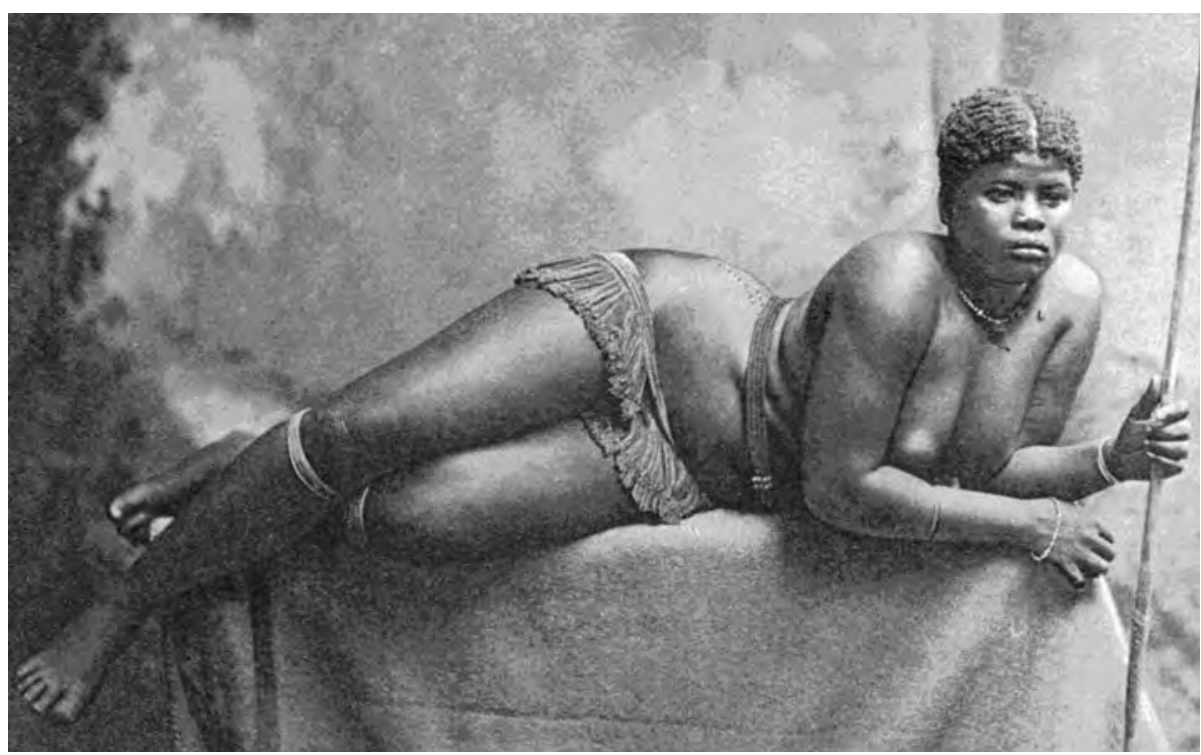

Picture of a Zulu girl.

Source: H.P.N. Muller, Zuid-Afrika. Reisherinneringen (Leiden, I 889). Collection ZuidAfrikahuis, Amsterdam.

ticles about South Africa and during the South African War published a special issue about the historical background of the conflict.

In other ways too, information and images of South Africa were made available to the general public. This is illustrated by Wormser's travelogue, which gave occasion to an evening lecture full of entertainment for a crowd of 3,000 people in Amsterdam. The vivid lecture in which he recounted his experiences was accompanied by lanternslide projections of beautiful landscapes and heroic Boers. The audience also enthusiastically sang along to the patriotic ballads that were performed.45 Muller's book also had noticeable sensationalist aspects. The Afrikaner literary critic Besselaar thought that his account of a shipwreck near Durban - based on a true story - was very appealing. The pictures of a voluptuous naked Zulu girl that are scattered throughout the book, however, could not carry his approval, and he thought it was 'no picturebook for a Dutch nursery'. ${ }^{46}$ Nevertheless, Muller's travel account was turned into an adventure book for schoolchildren - needless to say without the titillating images. One teacher was of the opinion that the text contained so many instructive descriptions of the land and the people that he adapted it into an inspiring story of a young man who is shipwrecked 
near Durban, travels throughout South Africa during the upheaval of the Transvaal War, settles as a cartwright in Pretoria and marries a local Afrikaner girl.47

This mix of fact and fiction is typical for many books about South Africa at the end of the nineteenth century. The most famous writer of pro-Boer adventure books in the Netherlands was Louwrens Penning (I 854 -I 927). ${ }^{8}$ In his autobiography he described how he wanted to emigrate to the Transvaal in the early i 88 os and, although the tears in his mother's eyes stopped him from leaving, that he never lost his devotion to the Boer cause. ${ }^{49}$ His two brothers did settle in South Africa and, until his death in the I920s, they kept in regular contact via letters, which provided him with material for his books. In addition, he was well acquainted with Dutch Africana. ${ }^{\circ}$ His first books appeared after the Jameson Raid, which infuriated him so much that - after he had taken a cold shower to regain his composure - he decided to do his bit for the pro-Boer movement. ${ }^{51}$ As a result he wrote a series of three historical novels about the Great Trek, the annexation of the Transvaal and the raid itself. The chapters of these books alternately told stories of fictional characters and provided descriptions of events that actually took place, making it a form of popular history. Penning made few references to the sources he used, but the times he did so prove that he drew his information from well-known publications. ${ }^{52}$ Jacques van der Elst has argued that in this respect, Penning's books largely reflected contemporary biases in the Netherlands. ${ }^{53}$ There was, however, also contemporary scepticism about Penning's early work, and the famous Lion Cachet even warned him that he would make a caricature out of the Boers because he did not have personal experience of South Africa. Nonetheless, Penning himself thought his connections were sufficient to provide him with enough knowledge and he continued writing - with huge success. 54

This illustrates how there was a distinct overlap between publications in the Netherlands and South Africa. By the end of the nineteenth century, the Dutch public had access to several sources from which they could draw information about the Boers. Accounts of emigrants and travellers naturally had a certain degree of authority because they wrote about their own experiences. There were also authors who had never been to South Africa but nonetheless became known as specialists because of their connection with the channels of information from the republics. In this way, a heterogeneous corpus of literature came into being, which is also reflected in the variety of views that emerged from it. The following section will explore such ambivalences, look- 
ing at accounts describing the history of the Dutch-speaking people in South Africa and their relations with their 'kinsmen' in the Netherlands.

\section{The ambivalences of stamverwantschap}

Although their opinions differed significantly, there was one certainty for all Dutch authors who wrote about this topic: the history of South Africa started with Van Riebeeck's landing in I 652. The white colonists near Cape Town, it was argued, developed into the Afrikaner people. It was acknowledged that non-Dutch blood was mixed in because of the arrival of Huguenot settlers from France and also German colonists, who were recruited by the Dutch East India Company. In 1902, the historian H. T. Colenbrander did extensive research in the Company's archives in The Hague and argued that about $50 \%$ of the Boers in the republics had Dutch ancestry, $27 \%$ German and I $7 \%$ French. ${ }^{55}$ From these figures he drew the conclusion that the Boers were a 'new race' because Dutch blood was blended significantly with 'foreign' elements. ${ }^{56} \mathrm{He}$ emphasised that this miscegenation mainly occurred amongst white peoples and that less than I\% of the Afrikaners had black forefathers. ${ }^{57}$

There seems to have been widespread agreement in the Netherlands on this point, and many authors asserted that the Boers were an independent ethnic group, while racially akin at the same time. Still, there were different views as to what degree these foreign influences had affected the 'Dutchness' of the Afrikaners. Looking at the surnames of influential Boers, for example, many people noted that French Huguenots left a substantial mark. Lion Cachet was of the opinion that the 'short-temperedness' of the Afrikaners was another French legacy. ${ }^{8}$ Nevertheless, he described how the Huguenots voluntarily assimilated into the Dutch colonial way of life, an opinion that was shared by Muller. ${ }^{59}$ Colenbrander also stressed that their historical influence had often been overemphasised, particularly in Britain. 'It seems that people over there preferred to be embarrassed by the "chivalrous" Frenchman than the coarse Dutchman.' ${ }^{90}$

Contemporaries did not consider genetic make-up to be the only factor that was relevant to the relationship between the Boers and the Dutch; they also noted how the colonial context played a role in the unique development of the inhabitants of the republics. It was not denied that there were already tensions between the Netherlands and the colonists in the Cape during the eighteenth century, caused by trade restrictions and corruption amongst offi- 
cials of the Dutch East India Company. Lion Cachet explicitly noted that this was a reason for Afrikaners to move away from the area around Cape Town and to settle in the Graaff-Reinet district. ${ }^{6 \mathrm{I}} \mathrm{He}$ argued that this strategy of trekking to avoid metropolitan meddling played an essential role in the nineteenth-century history of the Boers, during which they constantly tried to avoid British interference. ${ }^{62}$

This urge for freedom and independence was partly seen as a Dutch trait. In many sources, the struggle of the Boers against the British Empire was linked to the war of independence by the Dutch against the Spanish that took place in the sixteenth and seventeenth centuries. In reference to the premodern freedom fighters, the Boers were known as 'the gueux of the nineteenth century'. ${ }^{63}$ In addition, it was thought that the increasing isolation of the Boers who went inland meant that they preserved several characteristics that the first colonists brought with them from seventeenth-century Holland, of which a deep-rooted faith in the word of God was probably the most well known. There were many differences between Liberal and Protestant observers in the Netherlands and how they valued the staunch Calvinism of the Boers, but they did agree that the Dutch Authorised Version of the Bible, which was written in seventeenth-century Dutch, was the most important book for them and one of the most tangible legacies from the Netherlands in South Africa. ${ }^{64}$

Despite these markers of Dutch identity, many observers noted how frontier life had led to a growing gap between people in the Netherlands and the Boers. The struggle for existence during the journeys into the interior and the confrontations there with wild animals and 'savage' black Africans supposedly hardened the pioneers. Lion Cachet's vivid descriptions of these socalled Voortrekkers are exemplary. In the ox-wagon camps, or laagers, everybody joined the daily effort of preparing food and other essentials, only taking time off to pray and to read the Bible. ${ }^{65}$ In a fictitious paragraph, he crawled into the skin of a Boer, standing on top of the Drakensberg, overlooking the majestic landscapes of Southern Africa, which emphasised the spiritual link of the Boers with the land they colonised. ${ }^{66}$ Spruyt was sceptical about Lion Cachet's assumption that the pioneers were living the life as described in Genesis. He nevertheless characterised the lifestyle of the Voortrekkers as 'patriarchal' and thought it continued to influence the nature of daily life of the republics. ${ }^{67}$ In this way, an elevated and heroic image came about concerning the Great Trek and the foundation of the republics.

One noticeable aspect is that such heroism drew strongly on notions of 
gender in which particular qualities of each sex were celebrated. Men were mainly praised for their physical qualities and courage, which they needed to survive in the 'wilderness' of South Africa. Wormser characterised the male Voortrekkers as 'the real Boers; broadly shouldered, long bearded, rounded straight fellows, who bring forth a breed as brave and stout as they are themselves' ${ }^{68}$ Their favourite pastime - so many authors thought - was hunting, which explained their excellent shooting and riding skills, which boys already learned during early childhood. ${ }^{69}$

Boer women were considered at least as heroic as the men but in their own way. In his description of the Great Trek, Lion Cachet noted how they were not spared the hardships of frontier life, for instance suffering attacks from black Africans. $7^{70}$ Moreover, they played an essential role in organising the laager, taking care of the household when the men were out hunting or scouting. ${ }^{7 \mathrm{I}}$ During battles, women were occupied by nursing the wounded, casting bullets, and there were even stories of women who handled rifles themselves. ${ }^{72}$ But the Boer women were mostly admired for their patriotism. At critical moments in the history of their people, such as after the attack by the Zulus in 1838 and the Transvaal War, they convinced their husbands and sons to go out and fight. ${ }^{73}$ The retired army officer J. H. Rovers, who had been in the Transvaal in $\mathrm{I} 88 \mathrm{I}$, argued that in this way women guarded the moral integrity of the Boers in the 'wilderness' of the South African interior. ${ }^{74}$

Consequently, the simple lifestyle of the Boers was considered to be intertwined with the nuclear family, which was reflected in the political culture of the republics. In descriptions of the Transvaal, it was noted that the administration of the region was small-scaled and decentralised, which made it a communal concern for all Boer citizens and ensured good social order. ${ }^{75}$ In the Transvaal Parliament, the Volksraad, the president acted as a primus inter paribus, a true father of the nation, which illustrated the informal nature of the political system. ${ }^{76}$ Both Muller and Wormser described how easy it was to approach Kruger, who sat on his porch every morning, willing to talk to anyone who passed by. ${ }^{77}$

Despite the praise for the simple lifestyle of the Boers, observers from the Netherlands also saw disadvantages. Some were of a rather practical nature. Housing, for example, was considered to be downright primitive. Wormser complained extensively about the low standard of accommodation in Pretoria and other towns, where hotels provided no clean towels, had lousy service and served awful food..$^{8}$ Staying at a farm in the Transvaal, Muller noted with disgust how his hosts - father, mother and son - washed their faces and 
feet with water from the same bowl. 'The people here certainly possess many virtues, but not really that of cleanliness.'79

Another problematic feature of the Boer character was perceived to be their pugnaciousness and their strong partisan tendencies. During the early history of the SAR there were many internal conflicts, which even led to an armed conflict between different fractions of Voortrekkers. This political strife, which was intertwined with ecclesiastical issues, was generally considered to be a black page in the history of the Transvaal. Lion Cachet, who as a Calvinist minister and polemist was deeply involved in these matters, did not find it opportune to mention them in his account of Boer history because he did not want to stir up painful memories. ${ }^{80}$ Jorissen also mentioned party rivalry as one of the weak spots of the SAR but, aside from some bitter comments about his own dismissal, did not describe in any detail the political feuds that took place in the 188 os and early i 890 , which he witnessed from close by. ${ }^{8 \mathrm{I}}$

It was noted, however, that the internal bickering was nothing compared to the distrust towards external intervention that the Boers had developed during the Great Trek and which had led to a degree of isolation. ${ }^{82}$ These qualities, which had protected them from meddling by the British, also halted progress and alienated them from the modern world, several authors noted. Muller was explicitly worried about the underdeveloped state institutions of the Transvaal. In his view, the gold boom of the late I 880 s had propelled the archaic Boers into the age of high capitalism, which caused great social problems. He therefore noted with satisfaction that Kruger had been so wise as to appoint Hollanders to help him reorganise the state. ${ }^{83}$ In general, commentators thought the lack of a good education system in the Transvaal was particularly dangerous because it made the Boers, many of whom were illiterate, vulnerable. Such authors often mentioned that it was in this field that emigrants from the Netherlands could contribute most significantly. ${ }^{84}$

Despite the tempting prospects, people who were interested in emigrating were extensively warned not to take it too lightly. It was often noted how Dutch emigrants in the past had given the Netherlands a bad reputation in South Africa. Considering the mistrustful nature of the Boers, it was generally stressed that emigrants to the Transvaal had to be well-behaved because vices like alcohol abuse, swearing and arrogance were frowned upon. And if they were not religious themselves, they had to at least show respect for the church. Moreover, emigrants had to be educated and experienced professionals who were motivated to contribute to the well-being of the Dutch race. ${ }^{85}$ 
Despite these warnings, hate against Hollanders was a sensitive issue in Dutch sources, more so because it was tied up with internal rivalry in the SAR between the Kruger government and the opposition. It seems that most authors wanted to avoid controversy and did not express their personal views on such matters. There was one exception though: as will be examined in the following section, S. J. Du Toit, who was known as the main opponent of Hollander influence, was widely derided by critics in the Netherlands.

In Dutch publications about South Africa at the end of the nineteenth century, both the similarities and the differences between the Hollanders and the Boers were mentioned. Looking at the genealogy of the Boers, their Dutch descent was apparent, but authors also pointed out the influence of French blood. Likewise, many writers thought that the history of the Great Trek showed that the Boers possessed markers of Dutch identity such as an urge for independence and freedom. On the other hand, they pointed out that the pioneering life had developed some peculiar traits in the Boer character. Some of these, such as their outdoor skills and patriotism, were applauded, whereas others, such as stubbornness and partisanship, were lamented. These ambivalences show that the image of the Boers in the Netherlands was not univocal, but they should also not be overemphasised. In the light of the colonial competition between the two 'white races' in South Africa - the British and the Dutch - many of the ambivalences seemed to fall away. Most of the authors who have been discussed put forward the ideal of an independent Dutch South Africa and called upon their audience to contribute to achieving that goal. Racial unity, in the form of stamverwantschap, was considered the best panacea for the expanding British Empire. One issue in which these considerations were paramount was the language question, which will be discussed next.

\section{The language question}

For contemporaries, language was closely linked to the political context. At the end of the nineteenth century it seemed, depending on the viewpoints of individual authors, as if Dutch was either on the rise or under pressure in different parts of the globe. It was noted, for example, how in the United States of America emigrants from the Netherlands had lost knowledge of their mother tongue; this was a sign that they had completely assimilated into American society, and it was accepted as a fait accompli. ${ }^{86}$ The situation in Belgium, where the Flemish campaigned to get Dutch recognised as an offi- 
cial language with the same status as French, was considered to be more contentious. ${ }^{87}$ At the end of the nineteenth century, however, the struggle for the Dutch language was considered to be the most urgent in South Africa because it was linked to the question of whether British or Dutch influence would dominate in that region. In this respect it should be seen as a crucial aspect of the development of two different white identities in the region, and as such it played an important role in colonial politics. This was also a concern for the British, and there was great anxiety amongst administrators during the late nineteenth and early twentieth centuries that the Afrikaners would not submit to their rule because they kept their own language. ${ }^{88}$

At the same time, observers on the Dutch side were afraid that English cultural influence would swamp the republics and destroy their independence. The law from I 825, in which English was proclaimed to be the only official language of the Cape was mentioned as an early example of this hostile attitude. ${ }^{89}$ For contemporaries, the struggle for colonial dominance between the Boers and the British was therefore not only fought out on the battlefield but also in the press, in books and in classrooms. This sense of cultural strife was clearly shared by the protagonists of stamverwantschap in the Netherlands, and the sources on this topic contain many allusions to war. In I 896, for example, Muller called upon teachers to go to South Africa and help the Boers to preserve their identity: 'In fact, the struggle for the language is a struggle for the race. ${ }^{90}$ Like other aspects of the relations between the Netherlands and the Afrikaners, there were many different views on this matter and various strategies were developed to counter English influences and British colonial influence. At times, this led to great tensions between different groups of Dutch-speaking people.

At the end of the nineteenth century, the Afrikaners in the Cape started to organise themselves in order to promote the emancipation of the Dutch language in that colony. This can be considered to be the start of the process that led to the establishment of Afrikaans as an official language in $1925 .{ }^{9 \mathrm{I}} \mathrm{A}$ radical thinker from this so-called Taalbeweging (Language Movement) was S. J. du Toit. In I 876, he founded the Genootskap van Regte Afrikaners (Society of True Afrikaners), an organisation that promoted the development of Afrikaans as a written language, with its own spelling and grammar. At the time, Du Toit was known as the most prominent opponent of Hollander influence in the SAR, where he became superindentent for education after the annexation had ended..$^{2}$ One of his most notorious polemics was with Jorissen, who was fired as state attorney in 1883 , something the Hollander him- 
self thought to be the result of a campaign against him in the press and the Volksraad orchestrated by his opponent. ${ }^{93}$ This incident made Du Toit increasingly unpopular in the Netherlands. In addition, he stirred up much controversy as a member of the Transvaal deputation that visited the Netherlands in $\mathrm{I} 884$, and he was alienated from many people that had admired him at first, such as Kuyper. ${ }^{94}$ When he left the SAR in I 890 after a fallout with other members of the Kruger government, Du Toit was accused of dancing to the tune of Cecil Rhodes in many Dutch publications. 95

One Afrikaner from the Cape in whom people from the Netherlands put more trust was Jan Hofmeyr, the founder of the Afrikaner Bond (I88I). This political organisation came into being during the aftermath of the Transvaal War and campaigned with success for the recognition of Dutch as an official language in the Parliament and courts of the Cape. Although English was still dominant in daily life, this was generally seen as the greatest success of the Afrikaners in the colony. ${ }^{6}$ Hofmeyr also seemed to be better disposed towards Hoog-Hollandsch than Du Toit. In I 890 and I 897 , conferences were organised by the Taalbond, a branch of the Afrikaner Bond, to discuss the development of a local form of Dutch in South Africa. In general, this organisation was considered to be quite conciliatory towards influences of High Dutch, something that was appreciated in the Netherlands. ${ }^{97}$ But Hofmeyr's initial political alliance with Rhodes, who became prime minister of the Cape in 1890 , was frowned upon, and it was widely believed that he had been charmed by the charismatic empire-builder. It was only after the Jameson Raid that the two men drifted apart, which gave many people in the Netherlands hope that all white Dutch-speaking inhabitants of South Africa would form a united front against British imperial expansion. ${ }^{98}$ Nevertheless, there remained a measure of distrust of Afrikaner nationalists in the Cape.

Critics in the Netherlands were more optimistic about the development of Dutch in the two Boer republics, where both the Bible and official documents - the two main pillars of society - were written in High Dutch, which to contemporaries emphasised their independence from British rule. But there were also concerns. The OFs in particular was seen as a potential weak spot in the front line against English culture. Muller described how British settlers played an important role in the intellectual life of the republic and dominated education. ${ }^{99}$ Although the headmaster of the prestigious Grey College in Bloemfontein, J. Brill, was Dutch, the school had been founded with a grant from the former high commissioner of the Cape after whom it was named. ${ }^{\text {100 }}$ Despite these problems, the subsequent Presidents J. H. Brand, F. W. Reitz 
and M. T. Steyn were seen as people who upheld the Dutch element and resisted British pressure. ${ }^{\text {IOI }}$

Notwithstanding these hopeful developments in the OFS, the SAR was generally considered to be a more important bulwark of Dutch influence. Initially there had been concerns about the educational reforms initiated by Du Toit, whose policies to attract teachers from the Cape were seen as a way for English to get in through the backdoor, as these men and women could barely speak Dutch themselves. ${ }^{\text {I02 }}$ The appointment of the Hollander Nicolaas Mansvelt as superintendent of education in I 890 was therefore welcomed as a great improvement. In practically all publications that appeared in the Netherlands on this subject, Mansvelt was described as a great mediator, because he had been in South Africa from I 874 and at the same time kept strong ties with his mother country. Under his guidance, the schools in the Transvaal were reformed and he attracted teachers from the Netherlands to ensure a solid curriculum of Hoog-Hollandsch. ${ }^{\text {I03 }}$ In eulogies of his work, Mansvelt's efforts to promote the Dutch language were admired. Wormser, for example, emphasised how important this was for the future of the Dutch influence in the light of British cultural expansion.

May the Afrikaner people understand, the sooner the better, that the England, that can be driven away using Henri-Martins [sic] rifles, is a hundred times less dangerous than the English influences, that men like Dr Mansvelt have devoted their lives to combating. ${ }^{\text {IO4 }}$

Several commentators in the Netherlands felt connected to the development of Afrikaans. There are clear indications that several publications by Afrikaner nationalists were read and discussed by Dutch intellectuals. Hofmeyr's magazine Ons Land was available and probably also Di Patriot, edited by Du Toit. ${ }^{\text {I05 }}$ Writers in South Africa with roots in the Netherlands such as J. F. Van Oordt (better known under his pseudonym d'Arbez) and Jan Lion Cachet (brother of Frans) contributed extensively to these magazines and experimented with new forms of spelling. ${ }^{106}$ This highlights the fact that it is hard to make a distinction between literary circles of the Netherlands and South Africa around the turn of the twentieth century. ${ }^{107}$ Early literature in (haphazard) Afrikaans spelling mainly consisted of poetry and heroic stories about the past, mainly the Great Trek and related events. ${ }^{\text {Io8 }}$

Besselaar has argued that poetry was the post popular genre in Afrikaans in the Netherlands. ${ }^{\text {Iog }}$ One of the most prolific authors of that time was 
F. W. Reitz (I 844-I934). Originally born in the Cape Colony, he had a long political career in the Boer republics. In the 1870 , he was appointed as high court judge in the OFS and in I 889 , became president of that republic. Ill health forced him to retire in I 895 , but in I 898 he succeeded Leyds as secretary of state in the Transvaal, a post that he would occupy until the end of the South African War. Apart from his political achievements, which earned him the reputation of being a good patriot whose policies benefited the Dutch element in South Africa, Reitz was also known as a dedicated poet. In I 888, he edited a volume with fifty selected poems from Di Patriot, several of which were written by himself. A second extended edition, which was published in I 897 by Wormser, contained sixty-two poems. ${ }^{\text {I }}$ ' The topics ranged from doggerel about daily life in South Africa to emotionally charged verses about the struggle between the Boers and the British, in particular the Transvaal War. Other Afrikaners were also inspired by this conflict and wrote victory songs and patriotic ballads. Another politicised issue was the struggle to promote the Dutch language in the Cape and the clear and present danger of English at schools. These literary products were welcomed as examples of true patriotism by critics in the Netherlands. ${ }^{\text {II }}$ Besselaar noted that such rhymes were taught at schools in the Netherlands and so helped to bolster national identity there as well. ${ }^{\mathrm{II} 2}$

While there was appreciation for some aspects of nascent Afrikaner nationalism, there were also concerns about the disparity between the official written language - Hoog-Hollandsch - and the popular language spoken in daily life - Afrikaans. Several linguists in the Netherlands described how, over time, the vernacular of the Afrikaners had changed under the influence of other languages introduced by French Huguenots in the Cape and Malaysian slaves who had been brought from Asia by the Dutch East India Company. ${ }^{\text {II3 }}$ As has been mentioned, Du Toit's efforts to develop Afrikaans into a language in its own right was frowned upon by many people. Jan te Winkel, a professor of linguistics, was one of his most outspoken critics. $\mathrm{He}$ considered Afrikaans to be an amusing dialect, like Flemish or Amsterdam slang, but if it was to become a separate language, he predicted, it could never hold out against English in South Africa. 'He [Du Toit] could arouse some sort of literary life amongst Hottentots with it [Afrikaans], [but] civilised people would turn away from it.' ${ }^{\mathrm{II}} 4$

Most commentators from the Netherlands were not as blunt as Te Winkel, but it was a commonly held idea that the development of Dutch in South Africa should be closely linked to Hoog-Hollandsch. This was the premise of 
Mansvelt's education policy that was very popular amongst Dutch authors who wrote about it. ${ }^{\text {II } 5}$ However, Mansvelt himself had experienced the reluctance amongst Afrikaners to learn Hoog-Hollandsch, he told an audience of prominent pedagogues in a speech after his return to the Netherlands in I900. He recalled how, while lecturing at Stellenbosch, he had to work hard to win over his students by giving animated classes which eventually aroused their interest in the Dutch language. ${ }^{\text {II }}$ In the SAR he also tried to sugarcoat his policies by supporting the establishment of bookshops so that Transvalers could discover for themselves how much beautiful literature there was in Dutch. ${ }^{\text {I }}{ }^{7}$

Another method to promote Dutch amongst Afrikaners was the simplification of the language conventions. Mansvelt complained about the difficult spelling and grammar rules of High Dutch that made it unpopular with students in the Cape, who preferred English because it was considered to be far easier. ${ }^{\mathrm{II} 8} \mathrm{He}$ found many likeminded people amongst Afrikaners in the Taalbond, of which he himself was also a member. People like professor P. J. G. de Vos from Cape Town argued in favour of language reforms and a simplification of the rules and tried to persuade the literary establishment in the Netherlands of the necessity of these measures. ${ }^{\text {II } 9}$ In the SAR, the Hollander journalist F. V. Engelenburg was an enthusiastic supporter of such ideas, introducing simplified spelling in his newspaper De Volksstem. ${ }^{\mathrm{I} 20}$ In I897, he wrote an article for De Gids to mobilise support for these initiatives in the Netherlands. He complained about rigid linguists who wanted to keep the grammar pure, which complicated the use of the language as a unifying agent amongst people of Dutch descent in South Africa. Failure to do so led to the danger that 'the growth of the Dutch language in this part of the world is greatly harmed'. ${ }^{\text {I2I }}$

These proposals were met with some positive response in the Netherlands and were discussed by intellectuals. There was a lobby group called the Vereeniging tot vereenvoudiging van onze schrijftaal, which called for the reform of Dutch spelling and grammar using a model developed by R. A. Kollewijn. As has been mentioned, several influential figures from the pro-Boer movement such as J. P. Moltzer and H. J. Emous were members of this organisation. ${ }^{\mathrm{I} 22}$ Even a purist like Te Winkel, who was outspokenly conservative in this matter, acted as a spokesman for a group of Afrikaner and Dutch activists who wrote a letter in which they presented several proposals for possible reforms to a conference about the Dutch language in Dordrecht. Although Te Winkel did not support these plans, he found it important to dis- 
cuss them because he did not think spelling rules should come between the Dutch and the Afrikaners.

We feel ourselves to be one with the South African, because we know he is blood of our blood, because his ancestors went out from our country, because his character is closer to ours than that of any other people, because we understand what he writes in his own language, even though we have not consciously learned it, because we understand him completely when he comes to us and greets us as his brother in his own words. ${ }^{223}$

Despite this apparent goodwill, no official reforms of the Dutch language took place around 1900. ${ }^{\mathrm{I} 4}$ As was the case with many initiatives that were undertaken by the protagonists of stamverwantschap, these plans failed to be realised and at times the debate was quite heated. But there was more to it. It has been argued in this section that the language question should be seen as part of the overarching struggle for colonial dominance in South Africa. In the light of the competition with British influence, many of these ambivalences faded to the background, and according to some contemporary authors it was better for practical considerations to override grammatical principles in order to make Dutch a viable language in South Africa. Literature was also an important factor in the colonial question in other ways. Many English books about South Africa that were published during the second half of the nineteenth century were extremely negative about the two republics and argued that the Boers were not capable of responsible government. In the Netherlands, such publications were seen as harmful and several authors thought it necessary to put forward alternative views on South Africa to counter such allegations. On the other hand, texts by English-speaking writers with more positive ideas about the Boers were embraced and served as a source of inspiration. This shows that Dutch literary critics not only reflected on sources about South Africa that were written in their own language but also on those written in English.

\section{Dutch views on English Africana}

In many publications it was stressed that the development of Dutch influence in Southern Africa was not uncontested. In this sense, pro-Boer propaganda can be considered to be a direct reaction to what was seen as a British onslaught on the republics in the context of the expansion of their empire. One 
of the dangers was considered to be the ongoing media campaign by certain groups that wanted to discredit the Boers in Europe and legitimise expansionist policies in South Africa. One such group that was seen as an exponent of 'perfidious Albion' were British missionaries, particularly those from the London Missionary Society (LMS), who were active in the region from the first decade of the nineteenth century. Their leaders, which included Dr Phillip and Reverend Van der Kemp, accused the Boers of mistreating black people and using them as slaves. They sent such reports to the government in London, and these allegations reached the wider public via the humanitarian lobby groups based at Exeter Hall. These texts were also available in the Netherlands and contributed to the negative perception of Boers before I $880 .{ }^{\text {I } 25}$

After the Transvaal War, opinion on these sources changed dramatically, which was reflected in several publications by authors from different political currents such as P. J. Veth, Robert Fruin (both Liberals), Lion Cachet and Abraham Kuyper (both Protestants). ${ }^{\text {I26 }}$ These men accused British missionaries of tarnishing the Boers' reputation with false stories about cruelties committed against black people. In this connection, one of the men who had a particularly bad reputation amongst Boer supporters in the Netherlands at the end of the nineteenth century was David Livingstone. Lion Cachet asserted that the legendary missionary/explorer, who died in I 873, had despised the Voortrekkers and had systematically spread lies about them, which to him showed how 'small a great man can be'. ${ }^{\text {I27 }}$ It was said that much of Livingstone's resentment was aroused during an expedition by a Transvaal commando against chief Setyeli ( 1852 ). He accused the Boers of plundering his home while he was absent, using Setyeli as an eyewitness. According to the Boers, however, it was Setyeli who had plundered the settlement and lied about it. After textual evidence became available that supported the Boers, Livingstone was posthumously scorned on this point in numerous Dutch publications. $^{\text {I } 28}$

In addition, certain British policymakers were seen to be acting out of Machiavellian motives. These men were accused of deliberately spreading untruths about the Boers in order to legitimise their plans for imperial expansion in Southern Africa. The archetype of this group was Theophilius Shepstone, the man who was considered to be the mastermind behind the annexation of the Transvaal in I 877 . One of the principal reasons for intervention that he mentioned to the government in London was that the republic was a failed state on the verge of collapse. He claimed that the Transvaal was about 
to be invaded by the Pedi 'tribe', who would destroy the white population living there. Several Dutch authors were of the opinion that Shepstone was well acquainted with the situation, which they thought to be far less dramatic, and that he had deliberately given an incorrect account so that he would get the go-ahead to proceed with the annexation. ${ }^{129}$

But even after the British occupation of the Transvaal had ended, it was noted how this 'sordid' and 'corrupt' diplomacy continued. Imperialists from the I 890 , including the likes of Cecil Rhodes, Alfred Milner and Joseph Chamberlain, were seen as the main protagonists of a plot to destroy the independent Boer republics and establish a South African federation under the aegis of the British. ${ }^{\mathrm{I}}{ }^{\circ}$ It was argued that these men influenced the press coverage of South Africa, and many people in the Netherlands thought that they wilfully manipulated the public in Britain in order to generate more support for their plans. The Rhodes conglomerate owned many influential newspapers, and Milner and Chamberlain were deeply involved in propagandist organisations like the Imperial South Africa Association (ISAA) and the South African League (SAL). In the Netherlands, the journalist Charles Boissevain was the most prolific author to write about the 'corruption' of the British press in South African affairs. It was a recurring theme in his commentaries in his newspaper Het Algemeen Handelsblad. ${ }^{\mathrm{I} 3 \mathrm{I}}$ In the run-up to the South African War and during it, he also wrote several pamphlets in English in which he expressed his hope that the British people would cast off the lies of the imperialist press and would pressure the government into a policy shift. ${ }^{\mathrm{I} 32}$

Notwithstanding these examples, it should not be forgotten that there was also genuine respect for British politics at the end of the nineteenth century. Prominent Dutch opinion makers, particularly of the Calvinist creed, admired the venerable statesman William Gladstone, who was seen as a strong leader and the embodiment of Christian morality in politics. ${ }^{133}$ Much of his popularity amongst pro-Boers seems to have been derived from his standpoints on the South African question, which was perceived as the antithesis of jingoism. During the famous Midlothian speeches in the run-up to the I 880 elections, he explicitly condemned the annexation of the Transvaal, and although initially he had been reluctant to give in to the demands of the Boer deputation when he became prime minister, it was thought by many that Gladstone ensured the rapid British retreat after the battle of Majuba Hill. ${ }^{\mathrm{I} 4}$

Likewise, there was much praise for authors who were against the annexation policy in the early I 88 os. Sometimes it was an isolated excerpt that was referred to, such as a passage from J. A. Froude's Oceana in which he asserted 
that the Afrikaners in the Cape were oppressed by the British at the beginning of the nineteenth century and that this was the reason for the Voortrekkers to leave the colony. ${ }^{\mathrm{I}} 35 \mathrm{On}$ the other hand, parts of the book in which Froude expressed the hope that the Boers would become loyal subjects of the British Crown, were not mentioned. ${ }^{36}$ Other authors such as the former editor of Natal Witness, Reginald Stratham, who wrote several books and many articles about South Africa, were appreciated for their entire oeuvre, in which they argued that the republics had a definite right to exist. ${ }^{\mathrm{I}} 37 \mathrm{He}$ and also the Liberal MP G. B. Clark, who wrote several pro-Boer pamphlets and acted as consul-general for the SAR in London between I 884 and I 892, kept in contact with Boer supporters in Europe during the years that followed, even during the South African War. ${ }^{\mathrm{I}}{ }^{8}$

Other British authors that opposed the imperialist policy in South Africa had a more problematic relationship with the pro-Boer movement. J. A. Hobson, for instance, certainly cannot be seen as an admirer of Kruger, and he even described Leyds as the 'evil genius' behind the polarisation between the Boers and the British. ${ }^{\mathrm{I}} 39$ Although Hobson's arguments concerning the jingoist conspiracy were widely known in the Netherlands, particularly through Boissevain's writings, no reference can be found to his criticism on the propaganda campaign by the republics, and it seems that the contact between the English journalist and pro-Boer organisations was limited. ${ }^{\text {I }}{ }^{\circ}$ William Stead was another publicist who openly took sides against the British politics of expansion in South Africa. Remarkably, he was a great admirer of Rhodes, but after the Jameson Raid he became radically opposed to the increasing pressure on the republics. In his eyes, the British element in South Africa would not be able to withstand the combined forces of a pan-Afrikaner movement, which shows that for him dominance of the Anglo-Saxon race remained the main goal. ${ }^{\mathrm{I}}{ }^{\mathrm{I}}$ Despite these considerations, he stood in close contact with several pro-Boer leaders such as Leyds and co-ordinated the translations of several Dutch pamphlets into English and vice versa. ${ }^{\mathrm{I}}{ }^{2}$ Looking at the contents of his writings it appears that Stead's protests were more vocal than Hobson's and that he did not shy away from populism, declaring 'War against the War'. This sensationalism made him controversial in Great Britain but popular in the Netherlands, where he was praised for his efforts to make his compatriots see the wrongs of the imperialist policy in South Africa. ${ }^{\text {I43 }}$ Decades later, he was still remembered in a Dutch textbook as 'the conscience of his people' during the South African War. ${ }^{\text {I } 44}$

The most influential English-speaking author for pro-Boers in the Nether- 
lands was the historian George McCall Theal (I837-I919). Theal was born in Canada and arrived in the Cape in I 859, where he had an adventurous career as journalist, teacher, diamond digger and finally administrator for the native affairs department. On his journeys throughout the colony, he studied the languages and habits of different black communities, about which he wrote his first books. ${ }^{\mathrm{I} 45}$ At the end of the $\mathrm{I} 870$ s, he became increasingly interested in the archives in Cape Town. Meanwhile, Theal started writing on the history of South Africa, which resulted in a huge oeuvre. ${ }^{146}$ The History of South Africa is known as his magnum opus, which he continuously revised from the late I 88 os to his death. ${ }^{147}$ During the I 890 , he was known as the most prominent historian in South Africa, and as such, Rhodes provided him with funds to do research in European archives to find material about the colonial history of South Africa. ${ }^{148}$ Despite these close connections with the Cape administration, Theal himself claimed that he was an 'objective' historian because, as an outsider, he only rendered a factual account. ${ }^{\text {I49 }}$

Christopher Saunders has argued that Theal's views on South Africa are nonetheless characterised by a clear narrative, which is the racial superiority of white settlers over the black majority. Theal called for harmony between the colonists in Africa, both of Dutch and British descent, to face the black menace threatening them. ${ }^{\mathrm{I}}{ }^{\circ} \mathrm{He}$ was also against metropolitan meddling by both the imperial government and humanitarians who, in his eyes, threatened the unity of the two 'white races' in their policies. Despite Theal's explicit criticism of British imperial expansion and his pro-Dutch views, he himself cannot be considered to be an Afrikaner historian, according to Saunders. ${ }^{15 \mathrm{I}}$ This did not prevent his work from being appropriated by contemporary proBoers, however. In the I930s, the Afrikaner Izaak Bosman wrote a doctoral thesis about Theal at the University of Amsterdam, which still reflected many of these ideas. Bosman argued that the historian had much sympathy for the Afrikaner people and their lifestyle. ${ }^{\mathrm{I} 52}$ In addition, Theal took their side on the important issue of relations between black and white and argued that segregation was better than pretentious and naïve theories about the equality of races, as advocated by British policymakers. ${ }^{\mathrm{I} 33}$ The combination of Theal's descent, his thorough knowledge of South Africa and apparent pro-Boer views made his work an ideal source for the propagandists of stamverwantschap in the Netherlands because it lent their arguments scholarly weight and an aura of objectivity. In many Dutch publications about the history of South Africa, his books were mentioned as the most authoritative publications available on this topic. ${ }^{\mathrm{I}} 54$ Theal was even asked by the NZAV to 
write a textbook about South African history that could be used in Transvaal schools, but the historian declined because he was too busy. ${ }^{\mathrm{I}} 55$

Just as the image of the Boers in Dutch publications was not univocal, nor was there a monolithic view on British involvement in South Africa. Certain groups such as missionaries and statesmen were seen as agents of imperialism who deliberately slandered the Boers in order to legitimise their expansionist plans. Nonetheless, there was also genuine appreciation for those who were considered to be adversaries of such ruthless empire-building and who showed respect for the territorial integrity of the republics. Theal's work in particular became influential amongst Dutch-speaking authors, both in South Africa and in the Netherlands. His research contributed to the creation of a vision on the colonial past in which the 'race issue' was considered the dominant leitmotiv. In pro-Boer literature, two themes from this history were highlighted: firstly the so-called 'native' question, and secondly the increasing pressure by the British Empire on the republics. The depiction of these two issues, which were intertwined in the view of contemporaries, will be discussed on the remaining pages of this chapter.

\section{The 'native' question}

The British takeover of the Cape in I 806 was considered to be the beginning of the struggle for dominance in South Africa. Dutch authors did not deny that there were tensions between the Dutch East India Company and the Afrikaner colonists, but the new British rulers, it was argued, were far more intrusive. ${ }^{56}$ In general, the main point of rupture between the two white groups in the Cape was considered to be the 'native' question, or how to treat black subjects. In this view, the Afrikaners considered themselves to be inherently superior to the indigenous inhabitants of the Cape, the Hottentots (Khoikhoi), who were seen as exceptionally backward creatures. Although they were considered to be a little more developed, the Bantus of the interior were also depicted as uncivilised children. It was argued that the colonists' view was based on centuries of experience in South Africa and had been reinforced during conflicts that had taken place during the Great Trek. Feelings of white racial superiority were therefore considered to be of fundamental importance to both Afrikaner nationalists in the Cape and the Boers in the republics. ${ }^{\text {I5 }}$

It was mentioned how the British, by contrast, had less consistent attitudes towards the black population. On the one hand, groups such as the LMS 
preached equality between the races and managed to persuade the government in London to implement legislation that provided Hottentots with the same political rights as white people. ${ }^{158}$ At the same time, the imperial hunger for land resulted in great conflicts between the British and black 'tribes' living on the borders of the empire. ${ }^{159}$

Authors in the Netherlands believed that Boer attitudes towards black people were the most sensible. In addition, Theal, who wrote much about ethnography, expressed his scepticism about the idea that black people could develop rapidly. ${ }^{160}$ Several authors were therefore of the opinion that the seemingly backward Boers had modern ideas about the 'native' question that were backed by scientific evidence and more effective than the hypocritical 'love for negroes' of British humanitarians. ${ }^{\text {16I }}$ This attitude of racial superiority, based on historical experience and what was thought to be common sense, made Afrikaners the most suitable colonisers in the eyes of pro-Boers in the Netherlands. Some of them even considered them to be a race of white 'aristocrats'. ${ }^{\mathrm{I} 2}$

To contemporary writers, the nineteenth-century history of South Africa revealed that the differences of opinion on the 'native' question had become the most important rupture point between the Afrikaners and the British after the transfer of power in I806. In many ways, the new administration favoured black people over the white population, it was argued. One notorious incident took place in I 8 I 5 when an Afrikaner was put on trial after he had flogged his black servants in the Graaff-Reinet region. The local white population there was already disgruntled with the British regime, and this indictment led to a revolt. Lion Cachet and Theal wrote that this escalation was partly the work of some local hotheads, but both condemned the brutal response by the British authorities. Five rebels were condemned to death at Slachtersnek, and when the gallows from which they were hanged collapsed, they did not receive mercy even though the attending crowd considered it to be a sign that God did not want the execution to happen. ${ }^{163}$

In the decades that followed, tensions rose in the outlying regions of the Cape, where black 'tribes' such as the Xhosa attacked farms of Afrikaner settlers. Initially, the British undertook expeditions to restore order, but under pressure from the missionary lobby, such expeditions were ceased. At the same time, Afrikaners complained that after their disarmament they could not defend themselves against gangs who stole cattle, destroyed farms and killed farmers. ${ }^{164}$ For many, the abolition of slavery throughout the British Empire in I 834 was the last straw. In principle, the pro-Boer authors were 
not so much against this measure, emphasising that it was supported by the Afrikaners, who even proposed plans for gradual abolition. What they did condemn was the rash way in which it was implemented by the administration, so that farmers did not get a chance to secure enough labour. Moreover, the system for financial compensation was inadequate, and the Afrikaners complained that they only received a fraction of the sum they were entitled to. ${ }^{165}$ In pro-Boer literature, it was asserted that these factors caused the Afrikaners to leave the Cape and embark on the Great Trek in I836. Lion Cachet added another reason:

the sixth sense of the Boers. [...] But with the conviction, conscious or unconscious: We Afrikaners must trek, so that Africa can be civilised and the heathen nations won for Christianity: if we do not trek, South Africa will not become civilised. ${ }^{\text {I } 66}$

The Voortrekkers went north and east, looking for places to settle. At the beginning of the century the Zulus and Matabeles had invaded these lands, conquering the local population and killing scores of people. In the eyes of late nineteenth-century authors, the upheaval during the Mfecane lent legitimacy to the Boers occupying the land. It was argued that they had been in South Africa longer than the black newcomers who had invaded from the north. Moreover, much of the land had been depopulated and was there for the taking, because it was considered to be unoccupied. Finally, many of those who had been conquered were said to have asked the Boers to chase away the cruel kings that oppressed them. ${ }^{167}$ Nonetheless, the advent of the Boers in these lands resulted in violent confrontations with the Zulus and Matabeles. In descriptions of these wars, their leaders, Dingane and Moselekatse, were portrayed as cruel and cunning men who wanted to obliterate their white opponents. The most notorious incident was the so-called 'treason' of the Zulus in Natal, where a deputation of the Boers was killed during a ritual dance in I 838 . This was followed by attacks on laagers, during which women and children were not spared. Many publications described with much gusto how the Boers regrouped and sent out an expedition that wiped out the Zulu army at the battle of Blood River. ${ }^{\mathrm{I} 68}$ Likewise, Moselekatse and his men were also defeated on the battlefield and retreated northwards.

Pro-Boer authors who wrote about these wars believed that such violence was legitimate and that the Voortrekkers had won the land fairly, paying for it with their own blood and that of their loved ones. Eventually, the Boers set- 
tled in the interior, where they founded the Transvaal and the ofs, which were officially recognised by the British in the treaties of Zandrivier (I 852 ) and Bloemfontein (I 854). In these documents, the 'native' question featured prominently. The Boers promised that they would not allow slavery in their republics, while the British promised not to interfere in black and white relations north of the Orange River, including a ban on the arms trade. Despite these conventions, the British were repeatedly accused of meddling in the conflicts that took place between the Boers and surrounding 'tribes'. Cape administrators were blamed for siding with black chiefs in land disputes if it benefited them. ${ }^{169}$ Moreover, the British were accused of using black troops during several armed confrontations with the Boers, and the governments of the republics complained repeatedly about the supply of firearms to black people. ${ }^{170}$ This latter point in particular was considered to be a scandal because it caused white rule in the region to be threatened. Spruyt described how black people in South Africa were as 'numerous as the sand of the sea and fertile as rabbits', and he was afraid that they would engulf and destroy colonial settlements if they had the chance. ${ }^{\mathrm{I} 7 \mathrm{I}}$

At the end of the nineteenth century, the history of the 'native' question was also used to defend the Boers against ongoing accusations of cruelty against the black population of the republics. It was often emphasised that there was no slavery in the Transvaal, as was suggested in many English texts about South Africa. ${ }^{172}$ Also the numerous expeditions that were undertaken by the Boers against surrounding 'tribes' were perfectly justifiable, according to Dutch authors, because the republics had every right to defend their territorial integrity. Moreover, these wars were of a limited scale, only meant to punish warmongering kings in order to prevent conflicts in the future. ${ }^{173}$ This was contrasted with the British expeditions of that time, which were portrayed as being the result of a ruthless desire for expansion. This led to enormous bloodbaths, such as during the Zulu War ( I 879) and the First Matabele War (I 893). The latter conflict in particular, conducted by Rhodes's B SAC under the command of the infamous L. S. Jameson, became known for the excessive use of violence, and some Dutch observers even saw it as a 'war of extermination'. ${ }^{774}$

In addition, it was stressed how the effects of the Boer policy of segregation had been beneficial for both whites and blacks. Travellers noted how well-behaved black people in the republics were compared to those in the British colonies. This was considered of paramount importance, given the mobilisation of labour. Muller wrote extensively about what he thought to be the in- 
nate laziness of black people, which made strict discipline from their white masters a necessity. ${ }^{175}$ Another threat to social order was considered to be the insatiable sexuality of black people. Authors generally emphasised that Afrikaners, both in the Cape and the republics, condemned all intimacy with people with a different skin colour. European settlers who recently arrived in Africa were considered to be much more lax in their morals. As a result, a breed of half-castes came into being in the Cape who were seen as pitiful creatures, caught between civilisation and barbarity. ${ }^{176}$ For contemporaries, a more threatening aspect of this kind of frivolity was that black people in the British territories became unruly. Wormser described the rape of white women by black men, which in his eyes was an abhorrence, as the 'curse of Natal'. ${ }^{\text {I77 }}$

In the depiction of the history of the 'native' question, late nineteenth-century Dutch authors clearly juxtaposed the ways in which the British and the Boers dealt with the issue. The former were accused of hypocrisy and inconsistency, which was due to their lust for expansion, it was argued. Depending on their own short-term interests, they were either too soft or too harsh towards the black population, which led to social disorder and terrible bloodbaths respectively. By contrast, at the end of the nineteenth century, the Boers were generally praised for their strict but just treatment of black people. Their strong belief in white superiority, it was argued, constituted the reason why they had left the Cape and founded their own republics. To contemporaries, this view on the 'native' question legitimised the existence of an independent Dutch entity in the region, because the Boers had done more to promote 'civilisation' than their rivals. At the end of the nineteenth century, however, British imperialists tried to undermine the republics in order to expand their sphere of influence. During the I880s and I890s, Dutch contemporaries were increasingly alarmed by this menace and tried to expose it in their publications.

\section{The Uitlander question}

A recurring theme in pro-Boer literature was the host of political and legal tricks employed by British statesmen to expand their control over the Boers. The annexation of Natal (I 842) and the Kimberley diamond fields ( 1872 ) were seen as early examples, but the most flagrant incursion was considered to be the annexation of the Transvaal ( 1877 ). In the two most authoritative Dutch accounts of this episode, by Lion Cachet and Jorissen, it was empha- 
sised that the British reasons for annexation were false and that Shepstone had manipulated President Burgers. ${ }^{178}$ Initially the Boers, under the leadership of Kruger and Joubert, tried to restore independence through negotiations, which the two authors interpreted differently. Jorissen thought that the people of the Transvaal were not unified enough to muster armed opposition against the British. ${ }^{179}$ Lion Cachet saw the reluctance to fight as a typical characteristic of the Boer lifestyle. According to him, they were forced by the British to take up arms for the cause of 'freedom and justice'. ${ }^{180}$ Nevertheless, both authors agreed that the arrogance of British statesmen led to the escalation of the conflict. Time after time, cunning diplomats like High Commissioner Bartle Frere dodged the demand for independence put forward by the Boers, believing they could easily outwit the simple people of the Transvaal. ${ }^{\mathrm{I} 8 \mathrm{I}}$ In the eyes of the pro-Boers, the war of I 880 - I $88 \mathrm{I}$ proved that British arrogance was inappropriate. The famous battle at Majuba Hill, where a small commando repelled the British army, was considered a prime example of this. Lion Cachet (and many others with him) thought that it showed that the Boers were not inferior to the British in any way. ${ }^{182}$

After Majuba, the Gladstone government decided to cease hostilities and to restore a form of independence in the SAR. In the peace treaty of I $88 \mathrm{I}$, this was called 'suzerainty', which meant that the British claimed a form of paramount authority over the republic as well as the right to intervene in foreign and 'native' affairs. In I884, the treaty was revised and although the word suzerainty was not removed from the text, the possibilities for interfering in the SAR administration were scaled back. This compromise led to tensions in the following decades, however. Jorissen, who was a prominent negotiator in I 88I, was quite sceptical about the role of Transvalers in this matter, and he did not think they cared much about the exact meaning of the treaties. ${ }^{183}$ By contrast, other specialists on the Dutch side such as professor of international law J. de Louter argued that the SAR had regained full independence with the I 884 convention. ${ }^{\mathrm{I}} 84$

Nevertheless, in the run-up to the South African War, the Salisbury government, in the person of Joseph Chamberlain, asserted that Britain still had a form of suzerainty over the Transvaal. In the eyes of Dutch contemporaries, the renewed interest of the British in the SAR was linked to the discovery of vast gold deposits on its territory in I 886. This further aroused the greed of the imperialists, so it was thought, and British capitalists and statesmen tried everything they could to gain control over the mines. One particular threat caused by the gold boom was perceived to be the huge influx of white immi- 
grants who came to the mines, the majority of whom were of British descent: these were the so-called Uitlanders. Johannesburg, a town that was founded to accommodate miners, became a symbol of this menace. It was described as a den of iniquity, where vices such as prostitution and alcohol abuse were widespread. The Boer government, however, was applauded for doing a good job of isolating these depravities so that the population outside Johannesburg would not be affected. ${ }^{185}$ But there were graver problems with this group of foreigners. Although he travelled in the SAR barely two years after the discovery of gold, Muller already noted how the Uitlanders were dangerous because they had come to the SAR in great numbers and so threatened to outnumber the Boer population, which would make them politically dominant. This meant that the SAR's hard-won independence was at stake, because it was likely that the Uitlander leaders would forge close ties with the British colonies. ${ }^{186}$

The SAR government therefore undertook measures to restrict the political influence of immigrants by extending the period before which they were allowed full citizens' rights, including the vote, from two to fourteen years. To compensate for this, a toothless second chamber was installed in the Volksraad that was reserved for Uitlanders. These measures, in addition to the secondary status of the English language in schools and the existence of state monopolies, gave rise to grievances that were expressed by leading Uitlanders, united as the Reform Committee. The Dutch language press in the SAR severely criticised this group, and similar opinions were expressed in proBoer literature in the Netherlands. ${ }^{187}$ Generally, Dutch observers thought that the Kruger government did a good job of managing the rapid modernisation of the Transvaal and thought it legitimate to limit British influence. ${ }^{\mathrm{I} 88} \mathrm{It}$ was also asserted that the Reform Committee did not represent the general Uitlander population, who only came to the SAR to make money and did not care about whether they were ruled by the Boers or the British. ${ }^{189}$ In addition, the Uitlander leaders were accused of manipulating the press and forging petitions to create the impression that their viewpoints were widely supported. ${ }^{190}$ This sort of agitation was considered to be a serious danger because it increased the division between the British and Dutch elements in South Africa, and authors even argued that these feelings were a form of 'racial hatred'. ${ }^{\text {99 }}$

In addition to these internal troubles, a second threat lurked outside the borders of the republics: Cecil Rhodes. This man was considered to be the embodiment of imperialism, combining high capitalism with a sense of supe- 
riority of the British race. Several Dutch authors admired him and his energetic efforts to dominate Southern Africa. He tried to achieve this not only through the relentless amalgamation of mining companies and territorial expansion but also by spreading English culture through institutions like the University of Cape Town. ${ }^{192}$ Others were more cynical and described Rhodes as a wolf in sheep's clothing and 'the Napoleon of South Africa'. ${ }^{193}$ Despite these differences in tone, observers agreed that Rhodes's rampant expansionism was a threat to Boer independence and hoped that the republics, particularly the Transvaal, would be able to stop this onslaught. In this sense, Kruger was described as the antithesis of the Rhodes doctrine. ${ }^{194}$

Many authors thought that the stubborn Boer resistance forced Rhodes to adopt more radical measures. The most notorious example became the Jameson Raid, an invasion of 600 Rhodesian police officers, which was supposed to trigger a revolt amongst the Uitlanders in Johannesburg. The expedition ended in failure when the column was intercepted by a Boer commando and surrendered on New Year's Day of I 896. In the Netherlands, the 'invasion by Buccaneers of the Transvaal' was seen as a confirmation of the unscrupulous methods of the British to gain dominance in the region. Although there was no hard evidence for it, Rhodes was widely regarded as the main instigator of this plot. ${ }^{195}$ At the same time, the swift and decisive response of the Boers was praised as a great victory that renewed trust in the Transvaalers and their ability to defend themselves. The aftermath of the raid was considered to be even more typical. As a show of good faith, Kruger extradited Jameson and his men to Great Britain to be tried there. Even the Uitlander leaders, guilty of high treason, were let off with light sentences. Several commentators in the Netherlands thought this to be a prime example of the kindheartedness of the Boers. ${ }^{196}$ By contrast, they described the British attitude in this matter as utterly corrupt and petty. Jameson did face trial but received a light sentence and was released soon after, which for many was a sign that his actions were widely approved in Britain. Moreover, the results of a parliamentary inquiry into the role of Rhodes in the matter were swept under the carpet, which gave rise to the speculation that not only he but also senior members of government such as Chamberlain had been involved in the conspiracy. ${ }^{197}$

The Jameson Raid further deepened the crisis between the British and the Boers. The Kruger government started preparing for large-scale war, importing vast quantities of arms and ammunition. Also, ties between the SAR and the ofs were strengthened, and President Steyn pledged to help the Transvaalers in times of need. Even the Afrikaners in the Cape seemed to be better 
disposed towards the republics. Engelenburg saw this as a positive development. If the Dutch element in South Africa were to unite, he argued in an article that appeared in the Netherlands shortly after the Jameson Raid, surely they could withstand the British Empire. ${ }^{198}$ Meanwhile, it was noted with great concern how the British imperial elites continued their machinations. In South Africa, Rhodes was forced into the background after the defeat of Jameson, but he was soon replaced by others. The most prominent of these was Alfred Milner, who became high commissioner in the Cape in I 897. He took up the Uitlander grievances and with the help of journalists in Johannesburg, communicated these grievances to Britain via the press in order to mobilise public support for a possible war with the Boers. Likewise, Chamberlain continued his campaign. Boissevain considered the death of Gladstone in I 898 to be symbolic, as the British public was captured by a hysterical form of jingoism at the same time. ${ }^{199}$ Many authors in the Netherlands were therefore not surprised when war started in October I 899; indeed, they had been writing about the antagonism between the 'two white races' in South Africa for nearly two decades.

\section{Conclusion}

On the previous pages, it has been shown how information about the South African question was appropriated in Dutch literature at the end of the nineteenth century. It is important to remember that there were different sources available, written by different groups of authors. To begin with, there were the accounts of emigrants and travellers from the Netherlands who wrote about their personal experiences in South Africa. There were also authors who had never set foot there but were closely connected with the information channels that had been set up from the I880s onwards. Although in hindsight their opinions might seem inauthentic, such authors played a significant role in the knowledge formation about and popularisation of South Africa in the Netherlands. In addition, not all sources were written in the same language. Writings in early forms of Afrikaans were available in the Netherlands and seriously discussed, but these linguistic experiments were not uncontroversial. In addition, publications about South Africa in English were also known. The majority of works in this latter category were rejected as 'slander' that was aimed at discrediting the Boer cause and supporting British expansion. There were, however, also authors writing in English who openly supported the republics. Their work, and particularly that of the historian 
George McCall Theal, was welcomed by Dutch authors as an 'objective' analysis of the situation in South Africa and as such became quite influential.

Just as the range of sources varied considerably, their contents were heterogeneous as well. Although 'kinship' between the Boers and people from the Netherlands was a prevalent theme on the pages of many Dutch publications after the Transvaal War, differences between them were mentioned explicitly, which indicates that there were clear ambivalences. On the one hand, there was admiration for the simple lifestyle of the Boers in the republics but on the other hand, they were considered to be ill equipped to face the challenges of the modern world. However, such ambiguities largely fell away when looking at the overall picture of South Africa and the question of which 'white race' should become the dominant colonial power in the region. To contemporaries, language and cultural heritage were of vital importance in this connection. Although there were different opinions as to how to achieve this, it was considered imperative that the Dutch language in South Africa be strengthened in order to withstand the rising influence of English and to retain the independence of the Boer republics. But literary products were considered of interest for other reasons, too. During the I 880 os and I890s, a vision on South African history emerged that served to lend legitimacy to the existence of an independent Dutch entity in that region and to oppose British imperialist expansion. The Boers were portrayed as heroic and gallant pioneers who brought European 'civilisation' to the interior of Africa and subdued the black majority there in order to 'develop' the region. By contrast, the British were depicted as arrogant, selfish empire-builders, who cared about nothing other than their own interests and who achieved their goals by whatever means necessary.

This shows how the literary depiction of South Africa did not stand on its own but was related to the political situation in the region. Dutch contemporaries believed their rendering of the colonial past was an effective weapon for defending the independence of the Boer republics. The lines of communication between the Netherlands and South Africa were vital in this exchange. Much material became available to the Dutch public about the republics and their history. And on the other side, publishing houses from the Netherlands established branches in South Africa in order to circulate their publications so that the Boers, who had a limited cultural infrastructure, could take advantage of them. The views on the colonial question, although biased, were therefore not merely the product of overenthusiastic Dutch nationalists who projected their ideals onto the wider world but should rather be seen in the con- 
text of modern imperialism. The connection with the writings of British authors added another complicating factor, because the way in which these were valued depended on how they commented on the situation in South Africa. Critical remarks in Dutch sources therefore cannot simply be interpreted as the result of chauvinistic anti-English sentiments.

It has been argued in the past two chapters that, from the very beginning, propaganda was the most important feature of the pro-Boer movement in the Netherlands because it was considered by contemporaries to be an important instrument in shaping the colonial future of South Africa. When tensions arose during the I 890 s, such questions became more urgent and Dutch commentators felt that they had to speak out against the increasing pressure by the British Empire on the Boer republics. When war started in I899, it was seen as a direct result of the antagonism between the Boers and the British that had been present for almost a century and which had been the subject of studies from the I880s onwards. In many ways, the propaganda campaign during the South African War, which will be discussed in the next four chapters, showed a clear continuity with the depiction of the colonial past that had emerged in the previous period. 

PART II

War of words (I 899-I902) 



\section{A 'factory of lies'? The lines of communication of the Boers and their supporters}

In the early evening of 4 April I900, a train carrying the Prince of Wales arrived in Brussels. At the station, a young man jumped on the footboard of the prince's car and using a revolver fired two shots into it before he was arrested. Nobody was hurt. The next day, The Times reported that the assailant had declared that 'he wanted to kill the Prince of Wales because his Royal Highness had caused thousands of men to be slaughtered in South Africa'. The editors therefore argued that the attack was incited by the pro-Boer propaganda campaign on the continent, which was at its height at the time. Other opinion makers too pointed out that the office of the minister plenipotentiary of Transvaal, Willem Leyds, was located in Brussels and suggested that he was directly involved in the assassination attempt. One of the most outspoken accusations came from the Secretary for India, Lord George Hamilton, who addressed his constituents in Acton when the news became known. He said that 'if they had to seek for a reason for that foul attempt on the life of the heir-apparent they would recollect that Brussels had been the headquarters of that factory of lies of which Dr Leyds was the manager' ${ }^{\text {I }}$

Historians today assert that propaganda was an important aspect of the South African War, which was undoubtedly a 'media war'. ${ }^{2}$ Significantly, contemporaries were well aware of this, as is shown by the reactions to the incident cited above. Sympathisers of both sides continuously accused each other of manipulations that gave a distorted view of the events taking place in South Africa in order to corrupt public opinion. In this respect, supporters of the Boers were no less outspoken than Lord Hamilton. In a reaction to his accusations, Leyds sent a telegram in which he described this speech as 'new proof that during the present war people in England do not shrink from any means, not even the most perfidious slander, nor the most flagrant lie'. ${ }^{3}$ On another occasion, the Dutch journalist Charles Boissevain took offence when the Duke of Devonshire stated that Leyds had bribed the European press. Although he did not deny that he had much sympathy for the Boers, Boissevain 
argued that this was the result of genuine indignation at an unjust war. Instead, he accused the influential London dailies - and The Times in particular - of working together with the British government to turn the public against the Boers in order to legitimise the conflict. '[T]his war is their war,' he declared, 'This war is a newspaper war'. ${ }^{4}$

The remarks of Leyds and Boissevain show that pro-Boers on the continent were deeply concerned about the official British coverage of the conflict in South Africa. As a result, they avidly tried to provide an alternative. This can be considered to be their most important and successful activity. ${ }^{5}$ In fact, Leyds and other agitators managed to gather a large amount of material that was omitted by the British press, much of which was published in a wide range of genres. In this way, pro-Boer coverage of the war was disseminated throughout Europe and was received with great interest and enthusiasm by the public. Although pro-Boer authors legimitised their work by saying that they wanted to reveal 'the truth' about the war, it should be seen as a conscious attempt to spread a particular set of views on the war and its causes, and as such, it was nothing less than an orchestrated propaganda campaign. There remains, however, the question of how effective this actually was. Leyds anticipated that the British government would yield to public pressure from inside and outside Great Britain and halt the war, but that did not happen. ${ }^{6}$ It is therefore doubtful that his activities were of a truly 'industrial' scale, as the jibe by Lord Hamilton about the 'factory of lies' suggests. The assessment of the pro-Boer propaganda campaign must take into account the organisation of the bridgehead between South Africa and the Netherlands, which, as has been argued in chapter one, was an informal network rather than a solid system of information provision.

This chapter aims to investigate the lines of communication between the Boer republics and Europe during the South African War. The main questions will be how information supporting the Boer cause was transferred and which groups of people were involved in this. One remarkable feature of this network was the prominence of so-called Hollanders. Dutch emigrants had held influential positions in the state institutions of the Boer republics, and the Transvaal in particular, before the war. This was also the case with the diplomatic service, which under Leyds - the most famous of Kruger's Hollanders - assumed a central role in the co-ordination of the propaganda campaign. Aside from the diplomatic network, non-officials actively took part in the efforts to generate as much pro-Boer material as possible. During the war, thousands of Dutch-speaking people left South Africa, either as deportees or 
as refugees. A significant number of them ended up in the Netherlands, where many became involved in pro-Boer activities. Private letters from the war zone containing information about the situation there also arrived throughout the conflict. In this way, pro-Boers in Europe had a significant amount of information at their disposal, which fed into the propaganda campaign.

There were, however, serious hindrances. First and foremost, the neutral position of the Netherlands limited the freedom of officials to take sides in the conflict. Leyds respected this principle and was in close contact with prominent politicians in the Netherlands, several of whom he knew personally. He and several prominent Dutch pro-Boers were involved in clandestine ventures such as the recruitment of military volunteers for the republics, but these activities were kept out of the public eye so that the government would not be compromised. Aside from the political limitations on the pro-Boers, there were also financial limitations. The governments of the republics, particularly the one in the Transvaal, did make money available for their representatives in Europe to sustain the propaganda campaign. But, although some British opinion makers accused the Boers of smuggling out huge amounts of gold, the funds of the SAR legation were not infinite. Such limits become clear when compared to the huge sums that had been invested in the British lines of communication, which were under the patronage of both the government and big business. The most remarkable difference in this sense was the British monopoly on the telegraph lines running between South Africa and Europe, which meant that their news reached Europe first. Even more humiliating to the Dutch was the fact that the British prohibited the transmission of coded messages from the Dutch East Indies, which also had to pass through the imperial network. ${ }^{7}$

Apart from the problems arising from the relatively informal organisation of the European pro-Boer propaganda campaign and the Dutch lines of communication, the most severe obstacles came from developments that took place in South Africa. ${ }^{8}$ During the first phase of the conflict, things looked rather good for the Boers when they took the initiative with the invasion of Natal and the Northern Cape in October I 899. Although they did not push very far into British territory, their position initially seemed to be solid as the imperial armies under the command of Redvers Buller were reversed on several occasions between December I 899 and February I900. On the Boer side, it was hoped that these victories would have the same effect as the battle of Majuba Hill in I88I, which had forced the government in London to back down. The British did not retreat, however, and instead reinforced their army 
under the command of Buller's successors Frederick Roberts and Herbert Kitchener. The superior numbers of soldiers and arms forced a breakthrough, and the so-called British 'steamroller' advanced rapidly. On I 3 March I900, Bloemfontein was occupied by Roberts's columns, with Pretoria following on 5 June. By September, the complete territory of the republics was occupied and the British commander issued proclamations that announced that the OFS and the SAR - henceforward to be known as the Orange River Colony and the Transvaal respectively - had been annexed by the British Empire.

Despite these formal declarations, hostilities continued. The Boer forces were scattered and forced to flee into the fields in which they roamed around in small bands for the remainder of the war. Their leaders tried to make the best of this situation, devising a new strategy of hit and run, which led to a guerrilla-type war that would last for almost two more years. The British counter strategy, harshly implemented by Kitchener who took over command from Roberts, was to wear out the commandos left in the field. Huge 'drives' were organised during which the British force, consisting of tens of thousands of soldiers, pursued approximately I 5 , ,00 so-called Bittereinders, who refused to surrender. To restrict the movement of the commandos, a network of fences and blockhouses was set up in the countryside. Boer combatants who were captured were deported to prison camps overseas: on St. Helena, Bermuda, Ceylon and the Indian subcontinent. In addition to these drastic measures, the civilian population increasingly suffered. To cut off supplies to the Boer forces, farms were burned down, cattle slaughtered and civilians interned under dire conditions in concentration camps throughout South Africa.

These developments had serious consequences for the lines of communication between the Netherlands and South Africa because the British gained more control over them and imposed strict censorship. ${ }^{9}$ One of their priorities was to cut off the Boers' network, something which was already apparent at the start of the war when the telegraph lines, all of which passed British stations in either Cape Town or Aden, were censored. None of the official cables from the Boer republics to the outside world were transmitted, except the lists of casualties, and even those were only allowed through after much pressure from Leyds. ${ }^{10}$ Other means of communication came under increasing pressure, too. The independent mail service of the SAR, which was provided by the NZASM and a German shipping company via Delagoa Bay, was disrupted when the British began their advance in I900. After Pretoria was captured, the new authorities censored the mail services, commandeered the rail- 
way line to Mozambique and put the press under close surveillance. Moreover, the British army command ordered the deportation of all individuals who were not born in South Africa and who might have posed a threat to the occupation. This led to the expulsion of many Hollanders from the Transvaal, particularly those affiliated to the NZASM. ${ }^{\text {I }}$

Naturally, this was a great blow to the Boers' lines of communication. An unintended result of these measures was, however, that many of the people who were repatriated became involved in the pro-Boer propaganda campaign in Europe. Prominent members of the Pretoria elites headed organisations that mobilised help for their compatriots. In addition, their stories and those of other refugees from South Africa were published at length in the press, thereby drawing attention to British cruelty. Moreover, letters with useful information for the pro-Boer propagandists continued to reach the Netherlands via regular mail throughout the war. And at times even the Boer commandos in the field, although they were increasingly isolated, succeeded in exchanging letters and reports with their representatives in Europe. In this way, pro-Boers in the Netherlands gathered a significant amount of information that provided an alternative to the representation of the war that was put forward by official British sources and pro-war lobby groups. Analogous with the situation in South Africa, it can be said that, like the commandos in the field, pro-Boers in Europe had fewer means at their disposal than their adversaries but nonetheless quite successfully developed a guerrilla style of propaganda. In this way, they were able to provide alternatives to the British coverage of the war and create dramatic images that had strong appeal to contemporaries.

\section{Boer diplomats}

Leyds's legation in Brussels developed into the most important centre for proBoer agitation in continental Europe. In addition to his diplomatic duties, the minister plenipotentiary actively tried to influence the press and public opinion before the war in order to put pressure on the governments of the great powers to intervene on behalf of the republics and prevent war from breaking out. However, during the growing crisis of 1899 , he made it clear to the SAR government that, despite the widespread sympathy for the Boers, no official steps to prevent war could be expected and that none of the European nations were prepared to get involved in any conflict. ${ }^{\mathrm{I} 2}$ Nevertheless, throughout the war and thereafter, Leyds kept emphasising the importance of inform- 
ing the public on the war from a Boer perspective and of refuting the British depiction of events taking place in South Africa. In other words, propaganda remained the main priority of the SAR legation. ${ }^{\mathrm{I} 3}$ When the war started, its office became inundated with a huge amount of paperwork because initiatives were taken all over in Europe to relieve the needs of the Boer population. In this way, the propagandistic tidal wave was both a blessing and a curse to Leyds. On the one hand, his legation performed important tasks, gathering and distributing material on the plight of the Boers, something that was in great demand. On the other hand, there were great logistical problems, which show that the campaign did not always run as smoothly as Leyds intended.

The consuls of the SAR proved to be a valuable network for obtaining information from different countries, influencing opinion makers and co-ordinating activities. Arguably the most important post was the one in Lourenço Marques, occupied by Gerard (also known as George) Pott, who was simultaneously consul-general for the Netherlands, the SAR and the OFs. Being relatively close to the war zone, he was a vital link in the lines of communication between the Boer republics and Europe, handling everything from letters to contraband and helping both refugees on their way out and adventurers on their way into South Africa. These activities made the consul-general's position there increasingly difficult, as the Portuguese authorities were afraid to get into trouble with the British. Pott was therefore summoned to leave Mozambique at the end of 1900. ${ }^{14}$ This was a great blow for the Boer representatives in Europe, severely hampering their communication with the people in South Africa. In I90 I, Leyds did send one of his agents, Bas Veth, to Delagoa Bay in order to investigate the possibilities of establishing a secret route into South Africa. Veth was not able to set up anything that could replace Pott's activities, however. ${ }^{15}$

In Europe, one of the most important SAR representatives was Johannes Pierson, consul-general in Paris between I 896 and I902. He had roots in the Netherlands and was a nephew of the Dutch First Minister N. G. Pierson, who had been one of Leyds's professors at university. ${ }^{16}$ In addition to his consular activities, Pierson was an active propagandist. He had close contact with French journalists and, together with Leyds's agent Edgar Roëls, released a huge number of press releases. ${ }^{17}$ Moreover, Pierson took upon himself the organisation of the SAR pavilion at the I900 World Exhibition in Paris, which was one of the biggest showcases for pro-Boer agitation. Thousands of people from all across Europe visited the Transvaal exhibition to pay 
homage to the embattled republics and the heroic Boers who fought for their freedom. ${ }^{\mathrm{I} 8}$

Another important SAR consulate was the one in London, run by Montagu White, a South African of British descent. ${ }^{19}$ Like the other SAR diplomats, his activities increased significantly in the run-up to the war. In particular, White maintained close contact with several journalists in Britain who were opposed to the war. His work was considered to be too dangerous after the war started, when mobs assaulted people they believed to be on the side of the Boers. ${ }^{20}$ In December I 899, it was therefore decided that White should go to the US. ${ }^{21}$ After the removal of the formal SAR consulate from London, Leyds remained in contact with anti-war activists such as William Stead and several Irish nationalists. $^{22}$ This correspondence was kept secret because of fears that there would be negative repercussions if the public were to find out about it. Stead even refused to accept a reimbursement for stamps in order to avoid the impression that his work was financed using secret funds from the Transvaal. ${ }^{23}$

In other countries, the situation was quite the opposite. In the Netherlands, SAR representatives did not have to work to change public opinion because the population was already on the side of the Boers. Leyds's agents there did do important work, though. R. A. I. Snethlage was consul-general in Amsterdam and acted as a co-ordinator for providing shelter and charity to the repatriates and refugees who arrived from South Africa. As will be shown later, the fate of these men and women stirred up much public anger and, as such, fed into the propaganda campaign. ${ }^{24}$ In Germany, there were several sar consuls but their relationship with the legation in Brussels seems to have been rather strained. ${ }^{25}$ Leyds did, however, correspond extensively with local pro-Boer agitators about the propaganda campaign there. ${ }^{26}$ In Russia, there was no official consular representation of the Transvaal, but in fact the Dutch Calvinist minister H. A. Gillot acted as the Boer representative in St. Petersburg. ${ }^{27}$

In addition to the substantial correspondence with various consuls and other semi-official representatives, the legation in Brussels was flooded with letters from individuals offering all sorts of aid, volunteering to fight for the Boers or giving unsolicited advice in the form of bold battle plans and extravagant inventions of new weaponry. ${ }^{28}$ Although many of these letters did not contain much that was of interest, Leyds gave his staff strict orders to reply to every single one of them because he did not want to run the risk of losing the goodwill of the public. ${ }^{29}$ As a result of this order, the legation office was in a constant state of chaos during the first months of the South African War. To help out, more than a dozen administrative assistants were employed, often 
for a few weeks only. This could not have been conducive to a consistent policy, and in addition there was a constant fear of spies. ${ }^{30}$

Permanent members of staff did not prove themselves to be very competent either. Already before the war started, Leyds made it clear that he was not satisfied with the work of his chargé d'affaires, C. van Boeschoten. He tried to persuade his old friend F. V. Engelenburg to come to Europe to take over the job, but the editor and owner of De Volksstem did not want to leave his newspaper at that time. ${ }^{3 \mathrm{I}}$ Also during the war, the minister plenipotentiary was troubled by doubts about the abilities of his staff. On a personal level, he liked the secretary of the legation (Lex Goldman) very much, but he was not very confident in his abilities to run the office properly. In one letter to his wife, Leyds complained about the sloppy handling of paperwork by his clerks. Although he had ideas about how these matters could be improved, Leyds himself was unable to implement them because he was constantly travelling around Europe throughout the war and spent little time at the office. 'With my constant moving around I look like the wandering Jew. The longer it goes on, the worse it gets.' 32

Aside from these administrative troubles, Leyds complained about the finances of the legation. This seems to have mainly been in response to accusations in the British press about the 'Kruger millions' - the huge quantities of gold alleged to have been secretly extracted from the Rand and smuggled to Europe in order to finance the Transvaal agitation against Britain. Leyds denied these stories vigorously throughout his life, and there is no historical evidence that backs up the stories about the secret gold deposits. ${ }^{33}$ Nevertheless, the legation had substantial funds at its disposal, although exact figures are unknown. In I898, the SAR government had actually forwarded Leyds a large sum, which was kept by the Labouchère and Oyens bank in Amsterdam. After the occupation of Pretoria, the British government put pressure on the bank to freeze these funds, which led to conflict with Leyds. After mediation by several influential Dutch lawyers, a settlement was reached and most of the money was put into German and French accounts. ${ }^{34}$ In June I900, Leyds was also authorised by the SAR government to sell off assets of the republic in Europe in order to finance his activities as he saw fit. 35 For a large part, these were stocks in the NZASM, which became practically worthless after the British seized the company's railway lines in August I900. Nonetheless, the French arms factory Creusot, obviously sympathetic to the Boer cause, accepted payments in stocks of the confiscated railway company. ${ }^{36}$ In addition to the official funds provided by the SAR government, 
individuals from all across Europe donated money to the SAR legation, which came to a sum of approximately fl. 64I,000.37

The increased funds of the SAR legation were quite necessary because expenditures rose considerably during the war, gobbling up a large portion of the extra money. Substantial sums were spent on ammunition and other supplies for the Boer forces in the field. These items were meant to be smuggled into South Africa via Delagoa Bay but despite great investments in modes of transport, including the purchase of a steamboat to carry contraband, it is unlikely that most of these goods ever reached their destination. ${ }^{38}$ In addition, hundreds of thousands of guilders were sent to South Africa to provide humanitarian aid for the Boer republics' inhabitants. ${ }^{39}$ There were also many other activities in Europe that required extra spending. A number of SAR officials who had been extradited by the British received financial assistance, as did the wives of some of the Boer leaders who had left South Africa. $4^{\circ}$ Last, but certainly not least, the propaganda campaign was an expensive business. Leyds funded several institutions that had been set up to distribute pro-Boer material. Additionally, he provided money for individual publications. ${ }^{4 \mathrm{I}}$ Despite these extra costs, Leyds managed to leave a sum of about $£$ I70,000 (around fl. 2 million) at the end of the war, which he used to finance projects to promote Afrikaner nationalism in the decades that followed. ${ }^{22}$

The activities of Hendrik Muller, the representative of the ofs in the Netherlands, also increased significantly after the war broke out. Like Leyds, Muller thought it of vital importance that the public in Europe was won over to the Boer cause. He was also well connected with pro-Boer organisations and the press in Europe and the US. In this way he became a prominent propagandist for the Boer cause, and his writings were published all around the world. ${ }^{43}$ Other activities included support to volunteers who wanted to fight on the Boers' side, protests against companies that supplied the British, shipments of humanitarian aid to the inhabitants of the republics and help for refugees. ${ }^{44}$ His work was overshadowed, however, by the magnitude of Leyds's initiatives. Muller only received a small stipend from the ofs government, which was not enough to finance his propaganda activities. He therefore asked the SAR legation for money on several occasions, and in I899 and I 900 received thousands of guilders from Leyds. ${ }^{45}$

In addition to the financial problems, several diplomatic representatives of the ofs appeared to be untrustworthy, which hampered Muller's international campaign. The consul-general of the republic in London, William Dunn, turned out to be an ardent jingo, something that was pointed out to Muller 
by Leyds. ${ }^{6}$ There was also a row between Muller and the consul-general of the ofs in Paris, a certain Mr Mosenthal, which was only resolved after intervention by Johannes Pierson, who persuaded Mosenthal to resign his position. ${ }^{47}$ Despite Leyds's assistance in Muller's financial and diplomatic woes, relations between the two, who had always a personal dislike of each other, became increasingly strained. These tensions came to a head in I900, after the arrival of a deputation from the SAR and OFS in Europe, which raised questions about Muller's diplomatic status.

In March I900, the two Boer governments appointed a special deputation to go to Europe to ask the Western powers to intervene so that peace could be restored in South Africa without loss of independence. They travelled throughout Europe and the US for the remainder of the conflict, and their tour was extensively covered by the press. $4^{8}$ The members of the deputation were well-known figures in Boer politics: Danie Wolmarans (SAR), Abraham Fischer (OFS) and C. H. Wessels (OFS) were prominent members of the representative bodies in their respective homelands. When they arrived in Naples (April I900), Muller and Leyds met them to discuss their diplomatic tour. The Transvaal minister plenipotentiary was in favour of going to Germany immediately to try and win over Emperor Wilhelm II to the Boer cause, but Muller advised that a visit to the Netherlands would be better. After some deliberations, the deputation decided to go to The Hague first, also because the Boer governments preferred this. ${ }^{49}$

The good relationship between the deputation and Muller ended after an incident during the arrival of Paul Kruger in Europe in November 1900. Journalists from all over the world had gathered in Marseilles along with thousands of spectators to meet the exiled president of the Transvaal, who was to arrive on board of the Dutch cruiser Gelderland. Although there were some indications as to the date of arrival, there had been poor communication between the ship and the official representatives of the Boers, meaning that the large crowd had to wait for two days. Amidst that chaos, Muller presented himself as part of the official representation of the Boer republics, claiming that he stood in direct contact with the Gelderland and made haphazard statements about the delay to the press. A public relations disaster was avoided after the resolute intervention of C. G. S. Sandberg, a Hollander who had worked for the SAR government and who had returned to Europe in July I900. He had been dispatched by Leyds to meet Kruger at Suez and after his return to Marseilles explained to the waiting journalists there that the Gelderland had been caught in a storm..$^{\circ}$ Despite the positive outcome, Leyds was 
furious about this incident and accused Muller of endangering the good relations between the Boer diplomats and the press with his vanity. Fischer and the rest of the deputation clearly sided with the SAR legate in this matter. ${ }^{5}{ }^{\text {I }}$

The problems with Muller continued to worsen when he declared himself to be a 'special envoy' (speciale gezant) of the ofs. He quoted official letters, written in 1898 , in which the government of that republic referred to him as such..$^{2}$ However, Fischer argued that these letters only referred to specific activities by Muller in that year, for which the government had authorised him in that capacity. The Boer politician therefore officially declared that Muller had not been given diplomatic prerogative beyond his consular activities and that he and Wessels were the highest representatives of the ofs in Europe. ${ }^{53}$ Later during the war there were more incidents that seem to have had repercussions for the propaganda campaign. In February 1902, the deputation went to the US, followed by Muller who travelled through the country at the same time. He did so without consulting either Leyds or the deputation, as it was against their wishes. ${ }^{54}$ Several pro-Boers in America wrote to the SAR legation in Brussels to complain about Muller's embarrassing performance. Montagu White, for example, described how his behaviour was becoming a problem. 'Dr Muller, with the intention of making himself a very important person, intrigues for his own benefit, not necessarily to the detriment of others, though that, of course, results with considerable mischief at times'.55 Another critic was L. K. Pook van Baggen, an emigrant from the Netherlands who was secretary of the Transvaal Committee in California. He was irritated by Muller's continuing pretence but decided not to intervene because a scandal might have spoiled the work of other pro-Boers in America. ${ }^{56}$

What was considered to be even more damaging than Muller's ego was his opinion on relations between the ofs and the SAR. Muller had been complaining about overexposure of the heroic role of the Transvaal from the beginning of the war. To compensate for this, he actively tried to promote the ofs. This was not in line with the policy followed by Leyds and the deputation, who tried to emphasise the common cause of the two Boer republics in their struggle against the British Empire. ${ }^{57}$ Pook van Baggen reported that Muller continued to make these allegations in the US on an unprecedented scale and advised to have him be returned to Europe.

His statements are absurd in the three speeches I have heard, he talks about himself and his President and his government and in every lecture made insinuations against the Transvaal government in comparison to his government, that could not have been more strongly stated by an English jingo..$^{8}$ 
Such remarks show that there were clear tensions between the diplomatic representatives of the Boer republics. Given the scale of its activities, it can safely be said that Leyds's legation was by far the most important institution to produce propaganda for the cause of the republics in Europe. Via the network of SAR representatives, he had access to much information and was able to co-ordinate activities that were intended to support the Boer combatants in South Africa. However, there were also many difficulties, which indicate that the effect of these efforts was limited. The increased activities meant that the office of the legation was overloaded with work, which even Leyds himself conceded led to poor results. Moreover, his problematic relationship with Muller suggests that it was often difficult to follow a single diplomatic policy. The enormous egos of the two gentlemen undoubtedly lay behind many of these tensions, but the complaints by the ofs representative that the Transvaal received far more attention point to more fundamental issues. As will be discussed in later chapters, the primacy of the Transvaal in pro-Boer literature was considered to be a problem at times by other contemporaries as well. In addition to these difficulties, the official policy of neutrality followed by the government in the Netherlands sometimes led to embarrassments.

\section{Fraying at the edges: the Dutch policy of neutrality}

The Dutch diplomatic service had ties with the pro-Boer network that extended between the Netherlands and South Africa. This inevitably led to problems, because the government in the Netherlands strictly adhered to its neutral position towards the South African War in order not to antagonise the British, which, it was feared, might have threatened the territorial integrity of the Dutch colonial possessions in South-East Asia. ${ }^{59}$ There was, however, great personal sympathy for the Boers amongst leading figures in government, including Queen Wilhelmina herself. Leyds, whose former professor was first minister when the war erupted, had warm contact with the government in The Hague. He was discrete about these connections, however, because he did not want to compromise the policy of neutrality. ${ }^{60}$ It was often more difficult to maintain such discretion when it came to the activities of Dutch diplomats who had sympathies for the republics, some of whom even helped pro-Boer organisations. The position of George Pott was the most problematic in this sense, because he was the representative in Lourenço Marques not only of both Boer republics but also of the Netherlands. As has been 
mentioned, his involvement in the smuggling of illicit material to the war zone eventually caused the Portuguese authorities to extradite him.

There were also other Dutch diplomats in South Africa who caused controversy. As of I 888, the Netherlands had officially been represented in the Boer republics in the form of a consul-general in Pretoria. From I896, this post was held by F. J. Domela Nieuwenhuis. Despite his precarious position as envoy of a neutral power, he warmly sympathised with the Boer cause, something he did not make a secret of. Although he was not listed as an official correspondent, he was in direct contact with the executive committee of the NZAV and provided the society with 'important information', even before the South African War. ${ }^{6 I}$ During the conflict, Domela Nieuwenhuis became more active. He sent information about the fate of Hollanders who had been caught up in the war to the information bureau of the NZAV, which reported to friends and family about the fate of their loved ones. ${ }^{62} \mathrm{He}$ was also involved in the distribution of Dutch aid to the civilian population of the Transvaal. $^{63}$ In this capacity, he and other consuls in Pretoria visited the concentration camp at Irene and wrote a highly critical account of the situation there, which was published in the European press. ${ }^{64}$ These activities made his presence increasingly problematic to the British authorities and in September I90I, his position became untenable after he was openly accused of pro-Boer activities. As a result, the Dutch government ordered him to leave his post. ${ }^{65}$ Back in the Netherlands, the NZAV rewarded him with honorary membership. ${ }^{66}$

B. H. de Waal, the consul-general to the Cape Colony, initially had a more problematic relationship with the NZAV. When he visited the Netherlands in October 1898 , he gave an interview in which he criticised the society and accused it of arrogance. ${ }^{67}$ The executive committee wrote a reply in which they tried to persuade him of the use of the NZAV by listing their activities to strengthen the bonds between the Dutch-speaking people in Europe and South Africa on the basis of equality. ${ }^{68}$ This appears to have eased the tensions between the society and the consul-general and, like Domela Nieuwenhuis, De Waal acted on behalf of pro-Boer organisations in the Netherlands during the war. His main task was to co-ordinate support for prisoners of war (Pows) and other people leaving South Africa via Cape Town. ${ }^{69}$ In a letter, he promised to use the funds sent by Dutch pro-Boer organisations not only for Hollanders but 'for all Boers', to which he added 'it speaks for itself that I will do nothing for the natives and as good as nothing for the coloureds' ${ }^{70}$ In addition, De Waal distributed aid to Pows who had been 
transported to St. Helena and Bermuda. ${ }^{7 \mathrm{I}}$ This diplomat, too, was made an honorary member of the NZAV after his return to the Netherlands. ${ }^{72}$

Another person from the diplomatic service who contributed to the proBoer network was the consul-general in London, H. S. J. Maas. He sent a complete collection of British official documents about the conflict to the NZAV, which was used as a source for propagandistic publications. ${ }^{73}$ In addition, Maas was authorised by the Dutch government to look after the interests of SAR citizens in London after Montagu White had left for the US. Apparently, this did not make him very popular in Britain, as his house was besieged by a jingo mob in May I 900.74 These examples show that many Dutch diplomatic officials had strong sympathies for the Boer and at times acted accordingly, which led to their position being compromised. There were, however, also representatives who had a different outlook on the South African question, which brought them into conflict with the authorities of the republics.

On the battlefield, the Dutch army was represented by two military attachés on the Boer side - Captain J. H. Ram, Lieutenant L. W. J. K. Thomson. 75 These two men had an ambivalent attitude towards the republican forces, to say the least. Although they did express their sympathy for the Boers, Ram and Thomson also criticised the way in which they fought the war and in particular thought the lack of discipline of the commandos to be a problem. ${ }^{76}$ This kind of criticism was not exceptional in the Netherlands, but it seems that Thomson's personal dislike of the Afrikaners went further, which led to an incident in July I900. By then, the SAR leadership had left Pretoria and was temporarily seated in Machadodorp in northeastern Transvaal, where they were joined by the foreign attachés. There, several personal letters from Thomson, in which he made rather undiplomatic remarks about his hosts, were intercepted by a censor.

He basically asserted that the British pro-war propaganda was right about the Boers. 'Corruption, cowardice, treason, theft - that is what one runs into here every day. A biased press has pulled the wool over the eyes of the Europeans in general and us Dutch in particular!' 77 He also wrote that the hate of the Afrikaners against people from the Netherlands was still in effect and was even greater than their aversion to the British. Although he still felt that the war was not justified, he did not lament the fate of the Boers.

It will be a pity if England wins, a pity for us, from a selfish point of view; because we lose a debouche for many, and the territory in which our lan- 
guage is spoken - jabbered rather - will shrink. But the large majority does not deserve to remain independent $!^{78}$

The State Secretary, F. W. Reitz, took offence at these remarks and threatened to extradite Thomson. Despite protests by the attaché that his mail, which had diplomatic status, had been tampered with, he decided to leave on his own initiative and to inform the Dutch government on a strictly confidential basis so that a public scandal could be avoided. ${ }^{79} \mathrm{As}$ a result, these statements never reached the ears of the general public in the Netherlands. ${ }^{8 \circ}$

It can be said that, during the South African War, there were significant ties between the diplomatic services of the Netherlands and the Boer republics. Leyds was well acquainted with leading politicians in The Hague at that time, and Dutch representatives in Southern Africa corresponded with pro-Boer organisations in Europe. There were, however, limits to these activities. The Dutch government could not afford to break with its policy of neutrality, and as a result of this Pott and Domela Nieuwenhuis were forced to return to the Netherlands after the British accused them, not without reason, of helping the Boers. Moreover, there were several individuals who caused controversy and internal strife, which is evident from the departure of the Dutch attachés following Thomson's condescending remarks about the Boers. Although this dispute was kept out of the press during the war, it shows that the contact between the Netherlands and South Africa was not without complications. The informal nature of the Dutch pro-Boer movement, a result of the relatively weak international position of the Netherlands, limited the possibilities for effective control over the channels of information that provided them with material for the propaganda campaign in Europe. Still, a substantial amount of information did reach the Netherlands via contacts that existed between individuals that bypassed the formal institutions. How that happened will be discussed in the following sections.

\section{Repatriates and refugees}

During the course of the South African War, thousands of Dutch-speaking people - Hollanders, Boers and Cape Afrikaners - left South Africa and found refuge in the Netherlands. It is impossible to extract the exact number from the sources. The majority arrived after the British army had started its advance into the Boer republics. A substantial group of people who arrived in the Netherlands were Hollanders, mainly officials from the SAR and their 
families, who were considered to be 'undesirables' by the new authorities and were forcibly repatriated. Not all of the people leaving the war zone were deportees, however. Many others became refugees out of fear of British brutalities or because they did not think they could be of any use if they stayed put. The fact that these people left South Africa did not mean that they could not help the war effort anymore. A large number of individuals who left the fighting zone became active in the pro-Boer propaganda campaign in Europe, making a significant contribution to it. They managed to stay in touch with people in South Africa and so keep some lines of communication open, along which information about the conflict was transferred to Europe. In addition, the experiences of refugees and deportees were an important subject of propagandistic material. Pro-Boer organisations and the press published articles on the fate of these men, women and children which led to much public outcry. ${ }^{8 \mathrm{I}}$ In this respect, the exiles symbolised the horrors of the war in South Africa and the injustice inflicted upon the Boers by the British Empire. ${ }^{82}$

Gerrit Middelberg, the former director of the NZASM in Pretoria, set an example for repatriates to become involved in the pro-Boer movement. In the early months of $\mathrm{I} 899$, he resigned his position and voluntarily returned to the Netherlands. Middelberg had a good reputation amongst the Boers, and this also had an effect back home. At the general meeting of the NZAV on Io May I 899, he was elected as chairman of the executive committee, 'because of his many years' stay in the South African Republic, [he] appeared to be the most suitable person to lead the society'. ${ }^{8} 3$ Under Middelberg's leadership, which lasted for more than a decade, the NZAV remained in touch with the developments in South Africa, from the South African War to the formation of the Union in I9I0. His diary reveals that he kept up with these events but had a rather pragmatic attitude towards them. In October I 899, for example, he welcomed the ultimatum issued by the Transvaal that led to the invasion of the British colonies as 'a practical lesson in statesmanship'. ${ }^{84}$ At a time when public emotions ran high, Middelberg's realism and knowledge of South African affairs was considered to be important, and it probably contributed to the prominence of the NZAV amongst other pro-Boer organsiations. At the same time, there was also criticism of the society's executive committee and its lack of reform, which in the view of some meant that the organisation was failing to capitalise on the widespread enthusiasm for the republics. ${ }^{85}$

Another NZASM official who came to play a prominent role in the proBoer propaganda campaign was J. A. van Kretschmar van Veen (I 857 -I93 I), Middelberg's successor in Pretoria. He had been working for the NZASM of- 
fice in Amsterdam in the I890s and was elected as secretary of the NZAV in June $1897 .{ }^{86} \mathrm{He}$ did not remain in this position for long, as he went to the Transvaal the next year to take over the management of the railway company there. His directorship was affected by the South African War. In the run-up to the conflict, he strove to prepare the NZASM for performing auxiliary tasks for the Boer forces. His open loyalty to the SAR government worried directors of the company in Amsterdam, because they feared this might endanger the Netherland's position of neutrality. Van Kretschmar van Veen reacted strongly against this cautious attitude. In April I900, at the height of the British advance, he wrote that the NZASM would probably be punished for supporting the Boer war effort. Nevertheless, in this letter he refused to pretend that the company had been pressured by the Boer authorities to help them, in order to use it as an excuse later on. He did point out the fact that the concession allowed the SAR government to commandeer the NZASM but also raised an objection on moral grounds. 'We are a Dutch company that strives to make money, but we have a Transvaal railway. The first is in the position to be neutral, but the second is not. ${ }^{87}$ Apart from co-ordinating the wartime activities of the NZASM, he also played a large role in the establishment of local charities that were to become a pivot in the distribution of humanitarian aid that was sent from Europe.

Directly after the occupation of Pretoria on 5 June I900, Van Kretschmar van Veen was confined to his home and threatened with deportation. After he had personally protested to General Roberts, he was allowed to stay in order to handle the paperwork of the NZASM on the condition that he refrained from intervening in the actual running of the railway company anymore. Despite this arrangement, the documents of the company and all the assets of the NZASM in South Africa were confiscated by the British in August of that year. This left the director with no other choice than to return to the Netherlands, where he arrived in November 1900. ${ }^{88}$ Back home, Van Kretschmar van Veen became heavily involved in the pro-Boer propaganda campaign. He wrote an extensive report on what in his view was the illegal liquidation of the NZASM, which was published before the end of the war. ${ }^{89}$ In addition, he continued his activities co-ordinating humanitarian aid to the Boers. He was re-elected to the executive committee of the NZAV in May I90I and helped to centrally organise the activities by the pro-Boer charities in the Netherlands. In this capacity, he was also involved in the publication of reports on the concentration camps that were sent to the Netherlands by people who were distributing humanitarian aid in South Africa. $9^{\circ}$ 
The fact that the NZASM sided with the Boer republics during the war also had significant consequences for the employees of the company. The tasks they performed for the Boers included managing the growing number of services within the SAR, running the captured railway lines in northern Natal, performing special duties at the siege camp of Ladysmith and taking over the lines in OFS, which were owned by an English company. Moreover, they acted as sentries along the railways, organised ambulance trains and repaired cannons in their workshops. After the British advance started in February I900, NZASM engineers were also involved in the destruction of railway tracks and bridges so that the enemy would be unable to use them.9 ${ }^{\text {I }}$

These activities were conducted under growing hardships. The financial situation of the NZASM became more difficult, which resulted in cuts in salaries and eventually in the suspension of pay when the British captured Pretoria and took over control of the railway lines. During the British advance, NZASm employees tried to flee from South Africa via Delagoa Bay, but many were captured. Of these men, 6I were deported to POw camps overseas, while the rest was moved to Pretoria. ${ }^{92}$ From there, all who had not been born in South Africa were declared to be 'undesirables' and deported from June I900 onwards. NZASM employees and their families, a total of 3, OIO persons, were put on trains to the port of East London and from there were shipped to the Netherlands. ${ }^{93}$ These impoverished families stood together to put in a claim for compensation. This campaign attracted much attention in the Dutch press, and the government was forced by public opinion to take action on their behalf. ${ }^{44}$ It appealed to a special arbitration committee that had been set up by the British government, which in I 902 paid a sum of $£_{37,500}$ which was divided amongst the destitute families.95

There were also other Hollanders who were expelled from the SAR. One of the most prominent was Nicolaas Mansvelt, the superintendent of education who had been in South Africa for twenty-five years when the war started. After the occupation of Pretoria, he and his family were summoned by the British authorities to leave. Back in the Netherlands, he was warmly welcomed by the leaders of the pro-Boer movement. The secretary of the ANV, H. J. Kiewiet de Jonge, himself a teacher, was very much impressed by this icon of Hollander education and found it 'wonderful to have met him'. ${ }^{96}$ Despite this warm welcome and an offer to stay with Kiewiet de Jonge in Dordrecht, Mansvelt decided to take up residence in Utrecht. ${ }^{97}$ In addition, Mansvelt had financial concerns. He was deprived of an income after his departure from South Africa, and his property in Pretoria had been confiscated by the 
British. He complained bitterly about 'the great expenses of my destitute family' and asked Leyds for financial support. ${ }^{9}$ Kiewiet de Jonge once again came to his aid, asking him to write a pamphlet about education in the Transvaal for the ANV, which became a well-known publication. Mansvelt was also offered a position as a school inspector in the Netherlands, but he declined the offer and so a more permanent financial solution had to be devised. ${ }^{99}$

This happened early in I90I, when a substantial project for 'this highly meritorious fighter' for the Dutch language was proposed by Gerrit Kalff, professor of Dutch literature at the University of Utrecht. ${ }^{100}$ The initiative was supported by an influential committee, which raised fl. 5,000 for Mansvelt to write a book about the history of the relations between the Netherlands and South Africa since the establishment of British rule in the Cape Colony. ${ }^{\text {IOI }}$ After this project was completed in November 1902, it had become clear that it would be impossible for Mansvelt to return to South Africa, because the British authorities would not allow him in. It was only then that he formally became involved in various pro-Boer organisations in the Netherlands, sitting on several committees, something which made him an influential figure in the I900s. In his obituary he was called 'the heart, the soul and the spirit of everything that has been done from this side [the Netherlands] to promote relations between the Netherlands and South Africa. The heart first.' ${ }^{\text {I02 }}$

Hollanders who were active in the Transvaal press also experienced turbulent times during the South African War. When the hostilities started, F.W. Engelenburg was flooded with work. In addition to his busy schedule working for his own newspaper, De Volksstem, he was also asked to act as a correspondent for the international press. He did work for the French news agency Havas, The New York Journal of William Randolph Hearst and several newspapers in the Netherlands and the Dutch East Indies. ${ }^{103}$ Engelenburg, however, did not remain chained to his desk at his Pretoria office and, as he had done in the I 890 s during punitive expeditions against black Africans, joined the Boer commandos. In Natal, he was present at the battles of Elandslaagte and Colenso, of which he wrote reports, but did not partake in any military action. In addition to his work as a reporter, he set up and ran the mobile state press in a railway carriage in northern Natal. This installation was used to print official statements and memoranda but also a special field edition of De Volksstem containing the latest news from the front lines. ${ }^{104}$ After a few months, Engelenburg went back to Pretoria and witnessed the occupation of the city. The journalist was arrested in June when British authorities found an empty bandolier in his house. He was released on parole, but De Volksstem 
was closed down. ${ }^{105}$ Many years later, a business partner recounted how Engelenburg boldly recovered sensitive documents that were kept in his office: he dressed himself in his finest clothes, pinned on all the medals he could find and demanded access to the office. Legend has it that the guard was so impressed by Engelenburg's appearance that he was not only allowed in but was also politely saluted as he left. ${ }^{\text {I06 }}$

After his newspaper was banned, Engelenburg went to Europe, arriving in August I900. Contrary to what one might expect, he did not become one of the leading figures of the pro-Boer movement in Europe. In I 898, Engelenburg had already refused an offer by Leyds to join the SAR legation's staff and, although he did do some work for his old friend, did not become an official representative of the Boers when he came to Europe. ${ }^{107}$ To some extent, he continued with his journalistic activities and was appointed as Lisbon correspondent to De Nieuwe Rotterdamsche Courant (NRC), a prominent Dutch newspaper. ${ }^{108}$ Portugal was not exactly a hotbed for pro-Boer agitation, but there he wrote reports about the Boer refugees who arrived from Delagoa Bay. He also kept Leyds informed about the latest political developments concerning the border between Mozambique and the Transvaal. Despite these activities, it seems that his time in Europe was a welcome break from his busy life in South Africa. Engelenburg took the time to make several trips through the continent, during which he could really live up to his reputation of being a man of refined taste. In letters to Leyds and his wife, he wrote extensively about his visits to restaurants and art galleries, which led to the following verdict: 'I prefer Munich to Berlin, but Paris to all the rest.'

By contrast, one of Engelenburg's employees at De Volksstem, Frederik Rompel (I87I-I947), became a central figure in the Boer propaganda network after his return to Europe. Rompel, who was born in Amsterdam, went to Pretoria to work for the newspaper in I 896. It is likely that he got this job through his wife, who was related to an aunt of Engelenburg, Marie Koopmans-De Wet, a well-connected lady from Cape Town who was also known as the 'Madame de Staël of South Africa'. ${ }^{\text {Io }}$ Rompel clearly liked the journalistic profession and he boasted that he had been the only reporter present at the negotiations during the Bloemfontein conference, the failed attempt by President Steyn of the ofs to reconcile Milner and Kruger. ${ }^{\text {II }}$ After that, he became a war correspondent for De Volksstem and joined the Boer armies in the Northern Cape, where he witnessed the battle of Magersfontein alongside General Koos de la Rey. ${ }^{\text {II } 2}$ Rompel and his wife, who was a nurse for the Red Cross, left South Africa after the occupation of Pretoria, although it is 
not entirely certain whether they were forced to do so or not. When he arrived in the Netherlands, Rompel became the manager of the press office of the ANV, a position he occupied until I9I2. This organisation became an important link in the pro-Boer propaganda network that extended between Africa and Europe. During the war, the press office was one of the main distributors of pro-Boer propaganda on the continent. ${ }^{\text {II3 }}$ After the conflict, Rompel would become one of the most prominent liaisons of the South African Dutch-speaking press in Europe. ${ }^{\text {II } 4}$

The Netherlands also became a safe haven for Afrikaner refugees from South Africa. Even more than with Hollander repatriates, it is hard to estimate the numbers, but it seems that there were at least several hundred of them. Unlike many Hollanders, these people generally did not have family in the Netherlands and therefore depended even more on the pro-Boer organisations that set up special committees to help them. Journalists had a marked interest in their fate, and the experiences of the exiles were incorporated into the great corpus of pro-Boer propaganda.

Without a shadow of doubt, the most famous Boer exile was Paul Kruger, the president of the SAR. The statesman, better known as Oom Paul (uncle Paul) was already a popular figure in the Netherlands before I 899 , as a result of his heroic conduct during the Transvaal War. During a visit in I 884, for example, he was received with much enthusiasm. ${ }^{\text {II } 5}$ The old man's popularity was at its peak at the outbreak of the South African War, and after that he was to remain one of the most popular Boers, if not the most popular, even after he handed over his authority to Schalk Burger and left for Delagoa Bay in September I900. In the Netherlands, public pressure to intervene on behalf of the republics mounted at the time and the cabinet devised a cunning plan to calm emotions at home while at the same time not offending the British too much. Kruger was offered passage to Europe on the cruiser Gelderland by the Dutch government. The elderly statesman arrived in the port of Marseilles in November and, after a triumphant tour through France and a part of Germany, the party travelled to the Netherlands. There was no official reception by members of the Dutch cabinet - although there were private meetings with several ministers - but he was granted an audience with Queen Wilhelmina, who expressed her personal admiration for him. ${ }^{\text {I }}$ 6 In addition, he was continuously cheered in the streets near the royal residence. His visit to other cities in the Netherlands also drew massive crowds, and everywhere he was hailed as a hero by local dignitaries and pro-Boer organisations. The newspapers reported extensively about these events. ${ }^{\text {II } 7}$ After a short stay in Utrecht, 
the former president retired to a villa in the town of Hilversum, Casa Cara. Due to his poor health, it was impossible to stage other mass meetings and he largely retired from public life.

Despite the limited diplomatic impact of Kruger's arrival in Europe and his secluded life after December I900, he was still adored by the public. His household was flooded with objects that were sent to honour the former SAR president. ${ }^{\text {II } 8}$ Moreover, a continuous stream of prominent visitors from all over Europe stopped at Casa Cara to pay him homage. As was the case at the SAR legation in Brussels, the personal staff of the president had trouble coping with the overwhelming public interest. Frederik van Eeden, a famous writer at the time, complained to Leyds about the lax attitude of the staff after he had had to visit the villa four times before he could arrange an appointment with Kruger for a British pro-Boer journalist. ${ }^{\text {I9 } 9}$ This kind of complaint was not made public, however, and the former president was depicted in the press as the embodiment of the suffering of his people, who had fallen victim to the British hunger for gold and power. Kruger, who was forced to leave the country he himself had helped to build during the Great Trek, pined away in exile. As such, his presence in the Netherlands became a strong symbol in the pro-Boer campaign.

Another place where exiles from South Africa were housed was the socalled Afrikaner Tehuis, a building at the Nieuwe Herengracht in Amsterdam. It started as an ad hoc solution in August 1900, when no accommodation could be found for the new arrivals. Under the supervision of the Christelijk Nationaal Boeren Comité (Christian National Boer Committee, hereafter $\mathrm{CNBC}$ ), a Calvinist pro-Boer organisation, it came to be a permanent shelter for more than 70 people. ${ }^{\mathrm{I} 20}$ Many of the inhabitants of the Tehuis were Afrikaners from the Cape Colony who had joined the Boer forces and did not dare return to their homes because they were considered to be rebels by the British authorities and risked the death penalty if caught. Residents of the Tehuis were subjected to a strict regime, with compulsory Bible reading twice a day and a curfew. ${ }^{\text {I2I }}$ Despite this strict discipline, there were some disturbances, and three people were told to leave in $1902 .{ }^{\mathrm{I} 22}$ Nevertheless, there was a lot of sympathy for the Afrikaner refugees amongst the general public, which was illustrated by the important people who came to visit. Both Kruger and Wilhelmina went to the Tehuis to meet the people living there personally. ${ }^{123}$ In this way the shelter generated publicity about the fate of the Boer refugees.

A different group of refugees that caught the attention of the pro-Boer or- 
ganisations and the press in the Netherlands were people that had fled the republics and had gone to Lourenço Marques in the Portuguese colony of Mozambique. During the course of I900 and I90I, around I, 500 refugees were allocated to a camp there. Their circumstances were dire, which contemporaries thought was mainly due to the unhealthy climate. In I90I, the authorities decided to transport the Boer refugees to Portugal where they were accommodated in several camps in order to improve their situation. The СВNC was also active in these camps, and a representative from the charity co-ordinated the distribution of aid sent from the Netherlands. The representative's letters gave detailed reports of his activities, with particular emphasis on the success of the schools that were set up, allowing the young refugees to receive a proper education. Spiritual guidance of the inmates was also considered to be an important issue. ${ }^{24}$ Engelenburg, who acted as a correspondent from Portugal, covered the arrival of the Boers in the camps and reported on their fortunes in the Dutch press on several other occasions. ${ }^{125}$

Most exiles in the Tehuis and the refugee camps in Portugal were illiterate, and therefore only a few of them were able to create propaganda. ${ }^{\mathrm{I} 26} \mathrm{Mem}$ bers of the Boer elites who went to Europe made their voice heard more often. One way to do so was to give interviews, and in this way their views were disseminated via the newspapers. A more lively way to inform the public was by giving lectures. With the help of Dutch organisations, several Boers toured the Netherlands, Germany and France. This proved to be quite a lucrative enterprise and aside from raising money for the funds that provided humanitarian aid to the inhabitants of the republics, the speakers often earned a handsome sum themselves. This had some undesired effects, because it allowed them to dress in the latest European fashion and thus lose some of their rough appeal. Kiewiet de Jonge, who was an important co-ordinator of the lecture tours, was particularly worried about the fact that they started shaving: 'a Boer without beard is like a lion without a mane', he complained. ${ }^{\mathrm{I} 27}$ Still, such lectures continued to attract large crowds throughout the war. ${ }^{\mathrm{I} 28}$

The return of the majority of Hollander emigrants from South Africa and the arrival of other refugees did not mean these people were no longer useful for the pro-Boer propaganda campaign. Members of the Hollander elites from Pretoria such as Middelberg, Van Kretschmar van Veen and Mansvelt did important work for the organisations that supported the embattled republics. In this way, they became important middlemen in the network that transferred information from South Africa to Europe. Arguably the most important figure in this respect was Rompel, who became the manager of the 
ANV press office, a job he continued to do after the conflict ended. Other deportees and Afrikaner refugees were not left in obscurity either. The press in the Netherlands wrote about their fate, which became emblematic of the unjust war. The most famous symbol of the wrongs that the British Empire inflicted on the Boers was Paul Kruger; his fate appealed to many contemporaries, and large crowds gathered to see the heroic president for themselves when he arrived in the Netherlands. The Boers who went on lecture tours also made the tragedies of the war in South Africa tangible to people in Europe. There were, however, also other means to inform the public about the drama that was unfolding in the Boer republics. Throughout the war, stories from South Africa reached the public in the form of letters that were written by people who were witnessing the events as they took place or had heard about them firsthand.

\section{Evading censorship}

Although in all probability most Hollanders left South Africa, a number of them remained behind. From the beginning of the war, pro-Boers in Europe recognised the opportunities in using them as correspondents who could provide valuable information. Unlike British newspapers and news agencies, which probably had at least two hundred reporters in the field, the Dutch press had few official representatives and largely depended on the correspondence of private individuals as a source of information. ${ }^{\mathrm{I} 29}$ During the first months of the conflict, newspaper editors and the ANV press office called upon the public in the Netherlands to forward all letters they received from friends and relatives who were present at the war zone. ${ }^{\mathrm{I} 30}$ This appeal was successful: a large collection of writings was gathered not only about the battles but also about daily life in the towns of the republics. During the early phase of the war, there were other sources of information, too. All major Boer newspapers were available in the Netherlands, containing official statements by the governments of the republics and reports that often contradicted the British coverage of events. The biggest Dutch periodical from the Cape, Ons Land, was also considered to be an important source of information in this connection. During the first phase of the conflict, there was a large supply of such material because the republics' mail services were able to operate freely via the NZAS m railway line and the port of Delagoa Bay. Although the British press was a lot faster in providing news thanks to the telegraph lines, opinion makers in the Netherlands considered such documents to be impor- 
tant sources that allowed them to not have to depend on the London dailies only. ${ }^{\text {I } 3 \mathrm{I}}$

Things changed after the occupation of the Boer republics, however. To start with, the British authorities confiscated the NZAS M railway line to Delagoa Bay, which meant an effective end to the regular mail services of the Boers. Moreover, they started to impose censorship in the republics, which affected both the press and private correspondence. It was for the first time that such extensive measures were taken during a conflict, and Jaqueline Beaumont has argued that the South African War therefore represented an important phase in the development of modern censorship. Nevertheless it is hard to assess the effectiveness of this measure or even the guidelines used, due to the fact that the censors left few sources. ${ }^{\mathrm{I}}{ }^{2}$ Although there was a general dislike of British censorship amongst Dutch contemporaries, they also seemed to be largely left in the dark about the motives behind it and the true extent of its power. Newspapers explicitly stated it when they received letters that had passed the censors, so that the people knew they had probably been tempered with. Despite these complaints, it should be remembered that the haphazard organisation of the censorship clearly imposed limits to its effectiveness. Throughout the war, documents from South Africa containing statements that were considered to be important propaganda material still reached the Netherlands. In fact, some correspondents tried to dodge censorship and at times actually succeeded in doing so. In this way, private letters remained a valuable source of information to the pro-Boer propaganda campaign.

The most obvious form of censorship was the attempt to gain control of the press in South Africa. Beaumont has shown that the army increasingly interfered in the work of correspondents, much to the chagrin of the British media, including those who supported the war. ${ }^{\mathrm{I} 33}$ However, the authorities were far more aggressive towards the Boer periodicals. After the occupation of Bloemfontein and Pretoria, newspapers that had supported the republican governments were shut down. As mentioned above, Dutch journalists who worked at these periodicals such as Engelenburg and Rompel from $D e$ Volksstem were put under pressure to return to Europe or explicitly extradited. Other Boer newspapers were taken over by British journalists, who actively produced propaganda for the new regime. The most famous example was The Friend in Bloemfontein, to which the famous writer Rudyard Kipling contributed for a period of several months. ${ }^{\text {I } 34}$

These measures were not only confined to the republics but also affected Ons Land in the Cape. This periodical regularly published accounts of the 
war from the Boers' perspective, contradicting British coverage. As such, it was an important source for newspapers in the Netherlands, probably also because the mail services from Cape Town were quite reliable. ${ }^{135}$ This source of information petered out after the start of Boer guerrilla operations in the Cape Colony just before New Year's Day of I90 I, when martial law was proclaimed. One of the measures taken by the Milner administration was the further tightening of censorship, and the most obvious target was Ons Land. In January I90I, the journalist F. S. Malan was arrested, and the authorities prohibited the periodical from publishing editorials. After this clamp-down, newspapers in the Netherlands largely ceased to use it as a source because they thought it had lost its critical stance towards the authorities. ${ }^{136}$ It seems that, in this respect, the British were quite successful in curbing the supply of pro-Boer information coming from South Africa via the press. There were, however, also more informal sources, which were harder to control.

Much information reached the Netherlands from the Dutch emigrants who had settled in South Africa during the final decades of the nineteenth century. A few weeks before the war broke out, enthusiasts amongst this group decided to form their own commando in the Transvaal, the so-called Hollandercorps. The Dutch regiment consisted of 450 men, of whom around I 50 joined the Boer forces that invaded Natal. At first, newspapers in the Netherlands welcomed this news enthusiastically and praised their bravery in fighting for their 'kinsmen'. But disillusion soon set in when the commando was defeated during the infamous battle of Elandslaagte, which took place ten days after the war had started. The dramatic events became widely known in the Netherlands thanks to many of the veterans sending in accounts of the battle in letters, and it probably became the single most covered event by the Dutch press during the whole conflict. One of the major national newspapers in the Netherlands published no less than 27 accounts, a number of which were written by members of the field force of the Hollandercorps. ${ }^{\mathrm{I} 37}$ After Elandslaagte, these men continued to send letters in which they gave accounts of their adventures. Many of them were taken prisoner and so several accounts were about their experiences in British captivity.

The most prolific correspondent amongst the Hollander pows was B. G. Versélewel de Witt Hamer, an officer who was captured at Elandslaagte and was initially held near Cape Town. In June I900, he was one of the first to be sent to the prisoner camp on St. Helena, where he became one of the main spokesmen for the inmates. In this capacity he acted as a liaison for pro-Boer organisations that sent aid to the Pows, and he wrote extensive reports about 
daily life in the camp that were published in the Dutch press. Despite the fact that they were read by the censors, these letters contained clear assertions that many of the pows remained defiant and patriotic, which was discussed extensively in the newspapers. ${ }^{138}$ But there were also complaints about censorship. One of the most notorious incidents happened when two censors were found guilty of randomly burning letters after they had stolen the stamps from the envelopes. ${ }^{139}$

In the camp of Diyatalawa in Ceylon, there was also censorship. One of the Hollander inmates there, a teacher, devised a rather creative way of dodging it. After arriving there, he sent a wooden box as a present to H. J. Emous, the man who had recruited him to go to the Transvaal in the I 890 s. $^{\mathrm{I} 40} \mathrm{In}$ it, he hid a piece of paper with squares cut out and the accompanying instruction explained that this paper had to be put over the future letters, so that only the words in the squares were visible. The general contents of these letters were harmless and thus passed the censors without any trouble. The coded words, however, contained information about the situation in the camp and the morale of the inmates, which, he asserted, was still high. One such hidden message read: 'Here $[\ldots]$ there is complete $[\ldots]$ unity $[\ldots]$ fierce hatred $[\ldots]$ the greatest $[\ldots]$ resolve $[\ldots]$ hope for $[\ldots]$ revenge and $[\ldots]$ mistrust $[\ldots]$ with regard to all that [...] is English'. ${ }^{\text {I4I }}$

Another way in which authors in the POw camps tried to avoid censorship was by smuggling out their manuscripts. One of the most noteworthy examples is the war diary of Dietlof van Warmelo. This young man was the son of a Calvinist minister from the Netherlands who had settled in the Transvaal and married a local girl. Van Warmelo had studied in the Netherlands, where he became well acquainted with his uncle, the famous writer Frederik van Eeden. By the time the war started, Van Warmelo had finished his education, returned to South Africa, joined a Boer commando and fought for almost a year and a half. In April I90I, he was captured and sent to the Ahmednagar camp in northern India. There he wrote an account of his personal experiences during the war; which he had to do from memory because he had lost the diary he had kept in the field. This manuscript was smuggled out of the camp and reached Van Eeden, who immediately found a publisher for this 'remarkable' book. ${ }^{\mathrm{I}}{ }^{2}$

Besides the accounts of those who had been captured, there were also letters from civilians who had not joined the commandos and remained in the towns of the Boer republics. During the early phases of the war, such epistles were regularly printed in newspapers, but after censorship had been imposed 
they often ceased to contain interesting information. At times, however, controversial news did come out, describing the situation in the concentration camps and giving news from the battlefield. Although a substantial number of the secret correspondents were female, contemporaries paid relatively little attention to these women. This could explain why there are few sources available that give insight into their activities. The only woman who explicitly wrote about her experiences as an intelligence agent was one of Dietlof van Warmelo's sisters, Johanna. In I9 I3, she published a personal account of her adventures as a Boer informant, in the so-called 'kappie kommando'. After she had served as a nurse in the concentration camp of Irene between May and July I90I, she was recruited by a former Boer officer to help smuggle information and people in and out of Pretoria. ${ }^{\mathrm{I}} 33$

In this capacity, she also sent letters and reports to the Boer representatives in Europe, mainly about the situation in the camps. Such material was usually addressed to members of her family and to her fiancé, who lived in the Netherlands at the time. But this sort of information was not always received well. One report about the concentration camps that was carefully hidden in a bottle of 'Dr Williams' Pink Pills', was put away by the recipient because he, with 'unequalled stubbornness', did not think it was of any value. ${ }^{\mathrm{I} 44}$ Johanna van Warmelo also experimented with short reports which she sent directly to the SAR legation. These were written in lemon-juice on the inside of envelopes and became visible after heating. Despite this spectacular method, it does not seem likely that this information significantly contributed to the proBoer propaganda campaign. The notes only contained rudimentary information, and there is no evidence that they were ever published. Moreover, Leyds himself advised her to stop this dangerous activity after one envelope arrived with the text already visible. ${ }^{145}$

But not all of Johanna van Warmelo's projects petered out like this, as is shown by the Spoelstra case, which also reveals that there were significant risks for the correspondents. At the end of I900, the Hollander J. Spoelstra wrote a long letter to the Dutch newspapers in which he criticised the situation in the concentration camps and the general circumstances under the occupation. The courier who tried to carry this report to Europe was caught and Spoelstra was arrested. Despite protests from several prominent Pretoria residents, he was convicted to one year in prison and a fine of $£$ Io०. Although the controversial letter was confiscated, the contents still became known. During the hearings in his case, Spoelstra summoned around thirty witnesses who corroborated the indictments he had written. Secret agents op- 
erating in the circle of Johanna van Warmelo obtained a full report of these proceedings, hid it in a cocoa tin and gave it to a lady on her way to London. Once there, it reached the anti-war journalist William Stead, who published the full text in one of his pamphlets. ${ }^{\mathrm{I} 46}$

Another Hollander correspondent who was arrested because of his secret activities was Cornelis Broeksma, public prosecutor in Johannesburg and a prominent member of the charity committee in that town. He wrote highly critical reports about the concentration camp that had been set up at the local racetrack, which he visited regularly. It seems likely that he was the author, under the pseudonym 'Pax', of one of the first letters that complained about conditions in the camps, which was published in a Dutch newspaper in February I90I. ${ }^{147} \mathrm{He}$ continued to write about the deteriorating conditions and also gave estimates of the death tolls, which were not mentioned in official British sources at the time. Many of these letters, written under the pseudonym 'Charles Brooks' were addressed to 'Dr Williamson', one of the aliases of Willem Leyds. ${ }^{\text {I48 }}$

Broeksma was arrested by the British and charged with high treason, because he had allegedly written a pamphlet in which he had called for the murder of a prominent member of the British community in the Transvaal. As a result, he was condemned to death under the occupational law and executed

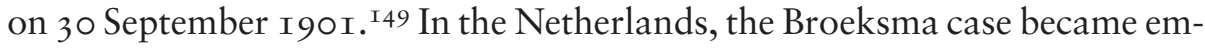
blematic of the way in which the British authorities tried to quell the coverage of the tragedy that was unfolding in the concentration camps. Leaflets were printed with a photo of him and his family, the subscript of which read: 'Cornelis Broeksma, [...] executed by the English on 30 Sept. I90I. Hero and martyr for mercy, public prosecutor in the most noble way: he indicted England before the court of humanity.' ${ }^{50}$

The fate of Broeksma shows that there were grave risks for people in South Africa who sent documents to the pro-Boer organisations in Europe. However, there was a substantial group of people, many of them Hollanders, who tried to do so nonetheless. Compared with British war journalism, it was quite a haphazard network which was not always able to provide a steady supply of news, particularly after censorship was imposed. The main consequences of the British occupation were that formal mail services were stopped and Dutch language periodicals in South Africa muzzled. All this did not prevent news from slipping through, however. Although private letters were screened, at times they contained some relevant information for the propagandists about the situation in the Pow or civilian camps. In addition, sev- 


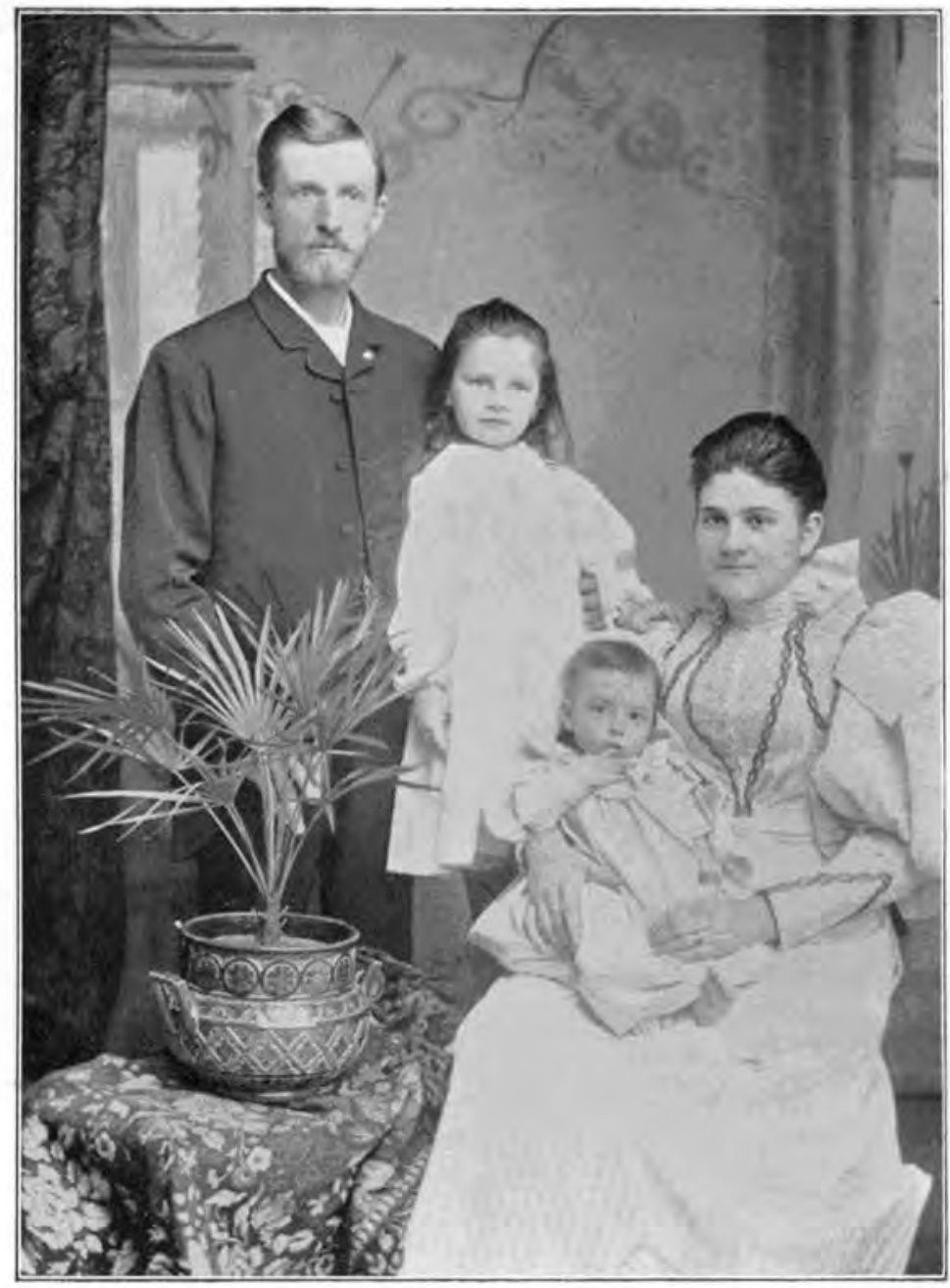

\section{CORNELIS BROEKSMA,}

geb. te Assen, 13 Aug. 1863, door de Engelschen gefusileerd 30 Sept. 1901.

Held en martelaar voor de barmhartigheid, publiek aanklager in den edelsten zin des woords:

hij klaagde Engeland aan voor de rechtbank der menschelijkheid.

Leaflet with picture of Broeksma's family (I90I).

Source: ZA, Emous Collection, EM 3, D 5 . Zuid-Afrikahuis, Amsterdam. 
eral individuals attempted to smuggle out letters with the explicit intention of influencing public opinion in Europe. Such material did contain statements about the situation on the battlefields, but because people in towns and camps hardly had any contact with the commandos who continued to fight, these descriptions were too vague to be of use in propagandistic material. However, there were more direct sources that provided information about the events at the front line.

\section{Letters from the front line}

The majority of people who travelled between South Africa and the Netherlands during the war left to find refuge in Europe. There were, however, several groups that went to South Africa to help the Boer war effort. These men (and a few women) often saw action at the front line and reported on their experiences in letters that were published in the press. The lingering war complicated the position of such correspondents, mainly because the Boer commandos became increasingly isolated when the guerrilla phase of the conflict started. Still, information from the battle zone did reach Europe on several occasions, and these heroic reports were eagerly published by pro-Boer propagandists.

During the first stages of the conflict, volunteers from all around the world went to South Africa to join the commandos. In the Netherlands, this was a sensitive issue because it endangered the policy of neutrality. Nevertheless, it became common knowledge that a number of volunteers were assisted by a clandestine organisation that was founded in November I 899 by H. J. Kiewiet de Jonge with the approval of the SAR legation. Another prominent figure in this committee was Frans Beelaerts van Blokland, son of the late consul-general of the SAR, who in later life was to become a prominent statesman. ${ }^{\mathrm{I} I \mathrm{I}}$ The members of the clandestine committee were well aware of the sensitivity of their work and were very discrete about it while openly paying lip service to the official policy of neutrality. Moreover, like Leyds, they were of the opinion that only trained soldiers, preferably artillerists, were of use to the Boers and thus carefully selected the people whom they assisted. ${ }^{152} \mathrm{~A}$ list in the personal papers of Beelaerts van Blokland reveals that the committee helped around twenty people to leave for South Africa between January and May I900. ${ }^{153}$

Lieutenant Gerrit Boldingh was probably the most well known of these men. This 28-year-old artillery officer resigned from the Dutch army after the 
war started and arrived at the front line in March 1900 . After seeing action at different battles, he joined the commando led by the famous Boer General Christiaan de Wet, whom he deeply admired. ${ }^{54}$ In September I90 , he died in the saddle after he was shot while being pursued by the British army. Before Boldingh left for South Africa, he was contracted by Charles Boissevain of Het Algemeen Handelsblad to act as a war correspondent. ${ }^{155}$ His letters reached the Netherlands throughout his stay in South Africa and were published in this newspaper. In 1903, his missives were collected in a book to which Boissevain himself contributed an introduction in honour of his memory. The editor of the volume explained that it also served a higher purpose: he held such a high view of Boldingh's writings that he was of the opinion that historians would in the future find it 'a source $[\ldots]$ of the most pure nature'. ${ }^{156}$

Another group of volunteers that left the Netherlands to serve in South Africa in the early stages of the war was the staff of the Red Cross ambulances. Already during the Jameson Raid, G. W. S. Lingbeek, a Hollander who worked as a medical doctor in Pretoria during the I 890 , set up an ambulance corps with the help of the NZAV and the Dutch Red Cross. ${ }^{157}$ The outbreak of the South African War led to the expansion of these activities. In November and December I899, three Dutch ambulances left the Netherlands under the leadership of Lingbeek, J. D. Koster and D. van Rijckevorsel, respectively. Also, a joint Dutch-Russian ambulance and one that was mustered in the Dutch East Indies went to the front lines in the months thereafter. In May I900, two additional physicians, J. H. Pameyer and D. J. E. MacLeod, arrived in Pretoria. ${ }^{\mathrm{I} 5}{ }^{8}$ The total staff of these ambulances consisted of 64 people. $^{\mathrm{I} 59}$

Several of these men and women wrote long letters about their experiences that were forwarded to newspapers by the executive committee of the Dutch Red Cross. In I901, a voluminous book was published containing the official reports of the doctors in charge. ${ }^{160}$ In addition, the personal memoirs of several nurses also appeared. ${ }^{16 \mathrm{I}}$ In these publications, the activities of the Red Cross were extensively described, as were the increasing problems with the British army, who considered them to be on the Boers' side. After the occupation of Pretoria, the staff members of one ambulance were even arrested, after which the men were sent to a Pow camp on Ceylon and the women deported to Europe. Such stories caused an outcry in the Netherlands. ${ }^{162}$ In addition to these problems, the changing tactics of the Boers, who started a guerrilla war with mobile hit-and-run attacks, complicated the work of the 
Red Cross. The majority of the medical staff therefore decided to leave South Africa, but a small number of them, including doctor J. C. J. Bierens de Haan and male nurse H. J. Poutsma, joined the commandos in the field on their exhausting journeys. During the first half of I90I, they returned to the Netherlands where they tried to organise new ambulances for the Boers, an initiative which failed because the British authorities refused them access to the war zone. ${ }^{163}$ Nevertheless, the stories of both Poutsma and Bierens de Haan did attract considerable attention from the media in the Netherlands. The former wrote a feuilleton in Het Algemeen Handelsblad and the latter granted a famous interview to De Nieuwe Courant in which he asserted that the Boers would never give up. ${ }^{164}$ After these men had returned, however, no Dutch Red Cross employees were left in South Africa to provide useful material for the newspapers to report on.

The increasing problems of the activities of the Red Cross in South Africa were in keeping with a general trend. As the war went on and the Boers' chances of a military victory waned, the stream of volunteers to help the commandos in the field dried up. Soldiers from Europe became less useful in the new circumstances, because they did not know the terrain and had no experience with guerrilla warfare. ${ }^{165}$ There was, however, a growing need for couriers. Because the British controlled all routes to the region, communication between the Boer representatives in Europe and the commandos in the field became problematic. After Pott's expulsion from Lourenço Marques at the end of I900, correspondence could only be taken back and forth via couriers who travelled all the way from the war zone to Europe and vice versa. ${ }^{166}$ At least twenty missions consisting of either one or two people left with letters from the Boer representatives in Europe to the leaders in the field between the beginning of I 901 and the middle of I 902 . Most recruits were people who had previously fought with the Boer commandos. ${ }^{167}$ It seems that the majority of the couriers did not arrive, either because they ran off or succumbed to the dangers along the routes via Delagoa Bay and South-West Africa, which became more and more difficult to pass. ${ }^{168}$

One of the men who attempted the hazardous journey (and that twice) was the former Dutch resident of the SAR Cornelis Plokhooy (I 877-I964), who fought with the Boers in the early stages of the war. In June I 900 , he was captured by the British and deported back to the Netherlands, where he became involved in the propaganda campaign by writing a book about his war experiences, which was followed by a successful lecture tour. In addition, he volunteered as a courier. ${ }^{169}$ In a handwritten report, he recounted how he had 
gone to Paris in December 1900 and there received a bundle of letters for the Boer leaders in the field reporting on the situation in Europe and $£$ Io to pay for the journey from Johannes Pierson. By the time he arrived at the port of Lourenço Marques, Plokhooy was penniless and fell ill with malaria. To make matters worse, he had a quarrel with the local Boer representatives, thereby depriving him of all support. When he heard that the journey to the Transvaal had become very dangerous because the British were extensively patrolling the borders with Mozambique, Plokhooy decided to call off the expedition in order to prevent the letters from falling into the wrong hands. $\mathrm{He}$ was interned as a Boer refugee and deported to Portugal. There he managed to escape from the camp, hand over his sensitive load to Engelenburg in Lisbon and reached the Netherlands in July I90 I. ${ }^{170}$ Despite this ill-fated adventure, Plokhooy volunteered for another mission early in 1902. This time he did reach the commandos via South-West Africa after an arduous journey during which he was allegedly chased by enemy spies. However, by the time he arrived, peace had been signed and he was once again deported by the British authorities. ${ }^{\mathrm{I} I \mathrm{I}}$

There were also couriers who attempted to carry documents from South Africa to Europe. Already during the early phases of the guerrilla campaign, the Transvaal leaders considered it important that their correspondence and reports be sent to their representatives in Europe so that papers containing intelligence would not fall into the hands of the British. Just before the occupation of Pretoria, C. K. Trotsenburg, a Hollander who was in charge of the telegraph department, gathered all the cables of the Boer generals from his office and took them to the temporary republican headquarters at Machadodorp (northeastern Transvaal). When this camp had to be abandoned, Botha ordered him to go to Europe and leave the collection with Leyds for safekeeping. The cables contained much sensitive information about mistakes made by the Boer commanders during the first phase of the war, so the minister plenipotentiary kept a close eye on them. Although the Dutch government showed great interest in the collection and even allowed them to be temporarily stored in the queen's offices, Leyds was not willing to grant permission for their publication in the Netherlands because he feared that some negative sides to the Boer strategy would be exposed. ${ }^{172}$

Besides concerns about the safety of some of their confidential correspondence, the Boer generals also thought it important to keep the Boer representatives in Europe - mainly Leyds, the deputation and President Kruger - informed about military developments in South Africa. Not all attempts to 
send reports were successful, but several of their accounts reached Europe and were reproduced in their entirety in newspapers and pamphlets. One of the most famous examples is a report about the failed attempt to negotiate peace between Botha and Kitchener in February I90I, which appeared in a Dutch newspaper the following May under the pseudonym of 'B.ot H. Anicus'. This alias would suggest that it was written by the general himself, but the author was in fact Bierens de Haan, who acted as Botha's personal physician during the talks and returned to the Netherlands carrying the minutes of the proceedings. ${ }^{173}$ Nevertheless, it is clear that the Boer commander considered it to be important that this account be published in Europe.

General Jan Smuts also considered the propaganda campaign in Europe to be of great value during the guerilla phase of the war. Smuts led a commando that infiltrated the Cape and eventually went to the barren northwestern part of the colony. There he wrote several reports about his activities during the final months of I90I. In confidential letters to the Boer representatives, he expressed his doubts about the war effort, but in reports that were explicitly marked for publication, he boasted about the high morale of his men and of their achievements. ${ }^{174}$ One of the couriers who arrived at the SAR legation told how Smuts had ordered him to set up more regular lines of communication running through the desert into German South-West Africa. Not only would it be easier to obtain supplies this way, but it was hoped that the positive reports coming from the Boers would influence the public in Europe, so that the British government would come under increasing pressure to end the war. Smuts had asked all the Boer generals to send him their reports in code so that he could forward them. ${ }^{175}$

\section{Conclusion}

By the time Smuts's initiative to strengthen the lines of communication between the commandos in the field and the Boer representatives in Europe began to take shape, talks had already begun that would eventually end the war and result in the Peace of Vereeniging, which marked the end of the Boer republics' independence. In this sense, these efforts to supply material for the propaganda campaign in Europe were too late. It does show, however, that it was considered important to keep channels of information between the commandos and the pro-Boer agitators in Europe open throughout the whole course of the war. The main goal was to counter the British coverage of events and so to put forward the other side of the story in order to influence public 
opinion and thus increase the pressure on the British government. This effort was successful in that a substantial amount of material from the battlefield reached Europe (and particularly the Netherlands), where it was used in propagandistic publications. Nevertheless, members of this network also encountered some serious problems that can be accounted for by the informal nature of the pro-Boer movement.

Probably the most important institution of pro-Boer agitation in Europe was the SAR legation run by Willem Leyds. He had an extensive network of informants and agents who helped him to gather and distribute material that was in support of the Boers' cause. Still, Leyds's activities were severely inhibited by the Dutch government's policy of neutrality. In addition, he had limited means available to him and his staff was not competent enough to properly handle the huge amount of paperwork involved. Moreover, the fact that there were conflicts, such as those with Hendrik Muller and the Dutch attaché L. W. J. K. Thomson, shows that there was controversy surrounding the way in which the Boers were to be depicted. However, the greatest problems experienced by the pro-Boer propagandists resulted from the changing situation in South Africa. Already from the beginning of the war, the monopoly on the telegraph lines was greatly to the advantage of the British in the coverage of events there. During the course of the conflict, they expanded their control over infrastructure in South Africa, which led to the deportation of unwanted groups, attempts to cut off Boer lines of communication and the imposition of stricter censorship. Despite these measures, a large amount of information was still transferred to Europe by exiles and refugees, in private letters from the POW and concentration camps and in reports from people who witnessed action on the front line. In this way, a significant body of proBoer literature came into being, heavily influencing the way in which the conflict was depicted in continental Europe.

Compared to British coverage of the war, the network that provided information to the pro-Boer propagandists was far less extensive and far less consistent. In this respect, Lord George Hamilton's jibe referring to the SAR legation as a 'factory of lies' was an exaggeration, because the legation was actually rather inefficient. As a result, its propagandistic activities did not achieve Leyds's main objective, namely to induce the great powers to intervene on behalf of the republics. Moreover, the massive public enthusiasm at times proved to be a burden rather than a blessing. Still, the importance of propaganda during the South African War should not be underestimated. The words of Lord Hamilton and the agitated response to them by pro-Boers re- 
veal that contemporaries were reflecting on the coverage of the conflict in the context of the age of an emerging mass media. In this respect, the pro-Boer propaganda campaign was successful because it managed to create gripping images based on the sources that made their way from South Africa to Europe. In order to publish and distribute this material, Leyds sought contact with organisations in the Netherlands, which affirms that these institutions were closely connected to the lines of communication that have been described in this chapter. The next chapter will further explore this link and show how the Netherlands became an important base in the war of words that accompanied the actual fighting in South Africa. 



\section{'A campaign of the pen': The Dutch pro-Boer organisations}

When the South African War started in October I 899, a wave of pro-Boer enthusiasm rippled through the Netherlands, greater than ever before and, for a while, support for the embattled republics dominated public life. In November I 899, Amsterdam was all abuzz with false rumours that the Boers had defeated the British army. At times, people even went out into the streets to celebrate this 'victory', infecting others with their enthusiasm. On one occasion, a huge crowd gathered at the Rembrandtplein for a spontaneous celebration: flags of the Boer republics were everywhere and the Transvaal anthem was sung heartily. ${ }^{\mathrm{I}}$ Although the feverish enthusiasm cooled somewhat later, people continued to sing songs in the streets in which they celebrated the Boers for their heroism and denounced British cruelties throughout the war. ${ }^{2}$ Advertisements from the time reveal the great popularity of the Boer leaders, several of whom literally became brand names. Paul Kruger's name, for instance, became attached to items such as beer, lemonade, tobacco, pipes and wallets. ${ }^{3}$ These examples show that the South African War prominently featured in Dutch popular culture, but it remains to be seen what effect these phenomena had on society in general. As will be discussed in this chapter, this is not only a question for historians: contemporaries also tried to grapple with it.

In historiography, much emphasis is placed on the official policy of neutrality that was adhered to by the Dutch government, which was pursued with even more rigor during the war. To ensure the integrity of the Netherlands' colonial possessions in the Indonesian archipelago, which bordered on the British Empire in Asia, it was considered of vital importance that incidents be avoided. ${ }^{4}$ The general public did not always share this view, and throughout the war there were loud complaints about the cautious official stance taken by the Netherlands. In this sense, the Dutch government was caught between a rock and hard place. On the one hand, it was concerned about how pro-Boer propaganda might endanger its relations with Great Britain, but on the other hand it had to take into account the sentiments of 
the domestic population, which were exploited in Parliament by the opposition leader, Abraham Kuyper. In order to appease the public, the Minister of Naval Affairs came up with a cunning plan in September I900, that would allow the government to save face while avoiding offending the British. He ordered the cruiser Gelderland to set course to Delagoa Bay and pick up Paul Kruger, who had fled Pretoria in June. The elderly president was brought to Europe and, after a successful tour through France and parts of Germany, went to the Netherlands, where he received a hero's welcome and was granted asylum. ${ }^{5}$ Despite this political master stroke, emotions ran high on several occasions during the later phases of the war. In I90I, for example, a crowd gave Edward VII a hostile welcome when he disembarked at the port of Vlissingen; they even went so far as to sing the Transvaal anthem. One British diplomat described it as 'the most disgraceful scene I ever witnessed in my life'. ${ }^{6}$

Despite such public embarrassments, the principle of neutrality was never seriously threatened and it was clear to all political parties that it was in the national interest to pursue a policy of careful diplomacy. Significantly, government policy remained unchanged on this issue when Kuyper was elected first minister in August I90I, even though some contemporaries considered his election victory to be a direct result of his vocal support for the Boers in Parliament. 7 Moreover, the established pro-Boer organisations respected the cautious attitude of the government in the light of the international position of the Netherlands. The NZAV, which was the largest of these, had many prominent politicians, businessmen and academics amongst its members, people who fully accepted the principle of neutrality. Therefore, the leaders of most pro-Boer organisations refrained from public protests against the government on this point. ${ }^{8}$ The diplomatic representatives of the Boer republics also understood the position of the Dutch government in this matter. The most prominent of them, Willem Leyds, had close connections with leading politicians in The Hague through his former professors - one of whom, N. G. Pierson, was first minister in I 899. Although they discussed the option of the Netherlands assuming a mediating role on several occasions, the Transvaal envoy was well aware that possibilities were limited due to the international balance of power, something which he clearly communicated to the government in Pretoria. 9

Although it is obvious to historians - as it was to contemporaries - that the Dutch government's policy of neutrality left Dutch pro-Boer propagandists little room for manoeuvre, there was more to the matter. The campaign in 
support of the republics and the emotions it provoked were not simply expressions of national frustration with the weak international position of the Netherlands nor the result of a temporary collective lapse of reason. As has been argued in previous chapters, the reporting on South African affairs was closely linked to the lines of communication that extended between the Boer republics and the Netherlands. Contemporaries themselves reflected on this network, which shows that they considered propaganda to be an important part of the struggle for colonial dominance that was taking place in the region. In the dawning age of modern media, a vital question in this respect concerned how one might mobilise and use public opinion. This chapter will explore such notions by examining the structure of the pro-Boer movement in the Netherlands during the South African War. The pertinence of these issues is shown by the fact that the great boom in sympathy for the republics caused problems for the organisations that advocated the ideal of stamverwantschap, with their leaders often having trouble directing the public agitation along what they believed were the right lines.

In general, historians consider the NZAV to be the most important proBoer organisation during the South African War, because it was the oldest and the largest. ${ }^{\text {I0 }}$ The huge increase in membership after the conflict seems to confirm this. In historiography, however, little attention has been given to how the society actually functioned or how contemporaries reflected on this question. In this sense, the primacy of the NZAV was not as straightforward as it might seem at first glance. Internally, there was significant criticism of the executive committee and their efforts to reach out to the public. In addition, several other pro-Boer organisations emerged, which could point to external competition for the NZAV. Henk te Velde argues that the process of pillarisation, during which public life in the Netherlands was divided along ideological lines, was one of the main explanations for this fragmentation. ${ }^{\text {II }} \mathrm{Al}$ though the NZAV's executive committee was aware that the organisation was considered to be a Liberal bulwark and did try to mobilise people from other political groups, this was not as important an issue as it might seem at first.

What weighed more was the connection with the lines of communication between South Africa and the Netherlands. Leyds was a central figure in this network, and he worked closely with several Dutch pro-Boer organisations. In addition, many Hollanders who returned from the Transvaal became active propagandists in Europe. There was, however, an unchecked proliferation of other activities outside this network, and at times these caused significant problems. There were examples of outright fraud by individuals who 
were trying to take advantage of the public's massive enthusiasm for the Boers. The situation was not always clear-cut, however, as bona fide initiatives were sometimes also considered to be harmful for the general Boer cause.

Such issues will be further discussed in this chapter by examining three aspects of the propaganda campaign: the dissemination of pro-Boer coverage of the war, the support given to emigrants and refugees and collections in order to provide humanitarian aid to the inhabitants of the republics. There was a certain degree of fragmentation in these fields, which worried many prominent pro-Boers. In response to this, there were attempts to centralise initiatives and encourage different organisations to co-operate more closely in order to maximise their effect. It is difficult to assess the results of these activities. At an institutional level, there were certain successes in streamlining the pro-Boer organisations, but at the same time it is hard to assess the impact on the general public. What is clear, however, is that contemporaries were aware of the wider context of the propaganda campaign and the pitfalls of modern media. Significantly, the main focus in this respect was not on domestic issues - although these did play a role - but on the channels by which material on the situation in South Africa was transferred and the way in which this information was disseminated. This shows that the pro-Boer movement in the Netherlands was not simply the result of a hysteric form of nationalism but rather an exponent of a complex discourse on Dutch identity in the global context in the early days of mass media.

\section{The NZAV from within}

The NZAV undoubtedly remained the most important Dutch pro-Boer organisation throughout the South African War. In August I 899, a successful address to the British people was presented, written by J. de Louter, a professor of law who was a member of the executive committee at the time. In I $88 \mathrm{I}$, around 6,000 people had signed P. Harting's petition against the annexation of Transvaal; eighteen years later more than I 40,000 signatures were collected to protest against the looming war. The address was sent to all major newspapers in Europe, many of which published it, even in Britain. ${ }^{\mathrm{I2}}$ Although the address did not prevent the war, its outbreak was not unfavourable to the NZAV. The membership of the association grew from 1,663 at the beginning of I 899 to 6,I I I in December of that year. The executive committee considered this to be a result of the recruitment campaign that the society started in 
November of that year in order to increase the society's activities in support of the Boer republics. The willing co-operation of the national newspapers, which published the NZAV's circular and encouraged their readers to join, was also mentioned with much satisfaction. ${ }^{\mathrm{I} 3}$ The activities of the NZAV expanded, too. Like the official representatives of the republics, the society considered propaganda to be an important means of helping the Boers from Europe. Moreover, a new 'bulpfonds' (aid fund) was started in order to provide humanitarian aid to 'those who suffer and those who fight' in the Boer republics. ${ }^{\mathrm{I}}$ Before I treat these activities in more detail, this chapter will discuss the composition and character of the NZAV and other organisations that originated in the context of the burgeoning enthusiasm for the Boers during the war.

The sharp increase of membership numbers of the NZAV after October I899, prompted questions concerning the structure of the society. The most direct outcome of this was the establishment of local branches throughout the country. At the beginning of I 899, the NZAV had just four subdivisions; a year later, this number had grown to $35 \cdot{ }^{\mathrm{I}} 5$ Looking at membership distribution, it can be said that the most active centres of NZAV activity were urban areas, where two-thirds of all members resided. Of these, Rotterdam, (706 members in I900), Amsterdam (65 I members) and The Hague (60I mem-

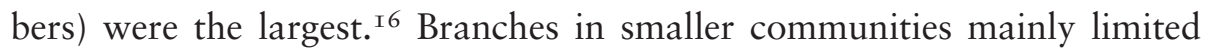
their activities to organising lectures during which new members were recruited for the society and donations collected in aid of Boer victims of the war. ${ }^{17}$

Compared to branches in other cities, the activities of the one in Amsterdam, which was established as late as March I90I, were rather limited. The explanation for this can be sought in the fact that the executive committee resided in the city too, which meant that there was not much left to organise. There were also many other pro-Boer gatherings held in the city, so there was no need to organise more lectures or meetings. The student branch in Amsterdam struggled with the same problem, although there was a successful fundraising campaign amongst its members in $1900 .{ }^{18}$ However, this group did not submit any reports to the executive committee in the years thereafter. The same problem was experienced with other student branches in Leiden and Delft, which was explained by the fact that the committee and members of these divisions consisted of a population that 'by its very nature changes completely every year'. ${ }^{\text {I9 }}$

Other branches were more active. The Rotterdam branch, which already existed before the war, introduced proposals that reflected the mercantile 
character of this city. The businessman A. S. van Reesema was involved in many of these schemes and unveiled several plans for improving commercial ties between the Netherlands and South Africa, some of which were less realistic than others. During the early phase of the war, he revived a plan to establish a shipping route between Dutch harbours and Delagoa Bay. In combination with the NZASM railway, he argued, this would offer the best route for mail services. More optimistically, he thought that it might later become an important itinerary for Dutch emigrants, who he expected would flock to South Africa, even if the British were to win the war. ${ }^{2 \circ} \mathrm{He}$ issued a prospectus advertising stocks, to which 288 people subscribed a sum of fl. 88,800 and donated fl. 3,886 . Later during the war, however, it became clear that this plan was unrealistic, and in 1903 Van Reesema informed his prospective shareholders that the deal was off. ${ }^{21}$ One of the initiatives by Rotterdam that did materialise, however, was the establishment of an information bureau for trade and industry with South Africa, the Bureau van Informatie voor den Handel en Nijverheid met Zuid-Afrika. ${ }^{22}$ In I90I, plans were drawn up in Rotterdam for a mortgage bank to help Afrikaners with reconstruction after the war; this came into being the following year. ${ }^{23}$

In The Hague, the focus was on charity. The NZAv branch there had close ties with other local committees that helped the Boers. Frans Beelaerts van Blokland was a central figure in this philanthropic network. As has been mentioned, this young gentleman joined a clandestine committee to smuggle volunteers into South Africa on the invitation of H. J. Kiewiet de Jonge. ${ }^{24}$ At the same time, however, Beelaerts van Blokland wrote a pamphlet in which he endorsed the policy of neutrality followed by the Dutch government and called upon the Dutch people to express their support for the Boers in peaceful ways such as by making propaganda and donating money to organisations that could relieve the needs of the Boer communities. ${ }^{25}$ In his view, humanitarian aid was nothing less than a patriotic duty: 'it is not benevolence that is expected of you [the readers]; now we have the opportunity to show the whole world, what the Dutch people understand by doing their duty and supporting their brothers in their struggle. ${ }^{26}$ Beelaerts van Blokland himself was involved in several fundraising initiatives as a member of the committee of the NZAV branch in The Hague (and later also of the national executive committee) and the Haagsche pro-Boer Vereeniging, a local charity. These schemes included the sale of postcards with photos of picturesque South African landscapes and heroic Boer leaders ${ }^{27}$, a charity shop where gifts were wrapped in special paper with a pro-Boer theme $\mathrm{e}^{28}$ and an international art lottery in I 902 to which many famous artists contributed. ${ }^{29}$ 
Besides an increase in activity by individual branches, there were more fundamental questions concerning the structure of the NZAV after the great expansion of I 899. Some local committees were of the view that power within the association should be decentralised, and this was discussed often at meetings between the executive committee and representatives from the various divisions. ${ }^{30}$ At a general meeting on 26 May I900, a lengthy dispute about changes to the regulations took place. The Rotterdam delegates proposed that article three, concerning the structure of the NZAV, should state that the organisation existed as the sum of its branches, meaning that the power of the executive committee would be transferred to the larger subdivisions. After much discussion, the meeting voted against this proposal. The executive committee remained a body consisting of I 5 members, who were not allowed to combine their positions with chairmanship of a local branch of the NZAV. The Rotterdam delegation did, however, successfully propose that the executive committee be required to meet with a council of the local presidents once a year. $^{3 \mathrm{I}}$

Attempts were made to introduce greater diversity in the executive committee. During its early years, the NZAV's executive committee was dominated by members from Utrecht and Amsterdam, and the regulations initially even stated that at least seven members were to reside in the latter city. ${ }^{32}$ That rule was abolished in the reforms that followed the meeting held in May I900.33 All the major branches were represented in the executive committee that was elected in I90I: Utrecht by professor J. de Louter, The Hague by Frans Beelaerts van Blokland and Evert van Gorkom (a former resident of Transvaal) and Rotterdam by A. S. van Reesema. Nevertheless, six of the I 5 members still came from Amsterdam, meaning that members from that city continued to exert a great deal of influence - the more so because the head office was also situated there. ${ }^{34}$ It seems that the calls for reform within the NZAV died down after 1900 or were at least no longer expressed as openly anymore. Recruitment efforts continued, although these were unsuccessful, which shows that the translation of public sympathy for the Boers into active involvement remained a difficult issue for the NZAV.

The most substantial attempt to attract new members took place in I90I, when a special propaganda committee was established within the executive committee. An open letter to the press was issued, signed by over I 77 dignitaries from all over the country, including politicians, mayors, academics, medical doctors, journalists and businessmen. In the letter, unity was the keyword. It was argued that the enthusiasm for the Boers should manifest itself 
in the form of strong ties between the Netherlands and South Africa that would last after the war had ended. In order to achieve this, it was proposed, a strong organisation was needed.

The Nederlandsch Zuid-Afrikaansche Vereeniging can be this kind of organisation, when many thousands of new members join her. [...] Now she can and must become a truly national organisation, with strong management-structures, with branches throughout the country, in the colonies, in Belgium and everywhere else where the Dutch live, and with an Executive Committee in which all confessions are represented. 35

In addition to this letter, the propaganda committee started a lecture tour featuring Paul Schutte, a Transvaal Member of Parliament who had fled to Europe. One of the organisers described him as 'one of the most steadfast and civilised Boers that I know. And not unsuitable for speaking in public.'36

Despite all these efforts, the campaign was not met with much enthusiasm, with only 234 new members joining the NZAV in I90I: 'a small increase' according to the annual report, and nowhere near the thousands of new members the executive committee had hoped for. ${ }^{37}$ Most disappointing of all was the result in the southern province of Limburg. In I900, there had been only twelve members of the NZAV in that province, which meant that it was a priority to the propaganda committee. By I902, however, that number had dropped to a pitiful five. ${ }^{3}$ Discussing the plans for Schutte's lecture tour in the province, it was already predicted that he would experience something of a culture shock, because the speaker would be arriving in 'such a total strange area, with a peculiar sort of people'. Moreover the Boer politician, who was naturally an orthodox Protestant, needed to be prepared for the fact that the local population was mainly Roman Catholic. ${ }^{39}$ Eventually the lecture tour to Limburg was even cancelled, as several local officials made it clear that there were already plenty of charities in the province at the time and that people would not be interested in becoming members of the NZAV. $4^{\circ}$

The discussion that took place within the NZAV about its composition shows that its primacy amongst the pro-Boer organisations in the Netherlands was not as clear as is suggested in secondary literature, despite the fact that it was the largest and the oldest of them all. After the large increase in the number of local branches at the beginning of the war, several of these local divisions developed their own activities and increasingly challenged the authority of the executive committee, which was based in Amsterdam. Attempts to 
decentralise the NZAV had limited results, however. This discussion should be seen in the light of issues surrounding the ability of the society to mobilise the public and attract new members. The campaign in I90I did not bring the results that were hoped for, which indicates that the great increase of membership during the first months of the war was a unique phenomenon. The problems that the NZAV encountered trying to mobilise active support of the public show that it, like other pro-Boer organisations, reflected on its position within society and the changes that were taking place in domestic politics. The question remains, however, whether such issues were the most important considerations.

\section{Pro-Boers and pillarisation}

From October I 899, there was also an increase in pro-Boer activity outside the NZAV, which led to a variety of new organisations. One of the most noticeable of these was the Christelijke Nationale Boeren Comité (Christian National Boer Committee, hereafter CNBC). After a meeting of the Amsterdam branch of the Anti-Revolutionary Party (the political party of the orthodox Protestants) on I November I899, a fund was started, which was later converted into a society in February I90I, to become the second largest proBoer organisation in the Netherlands with 4,000 members. It is tempting to see the founding of the $\mathrm{CNBC}$ as being the result of pillarisation and the growing ideological divides in Dutch society. The executive committee of the CNBC explicitly stated that it would focus on the religious ties that joined the Netherlands to South Africa, which in practice meant that it only drew members from the orthodox Protestant community. There were also strong connections with the Anti-Revolutionary Party. ${ }^{4 \mathrm{I}}$ It would be going too far, however, to see this initiative as an extension of earlier attempts by the Protestant leader Abraham Kuyper to monopolise the pro-Boer movement, because he was not officially involved in the CNBC..$^{2}$ Moreover, the executive committee of the CNBC openly stated that it did not seek to replace the NZAV but to complement it. As such, it should be seen as an initiative to mobilise a sector of the population that the NZAV, which was generally seen as a Liberal bulwark, found difficult to reach. 43

The overlap between the two organisations can be illustrated by the fact that several individuals worked for both. Significantly, one of the most active members of the Св С was H. J. Emous, a well-known figure in the pro-Boer

movement. This headmaster had already been active in several subcommit- 
tees of the NZAV during the I 890 s and continued this work throughout the war and thereafter. In addition, although he was not elected, his name was on the list of candidates that stood for election to the executive committee that was chosen during the general meeting in October I900.44 After the war, he continued to be active for the NZAV, becoming a member of the committee of the Amsterdam branch in 1903 and finally being elected to the executive committee in 1906.45 In addition to this important personal link, the СBNC and the NZAV co-ordinated their efforts for humanitarian aid to the Boer war victims, a matter that will be discussed in more detail later in this chapter. This indicates that the two organisations overlapped significantly and cannot be considered to have been competitors.

Apart from the good working relation with the $\mathrm{CNBC}$, the issue of pillarisation was a difficult one for the NZAV. The first article of the society's statutes stated that it was not allowed to influence the 'moral or religious position of the population here [the Netherlands]' ${ }^{46}$ At the general meeting in May I900, during which possible changes to the statutes were discussed, this topic was not mentioned. 47 It seems probable that Kuyper had found this sentence to be a reason to once again refuse membership of the NZAV when Middelberg had invited him to do so a few months after the war had started. The Protestant leader felt that it did not offer enough of a guarantee that his denomination would be represented in the society, and he feared that the Liberals would continue to dominate. $4^{8}$

Nonetheless, the NZAV's offer to Kuyper should be seen in the context of further attempts by the executive committee to diversify its membership with members of the various different 'pillars' in the Netherlands (although the Socialists were still excluded). In the spring of $1900, \mathrm{~J}$. P. Moltzer announced that he would step down from the executive committee in order to make place for a Catholic, his colleague from the Raad van State (Privy Council), J. P. R. M. de Nerée van Babberich. ${ }^{49}$ Despite this gallant gesture and the support of the executive committee, De Nerée van Babberich was not elected in the general meeting that followed, that May. ${ }^{50}$ The following year the Catholic sector of the population was represented in the leadership of the NZAv by W. H. Nolens, a Member of Parliament. This indicates that there was an awareness amongst pro-Boers of the domestic political situation, which should be considered in the light of attempts to mobilise the broadest possible segment of the population. The sources reveal, however, that those involved had other priorities.

In the historical debate on the political and ideological background of the 
NZAV, the career of Gerrit Middelberg is often mentioned in order to illustrate ongoing Protestant involvement in the society. In I9 I 2, he resigned as president of the NZAv to lead the Anti-Revolutionary Party in Parliament, of which he had been a member since I909. ${ }^{\mathrm{I}}$ However, this account ignores Middelberg's earlier career, when he was a member of the municipal council of Zwolle for the Liberals in the I870s. It was only during his stay in Pretoria that he gradually started to change his religious and political ideas under the influence of the Boers and adopted more orthodox views. ${ }^{2}$ This did not mean that he immediately enrolled in the Anti-Revolutionary Party after his return in the Netherlands in I899. In I90I, the NZAv branch in The Hague published a circular in which it gave advice on who to vote for when choosing the executive committee, and Middelberg is listed there as a Liberal.53 Moreover, in his later life too, he considered himself to be more of a practical administrator than a political or ideological heavyweight, and his career in Parliament was short-lived.54 This indicates that Middelberg's political background was not an issue of vital importance to members of the NZAV. Rather it was his fame as a former director of NZASM in Pretoria and his apparent knowledge of the situation in South Africa that were explicitly mentioned when he was elected as chairman of the society in I 899.55 A further indication that considerations related to the local political situation were not of the highest priority to the members of the NZAV is provided by the circular from I90I mentioned above, which listed three requirements for the composition of the executive committee. These included the desirability of including persons of all political persuasions and from all the major cities. First and foremost, however, leaders of the NZAV were to be 'persons, who are thoroughly acquainted with the situation in South Africa'. ${ }^{56}$

It cannot be denied that domestic politics and the process of pillarisation were considered relevant issues by contemporary pro-Boers. In order to mobilise as much of the population as possible, the NZAV executive co-operated with the CNBC and tried to broaden the composition of its membership with people from various confessional groups and different cities. Despite these points for attention, it seems the results were mixed and that it remained a constant concern. The sources indicate, however, that there were other concerns for the leaders of the pro-Boer organisations in the Netherlands, namely keeping open the channels of information with South Africa. In this way, people with close connections to this international network had an important place within the pro-Boer movement. As has been mentioned in the previous chapter, Hollander emigrants who returned from South Africa often be- 
came active propagandists, and the diplomatic representation of the republics also generated a lot of information. In the remainder of this chapter I will assess how Dutch pro-Boer organisations related to these groups and the wider propaganda campaign in order to support the Boers in South Africa.

\section{'A campaign of the pen': the ANV press office}

The refutation of the British coverage of events in South Africa and the publication of accounts that put forward the Boers' side of the story can be considered to be an important, if not the most important, activity of the pro-Boer movement in Europe. Historians agree that Leyds propagated such views tirelessly from 1898 onwards and that his achievements on the psychological battlefield were considerable in that his efforts helped to convince the majority of people outside Great Britain that the republics' cause was just. ${ }^{57}$ The widespread sympathy for the Boers also had its disadvantages, however. At times, such as after the victories of SAR and OFs forces in December I 899, emotions became overheated and Leyds even tried to temper the euphoria. ${ }^{8}$ Another problem in this regard was that the gullible public became an easy target for impostors who tried to cash in on pro-Boer enthusiasm. Throughout the war, the SAR legation issued warnings against men who collected money by pretending to have fought for the republics or making false promises to provide aid to the embattled Boers. Some swindlers could be easily unmasked, like those who claimed to have been born in Johannesburg while the town had existed for barely a decade when the war started. ${ }^{59}$ It was, however, not always easy to distinguish between useful initiatives and harmful ones. Leyds therefore sought contact with pro-Boer organisations to help him run the propaganda campaign along what he considered to be the right lines.

One of the most important institutions in this respect was a press office created by the Algemeen Nederlandsch Verbond (General Dutch Alliance, hereafter ANV), a patriotic society that had been founded in I 896 and which was based in Dordrecht. ${ }^{6}$ In terms of membership numbers - 2,002 in I 90I - the organisation was significantly smaller than both the CNBC and the NZAV during the South African War. ${ }^{61}$ Nonetheless, its resourceful secretary H. J. Kiewiet de Jonge succeeded in making it an important feature in the pro-Boer propaganda network. His personal connection with Leyds, whom he met for the first time in the I 880 o, was quite important in this respect. ${ }^{62}$ When Leyds returned to Europe as minister plenipotentiary, the two became better acquainted, which was the start of a long and intimate friendship. ${ }^{63}$ In October 


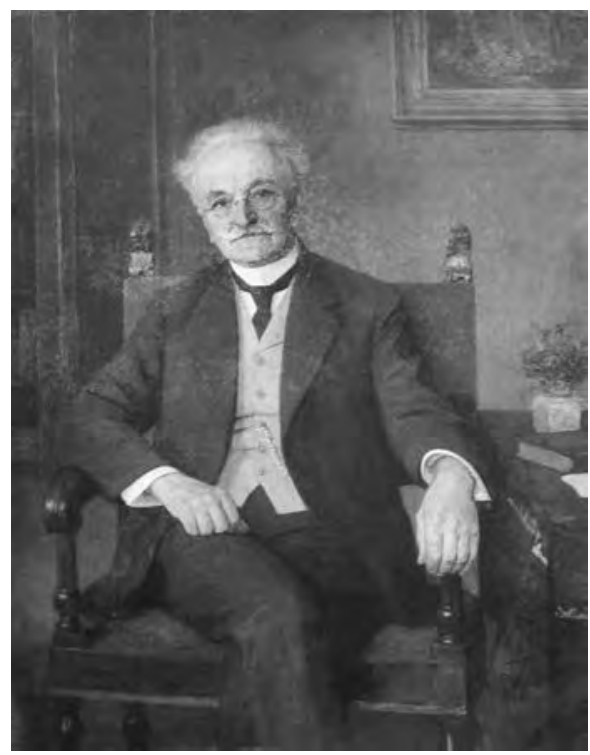

H.J. Kiewiet de Jonge (artist and year unknown).

Source: NZAV-fotoarchief, Amsterdam.

I 899, the first fruits of their collaboration became apparent when Kiewiet de Jonge proposed to set up a press office for the Boers. Leyds thought this was a splendid idea and went to Dordrecht at once to discuss the details. ${ }^{64}$

The press office became the most important pro-Boer activity of the ANV by far. It grew to be a well-known institution that gathered and distributed information that supported the Boer cause and countered the British coverage of events in South Africa. ${ }^{65}$ It made Kiewiet de Jonge a prominent figure amongst the pro-Boers, which in I 900 resulted in an invitation to join the executive committee of the NZAV on which he was to serve for decades. Kiewiet de Jonge's connections illustrate that the press office of the ANV was firmly linked to both the official Boer representatives and other organisations that propagated the concept of stamverwantschap and thus played a central role in the network that extended between South Africa and the Netherlands. ${ }^{66}$

The co-operation between the press office and the SAR legation in Brussels remained close throughout the war, and Leyds became the main source of funding. ${ }^{67}$ Initially, the ANV took over some tasks from the overburdened office of the legation in Brussels, acting as an information bureau for people in the Netherlands who wanted to know about the fate of their loved ones in South Africa. ${ }^{68}$ In addition, it began distributing press releases. ${ }^{69}$ Soon it became apparent that priority was to be given to the latter activity and the press office dedicated itself to the gathering, publication and dissemination of pro- 
pagandistic material. The first, and arguably biggest, success was the production of the pamphlet Eene eeuw van onrecht (translated as A Century of Wrong). The original Dutch text, written by the SAR State Attorney Jan Smuts, arrived in Europe in November I 899 and was translated into English, German and French. $7^{70}$ A less fortunate project, started at the end of I 899, was the publication of an address arguing for intervention to all the nations that had attended the Peace Conference in The Hague, the Beroep op de natien (Appeal to the nations). This plea was meant to be signed by dignitaries all across Europe and to be published simultaneously in different countries. However, there were problems with the collection of signatures, which led to the belated and uncoordinated publication of the pamphlet. As such, it was considered to be a fiasco by those involved. ${ }^{7 \mathrm{I}}$

Despite the varying results, the early activities of the press office were welcomed by other pro-Boer organisations. From the beginning, the NZAV saw the ANV as an ally rather than a competitor. ${ }^{72}$ This was confirmed when Kiewiet de Jonge asked for financial assistance in November I 899. His request was supported by the Utrecht branch of the NZAV. The executive committee did not agree to a monthly allowance, which the ANV asked for, because their contribution came from the funds of the NZAV itself and not from the money that was collected from the public, which was earmarked for humanitarian aid. Nevertheless, during the course of I900, fl. I0,000 was allocated to propaganda and given to the ANV press office and the Utrecht branch. ${ }^{73}$ In addition, a further fl. 2,000 was given in 1902 after a proposal from the Rotterdam and Hengelo branches. ${ }^{74}$

The co-operation between the NZAV and the ANV resulted in additional financial support for individual pamphlets, which reached a considerable international audience. One was the publication of Abraham Kuyper's article 'La crise Sud-Africaine' which first appeared in Le Revue des Deux Mondes in January I 900 . The two pro-Boer societies provided funds for the translation of the text into Dutch, German, English and Swedish. ${ }^{75}$ Also, the distribution of the three English pamphlets by Charles Boissevain - Open letter to the Duke of Devonshire, Open Letter to an American Lady and A Great Crime (an Appeal to the British Nation) - was actively supported..$^{76}$ In August I900, a joint collection was organised to raise money for a Transvaal issue of the magazine Hollandia, a periodical for Dutch emigrants, which drew much of its readership from the United States. 77 Another successful pamphlet was the one about education in the SAR, written by Nicolaas Mansvelt. With the help of Kiewiet de Jonge it was published in four languages. ${ }^{78}$ By I90I, the ANV 
press office had expanded considerably and in practice took over most of the tasks from the Utrecht branch of the NZAV, which ceased to be involved in the production of propaganda. 79

Kiewiet de Jonge was the driving force behind the activities of the ANV press office in its early years. There was only one permanent employee who did editorial work: Bas Veth, a freelance journalist and artist from Dordrecht. Otherwise, the organisation was rather unprofessional and casual. Occasionally, there was money to pay for temporary staff who took care of administrative jobs, but more often this was left to volunteers, whose amateurism at times led to frustrations. ${ }^{80}$ It seems that these activities took a heavy toll on the health of Kiewiet de Jonge, who - apart from running the press office was also headmaster of a grammar school, secretary of the regular ANV and a member of a secret committee to help volunteers who wished to go to South Africa. Just before New Year's Day of I900, he suffered a nervous breakdown. The elderly professor J. P. Moltzer, with whom he was editing the text of the Beroep op de natien at that time, noted with fatherly concern how 'it is very good for him, such a mandatory rest, after the very busy period he has been through. ${ }^{91}$

But instead of slowing down, the activities of the ANV press office only became more frenetic during the first part of I900. In April, problems with personnel grew when Veth left the press office to work for the SAR legation. ${ }^{82}$ At the same time, activities expanded rapidly, illustrated by the fact that by March I900, the costs of distributing propagandistic material had risen to a substantial sum of fl. 600 a month. ${ }^{83}$ The contributions of the NZAV and the SAR legation were no longer sufficient, so funds were secured from private donors, who Leyds suggested give their money directly to the press office. This shows how by that time the organisation was considered to be an important institution in the pro-Boer movement, which provided opportunities for a more professional approach. Kiewiet de Jonge wrote to Leyds that it had become desirable to find a permanent full-time editor for the press office, a patriot who was fully committed to the Boer cause and, most importantly, who was fully informed on South African affairs. ${ }^{84}$

A few months later, this wish was granted when Frederik Rompel took charge of the ANV press office. As has been mentioned, this former journalist of De Volksstem left the Transvaal and returned to the Netherlands after the occupation of Pretoria. ${ }^{85}$ His knowledge of the situation in the two republics was considered a great asset by Kiewiet de Jonge, who was very satisfied with his work. ${ }^{86}$ Rompel became a prolific author about the situation in 
South Africa and contributed to many magazines and newspapers. He also published several pamphlets and books, including a volume of biographies of Boer leaders that was published in Dutch, German and English and that was to become quite famous. ${ }^{87}$ In addition, he produced the bulk of other material as the editor of the press office. During the war, two press releases went out to periodicals throughout Europe every day. These newsletters mainly contained summaries of and excerpts from the most important articles that appeared in the papers. From time to time, the press office also published original material such as interviews with refugees about their experiences, letters from South Africa provided by private persons or reports from the Boer generals in the field that had been received by Leyds's office. ${ }^{88}$ The ANV also supplied information to journalists and authors of pamphlets on request. ${ }^{89}$

In this way, the press office gathered an extensive collection of pro-Boer propaganda, which Kiewiet de Jonge and Rompel tried to distribute as widely as possible. To what extent they succeeded in doing this, however, remains unanswered. Ulrich Kröll has noted that there are a number of problems in assessing the impact of their campaign. First of all, the ANV often asked the newspapers not to mention its name when they took over news from the circulars, which makes the identification of press office material difficult. It should also be borne in mind that much of the news in the circulars was 'secondhand', meaning that it was taken from other newspapers. Many of the major press offices were perfectly able to do that themselves and often had more direct sources; as will be discussed later, it seems that this was particularly the case in the Netherlands. $9^{\circ}$ Looking back on the early years of the ANV, Kiewiet de Jonge himself raised another point about the efficiency of the press office. He argued that during the South African War the organisation was too young to cope with 'an overwhelming amount of work', and that it was 'impossible to organise and manage both internally and externally at the same time'. ${ }^{91}$ In the following paragraphs, this complex question will be assessed in more detail by examining the ANV press office's relations with Dutch and international media.

Remarkably, the direct influence of the ANV press office seems to have been most limited in the Netherlands. This can be explained by the fact that public opinion there was already firmly in the Boers' favour. ${ }^{92}$ Another reason was that Dutch newspapers received a lot of information from South Africa independently. ${ }^{93}$ This seems to have made journalists in the Netherlands quite reluctant to tap into the stream of information provided by the 
ANV press office, much to the disappointment of Kiewiet de Jonge. In I900, he tried to get more material published in large national newspapers. He wrote letters in which he asked the $N R C$ if they could publish more of his articles on economics and politics, while he offered Het Algemeen Handelsblad personal accounts of war victims. ${ }^{94}$ Representatives of both papers thanked Kiewiet de Jonge cordially for his offers but wrote that they could not guarantee publication of texts provided by the ANV press office. The editor from $\mathrm{Het}$ Algemeen Handelsblad was the most frank, stating in his reply that the material was often too long to publish. 95

Kiewiet de Jonge's failure to get material from the ANV press office published in Dutch newspapers should not obscure the fact that relations between the press and the pro-Boer organisations were very good in the Netherlands. Many journalists were members of the NZAV, and newspapers already published favourable accounts of the republics in the I880s and I890s. ${ }^{96}$ Also in quantitative terms, there was an upward trend throughout this period, meaning that an increasing number of articles about South Africa was published. 97 The start of the South African War led to an unprecedented wave of news that swept the front pages of newspapers. During the years that followed, the quantity of the material that was published dropped, which can be explained by the fact that censorship was increased by the British and that it became harder for correspondents to report on the guerrilla war, which was scattered and unpredictable. Nevertheless, there seems to have been a sustained interest in South African affairs in the Dutch press up to the end of the conflict, more so than in Great Britain..$^{98}$

The sustained attention for the plight of the Boers was not simply the result of newspaper editors' efforts to capture the issues of the day. From the start of the war, they reflected on the broader meaning of their work, which was interwoven with the structure of information channels between South Africa and the Netherlands. It was embarrassing to journalists in the Netherlands that, because of the British monopoly on telegraph lines, they were dependent on sources from London for the latest news about the war. Readers were therefore explicitly warned that these reports should not be taken at face value. There was also an awareness that these telegrams were subject to censorship by the British army. From the beginning of the war, news about British successes was presented as exaggerated, while it was argued that Boer victories were structurally downplayed by official correspondents. ${ }^{99}$ But Dutch journalists did more than that: they also published alternative accounts. Although these often came from letters that reached the Netherlands weeks or 
even months after events had actually taken place, they were considered to be important, as they enabled the public to make up their own minds about what had actually happened in South Africa using information that was not provided in the British sources. In the view of several newspapermen, this was not only of significance for contemporaries but would also mean that in the future, historians would not have to depend on British sources only. ${ }^{100}$

In this sense, the activities of Dutch journalists were compatible with the work done by the ANV press office. There were therefore many positive responses to the organisation. Already in the 1890 s, some reformers within the journalists' union proposed the establishment of an institute that could refute foreign newspapers who wrote about matters that harmed the interests of the Dutch people, but this initiative did not yield any results. ${ }^{\text {IOI }}$ The ANV press office was therefore seen as a valuable contribution to public life in the Netherlands. ${ }^{102}$ In I900, one editorial entitled 'A Campaign of the Pen' praised the organisation for its work to 'explain to the people the true state of affairs'. ${ }^{103}$ There was more than just praise, however, and on several occasions the press actually did co-operate with the ANV to mobilise the public for its initiatives. In November I 899, for instance, an advertisement of Kiewiet de Jonge calling on people to forward the private correspondence they received from South Africa was published and explicitly endorsed by the editors of the $N R C .{ }^{104}$ At the same time, there was a willingness to exercise a certain degree of self-censorship, and at the request of the ANV press office, the journalists' union instructed its members to be careful with information that could expose Boer tactics. ${ }^{105}$ This shows that the fact that only a relatively small amount of press office material was published in the Dutch media was not the result of unwillingness. It was rather that newspapers in the Netherlands on their own could acquire plenty of material that supported the Boers' cause, so that they needed little help.

At first sight, the situation was quite different in other countries, so that the ANV seems to have had greater influence there. The massive number of press releases with the transcripts of pro-Boer clippings was published not only in Dutch but also in English, German and French. On one occasion, Kiewiet de Jonge was quite positive about the effect of these newsletters, which were sent to major newspapers throughout continental Europe. 'A lot of what you read in foreign periodicals, comes from us [the ANV press office]', he reported to Leyds. ${ }^{\text {Io6 }}$ But here too, assessing the true impact of the work of the press office is problematic. Besides the anonymity of the circulars and the fact that much of the material was not from original sources, it seems that Leyds himself used 
other means to counter the British coverage of the war in the continental press. He was able to reach newspapers in France and Germany through his correspondents Edgar Roëls and F. F. Eiffe respectively. ${ }^{107}$ Moreover, in August I90I another press office was established with a special focus on the Germanspeaking world, which can be seen as a competitor to the ANV.

The plan for this organisation came from P. A. Nierstrasz, who in I 896 had started a publishing house called „Nederland”, which focussed on Dutch-speaking readers outside the Netherlands and particularly in South Africa, where he opened an office in Pretoria. ${ }^{108}$ When the war started, Nierstrasz was forced to cease his activities in South Africa but became involved in the pro-Boer propaganda campaign in Europe. One of his most noticeable contributions was the Transvaal issue of Hollandia, a magazine that was owned by the publisher. Another remarkable project was a series of postcards featuring famous photographs of the war, which were sold to raise money for pro-Boer charities. ${ }^{109}$ On the surface, it appeared as if relations between Nierstrasz and the ANV were quite good. „Nederland” published the periodical of the organisation, Neerlandia, and also the German translation of Rompel's book with biographies of Boer heroes. On closer inspection, however, there seems to have been great personal animosity between Nierstrasz and the editor of the ANV press office, information which reached Leyds as gossip. ${ }^{\text {IIO }}$ These tensions manifested themselves more clearly when Nierstrasz started his own press office, funded by the SAR legation.

In August 1901, Leyds gave Nierstrasz the green light to start with a new press agency that would focus on the German-speaking world - Die Correspondenz ,Nederland”, a name that shows the strong link with Nierstrasz's publishing house. ${ }^{I I I}$ In a report on its first year, the publisher rubbished the activities of the ANV press office in Germany, Austria, Switzerland and Russia. According to the report, the circulars from Dordrecht were amateurish and because of their poor style and sensationalism ended up in the wastepaper baskets of serious newspapers without being read. 'Evidently, being a proBoer does not involve being a journalist, politician or diplomat!', Nierstrasz fumed. ${ }^{\text {II } 2}$

It is hard to discern Leyds's personal opinion on the matter, as he barely reflected on the activities of the ANV press office and Die Correspondenz ,Nederland". What is clear is that he lavishly supported Nierstrasz's initiative from his secret funds. In April I902, his secretary Dirk Balfourt, who co-ordinated these payments, complained about the great expenses of this press office, which by then had received - and spent - fl. 26,222. ${ }^{\text {II3 }}$ Subsequently, a 
new agreement was signed in which Nierstrasz promised that he would cut costs by no longer sending expensive telegrams and sticking to printed material only. ${ }^{I 4} 4$ The war ended soon after this arrangement was made, but Nierstrasz continued to work for Leyds, who forwarded him substantial sums of money in the years that followed to cover his high expenses. Only in I905, when the „Nederland" publishing house went bankrupt, were these ties cut. $^{\text {II }}{ }^{15}$

It remains difficult to get a sense of the real effects of the activities of the pro-Boer press offices on the European continent. In the end it seems that Nierstrasz mainly denounced the ANV press office in order to obtain funding from the SAR legation. On the other hand, his report might point to more fundamental problems that pro-Boer organisations grappled with in their attempts to get material published in newspapers. These were the result of a lack of professionalism and the fact that their contacts were often informal. The ANV press office encountered these kinds of problems - and worse - with its activities in Great Britain. Still, the London bureau was the only office outside Dordrecht that remained open after I902. This would suggest that its activities were considered to be the most important by those involved.

Besides trying to influence the continental press, the ANV press office aimed its arrows directly at British public opinion. To that end, contact was made with correspondents for Dutch newspapers in London. They informed the ANV about public opinion on the war and helped them to distribute material amongst opinion makers in Great Britain such as members of the press, political elites and the clergy. ${ }^{116}$ More structural contacts were established in May I90I when Kiewiet de Jonge was approached by M. van Beek, a Dutch translator and private tutor in London, who was working for the most prominent British organisation that protested against the war in South Africa, the Stop the War Committee. In his function for the so-called 'literature department', he had a close relationship with Harold Rylett, the editor of the radical magazine New Age. ${ }^{\mathrm{II} 7}$ It was arranged that the ANV would start correspondence with Van Beek in which they were to exchange material that could be used in their respective campaigns. Moreover, the ANV channelled a monthly subsidy of $E$ Io, which was raised by a small group of people in the Netherlands. ${ }^{\text {I } 8}$ Absolute secrecy was needed because Van Beek feared that if it became known that he, being a Dutch citizen, was working for the Stop the War Committee, 'surely they [the jingos] would have lynched me as one of "Leyds's or Kruger's spies" and tried to storm our offices'. ${ }^{\text {I19 }}$ Despite all this secrecy, the ANV press office and Van Beek were in regular contact with one 
another, and much information about pro-Boer agitation in Britain reached the Netherlands from this source. ${ }^{\mathrm{I} 20}$

As is the case with other activities of the ANV, it is difficult to assess the effects of this contact. On several occasions, the press office released public statements that there were signs that public opinion in Britain was shifting. ${ }^{\mathrm{III}}$ In letters to Leyds, however, Kiewiet de Jonge was critical about the results, which were hampered because of the discretion that had to be observed in contacts with anti-war propagandists in Great Britain. ${ }^{\mathrm{I} 22}$ Moreover, he did not expect that the British public would be open to their views because it was so 'biased and partial'. ${ }^{123}$ Nevertheless, the ANV press office remained active in Britain after the war and, with Leyds's backing, employed freelance correspondents in London at least until the start of the First World War. Their main task was to act as liaisons of the Dutch-speaking press in South Africa by writing reports about how the British newspapers covered South African affairs and by circulating material that supported the Afrikaner cause. ${ }^{\mathrm{I} 24}$ It therefore seems that the activities of the ANV in Great Britain, although they were performed under a cloak of secrecy, lasted the longest.

The ANV press office played a central role in the propaganda campaign during the South African War. It had close connections with both the SAR legation and the NZAV, and as such handled a lot of information that reached Europe via the pro-Boers' lines of communication and turned it into publications. It remains hard to assess the actual effects of this work. On the one hand, it led to the distribution of some of the most famous pamphlets, which were read in substantial numbers. On the other hand, it seems that the informal nature of the office and its haphazard way of working limited its efficiency considerably. Moreover, it is unlikely that newspapers depended on Rompel's press releases, and it remains unknown how much was actually published from them. Nevertheless, contemporaries did express appreciation for the activities of the ANV press office. At that time, there was no other similar organisation in the Netherlands that was trying to feed the international media with material that supported the interests of the Dutch as a race. The case of the ANV press office shows that the pro-Boer movement in the Netherlands actively reflected on the growing importance of mass media and tried to develop institutions that could manage the flow of propagandistic material. Such awareness was also apparent in other aspects of the pro-Boer campaign, which will be discussed below. 


\section{'Practical support' or 'impractical plans': emigration schemes}

A remarkable development during the early stages of the war was the increase in initiatives to promote emigration to South Africa. Before the fighting started, the emigration committee of the NZAV reported a sharp drop in the number of people that wanted to go to South Africa: just I4 people showed interest that year. ${ }^{\mathrm{I} 25}$ The successes of the Boer commandos against the British army in the Northern Cape and Natal in December I 899 led to a wave of euphoria amongst the Dutch public, which temporarily changed this situation. In January I900, the emigration committee received letters from I34 people who wished to settle in the republics because they anticipated that overall victory for the Boers would soon follow. Considering the dangerous situation there, they were advised not to go, but seven adventurers went to South Africa on their own accord. After the British victories of February I 900 , the enthusiasm waned again and the emigration committee changed its priorities to helping people that returned from South Africa. ${ }^{\mathrm{I} 26}$ The prudent attitude of the NZAV emigration commission towards potential settlers during the early stages of the war was in line with the policy of the Boers' official representatives. Willem Leyds often complained about what he considered to be an exaggeratedly optimistic mood in the Netherlands after the first battles. ${ }^{127} \mathrm{He}$ advised against emigration to the republics because the majority of settlers would be hindrances to the commandos rather than useful helpers. Only people who could contribute to the war effort, particularly artillery officers and couriers, were assisted by the SAR legation.

There were, however, people who thought differently about these matters. In December I 899, W. P. Noëls van Wageningen, the director of the Bataafsche bank in Amsterdam, founded a pro-Boer organisation that promised 'practical support' to the Boer republics - the fonds tot daadwerkelijken steun. Its main aim was to recruit 'strong young men' who could take over the work of 'the housefathers, who went to war and died defending the independence of their nation'. ${ }^{\mathrm{I} 28}$ Because of the neutrality of the Netherlands, they could not replace them on the battlefields but could take over other tasks on the farms and in the towns. Noëls van Wageningen saw advantages for those who went immediately, as they would have a head start on settlers from other countries, who were expected to flock to the Boer republics when the fighting was over. The fonds tot daadwerkelijken steun asked the public for money to pay for the journey, equipment and a guide so that they could reach the Boers safely. ${ }^{\mathrm{I} 29}$ In a prospectus, it was announced that 500 men had regis- 
tered for assistance, of which around twenty people had been selected for a first expedition led by J. H. Junius, a former inhabitant of landlocked Transvaal who claimed to be a naval officer. ${ }^{\mathrm{I}}{ }^{\circ}$ In addition to the emigration scheme, Noëls van Wageningen published a periodical, Op! Voor Transvaal. This magazine is known amongst literary historians for its doggerel, mainly written by the ultra-Calvinist author Willem Zuidema. ${ }^{\text {I3 I }}$ Apart from providing its readers with mediocre rhymes, Op! Voor Transvaal also tried to mobilise support for Noëls van Wageningen's emigration scheme with fiery editorials. ${ }^{\mathrm{I} 2}$

From the start, the initiative of the fonds tot daadwerkelijken steun was received cautiously by influential figures within the pro-Boer movement. After a meeting with Noëls van Wageningen and Junius, Leyds wrote a letter to the government in Pretoria in which he mentioned the scheme. He announced that he had carefully expressed doubts about the Junius expedition but that he was unable to stop it because he did not want to endanger the goodwill towards the Boer cause. This, he continued, was an example of a wider problem - namely how to deal with the massive support for the Transvaal.

It is often difficult to lead the enthusiasm of the public in Europe, that eagerly wants to do something for the Republic [SAR], along the right lines, and in many cases it brings forth the most impractical plans. And because the plans are often executed before the people who know something about the Republic are consulted, it is often difficult to answer them, as one does not want to insult the people or pour cold water on their enthusiasm. ${ }^{\mathrm{I} 33}$

The ofs Consul-General Muller also expressed his doubts when he met the delegation of the fonds tot daadwerkelijken steun. This did not stop Noëls van Wageningen from claiming in Op! Voor Transvaal that both of them had been informed about the scheme from the start and pledged their full support. Muller replied with a letter in which he complained about that statement. ${ }^{\text {I } 34}$ The next month, the two representatives of the Boer republics discussed whether they should tolerate the emigration scheme any longer. ${ }^{\mathrm{I}} 35$ Leyds ended the silence. In an interview that appeared in the newspaper Het Vaderland of I6 March I900, he openly declared that neither he nor Muller had supported the foundation of the fonds tot daadwerkelijken steun. Although he was not against the idea of emigration to South Africa in principle, he doubted whether the Boers actually needed new settlers who had limited knowledge of South Africa at that time. He added that he had advised the Junius ex- 
pedition, which by then had already left, to wait until more information was available about the situation in the region and the prospects for settlement. ${ }^{136}$ Noëls van Wageningen responded with a memorandum to the editors of all Dutch newspapers, in which he insisted that there had been sustained contact between him and both Leyds and Muller, and that there had been several meetings to discuss the details of the scheme. ${ }^{\mathrm{I} 37}$

This led to growing suspicion amongst other pro-Boers not only about the plans but also about the credibility of Noëls van Wageningen himself. The young civil servant Frans Beelaerts van Blokland started a campaign against the fonds tot daadwerkelijken steun. He himself was involved in many different pro-Boer initiatives, including a committee that secretly supported volunteers who wanted to go to South Africa to join the republican forces. After these activities were exposed in the press, Beelaerts van Blokland took upon himself the task of informing the public about emigration to South Africa in general. Via an old friend from university, he found out that Noëls van Wageningen had circulated lists with names of people who he claimed were active supporters of his scheme but in fact had only received a prospectus. ${ }^{138}$ Subsequently, Beelaerts van Blokland started to compile a dossier on the career of Noëls van Wageningen, asking various people from the financial world for information.

It appeared that Noëls van Wageningen's claims that he was a banker were true, but several of his colleagues reported that his business was moribund and that there were persistent rumours that he had been accused of fraud on several occasions, which had led to his dismissal from other positions. Some informants even claimed that 'Noëls' had been added to Van Wageningen's surname recently. ${ }^{139}$ Beelaerts van Blokland did not keep this information to himself. He wrote to several individuals who were associated with the fonds tot daadwerkelijken steun and told them, which led to their withdrawal from the organisation..$^{\mathrm{I}}{ }^{\circ} \mathrm{He}$ also warned them against other people involved in the fonds tot daadwerkelijken steun, such as Zuidema, whom he described as 'a man who had gone stark raving mad because of his hate of papists'. ${ }^{\mathrm{I}}{ }^{\mathrm{I}}$

In addition, Beelaerts van Blokland undertook action to warn the general public against Noëls van Wageningen and his plans. He did so in co-operation with Bas Veth, who at that time still worked for the ANV press office. They decided that the most authoritative statements against the fonds tot daadwerkelijken steun were provided by Leyds's interview in Het Vaderland. This article was therefore published as a leaflet by the ANV and sent to 568 periodicals, together with a reference to Beelaert van Blokland's emigration 
committee in The Hague. ${ }^{\mathrm{I} 22}$ In response, Noëls van Wageningen published a circular in which he accused the ANV of waging a campaign against him. ${ }^{\mathrm{I}}{ }^{43}$ Kiewiet de Jonge was at first alarmed by this pamphlet and asked Veth to publish and distribute Noëls van Wageningen's side of the story in order to refute his allegations about the partiality of the ANV. Veth managed to change Kiewiet de Jonge's mind, explaining that Leyds and Muller both agreed that the press office fulfilled a useful task by 'informing the public when it is at risk, while at the same time referring to an institution where it can obtain truthful information'. ${ }^{\text {I4 }}$

In April I900, evidence from South Africa arrived that proved that the scheme of Noëls van Wageningen was unrealistic if not downright fraudulent. Newspapers published a letter by one of the men who had joined the Junius expedition. He described how, on arrival in South Africa, he and his fellow emigrants were forced to join the Boer forces despite the promises that they were going to do peaceful work. Moreover, the unfortunate adventurers had to pay the largest share of the costs of the voyage themselves. ${ }^{\text {I } 45}$ Another letter from Pretoria mentioned the arrival of the ragged members of the Junius expedition, who were supported by a local charity and so wasted money that should have been spent on the Boers themselves. ${ }^{\mathrm{I}}{ }^{6}$ This information effectively meant the end of the fonds tot daadwerkelijken steun, which disappeared from the annals of the pro-Boer movement. ${ }^{\mathrm{I} 77}$ Likewise, the magazine Op! Voor Transvaal did not survive I900, and the last issue appeared in December of that year. It appears that Noëls van Wageningen himself was ruined too, and in March 1902, he received a three-year jail sentence for fraud while working as the director of a chemical factory. ${ }^{148}$ In this sense, the campaign by Beelaerts van Blokland to warn the public against the dubious emigration scheme of the fonds tot daarwerkelijke steun was successful. At the same time, he was also involved in attempts to create another organisation, which became an instrument for the Boer representatives and the NZAV to inform the public about their views on the matter.

In December I 899, another new organisation to promote emigration was founded: the Nederlandsche Emigratie-Maatschappij voor Transvaal en Oranje Vrijstaat (Dutch Emigration Company for the Transvaal and the Orange Free State, hereafter NEM). It had similar goals as the fonds tot daadwerkelijken steun - namely to support emigrants going to South Africa and thereby help to continue the presence of the Dutch race in that part of the world. Another similarity between the two organisations was that no military goals were pursued: it was asserted that the Boer republics needed farm- 
ers, artisans and entrepreneurs to keep daily life going. ${ }^{I 49}$ The main difference was that the NEM was set up as an investment company that offered loans and was not involved in the actual itineraries. The main initiator of this project, the financial journalist Otto Kamerlingh Onnes, emphasised the businesslike approach of the organisation, which tried to secure funds by selling stocks instead of asking the public for donations. ${ }^{150}$ Another difference with the scheme of Noëls van Wageningen was that the relationship between the NEM and other pro-Boer organisations were much better. At a meeting of shareholders on I9 March 1900, Gerrit Vissering, a prominent banker from Amsterdam, proposed that more co-operation was needed with the NZAV of which he himself was a member. The underlying idea was that, in this way, the emigration company would be able to work together with people who 'possessed sufficient knowledge of Africa and enough trust in the Netherlands.' ${ }^{5 \mathrm{I}}$

In April, negotiations between the NZAV and the executive of the NEM started. Kamerlingh Onnes wanted to make arrangements for the society to appoint two members to the board of the emigration company. Middelberg, however, refused to approve the resolutions, which led to a delay. ${ }^{152}$ In May, another proposal was made, but when Beelaerts van Blokland was consulted, he was 'not entirely positive' either. ${ }^{153}$ This cool attitude indicates that both Middelberg and Beelaerts van Blokland wanted to have a strong influence in the organisation in order to ensure that no further rash adventures were undertaken. Eventually this led to the establishment of a new conglomerate organisation, De Nederlandsche Maatschappij tot Handhaving van Stamverwante Belangen in Zuid-Afrika, which incorporated the NEM. Kamerlingh Onnes was appointed as president and Beelaerts van Blokland sat on the board of directors as a representative of the NZAV.

The prospectus of the new company indicated a radical change in its objectives. It was argued that the initial foundation of the NEM was to be considered the result of the 'electric shock' that had gone through the Netherlands after the outbreak of war, which led to '[s]pontaneous manifestations of a completely diverse nature'. ${ }^{\mathrm{I}}{ }^{4}$ However, further analysis led to the view that the initial plan to help Dutch people emigrate to South Africa would probably be an extra burden on the Boers. Considering the advance of the British army, priority was given to aid for refugees, which, it was argued, would be far more effective for the time being. Looking at the technical aspects of the statutes, the company retained its businesslike approach as a loans bank, but it co-operated with the NZAV in selecting the most feasible initiatives and suit- 
able individuals to strengthen the 'rational development of Dutch interests'. ${ }^{155}$ In addition, the money was distributed by the established subcommittees of the society. ${ }^{156}$ In this way, the new company was in keeping with the policy that was laid out by the emigration committee of the NZAV and the official representatives of the Boer republics.

The cases of the fonds tot daadwerkelijken steun and the NEM show that prominent pro-Boers intervened at times in order to protect the public from what they saw as misinformation about the situation in South Africa. It was not always easy to assess the value of initiatives, especially during the hectic first few months of the war, when public opinion was all ablaze. In this electric atmosphere, emigration plans were temporarily met with a strong response, which led to some unrealistic initiatives such as the one by Noëls van Wageningen. At first, the Boer representatives were very cautious not to insult him, but he lost their goodwill by making false claims about their unconditional support. Beelaerts van Blokland took it upon himself to start a publicity campaign, which eventually ruined the fonds tot daadwerkelijken steun. The case of the NEM was different, because it had far better contacts with the established pro-Boer organisations. Still, Middelberg and Beelaerts van Blokland took no risks and replaced it with a new company with strong institutional links to the NZAV in order to secure control. This led to a revision of the company's goals and instead of helping people to emigrate, it focussed on refugees coming from South Africa. This change is illustrative of the response of the pro-Boers in the Netherlands to developments in the war

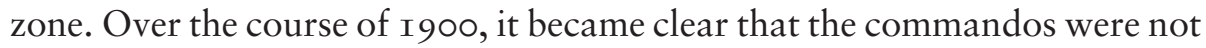
going to be able to keep the British army at bay, which was confirmed by the occupation of Bloemfontein and Pretoria. Hopes of a swift victory melted away, and instead priority was given to initiatives that would relieve the immediate suffering of the Boer population. The following section will explore how these humanitarian efforts were organised.

\section{Fundraising}

One of the most tangible results of the public enthusiasm for the Boers in the Netherlands was the money that was raised for humanitarian aid to the war victims in the two Boer republics. Looking at the figures of the most important Dutch pro-Boer organisations, it can be concluded that they received around fl.r. 8 million for that purpose. The NZAV's bulpfonds collected fl. I.4 million of that sum, which confirms the prominence of the society in the 
Netherlands. ${ }^{157}$ On the whole, contemporaries considered the results of the collections in the Netherlands to be a great success, and it was emphasised that many segments of the population contributed to the efforts to relieve the suffering of the Boers. Throughout the war, individuals from all walks of life organised fundraising events such as bazaars, charity shops and lecture tours. ${ }^{158}$ Even children did their bit, like the boy who collected fl. I2.50 for the war victims at his sixth birthday party. ${ }^{\mathrm{I} 99}$ Similarly, Leyds instructed his wife not to buy their children presents for the celebrations of St. Nicolas in December I90I and instead to donate the money to the funds for the women and children in the concentration camps. ${ }^{160}$

Despite the apparent satisfaction amongst those involved, the Dutch donations were dwarfed by the sum that was raised in Great Britain for war charity. There, approximately $£ 6$ million (at that time about fl. 72 million) was collected by non-governmental organisations for humanitarian aid to the dependents of the 22,000 fallen soldiers and 75,000 injured veterans for whom little state care was arranged. ${ }^{\mathrm{I} 6 \mathrm{I}}$ Andrew Thompson demonstrates that the success of this collection was far greater than those held during other colonial wars, which he attributes to the great media exposure of the South African War and the fact that an effective network of philanthropic organisations had come into being nationwide. ${ }^{162}$ This indicates that the organisation of fundraising was an important aspect of its overall success, something that was keenly felt by contemporaries, also in the Netherlands. The widespread enthusiasm of the Dutch public raised concerns amongst pro-Boers about the proper management and efficiency of collections. One particular difficulty was seen to be the fragmentation of the initiatives to raise and distribute money to help the Boers. Although pro-Boer organisations tried to hide this problem behind a façade of unity, it was exposed on occasion. Prominent members of the NZAV therefore undertook attempts to centralise these efforts and so to maximise the effects of the pro-Boer propaganda campaign.

The NZAV clearly put itself forward as the dominant organisation in the coordination of collecting money for the Boers in the Netherlands from the beginning of the war. On Io October I 899, it published a confidential circular about the plans for a new hulpfonds which, amongst other things, mentioned the need to send ambulances with the mediation of the Dutch Red Cross. ${ }^{\text {I63 }}$ This remark was not appreciated by the executive committee of that organisation, which was about to start its own campaign to raise money for its activities in South Africa. The efforts of the NZAV were considered harmful in particular, because the readers of the circular could conclude that the pro-Boer 
society was connected to the work of the Red Cross, which would give the impression that its independence and neutrality, the founding principles of the Geneva Convention, were imperilled. ${ }^{164}$ The NZAV replied with a cheque of $£_{4,000}$ (about fl. 48,000) and a pledge of a substantial amount of medical supplies, which, according to another circular, were meant to remove all doubts concerning the good relationship between the two organisations. ${ }^{\text {I65 }}$

Nonetheless, tensions continued to rise during the next few months because the successful collections of the NZAV obscured the campaign by the Red Cross. Some of these grudges spilled over into the pages of newspapers, when local committees of the Red Cross complained about the dominant presence of the pro-Boer society in the public sphere, overshadowing other initiatives that aimed to raise money for the republics. ${ }^{166}$ In December I 899, the conflict flared up once again when the president of the Dutch Red Cross re-asserted its independence from the NZAV in a letter to the executive committee. Furthermore, he remarked bitterly how in several places NZAV members had 'publicly thwarted donations to the Dutch Red Cross' ${ }^{\text {I67 }}$ Although he expressed great personal sympathy for the NZAV and what it stood for, he wrote that these incidents had made it necessary for the Red Cross to distance itself from the NZAV. ${ }^{168}$ In an agitated reply, Middelberg denied the 'improper' use of the name of the Red Cross and even threatened to withdraw the donation of $£ 4,000 .{ }^{\text {I } 69}$ This threat was not carried out, and in total the NZAV donated approximately fl. 80,000 to the Red Cross for its work in South Africa during the war.

There remained a measure of mutual resentment, however, and relations between the two organisations remained strained. In January I900, there was controversy over a donation by Dutch emigrants in the US, part of which ended up with the NZAV. The treasurer of the Red Cross published a letter in the newspapers in which he demanded that the whole sum be handed over to the Red Cross. Although the NZAV was of the opinion that this was not in line with the instructions from the US, the money was remitted in order to avoid more 'envy'. ${ }^{170}$ In a private letter, the treasurer of the Red Cross wrote that he had not meant to cause any hard feelings but at the same time repeated the accusation that the NZAV had started the trouble with the circular of October I 899. ${ }^{\text {I7I }}$ The harmful effects of the NZAV circular were also reiterated in the official report on the activities of the Dutch Red Cross published in October I90I. ${ }^{172}$ This issue even led to an exchange of angry letters between the presidents of the two organisations in the national press. ${ }^{\mathrm{I}}{ } 3$

Despite the fact that it was fought out in public at times, the polemic with 
the Red Cross did not challenge the prominence of the NZAV fundraising campaign for South Africa. The society also took a leading position in the network that provided aid to the Boer war victims, which raised another difficult question: how was the money to be properly spent? To increase efficiency, a dependable corresponding institution in South Africa was considered to be necessary. Middelberg therefore responded enthusiastically when in January I900, J. A. van Kretschmar van Veen wrote to him from Pretoria with the proposal of starting a local organisation that could distribute money collected in the Netherlands - Het Nederlandsch Bijstandsfonds voor Zuid-Afrika (The Dutch Assistance Fund for South Africa). ${ }^{174}$ Initially, the central committee was based in Pretoria and consisted of ten members - seven Hollanders chosen by the NZAV and three Boers appointed by the government of the SAR. Van Kretschmar van Veen acted as chairman. In addition, a subcommittee was established in Bloemfontein which consisted of six members, including several emigrants with roots in the Netherlands. ${ }^{175}$

The occupation of Pretoria, in June I900, affected the Bijstandsfonds significantly. Several Hollander members of the central committee returned to the Netherlands, including Van Kretschmar van Veen. These new circumstances meant that the ties between the Bijstandsfonds and the NZAV became much closer, and delegates of the two organisations met weekly. Even more illustrative of this close relationship is the fact that Van Kretschmar van Veen joined the executive of the NZAv. Members of the Bijstandsfonds in Pretoria (eight in January I902) implemented the policy set out by the delegates in Amsterdam. ${ }^{176}$ The occupation of the Boer republics also caused problems for the Bijstandsfonds because it was initially founded as a semi-official institution that had to account to the Boer governments, which by then had moved into the field. To avoid British interference, the Bijstandsfonds changed its constitution, making it a private charity. The subcommittee in Bloemfontein, however, reported that the military authorities there demanded more influence, and they proposed that British representatives be invited to join the organisation in order to avoid trouble in the future. This plan was resolutely opposed by the Pretoria committee, who even declared that they considered the Bloemfontein subcommittee to be dissolved. ${ }^{177}$ In the end it continued to exist, but only with two members. ${ }^{178}$

Not only the legal status of the Bijstandsfonds changed over the course of the war, also its objectives had to be adapted. The main purpose of the organisation was to provide help to the Boer war victims, which Van Kretschmar van Veen initially expected would not be necessary until after the hostilities 
had ceased. ${ }^{179}$ As the war lingered on, however, conditions amongst the civilian population deteriorated and a large part of the collected money was spent forthwith. With instructions from Amsterdam, the Bijstandsfonds committee in Pretoria co-ordinated the distribution of Dutch humanitarian aid in the whole of South Africa and set up local committees in concentration camps. ${ }^{\mathrm{I}} \textrm{ } 0$ This policy was not uncontested. In I90I, B. A. P. van Dam, a former inhabitant of the OFs who had returned to the Netherlands, wrote several letters in which he complained about the lack of knowledge about his former country of residence amongst the delegates of the Bijstandsfonds and the executive committee of the NZAV. He argued that money should be saved to help the veterans and widows after the war instead of spending it on the people in the camps, who were receiving enough help from the British. 'At the moment people are generously throwing the money into a bottomless pit.' ${ }^{\text {I8I }}$ Van Kretschmar van Veen refuted these allegations, claiming that influential people in South Africa applauded the immediate action of the Bijstandsfonds. Moreover, he continued, the situation in the camps had made it necessary for money to be spent there from a humanitarian point of view. ${ }^{\mathrm{I} 2}$

Another complaint that came from Bloemfontein was that most of the money went to the Transvaal, while the situation in the Orange River Colony was at least as dramatic. ${ }^{183}$ This reproach was not new to the NZAV: at the beginning of the war, of S consul-general Muller already complained about the society's perceived favouritism. ${ }^{184}$ In I90 I, he again asked the executive committee to look at this problem with reference to the letter from the Bloemfontein subcommittee, expressing the hope that an 'arrangement' could be reached so that more money went to Bloemfontein. ${ }^{185}$ Van Dam was less diplomatic and wrote bluntly, 'Mr. v. Kr. [Van Kretschmar van Veen] takes care of Transvaal. What does the executive committee [of the NZAV] do for the Free State?' 186 Such remarks point to ongoing concerns by representatives of the OFs that the Transvaal was eclipsing its sister republic in the propaganda campaign for the Boers in Europe. ${ }^{187}$ Although the NZAV, together with the Transvaal representatives, argued that no distinctions were made between the two republics, this issue seems to have caused significant tensions throughout the war and even thereafter. In addition to these continual internal problems, there were also external factors that caused concerns amongst the leaders of the NZAV about the effectiveness of their efforts to provide humanitarian aid to the Boers.

During the South African War, there was a proliferation of activities in the Netherlands to collect money for victims of the war. Several of these initia- 
tives grew into charities that set up their own network for distributing aid to destitute Boers all over the world. On the territory of the former republics, the Bijstandsfonds was dominant, but there was also attention for people outside the war zone. In Cape Town, the Dutch consul-general B. H. de Waal coordinated aid to POw camps on St. Helena and the Bermudas. Another important agent who distributed humanitarian aid to several places inside and outside South Africa was Marie Koopmans-De Wet, a famous figure in the Cape elite who also had warm ties with several prominent pro-Boers in the Netherlands, which had been the country of birth of her late husband. ${ }^{88}$ Inhabitants of the former republics who ended up in Europe also received help. The CNBC took care of Boer refugees who had been transported from Delagoa Bay to Portugal. It also ran a shelter for Afrikaners in Amsterdam. There was also much attention for the fate of the Hollanders who had been extradited from the Transvaal by the British authorities. This group organised itself into a committee that demanded compensation from the British, which was awarded after intervention by the Dutch government. ${ }^{189}$ Other former administrators received money from the SAR legation. The elitist Transvaal Comité in Amsterdam took care of the families of those fathers who had remained in South Africa or had been imprisoned. ${ }^{190}$

These various initiatives and organisations made it hard to keep an overview of all the activities that were undertaken, so further co-ordination of the humanitarian aid to the Boers became desirable. Once again, it was Van Kretschmar van Veen who took the lead in the efforts to centralise these initiatives on his return to the Netherlands. In May I90 I, a circular was sent out to all known pro-Boer organisations in the Netherlands, signed by the executive committee of the NZAV and the delegates of the Bijstandsfonds. It was asserted that because of the great need for aid, 'the energy and dedication of more than a few' were needed. ${ }^{\mathrm{I} 9 \mathrm{I}}$ The decentralisation that had accompanied the abundance of initiatives had clear disadvantages, however, because some individuals received money from different sources at the same time and 'people who are less needy did not hesitate to make all too eager use of this' ${ }^{192}$ It was therefore proposed that a joint meeting with the representatives of proBoer organisations be organised to discuss who would take care of what tasks. In order not to inhibit the spontaneity, the independence of the various organisations was guaranteed. ${ }^{193}$ This meeting came to be the so-called Vereenigde Comités voor de noodlijdenden ten gevolge van den ZuidAfrikaanschen oorlog (United Committees for the needy due to the South African war), a platform in which eleven of the most important pro-Boer or- 
ganisations participated. ${ }^{\mathrm{I} 94}$ Representatives from all these organisations met once a month, with Middelberg acting as chairman and Van Kretschmar van Veen as secretary. These two men also had weekly meetings with the leaders of the most important pro-Boer charities. ${ }^{195}$

It appears that the Vereenigde Comités contributed to a more effective management of the humanitarian aid to the Boers in South Africa and elsewhere. In the annual report of the NZAV, it was noted that the administration of the network was run at much lower costs. ${ }^{196}$ Another effect of the centralisation of the pro-Boer organisations in the Netherlands was that local charities in South Africa were asked to submit reports on how they spent their money. In this way, a substantial number of letters about the situation in the concentration camps was gathered. It seems that the co-ordination of this activity was left to H. J. Emous who, as a founding member of the CNBC, attended the weekly meetings of the Vereenigde Comités. ${ }^{\text {I97 }}$ Emous sent extracts of the reports to the Dutch press and thus tried to expose the 'hypocritical violence on the part of England'. ${ }^{198}$ Throughout the second half of I90I, newspapers published summaries of reports in which the hardships of the people in the camps were mentioned; the more positive ones were left out. When it appeared, early in I902, that the situation in the camps had improved structurally, these reports disappeared from the pages of the press. ${ }^{199}$

Encouraged by the apparent success of the Vereenigde Comites in the Netherlands, Van Kretschmar van Veen tried to extend its activities to other European countries. A circular was sent to the large foreign pro-Boer organisations in which they were asked to join the platform and make money available for the Bijstandsfonds. Despite the fact that Leyds endorsed this initiative, it did not have significant results. Some organisations donated a bit of money and others asked for information about the situation in South Africa, but none of them joined the Vereenigde Comités. ${ }^{200}$ Another initiative to integrate the pro-Boer organisations on the European continent was taken by Kiewiet de Jonge and the French senator Louis Pauliat. In March I90I, they organised an international conference in Paris after which the Union federative internationale pour l'indépendence des Boers (International Union for the independence of the Boers) was founded. ${ }^{20 I}$ But this committee lacked clout too, and aside from a few individual successes such as the lecture tour by the former SAR administrator C. G. S. Sandberg in France, it was not able to co-ordinate many activities in other European countries. ${ }^{202}$ These examples suggest that the influence of Dutch pro-Boer organisations was not great enough beyond the borders of the Netherlands to mobilise foreign funds for 
their own efforts to provide humanitarian aid to the victims of the war in South Africa.

It has been argued in this section that the collections for the Boers should be seen in the light of more general issues that arose from the pro-Boer propaganda campaign. Contemporaries grappled with questions on how to mobilise the public and how to maximise the effects of the money they spent on humanitarian aid. From the start of the conflict, the NZAV tried to assert its position as the most prominent organisation providing aid to the Boers by starting the hulpfonds and the Bijstandsfonds. Although there can be no doubt that these were important institutions, there was also controversy surrounding the way in which they operated. The Red Cross, for example, considered the NZAV collections to be harmful to its own activities to raise funds. Moreover, there was internal criticism on how the aid was distributed. Representatives of the Bijstandsfonds in the ofs objected to the fact that so much money was spent on direct aid to the concentration camps, while they felt that it should be saved for after the war to help with reconstruction. In addition, they accused Van Kretschmar van Veen of favouring Transvaal charities. Such tensions, in combination with the chaotic state of affairs resulting from the proliferation of organisations that collected money for the Boers, made it desirable to centralise these efforts. This was achieved in the Netherlands by the Vereenigde Comités, a platform for all major pro-Boer charities. This institution succeeded in lowering administration costs during the second half of I90I and also provided the press with material about the concentration camps. But the domestic success of this plan could not be repeated on an international level, which indicates that the influence of the Dutch pro-Boer agitation was limited.

\section{Conclusion}

The enormous enthusiasm for the stamverwanten that resounded through the Netherlands in the years around I900 was apparent to contemporaries, just as it is to historians today. But contrary to what one might think, such public emotions were not always considered unproblematic by the leaders of the pro-Boer movement. Established bodies such as the legation of the SAR and the NZAV tried to direct public enthusiasm, claiming that they were best equipped to take care of the needs of the Boers. They were aware of the limited options of the Netherlands as a neutral nation, a principle that they generally accepted. Moreover, domestic issues such as regional rivalry and pillari- 
sation were seen as factors that influenced the effective mobilisation of the public for the Boer cause. It has been argued in this chapter, however, that these considerations did not play as dominant a role in the propaganda campaign as has been suggested by some historians. First and foremost, the proBoers' priority was the management of the lines of communication that extended between South Africa and the Netherlands in order to provide an alternative to the British coverage of the South African War and to generate material support for the embattled republics. At times, the massive public enthusiasm was considered to be problematic in this respect because the established pro-Boer institutions lacked a clear overview of all the spontaneous outbursts of sympathy, which made it hard to distinguish between useful initiatives and harmful ones. This is why several organisations were founded during the course of the war in order to streamline efforts to help the Boers.

One of the most noticeable of these institutions was the ANV press office, which was closely linked to the NZAV and the diplomatic representatives of the Boer republics. As such, it handled much of the information that reached Europe from the Boers in South Africa and turned it into propagandistic material such as press circulars and pamphlets. Although it remains unclear to what extent these texts were actually taken up and used by the media, there was widespread appreciation in the Netherlands for this 'campaign of the pen'. Another example of how pro-Boers intervened in order to influence the public took place after the euphoria of December I 899, when several emigration schemes emerged that were unrealistic, if not outright fraudulent. Frans Beelaerts van Blokland - in co-operation with the ANV, the NZAV and Boer diplomats - led a campaign against the untrustworthy fonds tot daadwerkelijken steun and took over another emigration company in order to establish a reliable source of information for the public. A final headache for the NZAV was the organisation of humanitarian aid to the Boers. Although it ran the most important pro-Boer charity, there was criticism on its conduct, both externally and internally. It was J. A. van Kretschmar van Veen, a Hollander who had returned from Pretoria, who led the centralisation of the collections and the distribution of aid that resulted in the foundation of the Vereenigde Comités.

The cases mentioned in this chapter reveal that the pro-Boer movement in the Netherlands often relied on improvisation due to the haphazard organisation of its institutions, which was particularly apparent when compared to the British lines of communication with South Africa. Significantly, contemporaries in the Netherlands were aware of such problems and tried to find so- 
lutions. They clearly considered propaganda to be an important feature of the South African War, and although it is difficult to draw conclusions about the actual impact of the campaign, this demonstrates its historical significance. As such, pro-Boer enthusiasm in the Netherlands was not simply a temporary fit of hysteria but should be considered in the context of the rise of mass media and the globalisation of information in the age of modern imperialism. This chapter and the previous one have described how a large amount of information was transferred from South Africa to the Netherlands. Dutch organisations attempted to distribute this material in order to influence public opinion in Europe on the events taking place in the war zone and to mobilise support for the Boers. Such views were published in a great variety of genres and distributed amongst people from all walks of life. The following two chapters provide an analysis of the contents of these sources and how the South African War was depicted. 


\section{Chapter 5}

\section{'Dum-dums of public opinion': Pro-Boer propaganda, October I 899-June I900}

The public outcry against the South African War is generally seen as the climax of the pro-Boer movement in the Netherlands. The struggle by the Transvaal and the ofs against the British Empire was immortalised on countless pages and in many genres. Historians tend to see this dazzling amount of source material as the result of a unique and temporary phenomenon in Dutch history during which public opinion was captured by a form of mass hysteria. ${ }^{\mathrm{I}}$ Literary scholars also have trouble interpreting the enormous wave of propaganda that flooded the Netherlands during the war. Writing in the I9Ios, the Afrikaner literary critic G. Besselaar thought that only two works of the large collection of 'gunpowder texts' were worth reading. ${ }^{2}$ At the centenary of the South African War, Ena Jansen and Wilfred Jonkheere compiled a more substantial volume with excerpts from Dutch sources about the conflict, both in High Dutch and in Afrikaans. In the introduction, they rightfully note how the sheer number of texts and the diverse backgrounds of the authors - who ranged from well-known writers in Amsterdam to farmers' wives in the Karoo - made this corpus quite 'chaotic'. ${ }^{3}$

The literature on the conflict in the Netherlands was indeed a hotchpotch; different authors wrote about different aspects of the war, expressing themselves in different genres. In the following two chapters, the leitmotivs in this heterogeneous mass of historical sources will be highlighted. This chapter will discuss the coverage of the period up to the occupation of Pretoria, during which the largest battles took place; the following chapter will discuss the coverage of the guerrilla phase of the war. I have argued in the preceding chapters that the lines of communication between the Netherlands and South Africa came under mounting pressure during the conflict but that information from the war zone continued to trickle through. ${ }^{4}$ In this sense, there was continuity with the avenues of information that were set up in the I 880 os and I89os. Likewise, the contents of the debate should be seen in line with the feelings of stamverwantschap that took shape during the pre-war period. ${ }^{5}$ 
First of all, there were ambivalences towards both sides in the war. The Boers seemed to be well adapted to fighting a modern war but at the same time showed fundamental weaknesses in their overall strategy. Likewise, despite condemnation of the British military presence in South Africa, there was a certain amount of sympathy for the common soldiers who were ordered to fight and die in a war they did not ask for. But despite these nuances, the South African War was fundamentally seen as being the result of the great struggle for colonial dominance between the Dutch and British 'races' in South Africa, something that was considered to be the leading theme of the nineteenth-century history of the region. In that light, people in the Netherlands clearly took the side of the Boers and condemned the conflict as a deliberate attempt by imperialist statesmen to quash all resistance to their expansionist plans, not hesitating to use the most unscrupulous means available. Dutch commentators constantly accused the British army of atrocities on and off the battlefield, and the war was seen as a new episode in the history of the oppression of the Afrikaners that had started in I806. To pro-Boers, this showed the downsides of modern capitalism and imperialism: the 'ravenous hunger' (geeuwhonger) and the arrogant cruelty of 'perfidious Albion' (het perfide Albion). By contrast, the conduct of the Boers was considered to be noble on the whole.

As with all propaganda, the Dutch account of the events that took place in South Africa between October I 899 and June I902, certainly cannot be taken at face value. Contemporaries seem to have been aware of their biases to some extent but did not always consider them to be a problem. On the contrary, many publicists saw it as their duty to disseminate material about the South African War that highlighted the Boer perspective. British anti-Boer propaganda was seen as being part of the effort to strangle the Transvaal and the ofs, and the wave of pro-Boer publications that flooded the public on the European continent should be seen as a direct response to this perceived threat. How successful this was remains a question. On the one hand, propagandists did influence public opinion outside Great Britain to a large extent, but on the other hand they did not succeed in convincing European governments to intervene in the conflict. ${ }^{6}$ These limitations were acknowledged in contemporary sources, but it was nevertheless argued that the agitation was vital to the Boer cause. In this sense, propaganda in Europe was seen as an extension of the war in South Africa. At times, Dutch commentators even used military metaphors to describe the efforts to counter the British coverage of the war. For example, a volume with pro-Boer cartoons appeared with the ti- 
tle Dum-dums of public opinion, in reference to the expandable 'dum-dum' bullets that the British were accused of using against the Boers. ${ }^{7}$ The propaganda was considered to be important in an even wider sense. Several publicists asserted that they were providing future historians with material so that they would not have to depend on British sources alone. ${ }^{8}$

Although contemporaries were generally aware that they stood too close to the events that were unfolding to write a balanced account, they nevertheless attached much value to these efforts, which they thought might be of use in South Africa later on. As has been shown, the sums that were collected for the burghers during the South African War were initially earmarked for reconstruction of the republics after the conflict had ended. Similarly, the numerous publications describing British atrocities and Boer heroics were seen as an essential asset in the preservation of the Dutch cultural element in South Africa, because these stories would help to strengthen Afrikaner identity. This clearly shows that the interest taken by the public in the Netherlands in the war - and the wave of publications that was resulted from it - were not simply symptoms of collective hysteria but touched on Dutch notions of cultural identity and racial kinship in a global setting. This chapter and the next will discuss the coverage of the war in the context of these issues.

'We know so well how you drifted into this war ...'

In the run-up to the South African War, there was a lively discussion about the causes of the conflict. The outbreak of hostilities came by no means as a surprise to observers, both in the republics and in the Netherlands. Even though the Boers started the war, invading the Cape and Natal after issuing an ultimatum, it was generally seen as the result of attempts by the British to dominate the Dutch element in South Africa and was thus aligned with events such as the Great Trek and the Transvaal War of I880-I88I. Moreover, the government in London had already despatched a large expeditionary force to South Africa, which was considered by the public in continental Europe to be a hostile act. ${ }^{9}$ Meanwhile, several Boer statesmen wrote pamphlets to reveal the historical injustice they were facing. As tensions rose, the Boers and their supporters in Europe did not shy away from framing the conflict in South Africa in terms of a struggle between good and evil. At first sight at least, the crisis seemed to obscure the ambivalences and contradictions of stamverwantschap.

In August I 899, Piet Joubert, commander-in-chief of the Transvaal, pub- 
lished an open letter to Queen Victoria (in English) in the Johannesburg newspaper The Star. Despite Joubert's reputation as one of the most prominent political enemies of Paul Kruger and his Hollanders in the SAR, a Dutch translation instantly appeared in the Netherlands. Joubert's description of the Boers was rather exalted, comparing the Voortrekkers with the people of Israel, chosen by God to establish their republics in the middle of the African 'wilderness' to bring 'civilisation' there. He ended with a polite call upon the queen and the people of Great Britain to stop statesmen like Chamberlain from attacking the republics, thereby tarnishing the reputation of their nation. ${ }^{\mathrm{IO}} \mathrm{In}$ addition, a letter from SAR Secretary of State F. W. Reitz to his counterpart in the ofs, P. J. Blignaut, found its way to a publisher in the Netherlands. Reitz lamented the aggressive strategy followed by the British, who would do anything to get their hands on the goldfields of the Rand, the South African equivalent of Naboth's vineyards from the Old Testament. Continuing to use Biblical terms of reference, Reitz prophesied that God would be on the side of the Boers and help them withstand the imperial forces on the battlefield. ${ }^{\text {II }}$

The most famous - and most radical - of these pamphlets from South Africa was A Century of Wrong by Jan Smuts, the young state attorney of the Transvaal. ${ }^{12}$ Despite his upbringing in the Cape and his education at Cambridge University, which initially made him sympathetic towards the British cause, Smuts was deeply shocked by the Jameson Raid and opposed growing British pressure on the Boer republics. ${ }^{\mathrm{I}}$ In September I 899, he wrote a pamphlet that was intended to arouse his fellow Afrikaners to join the republics. The SAR government also thought it suitable for publication in Europe and the US and sent it to the diplomatic legation in Brussels, where it arrived in November of that year. ${ }^{\mathrm{I} 4}$ It became one of the most famous pro-Boer publications in the Netherlands, despite the fact that Smuts, who was sceptical about the political influence of Hollanders, did not write it with that audience in mind. He argued, for instance, that the Prince of Orange had 'sold' the Cape in I 8I4, which offended several Dutch critics. ${ }^{\mathrm{IS}}$

Nonetheless, there was much praise for his vivid description of the 'wrongs' the British had inflicted on the Afrikaners throughout the nineteenth century as well as of the 'native' and the Uitlander questions. In general, the account followed the work of historians like George McCall Theal, which Smuts supplemented with his own experiences in order to counter the allegations made by Chamberlain concerning the ill treatment of Uitlanders by the Boers. ${ }^{16}$ Towards the end of his historical overview, the young politician lost his academic tone somewhat. In the conclusion he sketched estranging visions, portraying 
Britain as 'this gentle and kind-hearted Mother of Nations, [...] wrapped in all the panoply of her might, riches, and exalted traditions', who approached the small population of the republics, 'the little child, grovelling in the dust', with a sharp knife in her hands. 'This is no War - it is an attempt to Infanticide.' ${ }^{17}$ In Smuts's view, the violent onslaught on the Boers was not only morally wrong but threatened the very existence of white settlement in South Africa because the British were not capable of withstanding the black majority alone. He continued with a ghostly dream in which the onlooker saw:

Bantu children playing amongst the gardens and ruins of the sunny south around thousands of graves in which the descendants of the heroes of Faith and Freedom lie sleeping. [...] And when the question is asked - why all this has happened? [...] An invisible spirit of mockery answers, 'Civilisation is a failure; the Caucasian is played out!'18

Not only Afrikaner authors wrote to protest against the outbreak of the South African War; many people in the Netherlands also could not keep their indignation to themselves. Throughout the country, churches organised prayer meetings for the Boers. Several of these sermons were published and show how the ministers called upon their flocks to Continue praying for the Transvaal! 19 Prominent publicists joined these pious protests. The journalist Charles Boissevain aimed his arrows directly at British opinion makers. In his Open Letter to the Duke of Devonshire, he accused them of deluding the public with anti-Boer rhetoric. ${ }^{20}$ His pamphlet was known in the Netherlands too, and the full text - in English - appeared on the front page of $\mathrm{Het} \mathrm{Al}$ gemeen Handelsblad, of which he was editor-in-chief. ${ }^{21}$ Writing the text on Christmas Day I 899, Boissevain poured out his indictment in exalted terms:

We know so well how you [the British] drifted into this war ... we know so well what this cruel unrighteousness means for each of those armed peasants, those husbands and fathers, who sacrifice their lives for their independence, that we could wish for ignorance, so that our eyes might be shut and our hearts hardened. But we cannot ... we see, we know and we appeal to God Almighty for justice. ${ }^{22}$

An opinion maker on the other side of the political spectrum, the Calvinist leader Abraham Kuyper, also wrote a famous pamphlet in defence of the Boer cause which appeared in French on the pages of the influential international 
magazine Revue des Deux Mondes in February I900. Soon after that, it was translated into English, Dutch, German and Swedish and published as a separate pamphlet. ${ }^{23}$ The publication was a great success - Kuyper received a personal compliment from Queen Wilhelmina herself; no less than sixteen editions appeared of the English translation of the pamphlet alone, and even his political opponents in the Netherlands praised the text. ${ }^{24}$ The historian Gerrit Schutte has called this brochure 'a masterpiece of propaganda' in which the case for the Boers was elucidated in a 'scholarly' fashion. ${ }^{25}$ As such, it was an important contribution to the pro-Boer campaign. Kuyper gave an overview of the race issue that largely followed the lines of other Dutch works on the nineteenth-century history of South Africa, supporting ideas on the inferiority of black people and pointing out the machinations of British statesmen. Moreover, while writing, the author was in direct contact with representatives of the SAR and the OFS, who provided him with source material and also read the proofs. ${ }^{26}$ Chris van Koppen, however, has pointed out that the pamphlet was Kuyper's only contribution to the propaganda campaign and should therefore be considered to be an exception to the otherwise troubled relationship between the Protestant leader and the pro-Boer movement. ${ }^{27}$

This sort of unity seems to have been widely present during the first months of the South African War. In the heat of the moment, domestic tensions fell away and people in the Netherlands rallied firmly behind the Boer cause. Both Boissevain and Kuyper were attacked by Yves Guyot, editor of the French magazine Le Siècle, and they both replied with similar indignation, claiming that Guyot did not have the same knowledge of South African affairs as authors in the Netherlands. The two Dutch opinion makers prided themselves in the fact that they had better access to information and that they backed their pamphlets with solid evidence based on documented research. In his bombastic style, Boissevain accused Guyot of being 'plus Anglais que [les] Anglais' and argued that he lacked the slightest knowledge of 'the small, free people [the Boers] that he denounced in favour of the great gobbler [Great Britain]' ${ }^{28}$ In a brotherly gesture, the Dutch press took the side of their two colleagues against 'that silly Frenchman', who had been accused of manipulating the news in favour of the British from the beginning of the war. ${ }^{29}$

The view that the South African War was the outcome of a 'century of wrong' was also apparent in less elitist publications, which is another indication that it was generally accepted in the Netherlands. The popular writer Louwrens Penning started writing a series of three books in which he described the war as it was unfolding. The first was published in 1899 , the last 
in 1903. In the first issue, he gave an overview of South African history from Slachtersnek onwards and the "foolish native policy of England [in the Cape] that pampered the Kaffers and oppressed the Boers'. ${ }^{30}$ Penning's work certainly cannot be considered to be an unbiased or trustworthy depiction of South Africa's history, but it was not all made up either. His chronicle of the war was based on sources like letters that reached Europe and were published in newspapers. ${ }^{3 \mathrm{I}}$ The fact that he received material from the ANV press office, such as press circulars and the gazettes from the republics, is further evidence of his close connection with Boer lines of communication. ${ }^{32}$ Nevertheless, his style was emotive and he certainly did not attempt to give a balanced account of events. In addition, his work contains many factual errors and where he lacked information, he seems to have filled the gaps with imaginary scenes. In addition, between I900 and I904, Penning wrote seven novels about the South African War in which he placed fictitious characters in real battles. 33 His varied work reflects the haphazard contents of pro-Boer propaganda: a set of highly biased - and sometimes contradictory - views on the South African question in which it is often hard to separate fact from fiction. Despite these shortcomings, or maybe because of them, Penning's work was massively popular. The first volume of his chronicle sold 40,000 copies, which was quite remarkable for the Netherlands at that time. ${ }^{34}$

With due satisfaction, Penning noted that the feelings of stamverwantschap were at their peak at the end of 1899 , both in South Africa, where the burghers of the SAR and OFS stood together, and in the Netherlands, where domestic partisan interests seemed to melt away. ${ }^{35}$ Apart from these apparent signs of racial unity, however, there remained tensions and ambivalences that spilled over onto the pages of pro-Boer writings too. As has been mentioned in chapter 4 , the most noticeable result of the renewed interest in the situation in South Africa was a huge rise in membership of the NZAV and the numerous initiatives undertaken to help the 'cousins' in the republics. But just as the increased number of activities posed problems for the leaders of the movement, who had difficulty co-ordinating these efforts, there was a variety of different views on the war. People in the Netherlands still had ambivalent ideas about their relationship with the Boers and the future of the Dutch race in South Africa, which was clearly a continuance of the way of thinking before October I 899. Throughout the South African War, the public in the Netherlands oscillated between fear and hope about the outcome of the conflict and the question of which group of white colonists would become dominant in the region, largely reflecting the fickle ideas about stamverwantschap. 


\section{'Afrika for the Afrikaner'?}

Many pro-Boers saw a united and 'free' South Africa - from the Zambezi to the Simons Bay - under Dutch rule as a possible outcome of the war. The motto 'Afrika voor den Afrikaner' ('Africa for the Afrikaner') was therefore a popular phrase at the time. ${ }^{36}$ In the light of the military and political situation, it was considered of great importance that the Afrikaners of the Cape join the Boer cause. Most of the white inhabitants in South Africa lived there, the majority of whom where Afrikaners, so that the combined Dutch-speaking population actually outnumbered the British settlers. Moreover, if the inhabitants of the Cape took up arms against the British Empire, this would add greatly to the military might of the Boer republics, not only in numbers but also because it would open a second front line. Some observers thought that this would cause the British army so much trouble that the public at home would force the government in London to order a retreat. ${ }^{37}$ Despite these high hopes, only a small number of Cape Afrikaners actually joined the commandos. Dutch commentators thought this to be the result of fundamental problems in the colony that stood in the way of unification. They argued that because of English influences, particularly in the educational system of the Cape, many Afrikaners there had become alienated from their kinsmen in the republics and had developed sympathy for the imperial cause. This was a topic of discussion in several novels and stories about families that were torn apart by the different allegiances of family members, some joining the British and some the Boers. ${ }^{38}$

Correspondents in Cape Town who wrote for the press in the Netherlands also pointed to political barriers that prevented the Afrikaners from affiliating themselves with the Boers. There was a degree of disappointment about the attitude of the nationalist leaders. Despite Jan Hofmeyr's swing away from Cecil Rhodes in 1896 and the electoral victory of his Afrikaner Bond in I 899, he had to walk a thin line, given the tense situation in South Africa. $\mathrm{He}$ tried to find a political solution in the run-up to the war, and he openly expressed his regret for the stubbornness of the Boer governments when the conflict started. In April I900, an Afrikaner correspondent wrote to defend this cautious position, saying that Hofmeyr had tried to achieve Dutch unification through peaceful means and denounced the war that was to bring so much grief. Not all commentators in the Netherlands found this convincing and thought that it was unrealistic 'to expect that they [the Boers in the republics] continue to see Hofmeyr as a true friend'. 39 In contrast with his polit- 
ical actions, Hofmeyr's magazine Ons Land contained more unambiguous pro-Boer accounts, which provided an alternative to the coverage of the war in the British jingo press, protested against atrocities committed against the republics, and critically assessed local politics. Because the mail services from the Cape Colony were more reliable than from the republics, the press in the Netherlands gratefully used this magazine as a source. Later on during the war, Ons Land became less influential because of the increasing censorship imposed by the British authorities, who in I90I arrested several editors and forbade the publication of editorials. ${ }^{\circ}$

Such measures were considered to be part of a wider campaign by the Milner government to quash all possible resistance in the Cape. Correspondents wrote in similar terms about the harsh treatment of Afrikaners fighting for the Boer commandos, who were considered to be rebels and thus risked the death penalty. ${ }^{4 \mathrm{I}}$ Despite the gravity of the situation, many pro-Boers in the Netherlands continued to nurture the hope that the Afrikaner population would be able to cast off the oppressive yoke of the British administration. At the end of I900, news about meetings by Afrikaner nationalists in the Cape in Paarl (women) and Worcester (men) - was welcomed as a clear sign that their spirit had not been broken. Although their protests against the ongoing war and their demand that the Milner administration be replaced had little impact, their patriotism was admired..$^{2}$

In pro-Boer literature, there was reflection not only on the attitude of the Cape Afrikaners but also on the morale of the inhabitants of the two republics, which was at times a controversial issue. From the I 880 os onwards, the focus of the pro-Boer movement in the Netherlands was clearly on the SAR. This republic was considered to be the most important destination for emigrants, as it was fertile and there were many opportunities for well-motivated settlers. ${ }^{43}$ It was also in the light of the political situation in South Africa that the Transvaal received the most attention in the Netherlands. It had been the I880-I88 I war for independence fought by the inhabitants of this republic that had aroused interest by the Dutch in their 'cousins' in South Africa, and the rapid development that took place under Kruger and his Hollanders was seen as highly promising for the Dutch race as they managed to strengthen the independence of the state.

There were more concerns about the ofs, where immigrants of British descent played an important role in public life, the education system and the railways, which made it dependent on Cape infrastructure. ${ }^{44}$ In a publication that appeared shortly after the war ended, the leader of the ANV press office, 
Frederik Rompel, had another explanation for the relative obscurity of the OF $S$ in the Netherlands. In an effort to avoid trouble with the British, the of $S$ government shied away from making propaganda in Europe, a choice that stood in stark contrast to the campaign headed by Leyds. ${ }^{45}$ This meant that, when the war broke out, the public in the Netherlands seemed to associate the war with the SAR, which is illustrated by numerous publications that only mentioned the Transvaal in their titles. ${ }^{46}$ To make matters worse, at the beginning of the war several rumours emerged that Free State troops lacked the motivation to fight and were considering laying down arms. ${ }^{47}$ Such indictments were a thorn in the flesh to representatives of the ofs. In interviews, Consul-General Hendrik Muller emphatically denied that these commandos were considering surrender. ${ }^{48}$ In private, he complained that the campaign by the pro-Boer organisations mainly focussed on the Transvaal and that he, as a representative of the ofs, was left out of the equation. 'They confer with Leyds, but without me', he lamented in a letter. ${ }^{49}$ Although Leyds and other Boer diplomats stated that they represented the interests of both republics, complaints about neglect of the ofs continued throughout the war. Muller even expressed these sentiments in public while he was touring the US in I $902.5^{\circ}$

There were, however, also efforts to brush up the image of the ofs during the South African War. Several publications appeared that were written by people who had lived in the republic - such as D. Aitton, a former teacher at Grey College in Bloemfontein - or who had travelled there such as W. A. van Ittersum. They tried to play up the heroic past of the Free Staters because they were of the opinion that they deserved the admiration of the civilised world for their conduct during the struggle against the British. Looking at the nineteenth-century history of South Africa, it was noted how they had been the victims of the imperialists' lust for expansion when the diamond fields of Kimberley were taken from them. ${ }^{5 \text { I }}$ Moreover, it was emphasised that the Boers of the ofs were 'unspoiled' descendants of the Voortrekkers. ${ }^{2}$ Their heroic character became apparent during the Transvaal War when, despite the official policy of neutrality, the Free Staters under President J. H. Brand expressed explicit support for their sister republic, which was seen as one of the reasons for the British to retreat. ${ }^{53}$ This kind of loyalty continued under the presidency of W. F. Reitz, who signed a treaty in which both republics pledged military support to the other if one was attacked. 54

President M. T. Steyn, who was head of state when the war started, was also considered to be a true hero. In the several biographical publications that 
appeared about him during and after the South African War, he was described as a typical Boer with simple tastes but good instincts and much common sense: truly a member of the Afrikaner 'aristocracy of South Africa'.55 After the Jameson Raid, which took place just after his election, he continued to seek closer ties with the Transvaal, which to some observers was a sign that he believed that the combined Boer forces would withstand and possibly defeat the British. ${ }^{6}{ }^{6}$ Nevertheless, Steyn did his best to avoid a military conflict, facilitating the Bloemfontein Conference between Kruger and Milner (May and June I 899) in a bid to find a political solution for the Uitlander question. When this effort failed, which the pro-Boers believed was Milner's fault, Steyn prepared to stand by the SAR during the looming war. ${ }^{57}$ On 22 September I 899, he made a famous speech at the Volksraad in Bloemfontein in which he accused the British of using the Uitlander question as a false casus belli and called upon the burghers of the ofs to join the Transvaal and fight for a just cause. When the text of this speech reached Consul-General Muller in the Netherlands, he instantly forwarded it to a newspaper in Rotterdam that published large parts of it, and Steyn's words were also quoted with much reverence in other publications. ${ }^{58}$

Despite this renewed attention for the ofs, in many ways the Transvaal remained the most telling symbol of the unjust war that was forced upon the Boers. It was this country that had been most affected by the British hunger for land in the past, during the annexation of I877-г $88 \mathrm{I}$. Moreover, by the end of the nineteenth century it had become clear that the world's largest deposits of gold lay on its territory, something that was considered to be a mixed blessing. On the one hand, authors pointed out that the capital generated by this new industry enabled the Kruger government to initiate reforms that had led to the rapid development of the republic and had strengthened the Dutch element in South Africa. On the other hand, it had also aroused the greed of the British capitalists - and Rhodes in particular - who seemed to be determined to end the independence of the SAR once and for all. 59

The Boers' struggle to cope with modernity was exemplified by Paul Kruger. The elderly president had grown up in the ox wagons of the Great Trek, had received virtually no education except from Bible reading and was considered to be inherently distrustful of the outside world. However, it was argued that his innate goodness, exceptional patriotism and common sense allowed him to accept the development of the SAR and chart out his policies accordingly. Although he did not always obtain perfect results, it was asserted that he did the best he could. ${ }^{60}$ This was illustrated by his solemn but deci- 
sive preparation for war. After the shock of the Jameson Raid, he started with an arms programme during which the SAR acquired modern rifles and artillery. Still, it was said that Kruger did everything he could to save his country from war because he knew what horrors it would bring to his people. In an intimate portrait of 'Oom Paul', Rompel, who had been present at the Bloemfontein Conference as a reporter, described how the SAR delegation offered to reduce the naturalisation period for Uitlanders in a bid to avoid conflict, an offer that was arrogantly rejected by Milner. The next morning, Rompel noticed that the elderly president had swollen eyes. His physician suggested that he had an infection because of all the tears he shed. "Yes," was [Kruger's] reply, simple, very sad, "I do not sleep anymore, doctor: I cry all night long." "6r

For many people in the Netherlands, Kruger's tears were proof that justice was on the side of the Boers, who had tried everything to avoid war. It was noticed that even Uitlanders in the SAR, mainly of non-British descent, took up arms to defend the independence of the republic. In the Netherlands there was particular attention for one of these foreign regiments, namely the $\mathrm{Hol}$ landercorps. ${ }^{62}$ At first sight, the formation of this commando seemed the ultimate expression of loyalty by the Hollanders to their kinsmen in the Transvaal. However, many descriptions of the short and tragic history of the Hollandercorps reveal that the difficulties between them and the Boers continued. The story of Herman Coster, one of the founders of the regiment, exemplified this. He went to the Transvaal after he finished his doctorate in law at the University of Leiden in I 890 and became state attorney five years later. Coster, who was considered to be a gifted man, had a problematic relationship with Kruger, a matter that was openly discussed in contemporary sources. In a dispute in I 897 , the president sneered at him that if there was to be a war, the Hollanders would remain behind their desks while the Boers would have to do the fighting. Coster was deeply insulted by this remark and resigned immediately, despite apologies from Kruger himself. ${ }^{63}$ He remained in Pretoria, though, and according to the Dutch banker Gerard Vissering, an old friend from university who wrote the most famous contemporary biography of Coster, he continued to be committed to the Boer cause. ${ }^{64}$ Nevertheless, Vissering thought that Kruger's insult was still echoing in his mind when he prepared to join the invasion of Natal, together with approximately I 50 other Hollanders. ${ }^{65}$

On 2I October I 899, they had their baptism of fire near the train station of Elandslaagte, which was also the last stand of the regiment. There, the Hol- 
landercorps was part of a Boer force of about $\mathrm{I}, 000$ men with three cannons facing a British column of approximately 3,000 soldiers with 18 pieces of artillery. ${ }^{66}$ The dramatic battle of Elandslaagte became the most notorious incident that took place during the first phase of the South African War and was probably the single event that was most mentioned in publications about the conflict that appeared in the Netherlands. ${ }^{67}$ Although the outcome was dramatic - almost half of the Dutch troops who fought at Elandslaagte were killed, wounded or captured - the battle was portrayed as the ultimate expression of unity in the Dutch race because Boers and Hollanders stood side by side and shed their blood together. Coster, who died after having been shot in the head while fighting off enemies with the butt of his rifle, became a hero, having given his life for Holland's glory ${ }^{68}$ In the Netherlands he was commemorated: in the I 900 s, streets in several cities were named after him. In addition, a committee collected money for a monument at the University of Leiden and a fund that supported Afrikaner students in the Netherlands. ${ }^{69}$

In addition to these signs of unity between Hollanders and Boers, Elandslaagte also showed up the disparities between the stamverwanten. Faced with British superiority in numbers, the Boer commandos retreated, which was in keeping with the hit-and-run tactics that they had developed in previous conflicts. Instead, the Dutch tried to hold their ground, which was considered to be a typical European way of fighting, which was brave but also prevented an orderly retreat, causing the high casualty rate. One veteran of the battle, the teacher Cornelis Plokhooy, described in his memoirs how at first he considered the retreat by his South African comrades as an act of cowardice. Later, however, he realised that they had been right. 'If all Boers had fought as hotheadedly as the Dutch [...] there would have been few left and then the enemy would have been lord and master in South Africa, while we now [in I90I] still see thousands of Boers in the field. ${ }^{70} \mathrm{He}$ also described how the Boer commanders were furious about the madcap performance of the Hollandercorps and decided to disband the regiment forthwith. ${ }^{71}$ In addition to these accounts, there was a particularly embarrassing rumour that appeared about the Hollanders and their conduct at Elandslaagte. The night before the battle, the regiment captured a supply train at the station, which contained a wagonload of whisky. Some sources reported that the Hollandercorps had spent the evening in drunken revelry and that this was the reason for their poor performance on the battlefield the next morning. Dutch veterans fervently denied these allegations. Plokhooy refuted them as 'low' and asserted that the bottles had immediately been smashed. ${ }^{72}$ However, it is telling that 
these incidents were not omitted from pro-Boer propaganda, which illustrates the ongoing tensions surrounding the concept of stamverwantschap. In the light of these ambivalences, authors in the Netherlands were torn between hope and fear concerning the military abilities of the Boers, which will be discussed in the following section.

\section{The Boer people's army}

Contemporaries considered the Boer military system to be a typical example of the decentralised and small-scale political structure of the republics. Apart from a small police force and a permanent artillery corps, both the OFS and the SAR had a people's army (volksleger) that was only raised in times of need. In principle, everyone who was allowed to vote (white adult men, mainly of South African descent) - the so-called 'burghers' - were obliged to join a commando when asked to do so by a local officer, the veldcornet. As a result, the structure of the army was loose and fluid, with generals presiding over several commandos and a commander-in-chief co-ordinating the overall strategy. These high-ranking officers had limited authority, however, because all important decisions had to be taken in consultation with lower officers who represented their men, during the so-called krijgsraad. This human aspect of the mobilisation system was emphasised in many sources. ${ }^{73}$ In general, the recruits were described as devoted fathers or loving sons, which drew on the idea that the family was the cornerstone of the republics.

While in reality no more than $65 \%$ of the burghers who were eligible for military service in the republics was mobilised at the outbreak of war ${ }^{74}$, it was implied in pro-Boer propaganda that every man was prepared to do his bit for the fatherland. Stories about young boys who eagerly wanted to fight were placed besides descriptions of older generations, the tough, bearded men of Voortrekker stock who took a more sober view because they knew of the horrors of the battlefield but realised the necessity of defending their independence. Penning used this kind of imagery in his novels. Writing about the outbreak of war, he described a discussion between his fictitious characters, an elderly farmer and his sons. The boys expressed great eagerness to fight and were confident that the republics could withstand the British, while the old man was gloomy, dreading the prospect of war. But when the hostilities did break out, these differences fell away and both old and young fulfilled their duty. ${ }^{75}$ In this way, the commandos were portrayed as a cross-section of all age groups. One iconic image that symbolised this idea of total mobilisa- 


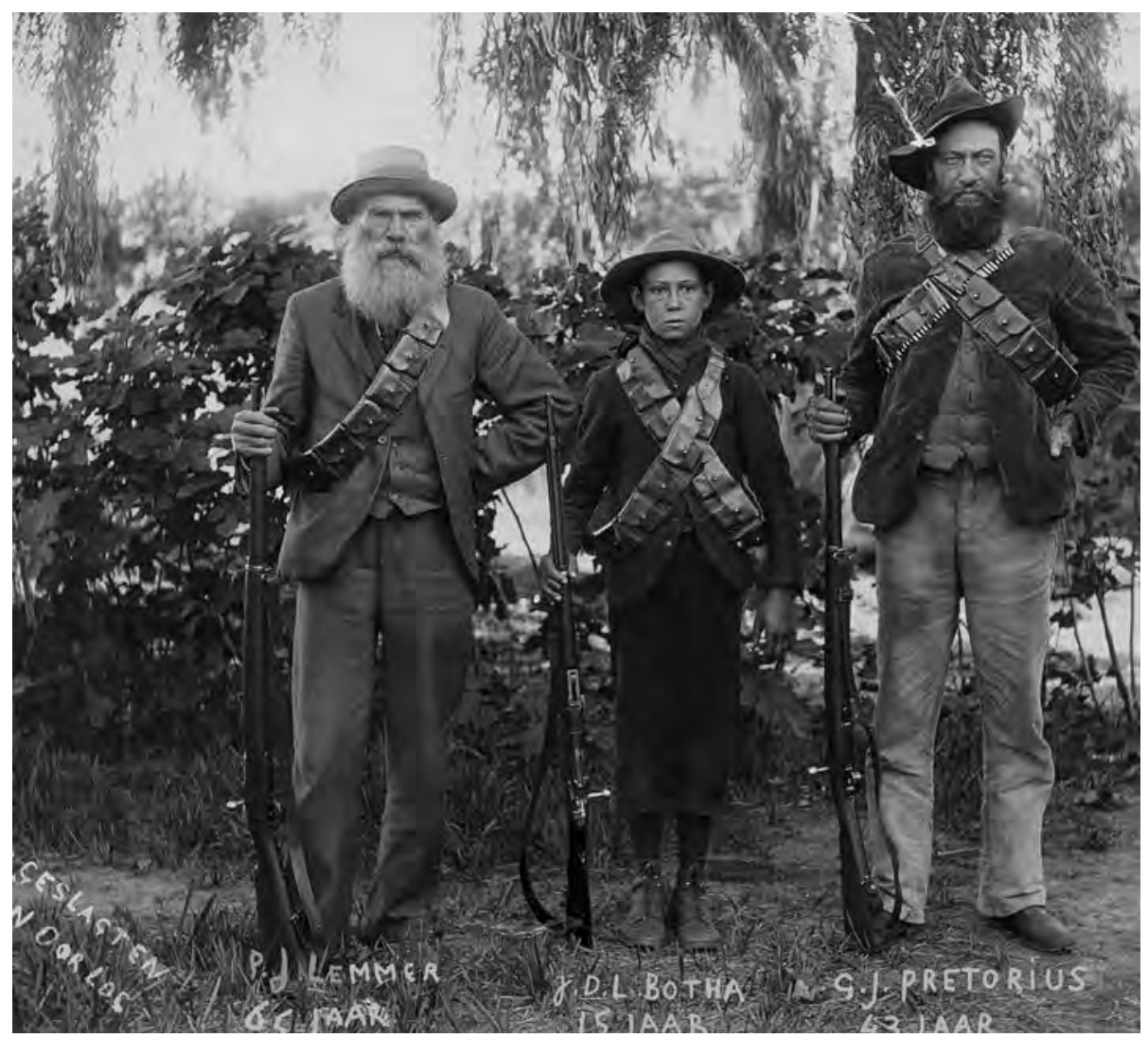

Three generations in the war. Photo taken by the Dutchman Jan Hoepen (I 899).

Source: NZAV-fotoarchief, Amsterdam.

tion was a photo that depicted 'three generations in the war'; a boy of $\mathrm{I}_{5}$, a man of 42 and an elderly man of 65 , all posing with rifles and bandoliers. ${ }^{76}$

As was the case in literature about the Voortrekkers, the wives of the Boers were considered to be patriotic too, in their own way. ${ }^{77}$ Many letters and memoirs contained descriptions of the emotional goodbyes that took place at train stations as the men left for the front lines. Although the authors noted that there was much personal grief, they also emphasised that the women fought back their tears and kept their composure, because they knew that their loved ones were fighting for a worthy cause. 'A suppressed sob, a sigh, a kiss and so the precious sacrifice to the fatherland and to freedom was made!', wrote one of them. ${ }^{78}$ Apart from this moral support, a few correspondents also described how women played an active role in the republics' war 
effort during the early phase of the war. They wrote about how housewives took over their husbands' work on the farms, cultivating the land and supervising the black servants. ${ }^{79}$ Some women even joined the commandos in the field, camping with their men in the laagers. Authors agreed that this was another sign of female bravery, but with hindsight it was also noted that the front line was no place for a lady. It was suggested, for instance, that General Piet Cronjé was severely hampered in his movements by the presence of about a hundred women in his camp, which led to his defeat. ${ }^{80}$ Despite these examples, it should be remembered that descriptions of female bravery were much rarer than those of the heroics of their men. In general, Boer women were seen as onlookers to the conflict who guarded the morale of the republics and urged their men to fight for independence.

Such ideas indicate that many contemporaries thought of the war in terms of mentality and national character. In general, there was much praise for the militia system from observers in the Netherlands because it was seen as the ultimate sign of patriotism. In I 897, C. B. Spruyt, who greatly admired the Boers for their character, was already predicting that the 'tough' men of the republics would be able to withstand the degenerate recruits that would be fighting on the British side. ${ }^{8 \mathrm{I}}$ In September I 899, he had not lost any of his enthusiasm and was one of the few authors in the Netherlands who actually welcomed the looming war as an exciting test for the Dutch race in South Africa: 'a spectacle through which people come to understand that it is worth to be human'. ${ }^{82}$ Another professor, Jan te Winkel, also saw moral advantages for the Boers over British soldiers, who were mainly professionals. He pointed out that the Boers fought for a just cause and to defend their families, homes and independence. Therefore, he concluded, they were better motivated to fight. ${ }^{83}$

People with a military background were more interested in the practical aspects of the commando structure, and one of the most interesting features of the war to them was to see a militia system in action. There was much discussion on the advantages and disadvantages of this way of fighting, which touched upon developing ideas about modern warfare and highlighted the troubled relationship that the Boers had with modernity. On the one hand, there was much praise for the technical aspects of the republics' military system. The swift mobilisation of the commandos in the weeks before the war made a good impression, and it was reported with due pride that the NZASM (the most important Dutch company in South Africa) played an important role in the transportation of the burghers to the front lines. ${ }^{8}{ }^{8}$ Another of the 
commandos' skills that was widely admired was their marksmanship. This was seen as a combined result of the typical Boer lifestyle in which boys learned how to shoot from a young age, and the fact that Kruger had armed his men with the latest model of Mauser rifles. Military commentators were amazed by the efficiency of the Boer forces during the battles that took place in the first months of the war. The burghers had entrenched and camouflaged themselves well and shot with great accuracy without exposing their position because they used smokeless powder, a recent invention. This combination of increased firepower and individual skill was considered to be of vital importance in modern warfare. ${ }^{85}$

The enthusiasm about the Boer fighting methods spilled over to a wider audience in the Netherlands. The news that the Boer forces had advanced swiftly into British territory, surprising their adversaries and laying siege to them in Ladysmith, Kimberley and Mafeking, was welcomed by many. The Boer victories in December I 899 and January I 900, when they reversed the British relief columns at the banks of the Tugela in Natal and the Modder River in the Northern Cape were celebrated enthusiastically. The Boers became heroic examples to men in the Netherlands, sometimes literally. Inspired by the commandos, an organisation that provided military training to citizens (Vereeniging 'Volksweerbaarbeid') was founded in I900 and from the start had the support of several prominent intellectuals and politicians. Two years later, it boasted that it had a membership of 14,000 , with members going on holiday camps and practising in field manoeuvres. ${ }^{86}$

The leaders of the pro-Boer movement also saw disadvantages to this huge enthusiasm, however. During the last months of 1899 , Leyds became concerned that the public in Europe might become overconfident about the military abilities of the Boer republics. This became apparent when he tried to launch a petition that called upon the international community to settle the conflict between the Boers and the British by means of diplomatic arbitration, so that the war could end quickly. His old friend J. P. Moltzer and his new assistant H. J. Kiewiet de Jonge edited the text, a draft of which had been provided by the French foreign office. The pamphlet was called For Justice and peace. Appeal to the nations represented at Peace Conference at The Hague, and described the principles of international justice and arbitration, 'soaring high above the reasons of state' ${ }^{87}$

Meanwhile they tried to persuade prominent intellectuals from the Netherlands to sign the petition. However, there was much reluctance to do so, particularly in academic circles. One of the main critics was Te Winkel, who 
wrote to Leyds just before the great Boer victories in December I 899, saying that he thought it a mistake to ask for arbitration at a time when the burghers were doing so well on the battlefield in their 'glorious struggle' ${ }^{88}$ Moreover, he did not agree with the contents of the petition, which he thought to be 'bombastic' and would make a 'comical impression' on many readers. ${ }^{89} \mathrm{Te}$ Winkel's resistance to the petition led to much delay, and although 3,000 intellectuals in the Netherlands eventually signed it when it was published in March I900, it did not have the intended effect. $9^{\circ}$ Instead, Te Winkel published a pamphlet in which he gave his own visions on 'the great importance of this mighty struggle in the southern hemisphere'. ${ }^{\mathrm{I}}$ In contrast to the carefully phrased Appeal to the nations, this publication can be seen as a rather uncontrolled and rash outburst. ${ }^{92} \mathrm{Te}$ Winkel warned his readers that the war would probably last a long time, although there was a ten to one chance that the Boers would win. That victory would have to be total, ridding South Africa of all British presence, he argued. If not, the linguist predicted, peace would be 'no more than a truce'. Instead, he expressed the hope that the 'persistent and lengthy' struggle would be crowned with a federal state of South Africa under Dutch rule. ${ }^{93}$

The hangover of this bold enthusiasm followed soon after. At the end of February, the reinforced British forces broke through the Boer positions and relieved Kimberley and Ladysmith. At the same time, General Cronjé was surrounded at Paardeberg and forced to surrender along with 4,000 men. These disasters brought to light the deficiencies of the military organisation of the republics. When they realised they were far outnumbered, many of the burghers took to their heels and fled, which enabled the British 'steamroller' to advance and occupy both Bloemfontein and Pretoria in a matter of months. This sudden demise of the Boers came as a shock to many people in the Netherlands. Nonetheless, some military experts had an explanation and wrote that the loose and individualistic structure of the commandos had its disadvantages in that it lacked a strong form of hierarchy, which made discipline a problem. ${ }^{94}$ Already during the sieges, correspondents complained about how the boring camp life eroded morale, and reported that many burghers wanted to return home to their families. 95 Initially, the views on the lack of discipline by the Boers had been met with scepticism by the enthusiastic public in the Netherlands, but the more that became known about the retreat after February I 900, the more credible they seemed.

The so-called desire to 'go home' (buis toe gaan) and the reluctance to fight an enemy that was growing in strength were recurrent themes in letters from 
the battle zone that appeared in newspapers and later in pro-Boer publications. Several of the Dutch who returned from South Africa during the war wrote about it, because they felt that the public in Europe was mistaken on this issue. Months after the great Boer defeats, Rompel published an essay in which he tried to explain the conduct of 'the Boer on the warpath' because he wanted to introduce some nuance to the idealised vision held by the public in the Netherlands and the great disappointment that followed. ${ }^{6}$ The retreat, he argued, was not cowardly behaviour but was in keeping with the character of the Boers, who were less reckless than Europeans. Instead of holding their ground and continuing to fight to the last man, they preferred to take cover and retreat to fight another day. ${ }^{97}$ Likewise, Cornelis Plokhooy, who fought in the Hollandercorps at Elandslaagte, tried to correct the view that the Boers lacked discipline. He described how the burghers kept on going while having to suffer hardships in the field, exposed to the elements. This to him showed that the Boers did have discipline, which was based not on a strict hierarchy like in Europe but on less tangible factors such as respect..$^{8}$ Not all veterans gave the Boers as much credit concerning the events taking place in the first half of I900. Dietlof van Warmelo was one of the most critical authors who wrote about this issue. In his view, the main reason for the crumbling morale of the Boer forces was the 'leave plague', which meant that during the sieges, many burghers randomly took off for visits home often without informing their officers. ${ }^{99}$ After the fall of Ladysmith, where he was stationed, this became worse and the morale of the commandos collapsed altogether, he argued. ${ }^{100}$

While Plokhooy and Van Warmelo thought differently about the courage of individual burghers, they both noted how Boer officers failed to stop the collapse of the morale of their men during the chaotic retreat. ${ }^{\text {IOI }}$ This supported more general criticism on the overall strategy of the Boers. Instead of pushing through in the early months of the war while they had the upper hand, the republics' forces halted to besiege towns where relatively small garrisons were stationed. As a result, the British had the opportunity to regroup in the south and reinforce the relief army. In several publications, the old Boer commanders, and Joubert in particular, were pointed out as the main culprits. One critic in Pretoria, a certain M. Mettius, had a rather peculiar theory on the lack of stamina displayed by him and other elderly generals of the Transvaal, which he explained in a pamphlet. The author suggested that they had been entranced by a fifth column of British hypnotists, who had infiltrated the republic in the years preceding the South African War. According to Met- 
tius, this explained why the Boer leaders, who had fought so bravely in the past, acted so indecisively. ${ }^{102}$

The majority of correspondents had explanations that were more downto-earth but often revealed contradictory feelings on the matter. This is shown in responses to the death of Joubert in March I900. Although there was admiration for his role during the Transvaal War of I 880-I 88 I, some letters and reports from the SAR contained explicit criticism of his political views and personality. His dislike of Hollanders in particular was mentioned as one of his weaknesses. ${ }^{103}$ Nevertheless, there were also people who were more positive about Joubert's achievements, and his admirers were at great pains to navigate between the controversies that surrounded him. J. A. Wormser, who had met the general in 1896 , wrote a biography in which he described him as a prime example of a Voortrekker and praised him as a great patriot. The author conceded that Joubert did have a strong polarising effect, but he explained this as a typical flaw in the Boer character and left out sensitive issues such as the general's hatred of Hollanders. ${ }^{104}$ Wormser also wrote about Joubert's strategic mistakes during the war, although he provided a more nuanced view on this matter than other authors. He thought the mistakes could possibly be the result of Joubert's miscalculation that the British would surrender after their first defeats, just as they did in I 88I. ${ }^{105}$ However, Wormser argued that it could also have been the result of the innate compassion of the general, who was aware that most of his men were fathers and therefore did not consider their lives disposable. ${ }^{\mathrm{I} 06}$ In this way, Joubert remained a hero, albeit a controversial one.

The failure of the old Boer generals and the hasty retreat of the republics' forces did not mean that all hope was lost. New leaders came forward who seemed to be well suited to continuing the struggle. Louis Botha, who became famous after his successes during the battles at the Tugela River such as Colenso and Spion Kop, succeeded Joubert as commander-in-chief of the Transvaal forces. After his surrender, General Cronjé, who in the view of commentators made serious mistakes by allowing himself to be cornered by Lord Roberts, was replaced by Koos de la Rey, who had become famous for his conduct at the victorious battles at the Northern Cape. Command of the of S forces was taken over by Christiaan de Wet, who probably became the most legendary of all Boer heroes, establishing his reputation with daring raids on convoys, outwitting the British army and getting the best out of his men. ${ }^{107}$

During the tense first half of $\mathrm{I} 900$, these new military leaders seemed to embody everything that was good in the Boer military system. They were 
seen as strong individuals who could inspire - or push - their men to continue the fight against the enemy. Moreover, in their battle plans they displayed an in-depth knowledge of the terrain and made full use of the shooting skills and mobility of the Boer combatants. Not everybody in the Netherlands despaired, therefore, when it became clear that the forces of the republics could not hold their positions and retreated. One military commentator, for instance, did not consider the relief of Ladysmith to be an important victory for the British because the Boer forces there had not been surrounded and had regrouped, which was a sign that they would keep on fighting. 'It cannot be said enough that the war in fact only has started now.' ${ }^{\text {I08 }}$ Such statements did not disappear from Dutch newspapers when the British army continued its advance. A few days before the capture of Pretoria in June I900, Leyds publicly announced that he 'still trusted in the courage of the Boers' and expected the struggle to continue. ${ }^{109}$ Another factor that gave hope to people in the Netherlands was the state of the British army, which, despite its enormous size, did not seem to be coping very well with the situation in South Africa. Just as the image of the Boers was marked by a degree of ambiguity, the depiction of the British military was by no means unequivocal, an issue that will be described in the following section.

\section{Britain's grave}

In general, most Dutch authors agreed with Smuts's metaphor of the mighty British Empire threatening to crush the tiny Boer republics. Schutte therefore argues that much of the sympathy for the commandos was the result of the Dutch public siding with the underdog, a phenomenon that can be explained by the highly moralistic view of foreign policy held by the country at the time. ${ }^{\text {I }}{ }^{\circ}$ Many commentators of the day expressed the hope that the injustice of the war would not go unpunished and referred, for example, to Bismarck's

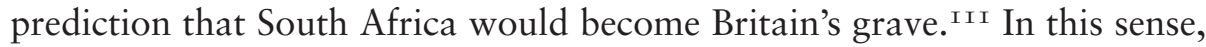
observers also drew parallels between the situation in South Africa and historical events. The comparison between the struggle of the Boers against the British and the Dutch war for independence against Spain in the sixteenth century - both portrayed as a fight of small people against imperial tyranny remained popular in the Netherlands. ${ }^{\text {II } 2}$ Likewise, many people saw similarities between the South African War and the American Revolution, hoping that the Dutch population would be able to forge a 'United States of South Africa' independent from the British Empire. ${ }^{\mathrm{II} 3}$ 
There was also much reference to the Irish question, which was considered the outcome of more than three centuries of British colonial oppression. ${ }^{\text {II } 4}$ Boissevain, who had started his journalistic career reporting on the Fenian movement in the I 860 s and had an Irish wife, argued that the Dutch race was of 'tougher fibre' than the Celts and predicted great trouble if the British tried 'to make a New Ireland in the South'. ${ }^{115}$ Kuyper noted how the crisis in South Africa might have had consequences for the political circumstances in the British Isles, where the Irish and the Welsh might have increased pressure on the government for greater autonomy. ${ }^{116}$ In fact, Leyds stood in direct contact with several figures from the Irish nationalist movement in the hope of pressuring the government in London. ${ }^{\mathrm{II} 7}$ Also in South Africa, a number of Irish emigrants chose the side of the Boers and formed their own regiment in the Transvaal, which became famous during the guerrilla war. Nevertheless, a greater number of Irishmen fought on the side of the British, who, in the eyes of many pro-Boers, used them as cannon fodder, sacrificing them in order to promote the interests of corrupt capitalists and statesmen - the same men who had oppressed their people for so long.

According to many pro-Boer propagandists, the higher echelons of the British army were of the same mould as deceitful imperialists such as Milner and Chamberlain. At the beginning of the war, there were a few exceptions, though. ${ }^{\text {II } 8}$ The commanders who withstood the sieges of Ladysmith and Mafeking - General George White and Colonel Robert Baden-Powell - were praised in the Dutch press for their steadfast defence of these towns, notwithstanding some incidents that were condemned such as the use of black troops at Mafeking. ${ }^{\mathrm{II} 9}$ The depiction of other high-ranking officers was more negative. According to many commentators, the incompetence of the army command was particularly striking during the first phase of the war, which resulted in the large defeats in Natal and the Northern Cape. It appeared that the British underestimated the power of the Boers and rushed forward without a proper assessment of the situation, after which they were repelled. The generals who suffered these humiliations - Redvers Buller and Lord Methuen were targeted in the pro-Boer press throughout the war. The disastrous way in which Buller commanded the battle of Spion Kop (24 January I900) became a famous example of his incompetence, which led to the butchering of his own men. The general failed to notice that the Boers occupied higher ground, and when the British troops reached the top of the hill they were exposed to heavy bombardment. Despite the triumph of their victory, burghers who witnessed the battlefield just after the fight described what they saw 


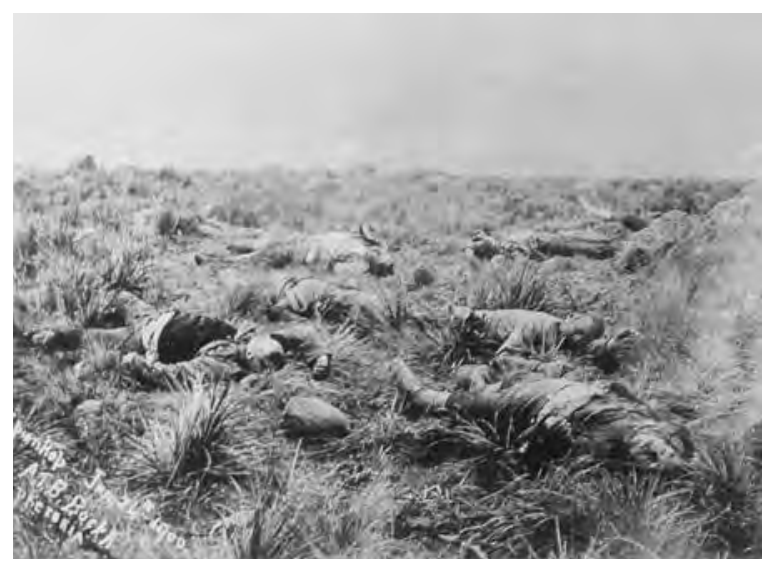

Dead British soldiers on the battlefield of Spion Kop. Photo taken by the Dutchman Jan van Hoepen (I900). Source: NZAV-fotoarchief, Amsterdam.

there as a 'terrible spectacle'. ${ }^{\text {I20 }}$ Photos showing scores of dead British soldiers littered on the rocky ground were banned in Britain, but in the Netherlands they were published in several magazines and even printed on postcards, making them icons of the horrors of war. ${ }^{\mathrm{I} 2 \mathrm{I}}$

In January 1900, Lord Roberts arrived in South Africa and took over supreme command from Buller, assisted by Herbert Kitchener. From a military point of view, there was admiration for the way they outflanked the Boer positions in a dazzling campaign, although it was also noted that the rapid advance exposed the British forces to raids. Both Roberts, who had fought a bloody guerrilla war in Afghanistan, and Kitchener, who had commanded the violent campaign against the Mahdist army in the Sudan, were notorious for the unscrupulous means they used to subdue their enemies. In the early months of 1900 , it appeared that they were not going to spare their own men either, exhausting them so much that many died of hunger and disease. In her memoirs, which appeared after the war, a farmer's daughter from the ofs described what she witnessed when the British army stopped at her farm. The officers arrogantly commandeered the comfortable house and had a lavish meal. ${ }^{122}$ By contrast, a regiment of ragged looking Scots was left out in the field. They had to find their own food and some were so hungry they ate from the pig's trough. 'Even the kaffers were surprised about that and did not understand that people could be starved to such an extent.' ${ }^{23}$

In this sense, the British servicemen were seen as victims of the war too. In many descriptions of the large-scale battles during the first phase of the war, there was quite a lot of sympathy for the ordinary soldiers, the 'Tommies'. What was most apparent was their bravery, as they kept advancing towards 
the Boer lines until the retreat was ordered, even though they came under heavy fire. According to commentators, this sort of rigid discipline was typical of the European style of military conduct, which was developed for professional armies. There were clear advantages to this system because the trained soldiers were not as fickle as the undisciplined Boers. ${ }^{\mathrm{I24}}$

But observers also noted disadvantages to this strategy, because the skills and intellect of the individual Tommies were inferior. This made them totally dependent on orders from their commanders, who were considered to be incompetent and careless about the fate of their men. Plokhooy described how, at the Tugela, officers fired at subordinates if they refused to advance, which to him proved that British pluck was born of the fear of their own leaders. ${ }^{\text {I25 }}$ Another example of this was the way in which the dead and wounded were treated. It was noted in several sources that the burghers were very caring with their casualties, showed respect for their wounded enemies and even helped to bury those who had died with genuine respect. By contrast, the British were ordered to leave their wounded comrades on the battlefield or dump the corpses of those who died in battle in mass graves, which shocked Dutch eyewitnesses. ${ }^{126}$

Another topic of discussion was the morale of the British soldiers. It was believed that they had been misled about their adversaries by the jingo press, which portrayed the Boers as bloodthirsty barbarians. In the Netherlands, many stories appeared about Tommies who discovered that the Boers were actually respectable after they met them. Plokhooy, for instance, wrote about it in his memoirs. He recalled how during a scouting mission after a nightly skirmish near Ladysmith he found a dying British officer. While the Boers did their best to make the last moments of this man as comfortable as possible, he told them that he had changed his mind about the inhabitants of the republics, who had been 'slandered' in England and were wrongly accused of not helping wounded men. With his last breath he asked for forgiveness. ${ }^{\text {I27 }}$ There were also many such stories about British prisoners of war who were taken in large numbers during the first months of the war. Correspondents in Pretoria reported that they were treated kindly by the Boers, a fact that was often acknowledged by the officers, who thanked their guards. ${ }^{\mathrm{I} 28}$

Besides these positive stories, Dutch accounts also described the dark side of 'Tommy Atkins' that was exposed during the war. As casualties rose and the British commanders asked for more men to subdue the Boers, the quality of the recruits declined considerably, according to Dutch commentators. ${ }^{\text {I29 }}$ There was some degree of sympathy for the Yeomanry, volunteers from the 
middle classes who joined with patriotic enthusiasm but had little experience. ${ }^{130}$ It was believed, however, that the majority of the new soldiers were dragged from the slums of London and that these men were in poor physical condition, ill-trained and had low moral standards. The longer the war went on, the more the degeneration of the Tommies became a topic of discussion, and in some sources it was even suggested that England's prisons had been emptied in order to raise enough men. ${ }^{\mathrm{I} 3 \mathrm{I}}$ Troops that were recruited in the dominions were considered more competent in military matters, but became notorious for their cruel behaviour. The recruits that were levied in South Africa in particular - including Afrikaners who joined the imperial forces - were believed to have committed war crimes, as they had an innate hatred of the Boers. ${ }^{132}$

The lack of competent and well-behaved soldiers showed a fundamental weakness in the British military system, and after the occupation of Bloemfontein and Pretoria the military commentator of the $N R C$ wrote that the territorial gain was just a sham victory. 'There is something rotten in the army', he declared with a due sense of drama. ${ }^{\mathrm{I} 33}$ This development was not only considered to be negative for the British war effort, it also threatened to destabilise public order in South Africa. Letter writers from Cape Town and the occupied republics increasingly complained about the behaviour of the troops. Apart from the systematic destruction of civilian property, which will be discussed in the following chapter, the British had a bad reputation for their loose morale. One problem was considered to be their preference for black prostitutes, which was strongly disapproved of by the inhabitants of the republics. ${ }^{\mathrm{I} 4} \mathrm{In}$ addition, accusations cropped up concerning the raping of Boer women, which was considered a severe stain on the reputation of the British army. It was the British journalist William Stead who published the most significant report on this matter after he had received documents concerning the Spoelstra case that had been smuggled out of Pretoria. ${ }^{135}$ Stead's pamphlet was translated and disseminated throughout Europe by the ANV press office. ${ }^{\mathrm{I}} 36$

Notwithstanding the outcry against the mischief committed by white soldiers, the worst affront in the view of Dutch commentators was the recruitment of black people to fight against the Boers. Throughout the war, there were reports that the British government was contemplating the large-scale transportation of coloured troops to South Africa. Citing the rumour that a contingent of Maoris had offered their services to the British Empire, the London correspondent of one Dutch newspaper shuddered at the very thought that the imperialists 'called on the help of barbarians against fellow Chris- 
tians'. ${ }^{137}$ Even more worrying was the recurring news that the British were attempting to recruit local black 'tribes'. Many historians today argue that contemporaries did not acknowledge this aspect of the war, which is probably true if one only looks at British sources. ${ }^{138}$ However, it was quite an important topic in the pro-Boer propaganda campaign. Already before the war, Dutch authors generally argued that the British 'native policy' endangered the stability of colonial rule in South Africa, while the segregation system in the republics was praised as a means to ensure social order. After October I 899, such views reappeared in pro-Boer propaganda, which asserted that the British recruited Africans while the Boers tried to keep them out of the 'white man's war'.

In most pro-Boer accounts, black people were depicted as treacherous spies who provided the British with intelligence. But it was also noted that they often provided inaccurate information, which was seen as an explanation for the large number of mistakes that appeared in the jingo press. In Dutch media, the exaggerated reports about British victories and Boer atrocities in the London newspapers on several occasions were mocked as ' $k a f f e r-$ stories'. ${ }^{\mathrm{I}} 39$ Accusations that the British supplied black people with firearms were considered to be far more serious. In interviews, both Leyds and George McCall Theal warned against the dangers of this policy, predicting that the 'tribes' would turn against all white settlers in South Africa. ${ }^{\mathrm{I}}{ }^{\circ}$ Officially, the British denied such allegations but from the beginning of the war, information reached the Netherlands that indicated that this was indeed taking place. These documents, like articles from South African newspapers and pictures, were widely distributed. ${ }^{\text {III }}$ One of the most famous pieces of evidence from the early phase of the conflict was a photo that was published in the London Illustrated News of January I 900 which depicted armed blacks in Rhodesia, with the text 'some of Khama's trained soldiers, now acting with us'. Leyds ordered his staff to send a circular to all the SAR consuls and the European press to draw their attention to this publication. ${ }^{\mathrm{I}}{ }^{2}$ In the view of many proBoer propagandists, such material exposed the moral bankruptcy of the British Empire. But the concerns about the use of black troops and other acts that were considered to be war crimes should also be seen in the context of emerging ideas about international law. The following section will explore how the pro-Boer media reflected on such matters. 


\section{From The Hague to Derdepoort: war atrocities}

In the light of the alleged atrocities committed during the South African War, many references were made to the Peace Conference that was held in The Hague from May to July I 899, a few months before the outbreak of hostilities. The Dutch government acted as host of this meeting and Foreign Minister W. H. de Beaufort had the onerous task of inviting the participants. He feared that the British might boycott the conference if the Boer republics attended, which would have endangered the overall success of the meeting, and so he decided to leave the SAR and the OF S off the list of those invited. In addition to criticism in the newspapers, there was also a political backlash when Kuyper, who at the time was the leader of the opposition, attacked the government on this matter in Parliament. Several historians consider this to be an opportunistic move by Kuyper to discredit his political rival De Beaufort, which eventually backfired. Initially, this attack was supported by several members of parliament, but in the end a vote of no confidence was not passed and De Beaufort's decision was condoned as a solid piece of realpolitik, which was in keeping with the overall policy of neutrality. ${ }^{\mathrm{I} 33}$ Leyds also accepted this but kept in contact with the Dutch government about the proceedings of the Peace Conference and its implications for the Boer republics. In order to avoid controversy, he did not visit The Hague during the conference, but he was invited by First Minister N. G. Pierson (his former tutor) and De Beaufort to discuss the outcome shortly afterwards. ${ }^{\text {I44 }}$

The British government argued that because the Boers had not officially signed the Hague Convention - which set out rules about international arbitration, conduct on the battlefield, treatment of pows and civilians, and the use of weaponry - the treaty did not apply to the South African War. While this was officially correct, Leyds and other propagandists reasoned that the new rules of engagement should nonetheless be implemented. The Boer republics, they argued, were civilised and independent nations, and so from a moral point of view they had the right to be treated according to European standards. ${ }^{45}$ In addition, the British were accused of violating the Geneva Convention which contained rules regarding the treatment of wounded soldiers and the conduct of the Red Cross, which had been signed by both republics. In 1902, the physician E. G. A. ten Siethoff wrote a pamphlet in which he asserted that, although there was still quite a lot of uncertainty as to how these rules should be applied in practice and many definitions remained vague, they represented 'fundamental principles'. ${ }^{\text {I46 }}$ 
In general, historians see such writings as evidence that there was great interest in international law in the Netherlands, which can be explained by its status as a small nation. ${ }^{147}$ There was, however, also a link with the South African question. In emphasising that the Boers had a right to be treated according to the Geneva and the Hague Conventions, it was asserted that they were a civilising force in Africa and could not be placed on the same level as the coloured enemies the British faced in other colonial wars. Moreover, the British atrocities were in keeping with the idea of a 'century of wrong' and were considered to be part of the violent attack on the republics, in which every means possible was used to subdue the Boers. The press in the Netherlands reported extensively on these issues in order to expose these machinations. In December I 899, Boissevain wrote about the atrocities that were committed on the battlefield by both sides, which he accepted as the unavoidable result of the 'merciless lust to cut and kill' that overcame all combatants in the heat of the moment. However, he accused the jingo press of giving a one-sided view, portraying the Boers as 'treacherous savages' and so inciting their troops to slaughter them like they did the Mahdi army at Omdurman. ${ }^{\mathrm{I} 48}$ An editor of the $N R C$ wrote in a similar vein, arguing that not all reports from the Boer governments were necessarily true, which could be explained by the confusing situation, but that they at least acted out of good faith while the British censors wilfully manipulated their dispatches in a 'despicable' way. ${ }^{\mathrm{I}}{ }^{49}$ Despite these virtuous words, the pro-Boer media were hardly less biased in their coverage of the alleged atrocities, and the evidence that was put forward to support these indictments was not always unproblematic.

One of the most persistent protests was against the use of expanding, or 'dum-dum', bullets. The Convention of The Hague banned this sort of ammunition in wars between the signatory nations, and there was much pressure on the British government not to use it against the Boers either. Already months before the war, there were rumours that Britain was shipping dumdum bullets to South Africa on a large scale, which Leyds used in his efforts to persuade the European powers to mediate. ${ }^{\mathrm{I}}{ }^{\circ}$ After the conflict had started, many reports appeared in the press and in pamphlets that suggested that the British actually used such ammunition. But these allusions appeared to be incorrect at times. In June I900, a military magazine, De Militaire Spectator, published a photo of wrappings of Mark II bullets, made by the dum-dum factory near Calcutta, that had been found on the battlefield at Nicholson's Nek. They did not provide any commentary, implying that these were the in- 
famous expandable bullets. Although they considered the use of such ammunition by the British to be a fact, the editors of $N R C$ criticised the magazine in this case because Mark II bullets were hard-nosed and therefore not forbidden by the Convention of The Hague, which banned Mark IV. What ensued was a lengthy and rather technical polemic about the exact nature of expandable ammunition, but at least this shows that the indictments against the British were not always uncontested. ${ }^{15 \mathrm{I}}$

In addition to this sort of material, there were many accounts of wounded burghers who had supposedly been shot with dum-dum bullets. One male nurse from the Dutch Red Cross graphically described how he was haunted at night by the sight of a young man whose shoulder had been blown off by expanding ammunition. ${ }^{152}$ But this sort of evidence was not unproblematic either. In I90I, Leyds's secretary sent out letters to three Red Cross doctors who had returned from South Africa, asking them for statements that they had seen wounds inflicted by dum-dum bullets. Most of them gave cautious replies. G. W. S. Lingbeek, for example, replied that he had encountered large wounds that could have been caused by expanding bullets but might also have been inflicted by conventional ammunition fired at close range; 'in my opinion all this is not incontestable proof', he wrote. ${ }^{\mathrm{I} 53}$ Needless to say, this letter was not published, but a statement by another doctor who had recently returned from the war zone and did declare that he had seem dum-dum-inflicted wounds was forwarded to the ANV press office, who made a press circular of it. ${ }^{\mathrm{I} 54}$

British reports on dum-dum bullets that had been found at Boer positions were assessed quite differently. Some correspondents admitted that in some instances, they might have been used by the burghers. They argued, however, that the Boers had not bought dum-dum bullets themselves but had taken them from the British, using them in retaliation and in far fewer instances. ${ }^{155}$ Others insinuated that the burghers used such ammunition for hunting only. ${ }^{156}$ In general, pro-Boer commentators preferred to discuss the 'humane' Mauser rifles used by the Boers. These were of a smaller calibre and fired steel-coated bullets that barely caused tissue damage. ${ }^{\mathrm{I}} 57$

Another recurrent complaint that was put forward by both sides was the violation of the Red Cross. On several occasions, British commanders claimed that the burghers shot at ambulances. These charges were dismissed by the Dutch press, however. The Boer governments sent an official letter of complaint to all foreign consuls in Pretoria in which they accused the British army of using the Red Cross as a cover for military convoys, making them justified 
targets. ${ }^{58}$ Later during the war, it was even rumoured that high-ranking British officers travelled in trains bearing the Red Cross sign so that they would not be attacked by the commandos. ${ }^{\mathrm{I}} 59$

By contrast, British acts against the Red Cross operating on the Boer side were extensively covered in the Dutch media, and letters from members of the ambulances about these violations were published at length. One incident that received a significant amount of attention took place in June I 900, when Kitchener stopped an ambulance train from the Dutch Red Cross and the NZASM near Pretoria. He ordered that the national tricolour of the Netherlands be removed, thereby breaking the Geneva Convention which stated that Red Cross convoys should always bear the flag of their country of origin. In letters home, the Dutch doctors reported that Kitchener had acted arrogantly, ignoring their protests and stating that he did not 'allow any other flag in this country except the British'. ${ }^{160}$ Another notorious incident was the arrest of an ambulance team led by Dr Koster outside Pretoria, also in June I900. The British accused him of carrying secret documents and ammunition for the Boers. In his official report, Koster denied these allegations, writing that the letters in his possession were harmless, including an epistle by the wife of Louis Botha to her husband accompanying a piece of biltong (dried meat). ${ }^{16 \mathrm{I}}$ The government in the Netherlands started an inquiry, but this did not prevent the male members of the ambulance from being deported to a Pow camp in Ceylon, while the female nurses were shipped back to Europe. The sluggish official response to these two cases was criticised by the president of the Dutch Red Cross, who felt that the reports on these incidents should have led to more decisive action because national honour had been offended. ${ }^{162}$

At issue was not only the violation of the Red Cross but also the behaviour of the doctors. In letters from the battlefields it was asserted that the British medical services were insufficient, and that doctors and nurses often left their own casualties behind. By contrast, the members of the Dutch Red Cross wrote about their hard work and also that they treated British injured soldiers where they could. ${ }^{163}$ To emphasise the value of these activities, the official report of the Dutch Red Cross on the South African War contained several letters of thanks to its medical staff, both from Boer leaders and from British soldiers. ${ }^{\mathrm{I} 64}$ There was much pride in the Netherlands about the work of these doctors and nurses and their compassion for all victims of an unjust war. Moreover, such stories were in keeping with the perception that the Boer side acted as humanely as possible because they did not ask for the conflict, whereas the British were ruthless in their corrupt efforts to conquer South Africa. 
In the view of Dutch commentators, events that occurred during actual battles also showed that the Boers held the moral high ground. The battle of Elandslaagte, which took place at the start of the conflict, was seen as the first clear example of British cruelty and remained a popular subject for propagandists throughout the war. ${ }^{165}$ As has been mentioned, this confrontation was extensively covered in the Netherlands because of the last stand of the Hollandercorps. In addition, it became notorious for numerous incidents, which, according to Dutch observers, were the result of the imperialist's lust for vengeance that had also affected the soldiers. These biases significantly affected Dutch coverage of the battle. After a large artillery bombardment, the British troops advanced, outnumbering the Boers almost ten to one. A chaotic mêlée followed. In official British reports, which reached Europe first, the republican forces were accused of raising a white flag while they continued shooting. This led to numerous casualties and infuriated the advancing soldiers, it was suggested. These allegations were questioned in the Netherlands as a possible slander from the start. A few weeks later, letters from the Boer side arrived that exempted the commandos from guilt. It was argued that because of the chaos in the lines, one section tried to surrender while other commandos who had not noticed this continued firing. Whatever the case, this incident was not a deliberate violation of the war conventions according to these sources. ${ }^{\mathrm{I} 66}$

Dutch authors were of the opinion that the fury of the British had other reasons, namely pent up frustration provoked by jingo propaganda. Several reports mentioned that the Highlander regiment broke through the Boer lines with the war cry, 'Remember Majuba!' The reference to Colley's defeat in I 88I was illustrative, according to pro-Boers, because it showed that the British were not fighting for a just cause but simply to take revenge for humiliations they had suffered in the past. ${ }^{167}$ This attitude became even clearer during the aftermath of the battle. After the Boers' defences had been breached, a wild and un-coordinated retreat ensued. This gave the $5^{\text {th }}$ Lancers cavalry regiment the opportunity to charge, during which many fleeing burghers were killed or taken prisoner. Throughout the war, numerous accounts were published of helpless Boers who were slaughtered even after they had been captured. ${ }^{168}$ What was even more scandalous in the view of Dutch authors was that this cavalry attack was described in British sources as a heroic and justified deed. The Times published a letter by an officer who wrote that it was 'the most excellent pig-sticking' and boasted that he managed to spear two men at once. These remarks became widely known in the Netherlands 


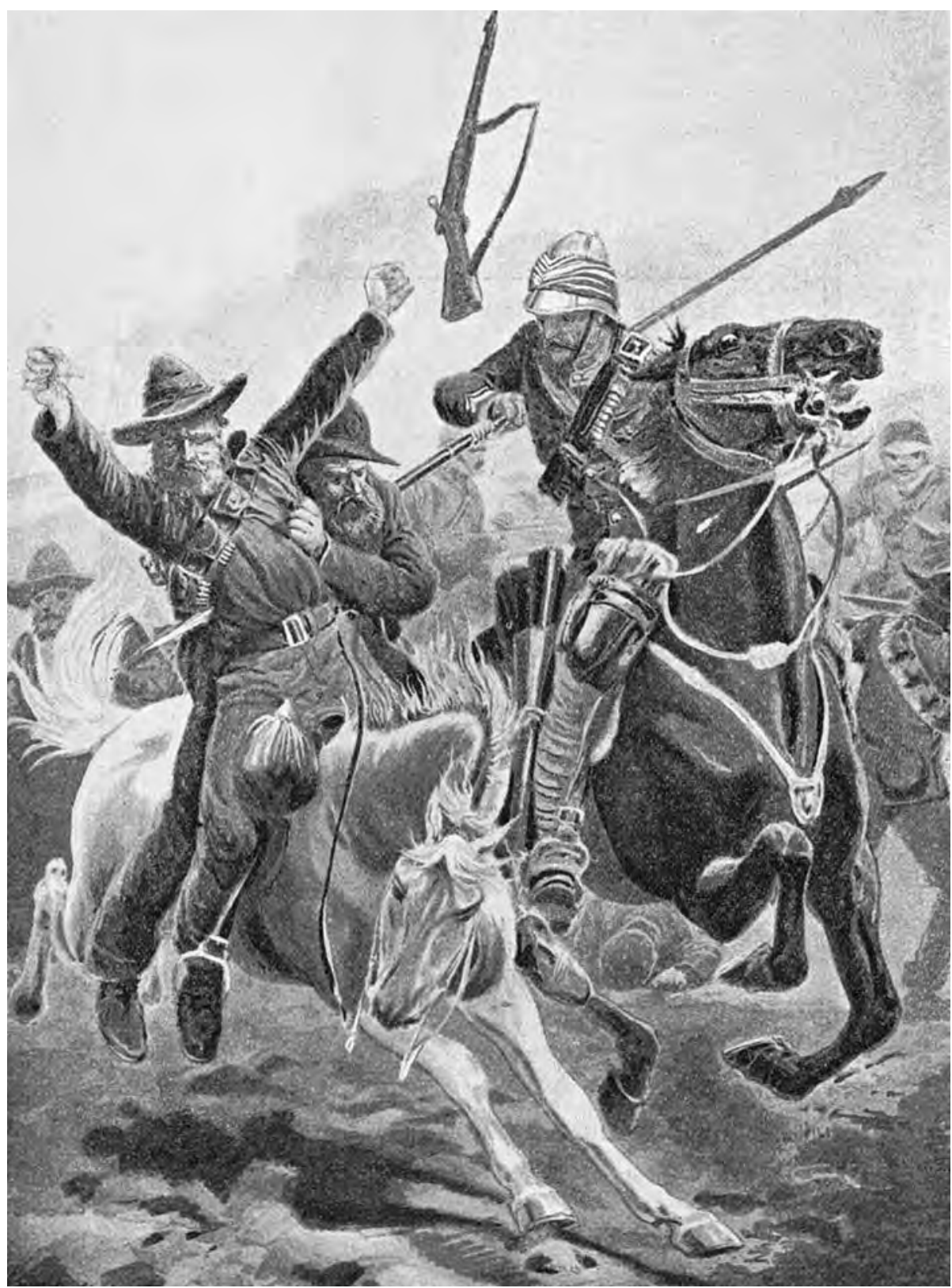

Drawing of the lancer attack at Elandslaagte. Dutch tekst reads: 'Battlefield hyenas. The Lancers kill defenceless Boers who surrendered - thereby breaking international law.' Source: G. H. Priem, De oorlog in Zuid-Afrika: bewerkt naar officieele telegrammen en particuliere brieven VIII (Amsterdam, I899-I90I). Collection Zuid-Afrikahuis, Amsterdam. 
and became a showcase of the arrogant cruelty of the British. It was noted with disgust that this sort of crime was condoned in the London press, which, it was said, illustrated how public opinion there had been 'blinded'. ${ }^{\mathrm{I}} 69 \mathrm{~A}$ drawing depicting the charge that first appeared in the London Illustrated News found its way to the Netherlands too. In Britain the caption described it as an 'incident' that was provoked by the Boers themselves when they kept firing at the advancing cavalry. ${ }^{170}$ By contrast, Dutch authors referred to it as a 'slaughter' during which 'defenceless Boers' were 'murdered'. ${ }^{\mathrm{I} 7 \mathrm{I}}$

Another event during the first phase of the war that was considered by the pro-Boers to be a heinous crime took place at Derdepoort in the western Transvaal on 25 November I 899. A local black 'tribe', the Bakgatla, raided this Boer settlement under the command of a number of British officers. They killed approximately twenty men and women, took eighteen of them as prisoners and drove them away together with their cattle. ${ }^{172}$ The impact of this skirmish on the course of the conflict was far less than the great battles that took place in Natal and the Cape, but it was nevertheless quite extensively reported on in the Netherlands as a 'disgraceful page from the history of this war'. ${ }^{173}$ This can be partly explained by the Dutch concern for international law. J. C. C. den Beer Poortugael, an expert in this field, listed Derdepoort as one of the atrocities that should be prosecuted under the Hague Convention. ${ }^{174}$ But most concerns were regarding the impact that this event would have in South Africa. In material that reached the Netherlands, the indignation from the Boer side about the incident was clearly present. Detailed descriptions of the fight at Derdepoort and the official protest by the governments of the republics against the supposed armament of Africans were published in full on the pages of the press in the Netherlands. ${ }^{175}$ Correspondents from the Transvaal wrote that the white inhabitants there were shocked by the events at Derdepoort, fearing great turmoil amongst the black population. They also stated that the Boers would never have considered using Africans against white opponents. ${ }^{176}$ The editors of the $N R C$ also saw Derdepoort as a continuation of the 'century of wrong'. Referring to earlier colonial wars, they noted that the British had not shied away from using indigenous troops in other conflicts either. In comparison to other atrocities during the South African War, they noted that 'the arousal of the black danger over the white minority in South Africa is an outrage, which can hardly be condemned too sharply'. ${ }^{\text {I77 }}$

The skirmish at Derdepoort was followed by a punitive expedition by the Boers, who defeated the Bakgatla in a battle on 22 December I 899, killing 
around I 50 people. Several villages were burned down during the days that followed. A report from the SAR newspaper The Rand Post that reached the Netherlands described these violent acts of revenge as a justified 'chastisement' of the 'barbarians' who had committed 'crimes'. ${ }^{178}$ The events at Derdepoort and its aftermath also inspired Penning. In his chronicle of the war, he provided his readers with a dramatic description of the 'Kaffer assassination' and the fate of the women who had been captured. ${ }^{179}$ The writer also considered the Boer expedition to be a 'justified punishment', and the chapter had a happy ending. The victorious burghers joyfully celebrated Christmas, enjoying the chickens they had taken from the smouldering huts of the Bakgatla. ${ }^{180}$

\section{Conclusion}

The strong responses by opinion makers in the Netherlands to what happened at Elandslaagte and Derdepoort were part of the ongoing debate about the colonial future of South Africa and the question of whether the Dutch or the British race would dominate there. It has been argued in this chapter that pro-Boer propaganda during the South African War was a continuation of the debate on stamverwantschap that had started in the I880s. At the beginning of the South African War, many publications appeared that considered the conflict to be the outcome of the 'century of wrong' following the British occupation of the Cape. The debate was not without ambivalence, even during the first months when there was much public enthusiasm for the men who defended the independence of Transvaal and the ofs. Certain doubts about the 'kinsmen' in South Africa continued to exist, for example concerning the reluctant attitude of the Afrikaners in the Cape and the lack of discipline in the Boer commandos. Similarly, the British military presence in South Africa was strongly condemned, but at the same time there was a measure of sympathy for the common British soldiers, who were seen as victims of a war that had been initiated by corrupt statesmen and capitalists. When given the overarching colonial issue, however, propagandists in the Netherlands clearly sided with the Boers and attempted to provide an alternative to British coverage of the war. Reports of the burghers' faults were largely glossed over or rejected as slander, while all available evidence of the atrocities committed by their adversaries was discussed extensively. In this regard, it was asserted that the republics were civilised nations that deserved to be treated according to international law. 
The longer the war continued, the more emotional the indictments by propagandists became against the British 'cruelties'. In April I900, H. Wefers Bettink, professor in chemistry at the University of Utrecht, wrote a letter to protest against matters such as the use of dum-dum bullets, the recruitment of black soldiers and the mistreatment of Boer Pows. He saw these as arrogant and cruel acts by the mighty British Empire, which were the result of its unscrupulous expansionism. He summarised the British point of view as: 'The Transvaal must be subdued; its citizens should be exterminated as far as possible. ${ }^{\text {'8I }}$ This sort of radical statement in which the British imperialists were accused of trying to wipe out the Dutch race in South Africa became more common after the territorial conquest of the Boer republics was completed in September I900.

But there were also more hopeful signs. Although there was much disappointment at the commandos' retreat, letters and reports from South Africa showed that the generals in the field continued fighting. The leaders of the pro-Boer movement in Europe used this material to emphasise that the war was far from over. This meant that the hope of a positive outcome for the Boers - the restoration of their independence at least, the unification of South Africa under Dutch dominance at best - lingered on. Many propagandists were of the opinion that the British atrocities had backfired in this regard. A correspondent in Cape Town wrote how the 'racial hatred' between the Dutch and English-speaking white colonists increasingly took 'concrete shape'. ${ }^{182}$ Rompel also mentioned it as a hindrance to English dominance. 'South Africa cannot come to rest under British rule. That has been made impossible by this war. ${ }^{{ }^{1} 8_{3}}$ Hence, the public in the Netherlands continued to oscillate between hope and fear concerning the future of South Africa from June I900 until the end of the war in June 1902. The next chapter will describe the contents of pro-Boer propaganda during that period. 



\section{'All will be well!' Pro-Boer propaganda, June I900-June I902}

Early in 1902, the Dutch-born P. J. Kloppers, who had been a teacher in the Transvaal and was deported back to the Netherlands by the British, published a volume of stories about his experiences during the South African War. The book had the stirring title: Alles zal rech kom! (All will be well), a reference to the famous words of the former president of the ofs, J. H. Brand. ${ }^{\mathrm{I}}$ These words were quite popular amongst pro-Boers between I 899 and 1902 and provided a glimpse of hope at a time when the future of the republics looked increasingly grim. Kloppers did not deny the gravity of the situation and extensively described the methods used by the British to subdue their adversaries, which - as far as he could tell from his own experiences - inflicted great suffering on the inhabitants of the republics, something he already mentioned in letters when he was still in South Africa. ${ }^{2}$ But he also wrote about how, despite his sorrow, the patriotism of the Boers and particularly that of the commandos still left in the field made him defiant. 'No dear reader, I do not even think about submitting myself, I will not make peace with Chamberlain, Milner and their band of robbers, I will continue writing: "All will be well!"';

Kloppers's words reflected the general feelings amongst pro-Boer propagandists during the last phase of the conflict. There was much pessimism concerning the chances of the burghers after the defeat of the commandos in the first half of 1900 and the occupation of the republics, finalised with proclamations by Lord Roberts announcing the annexation of the ofs (May I900) and the SAR (September 1900). What followed were further proclamations implementing harsh measures to end hostilities such as the deportation of Pows and other undesirables, farm-burning and concentration camps, which led to much suffering amongst the Boer forces and the civilian population of South Africa. But there were also reasons for optimism, according to the proBoers. The governments of the Transvaal and the ofs, although they had been severely weakened after having been forced to flee their capitals, still op- 
erated in the field and contested the annexations. Likewise, the Boer representatives in Europe continued to campaign for the restoration of independence. News about the military situation was also used to shore up the hope that the Boers would prevail in the end. Interviews with people returning from South Africa and several reports from Boer generals that were brought to Europe by couriers asserted that the commandos remained defiant, and were able to acquire enough supplies to continue their guerrilla campaign.

Historians tend to see the propaganda in the Netherlands during the South African War as a fleeting phenomenon, which ended when it became clear that the republics would not hold out. In this chapter it will be argued that there was a large degree of continuity in the debate about South Africa up until the end of the war. To many people, the events from this period such as the guerrilla campaign by the Boers and British proclamations that they would counter the Boers constituted a new phase in the ongoing struggle between the 'white races' for colonial dominance in South Africa. The South African War was considered the outcome of a century of British oppression of the Afrikaners, a notion that had become common amongst opinion makers in the Netherlands during the I 880 os and I 890 s. It should be remembered that this debate was never consistent and that there were continual ambivalences. In this sense, the mix of melancholy and hope that characterised the mood of propagandists between June 1900 and June 1902 was typical for the proBoer movement in the Netherlands. The tone of the propaganda did become increasingly radical, however.

The emotional reactions to events taking place in South Africa should be seen in the context of general ideas that existed about the South African question. To contemporaries, the struggle between the two 'white races' was not only fought out on the battlefield. In the view of many, the counter-guerrilla campaign by the British went beyond military conquest and territorial annexation of the republics and targeted the Afrikaner people as a whole, which was seen as an attempt to destroy the Dutch presence in South Africa. The propaganda campaign was therefore an appeal to the international community and the people in Britain to force the Salisbury government to stop this onslaught. Moreover, it was thought that the propaganda campaign could help the Boers in a real sense. Money that was collected was sent to relieve the most immediate needs. In addition, publications on the atrocities were supposed to preserve and rebuild Afrikaner identity after the war. In this way, there continued to be a direct connection between the pro-Boer movement in Europe and events in the war zone. 
In historiography, it is asserted that the Peace of Vereeniging, which signalled the formal surrender of independence by the Boers, came as a great shock to people in the Netherlands, who were very disappointed. 4 But even this dark cloud had a silver lining to some Boer supporters, which will be further discussed at the end of this chapter. Despite the loss of the republics, the people who remained defiant to the bitter end showed that they possessed moral fibre and would not accept Anglicisation, it was thought, and there was even hope that their sacrifice would mean that the Dutch-speaking population would still be victorious in the end. This state of mind concerning the future of the Afrikaners in South Africa was already apparent during the war itself.

\section{After the British occupation}

On I September I900, Lord Roberts announced the annexation of the Transvaal by the British Empire. Whereas the general stated that this proclamation would officially end the war, commentators in the Netherlands had other opinions on the matter. With regard to the legal aspects, it was noted that none of the European powers at that time recognised the annexations of Transvaal and the ofs. ${ }^{5}$ The diplomatic representatives of both republics officially protested against Robert's declarations and issued an address. ${ }^{6}$ In September I90I, they even tried to bring it before the newly formed Permanent Court of Arbitration in The Hague. Although this initiative came from the Dutch foreign office and was supported by prominent members of the political elite, the court did not hear the case on the formal grounds that it had no jurisdiction in it. ${ }^{7}$

What was considered even more important was that the Boer leaders in the field did not surrender. The SAR authorities had moved into the northeastern part of the country, where they set up a seat of government. Reports coming from that region suggested that the British occupation of the towns and railway lines had a limited effect on the rest of the country, where the Boers remained in control. ${ }^{8}$ In addition, several proclamations by the Boer leaders in which the annexation was rejected and the inhabitants of the SAR were called to remain loyal to the old leadership reached the Dutch press. 9 Similar actions were taken by President Steyn and his men, who also remained active, contesting the annexation of their republic. One former commando member recounted an adventurous mission in the occupied parts of the ofs during which he and a small band spread a proclamation by Steyn in which he de- 
clared that these lands were still under the rule of the Free State government. This group managed to mobilise an effective force that commandeered supplies and punished people who collaborated with the occupying forces. ${ }^{\mathrm{IO}}$ Such stories were presented as evidence that the British only ruled as far as their guns reached and that the Boers who roamed the countryside were far from beaten.

Nevertheless, the annexations made public opinion in the Netherlands increasingly discontented with the official policy of neutrality that prevented significant action. To appease these feelings of dissatisfaction, the government offered to help Paul Kruger to leave Africa in September 1900, after having transferred his duties to acting President Schalk Burger. Kruger's voyage on the cruiser Gelderland and his tour throughout Europe were extensively covered by the continental press, and great crowds of people came out to honour him everywhere he showed himself in public. Still, there was some controversy surrounding this masterstroke of publicity. Opposition leader Kuyper criticised the government for the fact that the Gelderland did not sail under the Transvaal flag. Kruger, he argued, was still head of state and should therefore have been treated with full protocol. ${ }^{\text {I }}$ Liberal commentators dismissed Kuyper's complaints as hair-splitting because the foreign minister had referred to Kruger as being president during the debate on this topic in Parliament, which showed that the government did not recognise the British annexation of the Transvaal. The motivation for helping him was humanitarian, however, as the elderly man was in poor health. He therefore travelled incognito after he had been forced to end his active service to his country. On a more practical level, it also ensured that the Gelderland was granted safe passage. ${ }^{\mathrm{I2}}$ Eventually Kuyper accepted these arguments, which ended the polemic about the flag on the Gelderland. ${ }^{13}$

In addition to sparking off political and diplomatic issues surrounding the neutrality policy of the Netherlands, Lord Roberts's proclamations were seen as being inherently part of British efforts to subdue the Boers at any cost and to secure dominance in South Africa - not only on the battlefield but also culturally. The sense that there was a continuous struggle between the two 'white races' that was more than just a military conflict grew stronger during the later phases of the war. Correspondents reported how the British regime became increasingly brutal after the occupation of the two Boer capitals. It was noted how people who had emigrated from continental Europe, and the Dutch in particular, were singled out. Many of them were ordered to leave South Africa, and from June 1900 they were actively deported. ${ }^{\mathrm{I} 4}$ This 
aroused much resentment of the British in the Netherlands, and the exiles were welcomed with compassion. Historians who have written about this subject attribute these sentiments to offended national pride. ${ }^{15}$

There was another aspect to the protests against the deportations that exposed the fear that the end of the independent Dutch presence in South Africa was imminent. In a letter from Pretoria written just before the occupation of the city, a correspondent predicted that the British would close Dutch schools and dismiss Hollander administrators, as they were seen as the greatest obstacles to Anglicisation of the occupied republics. 'The Englishman will trample us [the Dutch] wherever he can.' ${ }^{16}$ In numerous reports that reached the Netherlands after the occupation of Pretoria, it was asserted that the British discriminated against the remaining Dutch inhabitants, making life hard for them by shutting down their businesses and putting them on trial for no reason. ${ }^{17}$

The people who were deported also wrote about how badly they were treated during their forced journey to the coast in open cattle wagons, during which women and children were not sheltered from the elements. One of them, Cornelis Plokhooy, noted in his memoirs that Britain made many enemies in this way. 'Oh, we will never forget the scandalous conduct of England.' ${ }^{\text {} 8}$ The situation was not much better on the ships, he continued. The author was particularly offended by the lousy food; he suspected that tea was made with sea water and that bread was at least one week old when served. ${ }^{19}$ During the sea journey, which took longer than expected, there was little space to live and almost no washing facilities. ${ }^{20}$ Another deportee, J. C. Kakebeeke, wrote a feuilleton about his experiences, which were similar to those of Plokhooy. The article was cynically titled 'England's interpretation of martial law'. ${ }^{21}$ In a later essay, he argued that the racial antagonism of the British against the Dutch living in South Africa was largely the result of propaganda by the jingo press. To prove this, he quoted extensively from the Bloemfontein Post, a newspaper that had been taken over by English journalists who condoned the deportation policy, describing Hollanders in the SAR as 'parasites' who were paying for their misbehaviour. ${ }^{22}$

Naturally, it was clear to contemporaries that not only the Dutch were being targeted. From the moment the British army entered the territory of the Boer republics, the British high command issued dozens of proclamations that affected the population. The first of these demanded the immediate surrender of the combatants who were still fighting in order to end hostilities. As it became clear that the commandos were turning to guerrilla tactics, the tone 
of these documents became more menacing. People who did not surrender voluntarily or pledged to be neutral were threatened with penalties such as deportation and destruction of their property. These measures were not only implemented against the Boers who actually fought but increasingly also against civilians who were suspected of giving help to the commandos. By contrast, collaborators were rewarded and were able to carry on with their lives as normally as was possible under the circumstances. The leader of the ANV press office, Frederik Rompel, analysed these proclamations in a I90 I pamphlet. He argued that they were the result of the failure of the British military to subdue the Boer forces on the battlefield. As a result, the army command and policymakers chose other means to try and secure victory: "what I would like to point out is the ridiculousness of the policy of threats followed by England's government with regards to the Boers, and the cowardice of only daring to implement this policy of threats when it affects the vulnerable'. ${ }^{23}$ Rompel continued by pointing out that the British also tried to lure Afrikaners over to their side with all sorts of promises and rewards. But he concluded that this policy of carrots and sticks was failing: 'all these threats, pleas and promises did not help: the Boers persevered'. ${ }^{24}$ As the war went on, the commandos who continued to fight and the civilians who supported them were considered to be the only hope for the survival of the Dutch race in South Africa, and to opinion makers in the Netherlands they became heroic martyrs. At the same time, there was growing antipathy to those who laid down their arms, or worse, collaborated with the British army. In the following section, this emerging dichotomy between the imagery of the men who fought until the bitter end and those who surrendered will be discussed.

\section{Bittereinders and Handsoppers}

The Boers who continued fighting after the occupation of the republics became known as Bittereinders. ${ }^{25}$ In the Netherlands, they were admired for their courage, and reports of their exploits read like adventure stories. Plokhooy, for example, wrote in his memoirs how he and a comrade outwitted an enemy patrol of six men with rapid fire, which gave the British soldiers the impression that they were being ambushed by a large group. ${ }^{26}$ Another aspect of the guerrilla campaign that interested pro-Boer authors was the holding up of trains. Several memoirs of people who had fought with the commandos included detailed descriptions of how explosive charges could be used to derail trains or blow up locomotives. ${ }^{27}$ The British saw these attacks 
as war crimes but, although it was admitted that the railway personnel did sometimes suffer as a result, the Boers and their supporters in the Netherlands condoned them as legitimate means for the commandos to try and weaken the British army and to secure supplies for themselves. ${ }^{28}$

After the death of Piet Joubert and the capture of Piet Cronjé, a new generation of Boer generals assumed command, including Louis Botha, Koos de la Rey and Jan Smuts who became famous for their guerrilla-style tactics. Arguably the most legendary of these men was Christiaan de Wet, commanderin-chief of the OFs forces. Both Dutch and British reporters saw him as the main architect of the Boers' guerrilla campaign. De Wet's reputation made him a target of the British military, which organised so-called 'drives' to hunt him down and at times he and his commando were chased by many thousands of soldiers. Despite this great superiority in numbers, De Wet managed to escape time after time. The Dutch audience eagerly awaited news about his adventurous exploits, and commentators cheered when it appeared that he had outwitted his adversaries once again: 'Bravo De Wet!'29 Reports of people serving with him contained detailed descriptions of his bold plans. ${ }^{3 \circ}$ In such accounts, De Wet was described as an assertive leader who at times was a bit rash but inspired his men with patriotic speeches and commanded their respect with strict discipline. In addition to these moral qualities that distinguished him from older generations of Boer leaders, he was praised for his 'military genius'. ${ }^{\text {I }}$ In popular culture too, De Wet became an icon. He featured in a number of adventure books and in epic poems which celebrated his abilities as a scout in the veldt. ${ }^{32}$ In several plays that were written for amateur theatre, he was staged as an untouchable vigilante who punished the British. 33

In many ways, these images of the heroic Bittereinders resembled the Dutch literature that appeared about the Boer people before the war began. It was argued by many contemporaries that the essential skills for guerrilla warfare - including marksmanship, horse riding and scouting - had been ingrained in the Boer character during the pioneering days of the Great Trek. As has been mentioned, the attitude towards the Boers in the Netherlands was ambivalent in this respect. On the one hand, authors praised the individual qualities that the Voortrekkers had developed over the years while taming the wilderness, but on the other hand it was noted that they had lost touch with the outside world. Also during the first phase of the war, the lack of discipline in the republics' armies was considered a disadvantage that offset the advantage of their tenacity. ${ }^{34}$ Negative descriptions about the Boers continued to pop up 
throughout the war but became increasingly controversial. One of the most notorious incidents took place in January I902, when Mrs Junius from Arnhem wrote an article under the pseudonym 'Mimosa' which was published in the magazine Hollandia. She argued that the Boers were a petty and conservative people, deeply divided by a strong sense of partisanship and full of hatred towards outsiders, including people from the Netherlands. Willem Leyds responded furiously to these statements, which might have been used in the British press and were therefore harmful to the pro-Boer propaganda campaign. As a result, the publisher of the magazine, P. A. Nierstrasz, even stopped the publication of Hollandia altogether. ${ }^{35}$

Nevertheless, certain developments during the war made the majority of observers more positive about the morale of the commandos. When Boer forces regrouped after the occupation of Pretoria, it appeared that a much smaller number remained. Although this was disappointing at first sight, it was not only seen as a setback by Dutch commentators. Some argued that only well-motivated and able Boers had decided to continue and that in that sense the wheat had been separated from the chaff. ${ }^{36}$ The Bittereinders were considered to be the embodiment of the positive aspects of the Boer character. Their ability to cope with the harsh circumstances in the field was greatly admired. It was asserted in sources coming from the war zone that they were forced to lead a primitive lifestyle as a result of the British anti-guerrilla measures and the loss of control over towns and infrastructure. The fact that they were constantly on the move meant that they were not able to carry many supplies with them and that they had to mainly live on what they found in the field and captured from British convoys. Writings from commandos that reached the Netherlands contained descriptions of a monotonous diet of meat and corn, distasteful surrogates for coffee and tobacco, and their wornout clothes. ${ }^{37}$

Despite these hardships, from September I 900 onwards, the overall tone of reports coming from the commandos became more and more positive, and correspondents wrote about improving morale. In June I90I, J. C. J. Bierens de Haan, a Red Cross doctor returning from South Africa where he served with the commandos, gave an interview about 'the war and the character of the Boers'. He admitted that he had left the Netherlands with too high a view of the common Boers, many of whom he considered to be 'children with a good character, but who have been left too much on their own [...] and whose bad qualities - aside from their good ones - have sometimes grown to disturbing proportions.' However, he thought that the war had brought much im- 
provement in this respect. The Boers had set aside selfish interests and the discipline of the commandos had improved considerably, according to the doctor, who predicted that they would continue to fight in the foreseeable future. $3^{8}$

In letters from the war zone, this renewed fighting spirit was reiterated and it was also stated that the commandos were able to secure enough supplies to continue the struggle. Such information was widely published, while less positive news was suppressed. General Smuts, for example, wrote several reports that reached the Boer representatives in Europe via couriers. In private letters to the diplomatic deputation, he expressed his doubts about the situation, but he explicitly indicated that these were not for publication. ${ }^{39}$ By contrast, onesided official accounts, in which he mentioned the successes of the commandos and the cruelty of the British, were published and distributed by the ANV press office. In these writings Smuts boasted about the morale of his men:

The mood of my burghers is splendid. Although they have, perhaps, suffered more heavily than any other group of burghers in this war, today they look toward the future with hope, convinced that no difficulty or enemy force, whatever its size, can prevent this struggle from being continued until Right triumphs over Might. ${ }^{\circ}$

As was the case in the Voortrekker romance, in these sources the wives of the Boers were considered to be at least as heroic as their husbands, persevering when all appeared to be lost. Although the fortunes of the men fighting in the commandos were reported much more extensively, there was a certain amount of coverage about this aspect of the war too. In several letters it was reported how, when a number of men considered surrender after the breakthrough by the British army, their wives would not accept it and sent them back to fight. ${ }^{4 \mathrm{I}}$ In other ways too, women in the Transvaal and the ofs resisted the occupation of their republics. Stories appeared about how the British were not made welcome by them. Correspondents from Pretoria mentioned that only a few girls started affairs with soldiers from the occupying forces and were ostracised by the community as a result. ${ }^{22}$ Several sources even reported that women became actively involved in the resistance. They gathered intelligence, which they passed on to the commandos in the field, and there was even mention of women fighting with the commandos. Such rumours were rare, though, and did not receive much attention in the media. ${ }^{43}$

A subject that received far more coverage was the suffering of the women 
in the republics, which was considered to be the most typical aspect of the women's experience of the war. In I903, the publicist W. F. Andriessen wrote an article about the 'wives of the Boers' in which he noted that they were far more vulnerable to the British army than the men, who operated in the field and were less affected by the occupation. In addition to accusations that British soldiers and their black auxiliaries committed rape, many accounts noted how women were forced to witness the destruction of their homes and how they were deported to concentration camps, a matter that will be discussed later in this chapter. What matters here is that commentators like Andriessen emphasised that even these extreme hardships did not break the women's spirit. 'They have drunk the cup of sorrows that has been put to their lips to the last drop, and even then they remained standing, they have remained faithful and defiant.' 44 In the view of many people in the Netherlands, these women shared in the heroism of the Bittereinders because they kept faith in the Boers' cause. This sacrifice provided hope that all was not yet lost. There were other groups, however, who did seem to falter or even break under British pressure.

Of all the Dutch-speaking people in South Africa, at most 20,000 men fought against the British until the bitter end, a small minority considering the total population. Contemporaries were particularly disappointed about the situation in the Cape, where the majority of the white population lived. Even before the war started, there were doubts about the commitment of Afrikaner nationalists there to the overall struggle against British hegemony, as they had been subjects of the British Empire for many decades. These doubts persisted, but there also remained hope that the various Dutch-speaking groups would unify. The fact that the Cape government of Conwright Schreiner did not take a firm stance against the war led to much irritation among observers. ${ }^{45}$ Nevertheless, the neutral middle ground became increasingly limited. The longer the war continued, the more oppressive British rule became, which was seen by correspondents as an attempt by Milner to quell any form of opposition. Farmers were ordered to turn in rifles and horses, supplies were commandeered, censorship tightened and people who were suspected of sympathising with the republics were locked up. But these dark clouds gathering over the inhabitants of the colony did have silver linings as well in the view of Dutch commentators. Several letter writers argued that this 'reign of terror' had the opposite effect and undermined support for the British. ${ }^{46}$

Thus there was continuing hope in the Netherlands that the majority of the 
Afrikaners would rise up against the imperial administration if they had a chance. In this respect, much was expected from an invasion by the Boer commandos, which, it was hoped, would arouse these men into joining the republics' forces. Plans for such an operation were developed by the Boer leadership from September I900, resulting in an expedition under the command of General De Wet and President Steyn in February I90I. This operation failed when they encountered a large British force, but other, smaller, commandos did penetrate the border and become active in the wake of this invasion. Several thousands of Afrikaners joined these troops, but it was not nearly the mass rebellion the Boers and their supporters in Europe had hoped for. These disappointments were kept relatively quiet, though. In the official despatch about his operations between October and November I90I, Smuts maintained that the general situation in the Cape was 'very promising'. ${ }^{47}$ In more discrete correspondence, however, he was far less optimistic, asserting that the number of men joining his commando was far less than he had expected, which he attributed to British tactics and a lack of co-ordination between the commandos. ${ }^{8}$ As has been mentioned, the reports in which Smuts expressed such doubts never became propagandistic material.

Other painful matters that exposed the weaknesses of the Dutch position in South Africa were mentioned more explicitly in the pro-Boer coverage of the war. Also in the occupied territories of the republics, the British increased pressure on the population to prevent them from joining the commandos. One of their measures was an oath of neutrality. Men who had signed this document, known as Handsoppers, turned in their weapons and promised not to give support to the Boer forces in the field. ${ }^{49}$ In return, their farms would be left alone. In the writings of the commandos, such men were portrayed as selfish misers who only wished to save their own hide. The statesman W. F. Reitz wrote a poem about these men. He raged that while they sat peacefully at home they were selling 'their birth right' by surrendering to the enemy. ${ }^{50}$ This sort of opportunism was considered to be indicative of their lack of patriotism. Some even criticised Boers who broke their oath of neutrality. In his memoirs, the veteran Dietlof van Warmelo noted that burghers who had already surrendered to the British joined the commando of Koos de la Rey again. According to him this showed a great 'defect in the character' of these men who apparently had not only sworn the oath 'without any qualms', but easily broke it again too. ${ }^{51}$ Although he believed it not to be opportune to discuss this sort of behaviour at length while the war still went on, it is clear that Van Warmelo denounced such fickleness as a bad trait in his compatriots. 
To pro-Boers, the worst opportunists were people who not only signed the oath of neutrality but also worked for the British. In the view of Dutch opinion makers, several prominent Boers betrayed their 'brothers' by seeking conciliation with the occupying forces. They formed so-called peace committees (vredescommissies) and wanted to broker a deal between the Boers and the British, as they considered the republics' cause to be lost. In the Netherlands, these initiatives were rejected with great vehemence as a danger to the commandos who continued to fight. One of the most notorious of these 'traitors' was Piet de Wet, who of all people was a brother of the famous general: an astounding contrast, according to many commentators. ${ }^{22}$ Not only did he seek rapprochement with the enemy, he even formed a regiment that served the British forces. These so-called National Scouts were considered to be a great threat to the commandos. Besides the moral blow, it was pointed out that the Boers serving in them knew the tactics of the commandos and could therefore be quite dangerous. ${ }^{33}$ In letters from South Africa, the National Scouts - also known as 'National Scoundrels' or 'National Scandals' - were described as rascals who deserved to die. ${ }^{54}$ On several occasions, Boer commanders shot Afrikaners whom they accused of working for the enemy. The British protested against such executions, but the Dutch press argued that they were legitimate. ${ }^{55}$ Meanwhile, the protests against the British policies became more vocal as the war progressed.

\section{'Methods of barbarism'}

By June I90I, there was growing concern amongst certain groups in British society about the war dragging on in South Africa. Stories emerged about the campaign by the army to subdue the Boers that showed the ruthlessness of these efforts. In July I90I, Henry Campbell-Bannerman, leader of the Liberal opposition, attacked the government on its policies in South Africa. During a speech in the Holborn restaurant in London, he coined the phrase 'methods of barbarism'. This performance was met with mixed response in the Netherlands. Some saw it as a sign that the public mood in Britain was changing in favour of the anti-war party, a hope that proved to be in vain..$^{6}$ Others were sceptical about Campbell-Bannerman's dedication to trying to stop the war, as he had failed to do so when the conflict had started. ${ }^{57}$ Whatever the motives may have been behind these words, however, pro-Boer authors agreed with their meaning. In general, they condemned the counterguerrilla measures of the British army as 'barbaric'. ${ }^{5}{ }^{8}$ Many wondered how a 
progressive and morally upright nation such as Great Britain could trample their fellow Christians in such a way. One Calvinist minister expressed this indictment in a dramatic sermon delivered at Flushing that was also published in English:

If I mistake not, Great Britain is undoing the work God hath wrought in the sixteenth century [the Reformation], and preparing the way for the Antichrist. [...] The highest interests of humanity are at stake; faith in God, in man, in Government, in religion, in arbitration, in international laws, in the power of right. 59

Such prophetic words did not end the war, and only few people nurtured the hope that the rampant jingoism, which they believed had enchanted the public in Britain, would be replaced by common sense soon.

In this respect, Britain's military campaign was compared to notorious conflicts of the past and present. For instance, Milner's rule in the Cape and Roberts's occupation of the republics was believed by many to be similar to the reign of the Duke of Alva, who terrorised the Low Countries in the I $560{ }^{60}{ }^{6}$ Others saw resemblances to less distant events. The measures used to subdue the Boers were seen as the equivalent of those that were used in Cuba by the Spaniards to quell the guerrilla uprising there. ${ }^{6}{ }^{\mathrm{I}}$ Some went even further and likened the British army to the Turks and the atrocities they committed in Armenia. ${ }^{62}$

A number of contemporaries also saw a parallel with the campaign that the Dutch colonial army was conducting in Aceh, in Sumatra. Since the I 870 , it had tried to 'pacify' this region, and the war had developed into a bloody guerrilla struggle. Several military specialists noted that the British faced similar difficulties in attempting to overcome their adversaries in South Africa. The tone of these remarks was quite reserved because it brought up painful memories about the failure of the Dutch military to quickly put an end to this conflict. ${ }^{63}$ Several critics, such as the Socialist leader Troelstra, took a less cautious approach to this sensitive issue, arguing that the wars in South Africa and Aceh were both expansionist conflicts caused by the greed of capitalists. Moreover, the harsh methods used by the colonial army in the archipelago were considered to be at least as devastating as the conduct of the British in the SAR and the OFS. ${ }^{64}$ Such remarks caused an outcry, particularly amongst Liberal opinion makers. The Boers could not be put on a par with the inhabitants of Sumatra, one member of parliament argued, because they 
promoted 'European civilisation and industry', while the latter were 'a people [...] barbaric in its actions'. One of his colleagues added that there was also 'a difference in skin colour'. ${ }^{65}$ Such comparative remarks should be seen in the light of ongoing concerns about the race question in South Africa. Many of the people in the Netherlands considered the Boers to be a kindred developed people who had the right to be treated according to the conventions of international law. The British were accused of ignoring these principles and of using every means possible to subdue their enemies in the struggle for colonial dominance in South Africa. One of the concerns in this respect was the use of black people, which will be discussed first.

It is asserted in recent historiography that black people performed auxiliary tasks - as drivers, scouts and couriers - mainly for the British army. From the beginning of the war, the Boers and their supporters in Europe argued that black people should be left out of a war between white men. Such complaints continued to reach the Netherlands during the guerrilla campaign. The fact that the Boers also used black auxiliaries, the so-called agterryders, was barely mentioned in Dutch contemporary sources. ${ }^{66}$ In April 1902, a controversy arose when the former military attaché Lieutenant L. W. J. K. Thomson made a speech in which he suggested that Boers used black scouts on a large scale. After he was criticised in the press for these remarks, he publicly offered his apologies and stated that he had referred only to isolated incidents. ${ }^{67}$ In memoirs and novels, there was more frequent mention of black servants at farms who remained loyal to their masters, helping them to flee from the British. ${ }^{68}$ Some observers noted how this showed that the Boers were not as cruel to Africans as the British accused them of being. ${ }^{69}$

However, these examples should be considered the exception rather than the rule, and in general it was asserted in Dutch sources that the Boers could not trust black people. In his reports, Smuts repeatedly mentioned incidents during which he or other commandos were attacked by black troops armed with firearms. ${ }^{70}$ The commandos did not take half measures against them. From the beginning of the war, it was announced that every black person who was caught scouting or carrying messages for the British would be shot, which pro-Boer commentators thought perfectly legitimate..$^{7 \mathrm{I}}$ At times, the British themselves were even blamed for these harsh measures, as they had recruited the black people in the first place..$^{72}$ One of the most notorious incidents that took place was the gruesome execution of Abraham Esau, a coloured blacksmith from Calvinia in the Northern Cape. ${ }^{73}$ When the Boers invaded the colony he founded a scouting regiment. When Calvinia was tem- 
porarily occupied by a commando, Esau was arrested. After several beatings with a sjambok (bull whip), he was dragged behind a horse and shot outside town. British opinion makers condemned this execution, which they saw as a clear example of the deep-seated cruelty of Boers to black people. In the Dutch press, however, this view was rejected as jingo propaganda. A correspondent from Cape Town who wrote about the execution referred to a report by General Smuts in which it was asserted that Esau was the ringleader of black opposition against the Boers in the Northern Cape and was thus a legitimate target. Moreover, he suggested, Esau had probably 'taunted' his captors and so they 'were right to put [him] in his place'. 74

According to pro-Boer propagandists, the Esau case did not stand by itself. It was noted in many letters, reports and memoirs how British rule had corrupted Africans and imperilled social order. The same letter in which the execution of Esau was condoned contained a reflection on the relations between blacks and whites in the Cape. The author described how, in contrast to the Boer republics, black people had more rights there, which he felt was 'one of the most unpleasant things here'. He continued that, unlike what many people from Europe probably might have thought, the greater amount of freedom led to much disturbance in public life, as it made the black population more rowdy, lazy and insolent. ${ }^{75}$ Correspondents from the Transvaal and the OFS also wrote about how the 'Kaffers' there had become more unruly due to the British introducing a milder regime after the occupation. It was noted how servants on farms refused to work or had ran off altogether and how the miners had become lazy without the strict discipline previously imposed by governments of the republics. ${ }^{76}$ What was considered to be at least as problematic, if not worse, was that black people became increasingly abusive. Boer combatants who had been taken prisoner wrote about how they had been mocked by Africans as they were marched down the streets, which they considered degrading. ${ }^{77}$ Women who were brought to concentration camps also complained about this humiliation. ${ }^{78}$ There was, however, a greater threat menacing the Boer wives and daughters. In several letters, it was reported that the numbers of white women who were being raped by black men was rising. ${ }^{79}$

The repeated reports of involvement by black people in the war caused much concern amongst pro-Boer commentators. In one of his writings, Smuts predicted that it would form a grave threat to civilisation, and he condemned the use of armed 'Kaffers' as 'the biggest crime [...] that can ever be committed against the white race in South Africa' ${ }^{80}$ These remarks were sin- 
gled out in the press in the Netherlands, which highlights that the situation in South Africa was first and foremost considered in terms of race. ${ }^{81}$ As had been the case before the South African War, contemporaries did not only associate this question with relations between blacks and whites but also with the struggle between the two 'white races'. This issue became more important during the guerrilla phase, because the British were accused of attempting to exterminate the Dutch presence in South Africa using every means possible.

\section{'The English have a red haze before their eyes': farm-burning}

Many contemporaries considered the advance by Roberts's army into the Boer republics in early 1900 the first sign of the destruction that lay ahead. At the time, the endless columns in which many thousands of soldiers marched forward were known as the 'steamroller'. In her memoirs, one Boer woman described it as being a machine that literally flattened everything in its way. From her farm in the ofs, she saw the army approaching. 'A hellish spectacle! We cannot call it by any other name. With flames, fire and smoke they approach! The grass is consumed by fire and paves the way for them. ${ }^{92}$ The columns also confiscated livestock to supply them with food. In official reports, British officers claimed that they had neatly recorded everything they had taken so that farmers who had laid down their arms could ask for compensation. Correspondents said that things happened quite differently in practice. One member of the Boer deputation, for example, received news from his son that a large part of his cattle had been taken by the British, and no receipt was left. ${ }^{83}$ The devastation went beyond this sort of plunder, though. Eyewitnesses reported the slaughter of large herds of livestock and the destruction of crops so that the commandos could not make use of them. To pro-Boers, this showed the contrast between the good burghers of the republics who had worked hard to cultivate the lands where they had settled and the ruin the British Empire had brought upon South Africa. One correspondent described it as follows: 'The English have a red haze of revenge and bloodthirstiness before their eyes. They see nothing anymore, they only want death - away with it all!'84

What was considered even more illustrative for the British appetite for destruction was the policy of farm-burning. The family was widely seen as the cornerstone of Boer society, so the demolition of their homesteads was experienced as a traumatic event. News of farm-burnings reached Europe soon after the British advance began. At first, these were considered 'shameful' but 
isolated incidents, as it seemed as if only the homes of Boer leaders were being targeted. ${ }^{85}$ Later on during the war, it became clear that it was happening on a much larger scale and that British generals were issuing proclamations in which they condoned farm-burning as a legitimate means to combat the guerrilla tactics used by the Boers. ${ }^{86}$ In the Netherlands, many people took offence at these proclamations, denouncing them as criminal acts that targeted the Boer population as a whole. One commentator described the farm-burning as 'a kind of system of depopulation' which was used 'to turn everything into a wilderness'. ${ }^{87}$

One shocking aspect of the reports about farm-burnings was the apparent brutality of the British troops. The daughter-in-law of an ofs general wrote a letter in which she described how soldiers arrived after a small skirmish that had taken place nearby. Although she explained that she had no contact with the commandos, the men ordered her to move out her furniture and within an hour had set fire to the farm. The woman and her elderly parents were forced to spend the night in the open air before they could travel to the nearest town. ${ }^{8}$ It was reported how in other cases no time was given to empty the house, so that everything was burned. Other sources suggested that valuable belongings were stolen by soldiers, leaving the victims completely destitute. ${ }^{89}$ There were also accounts of women who had been killed during raids on their houses. On some occasions, their homes were bombarded, but other sources reported how women were shot in cold blood. $9{ }^{\circ}$

Such reports of farm-burnings were used in popular literature too, although the scenes were often dramatised. In his chronicle of the war, the author Louwrens Penning mentioned the letters about farm-burnings that the adventurous artillery officer Gerrit Boldingh sent to Het Algemeen Handelsblad. ${ }^{9 \mathrm{I}} \mathrm{He}$ probably also used these writings as a source of inspiration for his novels, which contained fictitious descriptions of such events. In one of his stories, he described how a group of British soldiers 'disgraced' (ontwijd) the farm of the family of Veldcornet Louis Wessels, the hero of the book. His mother who had remained behind stood by helplessly as these men with 'faces like bandits' (roverstronies) stuffed their pockets with loot. What they could not take they smashed to pieces, and furthermore they killed all the livestock and destroyed all the supplies. 'The Khakis danced with pleasure. Their hooliganism had no limits anymore, and while they scooped the precious butter from the pots with their dirty hands, they threw it at each other like snowballs. ${ }^{92}$ In another scene he described how soldiers cheered exuberantly when they set fire to yet another Boer farm. 'They joined hands and 
wildly danced in a circle as the flames rose high above the roof of the doomed house. ${ }^{93}$

Despite such dramatic imagery, there was still hope that the British public would put an end to such practices. Anti-war authors like William Stead and Alfred Marks were seen as whistleblowers who tried to expose the truth about the farm-burnings, which, they said, was kept out of the press by the government and jingo propagandists. Their publications about these matters were known in the Netherlands and were discussed in the media. ${ }^{94}$ One of the most notorious examples became the razing of the village of Dullstroom in northeastern Transvaal. Marks wrote an article about the destruction of this prosperous settlement, which had been founded by emigrants from the Netherlands in I 883. In it, he contested the figures published by the British government, which claimed that eleven houses had been burned, while military reports seemed to indicate that this number was forty-eight at the very least. Moreover, Marks disputed the claims by General Smith-Dorrien (who had ordered the action) that the village was a stronghold of the Boer forces, as there had been no fortifications. Instead, he argued, the main target of the soldiers had been the devout inhabitants of Dullstroom. They had even destroyed house organs and the edifying contents of the local library. The Dutch translation of this article was supplemented with a statement of J. H. Janson, one of the pioneers who had founded the village and who had returned to the Netherlands. He reported that Dullstroom had been revisited twice by the British, who had eventually blown up the local church, the last building left standing, with dynamite. 'Now nothing remains of Dullstroom, the product of years of labour and struggle. It has disappeared from the face of the earth.'95

Just as had been the case during the first phase of the war, the Tommies were not depicted as all being evil in pro-Boer propaganda. There was material that suggested that some of them were opposed to the farm-burnings. Antiwar activists in England published letters from British soldiers and officers who expressed their dislike of this policy but were forced to do it, and these documents reached the press in the Netherlands too. Their authors reiterated that the destruction of farms did not serve any useful purpose, and that they thought that the only result would be that the Boers would simply have nothing to lose anymore and so would continue fighting. ${ }^{6}{ }^{6}$ This kind of source reinforced the idea held by pro-Boers that such actions were inspired by jingo propaganda or ordered by British high command and worsened the 'racial hatred' between the Boers and the British. In their view, the destruction of the 
homes of the Bittereinders was not effective in stopping the war - quite the contrary. It also became clear, however, that not only the material belongings of the Boers were being targeted as a means of subduing them; the anti-guerrilla campaign was increasingly seen as an onslaught on the Afrikaner people as a whole.

\section{'That lethal idleness' of being locked up: the treatment of POWs}

The first people to suffer from these measures were the thousands of people who had been taken prisoner by the British. There were concerns about the treatment of captured Boers from the beginning of the South African War. In particular, the killings following the battle of Elandslaagte caused an outcry amongst the pro-Boers in the Netherlands. Throughout the conflict, this incident was described as one of the greatest offences by the British army. ${ }^{97}$ Accounts of executions continued to emerge during later phases of the war, particularly concerning Cape Afrikaners who had joined the Boer forces. Officially, they were subjects of the British Empire and were therefore branded as rebels by the British and faced severe punishments. A number of those who were caught even received the death penalty. In several cases, a comparison was made with the incident at Slachtersnek at the beginning of the nineteenth century, when colonists were hanged for rising up against the British authorities. Many authors saw this historical event as one of the earliest signs of the wilful oppression of the Afrikaner people. $9^{8}$ Likewise, the executions of the Cape rebels were seen as being excessive. In the view of commentators in the Netherlands, they had rightfully joined their brothers in the struggle against the British. Moreover, the acts for which they were prosecuted, such as the derailment of trains and the execution of black scouts, were legitimate wartime actions according to many pro-Boer authors. 99

One of the most notorious cases was the trial against Gideon Scheepers, who led a commando in the Cape. Dutch correspondents portrayed the trial as a farce because, for instance, Scheepers's claim that he was a citizen of the OFS was immediately dismissed by the court. Such reports were seen as evidence that the British falsified evidence and invented charges so that they would have a pretext to 'get rid of him, now that they have their hands on him' ${ }^{100}$ The death sentence therefore came as no surprise, but according to pro-Boers his execution was 'a murder, nothing else; it will forever be Eng-

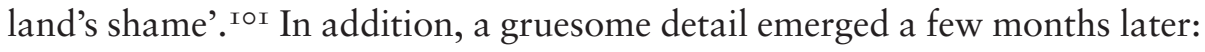
Scheepers, who had been severely ill since his capture, was shot while sitting 
on a chair because he had not had the strength to stand up. ${ }^{\text {I02 }}$ To many, this showed the British determination to eliminate the young commander.

In contrast to the indignation about the way in which his life was ended, commentators praised Scheepers's calm response and acceptance of his fate. In an obituary, Rompel described him as a dedicated officer who inspired his men. Moreover, his dramatic end did not diminish the hope that everything was not lost for the Boers - on the contrary. 'His blood, his martyr's blood will not have been shed in vain, because a man like Scheepers must have had innumerable friends who just like him will want to fight until the end. $\mathrm{He}$ probably will recruit more in death than in life.' ${ }^{103}$ Such eulogies underlined the fact that men like Scheepers remained defiant to the bitter end and even thereafter. Many Pows also shared in this kind of heroism, suffering captivity in distant and barren places.

During the first months of 1900 , prisoners of war were kept in camps in the Cape Peninsula and on ships in Table Bay. Many of them sent letters in which they described their fate to people in the Netherlands. Although there were some who were quite satisfied with their treatment, the majority of the letters contained complaints about the conditions the prisoners were subjected to. One notorious account of the situation was given by F. K. Kannemeyer, a former POW who had managed to escape to Europe. In an official statement and in interviews, he told of the poor sanitary conditions on board of the prison ships, where the inmates barely had room to move. The camps on the shore were better in that respect, but there was a general lack of food and clothing, he reported. ${ }^{104}$ Commentators in the Netherlands compared these descriptions with reports from the Boer side that described the 'humane' treatment of their prisoners. ${ }^{105}$ When Lord Roberts issued statements in which he protested about the situation of captured British soldiers at Pretoria, these were therefore met with great scepticism. Referring to the 'dirty, [...] contaminated ships' where the Boer Pows were 'packed like sardines', a commentator in the Netherlands accused him of hypocrisy. 'It seems that there exists no other people that is more candid in accusing others of things it is guilty of itself, than the English.' ${ }^{106}$ Just as with other issues, the treatment of POws was seen as a sign of the contrast between the Boers, who tried to accommodate their prisoners as well as possible, and the British, who tried to break the morale of their captives. When the army command started to deport POws to overseas camps, this was considered in line with this policy.

After the surrender of Cronjé and his commando of 4,000 men at Paardeberg, the locations near Cape Town were no longer sufficient for housing 
POws, and other solutions had to be found. The British authorities decided to deport them to overseas camps, the first of which was located on St. Helena, the barren island in the Atlantic Ocean where Napoleon had spent his final days. Other camps were set up in Ceylon (present-day Sri Lanka), northern India and the Bermuda Islands. In the view of pro-Boer authors, this solution was not simply a question of logistics, however: they also saw it as an attempt to neutralise the prisoners. The response of one commentator to the news that Cronjé and his men were to be shipped to St. Helena was quite cynical. Reports showed that the transport ships were a hotbed of disease, meaning that many Boers would die during the voyage, which, he argued, would be cheaper for the British government, as the bodies could be fed to the sharks and there would be fewer men to take care of. ${ }^{107}$ Although many correspondents did complain about the sanitary conditions on board the ships, such indictments were not repeated in later commentaries, because it appeared from letters that the casualty numbers remained relatively low, particularly in the overseas camps. ${ }^{\text {108 }}$

Still, the deportation of Pows was seen as a cruel act intended to break the morale of burghers by taking them away from their homeland. First of all, most inhabitants of the landlocked republics were puzzled by the sea, which many of them had never seen before, let alone crossed. Correspondents noted how these men were amazed by their journey and wondered how the ship was able to navigate the endless ocean, which these simple minds compared to the equally vast South African veldt. ${ }^{109}$ Having arrived at their overseas destinations, many of them felt homesick, a feeling that was aggravated by the fact that they worried constantly about their farms and their families. ${ }^{\text {IIO }}$ Moreover, it was added, a monotonous, sedentary life between barbed wired fences was opposite to the character of the Boers, who were used to living in open spaces and engaging in outdoor activities. 'How must that lethal idleness, that cruel dependency, that being locked up and guarded, have been experienced by the men who love their freedom, their independence as much as, yes even more than their own lives.' II I

Many contemporaries considered the deportations of pows to be part of the attempt to rid South Africa of people opposing British rule. In a proclamation, General Kitchener threatened to banish all those who continued their resistance. In the Netherlands, this proclamation was described as 'shameless' and an 'open acknowledgement of [England's] incompetence and moral degeneration'. ${ }^{\mathrm{I}}{ }^{2}$ In the camps an attempt was made to intimidate the inmates in a similar way, it was argued. In letters that slipped through, inmates com- 
plained about censorship and that they barely received news about the situation in South Africa other than from the British press. As a result they felt increasingly isolated. ${ }^{\mathrm{II}}$ In addition to these measures, the camp authorities tried to get everybody to sign the oath of neutrality in exchange for better treatment and the promise that they would be repatriated as soon as the war ended. These promises were also considered to be illegitimate means to subdue the Boers. In many accounts, however, it was asserted that most of the POws were not susceptible to this sort of manipulation and that only a small number of them gave in. Correspondents from several camps wrote that these people were seen as traitors who had to be kept in separate locations so-called 'Judas camps' - to prevent them from being attacked by their fellow inmates or being dipped in the latrines. ${ }^{\mathrm{II}} 4$ The defiance evident in the majority of letters from Pows reinforced the idea that a significant number of Boers, including those who had been deported, held on until the bitter end, refusing to give in to British machinations and retaining their Dutch identity.

Inspired by such sentiments, collections were held for the inmates of the POW camps in the Netherlands. Prominent inmates joined committees that corresponded about aid with Dutch pro-Boer organisations. On St. Helena, B. G. Versélewel de Witt Hamer, an officer from the Hollandercorps, was the main co-ordinator of such activities. In his reports, he emphasised that apart from tobacco, which was a popular commodity amongst the Boers, there was much need for intellectual guidance. To keep the burghers from becoming Anglicised, choirs, libraries and schools were set up in which they were acquainted with the Dutch language. These institutions, mainly run by Hollanders, were actively supported with book shipments by pro-Boer organisations in the Netherlands. In some camps, it was negotiated that periodicals be allowed too, so that the inmates might feel less isolated from the outside world. Initially, Versélewel de Witt Hamer warned in letters that the results would not come instantly, and he described how inmates tore out pages from the books they borrowed from the library because 'of a shortage of sanitary paper'. ${ }^{\text {I } 5}$ As time went by, the tone of his reports became more positive, especially about the schools, which were considered quite useful because many of the Boer Pows had never before received an education. ${ }^{\mathrm{II} 6}$

Other fruits of these patriotic initiatives were plays and concerts that were well attended by the inmates. The British also allowed national holidays like the birthdays of Kruger and Queen Wilhelmina to be celebrated, with sing-alongs, bazaars and sporting events. The public in the Netherlands learned about these activities from letters that reached the media and photo albums 


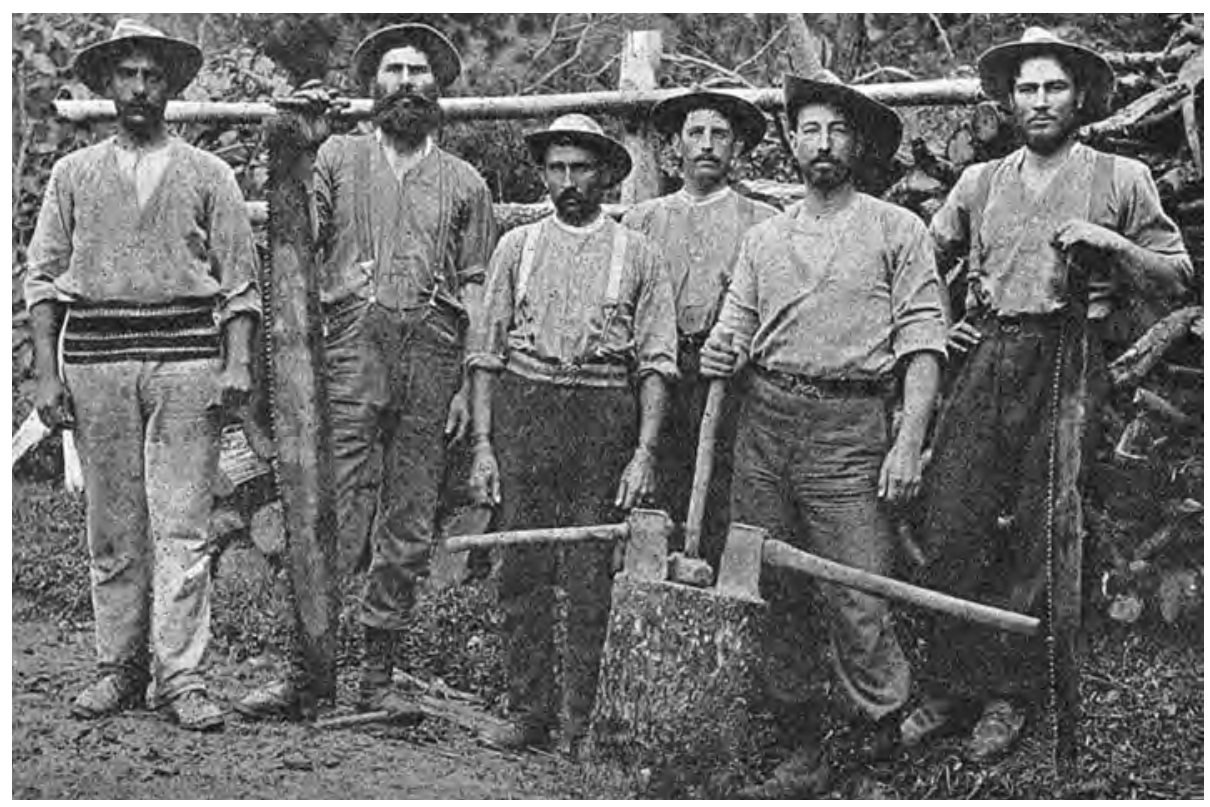

Photo of Boer Pow, working as woodcutters on St. Helena. The accompanying text mentions that the wooden objects that they made, were for sale in the Netherlands. Source: De Boeren op Sint-Helena (Amsterdam, I902), 74-75. Collection Zuid-Afrikahuis Amsterdam.

that depicted the daily life of the POws. ${ }^{I 17}$ There was even more tangible evidence that the Boers retained their Dutch identity in the camps. Many of them turned to woodwork to pass the time, and a number of objects, which often contained patriotic symbols or slogans, found their way to the Netherlands, where they became quite popular. Pro-Boer exhibitions held throughout the country displayed samples of this work, and visitors could buy them as souvenirs from stalls, the proceeds of which went to charities that helped people in POW and concentration camps. ${ }^{I 18}$ Through their handiwork, the camp inmates were seen as kind of Bittereinders: heroes who bravely suffered the cruel treatment by the British but clung onto their identity and resisted imperial dominance. Despite the outcry over the treatment of the Pows, their fate was not considered to be as bad as that of the women and children in the concentration camps. This important topic in pro-Boer propaganda will be discussed in the following section. 


\section{A 'policy of torturing women': concentration camps}

The policy of farm-burning caused problems for the British high command, because it left the farm inhabitants homeless. From the end of I900, the army set up concentration camps throughout South Africa to which these displaced people were deported. In total, hundreds of thousands of white inhabitants of the Boer republics were put in these civilian camps, as they were called by the British authorities. Black farm labourers were interned in separate camps. Because of the poor hygienic conditions, the death rate in the camps was very high. Between 25,000 and 28,000 Boers died there, no less than ten per cent of the white population in the republics before the war. It is estimated that tens of thousands of people lost their lives in black camps too. ${ }^{119}$ Although the existence of the latter was known to contemporaries, it was the fate of the Boers, particularly that of women and children, that caused great commotion amongst the public in Europe and the Liberal opposition in Great Britain. ${ }^{\mathrm{I} 20}$ Faced with this scandal, the British authorities reformed the management of the white concentration camps in accordance with the recommendations of a ladies' committee under the leadership of Millicent Fawcett. This proved to be effective, and the death rates decreased dramatically by the end of I $90 \mathrm{I} .{ }^{\mathrm{I} 2 \mathrm{I}}$ In historiography, there is much controversy about the meaning of the concentration camps. Afrikaner nationalists described them as an attempt to exterminate the Boers. Especially after the Second World War, such remarks became quite contentious because some authors equated the camps in South Africa between I900 and I902 with the Holocaust. Recently, such comparisons have rightfully been dismissed by academics such as Liz Stanley, Elisabeth van Heyningen and Iain R. Smith who have pointed out that they are anachronistic. ${ }^{122}$ Moreover, they argue, the deaths were not the result of a deliberate strategy, as is the case with genocide, but largely 'accidental, the unintended result of military policies that failed to consider the likely human consequences'. ${ }^{123}$

Valuable as these assertions are, these revisionist authors overlook the fact that the Afrikaner nationalists' standpoint on the concentration camps was not only constructed decades after the South African War ended but also rooted in the pro-Boer propaganda campaign in Europe during the period I 899-I902. The condemnation of the concentration camps as an attempt by the British to destroy the Dutch race in South Africa was evident in contemporary sources. Commentators in the Netherlands had already accused the British army of a policy of 'extermination' when they described alleged atroc- 
ities during the earlier phases of the South African War, before the camps were introduced. ${ }^{\mathrm{I} 4}$ Such terms became more common as the war dragged on. For instance, when Kruger arrived in Marseilles in November 1900, he gave a speech in which he assured his audience that the republics would only lose their independence 'after the two Boer peoples with their women and children have been exterminated'. ${ }^{\mathrm{I} 25}$ The Dutch response to the concentration camps must be seen in the context of this sort of rhetoric. To pro-Boers, they formed part of the onslaught the British were unleashing on the Afrikaners to wipe out all resistance to their colonial dominance, during which they did not spare even the most vulnerable groups. The concentration camp policy did lead to protests in Britain, and there was a significant exchange of information between certain figures from the Liberal Party and the pro-Boers in the Netherlands. The ways in which the camp system was interpreted on either side of the North Sea differed considerably, however. Whereas British dissidents saw it as an unfortunate excess, many Dutch observers saw it as the outcome of the racial struggle for colonial dominance in South Africa. This will be discussed in more detail below.

The debate about concentration camps was intertwined with the outcry over the farm-burnings, the very reason that so many people had been displaced. Besides the destruction of material goods, livestock and crops, the human costs were considered to be high too. While the men were still out fighting or had been put out of combat, it was argued, their wives, children and elderly family members were left without any means of subsistence. The British army command initially sent away these groups to live with the commandos in the field because they thought that the obligation to care for civilians lay with the Boer authorities. Pro-Boers argued that this meant that the British had chosen not only to fight the commandos in the field but also the women and children. In this regard, Kruger remarked that he had:

often fought against barbaric African tribes; but the barbarians we now have to fight against are much worse than the others. [...] [T] hey burn our farms; they chase away the women and children, whose husbands and fathers have been killed or taken prisoner; they leave her [sic] without protection, without a roof, without bread often. ${ }^{\mathrm{I} 26}$

Despite these hardships, there were accounts of women who managed to survive in the open field and who were portrayed as living the life of their heroic ancestors during the Great Trek. The most famous example was the wife of 
General Koos de la Rey, who camped out in her ox wagon for 19 months after Lord Methuen's troops burned down her house. ${ }^{\mathrm{I} 27}$ The defiance of these women was also mentioned in other sources. In one of his reports, Smuts wrote of an encounter with a band of destitute women roaming the countryside. Although he lamented their fate and condemned the 'indescribable barbarity' inflicted on them by the British, he described their 'unbreakable perseverance' rooted in their patriotism and their belief in God. ${ }^{\mathrm{I} 28}$

When the British set up camps to house the displaced persons, there was not much assurance that this would improve their situation. In December I900, one of the first accounts from a civilian camp near Port Elizabeth reached the Netherlands via Ons Land. It was written by an Afrikaner lady, S. Hofmeyr, who described the women and children as 'prisoners of war'. According to her, the conditions in which the destitute internees were living were shocking, suffering from disease, lack of food and want of clothes: 'no man however hard and strong, tears will spring from his eyes at the sight of this, and the mothers and daughters are not capable of speaking about the situation in which they find themselves without tears rolling from their eyes'. ${ }^{\text {I29 }}$ After a few months, more ominous news came from camps on the territory of the Transvaal and ofs. An anonymous correspondent who called himself 'Pax' wrote to Het Algemeen Handelsblad about the situation in Johannesburg, where he was a member of the local charity that provided aid to the inmates. The editors of the newspaper kept the identity of the author secret, but it is likely that 'Pax' was Cornelis Broeksma, a public prosecutor who had emigrated from the Netherlands. He sent a report of a meeting between his committee and British authorities, who in his view did not furnish the camp with sufficient building material and supplies. To back up these indictments, he included letters from British doctors that had been suppressed by the authorities in which they complained about the living conditions. ${ }^{\mathrm{I} 3{ }^{\circ}}$ In the months that followed, Broeksma sent several secret reports about the deteriorating conditions in the Johannesburg camp, including mortality figures, which were smuggled to the Transvaal legation in Brussels and published by the NZAV. ${ }^{\text {I3I }}$ Such accounts were supplemented by an increasing amount of material, especially from the committees that were established to provide aid to the internees of various camps throughout South Africa. Pro-Boer organisations in the Netherlands regularly published such letters, which were reproduced in newspapers. Also, letters from private individuals were occasionally smuggled past the censors and reached the press in Europe. ${ }^{\mathrm{I} 32}$

However, the most influential account of the concentration camps was 


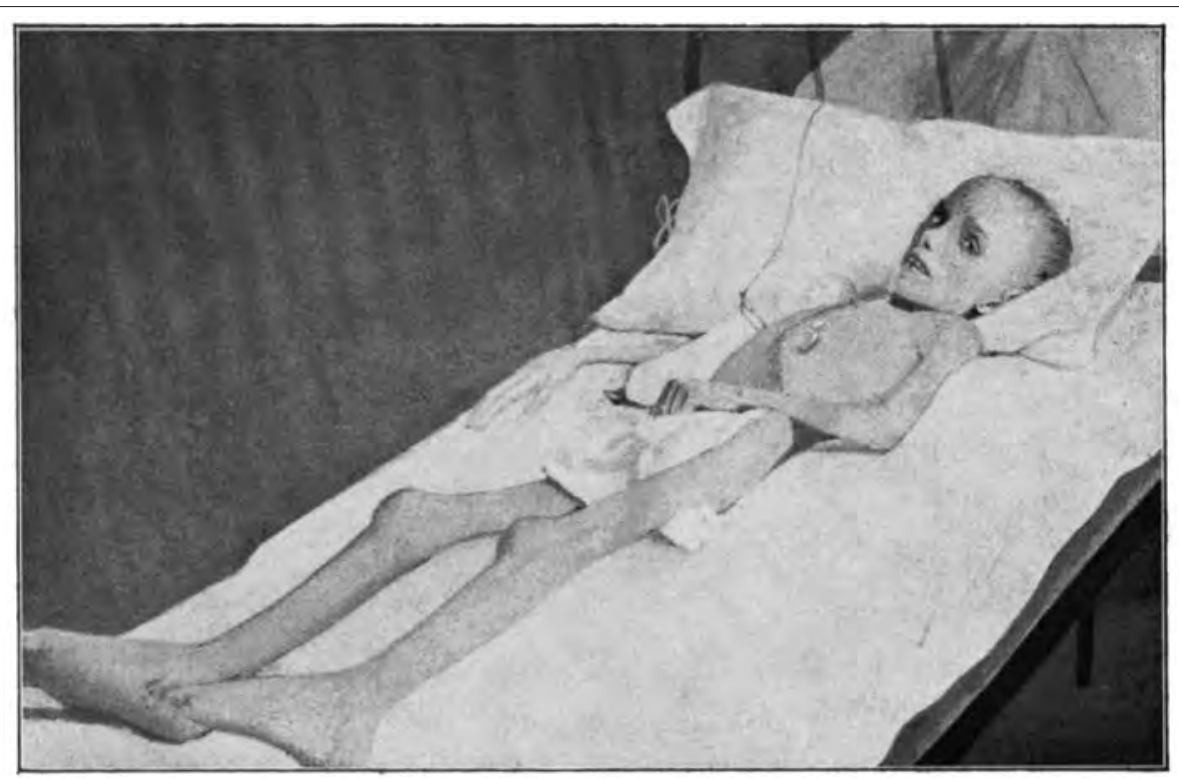

PHOTOGRAPH SENT HOME BY AN ENGLISH LADY FROM THE BOER WOMEN AND CHILDREN'S CAMP AT BLOEMFONTEIN.

She writes:-"Lizzie Van Zyl, about 8 years old-one of our little skeletons. The legs are out of proportion. Several have been emaciated like this. I fancy the food doesn't suit them and the great heat of the tents. It is piteous to see the children."

Postcard with a picture of Lizzie van Zyl. The Dutch text on the back of the card reads: 'Lizzie van Zyl, a starved girl, 8 years old, from the women camps. The Christian work of the English' (I90I).

Source: ZA, Emous Collection, EM 3, DI. Collection Zuid-Afrikahuis, Amsterdam.

provided by an English author: Emily Hobhouse. In October I 900, she established contact with the ANV press office via a mediator in London. In preparation for her journey to the camps on behalf of the Distress Fund for South African Women and Children, between December I900 and April I90 I, she asked for information about the humanitarian situation from people who had recently left the war zone and stayed in the Netherlands. ${ }^{\text {I3 } 3}$ There was not much information available at the time, and during her tour of the Cape, Transvaal and of s she visited many different sites, being the first to give a survey of conditions in all the camps. When the report of her journey reached the ANV press office, it was considered 'too important not to use' and was immediately translated and distributed in the Netherlands and continental

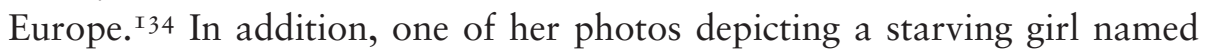


Lizzie van Zyl became an icon for the suffering children in the camps. In the Netherlands, it was published in many magazines and pamphlets and printed on postcards, which were greatly in demand. ${ }^{\mathrm{I}}{ }^{35} \mathrm{H}$. J. Kiewiet de Jonge ensured that a lanternslide was made of it that could be used during lectures about the camps: ' $[t]$ hat image, during a meeting, enlarged on a screen, [...] would have an enormous effect, more than a thousand books.' ${ }^{136}$

What made the Hobhouse report so important was that it provided a general overview of the state of affairs because she had been able to travel around, whereas other correspondents only focussed on the locations where they were. Although the situation differed per camp, such accounts contained similar explanations for the high death rates, and one Dutch author who had been an inmate himself praised the Hobhouse report as 'unbiased', 'dignified and true'. ${ }^{137}$ One point of concern was the lack of food and clean drinking water. In addition, there was almost no soap available, which made hygiene problematic. Other complaints concerned housing. The inmates were mainly accommodated in tents, which left them exposed to the bitterly cold South African winter nights. Moreover, there were few beds, so that many had to sleep on the bare floor, and there was hardly any fuel. All these factors meant that disease was rife in the camps, and the medical facilities were too limited to provide adequate help. Correspondents wrote that it was painful to see how the prosperous women of the republics had fallen to such poverty. ${ }^{\mathrm{I} 8}$ Just as the POWs were described as men who desperately longed for their lost freedom, the misery in the concentration camps was considered to be a stark contrast with the comfortable life the Boers had enjoyed before the war.

The Fawcett committee also noted deficiencies but concluded that the Boer women were responsible for the situation themselves to a large extent. The report described a terrible lack of hygiene and primitive remedies for illness, which was considered to be the result of the underdevelopment of the republics. These remarks were used by the jingo press and members of the British government such as Chamberlain. ${ }^{\mathrm{I}}{ }^{39}$ Before the war, several Dutch authors who wrote about South Africa did mention the primitive housing and bad hygiene conditions of Boer families. ${ }^{\mathrm{I}}{ }^{\circ}$ During the war, however, proBoers opposed such indictments. Together with Hobhouse, they emphasised the cleanliness and the moral strength of the Afrikaner women, who were portrayed as devoted mothers. The high death rates, they argued, were solely the fault of the British authorities, who did not provide adequate means to keep the inmates healthy. ${ }^{\mathrm{I}}{ }^{\mathrm{I}}$ To highlight this, an international campaign was 
started in October I90I. Charts with the death rates of the camps were taken from the British opposition paper The Morning Leader by the ANV press office and made into leaflets that were distributed throughout Europe. In addition, huge posters were hung on walls in cities on which the death rates in South Africa were compared to the mortality figures in the respective cities. ${ }^{\mathrm{I} 42}$

Besides these joint actions, there were also great differences between the protests by British activists and the pro-Boers in the Netherlands. Paula Krebs has shown that Hobhouse believed that the camps were beneficial in principle because they protected Boer women and children from the dangers of the open field, especially black men and their untamed sexual lusts. As such, her protests were directed against the mismanagement of the camps rather than their actual existence. ${ }^{\mathrm{I}} 43$ Dutch authors had a fundamentally different outlook on this matter. In several letters, claims by the British that they were protecting the women and children in the camps because the Boers

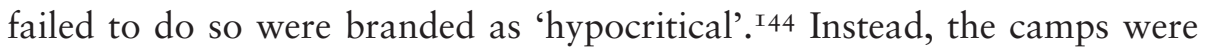
seen as a means to target the civilian population of the Boer republics and particularly the most vulnerable groups. Rompel saw the proclamation policy as a sign that the British army in South Africa had failed to subdue the commandos, which was a reason for soldiers to take out their frustrations on the families of their adversaries with a 'policy of torturing women'. ${ }^{45}$ In addition, he and others argued that the British used the camps as a means to force the Boer men to lay down their arms, which was confirmed by a Reuters report that stated that the families of men who were still fighting were put on half rations. ${ }^{\text {I46 }}$

The outrage at the concentration camps also touched upon another aspect of the race question in South Africa. In many Dutch texts it was suggested that the camps were used to deliberately wipe out the Boer population by killing the women so that reproduction was made impossible. In this context, the word 'murder camps' was used in several sources. ${ }^{\text {I47 }}$ The lack of food in particular was seen as the result of an orchestrated attempt by the authorities to starve the inmates. ${ }^{\mathrm{I}}{ }^{8}$ In the Netherlands, one of the most outspoken authors on this subject was H. J. Emous, a leading figure in the network that provided aid to the camps, who forwarded letters about the situation there to newspapers in the Netherlands. In a series of essays that were published in Het Algemeen Handelsblad in July and August of I901, he stated his views on the matter and tried to convince the public to donate money. ${ }^{\mathrm{I}} 49 \mathrm{He}$ described the poor conditions suffered by the Boer camp internees as an exam- 
ple of 'hypocritical wickedness' that was unprecedented in world history. The British, he argued, starved and exhausted women and children so that they did not have to kill them. He therefore coined the word 'strangling camps' ${ }^{\text {I }}{ }^{\circ}$ The consequences of the British lust for power were perfectly clear according to Emous: the Boers were being exterminated. He even went so far as to call it 'volksmoord', which is a word that had no equivalent in the English language at the time but can be considered to be an early form of the term genocide. ${ }^{\mathrm{I}} \mathrm{I}$ Of course, the meaning of this word was very different from the meaning it has acquired since the Second World War, and the radical statements made by Emous should be seen in the light of contemporary ideas on the South African War that were held in the Netherlands. In the heated atmosphere after the Hobhouse report, it seemed to some that the British were prepared to use any means possible to subdue their rivals during the struggle for colonial dominance and were even capable of mass murder.

The propaganda campaign against the camps reached its climax between July and November I90I, when death rates were the highest. The most tangible results were collections for women and children, which resulted in a steady flow of aid. In addition, several plans were developed to try and persuade the British to put the concentration camps under an international mandate so that the internees could be better taken care of. ${ }^{152}$ However, when news reached Europe that the number of casualties was dropping (around the New Year of 1902), this all came to an end rather quickly. The rapidly declining mortality rates were not only seen as the result of the changing policy of British authorities but were also interpreted in Darwinian terms. Some commentators argued that the weakest groups such as young children had largely died out, so that only the strong survived. ${ }^{\mathrm{I}} 53$ Others saw it as evidence that the Boers were a stubborn people. The Dutch press welcomed a Reuters report that stated that there had been thirty-eight births and twenty-seven deaths in the Bloemfontein camp in March I902. 'Bravo! The Afrikaner race is not easily exterminated.' 54 In the view of contemporaries, the women who survived the camps showed a feisty defiance against the British and in this respect shared in Bittereinder heroism, which made people in the Netherlands confident about the future of the Dutch race in South Africa. The declining death rates were probably not the only reason that the protests against the concentration camps dwindled, however. At the beginning of 1902, persistent rumours appeared about peace negotiations - news that started to dominate the coverage of the war. 


\section{The Peace of Vereeniging}

At several points during the war, news emerged about possible peace negotiations between the British army command and the Boer leadership in South Africa. In February I90I, for instance, the commander-in-chief of the Transvaal forces, Louis Botha, met Herbert Kitchener, acting commander of the British army in South Africa. The Dutch press was suspicious about the British reports of this encounter, and at first commentators dismissed them as jingo propaganda or a trick to stall for time. ${ }^{155}$ After a few months, however, it became clear that the meeting truly had taken place when a newspaper in the Netherlands received a Dutch account of the negotiations, written by someone with the remarkable pseudonym 'B.ot H. Anicus'. ${ }^{56}$ According to this report, the men had met on Kitchener's initiative and Botha had boldly stated that the restoration of independence to the republics was a prerequisite for peace. Although the British commander tried to make other offers, the Boer general refused to settle for anything less, and the negotiations were promptly ended. It was emphasised that the leaders of both the SAR and the OFs agreed with Botha on this point. ${ }^{\mathrm{I} 57}$ In other sources that reached the Netherlands, it was emphasised that the Boer leadership in South Africa would never have accepted peace without the annulment of Lord Roberts's annexations. President Steyn in particular was outspoken in this matter. ${ }^{158}$

This kind of report was in keeping with the romantic image of the Bittereinders held by Europeans. Accounts of the destruction of farms and the fate of the internees of POW and civilian camps caused much outcry and despondency. By contrast, official missives from Boer generals like Smuts that stated that things were going well, militarily speaking, and that the morale of the remaining Boer commandos was high fed the hope that the republics might somehow be restored. Even in May I902, less than a month before the peace was signed, a Dutch veteran who recently had returned from South Africa declared that the situation at the time actually looked better than in June 1900. ${ }^{159}$ Such sentiments were used by the Boer deputation in Europe and their propagandists. When in December I90 I and January I 902 several continental newspapers reported on rumours that new peace talks had started in South Africa, Leyds issued several statements. He declared that he had no information that supported these claims, that no serious negotiations would take place without the involvement of the deputation in Europe and that the restoration of independence to the Boer republics remained a conditio sine qua non for peace. ${ }^{160}$ These stout denials were soon made redundant 
by the actions of the newly elected government in the Netherlands, headed by Abraham Kuyper.

In August I90I, great political change took place when Kuyper's Protestant party won the elections and he came to head a government in the Netherlands for the first time. Some contemporaries were of the opinion that his attacks on the previous cabinet on issues related to the South African War contributed to his victory at the ballot box. As first minister, he made clear that the Netherlands would remain neutral but did state that he would do his best to end the war should he get the opportunity. ${ }^{16 \mathrm{I}}$ This happened in January I902, when he secretly offered the British government to mediate in the conflict in South Africa. Although the British government refused the Dutch offer, it instantly forwarded this memorandum to the Boer generals in South Africa. As a result, secret talks including representatives of the Transvaal and OFs forces were started. ${ }^{162}$

During the aftermath of the mediation attempt, the strained relations between Kuyper and the pro-Boer movement in Europe came to a head. In February, the Dutch government published a memorandum containing confidential correspondence with the British government. Kuyper had only consulted one member of the Boers' diplomatic deputation, Danie Wolmarans, who supported the initiative. In his memoirs, Leyds recounted how he, Kruger and Abraham Fischer were kept in the dark about this contact between the Protestant leader and the 'weaker brother' in the deputation, and how they had had to learn of the initiative from the newspapers. ${ }^{163}$ Even more painful was the fact that the memorandum stated that peace should be negotiated between the British army and the Boers who were left in the field in South Africa, thereby bypassing the envoys in Europe, who were demanding the restoration of independence.

Kuyper's sudden move received much attention from both international and domestic media. There was appreciation for his peace initiative. In the Netherlands, Protestant authors described the action as a prime example of philanthropy. Penning, for instance, praised the 'humanitarian motives' of the Dutch government that, as he saw it, had wanted to end the suffering of the Boer population during this 'terrible war'. ${ }^{164}$ Protestant journalists welcomed the memorandum as a diplomatic victory, arguing that it would force the British authorities to abandon demands of unconditional surrender. Moreover, it was argued that Kuyper's initiative had been very good for the international reputation of the Netherlands, providing a reminder of the country's glory days as a world power in the seventeenth century. ${ }^{165}$ These ar- 
guments could also be found on the pages of other newspapers. ${ }^{166}$ But there was also severe criticism about Kuyper's mediation attempt, particularly from Liberal journalists such as Charles Boissevain. He argued that Kuyper had given the British exactly what they wanted: a pretext to start negotiations that excluded the Boer diplomatic deputation, during which the independence of the republics would not enter the discussion. Moreover, he did not think the mediation attempt would improve the international reputation of the Netherlands as Kuyper's supporters argued - on the contrary. 'Such pompous and absurd self-glorification is particularly suited to making us look completely ridiculous in Europe.' ${ }^{\text {I } 67}$

Boissevain's castigation of Kuyper undoubtedly had to do with the domestic political situation. After the victory of the orthodox Protestants, the Liberals were in the opposition. ${ }^{168}$ But this sort of criticism should also be considered in the light of the public debate about the South African War itself. Although he refrained from commenting at the time, Kuyper later defended his actions by stating that he had tried to broker a peace deal 'to at least prevent the massacre of the Boer race', so that the possibility remained that it would 'revive even stronger in the future'. ${ }^{\mathrm{I}} 69$ This analysis of the situation in South Africa was clearly connected to the fear that the Dutch race in South Africa would be exterminated. At the same time, it went against the propaganda campaign by the pro-Boer movement, which tried to emphasise the positive as well by celebrating the perseverance of the Bittereinders. Leyds was of the opinion that nothing disheartening should come from Europe, so that the Boers would remain motivated to fight on. Although he did not openly condemn Kuyper's move at the time, he later made it clear that he was of the opinion that it undermined the position of the commandos, who were wearing out the British army with their guerrilla tactics. ${ }^{170}$

With the knowledge of hindsight, Kuyper's memorandum can indeed be seen as the event that launched negotiations between Kitchener and the Boer leaders that led to the Peace of Vereeniging, which finalised the annexations of the republics. ${ }^{17 \mathrm{I}}$ These talks were held in secret, though, and there was very little coverage of them at the time. A myriad of rumours reached the press in the Netherlands, often via English newspapers, but there was no clear picture of the proceedings. In the meantime, reports from the commandos that had been sent in February, before the negotiations had gotten underway, expressed confidence that the struggle would continue, so even during this uncertain period there was lingering hope that the Boers would be able to win back their independence. This explains the fact that when the news came 
on 2 June 1902, that peace had been signed and that the independence of the republics had been irrevocably lost, it hit the public in Europe like a lightening bolt. In their memoirs, several pro-Boer activists recounted that they had had no idea that it would come so soon and under those terms. Subsequently, the propaganda campaign was immediately suspended. ${ }^{172}$

After a few days, the dust started to settle a bit and the full implications of the treaty became known in the Netherlands. The primary feeling that dominated the initial response was one of disillusion at the loss of independence. All commentators extensively lamented this aspect of the treaty, and the Boers were not spared of criticism. Editors of newspapers spoke 'a few harsh words' to the burghers who had given up 'something so valuable'. ${ }^{173}$ At first sight, it seemed that the Handsopper mentality had prevailed over Bittereinder heroism. Historians today argue that it was as a result of this setback that the interest in the Boer cause by the public in the Netherlands, which had been so strong during the course of the South African War, suddenly seemed to evaporate. ${ }^{\mathrm{I} 74}$

These sentiments, although they signalled a significant change, do not tell the whole story, however. There were also positive responses to some of the articles of the treaty, particularly those that guaranteed amnesty for the Cape rebels and suspended political rights for black people. And some chose to highlight the fact that the surrender had at least not been unconditional and that the position of the white inhabitants of the former republics was protected to some extent. It was also emphasised that the Boers had shown themselves to be morally superior compared to the mighty British army which had lost all standing in the world. Moreover, there was sympathy for the conditions under which the commandos had surrendered in the end. In addition to the growing menace of black groups armed by the British, they had had to witness how their families pined away in the concentration camps. These views were confirmed in a declaration that the Boer leadership issued after they had signed the treaty, which was published in the press as soon as it reached the Netherlands. ${ }^{\mathrm{I}} 75$

These glimmers of hope came forth from the general ideas that existed about the South African question. Many authors predicted that the peace would only be temporary. Boissevain, for example, refused to call the treaty of Vereeniging a surrender. He thought that the devastation of the old republics had caused so much resentment amongst the Boers and the Cape Afrikaners that the two groups had been 'forged into the race that eventually will civilise and rule South Africa'. ${ }^{176}$ This once again shows that the war in 
South Africa was not seen in military terms only but was also considered to be part of a larger struggle for colonial dominance in the region, which touched upon ideas about race and culture. Even though the republics had been lost as political entities, such ideas continued to exist. Many of the people who were involved in the pro-Boer movement remained defiant and predicted that the end of the war did not rule out Afrikaner dominance.

A few days after he heard about the news of the peace treaty, Leyds wrote to his brother. 'I am glad to read in your letter that you believe that the Boers in South Africa will be victorious in the long run. I agree completely.' ${ }^{\mathrm{I} 77}$ As a result of these hopes, he devoted the rest of his life to assisting in the development of intellectual life amongst the Afrikaners. ${ }^{178}$ The same sentiment can be found in several Dutch publications from that time, and some people in the Netherlands were still prepared to do their bit in the racial and cultural struggle for colonial dominance in South Africa. Just as before, such sentiments were couched in belligerent terms, referring to Bittereinder heroism. The executive of the CNBC, for example, compared themselves with a sentry, a brandwacht: 'to guard and to wait, to stare into darkness perhaps, but thereby training the eye and serving our kindred nation'. ${ }^{179}$

\section{Conclusion}

The coverage of the South African War in Dutch pro-Boer propaganda during the last phase of the conflict showed great continuity with ideas that existed about the rivalry between the Boers and British during previous periods. The unilateral annexations of the republics and the proclamations issued by the British army command were seen as renewed attempts to crush the Dutch race in South Africa. Although some of the responses in the Netherlands can be accounted for by offended national pride and frustration about the policy of neutrality, the main concern was the apparent imminent destruction of the republics. In this heated atmosphere, the perception of the Boers became polarised, which was also the result of the fact that propagandists left out passages from reports that they considered to be in contradiction with their overall message. Those who continued to fight, the Bittereinders, were celebrated as heroes, while those who surrendered, the Handsoppers, were denounced as traitors to their people. This dichotomy also influenced the description of the so-called 'methods of barbarism' that the British used against their adversaries such as the armament of black people, farm-burning, the deportation of Pows and the introduction of concentration camps. Although these meas- 
ures caused great anxiety - some even saw it as an attempt to exterminate the Boers - there remained a glimmer of hope that was kept alive by reports of ongoing perseverance by the burghers and their wives. Even when the peace negotiations were well underway, propagandists in Europe boldly proclaimed that the Boers would never abandon their claim to independence.

It cannot be denied that the Peace of Vereeniging signalled a new phase in relations between the Dutch and the Afrikaners. The end of the Boer republics meant that the hopes for a colony in South Africa that would flourish and become a 'New Holland' were definitively dashed. To contemporaries, however, the question went beyond these geopolitical considerations. From the I 88 os onwards, the Dutch pro-Boer movement strongly emphasised cultural relations. The network that was set up by administrators, engineers, journalists, clergymen and teachers transferred information to the Netherlands, which provided public opinion there with a biased view on the situation in South Africa. It has been argued in the last few chapters that these lines of communication, although severely hampered by the hostilities, provided the material that furnished the pro-Boer propaganda campaign in $\mathrm{Eu}$ rope with material during the South African War.

The contents of such publications were never without ambivalences. Even before the war, authors from the Netherlands wrote about both the positive and the negative sides of the Boer character. These ambiguities continued in the depiction of many commandos during the war, who showed much bravery when things were going well but who lost discipline after the British started their advance. This attitude of ambivalence deepened during the later phases of the war and became polarised in the light of the worsening humanitarian situation. In historiography, it is asserted that despondence prevailed after the war suddenly ended, which appears to be true at first sight. However, many contemporaries within the Dutch pro-Boer movement were of the opinion that all was not lost.

The ongoing defiance of the propagandists should be seen in the context of the struggle between the Boers and the British for colonial dominance in South Africa. To contemporaries, this issue was fought out not only on the battlefield but also in books, pamphlets and classrooms. Pro-Boer propaganda from the I 880 os onwards, had the explicit aim of countering British claims on the region and providing the SAR and the OFS with material to justify their independence. When the republics were formally annexed by the British, however, the views that were put forward in such publications were not seen to have lost their relevance. Indeed, some thought they were more important 
than ever, especially when it became clear that self-governance could be expected for the white population (it was granted in 1906). The Dutch-speaking population outnumbered the English-speaking population and so could potentially achieve a majority in government. Both parties were aware that language represented a crucial divide between them that could be used to mobilise public opinion, making it a politically charged issue. In addition, South African history was a hotly debated issue because both sides tried to appropriate it for their own agenda. In this sense, the war of words about the country's colonial past and future continued after the fighting had ended in I902. The next chapters will explore how the pro-Boer movement in the Netherlands was connected to this ongoing struggle. 

PART III

The aftermath of pro-Boer propaganda (post-I902) 



\section{CHAPTER 7 \\ 'Whoever wants to create a future for himself cannot lose sight of the past': Willem Leyds and Afrikaner nationalism}

On I4 July 1904, Paul Kruger, the former president of the Transvaal, died in exile in the spa town of Clemens, Switzerland. His death can be seen as the symbolic end of the era of Boer independence after both the SAR and the OFS had been added to the British Empire. This was not the only way in which contemporaries interpreted the situation in South Africa, however. Despite the fact that they were officially citizens of the British Empire, there remained hope that the white Dutch-speaking inhabitants of South Africa would be able to unite and so become politically and culturally dominant. This optimism was also apparent in Kruger's political will, a document that was edited by one of his closest assistants, Willem Leyds. The text was addressed to all Afrikaners, calling upon them to take their future in their own hands and rebuild South Africa. In order to do so properly, it was argued, they should connect to their history, which was poured into the following famous words:

Because whoever wants to create a future for himself cannot lose sight of the past. Therefore: look into the past for all good and beautiful things that can be found there, and thereafter shape your ideals and attempt to realise those ideals for the future. ${ }^{\text {I }}$

The fact that Leyds was closely involved in the publication of this document prompts questions about the ties between the pro-Boer movement in the Netherlands and the Afrikaners in South Africa after I902. Several historians who have written about this topic emphasise that these ties lost much of their significance after the Peace of Vereeniging. The most substantial study of the post-I 902 ties between the Dutch and the Afrikaners is written by Bart de Graaff, who believes that the ideas about stamverwantschap became increasingly marginalised due to domestic and international developments. In the Netherlands, he argues, the heroic image of the Boers suffered greatly after they stopped fighting. In addition, the loss of independence by the republics 
meant that the opportunities for trade and emigration disappeared, with the public's interest also fizzling out. ${ }^{2}$ In South Africa, furthermore, the development of Afrikaner nationalism led to increased xenophobia and isolation, which led to a hostile response to influences from the Netherlands and vice versa. The most prominent feature of the Afrikaner nationalist movement was the development of Afrikaans as an independent language. Many leading nationalists considered the complicated grammar of High Dutch to be an impediment to their own efforts to make Dutch the language of the Volk. ${ }^{3}$ Ingrid Glorie also signals this latter phenomenon and even describes it as a 'double process of decolonisation of the Afrikaans language and culture with regard to the English as well as the Dutch cultural dominance that occurred during the first three decades of the twentieth century'. ${ }^{4}$

Other historians notice less change after 1902. Gerrit Schutte writes how in the Netherlands, 'factual interest' in South Africa 'quickly ebbed away' but there remained a 'general feeling of sympathy'. ${ }^{5}$ It is doubtful whether there was simply a growing dichotomy between the Dutch and Afrikaners up until the Second World War, and it seems that tensions climaxed over the language law of 1925 in South Africa, which declared Afrikaans to be independent of Hoog-Hollandsch. Afterwards, relations improved, which resulted in an increase in emigration to South Africa in the I930s and a plan for the establishment of a cultural treaty, which was endorsed by the Dutch government. ${ }^{6}$ Literary scholars also point to a lingering sympathy for the Afrikaner cause in the Netherlands after the end of the South African War. Siegfried Huigen argues that there was a lasting relationship between the literary establishment in the Netherlands and Afrikaner nationalism, at least up until I $925 .{ }^{7}$

This indicates that Dutch views on South Africa and its colonial history continued to exist. From the $188 \mathrm{os}$, this kind of imagery was connected to the transnational network between the Netherlands and South Africa, and this seems to have also been the case after I902. Isabel Hofmeyr has argued that Afrikaner propagandists successfully used the heroic vision of the past to mobilise support, focussing on the Great Trek and the South African War. ${ }^{8}$ Significantly, ideas about folklore that originated in the Netherlands and Germany were quite influential in this connection. ${ }^{9}$ Huigen points out that some works about South African history that were written and published in the Netherlands have been categorised as specimens of Afrikaner historiography. ${ }^{\text {I0 }}$ Some even argue that influences from the Netherlands contributed to the development of ideas about racial segregation that resulted in the apartheid system that was introduced by the Nasionale Party after it came to 
power in 1948. T. D. Moodie describes the apartheid ideology as a Calvinist 'civil religion', which was inspired by the Dutch Protestant party of Abraham Kuyper. ${ }^{\text {II }}$ Schutte refutes this view and emphasises that Calvinism in South Africa and the Netherlands were very different from each other. ${ }^{\mathrm{I}} \mathrm{He}$ does acknowledge, however, that certain Dutch authors (of various political persuasions) helped the Afrikaners to redefine their own history. ${ }^{\mathrm{I} 3}$ These remarks show the importance of looking at the interaction between the Netherlands and South Africa in order to assess the aftermath of the pro-Boer propaganda campaign.

This issue will be discussed by examining the activities of one of the most important pro-Boer propagandist who continued to be active after I902: Willem Leyds. The most important priority for him remained the influencing of public opinion in the hope of mobilising support for the efforts to counter British attempts to Anglicise South Africa. As was the case during previous periods, these efforts were not always successful, and Leyds continued to have an ambivalent view of his 'kinsmen' in the former Boer Republics. Still, he propagated a heroic vision of South Africa's past that was meant to mobilise the white Dutch-speaking population over there. Although the results of his efforts were mixed and he often became entangled in controversies, Leyds was instrumental in transferring several collections of historical material from the Netherlands to South Africa in order to bolster Afrikaner identity. To a certain extent, the flow of information along the lines of communication that had fed the European pro-Boer propaganda campaign during the South African War was reversed after the conflict ended.

\section{(Re)building Afrikaner nationalism}

In 1902, High Commissioner Alfred Milner embarked on a policy to Anglicise South Africa. The main rationale behind this policy was that it was not enough to annex the Boer Republics in order to make the region a solid part of the British Empire; also the cultural and political might of the main colonial rivals, the Afrikaners, had to be broken. In order to do that, Milner's administration set out to implement several schemes to boost British influence. There was an attempt to mobilise more emigrants from the British Isles to combat the numerical majority of Afrikaners, who significantly outnumbered white English-speaking inhabitants of South Africa. Another priority was to make English the dominant language at official institutions so that Dutch would be kept out daily life as much as possible and the Afrikaners 
would submit to British rule more quickly. Particular attention was given to schools, with the aim of Anglicising the future generations of white South Africans. These plans mainly failed, as immigration from Britain did not seriously rise and Milner left South Africa in I905, which was a blow to his supporters in the South African administration. Moreover, after the Liberals came to power in Britain after the landslide election of 1906, the executive power of the colonial government was significantly curtailed, and the South African territories acquired a large measure of self-government under white tutelage, which resulted in the Union of South Africa (I9IO). ${ }^{\mathrm{I} 4}$

This situation thus meant that the Afrikaners had the opportunity to have a serious say in the government of the newly formed Union. In the I90os, this gave rise to a second wave of Afrikaner nationalism, which aimed to mobilise the Dutch-speaking white population during the elections. This resulted in great victories and from the start of the twentieth century onwards, Afrikaners dominated South African politics. The rise of the nationalist movement can largely be explained by its successful opposition to Milner's policies by rebuilding the Dutch language education system and the Dutch press, which forged a new sense of Afrikaner identity. ${ }^{15}$ But there were also significant problems for the Afrikaners in the I900s. During the South African War, the British had implemented harsh censorship laws and had largely destroyed the Dutch infrastructure in the region. In the economic depression that hit South Africa after the war, the Afrikaners lacked the financial means to build their institutions.

This problem was also recognised by the pro-Boers in the Netherlands, who made it their priority to provide aid to the Afrikaner nationalists. During the I900s, the most substantial Dutch fund that could be used for these projects was kept by Leyds, the former minister plenipotentiary of the SAR, who had been in full control over the republic's assets in Europe since I 899 . At the end of the war, there was an amount of around fl. 2 million left in the fund. ${ }^{16}$ During negotiations between the Boer generals and the British government concerning the implementation of the Treaty of Vereeniging that took place in the months after it was signed, Chamberlain demanded on several occasions that this money be handed over to the British authorities. Botha considered giving in to these demands, but Leyds maintained that the sum did not fall under the terms of the treaty as they had been transferred to him before the Boer surrender, and he refused to hand over the money. Meanwhile, he was prepared to act as a trustee for a committee of prominent Afrikaners who would decide on projects that should be funded using the 
money on the condition that the British authorities would not have any say in how it was spent. ${ }^{\mathrm{I} 7}$

It seems that the majority of this sum went to the press. ${ }^{\text {I8 }}$ Leyds, for instance, provided funds to help re-establish Dutch language newspapers in South Africa. In I903, he was contacted by his old friend F. V. Engelenburg, who asked him for money to restart his newspaper De Volksstem. ${ }^{\text {I9 }}$ Together with Jan Smuts, who considered an independent Dutch language press 'the foundation of a steady national policy in future', they made a scheme in which $£ 30,000$ (approximately fl. 360,000) of the SAR assets in Europe were transferred to South Africa via middlemen to conceal the source of the money. With this sum, several periodicals were bought, amongst which De Volksstem in Pretoria, The Friend in Bloemfontein and De Afrikaner in Pietermaritzburg. ${ }^{20}$ In this way, the Transvaal's former treasure chest was used to build up the political and intellectual infrastructure of the Afrikaners.

In addition, Leyds and other pro-Boers continued to be interested in the international network of the South African press, wanting to provide a counterweight to British influences. There was ongoing distrust of the news agency Reuters, which dominated the news supply from and to Europe and was suspected of jingoistic tendencies. In I902, the most important pro-Boer organisation that worked in this field was the press office of the ANV. After the war ended, H. J. Kiewiet de Jonge and F. Rompel decided to continue its activities. The idea was to make the press office the European representative of the Dutch language press in South Africa. On the one hand, it acted as a correspondent, providing news to those South African periodicals, while on the other hand it acted as an agent for distributing Afrikaner views in the European press. $^{2 \mathrm{I}}$ In this way, the ANV press office was an intermediary between South Africa and Europe up until the First World War. Rompel did complain that it was hard to compete with Reuters, which had a far more advanced network and much more money at its disposal, and that it was not always possible to counter their coverage of South African affairs. ${ }^{22}$ In addition, the press office asked newspapers not to mention it as a source. These factors make it difficult to determine the actual impact of these activities, but they do show continuities with the period before 1902 .

Besides the main office at Dordrecht, the ANV employed several correspondents in London. This bureau was founded in I90I, when the Dutch translator M. van Beek offered his services as a liaison between the ANV and the Stop the War Committee and the radical magazine New Age. ${ }^{23}$ After the war, Van Beek continued to send propaganda to members of the press and politi- 
cians. ${ }^{24} \mathrm{He}$ was joined by E. B. Rose, a former journalist from Johannesburg and future MP for the Labour Party, and they both edited a pro-Boer news bulletin. However, the two men constantly argued about money, which led to several fallouts and even deteriorated into physical violence. After a failed mediation attempt by Rompel in I905, all contact with both brawlers was ended. ${ }^{25}$ Their work was continued by the London correspondent of the Dutch newspaper Nieuwe Courant, C. Thieme. He wrote to newspapers if they reported in a way that could harm Afrikaner interests. But also this journalist became a liability because of his huge debts, as a result of which he demanded pay rises. ${ }^{26}$

In I908, Thieme was replaced by J. E. A. Reyneke van Stuwe, who had served as Botha's secretary between I900 and I902. In London, Reyneke van Stuwe pretended that he was accredited as a correspondent by the Dutch newspaper Het Vaderland, but in reality he was acting as an agent for the ANV. ${ }^{27}$ In his extensive correspondence with Rompel, he explained that he kept up his ties with the well-known pro-Boer organisation a secret, as he was afraid that his writings would be refused by editors otherwise. ${ }^{28}$ In addition to his work of 'correcting' newspapers with letters, Reyneke van Stuwe wrote circulars to the Afrikaner press about the British coverage of South African affairs. Reyneke van Stuwe reported regularly on his activities for the ANV in London. He often relayed that his texts were published in various newspapers, and in a letter to Botha he boasted that his influence was growing. Because he constantly sent corrections to the London press, he reasoned, it made journalists 'more careful and fewer follies about South Africa appear in the newspapers'. ${ }^{29}$ The ANV executive committee also praised Reyneke van Stuwe as a talented writer with a valuable network..$^{\circ}$

It is hard to assess to what extent these remarks can be taken at face value, but there was a growing interest in the activities of the press office in both the Netherlands and South Africa. There were positive reactions from the nascent Afrikaner movement to the weekly circulars written by Rompel for the South African press, but in the end there was too little financial compensation to make this initiative feasible. Gustav Preller (who worked for De Volksstem at the time) reported that they were published and were greatly appreciated by the public. ${ }^{\text {I }}$ Nevertheless, there was a reluctance to pay for such services. Engelenburg did pay a sum for Rompel's letters, but this was far too little to cover the costs of all the activities of the ANV press office, leaving Leyds as the most important financier. ${ }^{32}$ When he ran out of funds in the I9Ios, Kiewiet de Jonge unsuccessfully tried to acquire capital from Afrikan- 
er publishers. In a letter, he mentioned that, besides the fact that no money had come from South Africa to reward the ANV for its loyal services, there had 'not even [been] a small token of gratitude'. 33

After Rompel emigrated to South Africa in I9I2, the press office was severely weakened, and at the start of the First World War, the ANV saw itself forced to largely suspend these activities because of a lack of money. ${ }^{34}$ But this was not the definitive end of the efforts to try and influence South African journalism. Both Leyds and Kiewiet de Jonge were involved in an attempt by the NZAV to set up a new press office in I9I7. Like its predecessor, one of its main activities was to provide the Afrikaner press with weekly newsletters, written by J. Visscher, who had been a journalist in Bloemfontein in the I 890 . As was the case with the ANV press office, Visscher was not able to acquire enough income with these activities to act independently and he relied on money from organisations in the Netherlands. The most tangible traces of Visscher's activities in the Afrikaner press were the columns that appeared regularly in De Burger. After this newspaper stopped using this service in 1923 , the NZAV press office ceased to exist. 35

Pro-Boer propagandists also attempted to transfer information to the Afrikaners via other channels than the press. As had been the case before the South African War, language was of vital importance for the nationalists, united in the so-called Tweede Taalbeweging (Second Language Movement). Just like its predecessor, this movement aimed to develop Afrikaans as a written language. ${ }^{36}$ But the relationship with the literary establishment in the Netherlands was different than in the late nineteenth century. Whereas previous language nationalists such as S. J. du Toit were notorious for their aversion to High Dutch, the members of the Tweede Taalbeweging seemed to accept more influences from outside, if only for the practical reason that they needed money from external sources. ${ }^{37}$ In 1905, a simplification of spelling was passed by all Dutch language organisations in South Africa, which had been judged by linguists in the Netherlands and Belgium as 'not unscholarly'. ${ }^{38} \mathrm{~A}$ leading figure from the Tweede Taalbeweging, Gustav Preller, thought it necessary to keep the development of Afrikaans linked to High Dutch. He argued in several essays that this was the only way to keep the language 'civilised' and save it from English and 'coloured' influences. ${ }^{39}$ In correspondence with Leyds and Rompel, Preller reiterated that the Netherlands remained a source of inspiration..$^{\circ}$ In several letters, he emphasised the difference between the Tweede Taalbeweging and the movement led by Du Toit, which was illustrated by the new motto, 'so na molik aan Nederlands'; 'as close as possible to Dutch'. ${ }^{4}$ 
There were groups within the post-I902 Afrikaner movement that were more negative about High Dutch. The leaders of the Nasionale Party, D. F. Malan and J. B. M. Hertzog - who themselves had studied in the Netherlands - publicly declared that it could never become the language of the Volk in South Africa. ${ }^{42}$ Such opinions became stronger, particularly after the First World War. In the I920s, there were several incidents during which fanatical Afrikaners expressed their dislike of High Dutch. The most notorious took place when a teacher in Rustenburg publicly burned all the books from the Netherlands that he could find in his school.43 Despite these events, it would be going too far to say that the Afrikaner nationalist movement was by definition hostile to High Dutch. Many of the tensions ebbed after Afrikaans was proclaimed as an official language of South Africa in I925, which led to closer cultural ties in the I930s. ${ }^{44}$ One reason was the revival of the idea amongst Afrikaners that they could make use of their ties with the Netherlands to counter the influence of English. ${ }^{45}$ Moreover, after initial hesitations about the 1925 language law, people in the Netherlands accepted it, which greatly helped to improve the relationship. ${ }^{46}$ This suggests that the intellectual gap between Afrikaner nationalists and the Dutch was not as wide as may seem at first sight.

This is illustrated by the attitude of some important members of the Dutch pro-Boer movement, who changed their ideas on the relationship between High Dutch and the language of the Afrikaners in the light of the new political situation after 1902. Nicolaas Mansvelt, the former superintendent for education in the SAR, is probably the most prominent example. 47 During his period in office (I892-I900), his policy was aimed at promoting High Dutch at schools in the Transvaal as much as possible, as he thought that this was the best way to protect Dutch cultural domination against English influences. After his return to the Netherlands, he started to propagate quite another view on the matter. In several lectures during the I900s, he supported the development of Afrikaans as a written language, which would be accessible to a large part of the population in South Africa. He therefore called upon the people in the Netherlands not to consider the Tweede Taalbeweging as hostile because they had 'the same goal' as the protagonists of High Dutch - namely to strengthen Dutch influences. ${ }^{8}$

After it became clear that he would not be allowed to return to South Africa, Mansvelt devoted his life to assisting in the development of the Afrikaners. He fulfilled many tasks within the NZAV and affiliated organisations. ${ }^{49}$ One of his most famous projects was the compilation of a volume of 
popular Dutch songs to counter the growing popularity of English music hall tunes. This plan had existed for a long time: already in the I 890s, Mansvelt and the NZAV discussed the possibilities for such a publication, but the South African War intervened. In I904, Mansvelt restarted the project. He set out to gather rhymes - in Afrikaans vernacular and in High Dutch - and select those that suited Afrikaner tastes, which proved to be a difficult task. Correspondents in South Africa were not co-operative, and it took a long time to collect material of sufficient quality. Moreover, most of the texts in Afrikaans had not been put to music, and so the director of the Dutch opera was called in to provide the arrangements. ${ }^{50}$ When the book finally appeared in I908, Mansvelt emphasised in the introduction, which was written in simplified spelling, the importance of patriotic songs for national identity. 'The song that has become communal property of a people', he argued, 'teaches the people to share their joy and sorrow, teaches them to feel one with their forefathers and with each other, it binds the hearts together and strengthens through unity'. ${ }^{5}{ }^{\mathrm{I}} \mathrm{He}$ included a great variety of songs in order to make the book appealing for the largest audience possible.

Despite the tedious process of compiling the book, it was enthusiastically supported by Rompel. The managing director of the ANV press office was an outspoken adherent of the Tweede Taalbeweging and in many of his reports to the Afrikaner press he pointed out the need to promote the Dutch language. Rompel noted how many Afrikaners were embarrassed to sing in their language, which he thought was a shame, as it was poetic and well-suited to putting to music. In one essay, he explained how French had been culturally dominant in the Low Countries in the middle of the nineteenth century, but that folksongs had quickly become popular amongst the Dutch-speaking audience after patriotic authors published volumes similar to that of Mansvelt. He expressed the hope that the same would happen in South Africa in order to replace English as the dominant language. ${ }^{52}$ The Afrikaner press shared these views. There were critical remarks about some of the choices Mansvelt had made, but the general consensus was that his volume was a valuable contribution to the development of Dutch cultural life in South Africa. ${ }^{53}$ This was reflected in sales: within a few months, the first two editions of the songbook had been sold out. 54

The examples mentioned above show that there was a significant measure of continuity in the lines of communication between the pro-Boers in the Netherlands and the Afrikaners in South Africa before and after 1902. Although the political situation changed fundamentally with the official annex- 
ation of the Boer Republics and the formation of the Union, the cultural struggle between the English and Dutch elements continued. Like before, Dutch pro-Boers tried to influence this struggle by providing the Afrikaners with the means to strengthen their institutions and the material to bolster their identity against attempts to Anglicise them. These efforts were not always successful, and some groups of Afrikaners at times reacted in quite a hostile way. But this also represented a continuity with previous periods, as relations between the people in the Netherlands and their 'kinsmen' in South Africa had been ambivalent from the I 88 os onwards. These continuities are also clearly present when looking at the activities of one of the pivots in the network between the Netherlands and South Africa: Willem Leyds.

\section{Willem Leyds and Afrikaner historiography}

After the SAR had officially ceased to exist, the legation in Europe was closed and Leyds, who had become stateless, successfully re-applied for Dutch citizenship. Although he was offered several prestigious jobs in the diplomatic service and academia, he refused these in order to focus on South Africa and help to (re-)build Afrikaner identity. Lynette van Niekerk provides the most extensive overview of these efforts in her biography about Leyds, quoting his words from I 929 with approval: 'I had devoted my life to South Africa; I did not want to give up that task'. ${ }^{55}$ Considering the results of his work, it remains to be seen whether this elevated view really is justified, but it cannot be denied that Leyds did expend much effort in fulfilling this task, which was mainly meant to awaken the historical awareness of the Afrikaners. The main source for the following sections is the enormous archive of Leyds's legation that is kept in the National Archives of South Africa in Pretoria. As will be explained, the transfer of these documents from the Netherlands to South Africa was meant to give a boost to Afrikaner identity and, as such, can be considered to be an act of propaganda in itself. Historians therefore have to be careful not to take this material at face value. Still, it will be argued that this extensive collection gives us a taste of how attempts were made to use pro-Boer propaganda for the development of Afrikaner nationalism after 1902. Such initiatives were not uncontroversial and more often than not ended in failure. Although Leyds did try to leave a record that depicted him in a positive light, such frustrations are clearly present in his papers.

The most tangible aid Leyds provided to the Afrikaners was in the form of money coming from the remnants of the Transvaal state assets to rebuild cul- 
tural institutions. These activities should be seen in the light of ideas about the ongoing struggle for colonial dominance between the white Dutch-speaking and white English-speaking communities. These efforts were a clear continuation of the ideals that Leyds propagated in the I 880 os and I 890 . He did accept the political changes that took place in South Africa after I902, however, and did not argue in favour of the restoration of the Boer republics. In his view, the Afrikaners would be able to wrestle power from the Englishspeaking population in the Union and eventually gain independence from the British Empire. For the time being, he accepted South Africa's position within the imperial sphere of influence. This became clear during the First World War, when Leyds was asked by the German government to become the political leader of the rebellion in South Africa. Although he opposed Botha's policy to pledge allegiance to Britain, he immediately refused this offer. ${ }^{56}$ Nonetheless, Leyds was quite a radical supporter of Afrikaner nationalism and one could say that, in a reversal of the famous phrase by Carl von Clausewitz, he considered South African politics after 1902 as a continuation of the war by other means. ${ }^{57}$ In this respect, the way in which the colonial past was depicted was essential for him.

Leyds's best-known activity after the South African War was history writing. He published two ample works about the relations between the Boer republics (mainly the Transvaal) and the British Empire up until the outbreak of the South African War. ${ }^{8}$ As he himself had played a part in the last period of that history as state secretary of the SAR, the question is whether these works can be considered to be proper academic studies. Although it can be argued that they have some historical significance because of his close involvement and his in-depth knowledge of the subject, there is a general consensus amongst historians from the I90os to the present day that they are too subjective to be serious historiography. ${ }^{59}$ Leyds himself claimed that his aim was to provide a factual account of events, but it is clear that he also saw the political significance of his work. ${ }^{60}$ His main source was an almost complete collection of British blue books (official government publications) on South Africa, to which he lovingly referred as his 'arsenal'. Extensive reference to this collection made it hard for English critics to dispel his views, Leyds argued. ${ }^{6 \mathrm{I}}$ In a letter replying to a review of the proofs for his second publication, he described it as follows:

[It] is a mine that others must draw from. I only wanted to provide material. I have silenced my own indignation. But they who announce the book, 
it is up to them to flog the British, in the light of the facts that I teach. I would also wish these facts to be acknowledged by our enemies, but the only chance of that happening is if I present it without passion, and without my own commentary. ${ }^{62}$

It can be argued that some of Leyds's motives for writing his historical works were personal, justifying his own decisions in the I 88 os and I 890 s. It certainly is likely that one of his goals was to exonerate the conduct of the Boer governments, and particularly that of Kruger, as is shown by the reaction of Leyds's successor as state secretary, F. W. Reitz who hailed the two books as 'an irrefutable defence of the politics of the Transvaal from its beginning'. ${ }^{63}$ This quote also suggests that there was a deeper meaning to Leyds's historical work - namely to rewrite the history of South Africa in order to dispel British views of the recent past. In this way, these activities were a continuation of the work by Dutch authors before I 899 and many propagandists during the South African War, who wanted to do much the same. It can therefore be argued that Leyds's work was primarily intended for the Afrikaner people to help them develop their own identity. In a somewhat dated but otherwise excellent critique, the South African historian F. A. van Jaarsveld shows that Leyds thus contributed significantly to the development of Afrikaner nationalism. ${ }^{64}$

Remarkably, Leyds himself did not attempt to write a complete history of the South African War, which was considered to be the most important event in modern South Africa. Eventually, he did edit four volumes of material from the archives of the SAR legation concerning his own activities. These books were more personal than his works about the rivalry between the Boer republics and the British Empire in the nineteenth century. To start with, they were only published for private use, with Leyds sending them to individuals and institutions he thought would be interested. The first volume, which appeared in I9I9, was intended as a refutation of the accusation in many British publications that he had advised the SAR government to initiate hostilities in $1899 .{ }^{65}$ When it appeared that the volume attracted a great deal of interest, Leyds decided to publish selected correspondences about his activities up until 1902, the last volume of which appeared in 1934. In contrast with the first book, the former minister plenipotentiary provided introductions in which he discussed some of the leading themes. In 1930, this resulted in a polemic with Hendrik Muller, the former consul-general of the ofs, who wrote his own account containing a biting criticism of the activities of the 
SAR legation. ${ }^{66}$ This text stirred up the old animosity between the two Boer representatives. Leyds wrote to influential Dutch academics and diplomats about the document, arguing that it was full of 'untruths, gibes and low insinuations' ${ }^{67}$ In addition, he wrote a pamphlet to counter Muller's views and in the third volume of his diplomatic correspondence published an appendix in which he accused the ofs representative of almost ruining the arrival of Kruger in Marseilles in I900. ${ }^{68}$

Such personal vendettas must not obscure the fact that Leyds had more profound motives with his writings about the South African War. While he himself did not discuss the situation on the battlefields, he certainly was of the opinion that it was an important topic that merited publication. In the I9oos, he was involved in several publications of accounts of people who had experienced the South African War firsthand, either in the field or in the camps. Because the inhabitants of the former Boer republics lacked the means to publish such works themselves, many were printed in the Netherlands and distributed in South Africa by bookshops like J. A. Wormser, J. H. de Bussy and Haum. These firms had established branches in South Africa before the war, and these were revived after I902.69 The demand for their books was rather limited, however, and the publishers complained about the lack of support from the Boer leaders for their activities, which led to serious financial problems. ${ }^{70}$ Nevertheless, contemporaries considered the memoirs of veterans to be important source material for later historians because they presented a Boer perspective on the South African War. Such views were often expressed by authors. None of them, however, claimed to give a complete account of the conflict and instead emphasised that their writings were strictly personal. Moreover, they often admitted that their personal diaries and notes had been lost during the fighting so that they wrote down their impressions from their own memories. ${ }^{7 \mathrm{I}}$

Leyds was aware of the fragmented nature of this corpus of literature and considered it to be a problem. Already during the South African War, he started thinking about how the Boer side could be presented in an effective way. This was an urgent matter because the first books supporting the British imperialists' point of view started to appear before the end of the conflict, such as Arthur Conan Doyle's The Great Boer War (I900) and The War in South Africa: Its Cause and Conduct (February 1902). Pro-Boers in the Netherlands dismissed these works as blatant jingo propaganda that exposed a misplaced sense of superiority on the British side. ${ }^{72}$ Nevertheless, Leyds took them seriously and worried about the influence they could exert in future. 
This was particularly the case with The Times History of the War in South Africa, a project started by Leo Amery, a young and ambitious reporter from The Times. In I900, a volume about the causes of the conflict appeared, with the second part covering the first few months of the fighting following in June 1902. The thorough approach by Amery and his co-authors meant that it took many years before the whole series (seven bulky volumes in all) was completed, in 1909. Because Amery had access to a wide range of sources from the British side through his remarkable network, which included many members of the imperial elites, his work was considered to be the most important historical publication about the war for many decades, despite the fact that it gave a biased and pro-British view. ${ }^{73}$ The Times History is a prime example of a so-called official history, an account mainly based on government and military sources. Contemporaries attributed great educational value to this genre and it can therefore be seen as an exercise in nation-building. ${ }^{74}$ This was certainly the case with Amery's project, whose main objective was to point out the worrying state of the British military and agitate for army reform in order to ensure the survival of the empire into the twentieth century. 75

Although Leyds did not have such a concrete agenda focussed on one particular lesson that could be learned from the war, he did have similar ideas about the value of such histories. His goal was to provide the Afrikaner people with building blocks for a new vision of their past that would make them proud of their heritage and strengthen their self-awareness. One of the people Leyds discussed this issue with quoted him as follows:

that [an] accurate record of the war, the refutation of misrepresentations, will be to the benefit of the Afrikaner people also at a later point in time, as this work will erect an everlasting monument for them as a nation, that people today and in posterity will look at with respect and admiration, through which the preservation and elevation of the Boers as an independent nation will be stimulated. ${ }^{76}$

On several occasions in the I900s, Leyds tried to organise the publication of a work that could compete with The Times History but never succeeded. Still, the failures show that the attempts to rewrite the history of the South African War were a direct extension of the propaganda campaign between I 899 and I902.

The first plan to publish an integrated history of the war from a Boer per- 
spective emerged just after the fighting had ended, when it became clear that Generals Botha, De la Rey and De Wet were going to visit Europe. They wrote to F. V. Engelenburg that they wanted to publish a book simultaneously in different languages across the world. Besides the political significance, the generals also saw commercial opportunities and anticipated that a book with such a famous line-up of authors would generate much money. It was proposed that Kruger and Steyn would sign the introduction. Part one would be a 'histoire politique', with three chapters about the pre-war situation in the Transvaal (by Engelenburg himself), the ofs (by Abraham Fischer, a prominent politician from the republic) and the Cape (by F. S. Malan, an Afrikaner journalist). This would be followed by three chapters on the events during the war in South Africa, a 'bistoire-bataille' written by the three Boer generals. Finally, Leyds was asked to write a 'histoire diplomatique' about his activities as minister plenipotentiary. 77

At first, Leyds was positive about the plan but he soon saw how it crumbled. After three weeks he replied to Engelenburg that 'this matter has completely been spoiled', which he thought was the fault of Kruger and De Wet. Both men had decided to publish their own books without consulting the others, and this narrow-mindedness harmed the overall cause, he argued. Kruger had dictated his memoirs to his personal secretary, and because the memory of the former president was somewhat clouded, Leyds feared that the book would be nothing more than 'a collection of anecdotes, while it could have become a monument of history'. In addition, he accused Kruger's family of exploiting the elderly man: in their lust for profit, they had sold all the rights to a German publisher, who had gained complete control over the text. De Wet made similar mistakes, said Leyds, because the famous general had sold the rights to his memoirs before he left South Africa in order to compensate for the losses he had suffered during the war; 'it is thus a private speculation'.$^{78}$ Ironically, Leyds was asked to act as an agent for the war memoirs of De Wet, a truly international enterprise, appearing almost simultaneously in Dutch, French, German, Russian and English. Its popularity is illustrated by the fact that it even sold well in Britain; in the Netherlands no less than twenty-three editions appeared within a year. 79 The failure of this plan for an integrated history of the South African War shows that it was no easy matter to publish such a work, requiring a lot of co-ordination and organisation.

During later attempts, the authors Leyds worked with were of a lesser stature than the Boer generals. One of them was P. A. Nierstrasz, who had been an active propagandist during the South African War. ${ }^{80}$ Several contem- 
poraries thought that the publisher was 'an untrustworthy person' and warned Leyds against him. ${ }^{8 \mathrm{I}}$ Nevertheless, the former SAR diplomat kept paying for his services after June 1902 and Nierstrasz initially wrote a huge number of reports on the South African press. ${ }^{82}$ After a while, the two men started discussing plans for a military history of the war. Nierstrasz, a former artillerist, had already been asked by the Russian army to write such a book in I90I. Nevertheless, Leyds was the main supporter of this project and it seems that the Russian assignment was used to cover up his involvement. ${ }^{83}$ As it turned out, in fact, Leyds provided all the funds, amounting to some fl. $40,000 . .^{8}$

In a letter explaining his plan for a standard book about the South African War, Nierstrasz recounted a discussion he and Leyds had had about the use of such a work for the Afrikaners. He argued that the authors of official British histories ignored many facts, provided a wrong impression of the Boer side and glorified their own deeds in order to create a vision of the past that suited their political purposes. None of the accounts that were written by Boers provided a coherent refutation of these views, however: '[they] are more like episodes, personal experiences, which are placed in the foreground by the author'. ${ }^{85}$ Other accounts, published by the French and German military, did not solve this problem either, as they focussed on the first months of the war only and also used unreliable British sources. ${ }^{86}$ Nierstrasz therefore wanted to write a synthesis of all the Boer sources, which would ensure more 'objectivity' because it would be comparable to the British accounts. Apart from the political advantages to the Afrikaners, the publisher added, this work would also be of importance to European powers, as it would give a profound insight into the nature of colonial warfare. ${ }^{87}$

Leyds wanted the book to be written as quickly as possible, but there were some delays caused by a conflict between Nierstrasz and one of his employees. ${ }^{88}$ Still, the printing proofs, amounting to ten volumes (more than $\mathrm{I}, 600$ pages), were handed over to Leyds after a little over two years, in March I 906. ${ }^{89}$ The first part, which consisted of two volumes written in French, described the geography of South Africa and the structure of the British colonies and the Boer republics. This was followed by a detailed account of the political history of South Africa up until I899, including short biographies of the most important generals and statesmen and an analysis of the 'Boer character' and the Boers' attitudes to warfare. The second part, seven volumes in German, provided an overview of the military system of both parties, followed by a chronology of the course of the conflict from day to day be- 
tween October I 899 and June I902. The third part was one volume with an index of 3,000 geographical names and $5 \mathrm{I}$ maps depicting the general geographical features, the course of particular battles, troop movements and the blockhouse system. ${ }^{90}$ For further illustration, there were 706 photos scattered throughout the work, coming from Nierstrasz's personal archive. ${ }^{91}$

There are no sources that reveal how Leyds judged these magnificent-looking proofs printed on high-quality paper. But his archives contain two reviews by Dutch military officers. They both agreed with Nierstrasz that it was the most complete account of the South African War from the Boer perspective up to date, and as such considered it to be an important text that merited publication. In comparison with The Times History, they noted that Nierstrasz gave a better, although at times somewhat biased, description of the run-up to the war, in which the role of the republics was extensively discussed. His use of Boer sources for his chronology of the war was also seen as an important addition to existing literature. Although the account of the combat situation itself was not elaborate enough to serve as an academic military exposition, they considered it to be a good historical text that provided important 'building material' for a standard work that could be written by future historians. ${ }^{92}$ Looking at both the contents and the reviews of Nierstrasz's history, it looks as if the proofs lived up to Leyds's expectations, of a 'monument' to honour the Boer combatants. Nonetheless, the book was never published.

The sources do not make it exactly clear why Leyds decided not to publish this history of the war. The most probable reason is that the costs would be too high to publish it in South Africa. To make the work accessible to the Afrikaners, it would have to be translated into Dutch and also into English to provide an alternative to The Times History. Another problem was the high printing costs of the elaborately illustrated book, because it was expensive to publish photos and maps at the time. ${ }^{93}$ From other correspondences, it appears that Leyds thought it important that cheap editions of history books be available to reach the widest audience possible. ${ }^{94}$ It is unlikely that the proofs were suitable for such a popular publication. Another, and possibly decisive, reason could have been the increasing financial problems of Nierstrasz. Despite the substantial sums Leyds provided him with, his publishing house „Nederland” went bankrupt in $1905 .{ }^{95}$ Decades later, a former associate, L. Simons, remembered Nierstrasz as an unreliable person. 
That $\mathrm{Mr}$ N. and his brother were - as it later became clearly apparent to me - not entirely trustworthy, and I am left with the impression, that they used the Boer cause to ensure a temporary position here in this country [the Netherlands] that they barely deserved and that has, I fear, not done all that much good to the cause of the Boers in our country. ${ }^{96}$

Nierstrasz did not only offer the printing proofs to Leyds, however. In November 1907, he contacted the Ministry of War in The Hague. In a confidential report, the director of the military archive recommended it for publication. ${ }^{97}$ Nevertheless, the minister declined the offer, deciding that the publication of such an elaborate text would cost too much. ${ }^{98}$ In the I920s, the text was dusted off again when Engelenburg announced that he had plans to write a history of the South African War. Leyds offered him the printing proofs, and his old friend considered recommending it for publication by the SuidAfrikaanse Akademie vir Wetenskap en Kuns. 99 This initiative also failed, and it looks as if Leyds once again consulted the Ministry of War. In I929, a final report was written by a retired major who largely agreed with earlier reports about Nierstrasz's history. In his conclusions, he reiterated the need for an 'Afrikaans standard work about the I 899-I902 war'. ${ }^{\text {I00 }}$ Although these recommendations did not lead to an actual publication, it shows that there was continual interest by officials in the Netherlands in publishing an official history of the South African War. This also became apparent in another attempt to publish an account of the conflict in the Netherlands.

After their return in I900, Captain J. H. Ram, Lieutenant L. W. J. K. Thomson and Lieutenant C. J. Asselbergs - three Dutch military attachés who had been assigned to the Boer forces - set out to write a report about their findings. On the same ship that Ram returned on, a large collection of war telegrams gathered by Botha was brought to the Netherlands under the supervision of the head of the Transvaal telegraph department, C. K. van Trotsenburg. On arrival in the Netherlands, Ram asked for permission to have access to this archive and to use it in the attachés' report. Leyds, as the representative of the SAR government, was apprehensive because of an incident that had taken place in South Africa after letters had been intercepted in which Thomson expressed his personal dislike of the Boers. ${ }^{\text {Io I }}$ In addition, Van Trotsenburg reported how Ram had already been denied access to official archives, because the SAR authorities thought that several of the cables were unsuitable for publication. Still, he advised Leyds to allow the attachés to see the telegrams as it could mend the strained relationship between them 
and the SAR officials. Moreover, he argued, a publication based on these sources could contribute to the Boer cause, as it would provide an alternative to the British historical accounts of the war. He also noted, however, that it would be important to keep an eye on the project because there was a chance that the attachés might submit the documents to an 'incorrect reading'. ${ }^{102}$ Subsequently, Leyds set several conditions: the attachés should ask for the approval of the SAR authorities to publish texts that used the telegram collection as a source. ${ }^{\mathrm{IO} 3}$

In subsequent years, Van Trotsenburg kept Leyds informed about the progress of the report. He and three other former Transvaal administrators were given a room in the offices of the queen in The Hague where they supervised the attachés. ${ }^{104}$ The Dutch government feared, however, that its involvement in the project would be exposed, which might have compromised the policy of neutrality. Leyds therefore paid fl. 400 a month for another office and for the salaries of the assistants. The first version of the report was completed in October I90I and circulated amongst several members of the government, including Queen Wilhelmina. Despite the fact that the report contained some passages that might have damaged the image of the Boers, Van Trotsenburg was of the opinion that it should be published nonetheless. He thought that the attachés would remove these remarks, considering public opinion and the desires of the queen of whom they knew that 'where there is a choice between various different depictions, the one that is good for us will be most welcome to her'. Moreover, Van Trotsenburg thought that it was a valuable addition to pro-Boer literature because it served as an 'encyclopaedia for future historians'. ${ }^{105}$ At first sight, the report by the Dutch attachés seemed to fit Leyds's ideas for an official history of the South African War based on Boer sources. Looking at the contents, however, it becomes clear that the perspective of the Dutch attachés made this impossible.

First of all, the manuscript only deals with the first few months of the South African War, up until the occupation of Pretoria, as the attachés left the war zone after that. ${ }^{106}$ The limited scope of the report seems not to have been the most important problem, however. Being strong advocates of the militia system in the Netherlands, the attachés' main aim was to extract lessons from the war that could be of use to the Dutch army and in particular to examine the value of the 'people's army'. At times, they were quite positive about the performance of the Boer commandos, who they considered to be excellent shots and well-adapted to outdoor life. But they also noted fundamental deficiencies, which they expounded in a whole chapter devoted to 'the character 
of the Boers'. They thought that the public in the Netherlands was under the wrong impression about the inhabitants of the republics in thinking they were good patriots. They argued that, apart from a few exceptions, the majority of the Boers had a strong sense of individual freedom, which made it impossible for them to make sacrifices for their country. ${ }^{107}$ In the descriptions of the battles, this bold assertion was supported by extracts from the war telegrams. They showed, for instance, that even during the famous battle of Colenso, many tactical errors were made due to the fact that the commanders had little authority. ${ }^{108}$ It seems likely that Leyds read the report (or at least part of it) and that he did not think it to be of value for his main goal - namely to strengthen Afrikaner identity in South Africa. ${ }^{109}$ Besides the assertion by the attachés that patriotism was virtually absent in the Boer republics, the excerpts from the telegrams did not contribute to the heroic image of the commandos and might have been embarrassing for the generals, some of whom had important political positions after the war.

It seems likely that this was the reason for Leyds to withhold his approval in 1905 , when Ram wrote to him saying that the Dutch government was wondering whether now, three years after the South African War had ended, it would be possible to publish the full report, including the parts that were based on the SAR telegrams. ${ }^{\text {IO }}$ By that time, Van Trotsenburg had handed over the collection to Leyds, thereby giving him full control over the source material. The former minister plenipotentiary forwarded Ram's letter to Botha requesting a formal reply, but he added in a personal letter that he advised him not to comply with the request. 'Many of the telegrams are completely unfit for use and in my opinion the attachés Ram and Thomson are not suitable people for making a selection from them.' ${ }^{\prime I I}$ Botha followed this advice and wrote a formal letter in which he made it clear that he could not allow the report's publication in the light of the political situation in South Africa and that permission should also be requested for publication in future. ${ }^{\text {II2 }}$ In a separate confidential letter, he made it clear that he completely agreed with Leyds's objections. ${ }^{\mathrm{II} 3}$

In the end, all of Leyds's efforts to turn the material he gathered during the South African War into a historical work that would strengthen Afrikaner identity failed. Nevertheless, the sources show the importance that contemporaries attached to the idea behind an official history, which was seen as an important exercise in nation-building. There were practicable problems, however, that made it hard to organise such an endeavour. These problems exposed a fundamental weakness in the pro-Boer movement in the Nether- 
lands, which lacked an effective structure. Although Leyds was in a relatively authoritative position because of his control over the sources from his extensive collection and his good contacts with the Boer generals, he could not exert influence over the individuals that were involved in the actual writing of the manuscripts. Some of them, like De Wet and Nierstrasz, seemed to have prioritised personal gain over the higher goal of nation-building. Others, like the attachés, had opinions that were considered to be harmful in the light of the political situation in South Africa. Despite these setbacks, Leyds did not give up on finding a purpose for the archives that he considered himself to be a trustee of. Eventually, he succeeded in moving several collections to South Africa, where he thought they would have the greatest effect on the continual struggle between the British and Dutch races.

\section{From Dordrecht to Pretoria: the collection of the Zuid-Afrikaansch Museum}

One of the most remarkable collections of pro-Boer propaganda came into being in the Dutch town of Dordrecht. On I July I902, barely a month after the Peace of Vereeniging, the Zuid-Afrikaansch Museum (South African Museum, hereafter ZAM) was opened there. The founder of this museum was Hidde Nijland, a wealthy merchant and well-known art collector who had accumulated a large number of objects of propagandistic value during the South African War and wanted to exhibit them. Although the conflict had already ended when the museum opened, Nijland explained in the opening speech, he still thought it of use to show this collection to the public in order to highlight the ongoing struggle of the Afrikaners against British dominance. Moreover, he added, he had become the 'owner [of the objects] not to possess, but to save and, if desirable, send everything back [to South Africa] later on.' II 4 The implication of these words was later a source of great controversy and became the subject of a legal battle between Nijland and Leyds that was to last for more than a decade. In order to place this conflict in perspective, something has to be said about the previous history of the collection, which was intertwined with the propaganda campaign during the South African War.

In I 897, the Transvaal government decided to participate in the Paris World Exhibition of I900. In the years that followed, a committee of prominent administrators co-operated with Johannes Pierson, a Dutch businessman who acted as consul-general of the SAR in Paris. Due to the war, only a 
limited number of objects could be sent from South Africa, early in I 900 . The shipment contained stuffed animals, plant specimens, gold nuggets, a collection of mineral specimens, a painting of the Kruger government, booty from an expedition against an African chief and large billboards with facts and figures about the growth of the education system of the SAR. ${ }^{15}$ Pierson managed to gather enough material to fill the Transvaal pavilion with the assistance of a special committee of the NZAV, which confidentially asked collectors in the Netherlands whether they could spare objects relating to the (natural) history of the Transvaal and its inhabitants. Even the 'original' interior of a model Boer farm was made by a furniture maker in Dordrecht. ${ }^{\mathrm{II}}{ }^{6} \mathrm{Al}-$ though strictly speaking, this was against the rules of the exhibition, the jury turned a blind eye, taking the circumstances into consideration. Indeed, the Transvaal government was honoured with I 5 certificates and I 2 medals, including two Grand Prix for the education exhibition. ${ }^{117}$ In addition, the public showed great interest, which was undoubtedly the result of the general dismay at the war in South Africa. The most tangible expression of these sentiments was the entrance hall, where two columns were covered with pro-Boer and anti-British slogans. A bust of Kruger was buried in flowers.

Despite the great propagandistic success of the pavilion, there were concerns about what would happen to the collection after the World Exhibition had ended. To avoid the British from getting their hands on the objects, a plan was made to secure them. A secret agent from the SAR legation, Bas Veth, established contact with Nijland, who was prepared to take the collection on loan. In order to avoid suspicion, this was arranged in a rather roundabout manner. In August I900, Nijland and Pierson signed two contracts. One concerned the gold nuggets for which the businessman from Dordrecht paid Io,०o० francs, thus becoming their rightful owner. The second document stated that the rest of the objects from the pavilion would be sold for 30,000 francs. However, it was verbally agreed that Nijland would not pay this latter sum and so did not really become the owner of these objects but rather a kind of temporary guardian with the purpose of the objects being returned to South Africa when circumstances allowed for it. ${ }^{I 18}$ At that point, there seemed to be no end in sight to the South African War, so the objects were transported to Dordecht. ${ }^{\text {II }}$

The continuation of the war probably was the reason that the objects were exhibited permanently in a special museum, the preparations for which started in I90г. Meanwhile, the collection grew considerably, not only due to purchases by and gifts to Nijland but also with the help of representatives of the 


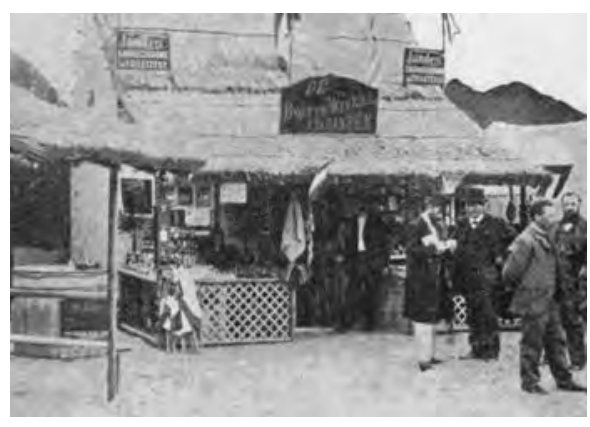

Photo of the souvenirshop of the ZuidAfrikaansch Museum (ZAM) in Dordrecht. Source: 'Afrikaner', De Zuid-Afrikaansche nederzetting in Dordrecht, ZuidAfrikaansche vlugschriften no. I 2 (Dordrecht, I902). Collection Zuid-Afrikahuis, Amsterdam.

Boer republics and pro-Boer organisations. One of the main sources was the household of Paul Kruger in Hilversum. The exiled president received an endless stream of tributes to the bravery of his people from all around the world. His family arranged with Nijland that these objects be given on loan so that he could exhibit them. ${ }^{\mathrm{I}}{ }^{20}$ In addition to the popular bust of Kruger from the Transvaal pavilion at the World Exhibition, which was displayed with the wilted garlands from Paris, one of the most eye-catching items was the socalled 'Bratina', a two metre-high silver ceremonial cup covered with diamonds and mounted on a marble foot: a gift from 70,000 Russians to honour General Piet Cronjé. ${ }^{\text {I2I }}$ Other special items in the collection were a number of portraits of Boer leaders made by famous contemporary Dutch artists such as Thérèse Schwartze and Jan Toorop. Besides the impressive homage to the embattled republics, which took up three galleries, there were seven other rooms. These contained items made by Boer Pows, material used by the Dutch ambulances, photos, ethnographical objects, education statistics, African crafts and a library with pro-Boer literature. In the courtyard, there were models of a rondavel (African hut), a Voortrekker farm and an ox-wagon. ${ }^{\text {I22 }}$

In I903, a committee from Dordrecht that included Kiewiet de Jonge and Rompel announced that it wanted to take over the management of the ZAM to ensure that the collection was available to the Afrikaners at all times. Their initiative was supported by the NZAV and by Leyds. The draft statutes explicitly stated that 'the executive committee shall always consider itself as trustees and the Museum as property of the SA people.' The next article designated the so-called 'foremen' as the representatives of the people's will. These were the leaders of the Afrikaner political parties in South Africa at the time, including Botha. ${ }^{\mathrm{I} 23}$ Initially, Nijland agreed to these proposals, which would have meant that his personal authority over the museum would have come to an end. ${ }^{124}$ But soon disputes arose between him and the committee concern- 
ing the poor conditions in the museum and the ownership of some of the objects that came from Kruger's family. ${ }^{\mathrm{I} 25}$ This conflict eventually led to Nijland's refusal to sign the draft statutes and hand over control of the ZAM. ${ }^{\text {I26 }}$ Initially, Leyds acted as a mediator and he had several meetings with both parties, but the differences could not be resolved and the provisional committee disbanded itself in March $1905 .{ }^{\mathrm{I} 27}$

Leyds's later attempts to persuade Nijland also failed, and he started to look for other ways to solve the problem. After South Africa had been granted self-government in 1906, Leyds saw an opportunity to do just that. In letters to Boer leaders and the president of the NZAV he proposed that, considering the political developments, it was time for the Afrikaners to ask for the collection, as by then they were able to keep it out of British hands themselves. ${ }^{\mathrm{I} 2} 8$ During a European tour, Botha wrote a letter to Nijland, asking for the objects from the ZAM in order to exhibit them in a new national museum that would be housed in Kruger's former official residence in Pretoria. ${ }^{129} \mathrm{Nij}-$ land agreed to discuss this plan with Leyds, but due to severe illness the latter sent a former official of the SAR legation, G. J. Bolman, to represent him. During their meeting, Nijland mentioned several conditions for handing over the collection, the most important of which were that the museum in Pretoria should carry his name and that he would be paid fl. 24,000. ${ }^{\mathrm{I} 30}$ Leyds, who had barely recovered from his illness, was not prepared to give in to these demands and started to prepare a court case. In 1908, the Afrikaner leaders in the Transvaal, who called themselves 'Boeren voormannen', formally accredited him to act on their behalf. ${ }^{\mathrm{I} 3 \mathrm{I}}$

After lengthy preparations during which Leyds was assisted by the lawyer H. J. F. Heijmans, the case started in December 1909. Almost eighteen months later, the court reached its verdict. In the meantime, some fundamental issues were covered. The plea of the 'Boeren voormannen', as formulated by Leyds, was that they were the rightful inheritors of the collection that had been the property of the former republic of the Transvaal and its late president. Nijland's lawyer argued that the legal status of the 'Boeren voormannen' was flawed and that they could hardly be considered to be the sole representatives of the people in South Africa. Moreover, he continued, the inhabitants of the former republics had become subjects of the British Empire and had thus lost their rights to previous possessions. ${ }^{\mathrm{I} 2}$ To counter the first point of the defence, Heijmans produced the document signed by the Transvaal leaders in which they claimed the ZAM collection, accompanied by a notarial statement from Pretoria that these men were recognised as the Boer 'fore- 
men'. ${ }^{133}$ These weighty-looking documents failed to persuade the court, which did not accept the status of the 'voormannen' as the representatives of the Boers. Still, the judges ruled that the inhabitants of the former republics did not cease to be members of 'a Boer people', despite the fact that they had been conquered by the British, and so had a right to the remaining assets of the Transvaal. Leyds was recognised as their representative and so his claim was awarded. ${ }^{\mathrm{I} 34}$ The practical effect of this interesting verdict was rather small, however. The court gave the two parties eight days to agree on the value of the collection, a sum that would have to be paid by Nijland in case he refused to hand it over. If that did not succeed, a committee of external mediators would have to be appointed. And that is indeed what happened.

After a failed attempt by Nijland to bring this matter to the High Court in I9I3, mediation started in I9I 5. The first two attempts to settle the differences between the two parties failed. These were conducted by E. C. Godée Molsbergen (lecturer in colonial history at the University of Amsterdam) and J. W. Pont (professor in Utrecht and president of the NZAV) respectively. ${ }^{\mathrm{I}}{ }^{3} \mathrm{Fi}-$ nally, a committee under the chairmanship of J. C. van Overvoorde, president of the Oudheidkundigen Bond (Archeology League), reached a compromise that was signed on 7 July I9I7. The collection was to be given to a foundation that was to carry Nijland's name in its official title, and he was to be awarded fl. 3,000 as compensation. Nevertheless, Leyds finally got his way when the members of the executive committee of the foundation, which included himself, Kiewiet de Jonge, Pont and the Afrikaner professor in South African Law, H. J. D. Bodenstein, decided that the collection of the museum in Dordrecht was to be transported to Pretoria. ${ }^{\mathrm{I}}{ }^{6}$ After many years of legal battles, the matter had become a sort of personal vendetta against Nijland, which is underlined by Leyds's actions after the transaction was made. In a letter to his old friend Engelenburg, he explained that the collection would not have to be associated with Nijland's name anymore after it had arrived in South Africa. Moreover, he tried to erase all traces of his opponent's association with the collection: a portrait of Nijland was removed from it and sold. ${ }^{\mathrm{I} 37}$

Due to the First World War, the Zam collection could not be moved to South Africa immediately. In the meantime, Bodenstein, who was responsible for its transportation, catalogued the objects together with a group of Afrikaner students in the Netherlands. They made a selection of items based on what would be most valuable for the Afrikaner nation, which meant that some of the stuffed animals, ethnographic material and pow crafts were sold. ${ }^{13}{ }^{8}$ Botha supported these plans and immediately provided the necessary 
funds for shipping the collection to South Africa. ${ }^{\mathrm{I} 9}$ By the end of $\mathrm{I} 920$, it had arrived in Pretoria where it was later exhibited in the Kruger House Museum in Church Street. Despite the long and tedious process required to get it there, it would prove to be a lasting monument - most of the objects are still on display there today. ${ }^{140}$

By the time the ZAM objects were transported to South Africa, Leyds started to make plans for the future of his own archive. In I920, he offered his extensive collection of pro-Boer publications to the University of Stellenbosch, an offer that was gratefully accepted. ${ }^{\mathrm{I} 4 \mathrm{I}}$ Leyds did not consider that to be the most important part of his archive, however. The most important in his opinion was the archive of the SAR legation, which had been stored at several addresses in The Hague and at the NZAV office since 1902. Leyds managed to solicit some money from the society to hire a larger office in which to organise the archive and prepare it for shipment to South Africa. ${ }^{\mathrm{I} 42} \mathrm{He}$ also contributed a considerable sum himself and put in a lot of his own time to select the most important documents, which proved to be a colossal task, as he had ordered that all incoming letters be preserved. ${ }^{\mathrm{I} 43}$ The archive also contains material about his terms as state secretary of the Transvaal and correspondence from after he resigned as minister plenipotentiary. In addition, he gathered and catalogued the archives of the Transvaal consulates in the Netherlands (Amsterdam and The Hague), London, the US, Portugal and Lourenço Marques. ${ }^{\text {I4 }}$ Finally, the papers of the ANV press office, which remained up and running until I9I3, were added to the collection.

In I930, the archive was ready for transport to South Africa, but despite all the preparatory work, it did not receive a very warm welcome. In letters to correspondents in Pretoria, Leyds complained about the lax attitude of the government regarding his offer to transfer the collection to the South African National Library in the Union Buildings. After a few months of silence, the Minister for the Interior, D. F. Malan, agreed to cover the costs of shipment but refused to provide Leyds with any form of financial compensation which he had asked for in recognition of the time and money he had invested. ${ }^{\text {I45 }}$ The former minister plenipotentiary was greatly grieved at the course of events and expressed his frustration in a letter to his old friend Engelenburg, who was an influential member of the Suid-Afrikaanse Akademie vir Wetenskap en Kuns at the time. In it, he complained that the inhabitants of South Africa barely showed an interest in their own country and past. 'The Afrikaners know little of their history nor do they care about it. Little stories that flatter their vanity, that is the only thing that goes down well with them'. ${ }^{446}$ 
Leyds also grumbled about party politics that prevented effective co-operation. Like in the Netherlands, he wrote, 'public life [in South Africa] has been politicised. It is the curse of the Dutch race that people prefer to argue amongst each other instead of working together.' ${ }^{247}$ Despite these complaints, the collection arrived in Pretoria, where it remains today. It is considered to be an important collection, and several Afrikaner historians who have written about the South African War have used it as a source. ${ }^{\mathrm{I} 48}$

Despite all the difficulties that Leyds encountered during his efforts to transfer historical source material to South Africa, he did receive praise for these activities. In the Netherlands he was awarded with the Ridderkruis in de Orde van de Nederlandse Leeuw for the publication of the volumes with his correspondence between I 899 and I902. Leyds himself was very happy with this knighthood, which can be considered to be a reward for his academic work. ${ }^{149}$ In South Africa this was also the case. In the late I930s, Leyds received honorary doctorates, both in absentia, from the University of Pretoria and the University of Stellenbosch. Despite his own non-attendance, these were prestigious events that drew an audience of leading politicians and academics. In the speeches, delivered by Jan Smuts and Professor E. C. Pienaar, Leyds's contribution to South Africa was mentioned not only as an administrator but also as a historian. In Pienaar's words, his 'monumental' work after 1902 made him 'one of the builders of the temple of Afrikaner nationalism'. ${ }^{5 \circ}$ Leyds was granted another honour when he was invited to address the South African people in a special radio broadcast for his $80^{\text {th }}$ birthday in May 1939. During this speech, he once again called upon the Afrikaner people to pay more attention to their past. ${ }^{\mathrm{I} I \mathrm{I}}$ Despite his self-confessed dislike of party politics, he also spoke about his concerns about the sympathies of certain sections of the Afrikaner movement for the Nazis. This publicity made Leyds nervous in the light of the impeding invasion of the Netherlands by Germany, and he feared prosecution. He therefore made preparations to flee to Britain, the country of his former arch enemies. He was spared this ironic twist of fate when he died on I4 May I94O in a hospital in The Hague, with the sound of Nazi bombers approaching the city of Rotterdam overhead. ${ }^{152}$

\section{Conclusion}

Leyds's dramatic end fitted his life's work, which was dedicated to the advancement of Dutch influences in South Africa. As a well-educated and cultured man of the world, he had an ambivalent relationship with the Afrikan- 
ers from the start. This makes it hard to assess the actual effect of his activities after I902. His outspoken views (partly a result of his own vanity) undoubtedly made him a controversial figure amongst several groups in South Africa. Nevertheless, it cannot be denied that his books contributed significantly to the re-interpretation of the colonial history of South Africa, which was an important aspect of the rise of Afrikaner nationalism. His attempts to make the records of the pro-Boer propaganda campaign in Europe available to the public in South Africa had the same purpose. Due to practical problems and personal controversies, he failed to publish an integrated history of the South African War that could serve as a monument to the Transvaal and the ofs. Nonetheless, he was instrumental in transferring important collections from the Netherlands to South Africa, which became lasting places of remembrance of the Afrikaner past.

Leyds's activities should be seen in a wider context. He was clearly an exponent of the ideal of stamverwantschap that took shape after the Transvaal War of I 880-I 88I; he was a leading administrator of the Kruger regime and played an essential role in the pro-Boer propaganda campaign in Europe during the South African War. His work - along with that of several other Dutch pro-Boers - did not end in 1902 . While most historians who have written about this topic rightly point out that the annexation of the republics was a great blow to contemporaries, they tend to overlook the fact that there was a fair amount of continuity too. During the first decade of the twentieth century, pro-Boer organisations contributed to the survival of Dutch institutions that Milner tried to close down in a drive to Anglicise South Africa. Such activities show that propaganda remained the main priority of the pro-Boer movement, but that it was also problematic. The institutions mainly drew from the funds that had been accumulated during the South African War and when these ran out, they were not able to generate their own capital because they lacked professionalism.

Nonetheless, the sources reveal ongoing attempts to help mobilise the Dutch-speaking population in South Africa. Looking at the work of Leyds, one could say that the lines of communication that existed between the Netherlands and South Africa were reversed. Before and during the South African War, the media in the Netherlands served as a cache for material that came from the war zone, which was used to provide an alternative to the British coverage of the situation. After I902, it appeared to Leyds that such material was mostly needed in South Africa in order to counter the policy of Anglicisation. In addition to the money that was made available for the re- 
construction of the Dutch language press, the support largely took the form of intellectual ammunition. Looking more closely at these activities, it appears that there were many problems in executing such projects, with many of them ending in failure. But this, too, was a continuation of the period before and during the South African War. From the start, the relationship of the pro-Boers in the Netherlands with the Afrikaners in South Africa was fraught with ambivalences and contradictions, which made it hard to mobilise the support of the public for initiatives to strengthen the ties between these 'racial kinsmen'. These problems were characteristic of the feelings of stamverwantschap, which was not an uncontested or unchangeable concept that was embedded in a solid system of official institutions but rather a set of views on Dutch identity that were communicated through an informal network. 



\section{From stamverwantschap to anti-apartheid: the significance of the pro-Boer movement in the Netherlands}

In January I984, the century-old library of the NZAV housed on the Keizersgracht in Amsterdam was stormed by anti-apartheid activists. They broke into the premises and threw part of the library, which includes an important collection of historical Africana and the archives of the society, into the water of the canal and sprayed the reading rooms with paint. This was one of the most radical actions undertaken by the Dutch anti-apartheid movement, which tried to break off all ties - including cultural - between the Netherlands and South Africa, where white supremacy rule continued. At the time, the NZAV was one of the few organisations that tried to maintain contact with the Afrikaners out of a feeling of kinship. Dutch society, however, had largely abandoned its sympathy for the ideal of stamverwantschap and in general supported the fight against apartheid, although the attack on the NZAV library was widely criticised as an act of vandalism. ${ }^{\mathrm{I}}$ This raises the question of how historically significant the pro-Boer movement was in the Netherlands and what its long-term effects were on Dutch society. The prominence of the anti-apartheid movement in the I980s would suggest that these were quite limited and that, in the course of the twentieth century, the ties between the Netherlands and South Africa had steadily declined.

This view is clearly reflected in the work of those historians who argue that I 902 marked a great discontinuity in the history of the Dutch pro-Boer movement. In general, it is argued that there was a significant drop in Dutch interest in South African affairs. As indicated in the previous chapter, Bart de Graaff identifies a growing gap between the Dutch and the Afrikaners, as both sides became disinterested in the concept of stamverwantschap. ${ }^{2}$ Martin Bossenbroek describes a more general trend. He argues that during the first decade of the twentieth century, overall interest of the Dutch public in overseas matters (including South Africa and the Dutch East Indies) declined. He uses the metaphor of the 'hop-skip-jump': the take-off took place in the I 870 s and I 880 s, the jump reached its peak during the I 890 s and the in- 
evitable 'landing' occurred in the I900s. ${ }^{3}$ These views would suggest that the great enthusiasm for the Boers in the Netherlands was a temporary phenomenon, an early example of how mass media could whip up mass hysteria amongst the general public, which ended with the Peace of Vereeniging.

Others discern more continuity in the way Dutch public opinion reacted to South African affairs after 1902. Gerrit Schutte acknowledges the decline in actual support for the pro-Boer movement in the Netherlands, but he argues that the idealised image of the Afrikaners continued to exist to some extent. ${ }^{4}$ His view is supported by the literary historian Wilfred Jonckheere, who notes that 'praise for the Afrikaner' in Dutch poetry and novels continued up to I960.5 Looking at the public perception of South Africa in the Netherlands, it could well be argued that this date marked a more significant discontinuity than I902. From 1960, the image of the Afrikaners, who clung on to their ideal of white supremacy, seems to have swung to the opposite extreme as a result of the growing protest against the apartheid regime, which was particularly strong in the Netherlands. Schutte has argued, however, that even then there was a significant measure of continuity. Although the attitude towards the Afrikaners underwent an about-face, activists tried to exert their influence on South African society just as their predecessors from the pro-Boer movement did. Schutte therefore argues that the anti-apartheid movement in the Netherlands was a form of Dutch 'cultural imperialism' which shared a great degree of continuity with previous periods. ${ }^{6}$

This notion of continuity will be further explored in the last sections of this book. In the previous chapter it was argued that the main purpose of the Dutch pro-Boer movement after 1902, was to help the Afrikaners withstand the attempts by the British to Anglicise South Africa. On these pages the meaning of this purpose in the Netherlands itself will be examined. In this respect it is important to remember that the Netherlands was a major colonial power up until the second half of the twentieth century. Therefore we have to consider not only domestic politics and social change but also the debate about the role of the Netherlands in the wider world and the feeling of Dutchness that was a result of its international position. In this respect, major change did occur after the Second World War, which led to a new moral horizon after the great traumas of the Holocaust and decolonisation. The changing debate about South Africa must be seen as part of this transformation. 


\section{Pro-Boers and public opinion in the Netherlands}

After the Peace of Vereeniging was signed, pro-Boers in the Netherlands continued to try to sway public opinion in order to collect money for the 'kinsmen' in South Africa. The NZAV executive made it clear that the Dutch-speaking people in South Africa needed help from the Netherlands more than ever, because the British were trying to top off their territorial control of South Africa with political and cultural dominance, while Afrikaner institutions had largely been destroyed during the war. At the same time, they noted with regret that many members did not see this necessity, arguing that after the annexations of the Boer republics, 'England should take care of the new subjects itself now'. 7 As a result, the society started losing members: from 6,632 in December I901 to 5,364 in December 1903. ${ }^{8}$ The decline continued during the years that followed, and by 1920 the NZAV had just I, 523 members. ${ }^{9}$ Despite this downturn, the organisation survived and still exists today. One possible reason for this might have been the fact that in 1909 the remainder of the financial assets of the NZASM was turned into a fund (the ZuidAfrikaansche Stichting Moederland) that structurally provided the NZAV with money. ${ }^{\mathrm{IO}}$ Other pro-Boer charities were less fortunate. The CNBC, which counted 4,000 members during the last phase of the war, suffered an exodus. After years of marginal existence, the organisation finally ceased to exist in I9II. II The ANV was the only organisation affiliated with the proBoer propaganda campaign that did not suffer such losses, but its membership never exceeded 6,000. ${ }^{\text {I2 }}$

De Graaff considers these dwindling numbers as evidence that the interest of the Dutch public in South Africa was in steady decline. This had a direct impact on the results of the activities that were organised to help the Afrikaners, he argues. In September 1902, the famous Boer Generals Louis Botha, Koos de la Rey and Christiaan de Wet visited the Netherlands. A deputation of the NZAV, headed by the prominent journalist Charles Boissevain who had become a member of the executive committee, visited the generals and discussed a plan for a national collection to raise money for the reconstruction of South Africa. However, the generals decided to form their own charity, the Generale Boerenhulpfonds, and independently issued an 'address to the civilised world' in which they announced the collection. ${ }^{\mathrm{I}}$ In the Netherlands, the organisation was co-ordinated with the municipalities. The results were found to be disappointing by contemporaries. The total amount collected was fl. I.2 million - a smaller sum than had been anticipated. ${ }^{\mathrm{I} 4}$ 
It remains the question, however, to what extent this result should be attributed to disinterest on the part of the public. At least this was the question asked by contemporaries. In the Dutch cities they visited, the Boer generals were welcomed by large crowds, who cheered for them like true heroes. ${ }^{\mathrm{I}}{ }^{5}$ It was therefore noted in the press that the failure of the collection could hardly have been caused by a lack of public interest. Several newspapers blamed the NZAV for not being able to capitalise on the enthusiasm of the people in the Netherlands. According to the editors of the newspaper De Amsterdammer, it had waited too long and as a result lost the opportunity to work together with the generals and encourage the people to give money during the collection. In their view, the NZAV was nothing more than 'the tail of a little club' and not a 'living organism' that reached out to the people. ${ }^{16}$ One of the main targets was Boissevain, who had to be restrained from writing a furious reply. Eventually it was Botha himself who managed to calm down the famous journalist with a personal letter. Boissevain made it clear that this was sufficient for him to put the 'hateful writing' of his colleagues behind him. ${ }^{17}$ Nevertheless, it seems that the dispute about the collection drained his enthusiasm for the NZAV and he resigned from the executive committee. In a private letter, he wrote that he was tired of the 'waffling' and the lack of effective action. ${ }^{\mathrm{I} 8}$

This example shows that the relation between pro-Boer organisations and public opinion in the Netherlands remained problematic, which resulted from the informal nature of the movement. These problems resembled those from earlier periods when the NZAV was criticised for its elitism which prevented the successful mobilisation of public opinion. ${ }^{19}$ It would go too far, however, to conclude from these organisational woes that the Dutch public had lost all interest in South Africa and the Afrikaners. Although events in South Africa at times caused controversy in the Netherlands, there are clear indications that some aspects of the idealised vision of the Afrikaners that came into being between I 880 and 1902 remained quite popular up until the Second World War and beyond.

\section{Dutch views on Afrikaner nationalism}

Although there was a marked decline in the coverage of South African affairs after 1902, newspapers continued to write about important events taking place there. However, the relationship between pro-Boer supporters from the Netherlands and Afrikaner nationalists became more problematic: severe tensions arose over certain issues, and there was more explicit criticism than 
in previous periods. One controversial issue was the political situation and the issue of the extent to which South Africa should accommodate British rule. Another was the development of Afrikaans into an independent language. At times, there was open hostility between certain groups in the Netherlands and South Africa over these two issues, but there are indications that the dichotomy was not as absolute as it might first appear. This indicates that a certain view of South Africa continued to exist in the Netherlands, which reveals the survival of ideas about racial kinship.

In general, Dutch opinion makers were quite positive about the granting of self-government to South Africa in 1906 and the formation of the Union in I9 10. ${ }^{20}$ The Afrikaners outnumbered white inhabitants of British descent and so became politically dominant. There were, however, increasing concerns about the strategy of the moderate South African Party (SAP), under the leadership of Louis Botha and Jan Smuts, to co-operate with British administrators, the same people they had fought against less than a decade before. The founding of the Nasionale Party (I9I4), which was more outspokenly opposed to British influence, was therefore welcomed by the press in the Netherlands. These sentiments deepened after the start of the First World War. ${ }^{21}$ In South Africa, there was growing controversy surrounding the question of whether the government should give military support to Great Britain. When it appeared that Botha was preparing an invasion of German Southwest Africa in I9I 4, some radicals formed a commando and went to the desolate parts of the Northern Cape. Botha and Smuts sent in the army and crushed the rebellion. In the Netherlands, there was widespread resentment of these measures and several petitions were sent to the South African government, including one from the NZAV, to plead for amnesty for the captured rebels. ${ }^{22}$

The pro-Boer society received unwanted media attention when the editor of its monthly magazine, M. P. C. Valter, wrote several articles and pamphlets in which he denounced Botha as a traitor who had already failed during the South African War. In addition to these embarrassing remarks, Valter also took an openly pro-German standpoint, which caused resentment at a time when the Dutch government was desperately trying to remain neutral. ${ }^{23}$ The NZAV dismissed Valter, and H. D. J. Bodenstein, the Amsterdam professor of law and an Afrikaner by birth who opposed Botha's policy during the First World War, wrote a pamphlet to defend the historical reputation of the prime minister. ${ }^{24}$

Not all publications about the political situation in South Africa or its re- 
cent past caused such controversy, however. On the contrary, the Afrikaners and their history were still admired by several well-known authors. At the time, the most popular writer of novels about South Africa was undoubtedly Louwrens Penning. It can be argued that he was very influential in shaping the image of South Africa in the Netherlands, despite the fact that he only ever visited the country once, a few years before his death in $1927 .{ }^{25}$ The novels Penning wrote during and directly after the South African War remained popular with young readers until the I950s, but after I904, he turned to other topics. During the next two decades, he wrote just one book about South Africa in I9I 5, describing the rebellion of the previous year. This novel was probably influenced by the general dissatisfaction in the Netherlands about the course of events, and the negative characteristics of the Boers such as partisanship are more explicitly mentioned than in previous works. The story is about a father and son who grow apart because of their opposing political views and even fight each other on the battlefield. Despite this drama, Penning did not break with his usual style and the story has a happy ending in which the two reconcile to end the suffering. ${ }^{26}$

Penning's interest in South Africa was renewed in 1923 , when his publishers asked him to travel to the archives in Cape Town and Pretoria to gather material for new novels about the history of the Afrikaners. The writer, who was nearly 70 years old, stayed in the country for five months and, apart from doing archival research, travelled around to visit his brothers who had settled in the Transvaal during the I 88 os. Looking back on the trip, Penning wrote that his 'greatest wish' had been fulfilled. ${ }^{27} \mathrm{He}$ met the Afrikaners, visited their homes and travelled to some of the places where their ancestors had fought for their freedom during the Great Trek, which made a great impression on the writer. 'My heart has danced during all this, and once again my great love for the "Boers" has been revived. ${ }^{28}$ Despite these intense experiences, Penning asserted that meeting the Afrikaner people in the flesh had not altered his views on South Africa. 'It was all exactly as I had expected. With the eye of love I had already seen Africa and had seen it correctly.'29

The journey resulted in four novels about the history of South Africa, in particular about the Great Trek, which appeared just before Penning's death. The emphasis in these works was on race relations and the dangers that the black majority posed to the white minority. Moreover, the conservative and patriarchal lifestyle of the Afrikaners was explicitly celebrated..$^{\circ}$ At the time, Penning was positive about their position in South Africa and thought that they had become politically dominant in their country. Looking at the out- 


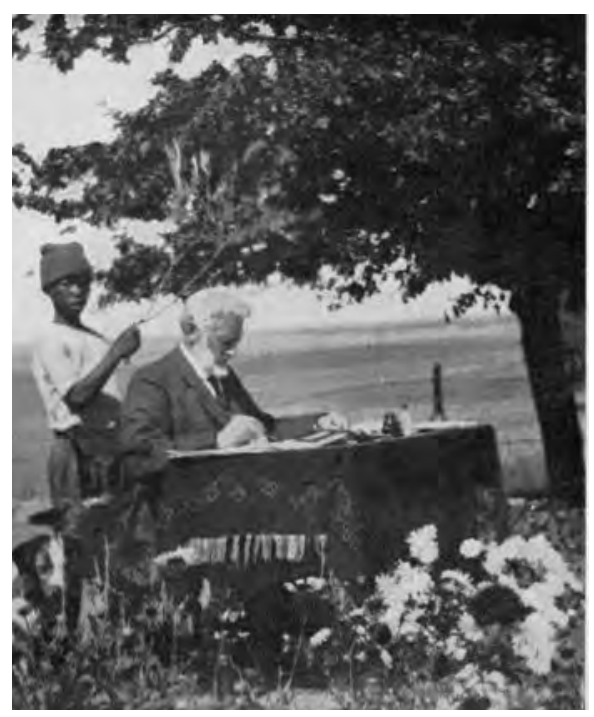

Louwrens Penning working in South Africa, I924.

Source: L. Penning, Uit mijn leven (Zwolle, I927[?]). Collection Zuid-Afrikahuis, Amsterdam.

come of the turbulent periods of their history, he concluded that 'the blood, spilled for freedom and peace, has not been shed in vain. The path led through the most sorrowful depths to the heights of victory.'3

Another successful project Penning started after his journey to South Africa was a lecture tour, which lasted up until his death. The elderly writer spoke about his beloved Afrikaners to sold-out crowds, sometimes six times a week. ${ }^{32}$ Local newspapers praised Penning's performance as an attractive mix of knowledge and entertainment. During the first half of the lecture he gave a general introduction to South Africa, illustrated with slides, during which he talked about famous people and places from the past and present. The second part was filled with anecdotes about his travels and the peculiarities of the people he encountered. Typically, these lectures were positive and lucid, emphasising the unity of the Afrikaners and their ability to take the lead in South Africa, which, he told his audience, opened up opportunities for people in the Netherlands as well. Even when explaining the political situation and the tensions between the SAP and the Nasionale Party, Penning managed to steer away from controversy and declared that he admired the Afrikaner people as a whole. ${ }^{33}$ This image clearly appealed to his audience, who on one occasion even welcomed him with a thunderous version of the national anthem of the Transvaal, a country that had ceased to exist two decades previously. ${ }^{34}$ The writer himself explained this enthusiasm by the fact that the people in the Netherlands still felt a 'warm love and strong sym- 
pathy' for the Boers. 'Their history is one continuous struggle for freedom and justice, a mighty fight of blood and tears. That struggle has found resonance in the hearts of our [Dutch] people. ${ }^{3} 3$

Although such emotions were clearly based on a biased and idealised image of South Africa and its past, they cannot simply be dismissed as misplaced nostalgia. ${ }^{36}$ It shows that there was significant continuity with the way in which such matters were depicted earlier. For people in the Netherlands, the key question remained whether the white Dutch-speaking population would be able to withstand the imperialists' attempts to submit them to British rule. In that respect, there was disappointment at Botha's support for the British Empire during the First World War, something that was even reflected in Penning's novel from I 9 I 5 . But the popular writer also extensively referred to the more heroic episodes from the Afrikaner past to mobilise support for his ideal: a South Africa ruled by the white Dutch-speaking population. Such discrepancies reveal the ambivalences that surrounded the concept of stamverwantschap at the end of the nineteenth century and continuing into the twentieth century. These ambivalences were also apparent in the debate about the development of Afrikaans as a separate language and cropped up in everything from popular culture to government policy.

\section{The cultural ties between the Netherlands and South Africa}

In the Netherlands, the responses to the development of Afrikaans by the Tweede Taalbeweging were varied. The simplification of grammar and spelling that was proposed by intellectuals in South Africa was already a topic of discussion at the end of the nineteenth century. There had been criticism from linguists in the Netherlands such as Jan te Winkel who thought such changes imperilled the very foundations of Dutch as a language. 37 This scepticism still existed at the beginning of the twentieth century, and at times the tone of literary critics was quite condescending. In I9I0, for example, C. Scharten wrote a cynical article about Afrikaans in the influential journal De Gids. Reviewing the work of J. F. E. Celliers, one of the most famous Afrikaner writers of the time, he ridiculed it as a failed attempt to make something out of 'this little deaf-and-dumb language [...]. Will it ever be possible to make beautiful music on this broken violin?' ${ }^{8} 8$ Such vicious attacks seem to have been the exception rather than the rule, however. Other critics chose more conciliatory words to express their doubts about the rapid development of Afrikaans. The publisher L. Simons was against spelling reforms be- 
cause he thought it affected the purity of Dutch, and he was of the opinion that linguists in the Netherlands should not give in to the 'urge' from South Africa. 'We can best maintain the mutual friendship, by each doing what we think is necessary for ourselves, and furthermore learning to appreciate each other's point of view.'39

Besides the critics, there were also intellectuals who supported the efforts of the Afrikaners to simplify the spelling and grammar of written Dutch. There had been an organisation that lobbied for such reforms in the Netherlands for decades, the Vereniging tot vereenvoudiging van onze schrifftal, which included many prominent pro-Boers amongst its members. ${ }^{4 \circ}$ After the South African War, this association watched the development of the Tweede Taalbeweging in South Africa closely and showed great interest in the spelling reforms of 1905 , which largely coincided with their own proposals. During an annual meeting in I906, it was noted that 'there [in South Africa] the movement proceeds with great power, so that they are much further than we are. ${ }^{4 \mathrm{I}}$ In I 908 , the society appealed to the Dutch government to promote a new system designed by R. A. Kollewijn. In their petition, they stated that linguistic developments in South Africa, and also Flanders, made it necessary to follow suit in order to preserve the unity of Dutch spelling around the world. ${ }^{42}$ In 1909, this petition was discussed in Parliament and an official committee was appointed to investigate the possibilities of a new law, but significant language reforms were introduced only after the Second World War. ${ }^{43}$ Despite the lack of concrete results in the short term, this does show that the debate about the global position of the Dutch language resurfaced after 1902 and continued to attract attention.

There was also appreciation for the Afrikaans lingual heritage amongst the Dutch public. Folksongs, for example, proved to be quite popular. When Mansvelt published his songbook, the press complimented him for this project and noted that it could also have a positive effect in the Netherlands, stimulating patriotism. ${ }^{44}$ In addition, Rompel and his wife organised a few concerts during which these songs were performed. Their main goal was to promote the Tweede Taalbeweging and to show that it was different from the movement headed by Du Toit. ${ }^{45}$ In the reports about these evenings, Rompel noted with satisfaction that they were a great success and that the audiences learned to appreciate the sweet sound of Afrikaans poetry. ${ }^{46}$ In this way, several rhymes and tunes in Afrikaans became part of popular culture in the Netherlands. One of the most tangible results was that they were widely sung at schools. Evergreens such as Sarie Marais remained part of the curriculum until the I950s. ${ }^{47}$ 
The ongoing undercurrent of sympathy for the Afrikaners and their cultural heritage amongst the general public in the Netherlands found an expression in actual government policy when the political situation allowed it. From I 9 Io onwards, the Dutch government had been tied to a policy of strict neutrality towards the Afrikaner government in order not to offend the British imperial authorities. After the Union obtained Dominion status in I 926, however, South Africa was allowed to start its own foreign service. In I929, Prime Minister Hertzog decided that the Netherlands should be the first country with which South Africa established official diplomatic ties. $4^{8}$ The tone of policymakers in The Hague remained cautious and, as had been the case before, much emphasis was put on the cultural and historical ties of the Dutch and the Afrikaners rather than on political alliance. The concept of stamverwantschap remained important in this respect. More concretely, plans emerged for a cultural treaty. Schutte points out the informal nature of this initiative that was taken in 1936 by a group of prominent academics in South Africa, who founded a committee that sought contact with the NZAV and the Dutch government. The plan was welcomed in the Netherlands, which led to the establishment of the Commissie tot bevordering van de culturele betrekkingen tussen Nederland en Zuid-Afrika. It consisted of representatives of the most important organisations that argued for closer ties with South Africa and university professors that distributed money that was made available by the government, mainly to promote academic ties. 49

The committee was presided over by Frans Beelaerts van Blokland, former foreign minister and at the time vice president of the Raad van State (Privy Council), which made him a close advisor to Queen Wilhelmina. This appointment shows the continuity with the pro-Boer movement around I900, as Beelaerts van Blokland had been very active in the propaganda campaign during the South African War. ${ }^{\circ}$ It seems that he remained an important pivot in Dutch-South African relations. In I938, he travelled to Pretoria to be present at the celebrations for the centenary of the battle of Blood River at Pretoria where a re-enactment of the Great Trek ended with a mass gathering. Also in the Netherlands there was attention for this event in the press, and in several cities the NZAV organised celebrations to honour the Voortrekkers. ${ }^{5 \text { I }} \mathrm{At}$ the eve of the Second World War, ties between the Netherlands and South Africa were closer than they had been in the preceding decades, and stamverwantschap remained an important concept..$^{22}$ The cultural treaty was to be the crown to this process, but the plan was put on hold when Nazi Germany 
invaded the Netherlands in May 1940. It turned out that the Second World War was not only disruptive in the short run, it also left its marks on DutchAfrikaner relations in the decades that followed.

\section{Dutch-South African relations after the Second World War}

The Second World War stands out as one of the most important discontinuities in Dutch history, which had lasting effects. The trauma of Nazi occupation has left a deep mark on national identity in the Netherlands. One of the most painful issues in that respect is the high percentage of Dutch Jews that were deported and exterminated during the Holocaust. After the war, the general public developed an aversion to racism, a concept that was increasingly associated with the Nazi atrocities. Another great trauma was the occupation of the Dutch East Indies by Japan in 1942. At the end of the war, Indonesian nationalists seized the opportunity and declared independence. The Dutch government considered the colonial possessions to be vital to the country's post-war recovery and therefore started two military expeditions to restore authority - without success. This, in combination with international pressure, forced the government to acknowledge Indonesia's independence in I949. Although the Netherlands kept some possessions in the West (Surinam and the Antilles) for some time thereafter, it effectively meant the end of its status as colonial power. This brought about a change in thinking about colonialism. Whereas the 'civilising mission' once had been a source of national pride, the historical 'exploitation' of Indonesia increasingly became a source of guilt and shame. ${ }^{53}$

In South Africa, the experiences of the war and decolonisation were quite the opposite. It did not suffer occupation by the Axis forces and, indeed, there seems to have been a large measure of sympathy for the Nazis amongst certain groups of radical Afrikaners. In I939, Prime Minister Jan Smuts pledged allegiance to Britain and provided troops. But there was great opposition against this decision from the Nasionale Party, who argued that South Africa should stay out of the war. This attitude was quite disappointing to many people in the Netherlands after 1945. During the South African War, they had protested vehemently against the occupation of the Boer republics, while radical Afrikaner leaders refused to criticise the invasion of the Netherlands by the Nazis. ${ }^{54}$ When the Nasionale Party won the South African elections in I948, there were therefore quite some negative reactions from the Netherlands. Also the policy of the new government seemed to be the opposite of 
what was happening in the Netherlands. While the Dutch lost their most prized colonial possession, the Afrikaners started to install the first apartheid laws which were meant to bolster white supremacy in South Africa. This policy was widely condemned by the international community, leading to the isolation of South Africa. The anti-apartheid movement in the Netherlands was particularly strong.

Looking at these developments, it is tempting to see the Second World War as marking a great discontinuity initiating domestic developments that unavoidably enlarged the gap between the Netherlands and South Africa. But there are indications that there was continuity as well. The psychological effects of the Second World War and decolonisation were not directly apparent in Dutch society, and the anti-apartheid movement would only gain momentum after 1960. Moreover, it would be wrong to see the resentment against apartheid as a result of the traumas of the Second World War and decolonisation only. Although domestic politics undoubtedly played a role in the Dutch anti-apartheid movement (which grew during a period of great social turmoil), it also was based on a view of what South Africa should look like in the future. This also constitutes a significant continuity with the ideal of stamverwantschap, which was aimed at helping the 'kinsmen' to bolster their institutions in order to shape the colonial order in the region.

Looking at the I950s, the continuity with the pre-war period is clearly present. The Dutch government did not send an official committee to the opening of the Voortrekker Monument in Pretoria in 1949, but it allowed a private delegation to go. They turned out to be the only foreign representation at this event, which became a massive rally of radical Afrikaners. One of the delegates even addressed the 200,000 attendants, emphasising the special ties between the Dutch and the Afrikaners. ${ }^{55}$ These feelings also seem to have had an effect on emigration from the Netherlands to South Africa, which rose to unprecedented levels after 1948 (some 48 , ooo people left). The Dutch government even provided financial support to emigrants who went to that part of the world. ${ }^{6}$ And the plans of Beelaerts van Blokland were at last implemented: a cultural treaty between the Netherlands and South Africa was signed in $195 \mathrm{I}$. At this occasion also diplomatic ties were reinforced and the legations of both countries were upgraded to embassies. ${ }^{57}$ The position of the NZAV was greatly strengthened by these policies, and the society became a pivot in Dutch-South African relations. It was appointed by the government to distribute subsidies to emigrants, and the organisation also had a permanent seat in the committee that oversaw the implementation of the cultural 
treaty. ${ }^{5}$ The executive committee considered the treaty to be an important document that would greatly strengthen existing ties. 59

Also in other ways, the ongoing popularity of the concept of stamverwantschap in these years can be detected. In 1952, there were widespread celebrations in both South Africa and the Netherlands to mark the 3 ooth anniversary of the landing of Jan van Riebeeck at the Cape of Good Hope. ${ }^{60}$ In October of that year, Prime Minister Willem Drees made an official visit to South Africa. The main reason was to celebrate the new route to Johannesburg operated by the Royal Dutch Airways. But Drees seems to have had more personal reasons as well. During a speech in Pretoria on the occasion of Kruger Day, he told his audience that his interests in politics had been roused as a small boy when he was present in the huge crowd when the Transvaal president arrived in Amsterdam. ${ }^{61}$ Two years later, Prince Bernhard made a three-week visit to South Africa in order to stimulate business ties. ${ }^{62}$ With his trip he actively contributed to the general image that South Africa could be very profitable for Dutch enterprise, which he reiterated in an interview he gave after his return. ${ }^{63}$

On these occasions, Dutch officials focussed on the cultural and historical ties and business opportunities but refrained from comments on the policy of apartheid. But an increasing number of Dutch opinion makers did comment on this issue. There was appreciation for the segregation policies amongst some conservatives and former colonials, who argued that it was the only way for white men to control the black majority. ${ }^{64}$ In general, however, there was growing discomfort about the racist policies of the Nasionale Party, which spilled over into the press and Parliament. After a stay of three months in South Africa, the progressive reverend J. J. Buskes published an influential book in which he condemned the apartheid system. He not only had moral objections but also foresaw practical dangers, as he thought the suppression of the black majority would inevitably lead to a race war. ${ }^{65}$ In addition, representatives from Surinam and the Antilles demanded more outspoken protests against the segregation laws, which made it difficult for the Dutch government to remain neutral on this issue. This became clear in the United Nations, where the Dutch delegation as a rule refrained from voting on resolutions against apartheid but explicitly condemned the system in its address to the assembly. ${ }^{66}$ This led to increasing tensions with the Afrikaners in the late I950s.

The Sharpeville Massacre in March I960, where the South African police killed 69 black demonstrators protesting against the pass laws, was in many ways a turning point in Dutch-South African relations. As in other countries, 
there was widespread outrage against this bloodbath in the Dutch press. ${ }^{67}$ In Parliament, the government was put under pressure to condemn the events openly. Although the confessional parties blocked a resolution forwarded by the left-wing parties that compared Sharpeville to Nazi atrocities, a more moderately worded official protest was adopted that was sent to the South African Parliament. The text invoked the ideal of stamverwantschap in an attempt to persuade the Afrikaners to change their ways. ${ }^{68}$ This indicates that some of the old reflexes of the old pro-Boer movement were still in effect to a certain extent. ${ }^{69}$ But even within the NZAv, it was noticed that attitudes were changing after the Sharpeville Massacre. The annual report of I96I mentioned that there was growing public criticism of the society because of its non-political stance. The executive committee stated, however, that it remained committed to strengthen the historical, cultural and economic ties between the Netherlands and South Africa, regardless of the political situation in either country. $7^{\circ}$

This facade of neutrality became increasingly problematic in the years that followed. The reactions to the Sharpeville Massacre marked a fundamental shift in Dutch policies towards South Africa. Whereas before this event the government had tried to remain neutral, after the massacre it started to put pressure on the Afrikaner regime. In I96I, the Netherlands was the only Western country to vote in favour of an anti-apartheid resolution in the UN, and in 1965 Foreign Minister Luns allocated fl. 100,000 to the Defence and Aid Fund that provided legal assistance to anti-apartheid activists. These actions were openly condemned by the Afrikaner government. ${ }^{7 \mathrm{I}}$ In the I970s, a progressive coalition greatly increased the funds it provided to the African liberation movement and eventually took direct sanctions against the apartheid regime. In reaction to the death of anti-apartheid activist Steve Biko while in police custody in I977, the cultural treaty was unilaterally frozen and later revoked. $7^{2}$ The Netherlands also joined international sanctions, although it refrained from imposing boycotts on its own accord, despite public pressure to do so. ${ }^{73}$ The NZAV strongly protested against these actions. Particularly the end of the cultural treaty was a painful blow, as it had been a cornerstone of the society's influence since the I950s. In its annual report of 1977, one prominent member accused the left coalition of 'shortsightedness' because the treaty had been a means to open a 'dialogue' with the Afrikaners in order to persuade them to end the apartheid system. 74

The NZAV became more isolated in other ways too. In the I960s, there was a substantial growth in the number of anti-apartheid organisations. At first, 
these groups were quite moderate, publishing texts against the apartheid regime and collecting money for the liberation movement. In the early seventies, several groups emerged that argued for more decisive action. Some of them focussed on public opinion in the Netherlands, calling for a boycott on South African products, which started with a successful ban on oranges from Outspan in I97I. These new organisations also led demonstrations against companies who traded with the apartheid regime..$^{75}$ In the I 980 , a few radical groups thought this was even too limited, and there were several bomb attacks on companies that continued their activities in South Africa. The storming of the NZAV library was also part of this violent campaign. ${ }^{76}$ In an interview, the activists declared that they had vandalised the collection as a symbolic act against 'an organisation that makes propaganda for a fascist and murderous regime'.77 Although the destruction of books was widely condemned, also by many anti-apartheid organisations, there was little sympathy for the NZAV itself. In a comment, the author Adriaan van Dis lamented the attack on the library, which according to him had great historical value. But he also took a swipe at the NZAV, describing it as a 'calcified society' whose members clung on to the outdated ideal of stamverwantschap. ${ }^{7}$

Despite the widespread resentment against the Afrikaners in the 1980s, it can be questioned whether this was such a great discontinuity with previous periods. The Dutch anti-apartheid movement can partly be seen as an element of the social revolution that took place in the West during the I960s. 79 But there was also a more direct link with the situation in South Africa. Although the word stamverwantschap increasingly became a politically incorrect anachronism, several groups of anti-apartheid activists in the Netherlands continued to consider the Afrikaners to be akin, and their motivations can be explained to some extent from a sense of shame. ${ }^{80}$ The ongoing feeling of connectedness explains why South Africa has been such a sensitive topic in the Dutch public debate from the late nineteenth century onwards. There was a sense of historical responsibility towards that part of the world, with the Dutch wanting to influence the way society took shape there. ${ }^{8 \mathrm{I}}$ This points to a strong measure of continuity, despite the fact that pro-Boers around 1900 had based their view on an ideology of white superiority that was completely different from the anti-racism of anti-apartheid activists eighty years later. 


\section{General concluding remarks}

At the end of the nineteenth century, Dutch pro-Boers set up a transnational network that greatly influenced relations between the Netherlands and South Africa in the following century. As is asserted in historiography, this initiative was undoubtedly a form of nationalism. To a certain extent, the Boers were idealised in order to serve as an example to the population of the Netherlands. Although these effects cannot be denied, the pro-Boer movement was also an informal and cultural form of imperialism. There were structural attempts to enlarge Dutch influence in the region, and feelings of kinship with the Boers - stamverwantschap - were clearly connected with ideas about the global position of the Dutch race. It has been argued in this volume that these international components had a profound influence on the pro-Boer movement in the Netherlands from the $\mathrm{r} 88 \mathrm{os}$ onwards. It was not merely an isolated and unique phenomenon in Dutch history, it was also connected with the shaping of modern South Africa and as a result there was a clear interaction with both Afrikaner nationalism and British imperialism.

The enthusiasm for the Boers in the I 88 os led to the establishment of several durable institutions that aimed to strengthen the ties between the Netherlands and South Africa. Although emigration numbers remained low, an influential group of so-called Hollanders settled in the Transvaal where they contributed significantly to the modernisation of the republic that took place under Paul Kruger. Moreover, these individuals became mediators, transferring information that supported Boer independence from South Africa to the Dutch media. During the South African War, this network was considered to be of great value in the propaganda campaign that was set up to support the fight of the Boers against British expansionism. Dutch pro-Boer organisations played an important role in distributing this information in Europe in order to counter British coverage of the war. Although the British army was increasingly successful in cutting off the official lines of communication as the conflict progressed, information continued to reach the Netherlands via more informal channels. This made it hard, however, to keep an overview and to distinguish useful initiatives to help the embattled Boers from those that were fraudulent. The NZAV, in co-operation with the Boer representatives and the ANV, therefore actively tried to streamline the propaganda campaign by creating new institutions.

Despite the feverish activism of this network during the South African War, how much effect these efforts actually had remains an open question. The 
main purpose of the propaganda campaign was to put pressure on the British government by mobilising public opinion. Although there was widespread enthusiasm for the Boers in continental Europe, it yielded few political results because none of the governments abandoned its policy of neutrality. This gulf between public enthusiasm and government inertia was probably most apparent in the Netherlands itself. In other ways too, the pro-Boers were confronted with the volatility of public opinion. Although at first sight the huge wave of enthusiasm might have been positive for the propagandists, they also had problems coping with the huge amount of work this entailed. The source material shows that the pro-Boer movement in the Netherlands was quite haphazard and relied on improvisation. This points to a more fundamental flaw in the Dutch press system at the time: its international connections were quite underdeveloped. It seems that the government's policy of neutrality and the reluctance of businessmen to invest money in global lines of communication were the main explanations for this limitation.

On the other hand, contemporary pro-Boers did actively reflect on these deficiencies, which indicates that to them the propaganda campaign fitted in with broader issues associated with the rise of mass media taking place at the time. The press office of the ANV in particular fulfilled a pioneering role in the Netherlands because it was the first organisation that tried to propagate Dutch interests in the international media. There was much appreciation for these activities, but they did not receive any structural support and the press office depended on funds from pro-Boer organisations. It is also difficult to assess how much of the ANV material was actually published in newspapers inside and outside the Netherlands. Still, it can be said that despite these limitations, several gripping images were distilled from the material that was transferred from South Africa, which was used to propagate a vision of the past and future of the region that legitimised the existence of an independent Dutch entity there. This corpus was the most important result of the pro-Boer propaganda network.

The general content of the pro-Boer literature that emerged in the I 880 os and I 890 s, was based on a view of the history of colonial South Africa that celebrated the supremacy of the white Dutch-speaking people. Although the tensions between the modern Dutch and the traditional Afrikaners were mentioned, opinion makers in the Netherlands generally supported Kruger's ideas on the Transvaal's independence. The imperial dreams of stamverwantschap at times overlapped with the ideals of certain groups of Afrikaner nationalists. Their common goal was to prevent the British from ending the 
independence of the Boer republics and gaining complete dominance over the region. Contemporaries did not reflect on this issue in terms of high politics and economics only but also believed that cultural differences were of importance. In their words, the two 'white races' were mainly separated by their heritage and language. Many of the efforts by Dutch pro-Boers were therefore aimed at strengthening national identity in the Boer republics.

In the pro-Boer propaganda during the South African War, the cultural aspects of the struggle between the republics and the British Empire was the leading theme. This led to a biased coverage of events on the battlefield as they were unfolding. From the beginning of the war, British atrocities were enumerated extensively. Although initially there was some sympathy for the 'Tommies' who were forced by their superiors to fight a war they did not ask for, reports also mentioned their atrocities which were seen as being emblematic of the injustice of the war. The tone used in publications about these 'war crimes' became more radical as the war continued. The measures taken by the British to counter the Boers' guerrilla tactics - such as farm-burning, the deportation of prisoners of war and the concentration camps - were depicted as barbaric. Although emotions ran high at times, it should be remembered that most Dutch opinion makers considered British statesmen and empire builders to be responsible for the war and did not blame the British nation as a whole.

The image of the Boers in Dutch publications also remained ambivalent. In the early phase of the war, there was a euphoric mood in the Netherlands which to some extent turned into disillusion when the British started their advance in 1900 , exposing the shortcomings of the Boers' informal military system. After the start of the guerrilla war, the atmosphere of hope and fear polarised. Those who surrendered, the 'Handsoppers', were seen as the embodiment of the negative traits in the Boer character such as selfishness and stubbornness. By contrast, those who continued to fight, the 'Bittereinders', were seen as true patriots. Prisoners of war and women in the camps who opposed British tyranny and did not give up hope shared in the same kind of heroism and were depicted as martyrs. Letters and reports about such defiance bolstered the hope that the Afrikaners would remain defiant against British attempts to Anglicise South Africa in the future.

Remarkably, such optimism to a certain extent continued to exist after the Peace of Vereeniging (1902), which brought a definitive end to the Boer republics. As a result, the interaction with Afrikaner nationalism entered into a new phase after I902. One of the main priorities of the pro-Boer organisa- 
tions was to help rebuild Afrikaner cultural infrastructure in order to withstand Milner's policy of promoting English. These efforts could not be sustained after the pro-Boers' funds ran out, but they did contribute to the survival of these institutions during the difficult years immediately after the South African War. In addition, there were ongoing attempts to provide Afrikaner nationalists with intellectual ammunition, particularly with material that could help sustain the heroic vision of the past that would mobilise grassroots support. With this goal in mind, Willem Leyds tried to make available to the Afrikaners the huge amount of propagandistic material that he had gathered during the South African War. Although his attempts to publish an integrated history of the conflict failed, he did succeed in moving several important collections to South Africa, which became lasting places of memory for Afrikaner nationalists. Such activities show that, to a certain extent, the old lines of communication were reversed and used to transfer pro-Boer propaganda back to South Africa.

In the Netherlands, there was also more continuity following the 1902 peace treaty than might appear at first sight. There was a clear drop in the activities of pro-Boer activists, but they continued to try to mobilise support for their efforts to keep Dutch influences in South Africa as strong as possible. The institutions that were used to do this originated in the previous periods and were mainly financed from the remnants of the money that was generated then. Attempts to set up new institutions that could operate independently failed, however, which limited the effects of these efforts. Even more than before, there were tensions and controversies, which highlights the complex relationship between the pro-Boer movement and public opinion in the Netherlands. Nonetheless, certain views on South Africa that originated in the I 88 os remained in vogue until after the Second World War. In this way, the reflexes of stamverwantschap continued to influence the relationship between the Netherlands and South Africa. Even at the height of the anti-apartheid movement, feelings of connectedness with that part of the world continued to exist.

The Dutch primary sources that have been presented in this volume match the views about imperial culture that have been developed in recent British historiography quite well. One fundamental premise is that concepts of nationalism and imperialism were not necessarily opposed to each other and sometimes overlapped, although there were often contradictions and tensions. In this way, Britishness resembled its Dutch counterpart stamverwantschap, even though the political context was obviously very different, as 
the former concept was embedded in a formal empire. Still, there are parallels regarding identity formation. In the dominions, imperialistic and nationalistic sentiments held by English-speaking groups existed side by side. At first sight, it might seem that Afrikaner nationalists were more wary of outside meddling, even if it came from people who claimed to be closely related. Hollanders, however, did contribute significantly to the development of their cultural institutions and helped to strengthen them against English influences. There was a reciprocal effect too, as propaganda in favour of Boer independence and against British expansion was quite popular in the Netherlands precisely because it fed into Dutch nationalism again. In this sense, the propaganda campaign during the South African War can be seen as a confrontation between ideas of Britishness and stamverwantschap.

Significantly, contemporaries were aware of this intricate interaction and often used military metaphors to refer to this war of words. Pro-Boer propagandists in the Netherlands actively tried to refute the views that were put forward by British advocates of expansion who wrote negatively about the Boers. Already in the I 880 os and I 890 s, they tried to provide an account of nineteenth century South Africa in which the existence of the Boer republics was legitimised. Attention shifted to current events during the South African War, but the goal was the same: to promote the concept of an independent Dutch-speaking entity in the region. Although the propaganda was quite negative about the British at times, this dichotomy was not as absolute as it might seem. In general, it was argued that jingoists had corrupted public opinion and politics and had thus provoked the war. In addition, there were people in Britain that opposed the conflict who were seen as allies, and proBoers in the Netherlands exchanged information with them. This had its limits, however, because even though both groups were appalled by some of the events taking place in the war zone, they had fundamentally different views on the colonial future of South Africa.

When looking at the institutional aspects, more differences become apparent. At the start of the war, the British media were represented by hundreds of journalists. Because of the British monopoly on telegraph lines, their news reached Europe first. By contrast, Dutch newspapers depended on informal correspondents who initially sent their letters via Delagoa Bay. When the British authorities tightened censorship after they had occupied the republics, these lines were increasingly disrupted. This points to fundamental differences between British and Dutch imperialism. As a small country, the Netherlands clearly lagged behind in establishing its own global communication 
lines. This can partly be explained by international power relations at the time which forced the government to adhere to a strict policy of neutrality. In addition, there seems to have been a great unwillingness amongst the business community to invest in institutions that could help to improve the situation. These problems were clearly apparent to the Dutch pro-Boers, and they tried to improve the situation by setting up organisations such as the ANV press office. These efforts were successful in the sense that a large amount of information that supported the Boer perspective was gathered and distributed throughout Europe. Analogous to the situation in South Africa, one could say that the pro-Boers developed a guerrilla style of propaganda that created powerful images which the British found hard to refute.

A final comparison can be made concerning chronology. Despite the fact that the public in Britain became increasingly demoralised, the South African War was not the beginning of the end of the British Empire. Many supporters of expansion were shocked by the inefficiency of the army and made plans to reform imperial institutions. Although the actual effects of these initiatives were probably rather limited, it shows that contemporaries reflected on such matters, which means that historians need to take them seriously. In I902, the loss of independence by the Boer republics caused a far greater shock in the Netherlands and, compared to their British counterparts, the Dutch organisations that propagated stamverwantschap were much weaker. Attempts to professionalise them after the South African War failed, in contrast with the ever-developing British press system. Nevertheless, the ongoing popularity of the heroic past of the Afrikaners, which lasted until after the Second World War, shows a parallel with the enduring appeal of popular imperialism in Britain.

To properly assess the long-term effects of the pro-Boer propaganda campaign in comparison to British imperial culture, one should also take into consideration the situation in South Africa. After they had secured territorial dominance, British administrators failed to Anglicise the white population, the majority of which took pride in their Dutch heritage and language. Although their attitude towards their cultural motherland, the Netherlands, was ambivalent and sometimes even openly hostile, to a large extent Afrikaner nationalists appropriated the views on South African history that had been written by Dutch authors. Some individuals actively tried to reverse the existing lines of communication and stimulate this process. It would be going too far to assert that this was the only factor that shaped Afrikaner nationalism, but it does dispel the views of those who argue that transnational feelings of 
Dutchness were simply a myth. From the I 880 s, stamverwantschap had different meanings to different groups of people in the Netherlands and South Africa and as such became a mixture of nationalism and ideals of transnational brotherhood, laced with racism and colonialism. This ideology undoubtedly reached its climax during the propaganda campaign from I899 to I902, but the cannon fire of this war of words clearly resounded far into the twentieth century. 


\section{Abbreviations}

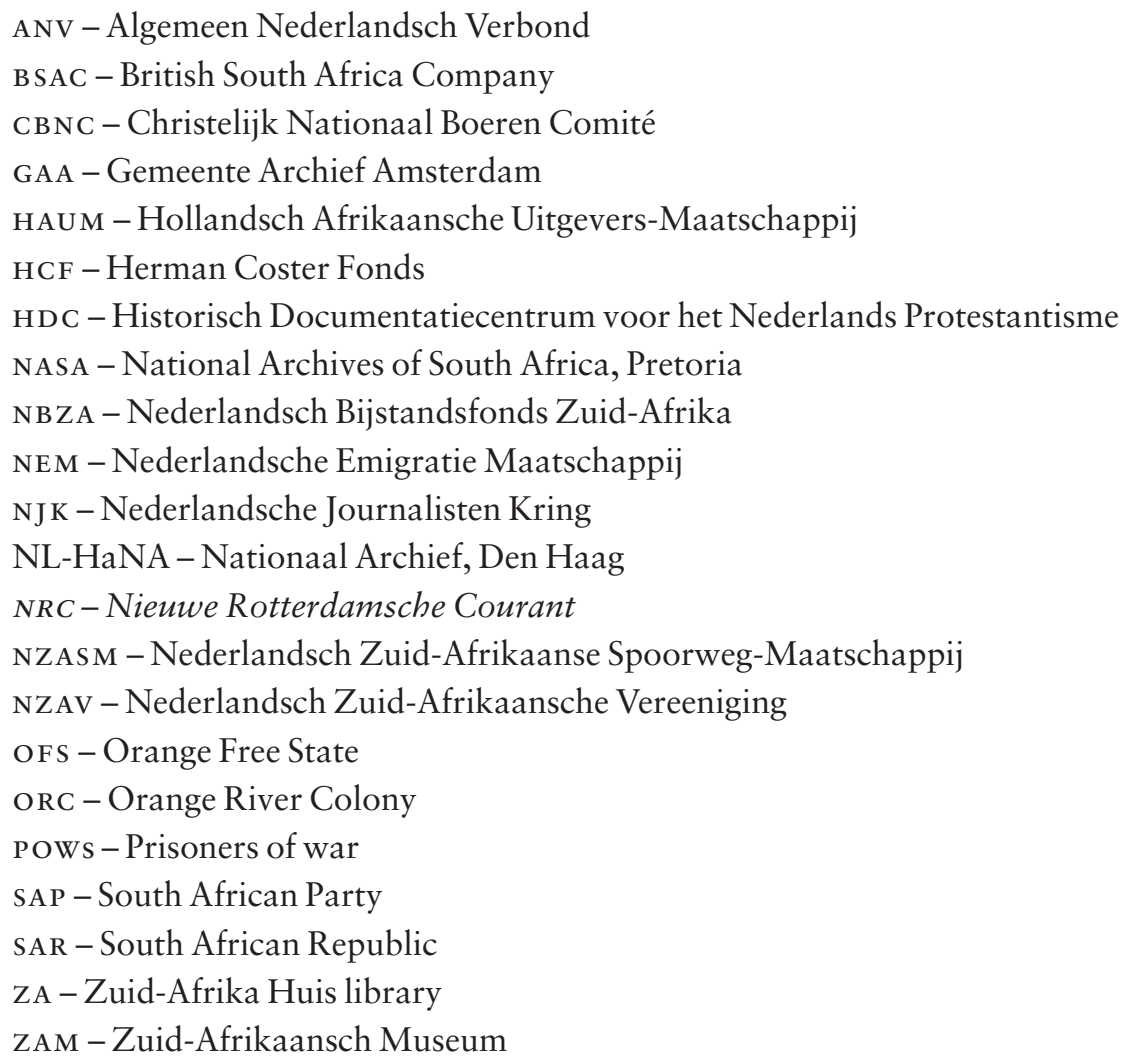





\section{Notes}

\section{Introduction}

I Hobson, The Psychology of Jingoism, I02.

2 Hobson, The War in South Africa, 33.

3 Porter, 'Sir Alfred Milner and the Press, I897-1899', 338; Smith, The Origins of the South African War, 399-400; Krebs, Gender, Race, and the Writing of Empire, 25-29; Potter, " "The Dark Stream of Shameless Falsehood”?'.

4 P. Geyl, 'Introduction', in: Bromley and Kossmann eds., Papers delivered to the Oxford-Netherlands historical conference, 9.

5 'Preface', in: Bromley and Kossmann eds., Britain \& the Netherlands in Europe and Asia, , 0 .

6 S. Conway, 'Introduction', in: Moore and Van Nierop, Colonial Empires Compared, I. 7 Papers given at these conferences can be found in the following special issues: Itinerario. Journal for Overseas History, vol. Io, no. I (I986); ibid., vol. I I, no. I (I987); ibid., vol. I 2, no. I (I988); ibid., vol. I3, no. I (I989).

8 Johnson, 'Problems of Comparison', 83-93.

9 MacKenzie, 'Empire and Metropolitan Cultures', 285.

Io Wesseling, 'Bestond er een Nederlands imperialisme?', I93-I94.

I I M. Kuitenbrouwer, Nederland en de opkomst, I29; Schutte, Nederland en de Afrikaners, 4I. In order to avoid misunderstandings, I will use the initials of Maarten Kuitenbrouwer in references to his work.

I 2 Nimocks, Milner's Young Men, chapters 3 and 4; Darwin, 'A Third British Empire?', 72-77.

I 3 MacKenzie, Propaganda and Empire, 7. This book was a starting point for the sizable Studies in Imperialism of which MacKenzie is the editor-in-chief.

I 4 Burton, Burdens of History; Hall, Civilising Subjects.

I 5 Porter, The Absent-Minded Imperialists, I3-I7 and 3 I 3 .

I 6 J. Darwin, 'Bored by the Raj', The Times Literary Supplement, I 8 February 2005; D. Kennedy, Review of Porter's The Absent-Minded Imperialists, H-Albion, H-Net Reviews, June 2005 .

I7 The following paragraphs are based on Lester, 'Imperial Circuits and Networks', I 24I 4 I.

I 8 Robinson and Gallagher with Denny, Africa and the Victorians. For the notions 'col- 
laboration' and 'excentric', see Robinson, 'Non-European Foundations of European Imperialism', I I7-I 42.

I9 Cain and Hopkins, Imperialism: Innovation and Expansion.

20 Fieldhouse, 'Can Humpty-Dumpty be Put Together Again?', I6.

2I Darwin, 'Imperialism and the Victorians', 629.

22 Lester, 'Imperial Circuits and Networks', I 29.

23 Darwin, 'Imperialism and the Victorians', 64 I-642.

24 Bridge and Fedorowich, 'Mapping the British World', 3.

25 Lester, 'Imperial Circuits and Networks', I 30.

26 Hopkins, 'Back to the Future', I98 and 207-208.

27 Bridge and Fedorowich, 'Mapping the British World', 6; Potter, 'Richard Jebb', I07.

28 Darwin, 'A Third British Empire?'; Bridge and Fedorowich, 'Mapping the British World', 8-i I.

29 Lester, Imperial Networks.

30 Laidlaw, Colonial Connections.

3 I Potter, News and the British World.

32 Potter, 'Webs, Networks, and Systems', 622.

33 Thompson, Imperial Britain.

34 Thompson, The Empire Strikes Back?

35 Potter, 'Empire, Cultures and Identities', 66.

36 Morris, Farewell the Trumpets, 91; Holland, The Pursuit of Greatness, , 0.

37 Price, An Imperial War; Attridge, Nationalism, Imperialism and Identity; Porter, The

Absent-Minded Imperialists, 2 I 5-21 6 and 234-237.

38 MacKenzie, Propaganda and Empire, 9 and 256.

39 Darwin, 'A Third British Empire?', passim; Thompson, Imperial Britain, I93; Potter, News and the British World, $2 \mathrm{I}$ I.

40 Darwin, 'Afterword: the Imprint of the War', 296.

4I Compare Porter, 'The South African War and Imperial Britain' and Thompson, 'Imperial Propaganda during the South African War'.

42 Because of the recent invention of the handheld Kodak camera, for example, there were far more photographs available than in previous wars that found their way to the upcoming illustrated press. Badsey 'A Print and Media War', I I-I 2; Dorward, 'Major Tunbridge's Boer War Album'; Searle, A New England?, 284.

43 Badsey, 'The Boer War as Media War', 70-83; Potter, News and the British World, 38. 44 See for example Beaumont, 'The Making of a War Correspondent'.

45 Beaumont, 'The British Press and Censorship'.

46 Potter, News and the British World, 2 I 2.

47 Nimocks, Milner's Young Men, I 8-I9.

48 Krebs, Gender, Race, and the Writing of Empire, 34-36.

49 Dubow, Scientific Racism, I7; Krebs, Gender, Race, and the Writing of Empire, I I 4.

50 Thompson, 'The Languages of Loyalism', 640-646.

5 I Surridge, “"All you Soldiers are what we call Pro-Boer”.

52 Nasson, The South African War, 283. 
53 Lowry, "'The World's no bigger than a Kraal".

54 For the most elaborate overview of the diplomatic aspects of the South African War, see Wilson, The International Impact of the Boer War.

55 For the most complete overview of the debate, see M. Kuitenbrouwer, 'Het imperialisme-debat in de Nederlandse geschiedschrijving', 56-73.

$56 \mathrm{M}$. Kuitenbrouwer, Nederland en de opkomst, 2I 7-2 I 8.

57 'regenten'. M. Kuitenbrouwer, 'Capitalism and Imperialism'; M. Kuitenbrouwer, 'Drie omwentelingen in de historiografie van het imperialisme'; Kuitenbrouwer and Schijf, 'The Dutch Colonial Business Elite', 6I-86.

58 Fasseur, 'De koloniale paradox'; Wesseling, 'Bestond er een Nederlands imperialisme?', I 88-г90.

59 Locher-Scholten, Sumatran Sultanate and Colonial State.

60 Bossenbroek, Holland op zijn breedst.

6I Taselaar, De Nederlandse koloniale lobby; Van der Velde, Een Indische liefde.

62 Legêne, De bagage van Blomhoff; Bloembergen, Colonial Spectacles.

63 The exact meaning in Dutch is rather unclear. 'Stam' can mean several things, such as stock and stem. In some contexts it related to the descent of people, meaning that they are of Dutch stock. In other contexts it was used as a metaphor of the Dutch language: a tree with branches all over the world. 'Verwantschap' means kinship.

64 Van Sas, 'Fin de siècle als nieuw begin', 586-568; M. Kuitenbrouwer, Nederland en de opkomst, I I9; Schutte, Nederland en de Afrikaners, 40-4I and 205; Bossenbroek, Holland op zijn breedst, I I-I2; Bank and Van Buuren, I90o: Hoogtij van burgerlijke cultuur, IOO-IO3.

65 M. Kuitenbrouwer, Nederland en de opkomst, ir9; Schutte, Nederland en de Afrikaners, 27; Bossenbroek, Holland op zijn breedst, I87-I90; Pretorius, 'The Dutch Social Democrats and the South African War'.

66 Van Koppen, De geuzen van de negentiende eeuw; Schutte, Nederland en de Afrikaners, 76-78.

67 Te Velde, Gemeenschapszin en plichtsbesef, 82.

68 M. Kuitenbrouwer, Nederland en de opkomst, I29. Protagonists of this ideal also argued that Flanders should become part of the Netherlands.

69 Van Vree, 'Tradition and innovation in the historiography of mass media', 89-100.

70 M. Kuitenbrouwer, Nederland en de opkomst, I20-I2I and 206-207; M. Kuitenbrouwer, 'Het imperialisme van een kleine mogendheid', 64-65.

7I Bossenbroek, Holland op zijn breedst, $20 \mathrm{I}-202$.

72 Kröll, Die internationale Buren-Agitation, 323-326; Van Niekerk, Kruger se regterhand, 2 IO.

73 ' haat-liefde verhoudingen'. Schutte, Nederland en de Afrikaners, IOI-I 42.

74 M. Kuitenbrouwer, Nederland en de opkomst, I25-I28; Schutte, Nederland en de Afrikaners, I03-I22; De Jong, Die Lewensomstandighede en Kulturele Bydrage, 236.

75 Schutte, Nederland en de Afrikaners, I98-204.

76 Te Velde, Gemeenschapszin en plichtsbesef, г80-г8 I; Bossenbroek, Holland op zijn breedst, $35 \mathrm{I}-352$. 
77 De Graaff, De mythe van de stamverwantschap, 299-308. 78 Moodie, The Rise of Afrikanerdom, 52-72; Schutte, Nederland en de Afrikaners, I 8 5I 86 .

79 Schutte, Nederland en de Afrikaners, I97-I98.

80 Ibid. 209-2 I 2; Schutte, 'Stamverwantschap als imperialisme', I9. See also M. Kuitenbrouwer, De ontdekking van de derde wereld, 209-229.

8I Besselaar, Zuid-Afrika in de letterkunde; Conradie, Hollandse skrywers, II. Conradie's second book appeared posthumously and was edited by Anna de Villiers.

82 Huigen, De weg naar Monomopata, I 7-I 8.

83 Jonckheere, Van Mafeking tot Robbeneiland, 209-2 Iо.

84 Van Koppen, De geuzen van de negentiende eeuw, I 8-2I.

85 Bossenbroek, Holland op zijn breedst, 344-352.

86 Gast ed., Catalogus van de Bibliotheek der Nederlandsch Zuid-Afrikaansche Vereeniging; Stubbings, Leyds-versameling van nie-boek materiaal.

87 Latsky, 'A Bibliography of Dutch Publications on the South African War', 443-468.

88 It appears that the newspaper collection was stored in Amsterdam in the I9Ios by the Welcker family and then was moved to the library at the Zuid-Afrika Huis when it was opened in the I930s. NASA, Leyds collection, LEY 2II; G. Schutte, 'De Boerenoorlog in telegrammen', in: Zuid-Afrika vol. 82 (2005), I 25.

89 Warwick, Black People and the South African War; Nasson, Adam Esau's War.

90 Nasson, The South African War, 283; Nasson, 'Africans at War'.

\section{Chapter I}

I Bank and Van Buuren, I90o Hoogtij van burgerlijke cultuur, Iо0-103.

2 'De Nederlandsch Zuid-Afrikaansche Vereeniging', in: De Gids, vol. 50, no. 4 ( ( 8886), I 85 -I 90 , I 85 .

3 Te Velde, Gemeenschapszin en plichtsbesef, 82 .

4 Ibid. 76-82.

5 Van Koppen, De geuzen van de negentiende eeuw, passim.

6 M. Kuitenbrouwer, Nederland en de opkomst, I I9; Schutte, Nederland en de Afrikaners, 27; Bossenbroek, Holland op zijn breedst, I87-г 89.

7 Bossenbroek, Holland op zijn breedst, 189-190; Pretorius, 'The Dutch Social Democrats'. During the South African War, some Socialists called for a general boycott of British goods, but there was little support from the leaders of the pro-Boer organisations and the representatives of the Boer republics.

8 M. Kuitenbrouwer, Nederland en de opkomst, I 8-г9.

9 Ibid. I 29-I30 and I90; Schutte, Nederland en de Afrikaners, $4 \mathrm{I}-42$ and 205. The volume Nederland en de Afrikaners by Schutte that is used in this thesis appeared a year later than Nederland en de opkomst van het moderne imperialisme by M. Kuitenbrouwer but contains articles that Schutte had published earlier. In fact, M. Kuitenbrouwer refers to these titles in his footnotes.

Io Schutte, Nederland en de Afrikaners, I4-I6; Schutte, Nederlandse publicaties over Zuid-Afrika, 9-Io. 
I I M. Kuitenbrouwer, Nederland en de opkomst, iा8; Schutte, Nederland en de Afrikaners, 22-23.

I 2 Schutte, Nederland en de Afrikaners, 23.

I 3 Van Koppen, De geuzen van de negentiende eeuw, 67-68.

I4 M. Kuitenbrouwer, Nederland en de opkomst, I I8-I I9; Schutte, Nederland en de Afrikaners, 24-28.

I 5 M. Kuitenbrouwer, Nederland en de opkomst, I2 I; Schutte, Nederland en de Afrikaners, 42-44.

I 6 ZA, NZAV Jaarverslag I $88 I-I 882$, appendix I.

I 7 Houwers, Nationalistische commotie in Nederland, 28-29. The Jameson Raid will be treated later in this chapter.

I 8 Van Koppen, De geuzen van de negentiende eeuw, 95-99.

I9 Schutte, Nederland en de Afrikaners, 78.

20 M. Kuitenbrouwer, Nederland en de opkomst, I25-I26; Schutte, Nederland en de Afrikaners, 47-50; Bossenbroek, Holland op zijn breedst, 349-35 I.

2I For the notion of imperial lobby groups as platforms or 'arenas', see Driver, Geography Militant, 46.

22 Schutte, 'De organisatie van de stamverwantschap'.

23 M. Kuitenbrouwer, Nederland en de opkomst, 204 and 207-209.

24 Schutte, Nederland en de Afrikaners, 30-3 I.

25 Van Winter, Onder Krugers Hollanders II, I3 and n. I4; Schutte, Nederland en de Afrikaners, 86.

26 Otterspeer, 'Boeren en academici'.

27 Bossenbroek, Holland op zijn breedst, 260.

28 Van Winter, Onder Krugers Hollanders II, 26.

29 Bossenbroek, Holland op zijn breedst, I 12.

30 Saunders and Smith, 'Southern Africa, I795-I910', 609.

3 I Van Winter, Onder Krugers Hollanders II, I 22 and I3 I-I48; Bossenbroek, Holland op zijn breedst, I02.

32 Van Winter, Onder Krugers Hollanders II, IOO-IO2. A shipping route between the Netherlands and South Africa was finally inaugurated in I9I9, when the whole region had become part of the British Empire. De Graaff, De mythe van de stamverwantschap, I34. For plans for a shipping line during the South African War, see chapter 4.

33 Bossenbroek, Holland op zijn breedst, 77.

34 Schutte, Nederland en de Afrikaners, 52.

35 Ibid. 56-57. In the course of the twentieth century, the student exchange programme would become more substantial. De Graaff, De mythe van de stamverwantschap, 3 I9320.

36 Van Koppen, De geuzen van de negentiende eeuw, I 27-I 30.

37 For the language question, see chapter 2.

38 Letters from J. P. Moltzer to H. J. Emous. ZA, collection Emous, EM I I.

39 Brinkman's Catalogus van boeken, I 89I-I900 and I9OI-I9IO. See chapter 2. 40 Schutte, Nederland en de Afrikaners, 5 I-52 and 87. 
4I Ibid. 86-87.

42 Lammers, Kent gij dat volk vol heldenmoed?, 55.

43 'heethoofden'. Te Velde, Gemeenschapszin en plichtsbesef, 73.

44 Bossenbroek, Holland op zijn breedst, 292-293.

45 Van Koppen, De geuzen van de negentiende eeuw, 25.

46 Geerts, Verzuilde Boerenliefde.

47 'niet alles, wat wij dienaangaande te zien krijgen ons voorkomt op juiste beschouwingen te berusten. In vele gevallen echter kunnen wij zeer tevreden zijn, over het licht dat op deze wijze verspreid wordt'. ZA, NZAV Jaarverslag I 888-I889, 23.

48 Hemels and Schneider, De Nederlandse Krant I 6I 8-1978, 473-477.

49 Wijfjes, De Journalistiek in Nederland, 45.

50 De Jong, Die Lewensomstandighede en Kulturele Bydrage, 28.

5I NASA, Gustav Preller collection, A 787, 206-209; Wallach, Die Volmaakte "Gentleman", 22-23.

52 Newspapers usually referred to this material as 'Afrikaansche mail', African mail.

53 Schutte, Nederland en de Afrikaners, 87.

54 Van Winter, Onder Krugers Hollanders II, 44.

55 Schutte, Nederland en de Afrikaners, 87.

56 Van Winter, Onder Krugers Hollanders II, 45-46; Schutte, Nederland en de Afrikaners, IO2-IO3.

57 The figures provided here are derived from the memoirs of the former SAR administrator, C. G. S. Sandberg (a Hollander) who returned to the Netherlands during the South African War. During the Second World War, he supported the Nazis and published his memoirs as anti-British propaganda. It seems, however, that Sandberg took the figures from SAR documents in his possession after he had smuggled them out of the British-occupied Transvaal. Sandberg, Twintig jaren onder Krugers Boeren, I 85.

58 Schutte, Nederland en de Afrikaners, I02.

59 Sandberg, Twintig jaren onder Krugers Boeren, I 85 . Compare with Smith, The Origins of the South African War, 47. Smith does not mention any figures but thinks it is possible that there were as many British Uitlanders as there were burghers who had the vote (male white adults who were born in South Africa). Looking at Sandberg's figures, this does not seem likely.

60 Smith, The Origins of the South African War, 90-9I.

6I Van Winter, Onder Krugers Hollanders I, i I 8; Gordon, The Growth of Boer Opposition, $132-\mathrm{I} 33$.

62 Schutte, Nederland en de Afrikaners, I03.

63 Ibid. I I 6-I I 8 .

64 Ibid. I 2 I-I 22.

65 Ibid. I24.

66 Gordon, The Growth of Boer Opposition, I 32.

67 Schutte, Nederland en de Afrikaners, I03-105.

68 In later life, Leyds himself mentioned this often. Although there are no sources that back this up, there are also no sources that dispel it. Van Niekerk, Kruger se regterhand, 384-385. 
69 Ibid. 4 I-I 85 ; Van Winter, Dr Leyds en Zuid-Afrika, 24. 70 Smith, The Origins of the South African War, 48-5I.

7 I Van Winter, Onder Krugers Hollanders I, I09.

72 Gordon, The Growth of Boer Opposition, I 27-I 30.

73 Ibid. 138.

74 De Jong, Die Lewensomstandighede en Kulturele Bydrage, , $о$.

75 Ibid. 236.

76 Van Winter, Onder Krugers Hollanders I, I09-I 30.

77 Gordon, The Growth of Boer Opposition, I 28.

78 Smith, The Origins of the South African War, 5 I-56 and 2I 2-2 I 8.

79 Van Niekerk, Kruger se regterhand, I 28.

80 Ibid. I02-IO3. During the South African War, the case came before a court in Brussels during which the financiers of the Selati railway were convicted of fraud.

8 I Van Winter, Onder Krugers Hollanders II, 39.

82 Ibid. $36-37$.

83 Ibid. I4-26.

84 'In persoonlijke ontplooiing meer dan het scheppen van belangrijke nationale krachtcentra vond de Nederlandsche volksgeest zijn uiting'. Ibid. 4 I-42.

85 Schutte, Nederland en de Afrikaners, I72-I75.

86 Van Winter, Onder Krugers Hollanders I, I I 3 -I I 4.

87 Leyds ed., Vierde Vezameling I, I 52. Leyds refuted such rumours and considered them to be in the same category as the fantasy story that he was secretly married to Emily Hobhouse. For Hobhouse, see chapter 6.

88 E. W. de Jong, 'Willem Leyds', in: Woord en beeld vol. 2 (I900), 6I-68, 65; Van Niekerk, Kruger se regterhand, I 7 .

89 Schutte, Nederland en de Afrikaners, I78-i 80; Van Koppen, De geuzen van de negentiende eeuw, 69-г 6r.

90 Schutte, Nederland en de Afrikaners, I05-107.

9I Hoogeveen, Lieve vrouw en kinders; Lammers, Kent gij dat volk, 66-69.

92 Ibid. I 24.

93 Smith, The Origins of the South African War, 49 and 83 .

$94 \mathrm{~J}$. A. Hobson was the first to analyse this phenomenon. Despite many flaws, modern historians have found that his observations are a good starting point for further research. Porter, 'Sir Alfred Milner and the Press, I897-I899'; Potter, “"The Dark Stream of Shameless Falsehood"?'; Smith, The Origins of the South African War, 399-400.

95 Quoted in: Smith, The Origins of the South African War, I34.

96 Gordon, The Growth of Boer Opposition, 87.

97 Ibid. xv-xvi and I 29-I 3 I; Schutte, Nederland en de Afrikaners, I 25-I4I.

98 Universiteitsbibliotheek Amsterdam, HSS-mag.: KVB PPA 480:3. Bedrijfsdocumentatie Hollandsch-Afrikaansche Uitgevers-Maatschappij, voorheen Jaques Dusseau \& Co. The company remained in existence up until the late twentieth century.

99 Huigen, De weg naar Monomopata, 96-I 24.

Ioo See chapters 4,6 and 7 . 
IOI ZA, NZAV Jaarverslag I896-I897, 22; NZAV Jaarverslag I897-I898, 26; NZAV Jaarverslag I 898, I4.

IO2 See chapter 2.

I03 For a biography of Wormser, see Van Schelven, Levensbericht van Johan Adam Wormser.

IO4 'noodlottige'. Jaarverslagen N.V. Boekhandel Wormser \& Höveker. HDC, Collection Wormser, 258/36; Schelven, Levensbericht van Johan Adam Wormser, I I; Schutte, De Vrije Universiteit I, I3 I.

I05 Van Winter, Onder Krugers Hollanders I, 248-250.

I06 M. Kuitenbrouwer, Nederland en de opkomst, I76-177; Bossenbroek, Holland op zijn breedst, 75 .

I07 Compare M. Kuitenbrouwer, Nederland en de opkomst, I I I-I I 4 and I42-I43; and Van Dijk, The Netherlands Indies and the Great War, 6-7. M. Kuitenbrouwer argues that the presence of Germany in the archipelago was seen as a good deterrent for the British, who were considered to be the biggest threat, while Van Dijk argues that there were also fears that Germany would use the colonial question as a prelude to annexation of the Netherlands.

Iо8 M. Kuitenbrouwer, Nederland en de opkomst, , 30.

I09 Ibid. I77.

I I0 Ibid. I78-I 80; Van Koppen, De geuzen van de negentiende eeuw, I 50-I6I.

I I I Historians mainly point out the restrictions that were imposed during the South African War. Bossenbroek, Holland op zijn breedst, 20I-202; Van Dijk, The Netherlands and the Great War, I 2-I4. See chapter 3 .

I 2 De Graaff, 'Kalm temidden van woedende golven', chapter 26.

I 3 ZA, NZAV Jaarverslag I 895-I896, 8. The following year, however, the number had fallen back to around I, 500 . Houwers, Nationalistische commotie in Nederland, 28.

I I 4 ZA, NZAV Jaarverslag I 895-I 896, 6.

I I 5 Schutte, Nederland en de Afrikaners, 88-89.

I 6 ' Wij Nederlanders kunnen, zelfs als wij vereenigd zijn, betrekkelijk zoo weinig doen. Wat is er dan van verspreide pogingen te verwachten?'. ZA, NZAV Jaarverslag I 895-I896, 8-9.

I 7 M. Kuitenbrouwer, Nederland en de opkomst, I77; Bossenbroek, Holland op zijn breedst, 252-253.

I 8 Van Berne, 'Het Algemeen-Nederlands Verbond I98 5-I995', 40-4I.

I 9 M. Kuitenbrouwer, Nederland en de opkomst, i 7.

I 20 Bossenbroek, Holland op zijn breedst, 252.

I 2 I Houwers, Nationalistische commotie in Nederland, 33.

I 22 Ibid. Shortly after the war started, however, the NZAV grew exponentially and the ANV lagged behind.

I 23 Bossenbroek, Holland op zijn breedst, 253.

I 24 ZA, NZAV Jaarverslag I 896-I 897, membership list.

I 25 See chapter 4 .

I 26 ZA, NZAV Jaarverslag I 896-I897, 33-37. This intensive relationship would remain 
intact, and in 1907 and 1908 it was even proposed by some executive members that the NZAV be merged with the ANV, which by that time had outgrown its sister organisation. This did not happen. See circular of a meeting of executive committee and local representatives of the NZAv, December I907. ZA, NZAV archive, VIII/I6; De Graaff, De mythe van de stamverwantschap, I I3.

I 27 See chapter 4 .

I 28 Van Niekerk, Krugers se regterhand, 205.

I 29 Ibid. I 92 and 197.

I30 Ibid. I95-I96 and I98; Leyds ed., Tweede verzameling I, 45-46. Because it was unclear if the terms of the London convention ( I 884) allowed the SAR to have ambassadors, Leyds was appointed as minister plenipotentiary in order to avoid controversy. In practice, all European powers except Britain treated him with full diplomatic protocol.

I3 I Van Niekerk, Kruger se regterhand, 2 I 5-2 I7. Van Niekerk argues that Roëls contributed to this shift, but she neglects to mention the influence of the Fashoda crisis (I 898). Ulrich Kröll points out that this event contributed greatly to the dislike of the British by the French public. Kröll, Die internationale Buren-Agitation, I98.

I 32 ZA, NZAV Jaarverslag I 895-I896, 39-40.

I33 Schutte, 'Muller, Hendrik Pieter Nicolaas (I 8 59-I94I)'.

I 34 M. Kuitenbrouwer, Nederland en de opkomst, I 2 I.

I35 'die rooi doekie voor die Britsche bull'. Quoted in: Rompel, Marthinus Theunis Steyn, 48.

I36 Ibid. 47-50.

I 37 Schutte, 'Muller, Hendrik Pieter Nicolaas'. See chapter 2.

I 38 Du Toit Spies, ' $n$ Nederlander in Diens van die Oranje-Vrystaat, 85.

I39 See chapters 3 and 7.

I 40 Potter, 'Webs, Networks, and Systems', 635. See introduction.

\section{Chapter 2}

I Schutte, Nederlandse publicaties over Zuid-Afrika, 9-Io. Schutte has calculated that the number of publications (books and articles) went up from an average of four per year in the period I $806-\mathrm{I} 880$ to $\mathrm{I} 4$ in the period I 885 - I 895 . After reaching a peak of 50 in I 896 as a result of the Jameson Raid, the number fell to 25 in I 897 and I 898 .

2 It was only in the mid-nineteenth century that Van Riebeeck's journal was rediscovered in the Cape archives and published, but at the end of the century it had achieved an iconic status. Ledden, Jan van Riebeeck, 37. For a reappraisal of this journal, see Jansen, 'Eva, wat sê hulle?'.

3 Besselaar, Zuid-Afrika in de letterkunde; Conradie, Hollandse skrywers uit Suid-Afrika II. Conradie's second book appeared posthumously and was edited by Anna de Villiers.

4 Steyn, Tuiste in eie taal; Zietsman, Die taal is gans die volk.

5 Huigen, De weg naar Monomopata; Jonckheere, Van Mafeking tot Robbeneiland; Jansen and Jonckheere, Boer en Brit. 
6 Huigen, De weg naar Monomopata, I 3 -I 4 and I 7-I 8.

7 Nasson, The South African War, 283.

8 Dubow, Scientific Racism in Modern South Africa, I7; Krebs, Gender, Race, and the Writing of Empire, I I 4 .

9 In I9I I, the white population of the Union of South Africa was around I.25 million and the black population 5 million. Marks, 'Southern Africa', 547.

Io Schutte, 'The Place of Dutch Historians in South African Historiography', 26.

I I Porter, 'Sir Alfred Milner and the Press, I897-I899'; MacKenzie, Propaganda and

Empire, I 53; Thompson, 'Imperial Propaganda during the South African War'. Simon Potter has shown that the relationship between the press and politicians who supported expansion was not unproblematic, however. Potter, News and the British World, 36-5 5 . I 2 For use of that phrase, see C. B. Spruyt, 'De exodus der Boeren', in De Gids, vol. 5 I, no. 4 (I 887), I 62-77, I75. He referred to Stratham, Blacks, Boers, and British.

I3 Schutte, Nederland en de Afrikaners, I 5-I 6.

I 4 'Behalve laf, zijn zij valsch, huichelachtig, meinedig, onredelijk, ongastvrij, lui, vuil en ondankbaar.' Tromp, Herinneringen uit Zuid-Afrika, I46; quoted in Schutte, Nederland en Afrikaners, I 8.

I 5 Van Koppen, De geuzen van de negentiende eeuw, 60-6I.

I 6 Ibid. 56-62. Lion Cachet was in the Netherlands between I 873 and I 875 , after which he went to the Transvaal for another five years. He returned to the Netherlands in I 880 .

I7 The struggle of the Transvaalers. Besselaar, Zuid-Afrika in de letterkunde, 64-65; Conradie, Hollandse skrywers II, 362-366; Schutte, Nederland en de Afrikaners, 52; M. Kuitenbrouwer, Nederland en de opkomst, I I 8-I I 9; Van Koppen, De geuzen van de negentiende eeuw, 62-63.

I 8 'uit de aard der zaken'. Lion Cachet, De worstelstrijd der Transvalers, 7.

I 9 Spruyt, Afrikaners en Nederlanders, 4-5, footnote; Bosman, Dr. George Mc. Call Theal, I 2 I; Conradie, Hollandse skrywers II, 365.

20 Van Koppen, De geuzen van de negentiende eeuw, 59-61.

2 I Ibid. 6I-63.

22 'taaiheid'. Lion Cachet, De worstelstrijd der Transvalers, 28 and 40-4 I.

23 Van Koppen, De geuzen van de negentiende eeuw, I63-164.

24 Jorissen, Transvaalsche herinneringen, 7-9. In I 884, Jorissen had already written a pamphlet in which he gave an account of the negotiations between the Boers and the British. It formed the basis for his book from I 897, supplemented with personal observations that were too sensitive to include in the $\mathrm{I} 88 \mathrm{os}$, including his controversial dismissal. 25 Blink, Britsche koloniale politiek in Zuid-Afrika, 32-33; Besselaar, Zuid-Afrika in de letterkunde, 68.

26 Schutte, Nederland en de Afrikaners, I 2 5- 26.

27 Jorissen, Transvaalsche herinneringen, 72-73. He even claimed to have coined the motto: 'Afrika voor den Afrikaner!' This phrase is usually attributed to Kruger. Ibid. I44. 28 'Voor hem draait de zon om de aarde.' Jorissen, Transvaalsche herinneringen, 17.

29 Rompel, ‘Dr. E. J. P. Jorissen', I 65.

30 'lui, gulzig, onbeschoft en onbehouwen'. Quoted in M. Kuitenbrouwer, Nederland en de opkomst, $\mathrm{I} 26$. 
3I For example, see Muller, Zuid-Afrika, I3-24, 43 and I07-I09. In I894, Muller received his PhD from the University of Giessen (Germany) on an ethnographical study of the Limpopo region. Schutte, 'Muller, Hendrik Pieter Nicolaas (I 8 59-I94 I)'.

32 Muller, Zuid-Afrika, I I 8-I 22 and 376-378.

33 Ibid. 108-109.

34 Wormser, Van Amsterdam naar Pretoria, I I 0 . For differences in tone between the descriptive Muller and more spirited Wormser, see Besselaar, Zuid-Afrika in de letterkunde, $5 \mathrm{I}-52$.

35 Wormser, Van Amsterdam naar Pretoria, , 08.

36 Te Velde, Gemeenschapszin en plichtsbesef, 98 and IOI-IO2.

37 'ziekelijke opgewondenheid'. Spruyt, Afrikaners en Nederlanders, vi; Te Velde, Gemeenschapszin en plichtsbesef, IоI.

38 C. B. Spruyt, 'Uit Zuid-Afrika', in: De Gids, vol. 55, no. 3 (I 89 I), I-I 5 , I 5.

39 Conradie, Hollandse skrywers, I 5 I-I 52.

40 Mansvelt, In memoriam: prof. dr. C. Bellaar Spruyt; Mansvelt, De betrekkingen tusschen Nederland en Zuid-Afrika, I58-I59. Mansvelt was a known Calvinist, while Spruyt was an outspoken Liberal, but this seems not to have mattered to either of them. There was also praise for Spruyt by the Protestant pro-Boer organisation CN BC. Voor de Boeren, Orgaan der Vereeniging: Het Christelijk Nationaal Boeren-Comité, no. I (4 May I900), 5 .

4I Bossenbroek, Holland op zijn breedst, I 8-I9.

42 ZA, NZAV Jaarverslag I900, I32; NZAV Jaarverslag I 90 I, I 3 I.

43 Blink, Transvaal en omliggende landen, 5-I7; Te Velde, Gemeenschapszin en plichtsbesef, 77 . The work of Theal will be discussed later in this chapter.

44 ZA, NZAV Jaarverslag I 888-I 889, 23.

45 Cutting from a newspaper describing a meeting in Amsterdam organised by Patrimonium, not dated. HDC, collection Wormser, 258 , doos I 5 .

46 'geen prentenboek [...] voor een Hollandsche kinderkamer.' Besselaar, Zuid-Afrika in de letterkunde, $5 \mathrm{I}$.

47 Gerraets, Dijkstra's ondervindingen in Zuid-Afrika.

48 Jonckheere, Van Mafeking naar Robbeneiland, 46-54.

49 Penning, Uit mijn leven, I34-I35.

50 Van der Elst, 'Die Anglo-Boereoorlog: 'n vertekende beeld vanuit die vreemde', I 50.

5 I Penning, Uit mijn Leven, I36.

52 In De helden van Zuid-Afrika about the Great Trek, he refers to a work by Pieter Harting, founder of the NZAV and to De worstelstrijd der Transvalers by Lion Cachet. Penning, De helden van Zuid-Afrika, 58, I63 and 198.

53 Elst, 'Die Anglo-Boereoorlog: 'n vertekende beeld vanuit die vreemde', I 5 I.

54 Penning, Uit mijn Leven, I37-I 38.

55 Colenbrander, De afkomst der Boeren, 7. Colenbrander took the situation in I 806 as a benchmark, because he argued that the genetic make-up of the Boer had not changed since then. In I97 I, J. A. Heese published his findings on the geneaology of the Afrikaners, which differed significantly, arguing that $36 \%$ of the Afrikaners had Dutch ancestry, 
$35 \%$ German, I $4 \%$ French and $7 \%$ black. Heese, Die herkoms, 2 I. 56 'nieuw ras'. Ibid. I23.

57 Ibid. I2 I.

58 'opvliegendheid'. Lion Cachet, De worstelstrijd der Transvalers, 4I9.

59 Ibid. 2 I; Muller, Zuid-Afrika, $387-389$.

60 'Men scheen daar liever door den "ridderlijken" Franschman, dan door de botte Hollander beschaamd.' Colenbrander, De afkomst der Boeren, 9.

6I Lion Cachet, De worstelstrijd der Transvalers, 23-27.

62 Ibid. 28.

63 'de geuzen van de negentiende eeuw'. For examples, see Fruin, A word from Holland on the Transvaal question, I4; Spruyt, Afrikaners en Nederlanders, 95-99. In secondary literature, see Schutte, Nederland en de Afrikaners, 40; M. Kuitenbrouwer, Nederland en de opkomst, II9; Te Velde, Gemeenschapszin en plichtsbesef, 77; Van Koppen, De geuzen van de negentiende eeuw, 6I-62.This analogy was also made in several English sources, for example the influential work by George McCall Theal. See Bosman, Dr. George Mc Call Theal, I24-I25. Gueux, the French word for 'beggars', was used to refer to the Dutch who opposed Spanish rule in the sixteenth century.

64 Compare Lion Cachet, De worstelstrijd der Transvalers, 407, and Wormser, Van Amsterdam naar Pretoria, I37; and Muller, Zuid-Afrika, I09.

65 Lion Cachet, De worstelstrijd der Transvalers, I I 5-I I 7.

66 Ibid. I 59-I6r.

67 'aardsvaderlijk'. Spruyt, Engeland en Transvaal, 9.

68 'de rechte Boeren; breedgeschouderde, langbebaarde, ronde rechte kerels, die een geslacht voortbrengen zoo stout en flink als ze zelf zijn'. Wormser, Van Amsterdam naar Pretoria, , 08 .

69 Lion Cachet, De worstelstrijd der Transvalers, 427; Spruyt, Engeland en Transvaal, 8; Rovers, De Transvalers en hunnen heldhaftige vrouwen, I 4-I 5 .

70 Lion Cachet, De worstelstrijd der Transvalers, I78-I8I. For a general description of women during the Great Trek, see W. F. Andriessen, 'De vrouwen der Boeren', in: De Gids, vol. 2I, no. I (1903), 64-88, 69-76.

7I Lion Cachet, De worstelstrijd der Transvalers, I I 5-I I 7.

72 Ibid. I 4O-I4I, I 8 I and 428; Rovers, De Transvalers en hunnen heldhaftige vrouwen, I 5 .

73 For an account of women during the war against Dingane, see Lion Cachet, De worstelstrijd der Transvalers, I92-193 and 212-213. On women during the Transvaal War, see Andriessen, 'De Vrouwen', 77-78; Rovers, De Transvalers en bunnen beldhaftige vrouwen, I7. In chapters 5 and 6, the depiction of women during the South African War will be treated.

74 Rovers, De Transvalers en hunnen heldhaftige vrouwen, I 5-I 6.

75 Lion Cachet, De worstelstrijd der Transvalers, 428-429; Muller, Zuid-Afrika, I 78.

76 Lion Cachet, De worstelstrijd der Transvalers, 207-209 and 297-299.

77 Muller, Zuid-Afrika, I72; Wormser, Van Amsterdam naar Pretoria, I 28.

78 Wormser, Van Amsterdam naar Pretoria, I I 7-I 24. 
79 'Vele deugden bezit de bevolking hier zeker, maar niet in hooge mate die der zindelijkheid.' Muller, Zuid-Afrika, I Iо. For poor hygiene, see Lion Cachet, De worstelstrijd der Transvalers, 348-349.

80 Lion Cachet, De worstelstrijd der Transvalers, 289-290.

8I Jorissen, Transvaalsche herinneringen, 20-2I.

82 Lion Cachet, Deworstelstrijd der Transvalers, 436.

83 Muller, Zuid-Afrika, I 72.

84 Lion Cachet, De worstelstrijd der Transvalers, 405-407; Muller, Zuid-Afrika, I 6 and I76-I77; Wormser, Van Amsterdam naar Pretoria, 93 and 210.

85 Lion Cachet, De worstelstrijd der Transvalers, 407 and 576-567; Muller, Zuid-Afrika, I4I-I 42; Wormser, Van Amsterdam naar Pretoria, 209 and 2I 2; Junius, De koloniën en staten van Zuid-Afrika; Blink, Transvaal en omliggende landen, 98-108. Despite these warnings, many people that went to South Africa were still disillusioned by their experiences. Schutte, Nederland en de Afrikaners, I 20-I 22.

86 Te Winkel, Het Nederlandsch in Noord-Amerika en Zuid-Afrika, 4-9.

87 Fredericq, De toekomst van den Nederlandschen stam, 4-6 and I3-I 4; Te Winkel, De Nederlandsche taal in Zuid-Afrika, 3 .

88 Nimocks, Milner's Young Men, I9-2 I and 55-56. These concerns continued to exist in the twentieth century. Darwin, 'A Third British Empire?', 72.

89 Te Winkel, Het Nederlandsch in Noord-Amerika en Zuid-Afrika, 23.

90 'Inderdaad, de strijd voor de taal is de strijd voor het ras.' Muller, De Zuid-Afrikaansche Republiek, 48 .

9I Conradie, Hollandse skrywers II, xxv.

92 Conradie has argued that he was not opposed to cultural influence from the Netherlands. Ibid. 83-95. Compare with Schutte, Nederland en de Afrikaners, I25-I26. Du Toit's reputation in the Netherlands was very poor, however.

93 Jorissen, Transvaalsche herinneringen, I 26-I30. Despite his anger, Jorissen continued to work in the SAR as a lawyer and was made high court judge in I 890, after Du Toit had fallen from grace. He considered this to be a full rehabilitation. Conradie, Hollandse skrywers II, 339; Schutte, Nederland en de Afrikaners, I 25 -I 26.

94 Schutte, Nederland en de Afrikaners, I77-I 80; Van Koppen, De geuzen van de negentiende eeuw, II9-I32 and I35-I37.

95 M. Kuitenbrouwer, Nederland en de opkomst, I73.

96 Muller, Zuid-Afrika, 377; Te Winkel, Het Nederlandsch in Noord-Amerika en ZuidAfrika, 60 .

97 Spruyt, Afrikaners en Nederlanders, 99-I00 and IOI-I02; Te Winkel, Het Nederlandsch in Noord-Amerika en Zuid-Afrika, 6I-66.

98 Spruyt, Afrikaners en Nederlanders, I 40-I 46.

99 Muller, Zuid-Afrika, 268.

Ioo Wormser, Van Amsterdam naar Pretoria, 92.

IоI Muller, Zuid-Afrika, 26I-268; Wormser, Van Amsterdam naar Pretoria, 9I-94; Te Winkel, Het Nederlandsch in Noord-Amerika en Zuid-Afrika, 59. Particularly the electoral victory of Steyn over a British candidate, J. G. Fraser, in I 895 was considered important. 
IO2 Van Winter, Onder Krugers Hollanders II, 70-72; Schutte, Nederland en de Afrikaners, I05-I07; M. Kuitenbrouwer, Nederland en de opkomst, I73. A noticeable exception is Lion Cachet, who was a personal friend of Du Toit and in I 882 praised his education reforms. Lion Cachet, De worstelstrijd der Transvalers, 407.

I03 Wormser, Van Amsterdam naar Pretoria, 205; W.F. Andriessen, 'Het onderwijs in de Zuid-Afrikaansche Republiek', in: De Gids, vol. 6o, no. 4 (I896), 284-299; Spruyt, Afrikaners en Nederlanders, I I2; 'Transvaler', Transvaal, 51; Te Winkel, Het Nederlandsch in Noord-Amerika en Zuid-Afrika, 6I.

I04 'Moge het Afrikaansche volk hoe spoediger hoe liever begrijpen dat het Engeland, 't welk met Henri-Martins geweren kan wegdrijven, voor geen honderdste deel zoo gevaarlijk is als de Engelsche invloed, aan welke bestrijding mannen als Dr. Mansvelt hun leven wijden.' Wormser, Van Amsterdam naar Pretoria, 205.

I05 Spruyt, for example, extensively quoted from Ons Land in an essay from I 896. Spruyt, Afrikaners en Nederlanders, I40-I 46. Another indication is that during the first part of the South African War, newspapers in the Netherlands used Ons Land as a source until British censorship became too strict in I90I. See chapter 3 .

I06 For Van Oordt, see Besselaar, Zuid-Afrika in de letterkunde, 63-64; Conradie, Hollandse skrywers II, I73-202; Huigen, De weg naar Monomopata, 96-I24. For Jan Lion Cachet, see Besselaar, Zuid-Afrika in de letterkunde, 8I; Conradie, Hollandse skrywers II, II 5-I 35 .

I07 Huigen, De weg naar Monomopata, I7-I 8.

Iо8 Besselaar, Zuid-Afrika in de letterkunde, I37-I79.

I09 Ibid. I 40.

I Io Reitz, Vijftig uitgesogte Afrikaanse Gedigte; Reitz, Sestig uitgesogte Afrikaanse Gedigte.

I I I Te Winkel, Het Nederlandsch in Noord-Amerika en Zuid-Afrika, 52-54.

I 2 Besselaar, Zuid-Afrika in de letterkunde, I40. During the South African War, many schools gave performances during which children recited Afrikaner songs. Also the Transvaal anthem, which was written by the Dutch Catherine F. van Rees in I 875, was widely known amongst the Dutch public. Kloppers, ,Alles zal rech kom!”, 76-77; M. Kuitenbrouwer, Nederland en de opkomst, I 87.

I 3 Compare Te Winkel, Het Nederlandsch in Noord-Amerika en Zuid-Afrika, I 5-22 and D. C. Hesseling, 'Het Hollandsch in Zuid-Afrika', in: De Gids, vol. 6I, no. I ( I 897), I3 8-I62. The first attributed the most influence to French, the latter to Malay.

I 44 'Onder de Hottentotten zou hij er een soort van litterair leven mee kunnen wekken, de beschaafden zouden er zich van afkeeren.' Te Winkel, De Nederlandsche taal in ZuidAfrika, 9-Io.

I 5 Van Winter, Onder Krugers Hollanders II, 72; Schutte, Nederland en de Afrikaners, I05-I07; M. Kuitenbrouwer, Nederland en de opkomst, I 73 and I 75.

I 6 N. Mansvelt, 'De Hollandsche taal en het onderwijs in Zuid-Afrika, van I 874 tot October I 899', in: De Gids, vol. 65, no. 3 (I901) 504-517, 505 .

I 7 Ibid. 5 I I. Still, Mansvelt was considered a hardliner by many of his critics. Schutte, Nederland en de Afrikaners, I39-I40. 
I 8 Mansvelt, 'De Hollansche taal', 509.

I 9 Winkel, De Nederlandsche taal in Zuid-Afrika, I 2. Wormser, who attended the first conference about language simplification in Cape Town (January I 897), noted however that there were not many attendants. Wormser, Van Amsterdam naar Pretoria, 202-204. I 20 Wallach, Die Volmaakte ,Gentleman”, 29.

I 2 I 'den groei der Hollandsche taal dit werelddeel groot nadeel wordt berokkend.' F. V. Engelenburg, 'De spellingskwestie met het oog op Zuid-Afrika', in: De Gids, vol. 6I, no. I (I897), 357-365, 36I.

I 22 See chapter I.

I 23 'Wij gevoelen ons één met den Zuid-Afrikaan, omdat wij weten, dat hij bloed is van ons bloed, omdat zijn voorgeslacht is uitgegaan van ons land, omdat zijn karakter nader staat tot het onze dan van eenig ander volk, omdat wij begrijpen wat hij schrijt in zijne eigene taal, ook al hebben wij die niet opzettelijk aangeleerd, omdat wij hem volkomen verstaan, wanneer hij tot ons komt en ons in eigen woorden als zijne broeder begroet.' Winkel, De Nederlandsche taal in Zuid-Afrika, I 5-I6.

I 24 See chapter 7 .

I 25 Schutte, Nederland en de Afrikaners, I 5-I6. For an early Dutch refutation of the accusation that the Boers in the Transvaal kept slaves, see Veth, Onze Transvaalsche broeders, 2I-38 and 6I-62. P. J. Veth was the father of Daniël Veth, who, as mentioned before in this chapter, died during an expedition to Angola. After the death of his son in I884, Veth largely retired from public life and did not publish about South Africa anymore. Van der Velde, Een Indische liefde, 300-301.

I 26 Veth, Onze Transvaalsche broeders; Fruin, A Word from Holland; Lion Cachet, De Worstelstrijd der Transvalers; Address to the Members of the Anti-Slavery and Aborigines Protection Societies. The Address was officially published by the Transvaal deputation that visited London in I 883-I 884, but Schutte argues that Kuyper wrote it. Schutte De Vrije Universiteit $\mathrm{I}, 50-52$.

I 27 'boe klein een groot man kan zijn'. Lion Cachet, De worstelstrijd der Transvalers, III.

I 28 George McCall Theal provided documents that supported the Boer version of this story, which was taken over by authors in the Netherlands. Theal, History of the Boers, 337-338; Bosman, Dr. George McCall Theal, 84. For contemporary references to this source, see Spruyt, 'De exodus der Boeren', I68-I70; Spruyt, Afrikaners en Nederlanders, I 8-25; Wormser, 'Petrus Jacobus Jourbert', 4I-86, 5 I. For authors who used different sources, see Veth, Onze Transvaalsche broeders, 56-60; Lion Cachet, De worstelstrijd der Transvalers, $4 \mathrm{I} 3$.

I 29 Compare Jorissen, Transvaalsche herinneringen, 23-33 and Lion Cachet, De worstelstrijd der Transvalers, 459-46I. Jorissen thought Foreign Secretary Lord Canarvon and High Commissioner Sir Bartle Frere ordered Shepstone, who acted out of what he thought best for South Africa, to provide them with skewed information. In contrast, Lion Cachet thought Shepstone manipulated the policymakers.

I30 Boissevain, Van dag tot dag, I29.

I3 I Several articles in: ibid. 
I32 Boisevain, 'The Case for Holland', 96; Boissevain, The Struggle of the Dutch Republics: Open Letter to the Duke of Devonshire, I 2-I3.

I33 Van Koppen, De geuzen van de negentiende eeuw, I 8-I9; Te Velde, Stijlen van leiderschap, 59 .

I 34 Compare Te Velde, Gemeenschapszin en plichtsbesef, 70 and M. Kuitenbrouwer, Nederland en de opkomst, I 20. Kuitenbrouwer argues that there was significant resentment against Gladstone in I88I. However, he does not make it clear whether that was against his person as such or against British policy in general. For an example of an instance where Gladstone's personality was praised but the policy of his government criticised, see Veth, Onze Transvaalsche broeders, 79-80.

I35 Froude, Oceana, 42-46. See also Muller, Zuid-Afrika, I3; Spruyt, Afrikaners en Nederlanders, 3-4; Kolstee, Transvaal album, I3. Concerning Froude's genuine respect for the Afrikaners and troubled relations with British expansion in South Africa, see Dubow, A Commonwealth of Knowledge, I26-I $3 \mathrm{I}$.

I 36 Froude, Oceana, 48 .

I 37 Spruyt, Afrikaners en Nederlanders, 5-6.

I 38 For example, see correspondence in the Leyds archive in Pretoria. NASA, Leyds collection, LEY 86, 3 I 5, 3 I 8, 324, 327 and 8I I.

I 39 Hobson, The War in South Africa, 33 and 74 .

I 40 There is evidence in the archives I have used that indicates that there was some contact between Dutch pro-Boers and Hobson, but this seems to have been limited. In one letter to Boissevain (which was probably written in the summer of I90I), Hobson mentioned that he had stayed with the Dutch journalist. J. A. Hobson to C. Boissevain, not dated. GAA, collection C. Boissevain, toegangsnummer 394, inventarisnummers 457494. There are also indications that Hobson received material from the ANV press office, although he used middlemen in order to conceal his ties with this prominent pro-Boer organisation. C. Thieme to F. Rompel, I6 March I90I. NASA, Leyds collection, LEY 8I I; [F. Rompel] to C. de Wilde, 26 April I902. NASA, Leyds collection, LEY 8I 8.

I 4I Stead's introduction to Rompel, The Heroes of the Boer War, ix; Thieme, 'William Stead', I 25; Davey, The British Pro-Boers, 83.

I 42 For correspondence about the publication of the English translation of the pamphlet Een Eeuw van Onrecht (A Century of Wrong) by J. Smuts, see Leyds ed., Tweede verzameling I.

I 43 Thieme, 'William Stead', I 16.

I 44 ' het geweten [...] van zijn volk'. Ritter, De Courant: haar opbouw en beteekenis/W. Stead, 60 .

I 45 Besselaar, Zuid-Afrika in de letterkunde, I I 5; Bosman, Dr. George McCall Theal, 32-35, Saunders, The Making of the South African Past, IO-I 2.

I46 Bosman, Dr. George McCall Theal, 7-8 and 35-40; Saunders, The Making of the South African Past, I3-I 5 .

I 47 It is hard to get a good overview of Theal's exact bibliography. Christopher Saunders asserts that eleven volumes of the History appeared throughout Theal's life. Saunders, The Making of the South African Past, I6. Bosman and Besselaar only mention five vol- 
umes that appeared during the last decades of the nineteenth century. Besselaar, ZuidAfrika in de letterkunde, I I 5 ; Bosman, Dr. George McCall Theal, 44. I have not used later editions for this chapter because Theal revised his work continuously, and therefore this went beyond the scope of this chapter.

I 48 Besselaar, Zuid-Afrika in de letterkunde, I I 5; Bosman, Dr. George McCall Theal, $48-52$.

I 49 Bosman, Dr. George McCall Theal, I I9; Saunders, The Making of the South African Past, 22.

I 50 Saunders, The Making of the South African Past, 24.

I 5 I Ibid. 25.

I 52 Bosman, Dr. George McCall Theal, I 20-I 29.

I 53 Ibid. I39-I 43 .

I 54 For example, see Lion Cachet, De worstelstrijd der Transvalers, 3 I 5 footnote; Blink, Transvaal en omliggende landen, 5; Aitton, Geschiedenis van Zuid-Afrika, x; Spruyt, Afrikaners en Nederlanders, 92; Spruyt, 'The case for the Boers', 61; Spruyt, Engeland en Transvaal. Also Dutch authors in South Africa like Van Oordt were inspired by Theal. Conradie, Hollandse skrywers II, I 80; Huigen, De weg naar Monomopata, I04.

I 5 Aitton, Geschiedenis van Zuid-Afrika, x. After Theal declined, D. Aitton, who had been a teacher in the ofs, was asked to write the textbook. Although Aitton did do some research himself, his work was mainly inspired by Theal. Theal's History of South Africa was translated into Dutch with the support of the NZAv. See Theal, De geschiedenis van Zuid-Afrika.

I 56 Theal noted how the Afrikaners were racially closely linked to the British, but this could not prevent the growing resentment about bad colonial government. Theal, History of the Boers, 59-60; Spruyt, Engeland en Transvaal, 6.

I 57 Lion Cachet, De worstelstrijd der Transvalers, 39 and 395-397; Theal, History of the Boers, 357; Muller, Zuid-Afrika, 49-50; Wormser, Van Amsterdam naar Pretoria, 2 I7-2 I 8; Spruyt, Afrikaners en Nederlanders, IO-I3 and 52-56; Spruyt, Engeland en Transuaal, 22.

I 58 Lion Cachet, De worstelstrijd der Transvalers, 45, 55-73 and I 26-I 27; Theal, History of South Africa I, 343-348; Muller, Zuid-Afrika, I 85-I 86; Wormser, Van Amsterdam naar Pretoria, 216; Spruyt, 'The Case of the Boers', 63; Spruyt, Engeland en Transvaal, I4-I 6 and 28.

I 59 Lion Cachet, De worstelstrijd der Transvalers, 85-86, 462-463 and 558-559; Muller, Zuid-Afrika, 248 and 335-336; Spruyt, Afrikaners en Nederlanders, 25-30; Spruyt, 'The Case for the Boers', 68.

I60 Theal, History of the Boers, 2 I; Spruyt, Afrikaners en Nederlanders, I 8.

I6I 'negerliefde'. Spruyt, Engeland en Transvaal, I I; Spruyt, 'The Case for the Boers', 6I-62; Wormser, Van Amsterdam naar Pretoria, 2 I 5.

I62 Muller, Zuid-Afrika, 6; Spruyt, Afrikaners en Nederlanders, Io and I 8. I 63 Lion Cachet, De worstelstrijd der Transvalers, 42-54; Theal, History of South Africa I, I87-I96; Aitton, Geschiedenis van Zuid-Afrika, 203; Penning, De helden van ZuidAfrika, 7-8. For secondary literature about the depiction of Slachtersnek, see Huigen, De weg naar Monomopata, I 2 I-I 23. 
I 64 Lion Cachet, De worstelstrijd der Transvalers, 85-9I; Theal, History of South Africa I, 374-378; Aitton, Geschiedenis van Zuid-Afrika, 2I3-2 I9.

I65 Lion Cachet, Deworstelstrijd der Transvalers, 73-79; Theal, History of South Africa I, 409-425; Muller, Zuid-Afrika, I84; Aitton, Geschiedenis van Zuid-Afrika, 2I I-2 I3; Wormser, Van Amsterdam naar Pretoria, 2 I 5.

I66 'het zesde zintuig der Boeren. [...] Maar wel met de overtuiging, bewust of onbewust: Wij Afrikaners moeten trekken opdat Afrika beschaafd en de heidensche natiën voor het Christendom gewonnen worden: indien wij niet trekken, wordt Zuid-Afrika niet beschaafd.' Lion Cachet, De worstelstrijd der Transvalers, 40.

I67 Ibid. I28-I3 I, I34-I3 8 and I63-I66; Theal, History of the Boers, 29-4I and 73-74; Muller, Zuid-Afrika, I90-5; Aitton, Geschiedenis van Zuid-Afrika, 219-220; Spruyt, 'The Case for the Boers', 63. Saunders has argued that the evidence that supported these views that the lands of South Africa were depopulated is flimsy. Saunders, The Making of the South African Past, 40.

I68 Lion Cachet, De worstelstrijd der Transvalers, I38-I44, I5I-I53 and I65-204; Theal, History of the Boers, I03-I I9; Aitton, Geschiedenis van Zuid-Afrika, 222-240; Penning, De helden van Zuid-Afrika, I $30-165$.

I 69 The most notorious of these incidents took place in Kimberley in I 872. Muller, ZuidAfrika, 249-250. See also Spruyt, 'Uit Zuid-Afrika', 538; Spruyt, Engeland en Transvaal, 26-27.

I70 Lion Cachet, De worstelstrijd der Transvalers, 462-463; Muller, Zuid-Afrika, I8 I; Spruyt, Afrikaners en Nederlanders, 25-27.

I7I 'talrijk als het zand der zee en vruchtbaar als de konijnen'. Spruyt, Afrikaners en Nederlanders, I3. Spruyt referred to Theal, History of the Boers. Compare with Saunders, The Making of the South African Past, 29.

I 72 Lion Cachet, De worstelstrijd der Transvalers, I 54-I 5 5, 230-232, 28 5, 395-397 and 463-465; Muller, Zuid-Afrika, I80-I82; Wormser, Van Amsterdam naar Pretoria, 2 I6; Spruyt, Afrikaners en Nederlanders, 4-5.

I73 Lion Cachet, De worstelstrijd der Transvalers, 462-463; Muller, Zuid-Afrika, I 27; Wormser, Van Amsterdam naar Pretoria, 21 8, Spruyt, Engeland en Transvaal, 26, 32 and 35 . Saunders argues that Theal largely ignored these conflicts, which is a sign that he approved of them. Saunders, The Making of the South African Past, 26.

I74 For Zulu War, see Lion Cachet, De worstelstrijd der Transvalers, 500-50I; Muller, Zuid-Afrika, 248; Spruyt, Afrikaners en Nederlanders, I8-25. For Matabele War, see Muller, De Zuid-Afrikaansche Republiek, 37 and 39; Spruyt, Engeland en Tranvsaal, 22. Spruyt even used the term 'war of extermination' to describe this conflict: 'verdelgingsoorlog'.

I75 Muller, Zuid-Afrika, I 5-I6, I27, I79-80 and 226-227; Spruyt, Engeland en Transvaal, I 2-I3; Wormser, Van Amsterdam naar Pretoria, I 87-1 88.

I 76 Muller, Zuid-Afrika, I I3-I I 4. Despite Muller's assertion that Afrikaners would never touch a black woman, of which he approved, his travelogue contains several photos of a naked Zulu girl and a long passage in which he expresses his own sexual attraction to a black girl. Ibid. 235-24I. 
I77 'vloek van Natal'. Wormser, Van Amsterdam naar Pretoria, I62. Muller also described the indecent behaviour, in his eyes, of black people in the streets of Natal. Muller, Zuid-Afrika, 64-65.

I78 Lion Cachet, De worstelstrijd der Transvalers, 459-485; Jorissen, Transvaalsche herinneringen, 23-33.

I79 Jorissen, Transvaalsche herinneringen, 2 I-22.

I 80 'vrijheid en recht'. Lion Cachet, De worstelstrijd der Transvalers, 28 and 488.

I 8 I Ibid. 505-506; Jorissen, Transvaalsche herinneringen, I9-20.

I 82 Lion Cachet, De worstelstrijd der Transvalers, 538.

I 83 Jorissen, Transvaalsche herinneringen, 84-85 and I I 3 .

I 84 De Louter, La Question du Transvaal, 8-I2; Leyds, The First Annexation of the Transvaal, 334-346.

I 85 Muller, Zuid-Afrika, I44; Wormser, Van Amsterdam naar Pretoria, I60-I62.

I 86 Muller, Zuid-Afrika, I I 4-I I 5 .

I 87 Schutte, Nederland en de Afrikaners, I22-I4I.

I 88 Andriessen, Jameson's rooftocht gerechtvaardigd?; Louter, La Question du Transvaal, I6; Muller, De Zuid-Afrikaansche Republiek, 43-44.

I 89 Muller, De Zuid-Afrikaansche Republiek, 45; Spruyt, Afrikaners en Nederlanders, $64-65$.

I90 Spruyt, Afrikaners en Nederlanders, 63-64; Andriessen, Jameson's rooftocht gerechtvaardigd?, 4 .

I9I 'rassenhaat'. Spruyt, Afrikaners en Nederlanders, 50; Spruyt, Engeland en Transvaal, 37; Louter, La Question du Transvaal, 20-2I.

I92 Spruyt, 'The Case for the Boers', 65-67; Spruyt, Engeland en Transvaal, 38-39. Blink, Britsche koloniale politiek in Zuid-Afrika, 56-57; Te Winkel, Waar het om gaat in Zuid-Afrika, I I-I 3 and I7-I9.

I 93 Van Gogh, Weestaat den Rhodesgeest, I 5 and 22.

I94 Muller, 'Oom Paul', 2 I 6; Van Gogh, Weerstaat den Rhodesgeest, I 5.

I 95 'inval van Boekaniers in de Transvaal'. Quoted in: M. Kuitenbrouwer, Nederland en de opkomst, I76. See also Andriessen, Jameson's rooftocht gerechtvaardigd?, 2; Spruyt, Afrikaners en Nederlanders, I32-I40; Spruyt, Engeland en Transvaal, 40-43. In I 899, a play appeared in which it was described how a meeting chaired by Rhodes decided to execute the raid. 'Antibull', De inval in Transvaal of de ware grieven der Uitlanders.

I 96 Jorissen, Transvaalsche herinneringen, I35-I 42. As high court judge, Jorissen was closely involved in this matter.

I97 Spruyt, Afrikaners en Nederlanders, I33; Andriessen, Jameson's rooftocht gerechtvaardigd?, 2; Spruyt, Engeland en Transvaal, 4. There was also praise for British opinion makers who protested against the failure of the parliamentary inquiry. A speech by the Liberal MP Sir William Harcourt was translated, for example. Harcourt, Een banierdrager der gerechtigheid.

I 98 F. V. Engelenburg, 'Zuid-Afrika "up to date”, in: De Gids, vol. 6o, no. 2 ( ( 896), Io24, I6-19.

I 99 Boissevain, The Struggle of the Dutch Republics: Open Letter to the Duke of Devonshire, $\mathrm{I} 8-20$ and 80 . 


\section{Chapter 3}

I The Times, 5 April 1900.

2 Badsey, 'The Boer War as Media War', 70-83; Potter, News and the British World, 38. 3 'une preuve nouvelle que dans la guerre actuelle on ne recule pas en Angleterre devant aucun moyen, pas $m$ me la calomnie la plus perfide, ni le mensogne le plus flagrant'. Leyds ed., Tweede verzameling I, 523.

4 Bossevain, The Struggle of the Dutch Republics: Open Letter to the Duke of Devonshire, I2.

5 Kröll, Die internationale Buren-Agitation, 323; Van Niekerk, Kruger se regterhand, $2 \mathrm{I} 5$.

6 Van Niekerk, Kruger se regterhand, 2I 7-2 I 8.

7 Bossenbroek, Holland op zijn breedst, 201-202; Van Dijk, The Netherlands Indies and the Great War, I 2-I4.

8 For good historical accounts of the war, see Pakenham, The Boer War; Nasson, The South African War. Chapters 5 and 6 will discuss the contemporary coverage of events in more detail.

9 This also affected British journalists. Beaumont, 'The British Press and Censorship' Io Leyds ed., Tweede verzameling I, viii; Van Niekerk, Kruger se regterhand, 2 I 4. I I NZASM in memoriam, I46-I47; M. Kuitenbrouwer, Nederland en de opkomst, I84I 85 ; De Jong, Die Lewensomstandighede en Kulturele Bydrage, 2 I 8-222.

I 2 Leyds ed., Eenige correspondentie, 79 and 82-83; Kröll, Die internationale Buren-Agitation, I6I. Leyds was accused in various British publications of advising the SAR government differently, provoking the Boer ultimatum of October I 899. In later life, Leyds tried to dispel this view. See chapter 7 .

I 3 Van Nierkerk, Kruger se regterhand, 297.

I 4 Leyds ed., Derde verzameling I, xiii; Leyds ed., De Vierde verzameling I, xlii-xliii. Pott's papers are kept in NASA, Leyds collection, LEY 45 5-48I.

I 5 Letters from Bas Veth from Lourenço Marques, June-September I90I. NASA Leyds collection, LEY 3 I 4 .

I 6 The archive of the Paris consulate of the Transvaal was not included in the Leyds collection but can be found in the National Archives in Pretoria. NASA, Pierson collection, KGP.

I7 Kröll, Die internationale Buren-Agitation, I98. Compare with Van Niekerk, Kruger se regterhand, $2 \mathrm{I} 7$.

I 8 For the Paris exhibition and its aftermath, see chapter 7.

I9 The papers of Montagu White - from his time both in London and the US - are kept in NASA Leyds collection, LEY 483-5 I 5 . After Montagu White left London, the documents were secretly transferred to Amsterdam by the vice-consul, the Dutch-born A. G. Baron Quarles de Quarles. Leyds ed., Derde verzameling I, I 48-I 49.

20 Meetings of British pro-Boers were disrupted by jingo rioters who attacked the participants. Koss ed., The Pro-Boers, xxiv and xxx; Davey, The British Pro-Boers, 85 and 88. 2I White was not particularly successful there either. Changuion, Uncle Sam, John Bull en Oom Paul, 204-205. 
22 These letters can be found in NASA, Leyds collection, LEY I9I and 326; NL-HaNA, Leyds, 2.2 I. I05, inv.no. 57. See also Davey, The British Pro-Boers, 86-87, I I 9 and I40I4I.

23 Leyds ed., Tweede verzameling I, I74.

24 The archive of Snethlage is kept in NASA Leyds collection, LEY 5 I 6-547.

25 There were SAR consulates in Berlin, Frankfurt and Hamburg. Leyds ed., Tweede verzameling II, 209. There were problems with Consul-General M. Winterfeldt in Berlin, who even gave his documents to the British. Leyds ed., Derde verzameling I, xx.

26 For example, see Kröll, Die internationale Buren-Agitation, I I I.

27 Van Niekerk, Kruger se regterhand, 2 I 2, 2 I 7 and 227.

28 Ibid. 229-23 I.

29 Leyds ed., Tweede Verzameling I, vii-viii; Van Winter, Dr. Leyds in Zuid-Afrika, I6.

30 The secret archive of the legation contains I4 sworn oaths of 'tijdelijke assistenten' (temporary assistants) between October I 899 and April I900. NASA, Leyds collection, LEY 3 I 7 .

3 I F. V. Engelenburg to M. Koopmans de Wet, I9 March I 899. NASA, Engelenburg collection A I 40 , file 42.

32 'Met mijn voortdurend verplaatsen lijk ik wel de wandelende jood. Het wordt hoe langer hoe erger.' Leyds ed., Vierde verzameling I, 3 Iо.

33 Ibid. xxix; Van Hoek, 'The Leyds Memoirs', I3. In June I900, a shipment of gold arrived from the SAR with the German vessel Bundesrath, earmarked for the Nederlandsche Bank en Crediet Vereeniging voor Zuid-Afrika. Another notorious incident took place in November I 900 when 30 boxes of gold were confiscated at the port of Hamburg by the German authorities on request of the British government. Leyds admitted that this money came from the Boers but that it had been payment for supplies that European firms had delivered at Delagoa Bay. Leyds ed., Derde verzameling I, xv-xvi.

34 Leyds ed., Tweede verzameling I, xvii, I44-I45, I83-I 84 and I92-I93; Van Niekerk, Kruger se regterhand, 269-270.

35 Leyds ed., Derde verzameling I, I 38 -I 39.

36 Leyds ed., Vierde verzameling I, xxvii.

37 Approximately $£_{53}, 500$. Van Niekerk, Kruger se regterhand, 223.

38 Leyds ed., Derde verzameling I, xiv-xv; Leyds ed., Vierde verzameling I, xxvi-xxvii.

39 Van Niekerk, Kruger se regterhand, 223.

40 Ibid. 224-225.

4I Ibid. 2 I 2-3. See chapter 4 .

42 Ibid. 274. See chapter 7.

43 Du Toit Spies, ' $n$ Nederlander in Diens van die Oranje-Vrystaat, 99.

44 Copy of report by J. W. J. Wessel Roux and A. E. Mackay (not dated), iii-vii. ZA, ANV collection, ANV II/29.

45 R. W. J. C. van der Wall Bake to Willem Leyds, Io March I900. NAsA, Leyds collection, LEY 32 I; Van Niekerk, Kruger se regterhand, 273.

46 Leyds ed., Tweede verzameling I, 359-360.

47 Ibid. 360-36I; Du Toit Spies, 'n Nederlander in Diens van die Oranje-Vrijstaat, I I I. 
48 For an overview of the activities of the deputation, see Scholtz, Europa en die tweede vryheidsoorlog, 97-I I I; Van Niekerk, Kruger se regterhand, 289-296.

49 Leyds ed., Derde verzameling I, 8-20. Leyds considered this decision to be a mistake, because the Dutch government was bound to its neutrality, while there were indications at the time that Wilhelm II was willing to meet them. This opportunity was lost later on. 50 Sandberg, Twintig jaren onder Krugers Boeren, 329-338.

5 I Leyds ed., Derde verzameling II, I 5 O-I 5 I; Du Toit Spies, 'n Nederlander in Diens van die Oranje-Vrijstaat, 193-I95. In the I930s, a polemic started between Leyds and Muller about this incident. See chapter 7 .

52 H. P. N. Muller to W. J. Leyds, 26 November I 900. NASA, Leyds collection, LEY 257. 53 W. J. Leyds to H. J. Kiewiet de Jonge, 20 January I9I7. NASA, Leyds collection, LEY 257; Leyds ed., Vierde verzameling II, 37. I have not recovered the original letter by Fischer but Leyds's account is supported by the fact that the relationship between the deputation and Muller deteriorated.

54 Leyds ed., Vierde verzameling I, xv and 642.

55 Ibid. 667.

56 Ibid. 729; Du Toit Spies, ' $n$ Nederlander in Diens van die Oranje-Vrijstaat, 217.

57 Du Toit Spies, ' $n$ Nederlander in Diens van die Oranje-Vrijstaat, I 89-I90. See chapters 4 and 5 .

58 'Zijn verhalen zijn absurt in de drie speeches die ik gehoord heb, hij praat over zichzelf en zijn President en zijne Regeering en maakte in elke rede insinuaties tegen het Transvaalsche Gouvernement in vergelijking met zijn Gouvernement, die niet sterker van een Engelsche jingo konden komen'. Leyds ed., Vierde verzameling I, 746.

59 M. Kuitenbrouwer, Nederland en de opkomst, I 83-1 84 .

60 This might be the reason why he did not publicly reflect on the Dutch position during the South African War or thereafter. The only reference I have found to the neutral position of the Netherlands, which Leyds thought to be the result of the precarious position of the colonial possessions, is Van Hoek, Gesprekke met Dr. W. J. Leyds, 3 I.

6I 'belangrijke informatie'. ZA, NZAV Jaarverslag I 896/I 897, 7 .

62 ZA, NZAV Jaarverslag I 899, 7 and 24.

63 Letters F. J. Domela Nieuwenhuis to H. J. Emous. ZA, Emous collection, EM I I, G3. 64 NRC, 24 August I90I. The report was published two months after the account of Emily Hobhouse appeared, and although the findings were similar, it did not attract as much attention. See chapter 6 .

65 NRC, 29 October, 9 and I 4 November I 901.

$66 \mathrm{ZA}$, NZAV Jaarverslag I902, 7.

67 Het Algemeen Handelsblad, 8 October 1898.

$68 \mathrm{ZA}$, NZAV Jaarverslag I 898,7 and 45-5 I.

$69 \mathrm{ZA}$, NZAV Jaarverslag I $900,8$.

70 'voor alle Boeren'; 'het spreekt vanzelf dat ik voor de imboorlingen niets en voor de kleurlingen zoo goed als niets doe'. B. H. de Waal to the executive committee of the NZAV, I I December I 899. ZA, NZAV collection, VI/I30.

7 I Those on Ceylon were assisted by Consul P. A. Wennink. ZA, NZAV Jaarverslag I 90o, $43-45$. 
$72 \mathrm{ZA}$, NZAV Jaarverslag $1902,7$.

$73 \mathrm{ZA}$, NZAV Jaarverslag I $900,8$.

74 Leyds ed., Derde verzameling I, I48-I49.

75 There were also two attachés from the colonial army in the Dutch East Indies - Lieutenants C. J. Asselbergs and M. J. Nix. Nix died of wounds he sustained during the battle of Sannah's Post (March I 900). Asselbergs left South Africa thereafter. For his diary, see Schultz ed., Dagboek van C.J. Asselbergs.

76 J. H. Ram, 'Report meeting Vereeniging ter beoefening van de krijgswetenschap (I90I-I 902)', I 54. Leyds collection, University of Stellenbosch, PAM 2; Pretorius, Kommandolewe tydens die Anglo-Boerenoorlog, 206. For doubts about the discipline of the Boer army, see chapter 5 .

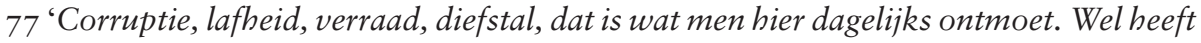
een partijdige pers de Europeanen in algemeen, ons Hollanders in de eerste plaats een rad voor de ogen gedraaid!'

78 'Het zou jammer zijn, als Engeland overwint, jammer voor ons, uit egoisme [sic]; want we verliezen een debouche voor velen, en het gebied waar onze taal gesprokenliever gebrabbeld -wordt, zal inkrimpen. Maar de overgroote meerderheid verdient niet, zelfstandig te blijven!' Typed extract of letter from L. W. J. K. Thomson to [unknown addressee], 26 June I900. NASA Leyds collection, LEY 328.

79 L. W. J. K. Thomson to F. W. Reitz, 4 July I 900; F. W. Reitz to Willem Leyds, I 4 July I900. NASA Leyds collection, LEY 328.

80 Despite the fact that this incident was kept quiet, there was a significant aftermath. See chapter 7 .

8 I M. Kuitenbrouwer, Nederland en de opkomst, i 85.

82 See chapter 6 .

83 'door zijn jaren-lange verblijf in de Zuid-Afrikaansche Republiek, de aangewezen persoon scheen te zijn de leiding der Vereeniging op zich te nemen'. ZA, NZAV Jaarverslag I899, 5 .

84 'een practische les in staatkunde'. Diary, I I October I899, page I I3. NL-HaNA, Middelberg, 2.2I.232, inv.no.I 5. The view that the Boers had been right to invade Natal and the Cape was common in Europe. It was argued that this would not leave time for Britain to send reinforcements. Leyds ed., Tweede verzameling I, 23-24.

85 For further discussion about the effectivity of the NZAV, see chapters 4 and 7 .

86 ZA, NZAV Jaarverslag I 897-I 898, 5 .

87 'Wij zijn een Nederlandsche Maatschappij om geld te verdienen, maar wij hebben een Transvaalschen spoorweg. De eerste kan neutraal zijn, maar de tweede niet.' Quoted in: Van Winter, Onder Krugers Hollanders II, 343-347.

88 In Memoriam: NZASM, I4O-I42.

89 Kretschmar van Veen, Rapporten van den directeur J.A. van Kretschmar van Veen. After the war, shareholders of the NZAS M started a legal procedure and in I 908 were awarded with approximately fl. 2.67 million by the British government. De Graaff, De mythe van de stamverwantschap, 75-87.

90 ZA, NZAV Jaarverslag I 90 I, 6. For Van Kretschmar van Veen's activities as co-ordinator of aid, see chapter 4 . 
9I For an overview, see In memoriam NZASM, IO5-I30; Van Winter, Onder Krugers Hollanders II, 340-343; De Jong, Die Lewensomstandighede en Kulturele Bydrage, 202-208. 92 De Jong, Die Lewensomstandighede en Kulturele Bydrage, 208-209.

93 Smit, Hoogtij der neutraliteitspolitiek, 26; De Jong, Die Lewensomstandighede en Kulturele Bydrage, 2 Iо.

94 NZASM in memoriam, I46-I47; M. Kuitenbrouwer, Nederland en de opkomst, I84I 85 ; De Jong, Die Levensomstandighede en Kulturele Bydrage, 2 I 8-222.

95 Smit, Hoogtij der neutraliteitspolitiek, 26. This suit was separate from the compensation that was paid to the shareholders of the NZASM in I908 that was mentioned in footnote 89 of this chapter.

96 'heerlijk hem te hebben leeren kennen'. H. J. Kiewiet de Jonge to W. J. Leyds, I7 September I900. NL-HaNA, Leyds, 2.2 I.105, inv.no. 5 I.

97 N. Mansvelt to H. J. Kiewiet de Jonge, I4 September I900. NASA, Leyds collection, LEY 826.

98 'de groote uitgaven van mijn berooide gezin'. N. Mansvelt to W. J. Leyds, I November I900. NL-HaNA, Leyds, 2.2 I.I05, inv.no. 55.

99 H. J. Kiewiet de Jonge to W. J. Leyds, I7 September, ıo December I 900 and not dated [probably January-February I90I]. NL-HaNA, Leyds, 2.2 I.I05, inv.no. 5 I.

Ioo 'dezen zoo hoogstverdienstelijken strijder'. G. Kalff to H. J. Kiewiet de Jonge, 27 January I9OI. NASA, Leyds collection, LEY 8 I 2.

IоI Circular, March I90I. NASA, Leyds collection, LEY 808. The circular was signed by the foreign minister, the president of the Upper Chamber of Parliament, leading businessmen and prominent members of the NZAV. It enabled the publication of: Mansvelt, De betrekkingen tusschen Nederland en Zuid-Afrika.

IO2 'het hart, de ziel en de geest van alles, wat aan deze zijde is gedaan om de betrekkingen tusschen Nederland en Zuid-Afrika te bevorderen. Het hart eerst.' 'Dr. N. Mansvelt', Zuid-Afrika, vol. Io (I933), 35-36, 36.

I03 See documents in: NASA Gustav Preller collection, A 787, files 206-209.

I04 Wallach, Die Volmaakte "Gentleman", 22.

I05 Ibid. 4.

I06 Ibid. 23.

I07 Ibid. 24. Also in later life, Engelenburg was reluctant to do diplomatic work. In I9I9, he was asked by another good friend of his, Prime Minister Louis Botha, to take a diplomatic position in Europe, but also then he refused. He did attend the Versailles conference, though.

I08 F. V. Engelenburg to mrs Leyds, 9 January I90I. NL-HaNA, Leyds, 2.21.105, inv.no. 48 .

I09 'Ik stel München boven Berlijn, maar Paris over the rest.' F. V. Engelenburg to W. J. Leyds, 20 October 1900. NL-HaNA, Leyds, 2.21.105, inv.no. 48. After his return to South Africa in 1903, Engelenburg's love for the more sophisticated aspects of life became well known and he became one of the leading figures in the cultural elites of the Union. Wallach, Die volmaakte ,Gentleman”, $30-34$.

I Io 'Madame de Staël van Suid-Afrika'. Quoted in: Malan, Marie Koopmans-De Wet, 
240. She was a well-known figure in the social life of the colony and had excellent contacts in the Boer republics as well, which she used to help Engelenburg when he first came to South Africa. Wallach, Die volmaakte ,Gentleman”, 20.

I I I Rompel, Uit den tweeden (Transvaalschen) vrijheidsoorlog, I 5.

I 2 Ibid. 38.

I 3 See chapter 4 .

I 4 See chapter 7 .

I 5 M. Kuitenbrouwer, Nederland en de opkomst, I 23-I 24.

I 6 There was some uncertainty about the exact status of the audience, however. Kruger was received by Queen Wilhelmina incognito, but he was taken to the palace in a royal carriage and wore his presidential sash. In addition, Leyds, who accompanied him, was dressed in his diplomatic costume. The newspaper Het Vaderland reported that the discussion had been about private matters only, such as the well-being of Kruger's family and Wilhelmina's impending marriage. Waszklewicz-Van Schilfgaarde ed., Paul Kruger's tocht, 56-57.

I 7 For a compilation of contemporary press reports of Kruger's tour, see WaszklewiczVan Schilfgaarde ed., Paul Kruger's tocht.

I 8 For what later became of this collection, see chapter 7 .

I 9 Leyds ed., Vierde verzameling I, 35 I. Leyds and Van Eeden knew each other from their student days.

I 20 Schutte, De Vrije Universiteit I, 93. For more on the CNBC, see chapter 4.

I 2 I Statuten Afrikaner tehuis. ZA, Emous collection, EM I.

I22 Verslag van de werkzaambeden der vereeniging Het Christelijk Nationaal BoerenComité, I3.

I 23 R. C. de Jong, 'Het “Afrikaans Tehuis” in Amsterdam I900-I902', in: Zuid-Afrika, vol. 58 (I98I), I70-I 7 I.

I 24 ZA, Emous collection, EM I, 3 and 4; Spanjaard, "Voor de Boeren", 45.

I 25 For an example of the coverage of the arrival Boers in Portugal, see NRC, 3 I March, 2, I0 and I 2 April I90I.

I 6 For examples, see Schutte, Van Amsterdam naar Krugersdorp, 5 I-5 I.

I 27 'een Boer zonder baard is als een leeuw zonder manen'. H. J. Kiewiet de Jonge to W. J. Leyds, 9 April I90г. NL-HaNA, Leyds, 2.21.105, inv.no. 5 I.

I 28 For papers concerning these tours, see NASA, Leyds collection, LEY 8I 2; ZA, Emous collection, EM I and I3.

I 29 For the British press, see Badsey, 'War Correspondents in the Boer War', I9I; Beaumont, 'The Making of a War Correspondent', I 25.

I30 For the ANV advertisement, see NRC, I November I 899; De Telegraaf, 4 November I 899 .

I3 I See chapter 4 .

I 32 Beaumont, 'The British Press and Censorship'.

I 33 Ibid.

I 34 Krebs, Gender, Race and the Writing of Empire, I 46.

I35 Kester, 'Uit de slaap gewekt', 226-227. 
I 36 NRC, 5 and I 2 February I 901 .

I 37 See Welcker collection of NRC cuttings in the NZAV library. For coverage of Elandslaagte, see chapter 5 .

I 38 See chapter 6 .

I 39 Letter from St. Helena. NRC, 9 January 1902.

I 40 For Emous, see chapters I and 4 .

I4I 'Hier [...] heerschen volkomen [...] eensgezindheid [...] innige haat [...] de grootse [...] beslist [...] heid, hoop op [...] wraak en [...] wantrouwen [...] van al wat [...] Engelsch is'. Quoted in: H. Wagenaar, 'De code van Diyat', in: Zuid-Afrika, vol. 86 (2007), I76-I77.

I42 'bizondere'. Van Warmelo, Mijn commando en guerrilla-commando leven, 7.

I43 Brandt-Van Warmelo, Die kappie kommando. Kappie refers to the headdress of Boer women. Cf. chapter 6.

I 44 'weergalooze eigenzinnigheid'. Ibid. I66.

I 45 A few of these notes can be found in NASA, Leyds collection, LEY 94. See also Van der Merwe, Johanna Brandt, I06-108.

I46 Stead, Methods of Barbarism, 68-9I; Brandt-Van Warmelo, Die kappie kommando, I67-I70; Krebs, Gender, Race and the writing of Empire, 99-I00.

I47 Algemeen Handelsblad, 2I February I901. The editors of this newspaper refused to identify the letters' author, even to the ANV. Correspondence between ANV press office and editors of Het Algemeen Handelsblad, 22 and 27 February I90I. NASA, Leyds collection, LEY 809 . See chapter 6.

I 48 A collection of the original letters is kept in NASA, Leyds collection, LEY 3 I 4 .

I49 Memorandum by F. E. T. Krause, June I932, I7-I 8. NASA, Leyds collection, LEY 256. Krause was a state prosecutor from Johannesburg who went to London during the war, where he was arrested in a related case a few days after Broeksma's execution. He was accused of inciting Broeksma to kill the British journalist John Douglas Forster and convicted to two years' imprisonment.

I 50 'Cornelis Broeksma, [...] 30 Sept. I90 I door de Engelschen gefusileerd. Held en martelaar voor barmhartigheid, publiek aanklager in den edelsten zin des woords: Hij klaagde Engeland aan voor de rechtbank der menschelijkheid.' These leaflets were meant to raise money for the orphaned family. The papers of the Broeksma fund are kept in ZA, Emous collection, $\mathrm{EM}_{3}$, file $\mathrm{D}_{5}$.

I 5 I In later life, Beelaerts van Blokland became a diplomat, foreign minister and vicepresident of the Raad van State (Privy Council). Woltring, 'Beelaerts van Blokland, Jhr. Frans (1872-1956)'.

I 52 C. Beelaerts van Blokland to F. Beelaerts van Blokland, 7 January I900. ZA, F. Beelaerts van Blokland collection, F В В I. See chapter 4.

I 53 List of names. NL-HaNA, Beelaerts, 2.2 I.253, inv.no. 72, bundel A.

I 54 Boissevain, 'Een jonge Nederlandsche held', in: Boldingh, Een Hollandsch officier in Zuid-Afrika, iv-xi, ix-x.

I 55 C. Boissevain to F. Beelaerts van Blokland, I4 January I900. ZA, F. Beelaerts van Blokland collection, ғв в I. 
I 56 'een bron [...] van den allerzuiverste aard'. Introduction by G. H. Priem to: Boldingh, Een Hollandsch officier in Zuid-Afrika, iii. Another memorial in remembrance of Boldingh is a granite bench bearing his name in front of his former barracks in Gorichem (the Netherlands), which was unveiled in 1903.

I 57 ZA, NZAV Jaarverslag I 896-I 897, 27-28. See chapter 4 for an account of the ties between the NZAV and the Dutch Red Cross.

I 58 De Jong, Buitenlandse Ambulances in de tweede Anglo-Boerenoorlog, 5.

I 59 Ibid. I I.

I 60 De Vereeniging Het Nederlandsche Roode Kruis.

I6I Wormser, Wat ik zag en hoorde op een ambulancetrein; Hellemans, Met het Roode Kruis mee; Jeltes, Uit het dagboek van H. Jeltes; Romeyn, Met de Ie Nederlandsche Roode-Kruis ambulance.

I 62 For the reception of these incidents in the Dutch press, see chapter 5 .

I63 De Jong, Buitenlandse Ambulances in de tweede Anglo-Boerenoorlog, $72-75$.

I64 Het Algemeen Handelsblad, June-August I90 I; De Nieuwe Courant, 9 June I90 I. See chapter 6.

I 65 Pretorius, Kommandolewe tydens die Anglo-Boereoorlog, I899-1902, I 66.

I 66 Leyds ed., Derde verzameling I, xiii; Leyds ed., Vierde verzameling I, xliii.

I67 Leyds ed., Derde verzameling II, I.

I68 W. J. Leyds to Judge Hertzog, I 8 November I902. NL-HaNA, Leyds, 2.2I.105, inv.no. 40 .

I69 Plokhooy, Met den Mauser, I33; Ploeger, Cornelis Plokbooy, I-2.

I70 Handwritten report by Plokhooy, I 8 July I90I. NASA, Leyds collection, LEY 324; Plokhooy, Met den Mauser, I38-I 5 I.

I7 I Ploeger, Cornelis Plokhooy, 4; file Plokhooy. NASA, Leyds collection, LEY 324. Initially, Plokhooy was refused a permit to go to South Africa again, but eventually he settled in Pretoria in I92 I, where he died in 1964.

I72 See correspondence in: NASA, Leyds collection, LEY 3 I 7 and 322. Also the strained relation with the Dutch attachés played a large role in this matter. See chapter 7.

I 73 This report was first published in NRC, 29 May I 90 I. It was also published as a pamphlet. 'B. ot H. Anicus', De onderhandelingen van Lord Kitchener; Leyds ed., Vierde verzameling I, xxli. See chapter 6.

I74 The original reports can be found in NASA, Leyds collection, LEY 94; Hancock, Smuts: The Sanguine Years, I 40 . See chapter 6.

I75 Memorandum of a conversation held between J. C. Smuts and J. H. Alleman, 20 December I90I; handwritten note by J. C. Smuts, not dated. NASA, Leyds collection, LEY 94 .

\section{Chapter 4}

I Kröll, Die internationale Buren-Agitation, 52; Te Velde, Gemeenschapszin en plichtsbesef, $\mathrm{I} 64$.

2 Schutte, Nederland en de Afrikaners, 82. 
3 An extensive collection of pro-Boer paraphernalia is kept at the Kruger House in Pretoria. See chapter 7 .

4 M. Kuitenbrouwer, Nederland en de opkomst, I 83-I 84 .

5 Ibid. I 85-1 86; Bossenbroek, Holland op zijn breedst, 9 and I 86-I 87.

6 Quoted in M. Kuitenbrouwer, Nederland en de opkomst, I87.

7 Ibid. I 87-I 88; Van Koppen, De geuzen van de negentiende eeuw, I $82-185$.

8 ZA, NZAV Jaarverslag I 895-I 896, I 5; Otterspeer, 'Boeren en academici', 207 and 2 I 9.

9 Leyds ed., Eerste Verzameling, 83-87. Leyds's contact with Kuyper, who became first minister in I90I, was not very close and when the latter undertook a mediation attempt early in I902, the Transvaal envoy was taken by surprise. See chapter 6 .

ıo Kröll, Die internationale Buren-Agitation, I39; M. Kuitenbrouwer, Nederland en de opkomst, I83; Schutte, Nederland en de Afrikaners, 73.

i I Te Velde, Gemeenschapszin en plichtsbesef, I69.

I 2 ZA, NZAV Jaarverslag I 899, I6-I7; M. Kuitenbrouwer, Nederland en de opkomst, I 83; Schutte, Nederland en de Afrikaners, 89; Bossenbroek, Holland op zijn breedst, $247-248$.

I 3 ZA, NZAV Jaarverslag I 899, 8-9.

I 4 'de lijdenden en strijdenden'. Ibid. I 8 .

I 5 Ibid. IO-I 2.

I 6 Houwers, Nationalistische commotie in Nederland, 3 I.

I7 ZA, NZAV Jaarverslag I900, 9-I8; NZAV Jaarverslag I 90 I, IO-I8; NZAV Jaarverslag I902, 9-2I.

I 8 ZA, NZAV Jaarverslag I900, IO.

I9 'die uit den aard den zaak jaarlijks geheel veranderen'. ZA, NZAV Jaarverslag I90 I, IO. 20 Van Reesema, Een stoomvaartverbinding met Zuid-Afrika, 4-9.

2I ZA, NZAV archive, VI/I33-VI/I36. A steamship line between the Netherlands and South Africa was established in I9I9. De Graaff, De mythe van de stamverwantschap, I34. See chapter I.

$22 \mathrm{ZA}, \mathrm{NZAV}$ archive, $\mathrm{VI} / \mathrm{I} 37$.

23 ZA, NZAV Jaarverslag I900, I7.

24 See chapter 3.

25 Beelaerts van Blokland, Wat zullen wij doen, 8-I4.

26 ' [...] is het geene weldadigheid, die van u verlangd wordt; thans hebben wij de gelegenheid aan de geheele wereld te toonen, op welke wijze het Nederlandsche volk het verstaat zijn plicht te doen en zijne broeders in hunne worsteling bij te staan.' Beelaerts van Blokland, Wat zullen wij doen, I4-I 5 .

27 A series of photos published by the Haagsche pro-Boer Vereeniging is kept in the Leyds pamphlet collection at the University of Stellenbosch.

28 Circular by Utrecht branch of NZAV, March I902. ZA, NZAV archive, V/I 5; papers concerning the charity shop of the Haagsche pro-Boer Vereeniging, I90I-I902. NZAV archive, $\mathrm{VI} / \mathrm{I} 64$.

29 Papers concerning the art lottery and the Scheveningen exhibition in July I902. ZA, NZAV archive, VI/I84. 
30 Minutes of the NZAV executive committee, 6 February I900. ZA, NZAV archive, IV/45 .

3 I Minutes of the NZAV executive committee, 26 May I900. ZA, NZAV archive, IV/4-5. 32 See chapter I.

$33 \mathrm{ZA}$, NZAV Jaarverslag I 899, 58 and 64 . The annual report for I 899 was published in I 900 after the meeting of 26 May.

$34 \mathrm{ZA}$, NZAV Jaarverslag I9OI, IOI-I 88. From the membership list in I90I it appears that members of the executive were not always affiliated to the branch in the place in which they lived. Van Reesema lived in Scheveningen. Charles Boissevain and treasurer J. B. Loman were members of the Amsterdam branch, although they lived in Haarlem and Naarden respectively. President Middelberg lived in a town where no branch of the NZAV existed at all.

35 'Zulk een Vereeniging kan de Nederlandsch Zuid-Afrikaansche Vereeniging worden, wanneer vele duizenden nieuwe leden tot haar toetreden. [...] Thans kan en moet zij worden tot een werkelijk nationale Vereeniging, met krachtige organisatie, met afdeelingen in het gansche land, in de koloniën, in België en overal elders, waar Nederlanders wonen, en met een Hoofdbestuur, waarin alle richtingen zijn vertegenwoordigd.' NZAV circular, Voor Zuid-Afrika (not dated). ZA, NZAV archive, VI/I 28 .

36 'een der meest solide en beschaafde Boeren die ik ken. En niet ongeschikt om in 't publiek te spreken.' J. A. Wormser to P. den Tex, I4 October I90I. ZA, NZAV archive, $\mathrm{VI} / \mathrm{I} 28$.

37 'een kleine vermeerdering'. ZA, NZAV Jaarverslag I90 I, 9; Houwers, Nationalistische commotie in Nederland, 28.

38 Houwers, Nationalistische commotie in Nederland, 29.

39 'zoo'n geheel vreemde streek, bij een eigenaardig slag van menschen.' E. van Gorkom to J. A. Wormser, 30 November I 90 I. NZAV archive, VI/I 28.

40 E. van Gorkom to P. den Tex, 5 January I902. NZAV archive, VI/I28. Compare with ZA, Jaarverslag NZAV I 90 I, 8-9. Van Gorkom only mentioned charity in general, while the annual report explicitly mentioned 'lectures about South African matters' ('leezingen over Zuid-Afrikaansche aangelegenheden').

4I Schutte, De Vrije Universiteit I, 90-9I.

42 Van Koppen, De geuzen van de negentiende eeuw, I 8 I; Schutte, De Vrije Universiteit I, 88-89. See chapter I.

43 Schutte, Nederland en de Afrikaners, 78-79; Houwers, Nationalistische commotie in Nederland, 22.

44 Minutes of the NZAV executive committee, Io October I900. ZA, NZAV archief, IV/45 .

$45 \mathrm{ZA}, \mathrm{NZAV}$ archief, VIII/34/I; ZA, NZAV Jaarverslag I903, 8-9; compare with De Graaff, De mythe van de stamverwantschap, I Io. De Graaff explains Emous's move to the NZAV by the fact that the CNBC had lost almost all of its members in I906. He does not refer to Emous's earlier activities within the NZAV.

46 'zedelijke of godsdienstige gesteldheid des bevolkings dezerzijds'. ZA, NZAV Jaarverslag 1900,77 . 
47 Minutes of the NZAV executive committee, 26 May I900. ZA, NZAV archief, IV/4-5. 48 Van Koppen, De geuzen van de negentiende eeuw, I 8 I.

49 Minutes of the NZAV executive committee, 24 March I900. ZA, NZAV archief, IV/4-5. Moltzer had serious health problems, which might be another reason why he stepped down.

50 Minutes of the NZAV executive committee, 26 May I900. ZA, NZAV archief, IV/4-5. 5I Schutte, Nederland en de Afrikaners, 78; Koppen, De geuzen van de negentiende eeuw, I 8 I.

52 Van Winter, Onder Krugers Hollanders I, 250.

53 Circular, I7 May i90i. NASA, Leyds collection, Ley 808.

54 A. J. Veenendaal, 'Middelberg, Gerrit Adriaan Arnold (I 846-I9I6)'.

$55 \mathrm{ZA}$, NZAV Jaarverslag I 899, 5 . See chapter 3.

56 'personen, die door en door bekend zijn met Zuid-Afrikaansche toestanden'. Circular, I7 May I90I. NASA, Leyds collection, LEY 808.

57 Kröll, Die internationale Buren-Agitation, 323; Van Niekerk, Kruger se regterhand, 205-2I 8 .

58 Leyds ed., Tweede Verzameling I, xI-xii; see chapter 5 .

59 Leyds ed., Vierde verzameling I, xxxi.

60 See chapter I. The thesis of Ulrich Kröll provides the best overview of the activities of the ANV press office during the South African War. Kröll, Die internationale Buren-Agitation, I76-I94; Kröll, 'The "Perskantoor", I3-28. In the following paragraphs, I will refer to the latter title, which is an English adaptation of an extract from the thesis, which was originally written in German. See also Van Niekerk, Kruger se regterhand, 2 Iо; Schutte, Nederland en de Afrikaners, 80.

6I Houwers, Nationalistische commotie in Nederland, 34-35. After I902, membership of the ANV increased, while membership of the NZAV declined. In I908, there were even proposals to merge the two organisations, although this did not happen. De Graaff, De mythe van de stamverwantschap, I I3-I I 4.

62 H. J. Kiewiet de Jonge to W. J. Leyds, 2 I February I 896. NL-HaNA, Leyds, 2.2 I.I05, inv.no. $5 \mathrm{I}$. From this letter it appears that Kiewiet de Jonge was acquainted with Leyds's uncle and had attended the party to celebrate Leyds's doctorate in I 884 .

63 Much of their extensive correspondence which lasted at least until 1932, can be found in the NL-HaNA, Leyds, 2.21.105, inv.no. $5 \mathrm{I}$ and 52.

64 Leyds ed., Tweede verzameling I, 8 I-82.

65 Kröll, 'The "Perskantoor"', I3.

66 Compare with Bossenbroek, Holland op zijn breedst, 252-253. Bossenbroek argues that the ANV was more radical than the NZAV, but he does not mention the close co-operation between the two organisations.

67 See chapter 7 for Leyds's involvement in the press office after 1902.

68 Van Niekerk, Kruger se regterhand 2 I I-2 I 2.

69 Kröll, 'The "Perskantoor"', I 5.

70 Ibid. I6; Van Niekerk, Kruger se regterhand, 235.

7 I Leyds ed., Tweede verzameling I, xi-xii; Kröll, Die internationale Buren-Agitation, 
I 78-I 84; Van Niekerk, Kruger se regterhand, 236-238. The contents of both Eene eeuw van onrecht and Het beroep op de natien will be discussed in chapter 5 .

72 See chapter I.

73 See correspondence between the ANV press office and the Utrecht branch with executive committee ZA, NZAV archive, VI/I26; ZA, NZAV Jaarverslag I 900, 32-34.

74 ZA, NZAV Jaarverslag I902, 69.

75 Kröll, 'The "Perskantoor", I8-ı9; Schutte, Nederland en de Afrikaners, 82; Van Koppen, De geuzen van de negentiende eeuw, 169.

$76 \mathrm{ZA}$, NZAV Jaarverslag I 900, 33-34. These texts were published in Het Algemeen Handelsblad and afterwards as individual pamphlets, mainly for the British and American public.

77 ZA, NZAV Jaarverslag I900, 34; The circular can be found in NASA, Leyds collection, LEY 808 .

78 Leyds ed., Tweede verzameling II, I I 3-I I 6; Leyds ed., Derde verzameling I, 262, footnote; Kröll, 'The "Perskantoor"', I6-I7.

79 ZA, NZAV Jaarverslag I90I, I7.

80 H. J. Kiewiet de Jonge to W. J. Leyds, I 5 May I900. NL-HaNA, Leyds, 2.2I.105, inv.no. 5 I; Kröll, 'The "Perskantoor", I 5.

8I 'Het is wel heel goed voor hem, zoo'n gedwongen rust, na den zeer ingespannen tijd, dien hij achter den rug heeft.' Leyds ed., Tweede verzameling I, 252.

82 H. J. Kiewiet de Jonge to W. J. Leyds, 7 April I900. NL-HaNA, Leyds, 2.2I.105, inv.no. 5 I. See chapter 3 for Veth's activities.

83 H. J. Kiewiet de Jonge to NZAV executive committee, Io March I900. ZA, NZAV archive, $\mathrm{VI} / \mathrm{I} 26$.

84 H. J. Kiewiet de Jonge to W. J. Leyds, 7 April I900. NL-HaNA, Leyds, 2.21.105, inv.no. $5 \mathrm{I}$.

85 See chapter 3 .

86 H. J. Kiewiet de Jonge to W. J. Leyds, I 4 January I90I. NL-HaNA, Leyds, 2.2I.I05, inv.no. $5 \mathrm{I}$.

87 Rompel, Uit den tweeden (Transvaalschen) vrijheidsoorlog; Rompel, Siegen oder Sterben; Rompel, The Heroes of the Boer War. The latter translation was overseen by William Stead. After the war, Rompel was also involved in the publication of Kruger's memoirs and wrote a biography of ex-President Steyn.

88 A very large number of these press releases can be found in NASA, Leyds collection, LEY 86I-869; a selected collection of about one hundred press releases can be found in ZA, ANV collection, ANV/B; Kröll, 'The "Perskantoor", 2 I, footnote 50.

89 ANV press office address list. NASA Leyds collection, LEY 889; Kröll, 'The "Perskantoor", $20-22$.

90 Kröll, 'The "Perskantoor", 23-24.

9I 'een overmacht van arbeid [...]; naar buiten en naar binnen tegelijk regelen en besturen was onmogelijk'. Kiewiet de Jonge, 'Een woord ter Inleiding', 9.

92 Kröll, Die internationale Buren-Agitation, I62; Van Niekerk, Kruger se regterhand, 216. 
93 ANV press office to P. J. Ketner, 25 November I90I. NASA, Leyds collection, LEY 809; A. G. Boissevain to F. Beelaerts van Blokland, 26 July I900. ZA, F. Beelaerts van Blokland collection, FB B I.

94 [H. J. Kiewiet de Jonge?] to NRC editors, 9 November I900. NASA, Leyds collection, LEY 809.

95 Representative NRC to [H. J. Kiewiet de Jonge ?], Io November I900; A. G. Boissevain to H. J. Kiewiet de Jonge, I9 November I900. NASA, Leyds collection, LEY 809.

96 See chapter I.

97 Geerts, Verzuilde Boerenliefde, I I 2-I I3. In his MA dissertation, Jan Geerts analyses the coverage of five important events in the history of South Africa: the annexation of the ZAR (I 877), the battle at Majuba Hill (г88I), the visit of the ZAR deputation to the Netherlands (I884), the Jameson Raid (I895-I896) and the outbreak of the South African War (1899). The papers he examined are: De Tijd, Het Algemeen Handelsblad and De Standaard.

98 Kröll, Die internationale Buren-Agitation, 52; Kester, 'Uit de slaap gewekt', 22 5; compare with Badsey, 'The Boer War as Media War', 8I-82.

99 NRC, 26 November I 899; Het Algemeen Handelsblad, 2 December I 899; Kester, 'Uit de slaap gewekt', 223-224.

Ioo Editorial by Charles Boissevain. Het Algemeen Handelsblad, 8 December I 899; Van Harpen, Nederland Zuid-Afrika, introduction. Van Harpen was the editor of the Amsterdamsche Courant.

I I Maandelijksche mededeelingen van het bestuur den Nederlandschen Journalistenkring (I 897), no. 8 (May) and no. I3 (October).

I02 Several state officials had the same opinion and during the I90os they took up contact with Kiewiet de Jonge on several occasions to help and refute 'lies about the Netherlands' in the foreign press.

I03 'Een Veldtocht met den Pen', 'de menschen de ware toedracht der zaak uit te leggen'. NRC, I 6 March I900.

I04 NRC, I November I 899 and I9 December I 900.

I05 Circular Anv, I6 November I899. NASA, Leyds collection, Ley 888. The NZAv asked the ANV to send such a circular. P. den Tex to ANV press office, I 5 November I 899. NASA, Leyds collection, LEY 808. See also Mededeelingen van den Nederlandschen Journalistenkring, no. 27 (December I900), 4.

Io6 'Zeer veel wat gij in buitenl. bladen leest, stamt van ons'. H. J. Kiewiet de Jonge to W. J. Leyds, I7 February I902. NL-HaNA, Leyds, 2.2I.I05, inv.no. 5 I.

I07 Kröll, 'The "Perskantoor"', 20.

Io8 See chapter I.

I09 Advertisement „Nederland”, in: Neerlandia, vol. 4 (I900), 56.

I Io E. G. A. ten Siethoff to W. J. Leyds, I2 October I902. NL-HaNA, Leyds, 2.21.105, inv.no. 78. Ten Siethoff was a medical doctor from Scheveningen who collected a great amount of material on the South African War with the purpose of writing a history about it.

I I I P. A. Nierstrasz to W. J. Leyds, Io August I90 I. NASA, Leyds collection, LEY 32 I. 
I I 2 'Pro-Boer sein heiszt [sic] eben noch lange nicht Journalist, Politik [sic] und Diplomat sein!' Report activities Die Correspondenz „Nederland”, 6-7. NASA, Leyds collection, LEY I97.

I 3 D. Balfoort to W. J. Leyds, 23 April I902. NASA, Leyds collection, LEY 322.

I 4 Financial report Die Correspondenz „Nederland”, Io May I902. Leyds collection, LEY 322.

I I 5 See chapter 7 .

I 6 H. J. Kiewiet de Jonge to W. J. Leyds, I 5 November I 900 and I 4 January I 90I. NLHaNA, Leyds, 2.2I.I05, inv.no. $5 \mathrm{I}$.

I 7 M. van Beek to [H.J. Kiewiet de Jonge?], 3 May I90I. NAsA, Leyds collection, LEY $82 \mathrm{I}$.

I 8 H.J . Kiewiet de Jonge to M. van Beek, I3 May I90I. NASA, Leyds collection, LeY $82 \mathrm{I}$. It is likely that Leyds was one of the contributors, if not the only one.

I I9 'zouden zij mij stellig als een van "Leyds' of Kruger's spionnen" gelynchd hebben en een aanval op onze kantoren beproefd hebben.' M. van Beek to [H. J. Kiewiet de Jonge?], 3 May I90I. NASA, Leyds collection, LEY 82 I.

I 20 For the extensive correspondence, see NASA, Leyds collection, LEY 82 I.

I2I NRC, 6 September I90I; ANV press circular, I 5 May I90I. NASA, Leyds collection, LEY 866.

I 22 H. J. Kiewiet de Jonge to W. J. Leyds, 3 August I90I. NL-HaNA, Leyds, 2.21.I05, inv.no. $5 \mathrm{I}$.

I 23 'bevooroordeeld en partijdig'. H. J. Kiewiet de Jonge to W. J. Leyds, 6 May I902. NL-HaNA, Leyds, 2.2 I.105, inv.no. 5 I.

I 24 See chapter 7 .

I 25 ZA, NZAV Jaarverslag I 899, 43.

I 26 ZA, NZAV Jaarverslag I 900, 2 I.

I 27 Leyds ed., Tweede verzameling I, xi-xii.

I 28 'flinke jongelui', 'de huisvaders, die voor de verdediging der onafhankelijkheid van hun land te velde trokken en sneuvelden'.

I29 Draft prospectus Fonds tot daadwerkelijken steun, 22 December I 899. ZA, NZAV archive, VII/I 42.

I30 Prospectus Fonds tot daadwerkelijken steun, not dated. ZA, F. Beelaerts van Blokland collection, Fв в 2.

I 3 I For Zuidema, see Jonckheere, Van Mafeking tot Robbeneiland, 3 8-39; Huussen, 'De Anglo-Boerenoorlog', I I 3-I I 5 .

I 32 The most complete set of issues of the magazine I have found is in the Leyds collection at the University of Stellenbosch.

I33 'Het is dikwijls moeilijk om in Europa den ijver van het publiek, dat graag iets voor de Republiek wil doen, in goede richting te leiden, en in zeer veel gevallen komt het met de meest onpractische plannen aan. En aangezien dikwijls die plannen al uitgevoerd zijn, vóórdat menschen die van de Republiek iets weten worden geraadpleegd, is het dikwijls moeilijk een antwoord te geven, waar men de menschen niet gaarne beleedigen wil of hun ijver bekoelen.' Leyds ed., Tweede verzameling I, 3 I 2-3 I 3 . 
I 34 Transcript of a letter by H. P. N. Muller to [W. F. Noëls van Wageningen?], 20 February I900. ZA, F. Beelaerts van Blokland collection, FB B 2.

I 35 H. P. N. Muller to F. Beelaerts van Blokland, I I and 2I March I900. ZA, F. Beelaerts van Blokland collection, FB B 2.

I 36 Cutting from Het Vaderland, I6 March I900. ZA, F. Beelaerts van Blokland collection, F в в 2. It seems that Leyds did not consult with Muller about this interview. H. P. N. Muller to F. Beelaerts van Blokland, II and 2I March I900. ZA, F. Beelaerts van Blokland collection, FB B 2.

I 37 Circular by W. F. Noëls van Wageningen, 2 I March I900. ZA, F. Beelaerts van Blokland collection, FB B 2.

I 38 J. L. Plemp van Duiveland to F. Beelaerts van Blokland, 9 February I900. ZA, F. Beelaerts van Blokland collection, Fв B 2. Beelaerts van Blokland induced Plemp van Duiveland to send a letter to the press about the matter. Cutting from NRC, IO February I 900. ZA, F. Beelaerts van Blokland collection, F в в 2. Noëls van Wageningen's response was published on I I and I 4 February I900.

I 39 G. Vissering to F. Beelaerts Blokland, I2 April s900; Memorandum probably by K. Zwaardemaker, not dated. zA, F. Beelaerts van Blokland collection, F в в 2.

I 40 Several letters to F. Beelaerts van Blokland. ZA, F. Beelaerts van Blokland collection, FBB 2.

I $4 \mathrm{I}$ 'een man die door zijn papenhaat stapelgek is geworden'. F. Beelaerts van Blokland to [H. J. Kiewiet de Jonge], I 5 February I900. NASA Leyds collection, LEy 808/43.

I 42 B. Veth to F. Beelaerts van Blokland, I6 March I900. NL-HaNA, Veth, 2.2 I.I67, inv.no. I9.

I43 Circular by Noëls van Wageningen, 2 I March I900; reprint from Op! Voor Transvaal, 25 March I900. ZA, F. Beelaerts van Blokland collection, ғв в 2.

I 44 'het publiek op de hoogte te stellen waar het gevaar loopt, tevens een inrichting te wijzen waar het eerlijke inlichtingen kan krijgen'. B. Veth to F. Beelaerts van Blokland, I 6 March 1900. NL-HaNA, Veth, 2.21.167, inv.no. I9. The ANV also sent other circulars for Beelaerts van Blokland's emigration committee. Kröll, 'The "Perskantoor", I 9.

I 45 Newspaper clipping [NRC?], 24 April I900. ZA, F. Beelaerts van Blokland collection, FB B 2.

I 46 Letter J. A. van Kretschmar van Veen to NZAV. NRC, I 5 May I900.

I 47 The last document I found in the Leyds archives was a letter of W. F. Noëls van Wageningen to ANV press office, 29 November I900. NASA, Leyds collection, LEY 808/43.

I 48 Het Algemeen Handelsblad, I 3 February and I I March I902; Kröll, Die Internationale Buren-Agitation, I 59.

I 49 O. Kamerlingh Onnes, Wat Verwachten wij van de Nederlansche Emigratie-Maatschappij voor Transvaal en Oranje-Vrijstaat? (Amsterdam, I900), I-4. ZA, NEM collection, I.

I 5 O Ibid. 9-IO.

I 5 I 'voldoende kennis van Afrika en genoegzaam vertrouwen in Nederland bezaten.' Clipping Het Algemeen Handelsblad, 2 April I900. ZA, NEM collection, I.

I 52 O. Kamerlingh Onnes to G. A. A. Middelberg, 25 April I900. ZA, NEM collection, I. 
I 53 J. Drost to G. Vissering, I 2 Mei I 900. ZA, NEM collection, I.

I 54 'electrische schok'; '[s]pontane uitingen van geheel uiteenlopenden aard'.

I 5 'rationeele ontwikkeling van Hollandsche belangen'.

I 5 Prospectus Nederl. Maatschappij tot de Handhaving van Stamverwante Belangen in

Zuid-Afrika. By the end of I900, fl. I70,000 had been raised by the company. ZA, NZAV Jaarverslag I900, 57 .

I 57 Overzicht van de verrichtingen; Schutte, Nederland en de Afrikaners, 79-80 and 9I. In addition to the money collected by the Dutch pro-Boer organisations, the ZAR legation received a total of fl. 64 I,98 I in private donations for humanitarian aid. A large part of this sum seems to have come from the Netherlands as well. Van Niekerk, Kruger se regterhand, 223.

I 58 The archive of H. J. Emous contains much material about these activities. ZA, Emous collection, EM.

I 59 Jantje Palmboom to H. J. Emous, I 2 November I90 I. ZA, Emous collection, EM 3 , DI.

I60 Leyds ed., Vierde verzameling I, 469. St. Nicolas is the Dutch equivalent of Father Christmas. His birthday is celebrated on 5 December.

I6I Measured per capita, people in the Netherlands ( 5 million at the time) paid fl. 0.36 . In Britain (population 40 million), this was fl. .80 .

I 62 Thompson, 'Publicity, Philanthropy and Commemoration', 29.

I 63 The text of the circular was published by the president of the Red Cross in NRC, I 5 November I90I. ZA, NZAV archive, VI/I32.

I64 Secretary of the Netherlands Red Cross to P. den Tex, 20 October I 899. ZA, NZAV archive, $\mathrm{VI} / \mathrm{I} 3 \mathrm{I}$.

I 65 Circular nZAV, I 5 November I 899. ZA, NZAV archive, VI/I32.

I 66 Cutting Zutphensche Courant, 8 November I 899. ZA, NZAV archive, VI/I3 I; Cutting from local paper from Leiden, not dated [probably November I899]. ZA, NZAV archive, $\mathrm{VI} / \mathrm{I} 32$.

167 'het geven van bijdragen aan het Ned. Roode Kruis in het openbaar tegengewerkt'.

I68 B. van den Wardenbroek van Bergambacht to G. A. A. Middelberg, 5 December I 899. ZA, NZAV archive, VI/I3 I.

I69 'ongepast'. Draft letter, not dated [December I 899]. ZA, NZAV archive, VI/I3 I.

I 70 'naijver [?].' Van Heel to the NZAV, 20 January I900. ZA, NZAV archive, VI/I3 I. Van Heel was a banker from Goes who handled the donation.

I7I B. van den Wardenbroek van Bergambacht to P. den Tex, 25 January I900. ZA, $\mathrm{NZAV}$ archive, $\mathrm{VI} / \mathrm{I} 3 \mathrm{I}$.

I72 De Vereeniging Het Nederlandsche Roode Kruis, 2-3.

I 73 NRC, I 2 and I 5 November I90I; several documents concerning this polemic from November I90 I can be found in ZA, NZAV archive, VI/I 32 .

I74 J. A. van Kretschmar van Veen to the NZAV, I 7 January I900. ZA, NBZA collection, I. I 75 Statuten Nederlandsch Bijstandsfonds voor Zuid-Afrika, I 4 March I900. ZA, NBZA collection, I.

I76 ZA, NZAV Jaarverslag I90I, 35 . 
I77 Transcripts of J. Brill to H. C. Jorissen, 8 September I900; H. C. Jorrisen to J. Brill, 24 September I900. ZA, NBZA collection, I.

I7 8 Transcript of Bloemfontein Sub-Committee to P. den Tex, 2I June I90I. ZA, NBZA collection, 3. Two members, A. Fischer and D. E. Wenting, had left South Africa and two members, J. J. Brill and D. Beest van Andel, had resigned, although the former remained active in the distribution of aid. P. J. Blignaut and J. J. Bisseux remained.

I79 J. A. van Kretschmar van Veen to NZAV, I 7 January I900. ZA, NBZA collection, I.

I $80 \mathrm{ZA}$, NZAV Jaarverslag I $90 \mathrm{I}, 40-4 \mathrm{I}$.

I 8 I 'Op 't oogenblik werpt men met milde hand het geld in een bodemlooze put.' B. A. P. van Dam to the NZAV, I 2 June I90I. ZA, NZAV archive, VI/I 5 I.

I 82 Report J. A. Kretschmar van Veen, I 5 July I90 I. ZA, NZAV archive, VI/I 5 I.

I 83 Transcript P. J. Blignaut to [J. A. van Kretschmar van Veen?], 25 August I90 I. ZA, NBZA collection, 3 .

I 84 H. P. N. Muller to A. S. van Reesema, 22 October I 899. ZA, NZAV archive, VI/I 29.

I 85 'regeling'. H. P. N. Muller to P. den Tex, 6 January I90 I. ZA, NZAV archive, VI/I70.

I 86 'De Heer v. Kr. zorgt voor Transvaal. Wat doet het hoofdbestuur voor de Vrijstaat?'.

B. A. P. van Dam to the NZAv, 5 August I90I. ZA, NZAV archive, V/I I.

I 87 See chapter 5 .

I 88 Malan, Marie Koopmans-De Wet, 208-2I 5; Notulen NZAv Bijstandsfonds, 2I August I90I. ZA, NBZA collection, I.

I 89 See chapter 3 .

I90 NZASM in memoriam, I46-I47; Kröll, Die Internationale Buren-Agitation, I46I47; M. Kuitenbrouwer, Nederland en de opkomst, I 84-г 85 ; Schutte, Nederland en de Afrikaners, 80; De Jong, Die Lewensomstandighede en Kulturele Bydrage, 2 I 8-222.

I9I 'de lust en toewijding van meer dan enkelen'.

I 92 ' minder hulpbehoevenden aarzelden niet een al te gretig gebruik daarvan te maken'.

I93 Circular signed by J. A. Van Kretschmar van Veen, May I90 I. ZA, NBZA collection, I.

194 Kröll, Die internationale Buren-Agitation, I5I-I52; Schutte, Nederland en de Afrikaners, 80.

I 95 For the minutes of these meetings, see ZA, NBZA collection, I.

I96 ZA, NZAV Jaarverslag I90I, 34 .

I97 For a substantial number of these reports, see ZA, Emous collection, EM 2-3 (concentration camps); ZA, Emous collection, EM I (POW camps); ZA, Emous collection, EM I (for refugee camp in Portugal). Emous also received many letters from teachers he had helped to move to the Transvaal in the I890s, which he published in the Christelijk Schoolblad, a pedagogic journal. These letters can be found in ZA, Emous collection, EM 7-II.

I98 'de huichelachtige geweldpleeging van de zijde van Engeland'. H. J. Emous to ANV press office, I9 August I90I. NASA, Leyds collection. LEY 809.

I99 See chapter 6.

200 Kröll, Die internationale Buren-Agitation, I $52-153$.

20 I Ibid. 242-253.

202 Ibid. $258-259$. 


\section{Chapter 5}

I Bossenboek, Holland op zijn breedst, $35 \mathrm{I}$.

2 'buskruitlektuur'. Besselaar, Zuid-Afrika in de letterkunde, 69-70.

3 'onoverzichtelijk'. Jansen and Jonckheere, Boer en Brit, 35 .

4 See chapter 3 .

5 See chapter 2.

6 Kröll, Die Internationale Buren-Agitation, IO-I I; Van Niekerk, Kruger se regterhand, 2I5-2I8.

7 Dum-dum's der publieke opinie.

8 Editorial by Charles Boissevain, Het Algemeen Handelsblad, 8 December I 899; Van Harpen, Nederland Zuid-Afrika, introduction. N. van Harpen was editor-in-chief of the Amsterdamsche Courant.

9 Leyds ed., Eenige correspondentie, I86; Leyds ed., Tweede verzameling II, 25; Van Niekerk, Kruger se regterhand, 280.

Io Joubert, Transvaal.

I I Brief van den heer F. W. Reitz.

I 2 The pamphlet appeared in the Netherlands as Een eeuw van onrecht. I will refer to the English translation. [Smuts], A Century of Wrong.

I 3 Hancock, Smuts. The Sanguine Years, ro9; Marks, 'Jan Christiaan Smuts'.

I 4 Editions from that time bear the name of W. F. Reitz on the advice of the British journalist William Stead, who thought the name 'Smuts' would not attract enough readers. The solution was found in the following formulation: 'issued by W. F. Reitz'. Leyds, ed., Tweede verzameling I, xv-xvi. However, it was widely known in the Netherlands that Smuts wrote the brochure after Kiewiet de Jonge made a statement to that effect in the national press. NRC, 20 January I900. For the involvement of the ANV in the publication, see chapter 4 .

I 5 Introduction by H. J. Kiewiet de Jonge in: [Smuts], Een eeuw van onrecht, i; biography of Smuts by Rompel. Het Algemeen Handeldsblad, I 5 July I90 I. The controversy was about a treaty from I 8 I 4, in which Great Britain handed back all Dutch colonial territories it had occupied during the Napoleonic Wars, except for the Cape of Good Hope and several other stations in the West (Ceylon had already been annexed by the British in I 802 ). In the I 880 s, some authors in the Netherlands and South Africa held that the Dutch had the opportunity to restore all her colonies and argued that Prince William of Orange willingly abandoned the Cape in exchange for money and thus 'sold' it. In I 898, Professor J. E. Heeres of the Colonial Institute in Delft published a pamphlet in which he argued that the Prince of Orange had had no choice in the matter because the British had risen to world dominance after they had defeated France, which was underlined by their strong position in the overseas territories. Given this situation, he argued, the Dutch prince had to give in to their demands for the colony in South Africa, where they were already in full control. In addition, British support was needed to rebuild the Netherlands after the French occupation. By I 899, Heeres's view had become common opinion in the Netherlands. Heeres, Heeft Nederland de Kaap verkocht; Muller, Is de Kaapkolonie 
verkocht. For Smuts's dislike of Hollanders, see Hancock, Smuts. The Sanguine Years, 69.

I 6 Hancock, Smuts. The Sanguine Years, ro8- I Io. Rompel pointed out that Smuts made some inaccurate remarks about the war between the Boers and the Zulus under Dingane. Biography of Smuts by Rompel. Het Algemeen Handeldsblad, I 5 July i 90 I. For these topics, see chapter 2.

I7 [Smuts], A Century of Wrong, 55 .

I 8 Ibid.

I9 Rudolph, Houdt aan in het gebed voor Transvaal.

20 Boissevain, The Struggle of the Dutch Republics: Open Letter to the Duke of Devonshire, $\mathrm{I} 2$.

2I Het Algemeen Handelsblad, 7 January I900.

22 Boissevain, The Struggle of the Dutch Republics: Open Letter to the Duke of Devonshire, 9 .

23 The ANV press office co-ordinated the publication, with financial assistance from the NZAV. See chapter 4.

24 Van Koppen, De geuzen van de negentiende eeuw, I78-г 80. For praise from Liberals, see Het Algemeen Handelsblad, 3 and 4 February I900. Kuyper's pamphlet was translated from French into Dutch by an editor of this Liberal newspaper, C. K. Elout.

25 'een meesterwerk van propaganda', 'wetenschappelijk'. Schutte, De Vrije Universiteit I, 82.

26 Leyds ed., Tweede verzameling I, 2I I-2 I 2, 220 and 3 IO. A file with information provided by Leyds can be found in NASA, Leyds collection, LEY, IO3.

27 Van Koppen, De geuzen van de negentiende eeuw, I 80.

28 'het kleine, vrije volk dat hij afvalt ten gunste van den grooten slokop'. Algemeen Handelsblad, I6 January I900. In his reply to Guyot, Kuyper used similar terms. De Standaard, 3 April 1900.

29 'dien gekken Franzoos'. NRC, I6 January I900; letter of Paris correspondent, NRC, 29 October I 899 .

30 'dwaze Kafferpolitiek van Engeland, die de Kaffers vertroetelde en de Boeren verdrukte'. Penning, De oorlog in Zuid-Afrika I, 3. Another popular chronicler of the war was Priem ed., De oorlog in Zuid-Afrika.

3 I Van der Elst, 'Die Anglo-Boereoorlog', I 50 . See chapter 3.

32 Address list ANV press office. NASA, Leyds collection, LEY 889.

33 For the most comprehensive bibliography of Penning during the South African War, see Jonckheere, Van Mafeking tot Robbeneiland, 45-46.

34 Interview with L. Penning in Arnhemsch Dagblad, 24 November I924. HDC, Penning collection, 87/3; Jonckheere, Van Mafeking naar Robbeneiland, 44.

35 Penning, De oorlog in Zuid-Afrika I, 82.

36 Penning, De Leeuw van Modderspruit, 29. See chapter 2 for the origins of this motto.

37 De militaire Gids, vol. I9, no. I (1900), 25.

38 Kloppers, “Alles zal rech kom!”, 8I-93; Boer en Brit.

39 'verlangen, dat zij in Hofmeyr een waren vriend blijven zien'. Editorial, NRC, 2 I April 
I900; letter from Afrikaner correspondent, Het Algemeen Handelsblad, 20 April I 900. 40 Editorial, NRC, I9 February I90I. See chapter 3.

4I Letters from Cape Town, NRC, I 2 March and 5 June I900. See chapter 6.

42 For reactions to Paarl, see 'Van dag tot dag' in: Het Algemeen Handelsblad, I 3 December 1900. For Worcester, see NRC, 7 December I900 and I January I90I; De Telegraaf, I 7 and I 8 December I 900 .

43 Lion Cachet, De worstelstrijd der Transvalers, 372-5; Junius, De koloniën en staten van Zuid-Afrika, 9.

44 W. F. Andriessen, 'De rol van den Oranje-Vrijstaat in den oorlog in Zuid-Afrika', in: De Gids, vol. 65, no. 2 (I90I), 40I-440, 43 I; Aitton, De Oranje-Vrijstaat, I6.

45 Rompel, Marthinus Theunis Steyn, 48; Van Ittersum, De Vrijstaters en hun geschiedenis, 37 .

46 See for example 'Etine', Voor Transvaal; Hartlooper, Transvaal A-B-C-; Kolstee, Transvaal album; Dordrecht-Transvaal album.

47 Editorial, $N R C, 24$ October I 899; editorial, NRC, 30 December I 899.

48 Interview of H. P. N. Muller, NRC, 3 I December I 899; excerpt from letter by H. P. N. Muller to Morning Leader, NRC, 9 February I900; excerpt from interview of H. P. N. Muller in Dordtsche Courant, NRC, 29 March I900.

49 'Men confereert met Leyds, maar zonder mij'. H. P. N. Muller to A. S. van Reesema, 22 October I 899. ZA, NZAV archive, VI/I 29.

50 Leyds ed., Vierde verzameling I, xv and 389-390. For complaints on neglect of the OFS, see chapters 3 and 4 .

5I Aitton, Eene bladzijde uit de geschiedenis; F. A. G. Beelaerts van Blokland, De OranjeVrijstaat, I 8-I 9; Van Ittersum, De Vrijstaters en hun geschiedenis, 26-29.

52 'onbedorven'. Andriessen, 'De rol van den Oranje-Vrijstaat', 402; Van Ittersum, De Vrijstaters en hun geschiedenis, 2.

53 Andriessen, 'De rol van den Oranje-Vrijstaat', 425-428. See also earlier publications: Lion Cachet, De worstelstrijd der Transvalers, 5I4 and 553; Jorissen, Transvaalsche herinneringen, $7 \mathrm{I}$ and 87-92. Compare with F. A. G. Beelaerts van Blokland, De OranjeVrijstaat, 2I-2. F. A. G. Beelearts van Blokland, librarian of the ministry of war in The Hague, argued that Brand was reluctant to help the sAR but was forced to do so by public opinion.

54 Van Ittersum, De Vrijstaters en hun geschiedenis, 32-34; Andriessen, 'De rol van de Oranje-Vrijstaat', 428-43I.

55 'adel van Zuid-Afrika'. Rompel, Marthinus Theunis Steyn, 5; F. A. G. Beelaerts van Blokland, De Oranje-Vrijstaat, 23-30; Van Ittersum, De Vrijstaters en hun geschiedenis, 35-7; Andriessen, 'De rol van de Oranje-Vrijstaat', 432-440; Reitz, 'President Steyn', I99.

56 F. A. G. Beelaerts van Blokland, De Oranje-Vrijstaat, 23; Andriessen, 'De rol van de Oranje-Vrijstaat', 434-436.

57 For European public opinion on the Bloemfontein Conference, see Leyds ed., Eenige correspondentie, 50 .

58 NRC, 5 February I900; Van Ittersum, De Vrijstaters en hun geschiedenis, 46-60; An- 
driessen, 'De rol van de Oranje-Vrijstaat', 436-439. For later references, see Reitz, 'President Steyn', 203-204; Andriessen, Gedenkboek van den Oorlog in Zuid-Afrika, 86-88.

59 [Smuts], A Century of Wrong, 26; Kuyper, De crisis in Zuid-Afrika, 27; Van Gogh, Weerstaat den Rhodesgeest. Compare with Te Winkel, Waar het om gaat in Zuid-Afrika, I I. Te Winkel argued that the perception of Rhodes as a perfidious capitalist menace was unfair and that he also deserved respect as a worthy adversary to the Boers.

60 [Smuts] A Century of Wrong, 26-27; Kuyper, De crisis in Zuid-Afrika, 27.

6I " "Ja," was het antwoord geweest, eenvoudig, diep treurig, "ik slaap niet meer nie, dokter: ik huil die heelen nacht." Rompel, Uit den tweeden (Transvaalschen) vrijheidsoorlog, 18 .

62 For the establishment of this regiment, see chapter 3 .

63 Vissering, 'Een Hollander in Zuid-Afrika', in: De Gids, vol. 64, no. I (I900), 46-72, 63-4. For other obituaries of Coster, see: Leiden Zuid-Afrika album; 'P.v.D.', 'Mr. H. J. Coster', in: Elsevier's Geïllustreerd Maandblad vol. 9, (July-December I 899), 550-558. 'PvD' probably was the journalist L. J. Plemp van Duiveland, who also knew Coster from his student days.

64 Vissering, 'Een Hollander in Zuid-Afrika', 67-68.

65 Ibid. 70.

66 Pakenham, The Boer War, I35.

67 See chapter 3. Later in this chapter it will be shown how the British were accused of war crimes after the battle.

68 This was emphasised in poems that appeared about his death. J. B. Scheepers, 'Dr. H. J. Coster. Ter gedachtenisse (sonnet)' in: Neerlandia, vol. 4, (January I900), 2; A. Verwey, 'H. J. Coster', in: NRC, I March I 900. See also historical accounts Vissering, 'Een Hollander in Zuid-Afrika', 7I; Penning, De oorlog in Zuid-Afrika I, I35; 'P.v.D.', 'Mr. H. J. Coster', 558 .

69 Gerard Vissering was one of the instigators of these initiatives. ZA, HCF collection I. Coster's portrait can be found in many publications about the war. In South Africa he was also remembered as a hero. Interview, $N R C, 3$ November I 900 ; Hofmeyr, Zes maanden bij de commando's, 90-9I; Meijer, Dr H. J. Coster, I 79-I 87.

70 'Als alle Boeren zoo doldriftig gevochten hadden als de Hollanders [...], dan waren er maar weinig overgebleven, en dan was de vijand bepaald al heer en meester in Zuid-Afrika, terwijl we nu nog duizenden Boeren in het veld zien.' Plokhooy, Met den Mauser, 33 . For Plokhooy see chapter 3 .

7I Plokhooy, Met den Mauser, 32; letter from Pretoria, NRC, 30 November I 899. In the chaos after the occupation of Bloemfontein in March I900, a new Hollandercorps was founded, consisting of 60 men and incorporated into a large Uitlander commando, which met its Waterloo under the command of the French commander Villebois de Marieull at the battle of Boshof on 5 April I900.

72 'min'. Plokhooy, Met den Mauser, I3-I4. See also 'Met het Hollandsche korps te velde', NRC, 7 December I 899; excerpt article from Volksstem, NRC, 2 January I 900.

73 'war council'. For contemporary descriptions of the Boer military system, see Lion Cachet, De worstelstrijd der Transvalers, 397-399; Rovers, De Transvalers en hunnen held- 
haftige vrouwen, 6-10; De Militaire Gids, vol I9, no. I (1900), 22-24. For the most extensive description of the military structure of the Boer republics in Afrikaner historiography, see Breytenbach, Die geskiedenis van die Tweede Vryheidsoorlog I, 29-76.

74 Grundlingh, Die 'hendsoppers' en 'joiners', 7.

75 For a dramatised version, see Penning, De leeuw van Modderspruit, 95-97.

76 Neerlandia, vol 4. (April I900), 46. The picture was also used for a postcard series published by P. A. Nierstrasz.

77 See chapter 2.

78 'Een onderdrukte snik, een zucht, een kus en daarmede was het dure offer aan vaderland en vrijheid gebracht!'. Kloppers, “Alles zal rech kom!”, ı 66. See also letter from Johannesburg, NRC, 25 October I 899; Hellemans, Met het Roode Kruis, I48-I49; Jeltes, Uit het dagboek van H. Jeltes, 4; W.F. Andriessen, 'De vrouwen der Boeren', in: De Gids, vol. 2 I, no. I ( 1903 ), 64-88, 79 .

79 Letter from Pretoria, NRC, 26 June I900. See also Andriessen, 'De vrouwen der Boeren', 80-8I.

80 Van Everdingen, De oorlog in Zuid-Afrika, 272; Andriessen, 'De vrouwen der Boeren', 80.

8 I 'stoere'. Spruyt, Engeland en Transvaal, 45. For Spruyt see chapter 2.

82 'een schouwspel, waardoor men er toe komt te begrijpen dat het toch de moeite waard is mensch te wezen'. C. B. Spruyt, introduction to: 'Ratane', Vrede in Zuid-Afrika, viii.

83 Te Winkel, Waar het om gaat in Zuid-Afrika', 2 I.

84 Steinmetz, De Nederlandsch Zuid-Afrikaansche Spoorweg-Mij.; Van Kretschmar van Veen, Rapporten van den directeur J. A. van Kretschmar van Veen, 87-I30; In memoriam NZASM, IOI and I04-Io8.

85 De Bloch, Wat wij uit den Transvaalschen oorlog leeren kunnen; De Bloch, Wat er uit den oorlog in Zuid-Afrika te leeren valt; Ram, and Thomson, Lessen uit den ZuidAfrikaanschen oorlog, 329-332.

86 M. Kuitenbrouwer, Nederland en de opkomst, I43; Te Velde, Gemeenschapszin en plichtsbesef, I7 I-I74; Bossenbroek, Holland op zijn breedst, 252.

87 'hoog boven de redenen van staat [...] stijgen'. Voor gerechtigheid en vrede. Beroep op de natiën vertegenwoordigd bij het Haagsche vredescongres ([no place], I900). Draft, not ready for publication. ZA, NZAV library, PI4. This pamphlet was rewritten several times and several versions can be found in different archival collections. Moreover, the translations show great disparities, so it is difficult to establish which text was read by the public.

88 'roemrijke strijd'. Leyds, ed., Tweede verzameling I, I $82-$ I 83.

89 'bombastische', 'komieken indruk'. Ibid. 202.

90 Leyds ed., Tweede verzameling I, xi; Kröll, Die internationale Buren-Agitation, I79I 84; Van Niekerk, Kruger se regterhand, 236-238.

9I 'de groote beteekenis van dezen machtigen worstelstrijd in ons Zuidelijk halfrond'. Te Winkel, Waar het om gaat in Zuid-Afrika, 3 .

92 Te Velde, Gemeenschapszin en plichtsbesef, I 66.

93 'niet meer dan een wapenstilstand', 'hardnekkig en langdurig'. Te Winkel, Waar het om gaat in Zuid-Afrika, 24-25. 
94 Analysis C. de Wit, NRC, I9 April I900.

95 Letter from Pretoria, $N R C$, 23 January I900. For more extensive descriptions of life in the siege camp, see Van Warmelo, Mijn commando en guerrilla-commando leven; Plokhooy, Met den Mauser, 32-78. Van Warmelo was negative about the situation around Ladysmith, while Plokhooy described it as quite adventurous.

96 'den Boer op oorlogspad'. Rompel, Uit den tweeden (Transvaalsche) vrijheidsoorlog, I I-I 2.

97 Ibid. I-3. For a similar analysis, see essay by F. V. Engelenburg. NRC, 27 February I900.

98 Plokhooy, Met den Mauser, 62-64.

99 'verlofplaag'. Van Warmelo, Mijn commando en guerrilla-commando leven, 29. For the publication of this book, see chapter 3 .

I 00 Ibid. 42.

Iо I Ibid. 42-3; Plokhooy, Met den Mauser, го०-го .

IO2 Mettius, Het hypnotisme in den oorlog. The pamphlet was initially written for the public in South Africa, but in the introduction the publisher wrote that it might have more effect in Europe. In NRC it was described as 'an eccentric pamphlet' ('een zonderling geschrift'). NRC, I9 June I900.

IO3 Letter from Pretoria, NRC I 3 May I900; letter from Pretoria, NRC, 26 June I900; Jeltes, Uit het dagboek van H. Jeltes, 7.

I04 Wormser, Drie en zestig jaren in dienst der vrijheid, 99 and Io6.

I05 Ibid. I 20.

I06 Ibid. 75-76 and I I9.

I07 For early biographies of this new generation of Boer generals, see Rompel, Uit den tweede (Transvaalsche) vrijheidsoorlog, 24-43. See chapter 6.

Io8 'Het kan niet genoeg gezegd worden, dat de oorlog eigenlijk nu eerst begonnen is.' Analysis C. de Wit, NRC, 7 March I900.

I09 'nog steeds vertrouwen had in de dapperheid van de Boeren'. Statement Leyds. NRC, 2 June I900; interview with Leyds, Algemeen Handelsblad, 8 June 1900.

I I Schutte, Nederland en de Afrikaners, 209.

I I Een sensationeele brief uit Zuid-Afrika, 26; De Boeren op Sint-Helena, 78 ; editorial from Le Petit Bleu, NRC, I 5 October I90I.

I 2 Boissevain, The Struggle of the Dutch Republics: Open Letter to an American Lady; Simons, Stambelangen, 26-30.

I I 3 Kuyper, De crisis in Zuid-Afrika, 3-5, 7 and I I; Boissevain, The Struggle of the Dutch Republics: Open Letter to an American Lady, 7; 'Buitenlandsch overzicht', in: De Gids, vol. 64 no. I (I900), I 90-I94; Essay in Het Algemeen Handelsblad, 23 January I 900; letter by the London correspondent, NRC I 8 December I900; editorials, NRC, I February, 2 I May, 6 and 20 September I90I; article from New Age, NRC, I 2 October I90I. For the term 'Vereenigde Staten van Zuid-Afrika', see Te Winkel, Waar het om gaat in Zuid-Afri$k a, 25$. The same comparison was made in many English contemporary sources. I 4 See cartoons in 'Korpl. Archilles', Aanleiding tot den Engelsch-Transvaalschen oor$\log ,[3]$; Kras and Ponten, Kronings-idylle, [7]. 
I I 5 Boissevian, The Struggle of the Dutch Republics: Open letter to the Duke of Devonshire, 45 .

I 6 Kuyper, De crisis in Zuid-Afrika, 60.

I I 7 NASA, Leyds collection, LEY I9I, 326 and 6I 5. The Irish movement was quite fragmented, however, and there were quite a lot of internal tensions. The relations of the European pro-Boers with the various fractions was therefore complicated and often strained. Davey, The British Pro-Boers, I43.

I 8 For an exception, see 'Britsche aanvoerders in Zuid-Afrika', De Militaire Gids, vol. I9 (I900), 26-3 I. The anonymous authors of this article argued that also the British generals were victims of the greed of the capitalists.

I I 9 For White, see editorial, NRC, 4 March I900; NRC, 30 March I900. For BadenPowell, see NRC, I7 May I900; Kloppers, “Alles zal rech kom!”, 43; Andriessen, Gedenkboek van den oorlog in Zuid-Afrika, I 5 I-I 54 and I 73-I 78. The appreciation for Baden-Powell might have been the reason why the Scouts movement was so popular in the Netherlands in later decades.

I 20 'verschrikkelijk schouwspel'. Letter from a veteran of Spion Kop, NRC, 20 March I900; report, probably by an officer who was present at the battle. NRC, IO March I900; Jeltes, Uit het dagboek van H. Jeltes, 9.

I I Neerlandia, vol. 4, (April I900), 47-48. The photos were taken by a Hollander, Jan van Hoepen (I856-I922), who had a studio in Pretoria. Zweers, De Boerenoorlog, I9 and 26.

I22 Van Helsdingen, Vrouwenleed. 33-34.

I 23 'De kaffers zelfs waren daarover verbaasd, en konden het maar niet verstaan, dat menschen zoo uitgehongerd konden zijn.' Ibid. 36.

I 24 Analysis C. de Wit, NRC, I9 April I900.

I 5 Plokhooy, Met den Mauser, 96-97.

I 6 Ibid. 92-93; Hellemans, Met het Roode Kruis mee, 106; Jeltes, Uit het dagboek van H. Jeltes, 24.

I 27 'belasterd'. Plokhooy, Met den Mauser, 73. For a similar account, see letter from Dutch veteran of Spion Kop, NRC, 20 March I 900.

I 28 Letter from Pretoria, NRC, 28 November I 899; editorial, NRC, 29 November I 899; Wormser Jr., Een der oorzaken van den oorlog in Zuid-Afrika, 8. One of the most famous prisoners was the young Winston Churchill, who also wrote that he was treated well by his captors, which was appreciated in the Netherlands. Kuyper, De crisis in ZuidAfrika, 45-46. After his famous escape from Pretoria, however, he fell in the pro-Boers' esteem. NRC, 3 I January I900.

I 29 Te Winkel, Waar het om gaat in Zuid-Afrika, 2 I 2; Kuyper, De crisis in Zuid-Afrika, 60 .

I30 Editorial, NRC, 30 December I 899.

I3I Feith and Van Ponten, Pillen voor Joe, [2I]; analysis C. de Wit, NRC, 8 November I90I.

I 32 Editorial based on ANV report, $N R C, 6$ October I900; report of a skirmish involving the Imperial Light Horse, $N R C$, I 2 January I90I. In I902, reports emerged on unlawful 
executions by the Australian Bushfield regiment. Several officers from this regiment were put on trial and executed, and the Dutch press gave detailed accounts of the court proceedings in order to show the cruelty of these men. NRC, 5, 6, 8, 9, I I and I9 April I 902. I33 Analysis C. de Wit, NRC, 27 July 1900.

I34 Kuyper, De crisis in Zuid-Afrika, 47; interview with former inhabitant of Bloemfontein, NRC, 8 May I 900.

I 35 Krebs, Gender, Race and the Writing of Empire, 99-I00. See chapter 3.

I36 NRC, 2 I May I902.

$\mathrm{I} 37$ 'de hulp van barbaren in te roepen tegen mede-christenen'. NRC, 30 December I 900. See also NRC, 28 December I900, I and 3 January I90I, 29 January and 9 April I 902. I 38 In recent decades, however, there has been a marked interest in black participation in the South African War. See Warwick, Black People and the South African War; Nasson, Adam Esau's War; Nasson, 'Africans at War'.

I39 NRC, I4 November I899; Letter from Cape Town in Zwolsche Courant, NRC, I 2 March I900; NRC, I3 April I900; interview of Dr Poutsma, NRC, I I June I90I; editorial, $N R C$, I 8 January I902.

I 40 Excerpt from interview with Leyds in Le Matin, NRC, 24 December I 899; interview with Theal, NRC, I February I900.

I 4 I For such material, see ZA, collection ANv/II, file I.

I 42 Leyds ed., Tweede verzameling I, 337. It was mentioned in several newspapers in the Netherlands. Editorial, NRC, I February I900; Het Algemeen Handelsblad, 2 February I900; De Telegraaf, 4 February I900.

I 43 M. Kuitenbrouwer, Nederland en de opkomst, I78-I80; Van Koppen, De geuzen van de negentiende eeuw, I 50-I6I. Compare with Schutte, De Vrije Universiteit I, 82, who argues that Kuyper won over public opinion.

I 44 Leyds ed., Eenige correspondentie, 83-87.

I 45 Voor gerechtigheid en vrede.

I 46 'les principes fondamentaux'. Ten Siethoff, La convention de Genève, 3 .

I 47 M. Kuitenbrouwer, Nederland en de opkomst, 209.

I 48 'medoogenlooze lust om te kerven en te dooden', 'verraderlijke wilden'. Editorial C. Boissevain, Het Algemeen Handelsblad, I 2 December I 899.

I 49 'verachtelijk'. NRC, 29 November I 899 and 28 April 1900.

I 50 Leyds ed., Eenige correspondentie, 58-60, 62 and 63-65.

I 5 I NRC I9, 23 and 27 June I900. In addition, a rectification was published that had been sent by the British ministry of war. Militaire Spectator, vol. 69 (I900), 628.

I 52 Jeltes, Uit het dagboek van H. Jeltes, 8.

I 53 ' $m$.i. [mijn inziens] zijn dit alles geen zekere bewijzen'. G. W. S. Lingbeek to L. Goldman [?], I3 April I90I. NASA, Leyds collection, LEY 92.

I 54 F. Rompel to SAR legation, 6 July I90I. NASA, Leyds collection, LEY 92; ZA, collection ANV/II, file I4. I have found no references to this circular in other sources.

I 55 Editorial, NRC, 3 March I900; excerpt from letter by T. J. Krogh to his daughter, $N R C$, I6 March I900; editorial, NRC, 6 August I900; speech Dr E. C. van Leersum, member of Russo-Dutch ambulance, $N R C, 29$ November I900; letter from C. de Wet delivered by German doctor, NRC, 27 April I90I. 
I 56 Excerpt from letter by Dr Romeyn to Militair Geneeskundig Tijdschrift, NRC, I 6 August 1900 .

I 57 Jeltes, Uit het dagboek van H. Jeltes, 8; NRC, 7 February I900.

I 58 Kuyper, De crisis in Zuid-Afrika, 45. For a similar explanation, see Plokhooy, Met den Mauser, 83.

I 59 NRC, 2 I April I90I and 23 February I902; Kloppers, “Alles zal rech kom!”, 97-99.

I 60 Letters of Red Cross doctors in NRC, 28 June I 900 and 26 July I 900; De Vereeniging

Het Nederlandsche Roode Kruis, 293-296; Templeman van der Hoeven, Gevangen op Ceylon, I8-i9. Templeman van der Hoeven's letters first appeared in the Utrechtsch Nieuwsblad.

I6I De Vereeniging Het Nederlandsche Roode Kruis, 20I-207. For an account of a female nurse who was also arrested and subsequently deported to the Netherlands, see Hellemans, Met het Roode Kruis mee, I 88-22I.

I62 NRC, 4 January, 28 February and I4 March I902; Templeman van der Hoeven, Gevangen op Ceylon.

I63 For examples, see letter Lingbeek. NRC, I 5 May I900; Jeltes, Uit het dagboek van $H$. Jeltes, 8 and 24.

I64 De Vereeniging Het Roode Kruis, 372-283; essay by J. C. Kakebeeke, NRC, I2 September I900. For praise from Boer side, see excerpt from Volksstem, NRC, 30 June 1900. I 65 For more recent descriptions of the battle, see Breytenbach, Die geskiedenis van die Tweede Vryheidsoorlog I, 245-258; Pakenham, The Boer War, I38-I4I.

I 66 Editorial based on official report by P. Joubert and letter from an Irish chaplain, NRC, I 8 November I 899; 'Met het Hollander Corps te velde', NRC, 23 January I900. For indirect accounts, see despatch by Steyn to Kruger. NRC, I9 January I900; Kloppers, “Alles zal rech kom!", 37. Throughout the war, both Boer and British sources accused each other of misusing the white flag.

I 67 Editorial commentary on letter from a Dutch veteran who was at Elandslaagte, $N R C$, 23 November 1899 .

I 68 Excerpt from letter by veteran of Elandslaagte, $N R C, 28$ November I 899; letter from POW ship Penelope, NRC, 5 December I 899; excerpts from letter by J. C. Kakebeeke, NRC, I9 December I899; interview of F. Kannemeyer, Het Algemeen Handelsblad, 30 May I900; Penning, De oorlog in Zuid-Afrika I, I38-I42. In a footnote, Penning referred to British accounts published by William Stead, and he also used Kakebeeke's story. See Rompel, Uit den tweede (Transvaalsche) vrijheidsoorlog, 94; Plokhooy, Met den Mauser, 28-3I.

I69 'verblind'. Editorial by Boissevain, Het Algemeen Handelsblad, I 7 December I 899; Kloppers, “Alles zal rech kom!”, 39.

I70 Cartoon from London Illustrated News, 2 December I 899. NASA Leyds collection, LEY 801 .

I7 I 'slachting', 'weerlooze Boeren', 'vermoorden'. Penning, De oorlog in Zuid-Afrika I, I 36-I 37; Priem, De oorlog in Zuid-Afrika II, [2]; Kolstee ed., De oorlog in Zuid-Afrika, coverpage and $[5]$.

I 72 The prisoners were released soon afterwards. Mbenga, 'The Role of the Bakgatla of the Pilanesberg', 9I. 
I73 'schandelijke bladzijde in de geschiedenis van dezen oorlog'. Letter from Pretoria, $N R C, 23$ January I 900.

I74 Letter by J. C. C. den Beer Poortugael to the Institute for International Law at Neufchatel, $N R C$, I 3 September I900. In the actual text of the Hague Convention, no references can be found to the use of black warriors against white people, but several contemporaries considered it to be a formal breach of the rules of engagement. See Andriessen, Gedenkboek van den oorlog in Zuid-Afrika, I 8 I-I 82.

I75 Eyewitness accounts, NRC, 27 January I900; interview by the Volksstem with officers Kirsten and Stoffenberg, NRC, 22 February I900; protests by SAR and OFS governments, NRC, I 4 April I900.

I76 Letter from Pretoria, NRC, I I January I900; letter from Pretoria, NRC 23 January I900; letter from J. Kiewit in De Standaard, NRC, I March I 900.

I77 ' het oproepen van het zwarte gevaar over de blanke minderheid in Zuid-Afrika is een wandaad, waarvoor men moeilijk zijn afkeuring te scherp kan witspreken'. NRC, I I January 1900 .

I78 'tuchtiging', 'barbaren', 'wandaden'. Report from the Rand Post, NRC, 22 February I900. For secondary literature see Mbenga, 'The Role of the Bakgatla of Pilanesberg', 9I92. Mbenga argues that, looking at the entire war, the Bakgatla thrived from the cattle they took from the Boers but also suffered heavy losses in terms of human life.

I 79 'Kaffer-Sluipmoord'. Penning, De oorlog in Zuid-Afrika I, 342. I 8 o Ibid. 35 I.

I 8 I 'Transvaal moet onderworpen worden; zijn burgers moeten zooveel mogelijk worden uitgeroeid.' Letter H. Wefers Bettink, NRC, 6 April I900.

I 82 'rassenhaat', 'vaste vormen'. Letter from Cape Town, NRC, 6 March I900.

I 83 'Zuid-Afrika kan niet tot rust komen onder Britsch bestuur. Dit heeft deze oorlog onmogelijk gemaakt.' Rompel, Uit den tweede (Transvaalsche) vrijheidsoorlog, 94 .

\section{Chapter 6}

I The original citation is: 'alles zal recht komen als elkeen zijn plicht doet' (all will be well if everyone does his duty), but it was the shortened version that became popular. In addition, it should be noted that Brand wrote these words in the I 880 os and used High Dutch. Kloppers made some sort of Afrikaans version of it.

2 Schutte, Van Amsterdam naar Krugersdorp, 44-45.

3 'Neen lezer, ik denk er niet aan, mij te onderwerpen, ik sluit geen vrede met Chamberlain, Milner en hun rooverbende, ik blijf schrijven: "Alles zal rech kom!'” Kloppers, “Alles zal rech kom!”, 6. Eventually Kloppers's pessimism prevailed and after the war he ended his affiliation with the pro-Boer movement. Schutte, Van Amsterdam naar Krugersdorp, 57-58.

4 M. Kuitenbrouwer, Nederland en de opkomst, I89-I90; Te Velde, Gemeenschapszin en plichtsbesef, I63; Bossenbroek, Holland op op zijn breedst, 352; De Graaff, De mythe van de stamverwantschap, 9 .

5 Editorial, NRC, 9 September 1900. 
6 Address by the Boer deputation, NRC, I 6 September 1900.

7 Leyds ed., Vierde verzameling I, xxxiv-xxxvi and 378-379; NRC, I3 September I90I; statement by the Dutch clergy (all denominations), NRC, 25 October I90I; Hoedemaker, A Plea on behalf of Equity and Truth, 2I-26.

8 Excerpt from letter by correspondent of the Laatste Nieuws (Belgium) in Nelspruit, $N R C$, I 8 October I900; map showing territory 'under control of the Boers', which was bigger than the British Isles, NRC, IO January I90I.

9 The text of a proclamation issued in October by Botha, NRC, I 2 December 1900.

Io J. C. Kakebeeke, 'Brazelle', NRC, I 5 September I 900.

i I Editorial by A. Kuyper, De Standaard, 22 September I900; Jager, 'De vlag op de Gelderland'. I would like to thank Jouke Turpijn for providing me with this paper, which brought this topic to my attention.

I 2 Letter by J. C. C. den Beer Poortugael in Het Haagsch Dagblad, NRC, 28 September 1900. See chapter 3 for the reception of Kruger in The Hague.

I 3 Editorial by A. Kuyper, De Standaard, 2 October 1900.

I4 See chapter 3 .

I 5 M. Kuitenbrouwer, Nederland en de opkomst, I 85.

I 6 'Den Engelschman zal ons vertrappen waar hij kan.' Letter from Pretoria, NRC, 27 June 1900 .

I7 Letters from $N R C$ correspondent in Pretoria, NRC, 23 August I900, 2I April, I3 September and I October I90I.

I 8 'O, nooit vergeten zullen wij de schandelijke handelswijze van Engeland.' Plokhooy, Met den Mauser, I35-I 36 .

I 9 Ibid. I37-I 38 .

20 Ibid. 137.

2 I J. C. Kakebeeke, 'Engelands opvattingen van het oorlogsrecht', NRC, 28 August - 2 September I900.

22 'parasieten'. J. C. Kakabeeke, 'De haat tegen Hollanders', NRC, 5 September I 900.

23 '[...] waar ik op wil wijzen is op het bespottelijke der dreig-politiek van Engeland's regeering tegenover de Boeren, op het laffe om alleen deze dreig-politiek te durven uitvoeren wanneer zij weerlozen geldt'. Rompel, Een studie in proclamaties, 4 .

24 'al deze dreigingen, smeekingen en beloften mochten niet baten; de Boeren hielden vol'. Ibid. I 5 .

25 The term referred to the fact that these men continued to the bitter end (bitter eind). 26 Plokhooy, Met den Mauser, I 2 I-I 23. This story was also published in a feuilleton: C. Plokhooy, 'Een reis met hindernissen', Het Algemeen Handelsblad, 5 and 6 July I 90 I.

27 Jeltes, Uit het dagboek van H. Jeltes, 30 and 32; Kloppers, "Alles zal rech kom!", 97I02; Speech VerLoren van Themaat, NRC, 2 June I902; Reitz, De dochter van den Handsopper, 66-70 and 86-88; Viljoen, Mijne herinneringen, 327-333.

28 Editorial, $N R C, 24$ May I90I; Letter of Smuts to Steyn, NRC, 23 June I90I; Editorial, $N R C$, I 9 October I90 I; editorial, NRC, 25 January 1902.

29 Editorial, NRC, I 8 August I900.

30 Boldingh, Een Hollandsch officier in Zuid-Afrika; feuilleton by 'Si Omong', NRC, I 5 
and 24 October, 7, 9, I0 and 13 November 1900.

3 I 'militair genie.' Editorial, NRC, I 8 August 1900.

32 Mijnssen, De depecherijder van De Wet; Penning, De verkenner van Christiaan de Wet.

33 Reineker, Lord Kitchener en De Wet; Hogeweg, Een Engelsche spion in de knel, of, hoe Generaal De Wet trakteert.

34 See chapters 2 and 5 .

35 See correspondence in NASA, Leyds collection, LEY 95; H. J. Kiewiet de Jonge to W. J. Leyds, 27 January 1902. NL-HaNA, Leyds, 2.21.105, inv.no. 5I.; W. J. Leyds to P. A. Nierstrasz, 23 January I902. NL-HaNA, Leyds, 2.21.105, inv.no. 73. For Mr Junius, see chapter 4 .

36 Analysis C. de Wit, NRC, 22 July I900; Van Warmelo, Mijn commando en guerrillacommando leven, 50.

37 For example, see excerpt from a diary found at Roodewal, NRC, I9 September I90I; Boldingh, Een Hollandsch officier in Zuid-Afrika, 88-89.

38 'De oorlog en het volkskarakter der Boeren'; 'kinderen met een goed karakter, die echter te veel aan zich zelf overgelaten zijn geweest [...] en waarvan de slechte eigenschappen - naast de goede - tot soms aanstootelijke proportiën zijn gegroeid.' De Nieuwe Courant, 9 June I90I.

39 Report by Smuts, not dated. NASA, Leyds collection, LEY 94; Hancock, Smuts: The Sanguine Years, I40.

40 'De stemming mijner burgers is prachtig. Hoewel zij misschien zwaarder geleden hebben dan eenig ander klompje burgers in deze oorlog, zien zij vandaag met blijmoedigheid de toekomst tegemoet, overtuigd dat geen moeilijkheid of vijandelijke overmacht, hoe groot ook, zal kunnen verhinderen dat deze strijd zal worden voortgezet tot Recht zegeviert boven Macht.' Report by Smuts, not dated, NASA, Leyds collection, LEY 94; Ambtelijke verslagen van generaal J. H. De la Rey en generaal J.C. Smuts, 33; NRC, 20 April 1902. English version of this text quoted in Hancock, Smuts. The Sanguine Years, I 40.

4I Articles from De Volksstem, NRC, 27 April and 8 June I900; Rompel, Uit den tweede (Transvaalsche) vrijheidsoorlog, 50-5I; W. F. Andriessen, 'De vrouwen der Boeren', in: De Gids, vol. 67, no. I (1903), 64-88, 8I.

42 Letter from Pretoria, NRC, 23 April I90I; letter from Pretoria, NRC, I December I90I; Rompel, Uit den tweede (Transvaalsche) vrijheidsoorlog, 60. It was the central theme in a novel by Hjalmar Reitz: Reitz, De dochter van den Handsopper.

43 For women gathering intelligence, see Andriessen, 'De vrouwen der Boeren', 84. Andriessen referred shortly to Blackwood Magazine. For women fighting, see article from Advertentieblad, NRC, I 5 September I90I. Only years later did significant publications appear on this subject. Brandt-Van Warmelo, Die Kappie kommando; Raal, Met die boere in die veld. For Brandt-Van Warmelo, see chapter 3.

44 'Den lijdensbeker, die haar aan de lippen werd gezet, hebben zij tot den laatsten druppel leeggedronken en toen ook nog hebben zij pal gestaan, zijn zij gebleven trouw en onbezweken.' Andriessen, 'De vrouwen der Boeren', 65-66. 
45 Editorial, NRC, 20 June I900; interview of Mrs Reitz by Het Algemeen Handelsblad, $N R C, 6$ August I900; article from Ons Land, $N R C$, I 3 November 1900.

46 'terreur bewind'. Letters from Cape Town, NRC 3 I July, I7 and 25 September I9OI; Elout and Rompel, 'Olive Schreiner', I I 3 - I I 4.

47 'zeer gunstig'. Report by Smuts, not dated. NASA Leyds collection, LEY 94; Ambtelijke verslagen van generaal J. H. De la Rey en generaal J. C. Smuts, 33 ; Hancock, Smuts. The Sanguine Years, I40.

48 Report by Smuts, not dated. NASA, Leyds collection, LEY 94; Hancock, Smuts. The Sanguine Years, I40.

49 The term Handsopper, or Hendsopper, is derived from the phrase 'hands up'.

50 'zyn geboorte reg'. Quoted in: Reitz, De dochter van den Handsopper, 5-6. This novel by W. F. Reitz's son Hjamlar after the war was about the love of a young Bittereinder for the patriotic daughter of a Handsopper, which represented the love for the Afrikaner nation prevailing in the end.

5 I 'karakterfout', 'zonder eenige gewetenswroeging'. Van Warmelo, Mijn commando en guerrilla-commando leven, $7 \mathrm{I}$.

52 Editorial about speech Piet de Wet, NRC, I April I902. See letter from Christiaan de Wet's wife, NRC, 24 March I90I.

53 Analysis C. de Wit, NRC, 7 February I902; editorial, NRC, I7 April 1902.

54 Letter from German lady in Alldeutscher Blätter, NRC, 26 March I902; letter from Johannesburg, NRC, 2 I May I 902.

55 Editorial, NRC, 9 June I90I; interview Leyds, NRC, 2I December I90I.

56 Letter London correspondent, NRC, 23 June I $90 \mathrm{I}$.

57 Editorial, NRC, 28 July I 900.

58 The words of Campbell-Bannerman reached the Boers in South Africa. In an article in State Gazette of the ofs, Steyn declared that he agreed with the term 'methods of barbarism'. NRC, I2 March I 902.

59 Hoedemaker, A Plea on behalf of Equity and Truth, 20.

60 Letter P. J. Blok, NRC, 3 September I 900; Letter prof. Wefers Bettink, NRC, 23 November I 900; Boissevain, A Great Crime, I4-I 5 ; letter from Cape Town, NRC, 29 September I 90I; analysis C. de Wit, NRC, I6 October I90I and 25 May I 902. For British references to the Dutch revolt, see speech by Frederick Harison, NRC, IO October I 90 I.

6I Letter P. J. Blok, NRC, 3 September I900; London correspondent, NRC, 9 December I 900; Boissevain, A Great Crime, I4-I 5; Boldingh, Een Hollandsch officier in Zuid-Afri$k a, 52$. One correspondent reported that the people of Cuba supported the Boers. Letter from Havana, $N R C$, 27 January 1900.

62 Editorial, NRC, 6 October I900; Boissevain, A Great Crime, 47; Kloppers, “Alles zal rech kom!", I 47 .

63 Interview of Lieutenant M. J. Nix (military attaché) in the SAR press, NRC, 7 June I900; analyisis by C. de Wit, NRC, 2 February I90I; editorials, NRC, 3 I December I90I and 30 January I 902 .

64 M. Kuitenbrouwer, Nederland en de opkomst, I92. For a similar comparison, see Bastings, Brochure contra Leyds, 5 . Bastings was a Belgian radical Catholic author. 
65 'Europeesche beschaving en industrie', 'een volk [...] barbaarsch in zijne handelingen'. 'verschil in huidskleur'. Quoted in: M. Kuitenbrouwer, Nederland en de opkomst, I9I. The journalist Charles Boissevain also attacked Troelstra. Het Algemeen Handelsblad, 3 I October, I, 4, I 5 and I 6 November I90 I.

66 Fransjohan Pretorius estimates that there were at least I 4,000 agterryders. Pretorius, 'Boer Attitudes to Africans in Wartime', I04-I 20.

67 NRC, 20, 22 and 27 April I902. Thomson wrote his letter of apology on the advice of his fellow attaché Captain J. H. Ram, who believed that the remarks about black scouts had been harmful to their public image. J. H. Ram to C. J. Asselbergs, 23 April I902. NLHaNA, Asselbergs, 2.2 I.OI3, inv.no. I 2. For Ram and Thomson, see chapters 3 and 7. 68 Memoirs: Kloppers, “Alles zal zal rech kom!”, I 46-I47; Kestell, Met de Boeren-commando's, 2 I0-2I I; Helsdingen, Vrouwenleed, 40-4I. Novels: Penning, De overwinnaar van Nooitgedacht, I2 I-I36; Reitz, De dochter van den Handsopper, I4.

69 Letter from Cape Town in Nieuws van den Dag, NRC, 25 November I900; speeches by H. D. van Broekhuizen, NRC, I and I 6 December 1900.

70 Report by Smuts to Steyn, NRC, 24 June I90I; report by Smuts, NRC, 20 May I902. Ambtelijke verslagen van generaal J. H. De la Rey en generaal J. C. Smuts, 9, I6-I7 and 27-3 I. Novels: Penning, Vredeburg, 93 and I I9; Reitz, De dochter van den Handsopper, 56 and I99-20I; Penning, De overwinnaar van Nooitgedacht, Io.

7I Letter from Johannesburg in Zwolsche Courant, NRC, 2I March I900; NRC, 5 August I 90I; NRC, I9 September I90I; editorial about Lotter case, NRC I9 October I90 I; editorial about Scheepers case, $N R C, 25$ January I902; editorials about Kritzinger case, $N R C$, I 6 February and 9 April I902; Boldingh, Een Hollandsch officier in Zuid-Afrika, I 87. 72 Interview of Leyds, $N R C$, 2I December I90I; editorial about Kritzinger case, NRC, 7 March I902.

73 For an excellent discussion on this incident and its effects on Cape identity, see Nasson, Abraham Esau's War, I20-I40.

74 'getard', 'gelijk hadden met [...] op zijn plaats te zetten'. Letter from Cape Town in Arnhemsche Courant, NRC, I6 March I90I.

75 'Een der onaangenaamste dingen hier'. Letter from Cape Town in Arnhemsche Courant, NRC, I6 March I90I. See also article from Advertentieblad (Cape Town), NRC, I 6 April I902.

76 NRC, 5 July I 900 ; letter by Dr Rijckevorsel, NRC, I 2 July I 900; letter from ofs in Ons Land, NRC, I6 December I900; diary from Pretoria, NRC, 7 March I900; article from Advertentieblad (Cape Town), NRC, I 3 March I900.

77 Feuilleton by H. Oost, NRC, 22 September I90I; Kloppers, “Alles zal rech kom!”, 40. 78 Letter by a prominent woman in the ofs, NRC, 3 I August I90I; Hobhouse, Report to the Committee, 37-39. For secondary literature see Krebs, Gender, Race, and the Writing of Empire, 64; Jansen, “Ek ook het besluit om van my bittere lydingskelk te vertel”, I74-I76.

79 Letter from Pretoria, NRC, 20 September I900; article from Advertentieblad, NRC, I6 April I902. For the contemporary fear of black male sexuality, see Krebs, Gender, Race, and the Writing of Empire, 65 and 78. 
80 'de grootste misdaad [...] die ooit tegen het blanke ras in Zuid-Afrika gepleegd kan worden'. Report by Smuts, NRC, 20 May I902.

8 I Editorial, NRC, 22 May I902.

82 'Een helsch tooneel! Met geen andere naam kunnen wij het bestempelen. Met vlammen, vuur en rookdamp naderen zij! Het gras wordt door het vuur verteerd en baant hun den weg.' Helsdingen, Vrouwenleed, 32.

83 Editorial about a letter from the son of C. H. Wessels to his father, NRC, 9 December I900.

$84^{\prime} t$ Wordt den Engelschen rood voor de oogen van wraakzucht en bloeddorst. Ze zien niets meer, ze willen maar dood hebben - weg met alles!' Letter from Cape Town correspondent of Zwolsche Courant, NRC, 2I November I90I.

85 'schandelijk'. Editorial, NRC, 28 April I900; interview with C. de Bruin, NRC, 8 May I900; excerpt from letter by Blignaut, $N R C$, Io June I900; letter from Cape Town, NRC, 27 June 1900.

86 Excerpt from proclamation by Colonel Beauchamp Duff, NRC, 8 December I900; Rompel, Een studie in proclamaties, IO-I I.

87 'een soort van ontvolkings-systeem', 'om alles tot een woesternij te maken'. Editorial, $N R C$, I9 October I900. See also letter by Smuts to Steyn, NRC, 23 June I 90 I.

88 Letter Mrs Cronjé, NRC, Io December I900; Boldingh, Een Hollandsch officier in Zuid-Afrika, 45 .

89 Letter from a Welsh soldier, $N R C$, I 4 November I900; letter from Ons Land, NRC, I I December I900; letter from Alldeutsche Blätter, NRC, 2I February 1902; Boldingh, Een Hollandsch officier in Zuid-Afrika, 46.

90 Letter from Pretoria, NRC, 22 January I90I; Ambtelijke verslagen van generaal J. $H$. De la Rey en generaal J. C. Smuts, 6; NRC, 8 April I902.

9I Penning, De oorlog in Zuid-Afrika II, 959, footnote. For Boldingh, see chapter 3.

92 'De Khaki's dansten van plezier. Hun baldadigheid kende geen grenzen meer, en terwijl hun vuile handen de kostelijke boter uit de potten klauwden, gooiden zij er elkander mee, alsof het sneeuwballen waren.' Penning, De overwinnaar van Nooitgedacht, Io8I IO. For another dramatised account of the brutality of the British soldiers, see Reitz, De dochter van den Handsopper, 58.

93 'Zij grepen elkaar bij de hand en maakten een woeste rondedans, terwijl de vlammen hoog uitsloegen uit het dak van het ten ondergang gedoemde huis.' Penning, De held van Spionkop, 74 .

94 Reference to letter by Leonard Courtney in which he protested against farm-burning, NRC, 29 November I900; reference to protests by Dillon MP, NRC, I March I90I; London correspondent about protests in British press, NRC, I7 May I90I; references to protests by Marks, NRC, 23 May and 8 June I 90 I.

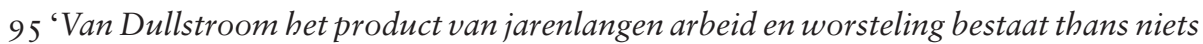
meer. Het is alles van de aarde verdwenen.' Janson jr. ed., Het verbranden van hoeven in Zuid-Afrika.

96 Review of Hell let loose, NRC, I7 and I 8 November I900. This pamphlet was followed by Stead, How not to make Peace. In it, all the material on which Hell let loose was 
based was published in full. See also Stead, 'Methods of Barbarism, 56-66, in which he referred to eyewitness accounts from both soldiers who condoned and condemned farmburning. For a review, see NRC, 20 July I90I.

97 Editorial in Frankfurter Zeitung, NRC, I7 July I90I; editorial, NRC, 3 I July I90I; letter by S. van Lier, $N R C, 3$ August I90I; editorial, $N R C$, I 5 December I90 I; editorial, NRC, 7 March I902. See also Penning, De verkenner van Christiaan de Wet, I4-I6.

98 See chapter 2.

99 Report of execution of J. P. Coetzee, NRC, I9 March I90I; editorial, NRC, 22 March I90I; analysis by C. de Wit, NRC, 26 March I90I; letter by Smuts to Steyn, NRC, 23 June I 90 I; editorial, $N R C, 9$ August I 90 I.

Io० 'uit den weg te ruimen, nu zij hem in handen hebben.' Editorial based on Reuters telegrams, NRC, 22 December I90I. See also editorial based on Reuters telegrams, NRC, I 5 October I90I; editorial based on Reuters telegrams, $N R C$, 3 I December I 90I; editorial based on report in Petit Bleu, NRC, I January 1902.

IOI 'een moord, niets anders; zij zal Engeland altijd tot schande zijn'. Editorial, NRC, 25 January I902.

IO2 Question in the British parliament, NRC, IO March I902; abstract of report in the Manchester Guardian, NRC, 26 March I902; Penning, De oorlog in Zuid-Afrika III, I 25 I-I 253 .

IO3 'Zijn bloed, zijn martelaarsbloed, zal [...] niet noodeloos hebben gevloeid, want een man als Scheepers moet oneindig veel vrienden hebben gehad die nu beslist als hij, zullen willen strijden tot het einde. Bij zijn dood maakt hij wellicht meer recruten dan bij zijn leven.' Obituary Scheepers in Het Algemeen Handelsblad, NRC, 22 January I902. See also editorials, NRC, 23 and 25 January I 902; statement Hobhouse, NRC, 25 February 1902. I04 Statement by F. K. Kannemeyer to J. Pierson, NRC, 29 May I900; interview of F. K. Kannemeyer, NRC, I June I900.

I05 See chapter 5 .

I06 'vuile, [...] besmette schepen', 'als haringen in een ton'. 'Er lijkt geen ander volk te bestaan, dat met grooter vrijmoedigheid anderen verwijt waaraan het zelf schuldig is, als het Engelsche.' Editorial about Roberts, NRC, I 6 May I900. See also editorial about report by Lieutenant-Colonel Hunt, NRC, I 5 September 1900.

IO7 Editorial, $N R C, 30$ March I 900.

Io8 Excerpt from a camp periodical on St. Helena, De Krijgsgevange, NRC, 22 August I 90 I; letter from St. Helena, NRC, 24 October I90I.

Io9 Letter from St. Helena, NRC, I I June I900. See also Van Warmelo, Mijn commando en guerrilla-commando leven, 2 I3-2 I4. Van Warmelo was sent to India.

I Io Letter from St. Helena, NRC, 26 October I900; letter from a visitor in a Ceylon camp, $N R C$, I 6 December I900; letter from St. Helena, NRC, 2 May I 90 I.

I I ' Hoe moet die doodende werkeloosheid, die wreede afhankelijkheid, dat opgesloten zijn en bewaakt, wel worden gevoeld door mannen die hun vrijheid, hun onafhankelijkheid zoo liefhebben als, ja liever dan hun leven.' De Boeren op Sint-Helena, 50.

I I 2 'onbeschaamde', 'openlijke erkenning van onvermogen en zedelijk verval'. Editorial, NRC, IO August I9OI. 
I 3 For example, see letters from St. Helena, NRC, 2 August I900, I 3 June, 28 July and 20 September I90I.

I I 4 'Judaskampen'. Letter from St. Helena, NRC, 28 July I90I; letter from Ceylon, NRC, 2 May I901; letters from Bermuda, NRC, 5 February and Io March I902; letters from India, NRC, 25 March, I 2 April and I 8 May I 902.

I I 5 'bij gebrek aan saniteitspapier'. Letter by Versèwel de Witt Hamer, NRC, 3 I July I 900. I 6 Letters by Versèwel de Witt Hamer, NRC, 24 November and 30 December 1900.

I 7 Letter from Ceylon, NRC, 8 October I90I; Ihle, Dagelijks leven van de Boeren krijgsgevangeven; De Boeren op Sint-Helena; Douwes Dekker, Wilhelmina-dag op Ceylon .

I 8 Zuid-Afrikaansche tentoonstelling; De Boeren op Sint-Helena, 74.

I I 9 After the war, Botha commissioned an inquiry, which yielded the number of 27,927 Boer casualties. Recently, the historians Iain R. Smith and Elizabeth van Heyningen have compiled a databank in which they counted 'around 25,000' deaths. Van Heyningen, 'Costly Mythologies', 496 and 507. There are far fewer sources left about the black camps, so it is even harder to establish those figures. The official number was I 4,000 , but Smith and Van Heyningen estimate that the number of deaths there might have been as high as in the white camps. Ibid. 496 , footnote 5 .

I 20 For reference to black camps, see Hobhouse, Report to the Committee, I3. Compare with Krebs, Gender, Race, and the Writing of Empire, 79. Paula Krebs argues that Hobhouse did not mention the black camps at all, while in fact she did note, albeit briefly, how there were similar problems in these camps, and recommended that these be taken into consideration too.

I 2 I Pakenham, The Boer War, 553-554.

I 22 Stanley, Mourning becomes, 3-4; Heyningen, 'Costly Mythologies', passim.

I 23 Stanley, Mourning becomes, 7.

I 24 Letter by H. Wefers Bettink, NRC, 6 April I900.

I25 'nadat de twee Boerenvolkeren met hunne vrouwen en kinderen zullen zijn uitgeroeid'. Waszklewicz-Van Schilfgaarde ed., Paul Kruger's tocht, I 4.

I 26 'meermalen tegen barbaarsche Afrikaansche stammen moeten strijden; maar de barbaren, met wie we nu moeten vechten, zijn veel erger dan die anderen. [...] zij verbranden onze hoeven; zij jagen de vrouwen en kinderen weg, wier mannen en vaders gedood of krijgsgevangen zijn; zij laten haar [sic] zonder bescherming, zonder dak, zonder brood vaak.' Waszklewicz-Van Schilfgaarde ed., Paul Kruger's tocht, I3-I4.

I 27 After the war, her memoirs were published by J. A. Wormser. De la Rey, Mijne omzwervingen en beproevingen. See also Ambtelijke verslagen van generaal J. H. De la Rey en generaal J. C. Smuts, 5; anonymous letter, NRC, 20 March I902.

I 28 'onbeschrijfelijke barbaarschheid', 'onbreekbare volharding'. Letter by Smuts to Steyn, NRC, 23 June I90I.

I 29 'geen mensch, al is hij ook hoe hard of sterk, tranen barst hem uit de ogen bij het aanschouwen van dit, en de moeders en dochters zijn niet in staat om te spreken van den toestand waarin zij verkeeren zonder dat de tranen hun uit den oogen rolden'. Article from Ons Land, NRC, 23 December 1900.

I 30 Letter by 'Pax', Het Algemeen Handelsblad, 2 I February I90 I. 
I3 I His reports addressed to 'dr. Williamson' and signed with 'Chr. Brooks' (codenames for respectively Leyds and Broeksma) can be found in the secret files of the SAR legation. NASA, Leyds collection, LEY 3I5. In September I90I, Broeksma was executed by the British after he was convicted of high treason. See chapter 3 .

I 32 For an overview of these sources, see chapters 3 and 4 .

I 33 Correspondence between W. Roosegaarde Bisschop and the ANV press office, 20 October, 6 and I9 November I900. NASA, Leyds collection, LEY 8 I I.

I 34 'te belangrijk om niet te gebruiken'. F. Rompel to H. Tiedeman, 20 June I90I. NASA, Leyds collection, LEY 8I I.

I 35 Correspondence about photograph Lizzie van Zyl, July i90 I. NASA, Leyds collection, LEY 8 I I.

I36 'Dat beeld, in een vergadering, vergroot op een scherm, [...] zou een geweldige uitwerking hebben, meer dan duizend boeken'. H. J. Kiewiet de Jonge to W. J. Leyds, 2 I June I90I. NL-HaNA, Leyds, 2.2 I. I05, inv.no. 5 I. For use of this photo in later Afrikaner nationalism, see Stanley, Mourning becomes, I 27-I 3 I.

I 37 'onbevooroordeeld', 'waardig en waar'. Statement by H. A. Cornelisse, who lived in a camp for several months. NASA. Leyds collection, LEY 809. See also editorials, NRC, 2 I and 22 June I90I.

I 38 Letter by nurse H. Broers from Norvalspont, NRC 4 July I90I; letter from Irene, NRC, 30 August I 901 .

I39 Krebs, Gender, Race, and the Writing of Empire, 73-76.

I 40 See chapter 2.

I 4I Editorial, $N R C, 28$ July I90I; editorial, $N R C$, I7 December I90I; editorial, NRC, 22 February I902; letter in Daily News, NRC, 9 March I902; letter by German lady, NRC, 26 March I902. See also Krebs, Gender, Race, and the Writing of Empire, 70 and 74.

I 42 Letters ANV press office to OFs consul-general's office, 23 October and 8 November I90I. NASA, Leyds collection, LEY 809. The leaflets can be found in ZA, Emous collection, EM I 3 .

I 43 Krebs, Gender, Race, and the Writing of Empire, 64-66.

I 44 'schijnheilig'. Letter from J. C. Pretorius, $N R C, 22$ January I9OI; editorial, NRC, 20 December I90I.

I 45 'vrouwenmartel-politiek'. Rompel, Een studie in proclamaties, I 2.

I 46 Ibid. Io and I 5 ; letter by J. C. Pretorius, NRC, 22 January I9OI; letter in Advertentieblad, NRC, I 2 February I9OI; letter by German lady in Alldeutscher Blätter, NRC, 26 March I902.

I 47 'moordkampen'. De Boeren op Sint-Helena, cover page; Janson jr. ed., Het verbranden; Penning, De oorlog in Zuid-Afrika III, I I95; Penning, De kolonist van Zuid-Afrika, I 5 .

I 48 Letter from visitor Potchefstroom camp, NRC, I7 September I90I; interview with refugee, $N R C$, I 8 January I902; letter by Mrs Joubert, $N R C$, 22 January 1902.

I 49 Letter H. J. Emous to ANV press office, I 6 August I90I. NASA, Leyds collection, LEY 809 . For Emous's work during the war, see chapter 4.

I 50 'buichelachtige snoodheid', 'worgerkampen'. Letter by H. J. Emous, Algemeen Handelsblad, 6 July i90 I. 
I 5 I Ibid. For similar term 'volkerenmoord', see Penning, De kolonist van Zuid-Afrika, I7. This book was originally published in I904.

I 52 Waszklewicz-Van Schilfgaarde, Plea for the grand of a neutral territory. A Socialist Member of Parliament proposed to move the camps to Europe and even received support from orthodox Protestant pro-Boers. See Voor de Boeren, I4 December I 901, 3.

I 53 Letter by Commissie voor de Vrouwenkampen, NRC, I9 March I902; editorial, NRC, 2 I March I902.

I 54 'Bravo! Den Afrikaander stam wordt niet licht uitgeroeid.' Editorial, NRC, I 6 April I902. The question of who fathered the children, after almost two-and-a-half years of war, was not mentioned. For illegitimate children in concentration camps, see Stanley, Mourning becomes, I34-I37, I 47 and I62-I63.

I 55 Analyses by C. de Wit, NRC, 27 February and I 2 March I 90 I.

I $56 \mathrm{~J}$. H. Bierens de Haan, the former physician of General Louis Botha, wrote the account. See chapter 3. It was first published in NRC, 29 May I9OI. Later it appeared as a separate pamphlet. 'B. ot H. Anicus', De onderhandelingen van Lord Kitchener en Louis Botha.

I 57 Ibid. I 2.

I 58 Proclamation by Steyn and Schalk Burger, NRC, 24 August I90I; letter by Steyn to Kitchener, $N R C$, 30 October and I I November I90I. The former letter was also published as a pamphlet by the ANV press office.

I 59 Interview of $\mathrm{H}$. VerLoren van Themaat, $N R C$, I 5 May 1902.

I60 W. J. Leyds to H. J. Kiewiet de Jonge, 5 December I90I; correspondence between W. J. Leyds, A. Fischer and P. A. Nierstrasz, 24-26 December I 90I. NASA, Leyds collection, LEY IO3.

I6I M. Kuitenbrouwer, Nederland en de opkomst, i87-188; Van Koppen, De geuzen van de negentiende eeuw, I83-I 85 .

I62 For an overview of this mediation attempt and its effects, see Van Koppen, De geuzen van de negentiende eeuw, I85-197; M. Kuitenbrouwer, Nederland en de opkomst, I88-1 89 .

I63 'zwakke broeder'. Leyds ed., Vierde verzameling I, xlvii-xvliii. The role of the third member of the deputation, C. H. Wessels, is not clear.

I64 'menschlievende beweegredenen', 'schrikwekkende [...] oorlog'. Penning, Den oor$\log$ in Zuid-Afrika III, I 282.

I 65 De Standaard, 6 February I 902; Voor de Boeren, I 5 February I902, 2.

I 66 For responses in domestic and international press, see De Standaard, 6 and 8 February I902; NRC, 7 and 8 February 1902.

I 67 'Zulke hoogdravende onzinnige zelfverheerlijking is buitengewoon geschikt om ons volkomen belachelijk te maken in Europa'. Het Algemeen Handelsblad, 7 February 1902. Similar criticism was heard from the Socialists. See Van Koppen, De geuzen van de negentiende eeuw, I98-I99. Other Liberal newspapers were less critical. The NRC expressed its concerns about the memorandum, but De Nieuwe Courant was very positive. I 68 Also the Socialist leader Troelstra was sceptical about Kuyper's actions, probably for similar reasons. 
I69 'althans de uitmoording van de Boerenstam verhinderd werd [...] in de toekomst het krachtiger weer opleven'. Quoted in: Leyds ed., Vierde verzameling, xlvii. Leyds referred to a publication from I9I7. See also M. Kuitenbrouwer, Nederland en de opkomst, I 88; Van Koppen, De geuzen van de negentiende eeuw, $20 \mathrm{I}$.

I70 Leyds ed., Vierde verzameling I, xliii-iv; Van Winter, Dr. Leyds en Zuid-Afrika, I 8I9; W. H. de Beaufort, 'De Zuid-Afrikaansche republieken en de vredesconferentie van I 899', in: De Gids, vol. 80 (I9I6), 465-478.

I7 I Leyds ed., Vierde verzameling I, xlix; Van Koppen, De geuzen van de negentiende eeuw, 199. Compare with M. Kuitenbrouwer, Nederland en de opkomst, I 89.

I 72 Leyds ed., Vierde verzameling I, 1; Sandbergen, Twintig jaren onder Krugers Boeren, 365 .

I73 'een enkel hard woord', 'kostbaar goed'. Editorial, NRC, 3 June I902.

I74 M. Kuitenbrouwer, Nederland en de opkomst, I89-I90; Te Velde, Gemeenschapszin en plichtsbesef, 163; Bossenbroek, Holland op zijn breedst, 352; De Graaff, De mythe van de stamverwantschap, 9 .

I75 NRC, I I June I902. This version was taken from The Standard and seems to have been censored, as it did not contain the passage in which the armament of black people and the concentration camps were described as reasons to surrender, matters that were mentioned in the original document. These quotes can be found in other publications. See Transcript Boer statement, 3 I May I902. NASA, Leyds collection, LEY 869; publication of letter Boer leaders to former inhabitants of the Republics, 3 I May I902. NASA, Leyds collection, LEY 206; Reitz, De dochter van den Handsopper, 276.

I76 'gehamerd tot het ras dat Zuid-Afrika ten slotte beschave [sic] en regeeren zal'. Het Algemeen Handelsblad, 2 June I902. See also Scholtanus, De reakties in Nederland op het einde van de Boerenoorlog, 77-78.

$\mathrm{I} 77$ 'Ik ben blij in je brief te lezen dat naar je meening, op den duur het Boeren-element in Zuid-Afrika zegenvierend zal zijn. Daarmede stem ik volkomen in.' Leyds ed., Vierde verzameling I, 757.

I 78 Van Niekerk, Kruger se regterhand, preface. For an extensive discussion of these activities, see chapter 7 .

$\mathrm{I} 79$ 'te waken en te wachten, in het duister staren wellicht, maar daardoor het oog te oefenen en onze broedernatie te dienen'. Voor de Boeren, I4 June I902, appendix.

\section{Chapter 7}

I 'Want wie zich een toekomst scheppen wil, mag het verledene niet uit het oog verliezen. Daarom: zoekt in het verledene al het goede en schoone dat daarin te ontdekken valt, vormt daarna Uw ideaal en beproeft voor de toekomst dat ideaal te verwezelijken.' Quoted in: Van Niekerk, Kruger se regterhand, 329-330; Bossenbroek, 'Geschiedschrijving als hoger beroep', I9 I.

2 De Graaff, De mythe van de stamverwantschap, 299-303.

3 Ibid. 304-308.

4 'dubbele dekoloniseringsproces van de Afrikaanse taal en cultuur ten opzichte van de 
Engelse zowel als de Nederlandse culturele dominantie dat zich in de eerste drie decennia van de twintigste eeuw...'. Glorie, ““...Een reuze taak, die bijna 't onmogelijke vordert...", 42 .

5 'feitelijke belangstelling'; 'ebde [...] snel weg', 'een gevoel van sympathie alom'. Schutte, Nederlanders en de Afrikaners, 207.

6 Schutte, 'De organisatie van de Stamverwantschap'; Hemstra, De culturele betrekkingen tussen Nederland en de Afrikaners, 2 I and 59. I would like to thank Barbara Henkes for providing me with the latter text.

7 Huigen, De weg naar Monomopata, I 8.

8 Hofmeyr, 'Building a Nation from Words', ı०9-I I I; Hofmeyr, 'Popularizing History', $52 \mathrm{I}-535$.

9 Hofmeyr, 'Building a Nation from Words', i I I.

Io Huigen, De weg naar Monomopata, I7.

I I Moodie, The Rise of Afrikanerdom, 52-72; Schutte, Nederland en de Afrikaners, I 8 5I 86 .

I 2 Schutte, Nederland en de Afrikaners, I97-I98.

I3 Ibid. 200-204.

I 4 Nimocks, Milner's Young Men.

I 5 Giliomee, The Afrikaners, 268-273.

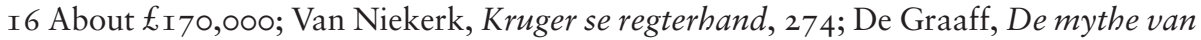
de stamverwantschap, 96. By the I920s, this sum had largely been spent. Van Niekerk, Kruger se regterhand, 3 I9.

I7 W. J. Leyds to L. Botha, 8 December I902. NASA Leyds collection, LEY 262.

I 8 Another important movement that received a lot of money from the Netherlands was the Christelijk Nationaal Onderwijs (Christian National Education, CNO), which lobbied for Dutch language education in schools. De Graaff, De mythe van de stamverwantschap, IOI; Schutte, De Vrije Universiteit I, I27-I 29 and I37-I 39.

I9 Several letters from F. V. Engelenburg to W. J. Leyds. NL-HaNA, Leyds, 2.21.105, inv.no. 48. For Engelenburg, see chapters I and 3.

20 ' het fondament voor een vaste nationale politiek in de toekomst'. J. C. Smuts to W. J. Leyds, I 8 April and 24 September I903. NASA Leyds collection, LEY 259; Van Niekerk, Kruger se regterhand, 325-326.

2I H. J. Kiewiet de Jonge to W. J. Leyds, I4 December I902. NL-HaNA, Leyds, 2.2I.105, inv.no. 5 I.

22 F. Rompel to W. J. Leyds, 25 March I 903. NASA, Leyds collection, LEY 208.

23 M. van Beek to H. J. Kiewiet de Jonge, 7 May I9OI. NASA, Leyds collection, LEY 82 I. 24 For a large number of letters from M. van Beek, see NASA, Leyds collection, LEY 82 I and 822 .

25 F. Rompel to H. J. Kiewiet de Jonge, I 4 November I905. NASA, Leyds collection, LEY 820.

26 Letters from C. Thieme to ANV press office. NASA, Leyds collection, LEY 8 I 5 .

27 After his return to the Netherlands in I902, Reyneke van Stuwe secured a job at Het Vaderland thanks to his brother-in-law, the famous writer Willem Kloos. Langendorff, Brieven van J. E. A. Reyneke van Stuwe, 43. 
28 J. E. A. Reyneke van Stuwe to F. Rompel, 29 January I908. NASA, Leyds collection, LEY 806.

29 'voorzichtiger en er komen minder dwaasheden over Zuid Afrika in de krant'. NASA, Leyds collection, Ley 806. Transcript J. E. A. Reyneke van Stuwe to L. Botha, 24 October 1908 .

30 H. J. Kiewiet de Jonge to Wallach Brothers, 28 November I9I3. NASA, Leyds collection, LEY 8 I I.

3 I G. Preller to H. J. Kiewiet de Jonge, 23 March I903. NASA, Leyds collection, Ley 825. 32 Engelenburg paid $£_{7}$ for newsletters, while $£_{25}$ was needed. F. V. Engelenburg to F. Rompel, I June I903. NASA, Leyds collection, LEY 825.

33 'zelfs niet een klein bedankje'. H. J. Kiewiet de Jonge to Wallach brothers, 28 November I9I3. NASA, Leyds collection, LEY 808.

34 Rompel became editor of De Volksstem and later of De Burger. Reyneke van Stuwe remained in London and continued to do freelance work for the ANV. During the First World War, he was mainly involved in the distribution of aid to Flemish refugees. He was also involved in the endowment of the chair for Dutch history at the University of London. 35 Muller, Sonop in die suide, I7I-I78; G. J. Schutte, 'De marxistische correspondent van De Burger', in: Zuid-Afrika, vol. 68 (I99I), I98-I99; De Graaff, De mythe van de stamverwantschap, I28-I 29.

36 See chapter 2.

37 Hofmeyr, 'Building a Nation from Words', I02.

38 'niet onwetenschappelik [sic]'. Besselaar, Zuid-Afrika in de letterkunde, 225.

39 Hofmeyr, 'Building a Nation from Words', I05.

40 For this correspondence, see NASA, Leyds collection, LEY 2 I 8 and 806 . By the I930s, the friendship between Preller and Leyds cooled, as the former adhered to more radical political views and had outspoken fascist sympathies. W. J. Leyds to F. V. Engelenburg, 25 August I930. NL-HaNA, Leyds, 2.2 I.I05, inv.no. 48.

4I G. Preller to F. Rompel, I July I9IO. NASA Leyds collection, LEY 806.

42 Giliomee, The Afrikaners, 364 and 365-366.

43 Glorie, ““...Een reuze taak, die bijna 't onmogelijke vordert...”, 4 I.

44 Hemstra, De culturele betrekkingen tussen Nederland en de Afrikaners, 2I and 59.

45 Ibid. 2 I-22.

46 Ibid. I 8.

47 Conradie, Hollandse skrywers II, I 52 -I 54.

48 'hetzelfde doel'. Mansvelt, Taalverwantschap en het gemeen belang van Nederland en Zuid-Afrika, 8; Press circulars by F. Rompel, 5 January I906, 2 January I 908 and 3 September I908. NASA, Leyds collection, LEY 870 and $87 \mathrm{I}$.

49 De Graaff, De mythe van de stamverwantschap, 96-97.

50 Mansvelt ed., Hollands-Afrikaanse Liederbundel, introduction.

$5 \mathrm{I}$ 'Het lied, dat het gemeenschappelik eigendom van een volk geworden is [...] leert de mensen delen in elkanders vreugde en smart, leert hen zich één gevoelen met het voorgeslacht en met elkander, bindt de harten samen en maakt door eendracht sterk.' Ibid.

52 Press circular by F. Rompel, 6 September I 907. NASA, Leyds collection, LEY 870. 
53 Zuid-Afrikaansche Post, 5 and I 2 March and 23 April I908; several newspaper cuttings from South Africa. ZA, NZAV archive, XI B/2.

54 ZA, Jaarverslag NZAV I908, 47.

55 ' $i k$ had mijn leven aan Zuid-Afrika gewijd; ik wilde die taak niet opgeven'. Van Niekerk, Kruger se regterhand, 3 I 3-3 I 4 .

56 Ibid. 352 . Leyds's dislike of the German government of Wilhelm II was probably also the result of the emperor's refusal to meet with Kruger in I900. W. J. Leyds to M. P. C. Valter, I9 August I9 I4. NASA, Leyds collection, LEY 2 I 4.

57 Bossenbroek, 'Geschiedschrijving als hoger beroep', 2 I I.

58 Leyds, The First Annexation of the Transvaal; Leyds, The Transvaal surrounded. The Dutch and English versions of the former book both appeared in I906. The second book appeared in I9 4 in Dutch, but its publication in English was delayed until I9I9 because Leyds did not think it was opportune to publish it during the First World War.

59 Colenbrander, Het boek van Dr. Leyds, I 58 ; Van Winter, Dr. Leyds en Zuid-Afrika, I 9; Van Jaarsveld, 'n Methodologies-kritiese ondersoek', I05; De Ru, 'Het beeld van de Zuidafrikaanse geschiedenis', 90-I; Bossenbroek, 'Geschiedschrijving als hoger beroep', I96-205.

60 W. J. Leyds to dr J. W. G. Van Oordt (Cape Town), 9 July I 903 and W. J. Leyds to prof. P. J. Blok, I 2 September I903. NL-HaNA, Leyds, 2.2 I.I05, inv.no. 40.

6I 'arsenaal'. W. J. Leyds to D. Reitz, 26 August I930. NASA, Leyds collection, LEY 22 I. 62 'bet is een mijn waar anderen uit putten moeten. I $k$ heb slechts materiaal willen leveren. Mijn eigen verontwaardiging heb ik het stilzwijgen opgelegd. Maar zij die het boek aankondigen, aan hen is het de Britten te geeselen, naar aanleiding van de feiten die ik bijbreng. Ik wensch die feiten ook door onze vijanden erkend te zien, maar alleen dan is daar kans op, als ik er zonder hartstocht mee aankom, en zonder mijn eigen commentaren.' W. J. Leyds to H. J. Kiewiet de Jonge, 26 August I9I3. NASA, Leyds collection, LEY $2 \mathrm{I} 3$.

63 'een onweerlegbare verdediging van de politiek door de Transvaal vanaf zijn bestaan gevolgd'. F. W. Reitz to W. J. Leyds, 4 March I920. NASA, Leyds collection, LEY 259.

64 Jaarsveld, ' $n$ Methodologies-kritiese ondersoek', I06-I07; Ru, 'Het beeld van de Zuid-Afrikaanse geschiedenis', 90.

65 He did so by referring to a telegram in which he warned the government that no intervention was to be expected from the European powers. W. J. Leyds, F. V. Engelenburg, I 4 June I907 NASA, Engelenburg collection, A (I40), 24; W. J. Leyds to G. Preller, 20 December I9II. NASA Leyds collection, LEY 2II; W. J. Leyds to J. de Louter, I I March I9I9. NL-HaNA, Leyds, 2.21.I05, inv.no. I2; Bossenboek, 'Geschiedschrijving als hoger beroep', 206-207.

66 NL-HaNA, Leyds, 2.21.105, inv.no. 72.

67 'onwaarheden, schimpscheuten en lage insinuaties'. Transcript W. J. Leyds to N. Japikse, I October 1930. NL-HaNA, Leyds, 2.21.105, inv.no. 72. In this letter, Leyds mentioned that Frans Beelaerts van Blokland, who was the foreign minister at the time, expressed his dismay at Muller's pamphlet.

68 Leyds, Een geschrift van Dr. H.P.N. Muller; Leyds ed., Derde verzameling II, I 5 O-I. See chapter 3 . 
69 See chapter I.

70 Report of meeting to discuss bankruptcy of Wormser, 3 I May I907. HDC, Wormser collection 258/36; Engelsche uitgevers en de propaganda van het boek in Transvaal, (reprint Het Nieuwsblad van den Boekhandel, 24 April I908). NASA, Leyds collection, LEY 8I 5 .

7I For examples, see Kestell, Met de Boeren-commando's, vii; VerLoren van Themaat, Twee jaren in den Boerenoorlog, iv; De Wet, De strijd tusschen Boer en Brit, introduction.

72 NRC, I 6 February I902; Ten Siethoff, Een verdediging van Engeland?

73 Pakenham, The Boer War, xv.

74 Surridge, 'Official History', 29-3 I; Beckett, 'British Official History', 33-42.

75 Beckett, 'British Official History, 35 ; V. Kuitenbrouwer, 'No End of a Lesson'.

76 'dat [een] nauwkeurige vastlegging van de geschiedenis van den oorlog, de weerlegging van valsche voorstellingen, ook nog in lateren tijd het Afrikaansche Volk ten goede zal komen, waar dit werk, voor hen als natie een overgankelijke eerezuil opricht, waartegen tijdgenoot en nageslacht met eerbied en bewondering zullen opzien, waardoor de handhaving en opbouwing der Boeren als zelfstandige natie wordt bevorderd'. P. A. Nierstrasz to W. J. Leyds, I I January I904. NASA, Leyds collection, LEY 3 I 7.

77 F. V. Engelenburg to W. J. Leyds, 6 August I902. NL-HaNA, Leyds, 2.21.I05, inv.no. 48 .

78 '[d]eze zaak is totaal bedorven'; 'eene verzameling van anecdoten, terwijl het had kunnen worden een monument van historie'; '[h]et is dus eene private speculatie'. W. J. Leyds to F. V. Engelenburg, 28 August I902. NL-HaNA, Leyds, 2.2 I.I05, inv.no. 40.

79 Correspondence about publication of De Wet's book, NASA, Leyds collection, LEY 26I. Despite the commercial success, however, the two never got along personally. Van Niekerk, Kruger se regterhand, 3 I 9.

80 See chapter 4 .

8 I 'een onbetrouwbaar mensch'. E. G. A. ten Siethoff to W. J. Leyds, 28 June I904. NASA, Leyds collection, LEY 2 IO. Ten Siethoff was a medical doctor from The Hague who accumulated a large library during the South African War, mainly consisting of newspaper cuttings and official publications. His attempt to write a history of the war also failed, and his collection (or part of it at least) ended up in the NZAv library in Amsterdam. See several letters in NASA, Leyds collection, LEY 208, 209, 2 IO and 2 I I.

82 This collection, including many thousands of pages in German can be found in NASA, Leyds collection, LEY I 98-205.

83 P. A. Nierstrasz to W. J. Leyds, 20 March I905. NASA, Leyds collection, LEY 3 I7.

84 At that time approximately $£_{3}, 333$. Report by Major C. A. Jorissen, I 8 September I929, pp. 3-4. NASA, Leyds collection, LEY 778.

85 'het zijn veelmeer episoden, het persoonlijk beleefde, hetwelk door den schrijver op den voorgrond wordt gebracht'. P. A. Nierstrasz to W. J. Leyds, I I January I904. NASA, Leyds collection, LEY 3 I 7 .

86 Ibid.; P. A. Nierstrasz to W. J. Leyds, 4 July I903. NASA, Leyds collection, LEY 209. In 1904, Nierstrasz accused the authors of a series about the South African War in the 
Dutch periodical Militaire Spectator of the same thing. P. A. Nierstrasz, 'De oorlog in Zuid-Afrika', in Militaire Spectator, vol. 73, no. 5 (May I 904), 380-409, 380-38 I.

87 'objectiviteit'. P. A. Nierstrasz to W. J. Leyds, I I January I904. NASA, Leyds collection, LEY 317.

88 P. A. Nierstrasz to W. J. Leyds, 20 March and I 6 July I905. NASA, Leyds collection, LEY 3 I 7 .

89 P. A. Nierstrasz to W. J. Leyds, I March I906. NASA, Leyds collection, LEY 2I I. The proofs can be found in NASA, Leyds collection, LEY 766-776. It does not contain all the maps.

90 Another fourteen maps were published in the text itself.

9I Brochure from I905 with preface and table of contents of Nierstrasz's history, in French. NASA, Leyds collection, LEY 778.

92 'bouwmateriaal'. Transcript of report by General F. de Bas to Chief of Staff, I 2 February I908; report by Major C. A. Jorissen, I 8 September I929. NASA, Leyds collection, LEY 778 .

93 Both these problems are mentioned in the report by C. A. Jorissen. In fact, The Times History also appeared in an expensive version only, which to a large extent can explain its limited sale numbers, and the enterprise ended with a severe loss. V. Kuitenbrouwer, 'No End of a Lesson', 17 and 34.

94 In 1907 he tried to arrange a popular edition of his book about the annexation of Transvaal. It seems likely that this plan did not materialise. For a dossier with this correspondence, see NASA, Leyds collection, LEY 2 I I.

95 Report by Major C. A. Jorissen, I 8 September I929. NASA, Leyds collection, LEY 778. 96 'Die heer N. en zijn broeder waren - het is mij later duidelijk gebleken - nu niet zoo heel veel zaaks, en ik heb den indruk gekregen, dat zij zich van de Boerenzaak bediend hebben, om zich hier te lande een tijdelijke positie te verzekeren, die zij nauwelijks verdienden en die de zaak der Boeren in ons land, naar ik vrees, niet al te veel goed heeft gedaan'. L. Simons to W. J. Leyds, 6 November I93 I. NASA, Leyds collection, LEY 95.

97 Transcript of report by General F. de Bas to Chief of Staff, I 2 February I908, pp. I920. NASA, Leyds collection, LEY 778.

98 Transcript of Minister of War to P. A. Nierstrasz, 2 I April I908. NASA, Leyds collection, LEY 778.

99 F. V. Engelenburg to W. J. Leyds, 4 October 1927 and 4 September I928. NAsA, Engelenburg collection, A ( I 40), 24. Nierstrasz died in I9I 6.

Io० 'Afrikaanse standaardwerk over den oorlog I899-I902'. Report by Major C. A. Jorissen, I 8 September I929, p. I I. NASA, Leyds collection, LEY 778.

IоI See chapter 3 .

IO2 'foutieve leezing'. C. K. van Trotsenburg to W. J. Leyds, 24 October I900. NASA, Leyds collection, LEY 322.

I03 W. J. Leyds to C. K. van Trotsenburg, 28 November I900. NASA, Leyds collection, LEY 322.

Io4 C. K. van Trotsenburg to W. J. Leyds, 3 February I902. NASA, Leyds collection, LEY 322. 
I05 'waar er een keuze bestaat tusschen voorstellingen van verschillende aard, de ons goede haar het meest welkome is'; 'vraagbaak voor toekomstige geschiedschrijvers'. C. K. van Trotsenburg to W. J. Leyds, 23 February I902. NASA, Leyds collection, LEY 322. I06 The manuscript can be found in NL-HaNA, Asselbergs, 2.2 I.0I3.

I07 Report of the attachés, part I, C. 'Schets van het karakter der Boeren', 337-355. NLHaNA, Asselbergs, 2.21.013, inv.no. 27.

I08 Report by the attachés, part IV, 'Overzicht van den loop der krijgsgebeurtenissen gedurende de eerste maanden van den oorlog', 3i8-320. NL-HaNA, Asselbergs, 2.21.013, inv.no. 29.

I09 The Leyds archive contains five of the nine volumes. NASA, Leyds collection, LEY 779-78I.

I IO J. H. Ram to W. J. Leyds, not dated [May I905?]. NASA, Leyds collection, LEY 3 I7; several letters in: NL-HaNA, Asselbergs, 2.2 I. OI 3 , inv.no. I 2.

I I 'Vele der telegrammen zijn voor gebruik-making geheel ongeschikt en de attachés Ram en Thomson zijn m.i. niet geschikte personen om daaruit een keuze te doen'. W. J. Leyds to L. Botha, 9 June I905. NASA, Leyds collection, LEY 3 I 7.

I I 2 L. Botha to W. J. Leyds, 27 August 1906. NASA, Leyds collection, LEY 3 I 7.

I 3 L. Botha to W. J. Leyds, 27 August I906. NASA, Leyds collection, LEY 3 I 7 ; Leyds ed., Derde verzameling II, I $30-\mathrm{I} 3 \mathrm{I}$.

I 4 '[e]igenaar niet om het bezit, doch om te redden en zoo gewenscht, later weer alles terug te zenden.' Speech by Hidde Nijland, I July I902. NASA, Leyds collection, LEY 9 I 2. I I 5 S. Aubert to J. Pierson, 5 April I900. NASA, Pierson collection, KGP 37. The French Consul-General in Pretoria, S. Aubert, was a member of the world exhibition committee and after the war started, he arranged for the items to be shipped in March and April I900. Another important figure in this respect was Consul-General G. Pott in Lourenço Marques.

I 6 For correspondence concerning the collection of SAR material from the Netherlands, see NASA, Pierson collection, KGP 33 and 3 I.

I I 7 J. Pierson to W. J. Leyds, I 4 August I900. NASA, Leyds collection, LEY 908.

I 8 Statement by B. Veth, 6 November I9I I, and copies of the contracts sent by J. Pierson. NASA, Leyds collection, LEY 907. The consul-general even gave Nijland a fake receipt for the 30,000 francs.

I I 9 List of objects sent from Paris to Dordrecht, NASA, Leyds collection, LEY 907.

I 20 H. C. Bredell to F. Rompel, I 4 September I904. NASA, Leyds collection, LEY 907.

I2I The Bratina reached Nijland via the Boer representative in St. Petersburg H. A. Guilot and Hendrik Muller who had at first tried to store it at the national gallery at the Rijksmuseum. H. P. N. Muller to H. A. Guillot, 28 May I9I6. NASA, Leyds collection, LEY 907.

I 22 Transcript letter F. Rompel to W. J. Leyds, [September I904?]. NASA, Leyds collection, LEY 907.

I 23 '[h]et bestuur zal zich steeds beschouwen als trustee's en het Museum als een leengoed van het Z.A. volk.' Draft statutes for Stichting Zuid-Afrikaansch Museum. NASA, Leyds collection, LEY 907. 
I 24 H. J. Kiewiet de Jonge, S. H. J. de Graaf, F. Stoop and F. Rompel to Willem Leyds, 30 March I905. NASA, Leyds collection, LEY 907.

I 25 Minutes of meeting ZAM committee, I 5, 20 and 27 September and I 8 October I 904. NASA, Leyds collection, LEY 907.

I 26 Minutes of meeting ZAM committee, 25 October I904. NASA, Leyds collection, LEY 907.

I 27 Minutes of meeting ZAM committee, 2 November I904. NASA, Leyds collection, LEY 907.

I 28 W. J. Leyds to F. C. Eloff, I7 December 1906 [incomplete]; G. A. A. Middelberg to W. J. Leyds, 9 April I907. NASA, Leyds collection, LEY 909.

I 29 L. Botha to Hidde Nijland, 26 April I907. NASA, Leyds collection, LEY 909.

I 30 Transcript of G. J. Bolman to Hidde Nijland, I 7 June I907. NASA, Leyds collection, LEY 909. In addition, Nijland demanded that Rompel would not be allowed to have anything to do with the museum and that Botha would ask the Dutch government for a high decoration for the Dordrecht businessman.

I 3 I 'Boer foremen'. Secretary Het Volk to W. J. Leyds, 5 February I908. nAsa, Leyds collection, LEY 909.

I 32 W. J. Leyds to [illegible], 23 January I9 I I. NASA, Leyds collection, LEY 908.

I 33 'Voormannen der Boeren'. Notarial documents, signed in Pretoria, 4 February 1908. NASA, Leyds collection, LEY 909.

I34 'een Boerenvolk'. Copy of verdict of the court at Dordrecht, dated 7 July I9I I; ANV press circular 24 June I9I I. NASA, Leyds collection, LEY 908.

I 35 'rechtvaardige Boeren-zaak'. W. J. Leyds to H. J. D. Bodenstein, 29 November I9I 6. NASA, Leyds collection, LEY 9IO. The main point of controversy seems to have been the fake contracts. J. W. Pont to W. J. Leyds, 30 October I9I6. NASA, Leyds collection, LEY 9 IO.

I 36 W. J. Leyds to F. V. Engelenburg, 6 August I9I7. NASA, Leyds collection, LEY 9I I. I 37 W. J. Leyds to F. V. Engelenburg, 6 and 7 August I9I 7. NASA, Leyds collection, LEY 9II. The painting was eventually sold in I924. W. J. Leyds to F. Muller, 20 February I924. NASA, Leyds collection, LEY 9I 2.

I 38 Apparently there was a great interest in these objects when they were auctioned. H. J. van Bijleveld to W. J. Leyds, 29 September I920. NASA, Leyds collection, LEY 9I 2.

I 39 G. Brebner [secretary to Botha] to H. J. D. Bodenstein, 23 June I9I9. NASA, Leyds collection, LEY 9I 2.

I 40 V. Kuitenbrouwer, 'De geografie van de stamverwantschap'. Some parts of the collection have been moved to other museums, such as the portraits of the Boer leaders that can be found at the African Window in Pretoria and the Anglo-Boer War Museum in Bloemfontein.

I 4 I J. W. Pont to Willem Leyds, 3 I July I920. NASA, Leyds collection, LEY 9I 2. This collection can still be consulted at the University Library of Stellenbosch.

I 42 J. W. Pont to Willem Leyds, I7 June I920. NASA, Leyds collection, LEY 9I 2.

I 43 W. J. Leyds to F. V. Engelenburg, 5 March I930. NAsA, Engelenburg collection, A (I4O), 24. 
I 44 Leyds also asked the SAR Consul-General in Paris, J. Pierson, for his archive, but for unknown reasons this collection was not added. The Pierson papers did end up in Pretoria though, where they are kept in the National Archive. For letters about the transfer, see NASA, Pierson collection, KGP 44.

I 45 Copy of letter from D. F. Malan to W. J. Leyds, I 7 July I930. NASA, Engelenburg collection, A (I 40), 24.

I 46 'De Afrikaners weten weinig van hun geschiedenis en geven er ook niet om. Verhaaltjes die hun ijdelheid streelen, dat is het eenige dat er bij hen ingaat.' W. J. Leyds to F. V. Engelenburg, 25 March I930. NASA, Engelenburg collection, A ( I 40), 24.

I 47 'het publieke leven is geheel verpolitiekt. Het is de vloek van het Dietsche ras dat men liever onderling twist dan samen te werken.' W. J. Leyds to D. Reitz, 26 August and 8 November I930. NASA, Leyds collection, LEY 22 I.

I 48 For examples of Afrikaner nationalists, see J. H. Breytenbach, Die Tweede Vryheidsoorlog (Kaapstad, I949); J. C. Otto, Die konsentratiekampe (Bloemfontein, 1954). For a revisionist vision, see Pretorius, Kommandolewe tydens die Anglo-Boereoorlog.

I 49 Bossenbroek, 'Geschiedschrijving als hoger beroep', 209.

I 50 'monumente', 'een van die bouers aan die tempel van Afrikaanse nasionalisme was'. Quoted in Van Niekerk, Kruger se regterhand, $357-358$.

I 5 I Ibid. $358-359$.

I 52 Ibid. 359-360; Bossenbroek, 'Geschiedschrijving als hoger beroep', 209-2 I0.

\section{Chapter 8}

I ZA, Scrapbook with newspaper excerpts about the attack on the NZAV library.

2 See chapter 7.

3 'hink-stap-sprong'. Bossenbroek, Holland op zijn breedst, 344-352.

4 See chapter 7 .

5 'ophemeling van de Afrikaner'. Jonckheere, Van Mafeking tot Robbeneiland, 209.

6 Schutte, Nederland en de Afrikaners, 209-2 I 2; Schutte, 'Stamverwantschap als imperialisme', I9.

7 'Engeland nu maar zelf voor de nieuwe onderdanen moet zorgen'. ZA, NZAV Jaarverslag $1902,8$.

8 De Graaff, De mythe van de stamvewantschap, 92.

9 Ibid. 146.

Io Ibid. I I 6-I I 8. See also G.J. Schutte, 'Stichting ZASM vier eerste eeuwfeest', in: ZuidAfrika, vol. 86, no. 2 (2009), 32-34.

I I De Graaff, De mythe van de stamverwantschap, i Io, footnote 4.

I 2 Ibid. 63.

I 3 'Beroep op de beschaafde wereld'.

I4 Approximately $£_{103,500}$. Van Niekerk, Kruger se regterhand, 3 I7; De Graaff, De mythe van de stamverwantschap, 92.

I 5 Het Algemeen Handelsblad, I I September 1902.

I6 'staart van een clubje', 'levend organisme'. Cutting from De Amsterdammer, 9 November I902. ZA, NZAV archive, $\mathrm{VI} / \mathrm{I} 83$. 
I7 'hatelijk geschrijf'. Several letters and cuttings in ZA, NZAV archive, VI/I 83 .

I 8 'geleuter'. C. Boissevain to P. den Tex, I I November I902. ZA, NZAV archive, V/I 4.

I9 See chapter 4 .

20 For an overview of responses by the Dutch press to events taking place in South Africa between I 902 and I930, see De Graaff, De mythe van de stamverwantschap, 55-74. For the views of Abraham Kuyper, see Van Koppen, De geuzen van de negentiende eeuw, I $62-208$.

2I There is increasing attention by historians for the position of the Netherlands during the Great War, when it remained neutral. Ismee Tames has shown that some Dutch authors referred to the South African War in the public debate about neutrality, arguing that Great Britain should not be trusted completely, because its imperialistic tendencies were strong. Tames, Oorlog voor onze gedachten, 95, I 53 and 256.

22 De Graaff, De mythe van de stamverwantschap, 68.

23 Hollandsch Zuid-Afrika, I 5 August I9I4, appendix; Valter, Louis Botha contra Generaal Christiaan de Wet; Valter, Generaal Botha tijdens de Engelsch-Afrikaanschen Oorlog.

24 Bodenstein initially published his account as a series of newspaper articles: De Telegraaf, I9, 2 I and 22 June I9I 5 . A year later, a booklet appeared: Bodenstein, Was generaal Botha in I 900 'n verrader? Leyds furnished Bodenstein with material from the archives of the Transvaal legation. See documents in NASA, Leyds collection, LEY 2 I 4 and 2 I 5 .

25 Jonckheere, Van Mafeking tot Robbeneiland, 96; compare with De Graaff, De mythe van de stamverwantschap, 55 .

26 Jonckheere, Van Mafeking tot Robbeneiland, 90-91.

27 'lievelingswensch'. Penning, Uit mijn leven, 200.

28 'Mijn hart heeft getinteld bij dit alles, en opnieuw is de groote liefde voor het "Boerenvolk" aangewakkerd.' Ibid. $20 \mathrm{I}$.

29 'Het was alles precies zoo als ik dacht. Met het oog der liefde had ik Afrika reeds gezien en goed gezien...' Interview with L. Penning in Het Arnhemsch Dagblad, 24 November I924. HDC, Penning collection, $87 / 3$.

30 For a complete bibliography, see Jonckheere, Van Mafeking tot Robbeneiland, 92-96. 3 I 'Het bloed, voor vrijheid en vrede gestort, is niet te vergeefs geplengd. Het pad leidde door de smartelijkste diepten naar de berghoogte der zegepraal.' Penning, Uit mijn leven, 202.

32 Cutting with interview in De Standaard, 29 November I924. HDC, Penning collection, $87 / 3$.

33 Cutting from De Zwolsche Courant, 29 November 1924. HDC, Penning collection, 87/19.

34 Penning, Uitmijn leven, 225.

35 'warme liefde en sterk meeleven [...]. Hun geschiedenis is een doorloopende strijd voor vrijheid en recht, een machtige kamp van bloed en tranen. Die strijd heeft weerklank gevonden in de harten van ons volk.' Ibid. 2 I 8.

36 For this view, see De Graaff, De mythe van de stamverwantschap, 55 . 
37 See chapter 2.

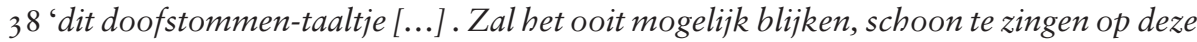
gebarsten viool?'. C. Scharten, 'Overzicht der Nederlandsche letteren', in: De Gids, vol. 74, no. 2 (I9IO), 538-539; press circular by F. Rompel, 4 June I9IO. NASA, Leyds collection, LEY 87 I.

39 'drang', 'We onderhouden de wederzijdsche vriendschap best, als we elk voor ons doen wat we voor ons zelf noodig achten, en daarbij elkanders standpunt leeren waardeeren.' L. Simons, 'Van onder 't kouter', in: De Ploeg. Geïllustreerd maandblad van de wereld-bibliotheek, vol. 2 (1909-1910), 63-64, 64; Press circular by F. Rompel, not dated [August I 909?]. NASA, Leyds collection, LEY 87 I.

40 See chapters I and 2.

4I '[d]aar gaat de beweging met grote kracht voorwaarts, zodat ze veel verder zijn dan wij'. 'Verslag', in: Vereenvoudiging. Orgaan van de Vereniging tot vereenvoudiging van onze schrifftaal, vol. Io ( I 5 July I906), I I-I3, I 2; Press circulars by F. Rompel, not dated [May I906?] and I June I909. NASA, Leyds collection, LEY 870 and 87 I.

42 'Ons adres', in: Vereenvoudiging. Orgaan van de Vereniging tot vereenvoudiging van onze schrijftaal, vol. I 2 (30 November I908), 47-52, 47 and 5I.

43 Press circular by F. Rompel, 25 June 1909. NASA, Leyds collection, LEY 87I. The Vereniging tot Vereenvoudiging van onze schriftaal opposed the plan of an official committee, as it feared (and rightfully so) that it would delay the reforms. Vereenvoudiging. Orgaan van de Vereniging tot vereenvoudiging van onze schriftaal, vol. I 2 (30 November I908), I-2.

44 Newspaper cuttings from the Netherlands, ZA, NZAV archive, XI B/2.

45 Press circular by F. Rompel, 27 April I906. NASA, Leyds collection, LEY 870.

46 Press circulars by F. Rompel, 6 September 1907, not dated [October I908?]. NASA, Leyds collection, LEY 870 and $87 \mathrm{I}$.

$47 \mathrm{~J}$. Klöters argues that this song became known in the Netherlands around I920. Klöters, In die grote stad Zaltbommel, 229.

48 Hendricks, Die Betrekkinge tussen Nederland en Suid-Afrika, 7.

49 Schutte, 'De organisatie van de Stamverwantschap', n.p.

50 See chapter 4 .

5I Hendricks, Die betrekkinge tussen Nederland en Suid-Afrika, I 3-I 4.

52 Hemstra, De culturele betrekkingen tussen Nederland en Zuid-Afrika, 2 I and 49.

53 M. Kuitenbrouwer, De ontdekking van de Derde Wereld, 249-250.

54 Hendricks, Die betrekkinge tussen Nederland en Suid-Afrika, 3 I-32 and 36; Schutte, Stamverwantschap onder druk. Jan Smuts, however, was welcomed as a war hero when he visited the Netherlands in I946. Ibid. 47-50; Buis, Verre vrienden, 32.

55 Hendricks, Die betrekkinge tussen Nederland en Suid-Afrika, I 23 - 25.

56 Ibid. 220-222; M. Kuitenbrouwer, De ontdekking van de Derde Wereld, 2I3-2I4.

Canada and Australia, however, were more popular destinations.

57 Hendricks, Die betrekkinge tussen Nederland en Suid-Afrika, I 38 - 39.

58 Schutte, Stamverwantschap onder druk, I 26-I 38.

59 ZA, NZAV Jaarverslag I 95 I, I. 
6o Ledden, Jan van Riebeeck, 56-98.

6I Hendricks, Die betrekkinge tussen Nederland en Suid-Afrika, I75.

62 Ibid. I $8 \mathrm{I}-\mathrm{I} 82$. Queen Juliana refused to go in protest against the apartheid regime.

63 R. Rozenburg, De Bloedband Den Haag-Pretoria, I 5-I 6.

64 M. Kuitenbrouwer, De ontdekking van de Derde Wereld, 2 I 4.

65 Buskes, Zuid-Afrika's apartheidsbeleid, 286; M. Kuitenbrouwer, De ontdekking van de Derde Wereld, 2 I 5 .

66 Hendricks, Die betrekkinge tussen Nederland en Suid-Afrika, I 8-190 and 200-202. 67 De Boer, Van Sharpeville tot Soweto, 8 I-85.

68 Hendricks, Die betrekkinge tussen Nederland en Suid-Afrika, 2 I3-2 I 7; Schutte, De roeping ten aanzien van het oude broedervolk, I I-24.

69 Hendricks, Die betrekkinge tussen Nederland en Suid-Afrika, 248.

$70 \mathrm{ZA}$, NZAV Jaarverslag I96 I, 3.

7I Hendricks, Die betrekkinge tussen Nederland en Suid-Afrika, 240; Schutte, De roeping ten aanzien van het oude broedervolk, 25-32; M. Kuitenbrouwer, De ontdekking van de Derde Wereld, 2I7; De Boer, Van Sharpeville tot Soweto, I34-I 54.

72 Schutte argues that this was meant to avoid having to make a decision about economic boycotts. Schutte, De roeping ten aanzien van het broedervolk, 5 I. Compare with M. Kuitenbrouwer, De ontdekking van de Derde Wereld, 222-223; De Boer, Van Sharpeville tot Soweto, 349-353.

73 M. Kuitenbrouwer, De ontdekking van de Derde Wereld, 224-225.

74 'kortzichtigheid'; 'dialoog'. ZA, NZAV Jaarverslag I977, 4-I4; De Boer, Van Sharpeville tot Soweto, 360.

75 M. Kuitenbrouwer, De ontdekking van de Derde Wereld, 220-22 I.

76 Ibid. 227.

77 'een organisatie die propaganda maakt voor een fascistisch en moorddadig regime'. ZA, Scrapbook with newspaper excerpts about the attack on the NZAV library.

78 'verkalkt gezelschap'. ZA, Scrapbook with newspaper excerpts about the attack on the NZAv library.

79 Schutte, Nederland en de Afrikaners, 66; Schutte, De roeping ten aanzien van het oude broedervolk, 48-52.

80 De Boer, Van Sharpeville tot Soweto, 370.

8 I Schutte, 'Stamverwantschap als imperialisme', I9. 



\section{Bibliography}

\section{Primary sources}

\section{Archival sources}

National Archives of South Africa (NASA), Pretoria

Collection W. J. Leyds (LEY)

Collection F. V. Engelenburg (A I 40)

Collection J. Pierson (KGP)

Collection Gustav Preller (A 787)

\section{University of Stellenbosch}

Pamphlet Collection W. J. Leyds

\section{Zuid-Afrikahuis (ZA), Amsterdam}

NZAV archives

NZAV Jaarverslagen

Collection Algemeen Nederlandsch Verbond (ANV)

Collection F. Beelaerts van Blokland (ғв в)

Collection Herman Coster Fonds (HCF)

Collection H. J. Emous (EM)

Collection Nederlandsche Emigratie Maatschappij (NEM)

Collection Nederlandsch Bijstandsfonds Zuid-Afrika (NBZA)

Collection A. Welcker (newspaper cuttings)

\section{Nationaal Archief (NL-HaNA), Den Haag}

Collection W. J. Leyds. Collection number 2.21.105

Collection C. J. Asselbergs. Collection number 2.2 I.OI 3

Collection familie Beelaerts van Blokland. Collection number 2.2 I.253

Collection familie Middelberg. Collection number 2.21.232

Collection Bas Veth. Collection number 2.21.167 
Historisch Documentatiecentrum voor het Nederlands Protestantisme (HDNP), Free University Amsterdam

Collection L. Penning. Collection number 87

Collection J. A. Wormser. Collection number 258

Universiteitsbibliotheek, University of Amsterdam

Collection Hollandsch-Afrikaansche Uitgevers-Maatschappij

Gemeente Archief Amsterdam (GAA)

Collection Charles Boissevain. Collection number 394

\section{Periodicals}

Het Algemeen Handelsblad

Het Christelijk Schoolblad

Elsevier's Geillustreerd Maandblad

De Gids

Hollandsch Zuid-Afrika

Maandelijksche Mededeelingen van het bestuur den Nederlanschen Journalisten Kring

De Militaire Gids

Militaire Spectator

Neerlandia

De Nieuwe Courant

De Nieuwe Rotterdamsche Courant (NRC)

Op! Voor Transvaal

De Ploeg. Geillustreerd maandblad van de wereld-bibliotheek

De Standaard

De Telegraaf

The Times

Voor de Boeren, Orgaan der Vereeniging: Het Christelijk Nationaal Boeren-Comité Woord en beeld

Vereenvoudiging. Orgaan van de Vereniging tot vereenvoudiging van onze schriftaal Zuid-Afrika

\section{Publications}

Address to the Members of the Anti-Slavery and Aborigines Protection Societies upon the Native Question. By the Transvaal Deputation (London, I883).

'Afrikaner', De Zuid-Afrikaansche nederzetting in Dordrecht, Zuid-Afrikaansche vlugschriften, no. I2 (Dordrecht, I902).

Aitton, D., Geschiedenis van Zuid-Afrika met een inleiding over de algemeene geschiedenis voor de scholen in de Zuid-Afrikaansche Republieken (Amsterdam/Pretoria, I 897).

Aitton, D., Eene bladzijde uit de geschiedenis van den Oranje-Vrijstaat, Zuid-Afrikaansche vlugschriften, no. 4 (Dordrecht, I 899). 
Aitton, D., De Oranje-Vrijstaat. Schets van land en volk (Leiden, I900).

Ambtelijke verslagen van generaal J. H. De la Rey en generaal J. C. Smuts, als ook andere stukken betreffende de oorlog in Zuid Afrika, kort geleden ontvangen door de Boerenvertegenwoordigers in Europa, en met hun toestemming openbaar gemaakt (Amsterdam, I902).

Andriessen, W. F., Jameson's rooftocht gerechtvaardigd? (Amsterdam, I 896).

Andriessen, W. F., Gedenkboek van den oorlog in Zuid-Afrika (Amsterdam/Cape Town, I904).

'Antibull', De inval in Transvaal of de ware grieven der Uitlanders, 'n waarachtig verhaal (Haarlem, I 899).

'B. ot H. Anicus', De onderhandelingen van Lord Kitchener en Louis Botha, zooals de Commandant-Generaal Louis Botha mij deze gebeurtenis verteld heeft (Amsterdam, I90I).

Badenhorst, C. C. J., Uit den Boerenoorlog I 899-I902 (Amsterdam/Pretoria, I903).

Bastings, E., Brochure contra Leyds (Luik, I902).

Beelaerts van Blokland, F., Wat Kunnen wij doen voor onze broeders in Zuid-Afrika?, Zuid-Afrikaansche vlugschriften, no. ( Dordrecht, I 899).

Beelaerts van Blokland, F. A. G, De Oranje-Vrijstaat (Amsterdam, I900).

Blink, H., Transvaal en omliggende landen (Amsterdam, I 889).

Blink, H., Britsche koloniale politiek in Zuid-Afrika en de vrijheidsstrijd der Boeren. Historische schets (Amsterdam, I 899).

Bloch, J. de, Wat wij uit den Transvaalschen oorlog leeren kunnen (Haarlem, I900).

Bloch, J. de, Wat er uit den oorlog in Zuid-Afrika te leeren valt (Haarlem, I90I).

Bodenstein, H. D. J., Was generaal Botha in I 900 'n verrader? (Amsterdam/Pretoria/ Johannesburg/Cape Town, I916).

Boissevain, C., 'The Case for Holland' in: C. B. Spruyt, C. Boissevain and L. Enfield, The Transvaal Question (London/Amsterdam, I 896), 8 I-97.

Boissevain, C., The Struggle of the Dutch Republics: Open Letter to the Duke of Devonshire (Amsterdam, I900).

Boissevain, C., The Struggle of the Dutch Republics: Open Letter to an American Lady (Amsterdam, I900).

Boissevain, C., A Great Crime: An Appeal to the Consciousness of the British Nation (Amsterdam, 1900).

Boissevain, C., Van dag tot dag: verzamelde opstellenvan Charles Boissevain, L. Aletrino ed. (Amsterdam, I925).

Boldingh, G., Een Hollandsch officier in Zuid-Afrika. Nagelaten geschriften van Luitenant Gerrit Boldingh, G. H. Priem ed. (Rotterdam, I903).

Boer en Brit (Amsterdam/Cape Town, not dated).

Bosman, I. D., Dr. George Mc Call Theal as die geskiedskrywer van Suid-Afrika (Amsterdam, I93I).

Brandt-Van Warmelo, J., Die kappie kommando of Boerevroue in geheime dienst (Cape Town/Amsterdam, I9I3).

Brief van den heer F. W. Reitz, Staats-Secretaris van de Zuid-Afrik. Republiek aan den 
heer P. J. Blignaut, Gouvernements-Secretaris van den Oranje-Vrijstaat (Dordrecht, I 899).

Buskes, J. J., Zuid-Afrika's apartheidsbeleid: onaanvaardbaar (The Hague, I955).

Colenbrander, H. T., De afkomst der Boeren (Amsterdam, I902).

De Boeren op Sint-Helena. Album met afbeeldingen en bijschriften van S. J. E. (Amsterdam/Pretoria, [no date]).

De Vereeniging Het Nederlandsche Roode Kruis in den Transvaalsch-Engelschen oorlog, I 899-I90I (The Hague, I90I).

Dordrecht-Transvaal Album van "De Zondagsbode voor Stad en Land" (Dordrecht, I900).

Douwes Dekker, E. F. E., Wilhelmina-dag op Ceylon. Herineringsalbum van de Ragamafeesten op 3 I Augustus I90 I. I 8 platen in lichtdruk met voorrede van J. B. Schepers (Haarlem, not dated).

Dum-dum's der publieke opinie (Amsterdam, [1900]).

Een sensationeele brief uit Zuid-Afrika. Onthullingen omtrent den werkelijken toestand (Amsterdam, [i 899]).

Elout, C. K., and F. Rompel, 'Olive Schreiner', in: J. Kalff ed., Mannen en Vrouwen van Beteekenis in onzen dagen. Levensschetsen en portretten, vol. 3 I (Haarlem, I900), 87-I I6.

'Etine', Voor Transvaal: zes gedichten (Leiden, I 899).

Everdingen, W. van, De oorlog in Zuid-Afrika. Eerste tijdvak (Delft, I902).

Feith, J. and K. van Ponten, Pillen voor Joe (Amsterdam, [I900]).

Fredericq, P., De toekomst van den Nederlandschen stam. Rede den 26 en Augustus I 897 op het XXIVe Ned. taal- en letterkundig congres te Dordrecht gehouden ([Dordrecht], [I897]).

Froude, J. A., Oceana or England and her Colonies (Leipzig, I 887).

Fruin, R., A word from Holland on the Transvaal Question (Utrecht, I88I).

Gerraets, J.H., Dijkstra's ondervindingen in Zuid-Afrika. Een verhaal voor jongens (Amsterdam, I 898).

Gogh, H. A. van, Weerstaat den Rhodesgeest!, Zuid-Afrikaansche vlugschriften, no.2 (Dordrecht, I 899).

Harcourt, W., Een banierdrager der gerechtigheid. Sir W. Harcourt's rede gehouden in het Eng. Parlement (L.-H.) op 8 mei I 896. Het onrecht der Zuid-Afrikaansche Republiek aangedaan, door een Engelsch staatsman in een schitterend daglicht gesteld (The Hague, I 896).

Harpen, N. van, Nederland Zuid-Afrika ten voordele van het Roode Kruis in de ZuidAfrikaansche Republieken (Amsterdam, I899).

Hartlooper, L., Transvaal A-B-C-: coupletten (Rotterdam, I 899).

Heeres, J. E., Heeft Nederland de Kaap verkocht. Eene lezing (Amsterdam/Pretoria, I 898).

Hellemans, Zuster, Met het Roode Kruis mee in de Boeren-Vrijheidsoorlog (Amsterdam, I90I).

Helsdingen, J. van, Vrouwenleed. Persoonlijke ondervindingen in den Boerenoorlog (Amsterdam/Cape Town, I903). 
Hobhouse, E., Report to the Committee of the Distress Fund for South African Women and Children (London, I90I).

Hobson, J. A., The War in South Africa: Its Causes and Effects (London, I900).

Hobson, J. A., The Psychology of Jingoism (London, I90I).

Hoedemaker, P. J., A Plea on behalf of Equity and Truth: Message to the Churches of Great Britain (Amsterdam, I90I).

Hofmeyr, N., Zes maanden bij de commando's (The Hague, 1903).

Hogeweg, G., Een Engelsche spion in de knel, of, hoe Generaal De Wet trakteert: samenspraak voor zeven personen, ten dienste van jongelings-, zang, en reciteervereenigingen (Oostwolde, I908).

Hoogeveen, J., Lieve vrouw en kinders. Brieven van een Urker onderwijzer op zoek naar een nieuwe toekomst in Zuid-Afrika, Ena Jansen ed. (Baarn, I983).

Ihle, D. D., Dagelijks leven van de Boeren krijgsgevangeven [sic] te Diyatalawa, Ceylon, van photografen door een der krijgsgevangeven [sic], bijgestaan door H. Meester en andere krijgsgevangeven [sic] (Colombo, I900).

In memoriam NZASM (Amsterdam, I909).

Ittersum, W. A. van, De Vrijstaters en hun geschiedenis (Leiden, I900).

Janson, J. H., jr. ed., Het verbranden van hoeven in Zuid-Afrika: het verbranden en plunderen van Dullstroom (reprint from New Age; Amsterdam, I901).

Jeltes, H., Uit het dagboek van H. Jeltes, verpleger bij 't Nederlandsche Roode Kruis in den oorlog van Engeland tegen de Zuid-Afrikaansche Republieken (Enkhuizen, I90I).

Jorissen, E. J. P., Transvaalsche herinneringen, I 876-I 896 (Amsterdam/Pretoria, I 897).

Joubert, P. J., Transvaal. De lijdensgeschiedenis van de Hollandsche Kaapbewoners onder Engelsche heerschappij (Rotterdam, I 899).

Junius, J. H., De koloniën en staten van Zuid-Afrika. Gids voor hen, die zich naar die streken wenschen te begeven (Tiel, I882).

Kestell, J. D., Met de Boeren-commando's. Mijne ervaringen als veldpreker (Amsterdam/Pretoria, I902).

Kiewiet de Jonge, H. J., 'Een woord ter Inleiding', in: 'Een Gedenkboek van het Algemeen Nederlandsch Verbond bij Geleegenheid van zijn 25-jarig bestaan: Geschiedenis en Invloed van den Nederlandschen Stam (Amsterdam, I923), 8-I 2.

Kloppers, P. J. ,Alles zal rech kom!” Schetsen uit den strijd tusschen Boer en Brit (The Hague, I902).

Kolstee, H. J., Transvaal album bevattende een overzicht der geschiedenis van Zuid-Afri$k a$ tot den tegenwoordigen tijd (Amsterdam, I 899).

Kolstee, H. J., ed., De oorlog in Zuid-Afrika in woord en beeld (Delft, I 899).

'Korpl. Archilles', Aanleiding tot den Engelsch-Transvaalschen oorlog. Feiten op waarheid gegrond en voor het nageslacht verzameld (The Hague, not dated).

Kras, C. and K. Ponten, Kronings-idylle (Amsterdam, not dated).

Kretschmar van Veen, J. A. van, Rapporten van den directeur J. A. van Kretschmar van Veen aan den raad van commissarissen betreffende de verrichtingen der mij. in ZuidAfrika tijdens de oorlog I899-I900 (Amsterdam, I902). 
Kuyper, A., La Crise Sud-Africaine (Paris, I900).

Kuyper, A., De crisis in Zuid-Afrika, C. K. Elout ed. (Amsterdam, I900).

Kuyper, A., The South African Crisis, A. E. Fletcher ed. (London, I900).

Leiden Zuid-Afrika album (Leiden, I 899).

Leyds, W. J., The First Annexation of the Transvaal (London, I906).

Leyds, W. J., The Transvaal Surrounded: a Continuation of the 'First Annexation of the Transvaal' (London, I9I9).

Leyds, W. J., ed., Eenige Correspondentie uit I 899 (The Hague, I919).

Leyds, W. J., Een geschrift van Dr. H. P. N. Muller (Dordrecht, I930).

Leyds, W. J., ed., Tweede verzameling (Correspondentie I899-I900) II (The Hague, I930).

Leyds W. J., ed., Derde verzameling (correspondentie I900) II (Dordrecht, I93 I).

Leyds W. J., ed., Vierde verzameling (Correspondentie I900-1902) II (The Hague, I934).

Lion Cachet, F., De worstelstrijd der Transvalers aan het volk van Nederland verhaald (Amsterdam, I882).

Louter, J. de, La Question du Transvaal (Brussels/Amsterdam/Paris, I 896).

Mansvelt, N., In memoriam: prof. $d r$. C. Bellaar Spruyt (Amsterdam, I901).

Mansvelt, N., De betrekkingen tusschen Nederland en Zuid-Afrika sedert de verovering van de Kaapkolonie door de Engelschen (Utrecht, 1902).

Mansvelt, N., ed., Hollands-Afrikaanse Liederbundel (Amsterdam/Cape Town/Pretoria, I907).

Mansvelt, N., Taalverwantschap en het gemeen belang van Nederland en Zuid-Afrika (reprint from Letterbode; not dated).

Mettius, M., Het hypnotisme in den oorlog, of het vreemde gedrag der dappere strijders van voorheen verklaard en toegelicht (Kampen, I900).

Mijnssen, F. J., De depecherijder van De Wet (Utrecht, I901).

Muller, H. P. N., Zuid-Afrika. Reisherinneringen (Leiden, I889).

Muller, H. P. N., De Zuid-Afrikaansche Republiek en Rhodesia (The Hague, I 896).

Muller, H. P. N., 'Oom Paul', in: E. D. Pijzel ed., Mannen en Vrouwen van Beteekenis in onzen dagen. Levensschetsen en portretten, vol. 27 (Haarlem, I 896).

Muller, H. P. N., Is de Kaapkolonie verkocht? (Amsterdam, I9I9).

Overzicht van de verrichtingen der Nederlandsche Vereenigingen en Comités voor de noodlijdenen door den Zuid-Afrikaanschen oorlog (Amsterdam, I902).

Penning, L., De oorlog in Zuid-Afrika. De strijd tusschen Engeland en de verbonden Boeren-Republieken Transvaal en Oranje-Vrijstaat in zijn verloop geschetst III (Rotterdam, I899-I903).

Penning, L., De helden van Zuid-Afrika. Een verhaal uit den "Trek" der Afrikaansche Boeren uit de Kaapkolonie naar Transvaal (Gorichem, I900).

Penning, L., Vredeburg: een novelle uit den Kaapschen Boerenopstand van I899-1902 (The Hague, 1902).

Penning, L., De overwinnaar van Nooitgedacht. Verhaal uit den Boeren-Oorlog (Zwolle, I925).

Penning, L., De leeuw van Modderspruit. Verhaal uit den Boeren-Oorlog (I899-I902) (Zwolle, I927). 
Penning, L., De verkenner van Christiaan de Wet. Verhaal uit den Boeren-Oorlog (Zwolle, I927).

Penning, L., De kolonist van Zuid-Afrika. Verhaal uit den Boeren-Oorlog (Zwolle, I927).

Penning, L., Uit mijn leven (Zwolle, I927[?]).

Penning, L, De held van Spionkop (Zwolle, I949).

Plokhooy, C., Met den Mauser. Persoonlijke ervaringen in den Zuid-Afrikaanschen oor$\log$ (Gorichem, I90I).

Priem, G. H., ed., De oorlog in Zuid-Afrika: bewerkt naar officieele telegrammen en particuliere brieven VIII (Amsterdam, I 899-I90I).

Prospectus Nederl. Maatschappij tot de Handhaving van Stamverwante Belangen in Zuid-Afrika (Amsterdam, I900).

Raal, S., Met die boere in die veld: die ervarings van die skryfster (Cape Town, I937).

Ram, J. H., and L. W. J. K. Thomson, Lessen uit den Zuid-Afrikaanschen oorlog (Haarlem, [1902]).

'Ratane', Vrede in Zuid-Afrika (Amsterdam/Pretoria, I 899).

Reesema, A. S. van, Een stoomvaartverbinding met Zuid-Afrika, Zuid-Afrikaansche vlugschriften, no. 3 (Dordrecht, I900).

Reineker, J., Lord Kitchener en De Wet, of, zoo zie je iemand en zoo zie je niemand! Sensatie-voordracht voor twee heeren (Amsterdam, not dated).

Reitz, F. W., Vifftig uitgesogte Afrikaanse Gedigte (Cape Town, I 888).

Reitz, F. W., Sestig uitgesogte Afrikaanse Gedigte (Amsterdam/Pretoria, I 897).

Reitz, F. W., 'President Steyn', in: J. Kalff ed., Mannen en vrouwen van beteekenis in onzen dagen. Levensschetsen en portretten, vol. 32 (Haarlem, I902), I97-220.

Reitz, H., De dochter van den Handsopper (Amsterdam, I903).

Rey, Mevrouw De la, Mijne omzwervingen en beproevingen gedurende den oorlog (Amsterdam/Pretoria, I903).

Ritter, P. H., De Courant: haar opbouw en beteekenis/W. Stead (Groningen, I93 I).

Romeyn, D., Met de ie Nederlandsche Roode-Kruis ambulance naar Zuid-Afrika (no place, not dated).

Rompel, F., Uit den tweeden (Transvaalschen) vrijheidsoorlog (Amsterdam, I900).

Rompel, F., Een studie in proclamaties, Zuid-Afrikaansche vlugschriften, no. I I (Dordrecht, I90I).

Rompel, F., Siegen oder Sterben (The Hague, I902).

Rompel, F., Marthinus Theunis Steyn (Amsterdam, I902).

Rompel, F., The Heroes of the Boer War (The Hague/Pretoria/London, I903).

Rompel, F., 'Dr. E. J. P. Jorissen', in: J. Kalff ed., Mannen en Vrouwen van Beteekenis in onzen dagen. Levensschetsen en portretten, vol. 35 (Haarlem, I905).

Rovers, J. H., De Transvalers en hunnen heldhaftige vrouwen (Amsterdam, I 896).

Rudolph, R. J. W., Houdt aan in het gebed voor Transvaal! Predikatie uitgesproken op woensdag 30 November 1899 in den bidstond der Geref. kerken te Leiden A, B en C (Kampen, I899).

Sandberg, C. G. S., Twintig jaren onder Krugers Boeren in voor-en tegenspoed (Amsterdam, I943). 
Schultz, W. L. v. R., ed., Dagboek van C. J. Asselbergs (Pretoria, I978).

Siethoff, E. G. A. ten, Een verdediging van Engeland? (reprint Onze Eeuw; Haarlem, I902).

Siethoff, E. G. A. ten, La convention de Genève et les ambulances des sociétés de la CroixRouge, avec appendice: la décalaration $d u d r$. Florian Albrecht (Amsterdam, I902).

Simons, L., Stambelangen: een korte toespraak gehouden te Antwerpen 6 October 1900 (The Hague/Pretoria, I900).

[Smuts, J. C.], Een eeuw van onrecht (2nd edition; Dordrecht, I900).

[Smuts, J. C.], A Century of Wrong (London, [1 899]).

Spruyt, C. B., Afrikaners en Nederlanders. Bijdragen tot verspreiding van kennis aangaande Zuid-Afrika (Amsterdam, I896).

Spruyt, C. B., 'The Case for the Boers', in: C. B. Spruyt, C. Boissevain and L. Enfield, The Transvaal Question (London/Amsterdam, I 896), 61-72.

Spruyt, C. B., Engeland en Transvaal (Amsterdam, I 897).

Stratham, F. R., Blacks, Boers, and British: A Three-Cornered Problem (London, I 88I).

Stead, W. T., How not to make Peace (London, I900).

Stead, W. T., 'Methods of Barbarism'. The Case for Intervention (London, I901).

Steinmetz, T., De Nederlandsch Zuid-Afrikaansche Spoorweg-Mij. in den TransvaalschEngelschen oorlog I 899-I900 (reprint De Ingenieur; The Hague, I900).

Templeman van der Hoeven, P., Gevangen op Ceylon. III: open brief aan den minister van buitenlandsche zaken (Utrecht, I902).

Theal, G. McCall, History of the Boers in South Africa (London, I 887).

Theal, G. McCall, History of South Africa (London, I 897).

Theal, G. McCall, De geschiedenis van Zuid-Afrika (The Hague/Johannesburg I 897).

Thieme, C., 'William Stead', in: J. Kalff ed., Mannen en Vrouwen van Beteekenis in onzen dagen. Levensschetsen en portretten, vol. 33 (Haarlem, I903), 83-I 26.

'Transvaler', Transvaal (Rotterdam, I 897).

Tromp, M. Th., Herinneringen uit Zuid-Afrika ten tijde der annexatie van de Transvaal (Leiden, I 879).

Valter, M. P. C., Louis Botha contra Generaal Christiaan de Wet (uit onuitgegeven stukken) (Amsterdam/Rotterdam, I9I 5 ).

Valter, M. P. C., Generaal Botha tijdens de Engelsch-Afrikaanschen Oorlog in 1900 (Amsterdam/Rotterdam, I9 I 5).

VerLoren van Themaat, H., Twee jaren in den Boerenoorlog (Haarlem, I903).

Verslag van de werkzaambeden der vereeniging Het Christelijk Nationaal BoerenComité, gedurende het jaar 1902 (no place, not dated).

Veth, P. J., Onze Transvaalsche broeders (Amsterdam, I88I).

Viljoen, B. J., Mijne herinneringen uit den Anglo-Boerenoorlog (Amsterdam, I902).

Wallach, I., Die Volmaakte „,Gentleman”: intieme kykies op die lewe van dr. F. V. Engelenburg, na 'n vennootskap en vriendskap van sowat veertig jaar (Pretoria, 1945 [?]).

Warmelo, D. S. van, Mijn commando en guerilla-commando leven (Amsterdam, I90I).

Waszklewicz-Van Schilfgaarde, B., ed., Paul Kruger's tocht. Getrouwe beschrijving van Oom Paul's bezoek aan Frankrijk, De Rijnprovincie en Nederland, opgeluisterd door illustratiën naar moment photographieën (The Hague/Leiden, I90I). 
Waszklewicz-Van Schilfgaarde, B., Plea for the grant of a neutral territory of the Boer women and children (The Hague, I90I).

Wet, C. de, De strijd tusschen Boer en Brit (Amsterdam/Pretoria, I903).

Winkel, J. te, Het Nederlandsch in Noord-Amerika en Zuid-Afrika (Amsterdam, I 897).

Winkel, J. te, De Nederlandsche taal in Zuid-Afrika. Rede den 25 sten Augustus I 897 op het XXIVe Ned. taal-en letterkundig congres te Dordrecht gehouden (Dordrecht, I897).

Winkel, J. te, Waar het om gaat in Zuid-Afrika. Een woord tot het Nederlandsche volk (Haarlem, I 899).

Wormser, J. A., Van Amsterdam naar Pretoria, acht maanden in Zuid-Afrika (Amsterdam/Pretoria, I 898).

Wormser, J. A., 'Petrus Jacobus Jourbert', in: J. Kalff ed., Mannen en Vrouwen van Beteekenis in onzen dagen. Levensschetsen en portretten, vol. 3 I (Haarlem, I900).

Wormser, J. A., Drie en zestig jaren in dienst der vrijheid. De levensgeschiedenis van generaal Joubert aan de jongens van Hollandschen stam verhaald (Amsterdam/Pretoria, I900).

Wormser, J. A. jr., Wat ik zag en hoorde op een ambulancetrein: ervaringen van een rodekruis-man, Zuid-Afrikaansche vlugschriften, no. 8 (Dordrecht, I900).

Wormser, J. A. jr., Een der oorzaken van den oorlog in Zuid-Afrika en iets over het onderwijs in Transvaal. Gevolgd door een bibliografisch overzicht van de voornaamste werken verschenen over Zuid-Afrika (Amsterdam/Pretoria, I900).

Zuid-Afrikaansche tentoonstelling. Catalogus der Zuid-Afrikaansche tentoonstelling van de Vereeniging, het Noorden te Rotterdam in 'Transvalia' en op het daarnaast gelegen terrein Bergweg-Benthuizenstraat (Rotterdam, I901).

\section{Secondary literature}

Attridge, S., Nationalism, Imperialism and Identity in Late Victorian Culture, Civil and Military Worlds (Basingstoke/New York, 2003).

Badsey, S. 'A Print and Media War', in: C. Wilcox ed., Recording the South African War: Journalism and Official History (London, I999), 5-I6.

Badsey, S., 'The Boer War as Media War', in: P. Dennis, and J. Grey eds., The Boer War. Army Nation Empire (Canberra, 1999), 70-83.

Badsey, S., 'War Correspondents in the Boer War', in: John Gooch ed., The Boer War. Direction, Experience and Image (London, 2000) I 87-202.

Bank, J. Th. M. and M. van Buuren, I900: Hoogtij van burgerlijke cultuur (The Hague, 2000).

Beaumont, J., 'The British Press and Censorship during the South African War I899I902', in: South African Historical Journal, vol. 4I (I999), 267-289.

Beaumont, J., 'The Making of a War Correspondent: Lionel James of the Times', in: D. Omissi and A. S. Thompson eds., The Impact of the South African War (Basingstoke, 2002), I 24-I 37 .

Beckett, I., 'British Official History and the South African War', in: C. Wilcox ed., Recording the South African War: Journalism and Official History (London, I999), $33-42$. 
Berne, F. van, 'Het Algemeen-Nederlands Verbond I 98 5-I995', in: P. van Hees and H. de Schepper eds., Tussen Cultuur en Politiek Het Algemeen-Nederlands Verbond I 895I995 (Hilversum/The Hague, I995), 29-I I7.

Besselaar, G., Zuid-Afrika in de letterkunde (Johannesburg/Pretoria/Cape Town/Amsterdam, I9I4).

Bloembergen, M., Colonial Spectacles: The Netherlands and the Dutch East Indies at the World Exhibitions, I 880-I93 I, translated by B. Jackson (Singapore, 2006).

Boer, S. de, Van Sharpeville tot Soweto. Nederlands regeringsbeleid ten aanzien van apartheid, 1960-1976 (The Hague, 1999).

Bossenbroek, M., Holland op zijn breedst: Indië en Zuid-Afrika in de Nederlandse cultuur omstreeks I900 (Amsterdam, I996).

Bossenbroek, M., 'Geschiedschrijving als hoger beroep. Willem Johannes Leyds, advocaat van de Boeren (I 859 -I940)', in: M. Bossenbroek ed., Historici in de politiek (Leiden, I996), I9I-2II.

Breytenbach, J. H., Die geskiedenis van die Tweede Vryheidsoorlog I 899-I902 V (Pretoria, I969-I983).

Bridge, C. and K. Fedorowich, 'Mapping the British World', in: The Journal of Imperial and Commonwealth History, vol. 3 I (2003), I-I 5.

Bromley, J. S. and E. H. Kossmann eds., Papers delivered to the Oxford-Netherlands historical conference I959 (London, I960).

Bromley, J. S. and E. H. Kossmann eds., Britain \& the Netherlands in Europe and Asia: Papers delivered to the Third Anglo-Dutch Historical Conference (London/Melbourne/Toronto, I968).

Buis, H., Verre vrienden. Het Nederlands buitenlands beleid tegen Zuid-Afrika in de periode I945-I973 (unpublished MA thesis, University of Amsterdam, I99[?]).

Burton, A., Burdens of History: British Feminists Indian Women and Imperial Culture (Durham, I994).

Cain, P. J. and A. G. Hopkins, Imperialism: Innovation and Expansion, I688-I9I4 (London, I993).

Changuion, L., Uncle Sam, John Bull en Oom Paul. Amerika en die Anglo-Boereoorlog I 899-I 902 (Pretoria, 200I).

Colenbrander, H. T., Het boek van Dr. Leyds (Amsterdam, reprint De Gids; I906).

Conradie, E., Hollandse skrywers uit Suid-Afrika II (Cape Town/Pretoria, I934-I949).

Darwin, J., 'Imperialism and the Victorians: The Dynamics of Territorial Expansion', in: The English Historical Review, vol. I I 2 (I997), 6I4-642.

Darwin, J., 'A Third British Empire? The Dominion idea in imperial politics', in: Wm. Roger Louis and J. Brown eds., The Oxford History of the British Empire: The Twentieth Century, vol. IV (Oxford, I999), 64-87.

Darwin, J., 'Afterword: the Imprint of the War', in: D. Omissi and A. S. Thompson eds., The Impact of the South African War (Basingstoke, 2002), 289-302.

Davey, A., The British Pro-Boers, I877-1902 (Cape Town, I978).

Dijk, K. van, The Netherlands Indies and the Great War, I9I4-I9I 8 (Leiden, 2007).

Dorward, D., 'Major Tunbridge's Boer War Album: An Australian Construction of "the Other"', in: Kunapipi, Journal of Post-Colonial Writing, vol. 2 I (I999), 7 I-80. 
Driver, F., Geography Militant Cultures of Exploration and Empire (Oxford, 200I).

Dubow, S., Scientific Racism in Modern South Africa (Cambridge, 1995).

Dubow, S., A Commonwealth of Knowledge. Science, Sensibility, and White South Africa I 820-2000 (Oxford, 2006).

Elst, J. van der, 'Die Anglo-Boereoorlog: 'n vertekende beeld vanuit die vreemde', in: $L i$ terator, vol. 20/3 (November I999), I 47-I60.

Fasseur, C., 'De koloniale paradox. De Nederlandse expansie in de Indonesische archipel in het midden van de negentiende eeuw (I 830-I 870)', in: Tijdschrift voor Geschiedenis, vol. 93 (I979), I 62-186.

Fieldhouse, D. K., 'Can Humpty-Dumpty be Put Together Again? Imperial History in the I 980 ', in: The Journal of Imperial and Commonwealth History, vol. I 2 (I984), 9-23.

Gast A., ed., Catalogus van de Bibliotheek der Nederlandsch Zuid-Afrikaansche Vereeniging (Amsterdam, I939).

Geerts, J., Verzuilde Boerenliefde. Een studie naar de berichtgeving over de eerste en tweede Boerenoorlog door De Standaard, De Tijd en Het Algemeen Handelsblad in de periode I880-I 902 (unpublished MA dissertation, University of Amsterdam, 2005).

Giliomee, H., The Afrikaners. Biography of a People (London, 2003).

Glorie, I., ““...Een reuze taak, die bijna 't onmogelijke vordert...”. De Boekzendingen van het Algemeen Nederlands Verbond (I902-1927)', in: Tydskrif vir Nederlands \& Afrikaans, vol. I I, no. I (2004), 4I-64.

Gordon, C. T., The Growth of Boer Opposition to Kruger I 890-I895 (Cape Town/London, I970).

Graaff, B. de, 'Kalm temidden van woedende golven'. Het ministerie van Koloniën en zijn taakomgeving, I912-I940 (The Hague, I997).

Graaff, B. J. H. de, De mythe van de stamverwantschap. Nederland en de Afrikaners, I902-I930 (Amsterdam, I993).

Grundlingh, A. M., Die 'hendsoppers' en 'joiners'. Die rasionaal en verskynsel van verraad (Pretoria/Cape Town, I979).

Hall, C., Civilising Subjects: Metropole and Colony in the English Imagination, I830I 867 (Cambridge, 2002).

Hancock, W. K., Smuts: The Sanguine Years I 870-I9I9 (Cambridge, I962).

Heese, J. A., Die herkoms van die Afrikaners I657-1867 (Cape Town, I97I).

Hemels, J. and M. Schneider, De Nederlandse krant I6I 8-I978: van 'nieuwstydinghe' tot dagblad (Baarn, I979).

Hemstra, S., De culturele betrekkingen tussen Nederland en de Afrikaners in de jaren dertig. Een onderzoek aan de hand van de reis van Pieter Geyl door Zuid-Afrika in 1937 (unpublished MA thesis, University of Leiden, 2007).

Hendricks, G. W., Die betrekkinge tussen Nederland en Suid-Afrika I946-I96 I (unpublished PhD thesis University of Pretoria, I984).

Heyningen, E. van, 'Costly Mythologies: The Concentration Camps of the South African War in Afrikaner Historiography', in: Journal of South African Studies, vol. 34 (2008), 495-5 I3.

Hoek, K. van, 'The Leyds Memoirs', in: The Dalhousie Review, vol. I9, no. I (1939), 924 . 
Hoek, K. van, Gesprekke met Dr. W. J. Leyds (Pretoria, I939).

Hofmeyr, I., 'Building a nation from words: Afrikaans language, literature and ethnic identity, I902-I924', in: S. Marks and S. Trapido eds., The Politics of Race, Class and Nationalism in Twentieth-Century South Africa (London/New York, I987), 95-I 23.

Hofmeyr, I., 'Popularizing History: the Case of Gustav Preller', in: Journal of African History, vol. 29 (I988), 52I-535.

Holland, R. F., The Pursuit of Greatness. Britain and the World Role I900-I970 (London, I99I).

Hopkins, A. G., 'Back to the Future: From National History to Imperial History', in: Past and Present, vol. I64 (1999), I98-243.

Houwers, J. D., Nationalistische commotie in Nederland rond de vrijheidsoorlogen in Transvaal I880-I902 (unpublished undergraduate paper, University of Utrecht, I988).

Huigen, S., De weg naar Monomopata: Nederlandstalige representaties van geografische, historische en sociale werkelijkheden in Zuid-Afrika (Amsterdam, 1996).

Huussen, A. H., 'De Anglo-Boerenoorlog in de Nederlandse poëzie I899-I902. Historische studie', in: Joernaal vir Eietydse Geskiedenis/Journal for Contemporary History, vol. 27, no. 2 (2002), 97-I 25.

Jaarsveld, F. A. van, 'n Methodologies-kritiese ondersoek naar die werk van Dr. W. J. Leyds', in: Tijdskrif vir Wetenskap en Kuns (1954), 98-107.

Jager, M., 'De vlag op de Gelderland': een discussie aangaande het beleid van het Kabinet Pierson inzake Zuid-Afrika (unpublished undergraduate paper, University of Amsterdam, 2007).

Jansen, E., “"Ek ook het besluit om van my bittere lydingskelk te vertel.” Het meervoudige (post) koloniale vertoog in autobiografische vrouwenteksten over de ZuidAfrikaanse Oorlog (г 8990-I902)', in: Tydskrif vir Nederlands en Afrikaans, vol. 6 (I999), I 62-I 86.

Jansen, E. and W. Jonckheere, Boer en Brit: ooggetuigen en schrijvers over de AngloBoerenoorlog in Zuid-Afrika (Amsterdam, 200I).

Jansen, E., 'Eva, wat sê hulle?' Konstructies van Krotoa in Suid-Afrikaanse teksten (Amsterdam, 2003).

Johnson, G., 'Problems of Comparison: Colonial India and Indonesia in the Nineteenth Century', in: Itinerario. European Journal of Overseas History, vol. I I ( I987), 83-93.

Jonckheere, W., Van Mafeking tot Robbeneiland: Zuid-Afrika in de Nederlandse literatuur I 896-I996 (Nijmegen, I999).

Jong, C. de, Buitenlandse ambulances in de tweede Anglo-Boerenoorlog (Pretoria, I999).

Jong, R. C. de, 'Het “Afrikaans Tehuis” in Amsterdam I900-I902', in: Zuid-Afrika, vol. 58 (I98I), I70-I7I.

Jong, R. C. de, Die Lewensomstandighede en Kulturele Bydrage van die Nederlandse NZASM-Medewerkers, I887-I909 (Amsterdam, I992).

Kester, B., 'Uit de slaap gewekt. Nederlandse dagbladen verslaan de oorlog, I870-I9I4', in: P. Dassen en P. Groen eds., Van de barricaden naar de loopgraven. Oorlog en samenleving in Europa, I789-I9I4 (Amsterdam, 2008), I99-236. 
Klöters, J., In die grote stad Zaltbommel. Liedjes van school, club en kamp (Amsterdam, I993).

Koppen, C. J. A. van, De geuzen van de negentiende eeuw: Abraham Kuyper en ZuidAfrika (Wormser, I992).

Koss S., ed., The Pro-Boers: The Anatomy of an Antiwar Movement (Chicago/London, I973).

Krebs, P. M., Gender, Race, and the Writing of Empire. Public Discourse and the Boer War (Cambridge, I999).

Kröll, U., Die internationale Buren-Agitation I 899-I902: Haltung der Öffentlichkeit und Agitation zugusten der Buren in Deutschland, Frankreich und den Niederlanden während des Burenkrieges (Münster, I973).

Kröll, U., 'The "Perskantoor van het Algemeen Nederlandsch Verbond” in Dordrecht an International Propaganda Centre during the South African War, in: Gazette, International Journal for Mass Communication Studies, vol. I9 (I973), I3-28.

Kuitenbrouwer, J. J. V., 'No End of a Lesson'. Leo Amery, The Times History of the War in South Africa and Army Reform in the I900's (unpublished MSt. dissertation, Oxford University, 2005).

Kuitenbrouwer, J. J. V., 'De geografie van de stamverwanstchap. Op zoek naar Nederlandse plaatsen van herinnering in Zuid-Afrika', in: Tijdschrift voor Geschiedenis, vol. I 24 (20I I), 334-349.

Kuitenbrouwer, M., Nederland en de opkomst van het moderne imperialisme: koloniën en buitenlandse politiek I870-1902 (Amsterdam, I985).

Kuitenbrouwer, M., 'Het imperialisme van een kleine mogendheid: de overzeese expansie van Nederland I 870-I9I4', in: N. C. F. van Sas ed., De kracht van Nederland: internationale positie en buitenlands beleid in historisch perspectief (Haarlem, I99I), $42-72$.

Kuitenbrouwer, M., De ontdekking van de Derde Wereld: beeldvorming en beleid in Nederland (The Hague, I994).

Kuitenbrouwer, M., 'Capitalism and Imperialism: Britain and the Netherlands', in: Itinerario. European Journal of Overseas History, vol. I 8 (I994), I05-I I 6.

Kuitenbrouwer, M., 'Drie omwentelingen in de historiografie van het imperialisme: Engeland en Nederland', in: Tijdschrift voor Geschiedenis, vol. Io7 (I994), 559-585.

Kuitenbrouwer, M. and H. Schijf, 'The Dutch Colonial Business Elite at the Turn of the Century', in: Itinerario. European Journal of Overseas History, vol. 22 (I998), 6I-86.

Kuitenbrouwer, M., 'Het imperialisme-debat in de Nederlandse geschiedschrijving', in: Bijdragen en Mededelingen betreffende de Geschiedenis der Nederlanden, vol. I I 3 (1998), 56-73.

Laidlaw, Z., Colonial Connections, I8I5-45: Patronage, the Information Revolution and Colonial Government (Manchester, 2005).

Lammers, J. C., Kent gij dat volk vol heldenmoed? Nederlandse onderwijzers en boeken in Transvaal, I880-I900 (unpublished MA dissertation, Vrije Universiteit Amsterdam, I985).

Langendorff, G., Brieven van J. E. A. Reyneke van Stuwe (I876-1962) uit Zuid-Afrika. 
Een documentair-kritische deeleditie van het jaar I 899 (unpublished MA thesis University of Leiden, 2002).

Latsky, H., 'A Bibliography of Dutch Publications on the South African War, Published in the Netherlands, I899-I997', in: South African Historical Journal, vol. 4I (I999), 443-468.

Ledden, W. P. van der, Jan van Riebeeck tussen wal en schip. Een onderzoek naar de beeldvorming over Jan van Riebeeck in Nederland en Zuid-Afrika omstreeks I90o, I 950 en 2000 (Hilversum, 2005).

Legêne, S., De bagage van Blomboff en Van Breughel. Japan, Java, Tripoli en Suriname in de negentiende-eeuwse cultuur van het imperialisme (Amsterdam, I998).

Lester, A., Imperial Networks: Creating Identities in Nineteenth-Century South Africa and Britain (London/New York, 200I).

Lester, A., 'Imperial circuits and Networks: Geographies of the British Empire', in: History Compass, vol. 4 (2006), I24-I4I.

Locher-Scholten, E. B., Sumatran Sultanate and Colonial State: Jambi and the Rise of Dutch Imperialism, I830-I907, translated by B. Jackson (Ithaca, 2004).

Lowry, D., "“The World's no bigger than a Kraal”: the South African War and International Opinion in the First Age of "Globalization", in: D. Omissi and A. S. Thompson eds., The Impact of the South African War (Basingstoke, 2002), 268-288.

MacKenzie, J. M., Propaganda and Empire: The Manipulation of the British Public (2nd paperback edition; Manchester, I997).

MacKenzie, J. M., 'Empire and Metropolitan Cultures', in: A. Porter ed., The Oxford History of the British Empire: The Nineteenth Century, vol. III (Oxford, I999), 270293.

Malan, F. S., Marie Koopmans-De Wet (Cape Town, I924).

Marks, S., 'Southern Africa', in: W. Roger Louis and J. Brown eds., The Oxford History of the British Empire: The Twentieth Century, vol. IV (Oxford, I999), 545-73.

Mbenga, B., 'The Role of the Bakgatla of the Pilanesberg in the South African War', in: G. Cuthberston, A. Grundlingh, and M.-L. Suttie eds., Writing a Wider War. Rethinking Gender, Race and Identity in the South African War, I899-I902 (Athens, Ohio/Cape Town, 2002), 8 5-I I 4 .

Meijer, J. W., Dr H. J. Coster I 865-I 899 (unpublished MA dissertation, UNISA, I983).

Merwe, R. van, Johanna Brandt en die kritieke jaren in die Transvaal I 899-I 909 (Pretoria, 2004).

Moodie, T. D., The Rise of Afrikanerdom: Power, Apartheid and the Afrikaner Civil Religion (Berkeley/Los Angeles/London, I975).

Moore B. and H. van Nierop eds., Colonial Empires Compared: Britain and the Netherlands I750-I 850 (Aldershot, 2003).

Morris, J., Farewell the Trumpets: an Imperial Retreat (London, I979).

Muller, C. F. J., Sonop in die suide. Geboorte en groei van die Nasionale Pers 1915-1948 (Cape Town, I990).

Nasson, B., Adam Esau's War. A Black South African War in the Cape, I899-1902 (Cambridge, I99I). 
Nasson, B., The South African War, I899-I902 (London, I999).

Nasson, B., 'Africans at War', in: J. Gooch ed., The Boer War. Direction, Experience and Image (London, 2000), I 26-I 40.

Niekerk, L. E. van, Kruger se regterhand: 'n biografie van dr. W. J. Leyds (Pretoria, I985).

Nimocks, W., Milner's Young Men: The 'Kindergarten' in Edwardian Imperial Affairs (London, I967).

Otterspeer, W., 'Boeren en academici. De Leidse universiteit en het enthousiasme voor de Zuidafrikaanse Boeren rond de eeuwwisseling', Negentiende Eeuw, vol. I 5 (I99I), 203-22I.

Pakenham T., The Boer War (New York, I979).

Ploeger, J., Cornelis Plokhooy (I 877-I 964) aanvullende aantekeninge in verband met sy levensloop, sy gekrif "Met den Mauser" en die boodskappe wat by oorgebring het (reprint from Hertzog-Annale; December 1965 , Pretoria).

Porter, A., 'Sir Alfred Milner and the Press, I 897-1 899', in: The Historical Journal, vol. I6 (1973), 323-339.

Porter, A., 'The South African War and Imperial Britain', in: G. Cuthberston, A. Grundlingh, and M.-L. Suttie eds., Writing a Wider War. Rethinking Gender, Race and Identity in the South African War, I 899-I902 (Cape Town, 2002), 287-305.

Porter, B., The Absent-Minded Imperialists: Empire, Society and Culture in Britain (Oxford, 2004).

Potter, S. J., "The Dark Stream of Shameless Falsehood”? The British Press and New Gathering Strategies During the Boer War', C. Wilcox ed., Recording the South African War: Journalism and Official History (London, I999).

Potter, S. J., News and the British World: The Emergence of an Imperial Press System (Oxford, 2003).

Potter, S. J., 'Webs, Networks, and Systems: Globalization and the Mass Media in the Nineteenth- and Twentieth-Century British Empire', in: Journal of British Studies, vol. 46 (2007), 62 I-646.

Potter, S. J., 'Richard Jebb, John S. Ewart and the Round Table, I898-1926', in: The English Historical Review, vol. I22 (2007), I05-I32.

Potter, S. J., 'Empire, Cultures and Identities in Nineteenth- and Twentieth-Century Britain', in: History Compass, vol. 5 (2007), 5 I-7 I.

Pretorius, F. J., Kommandolewe tydens die Anglo-Boereoorlog, I899-1902 (Cape Town, I99I).

Pretorius, F., 'The Dutch Social Democrats and the South African War, I899-I902', in: European Review of History, vol. 6 (I999), I99-220.

Pretorius, F., 'Boer Attitudes to Africans in Wartime', in: Donal Lowry ed., The South African War Reappraised (Manchester, 2000), I04-I 20.

Price, R., An Imperial War and the British Working Class. Working-Class Attitudes and Reactions to the Boer War I 899-I 902 (London/Toronto, I972).

Robinson, R. and J. Gallagher with A. Denny, Africa and the Victorians: The Official Mind of Imperialism (London, I96I). 
Robinson, R., 'Non-European Foundations of European Imperialism: Sketch for a Theory of Collaboration', in: R. Owen and B. Sutcliffe eds., Studies in the Theory of Imperialism (London, I972), I I 7-I 42.

Rozenburg, R., De Bloedband Den Haag-Pretoria: het Nederlandse Zuid-Afrika beleid sinds I945 (Amsterdam, I986).

Ru, A. de, 'Het beeld van de Zuidafrikaanse geschiedenis in Nederland van I899-1956', in: Hertzog-Annale van die Suid-Afrikaanse Akademie vir Wetenskap en Kuns, vol. 7 (December, I960), 74-I I7.

Sas, N. C. F. van, 'Fin de siècle als nieuw begin. Nationalisme in Nederland rond 1900', in: N. C. F. van Sas ed., De Metamorfose van Nederland (Amsterdam, 2004), 57759I.

Saunders, C., The Making of the South African Past (Cape Town/Johannesburg, I988).

Saunders C. and I. R. Smith, 'Southern Africa, I795-1910', in: A. Porter ed., The Oxford History of the British Empire: The Nineteenth Century, vol. III (Oxford, I999), 597624 .

Schelven, A. A. van, Levensbericht van Johan Adam Wormser (Leiden, I9I7).

Scholtanus, F. B., De reakties in Nederland op het einde van de Boerenoorlog. Het standpunt van de regering, in het parlement en van de publieke opinie inzake de vrede van Vereeniging, 3 I mei I 902 (Langbroek, I980).

Scholtz, G. D., Europa en die tweede vryheidsoorlog, I899-I902 (Johannesburg/Pretoria, I939).

Schutte, G. J., Nederland en de Afrikaners: adhesie en aversie (Franeker, I986).

Schutte, G. J., Nederlandse publicaties over Zuid-Afrika (Pretoria, I989).

Schutte, G. J., De roeping ten aanzien van het oude broedervolk: Nederland en ZuidAfrika I960-I990 (Amsterdam, I993).

Schutte, G. J., De Vrije Universiteit en Zuid-Afrika II (Zoetermeer, 2005).

Schutte, G. J., 'De organisatie van de Stamverwantschap. Een kanttekening bij I 25 jaren Nederlands-Zuid-Afrikaanse betrekkingen'. Unpublished paper delivered at the HASA conference, University of Pretoria, 26-28 June 2006.

Schutte, G. J., Van Amsterdam naar Krugersdorp en weer terug. P. J. Kloppers (I 848I9I 2), schoolmeester en schrijver (Amsterdam, 2007).

Schutte, G. J., 'The Place of Dutch Historians in South African Historiography', in: African Historical Review vol. 39 (2007), 25-40.

Schutte, G. J., 'Stamverwantschap als imperialisme', in: S. W. Couwenberg ed., Apartheid, anti-apartheid, post-apartheid. Terugblik en evaluatie. Civis Mundi jaarboek 2008 (Budel, 2008), I I-I9.

Schutte, G. J., Stamverwantschap onder druk. De betrekkingen tussen Nederland en Zuid-Afrika, I940-I947 (Amsterdam, 20I I).

Searle, G. R., A New England? Peace and War I 886-19I 8 (Oxford, 2004).

Smit, C., Hoogtij der neutraliteitspolitiek. De buitenlandse politiek van Nederland I 899I9I9 (Leiden, I959).

Smith, I. R., The Origins of the South African War, I 899-1902 (London, I996).

Spanjaard, P. R., "Voor de Boeren". De pro-Boerenbeweging in Europa en het Chris- 
telijk Nationaal Boeren Comité in Nederland (unpublished MA dissertation, Vrije Universiteit Amsterdam, I982).

Stanley, L., Mourning becomes... Post/memory, Commemoration and the Concentration camps of the South African War (Manchester/New York, 2006).

Steyn, J. C., Tuiste in eie taal. Die behoud en bestaan van Afrikaans (Cape Town, I980).

Stubbings, E. O., Leyds-versameling van nie-boek materiaal (meestal oor die SuidAfrikaanse Oorlog, I899-I902) in die universiteitsbibliotheek, Stellenbosch (unpublished catalogue).

Surridge, K., "“All you Soldiers are what we call Pro-Boer”: The Military Critique of the South African War, I899-I902', in: History, vol. 82 (I997), 582-600.

Surridge, K., 'Official History', in: C. Wilcox ed., Recording the South African War: Journalism and Official History (London, I999), 29-3 I.

Tames, I., Oorlog voor onze gedachten. Oorlog, neutraliteit en identiteit in het Nederlandse publieke debat I9I4-I9I 8 (Hilversum, 2006).

Taselaar, A., De Nederlandse koloniale lobby: ondernemers en de Indische politiek I9I4I940 (Leiden, I998).

Thompson, A. S., Imperial Britain: The Empire in British Politics c. I880-1932 (Harlow, 2000).

Thompson, A. S., 'Publicity, Philanthropy and Commemoration: British Society and the War', in: D. Omissi and A. S. Thompson eds., The Impact of the South African War (Basingstoke, 2002), 99-I2I.

Thompson, A. S., 'Imperial Propaganda during the South African War', in: G. Cuthberston, A. Grundlingh, and M.-L. Suttie eds., Writing a Wider War. Rethinking Gender, Race and Identity in the South African War, I 899-I 902 (Cape Town, 2002), 306-327.

Thompson, A. S., 'The Languages of Loyalism in Southern Africa c. I 879-1939', in: English Historical Review, vol. I I 8 (2003), 617-650.

Thompson, A. S., The Empire Strikes Back? The Impact of Imperialism on Britain from the Mid-Nineteenth Century (Harlow, 2005).

Toit Spies, F. J. du, 'n Nederlander in Diens van die Oranje-Vrystaat (Amsterdam, I946).

Velde, H. te, Gemeenschapszin en plichtsbesef: liberalisme en nationalisme in Nederland, I870-I9I8 (The Hague, I992).

Velde, H. te, Stijlen van leiderschap: persoon en politiek van Thorbecke tot Den Uyl (Amsterdam, 2002).

Velde, P. G. E. I. J. van der, Een Indische liefde: P. J. Veth (I8I4-I 895) en de inburgering van Nederlands-Indië (Amsterdam, 2000).

Vree, F. P. I. M. van, 'Tradition and innovation in the historiography of mass media', in: N. C. F. van Sas and E. Witte eds., Historiocal Research in the Low Countries (The Hague, I992), 89-100.

Wagenaar, H., 'De code van Diyat', in: Zuid-Afrika, vol. 86 (2007), I76-I77.

Warwick, P., Black People and the South African War, I 899-1902 (Cambridge, I983).

Wesseling, H. L., 'Bestond er een Nederlands imperialisme?', in: H. L. Wesseling ed., Indië verloren rampspoed geboren en andere opstellen over de geschiedenis van de Europese expansie (1988), I77-I94. 
Wijfjes, H., De Journalistiek in Nederland I 850-2000: Beroep, Cultuur en Organisatie (Amsterdam, 2004).

Wilson, K., The International Impact of the Boer War (Acumen, 200I).

Winter, P. J. van, Onder Krugers Hollanders. Geschiedenis van de Nederlandsche ZuidAfrikaansche Spoorweg-Maatschappij I (Amsterdam, I937).

Winter, P. J. van, Onder Krugers Hollanders. Geschiedenis van de Nederlandsche ZuidAfrikaansche Spoorweg-Maatschappij, vol. II (Amsterdam, I939).

Winter, P. J. van, Dr. Leyds en Zuid-Afrika/Willem Johannes Leyds (Leiden, I942).

Zietsman, P. H., Die taal is gans die volk. Woelinge en dryfuere in die stryd om die Afrikaner se taal (Pretoria, I992).

Zweers, L., De Boerenoorlog (The Hague, I999).

\section{Internet sources}

Marks, S., 'Jan Christiaan Smuts', in: The Oxford Dictionary of National Biography. www.oxforddnb.com/view/article/36I7I?_fromAuth=I [08-OI-2008].

Schutte, G. J., 'Muller, Hendrik Pieter Nicolaas (I 859-I94I)', in: Biografisch Woordenboek van Nederland. http://www.inghist.nl/Onderzoek/Projecten/BWN/lammata/ bwn 5/muller [17-03-2004].

Veenendaal, A. J., 'Middelberg, Gerrit Adriaan Arnold (I846-I9I6)', in: Biografisch Woordenboek van Nederland. www.inghist.nl/Onderzoek/Projecten/BWN/lemmata/bwni/middelberg [05-09-2003].

Woltring, J., 'Beelaerts van Blokland, Jhr. Frans (1872-1956)', in: Biografisch Woordenboek van Nederland. www.inghist.nl/Onderzoek/Projecten/BWN/lemmata/bwnI/ beelaerts [05-09-2003]. 


\section{Index of names}

Aitton, D. I 88, 325n

Amery, L.S. 268

Andriessen, W.F. 224

Asselbergs, C.J. 272, 33 In

Baden-Powell, R. 200, 35 In

Beatrix, Queen $3 \mathrm{I}$

Beaufort, W.H. de 4I, 57, 205

Beaumont, J. I6, I 29

Beek, M. van I62-3, 259

Beelaerts van Blokland, F. I35, I 48-9, I 66-9, I77, 294-6, 334n

Beelaerts van Blokland, G.J.T. 4I, 60

Beer Poortugael, J.C.C. den 2 I I

Bernhard, Prince 297

Besselaar, G. 25, 28, 65, 74, 83-4, I79, $324 \mathrm{n}$

Betts, R.F. 18

Bierens de Haan, J.C.J. I37, I39, 222, $363 n$

Biko, S. 3I, 298

Blignaut, P.J. I $82,344 \mathrm{n}$

Blink, H. 73

Bloembergen, M. I9

Bodenstein, H.J.D. 279, 289, 373n

Boeschoten, C. van I I 2

Boissevain, Ch. 44, 88, 99, го5-6, I36, I 56, I 83-4, 200, 206, 247-8, 287-8, $324 \mathrm{n}$

Boldingh, G. I35-6, 23 I, 335n

Bolman, G.J. 278

Bos, S. 3 I
Bosman, I. 90, 324n

Bossenbroek, M. I9, 27, 42, 59, 73, 285

Botha, L. I3 8-9, I98, 208, 22 I, 245, 258-60, 269, 272, 274, 277-9, 287-9, 332n, 36In, 363n, 37 In

Brand, J.H. 82, I 88, 2 I 5, 347n, 354n

Brill, J. 82, 344n

Broeksma, C. I33-4, 240, 334n, 362n

Buller, R. I07, 200-I

Burger, S.W. I 25, 21 8

Burgers, F. 69-7I, 96

Burton, A. I2

Buskes, J.J. 297

Bussy, J.H. de 54, 58, 267

Cain, P.J. I 2-3, I 8

Campbell-Bannerman, H. 226, 357n

Celliers, J.F.E. 292

Chamberlain, J. 88, 96-9, I 82, 200, 2I 5, 242,258

Clark, G.B. 89

Colenbrander, H.T. 76, 3 I 9 n

Conan Doyle, A. I 62, 267

Conradie, E. 25, 28, 65, 32 In

Coster, H.J. I90-I, 348n

Cronjé, P. I94-6, I98, 22 I , 234-5, 277

Dam, B.A.P. van 173

Darwin, J. I3

Devonshire, Duke of 105

Dingane, King 93, 320n, 346n

Dis, A. van 3I, 299 
Domela Nieuwenhuis, F.J. I I 7-9

Drees, W. 297

Duyl, A.G.C. van 44

Edward VII, King I44

Eeden, F. van I26, I3 I, 333n

Eiffe, F.F. I6I

Elst, J. van der 75

Emous, H.J. 44, 58, 85, I3 I, I 5 I, I 75, 243-4, 343n, 344n

Engelenburg, F.V. 46, 53-4, 85, 99, I I 2, I 23-4, I 27, I 29, I 38, 259-60, 269, 272, 279-80, 332n, 333n, 366n

Esau, A. 228-9

Fasseur, C. I 8

Fawcett, M. 238, 242

Fieldhouse, D. I3

Fischer, A. I I 4-5, 246, 269, 330n, 344n

Froude, J.A. 89

Fruin, R. $43,58,87$

Galbraith, J. I8

Gallagher, J. I 2, I 8

Gillot, H.A. I I I

Gladstone, W. 88, 96, 99, 324n

God e Molsbergen, E.C. 279

Goldman, L. I I 2

Graaff, B.J.H. de 24, 255, 285, 287, $337 n$

Gunning, J.W. 43

Guyot, Y. I 84

Hall, C. I 2

Hamelberg, H.A.L. 6I

Hamilton, G. I05-6, I40

Harting, P. 39-40, 3 I 9 n

Hearst, W.R. I 23

Hertzog, J.B.M. 262, 294

Heyningen, E. 238, $36 \mathrm{In}$

Hobhouse, E. 24I-4, 330n, 36 In

Hobson, J.A. 9, 89, 3 I 5n, 324n,

Hofmeyr, I. 256
Hofmeyr, J. 50, 82, I 86,

Hofmeyr, S. 240

Hopkins, A.G. I 2-3, I 8

Huigen, S. 25, 66, 256

Ittersum, W.A. van I 88

Jaarsveld, F.A. van 266

Jameson, L.S. 39, 45, 56-62, 72-5, 82, 89, $94,98-9$, I 36, I 82, I 89-90

Jansen, E. 66, I79

Janson, J.H. 232

Jonckheere, W. 25, 66, 286

Jong, R. de 50

Jonkman, H.F. 40

Jorissen, E.J.P. 7I, 79, 8I, 95-6, 3I8n, $32 \mathrm{In}, 323 \mathrm{n}, 327 \mathrm{n}$

Joubert, P. 50, 7 I, 96, I 8 I, I97-8, 22 I

Junius, J.H. I65-7

Kakebeeke, J.C. 2 I9

Kalff, G. I 23

Kamerlingh Onnes, O. I68

Kannemeyer, F.K. 234

Kern, H. 59

Kiewiet de Jonge, H.J. 59, I 22, I 27, I 48 , I 54-63, I67, I75, I95, 242, 259-6I, 277, 279, 338n, 340n, 345n

Kipling, R. I6, I 29

Kitchener, H. I08, I39, 20I, 208, 235 , 245,247

Kloppers, P.J. 2I 5, 354n

Kollewijn, R.A. 293

Koopmans-De Wet, M. I24, I74

Koppen, C.J.A. van 2I, 70, I 84

Koster, J.D. I36, 208

Krebs, P. I7, 243, 36In

Kretschmar van Veen, J.A. van I 20-I, I 27, I72-7

Kröll, U. 23, 28, I 58, 3 I 7n, 338n

Kruger, S.J.P. 23, 47-57, 59, 63, 7 I, 78 80, 82, 89, 96-8, I I 2, I I4, I 24-8, I 38 , I 44, I 82, I 87, I 89-90, I95, 2 I 8, 236, 
$239,246,255,266-7,269,276-7,280-$ 2, 297, 300

Kuitenbrouwer, M. I 8, 2 I, 36-7, 309n, 3 I 2n, 3 I 6n, 324n

Kuyper, A. 20, 36, 40-I, 43-5, 52, 55-7, $59,70,82,87$, I 44, I 5 I-2, I 83-4, 200, 205,2 I $8,246-7,257,323 \mathrm{n}, 336 \mathrm{n}$, $346 \mathrm{n}, 352 \mathrm{n}$

Laidlaw, Z. I4

Legêne, S. I9

Lester, A. I3-4

Leyds, W.J. 9, 27-8, 49-53, 60-2, 84, 89, I05-8, I09-I6, I I9, I23-4, I 26, I 32-3, I $35^{-8}$, I 40-I, I44-5, I 54-7, I 60-3, I64-7, I70, I75, I 88, I95-6, I99-200, 204-6, 222, 245-9, 255-6I, 264-82, $303,3 \mathrm{I} 4 \mathrm{n}, 3$ I $5 \mathrm{n}, 3 \mathrm{I} 7 \mathrm{n}, 328 \mathrm{n}, 329 \mathrm{n}$, $330 n, 333 n$, 34 In, 342n, 362n, 364n, 367n, 372n, 373n

Lingbeek, G.W.S. I 36, 207

Lion Cachet, F. 70-9, 87, 92-6, 3 I 8n, 322n, $323 n$

Lion Cachet, J. 83

Livingstone, D. 87

Locher-Scholten, E. I 8

Louter, J. de 40, 43, 96, I 46, I 49

Luns, J.A.M.H. 298

Maas, H.S.J. I I 8

MacKenzie, J.M. I 2, I 6, I9, 26, 309n

Mac-Leod, D.J.E. I36

Malan, D.F. 262, 280

Malan, F.S. I30, 269

Mansvelt, N. 52-3, 73, 83-5, I22-3, I27, I 56, 262-3, 293, 3 I9n, 322n

Marks, A. 232

Meert, H. van 59

Methuen, Lord 200

Mettius, M. I97

Middelberg, G. 50, I 20, I 27, I 53, I 68-9, I7I-2, I75, 337n

Milner, A. I7, 88, 99, I 24, I30, I87-90, 200, 2 I 5, 257-8, 282
Moltzer, J.P. 43-4, 49, 58, 60, 85, I 52, I 57, I $95,338 \mathrm{n}$

Moodie, T.D. 24, 257

Moselekatse, King 66, 93

Muller, H.P.N. 6I-2, 72-6, 78-82, 94, 97, I I3-6, I 40, I65-7, I73, I 88-9, 266, 3 I9n, $327 \mathrm{n}, 33 \mathrm{On}, 342 \mathrm{n}, 37 \mathrm{On}$

Naamen van Eemnes, A. 4I

Nasson, B. I7, 30

Nerée van Babberich, J.P.R.M. de I 52

Niekerk, L. van 23, 28, 49, 5 I, 264, 3I 7 n

Nierstrasz, P.A. 54, I 6I-2, 222, 269-72, 275, 368n, 369n

Nijland, H. 275-9, 370n, 37 In

Noëls van Wageningen, W.P. I64-9, $342 \mathrm{n}$

Nolens, W.H. I 52

Ockerse, G.R. 5 I

Oordt, J.F. van 54, 83, $325 \mathrm{n}$

Overvoorde, J.C. van 279

Pameyer, J.H. I36

Pauliat, L. I 75

Penning, L. 75, I 84-5, I92, 2I 2, 23 I, 246, 290-2, 346n, $353 \mathrm{n}$

Pienaar, E.C. 28I

Pierson, J. I IO, I I4, I3 8, 275-6, $372 \mathrm{n}$

Pierson, N.G. 59, I IO, I 44, 205

Plokhooy, C. I38-9, I9I, I97, 202, 21920, $335 \mathrm{n}, 35 \mathrm{on}$

Pont, J.W. 279

Pook van Baggen, L.K. I I 5

Porter, B. I 2

Postma, D. 52

Pott, G. I Io, II6, I I9, $370 \mathrm{n}$

Potter, S.J. I4-6, 26, 37, 3 I $8 \mathrm{n}$

Poutsma, H.J. I 37

Preller, G. 260-I, 366n

Ram, J.H. I I 8, 272-4, $358 \mathrm{n}$

Reesema, A.S. van 48-9, $337 \mathrm{n}$ 
Reitz, F.W. 82, 84, I I9, I 82, I 88, 225 , 266, 345n

Rey, K. de la I24, I98, 22 I, 225, 240, 269, 287

Reyneke van Stuwe, J.E.A. 260, 365n, 366n

Rhodes, C.J. 50, 60, 82, 88-90, 97-9, I 86, I 89, 327n, 348n

Riebeeck, J. van 38, 65, 73, 297

Rijckevorsel, D. van 136

Roberts, F. IO8, I 2I, I98, 20I, 2I 5, 2 I 7, 234

Robinson, R. I 2, I 8

Roëls, E. 60, I Iо, I 6I, 3 I 7 n

Rompel, F. I 24-5, I 27-9, I 57-8, I 88-90, I97, 2I3, 220, 234, 243, 259-63, 277, 293, 339n, 346n, 366n, 37 In

Rose, E.B. 260

Rovers, J.H. 78

Rylett, H. I62

Said, E. I9

Sandberg, C.G.S. I I 4, I75, 3 I $4 \mathrm{n}$

Sas, N.C.F. van 20

Saunders, Ch. 90, 324n, 326n

Schaepman, H.J.A.M. 59

Scharten, C. 292

Scheepers, G. 233-4

Schmüll, D.H. $5 \mathrm{I}$

Schutte, G.J. 2I-4, 28, 36-7, I 84, I99, 256-7, 286, 294, 3 I 2n, 3 I 7n, 323n, $375 \mathrm{n}$

Schutte, P. I 50

Schwartze, T. 277

Shaka Zulu, King 66

Siethoff, E.T.A. ten 29, 205, 230n, 368n

Simons, L. 27I, 292

Smith, I.R. 238, 3 I 4n, 36 In

Smith-Dorrien, H.L. 232

Smuts, J.C. I39, I 56, I 82, 22 I-9, 240, 245, 259, 28I , 289, 295, 345n, 346n, $374 \mathrm{n}$

Snethlage, R.A.I. I I I, 329 n
Spoelstra, J. I 32, 203

Spruyt, C.B. 43, 72-3, 77, 94, I94, 3I9n, 322n, 326n

Stanley, L. 238

Stead, W.T. 89, I I I, I33, 232, 339n, $345 \mathrm{n}, 353 \mathrm{n}$

Steyn, M.T. 6I, 83, 98, I 24, I 88-9, 2 I 7, $225,245,269,32 \mathrm{In}, 357 \mathrm{n}$

Shepstone, Th. 87-8, 96,323n

Stratham, R. 89

Theal, G.M. 73, 90-2, 100, I 82, 204, $323 n, 325 n, 326 n$

Thieme, C. 260

Thompson, A.S. I 5-7, I70

Thomson, L.W.J.K. II 8-9, I40, 228, 272-4, $358 \mathrm{n}$

Toit, S.J. du 8I-4, 26I, 293, 32In, $322 \mathrm{n}$

Toorop, J. 277

Troelstra, P.J. 227, 358n, 363n

Tromp, T.M. 69

Trotsenburg, C.K. I3 8, 272-4

Valter, M.P.C. 289

Veen, H. van 3 I

Velde, H. te 2I, 35, 72, I 45

Versélewel de Witt Hamer, B.G. I30, 236

Veth, B. I IO, I 57, I66-7, 276

Veth, D. 72, 323n

Veth, P.J. 87, 323n

Victoria, Queen $\mathrm{I} 82$

Visscher, J. 26I

Vissering, G. I68, I90, 348n

Vos, P.J.G. de 85

Waal, B.H. de II7, I74

Warmelo, D. van I3I-2, I97, 225, 350n, $360 n$

Warmelo, J. van I32-3

Warwick, P. 30

Wefers Bettink, H. 2 I 3

Welcker, A. 29, 3I $2 \mathrm{n}$

Wesseling, H.L. 18 
Wessels, C.H. I I4-5

Wet, Ch. de I36, I98, 22 I, 225-6, 269, 275,287

Wet, P. de 226

White, G. 200

White, M. I I 5 , I I $8,328 \mathrm{n}$

Wildt, M.E. de 46

Wilhelm II, Emperor I I 4, 330n, $367 \mathrm{n}$

Wilhelmina, Queen 22, I I6, I25-6, I 84, 236, 273, 294, 333n
Winkel, J. te $84-5$, I94-6, 292, 348n

Winter, P.J. van $5 \mathrm{I}$

Wolmarans, D. I I 4, 246

Wormser, J.A. 54-5, 72, 78, 83-4, 95, I98, 267, 319n, 323n

Zuidema, W. I65-6

Zyl, L. van 24I-2 



\section{Index of subjects}

Aceh - see Dutch East Indies

Aden I08

Afrikaans 25, 30-I, 43, 65-6, 68, 8I-4, 99, I79, 256, 26I-3, 289, 292-3

Afrikaner nationalism $23-6,63,66,84$, II3, 25 5-8, 264-6, 28I-2, 288-92, 300, 302, 305

Algemeen Handelsblad 44, I36-7, I59, I 83, 23 I, 240, 243, 339n, 340n

Algemeen Nederlandsch Verbond

(ANV) 28, 59, I 22-3, I 25, I 28, I 54-63, I 66-7, I77, I 85, I $87,203,207,220$, 223, 24I-3, 259-6I, 263, 280, 287, 300-I, 305

Amsterdam 28-9, 39, 42, 44, 49-5 I, 54, 60, 72, 74, 84, 90, I I 2, I 2 I, I 24, I 26, I47, I49-50, I 5 I-2, I64, I68, I72, I 74, I 80, 279, 280, 285, 289, 297

Anglicisation II, 2I 7, 2I9, 236, 257-8, 264, 282, 286, 302, 305

Anglo-Zulu War 38, 94

Apartheid 24-5, 27, 256-7, 28 5-6, 296-9

Bermuda I08, I 18,235

Bijstandsfonds voor Zuid-Afrika I72-6

Bittereinders I08, 220-4, 233, 237, 244, $245,247-9,302$

Black population of South Africa I7, 30 , 38, 66-8, 69-70, 72, 77-8, 87, 90-5, I00, I 23, I 83, I94, 200, 203-5, 2 I I, $2 I_{3}, 224,228-30,233,238,243,248$ 9, 290, 297
Bloemfontein 82, 94, I08, I 29, I69, I723, I88-9, I96, 203, 2 I9, 244, 259, 26I

Bloemfontein Conference I 24, I 89-90,

Borneo - see Dutch East Indies

British Empire I0-9, 20-4, 26, 30, 35, 37, 56-7, 63, 68, 77, 80, 9I-2, 99, IOI, IO8, I I 5, I 20, I 28, I 43, I 79, I 86, I 99-204, $2 I 3,2 I 7,224,230,233,255,257,265^{-}$ 6, 278, 292, 302, 305

Britishness I3-4, 20, 63, 303-4

Cape Colony I4, I9-20, 30, 38, 4I, 43, 48-50, 52, 66, 69, 72, 76, 8I-5, 89-90, 9I-5, 98-9, I07, I I 7, I 23, I 26, I 28-30, I39, I64, I74, I8 I-2, I 85-7, I95, I98, 200, 2 I I-2, 224-5, 227-9, 233-4, 24I, 248, 269, 289, 345n

Cape Town 54, 76-7, 84, 90, 98, 108, I I 7, I24, I30, I74, I86, 2I3, 229, 234, 290

Ceylon I08, I3 I, I36, 235, 345n

Christelijk Nationaal Boeren Comité (CNBC) I 26, I 5 I-4, I 74-5, 249, 287, $337 n$

Colenso I23, I98, 274

Concentration camps I08, II7, I2I, I 32-3, I 40, I 70, I73, I75-6, 2 I 5, 224, 229, 237-244, 248-9, 302, 363n

Convention of The Hague - see The Hague Peace Conference

Couriers I32, I37-9, I64, 216, 223, 228 
De Burger 216, 366n

De Gids 73, 85, 292

De Standaard 45, 70, 340

De Volksstem 46, 53-4, 85, I I 2, I 23-4, I 29, I 57, 259, 366n

Delagoa Bay - see Lourenço Marques

Derdepoort 2II-2

Dordrecht 59, 85, I 22, I 54-5, I 57, I6I2, 259, 275-7, 279

Dullstroom 232

Dum-dum bullets I 8 I, 206-7, 2 I 3

Dutch East India Company 20, 38, 72 , $76-7,84,9$ I

Dutch East Indies I I, I 8-9, 22, 38, 4I-2, 56-7, I07, I23, I23, I3 6, 227-8, 285 , 295

Dutch nationalism 20-I, 35-6, 304

Dutch Red Cross I3 6-7, I70-I, 207-8

Elandslaagte I30, I90-I, I97, 209-I 2, 233

Farm-burning 2I 5, 230-2, 238, 249, 302 First World War I63, 259, 26I-2, 265, 279, 289, 292, 366n, 367n

Fonds tot daadwerkelijken steun I64-9, I 77

France 60, 76, I 25, I27, I 44, I6I, I75, $345^{n}$

Gelderland I I4, I25, I 44, 2 I 8

Generale Boerenhulpfonds 287

Geneva Convention I7I, 205-6

Germany 42, II4, I 25, I 27, I44, I6I, 256,28 I , 294, 3I $6 \mathrm{n}$

Great Britain 9-10, I 2-9, 30, 38, 4I, 56, 60-І, 76, 88-90, 96-9, І 06, І I 2, І I 8, I 43, I 46, I 54, I 59, I 62-3, I 70, I 80, I 82-4, 20I, 206, 2 I I, 2 I 6, 2 I9, 226-7, 238-9, 258, 265, 269, 28 I, 289, 295, 304-5, 33 In, 343n, 345n, $372 \mathrm{n}$

Great Trek 38, 49, 66, 75, 77-80, 83, 91, 93, I26, I 8 I, I89, 22 I, 239, 256, 290, 294
Handsoppers 225-6, 248-9, 302, 357n

Havas 45-6, I 23

Het Vaderland I65-6, 260, 333n, $365 \mathrm{n}$

Hilversum I 26

Hollandercorps I30, I90-I, I97, 209, $236,348 n$

Hollanders 23, 29, 46-56, 63-4, 69, 7I, 73, 79-8 I, 83, 85, I06, I09, II4, II7, I I9, I 22-3, I25, I 27-8, I30-3, I36, I 38, I 45, I 53, I 724, I77, I 82, I 87 , I90-I, I97-8, 209, 2I9, 236, 300, 304, 3I $4 \mathrm{n}, 320 \mathrm{n}$

India IO-I, I 5, I 8, I3 I, 235

Irish nationalism I 8, 39, I I I, 200

Jameson Raid 39, 45, 56-62, 72, 75, 82, 89, 98-9, I 36, I 82, I 89-90, 3 I $7 \mathrm{n}$

Java - see Dutch East Indies

Jingoism 9, 88, 99, 227

Johannesburg 47, 53, 97-9, I33, I 54, I $82,240,260,297,334 \mathrm{n}$

Kimberley 50, 95, I88, I95-6, 326n

Kruger House Museum 280, $336 \mathrm{n}$

Ladysmith I22, I95-7, I99-200, 202

London I 2-4, 42, 60, 87, 89, 92, I06-7, I I I, II3, I I 8, I 29, I 33, I 59, I 62-3, I $8 \mathrm{I}, \mathrm{I} 86,200,203-4,2 \mathrm{II}, 226,24 \mathrm{I}$, 259-60, 280, 323n, 328n, 334n, 366n

Lourenço Marques 42, 50, 58, I08, I IO, II3, II6, I 22, I 24-5, I 27-9, I 37-8, I 44, I 48, I74, 280, 304, 329n, 37on

Machadodorp I 8 , I 38

Mafeking I6, I95, 200

Majuba Hill 45, 88, 96, I07

Marseilles I I 4, I 25, 239, 267

Mfecane 66, 93

Nasionale Party 256, 262, 289, 29I, 295, 297 
Nederlandsch Zuid-Afrikaansche

Vereeniging (NZAV) 39-46, 47, 5 I, 545, 57-6I, 72-3, 90, I I 7-I II, I 36, I445 I, I 5 I-4, I 5 5-7, I 59, I63-4, I67-9, I 70-8, I 8 5, 240, 26I-3, 276, 277-80, 285, 287-9, 294, 296-300

Nederlandsche Zuid-Afrikaansche Spoorweg Maatschappij (NZASM) 42, 45, 50, 54-5, IO8-9, I I 2, I 20-2, I 28-9, I 48, I 53, I94, 208, 287, 33 In, $332 \mathrm{n}$

Nieuwe Courant I37, 260

Nieuwe Rotterdamsche Courant (NRC) 29, 46, I 24, I 59-60, 206-7, 2I I, 35 on

Ons Land 83, I28-30, I87, 240, $322 \mathrm{n}$ Orange Free State (OFs) I 9, 30, 38, 57, 6I-2, 72, 82-4, 94, 98, І 8 , I Iо, I I 3-6, I 22, I 24, I 54, I65, I73, I76, I79-80, I 82, I84-5, I87-9, I92, I98, 20I, 205, 2I 2, 2I 5, 2I 7, 22I, 223, 227, 229-3I, 233, 240-I, 245-6, 250, 255, 266-7, $269,282,325 \mathrm{n}$

Outspan boycott 299

Paardeberg I69, 234

Paris 60, IIO, II4, I24, I3 8, I 75, 275 , 277, 328n

Peace of Vereeniging $139,217,247-8$, $250,255,258,287,302$

Pillarisation 20, 29, 40, I45, I 5 I-3

Port Elizabeth 240

Portugal I 24, I27, I3 8, I74, 280

POW camps I22, I3 I, I33, I36, I40, I 74, 208, 233-44

Pretoria 27-8, 42, 48, 50-I, 54-7, 75, 78, I05, I08-9, I I 2, I I 7-8, I 20-4, I 27, I 29, I 32 , I 36, I 38, I 44, I 53, I 57, I 6 I, I 65, I67, I69, I72-3, I77, I79, I90, I96-7, I99, 202-3, 207-8, 219, 222-3, 234, 259, 264, 273, 275, 278-8 I, 290, 294, 296-7
Reuters 45, 243-4, 259

Rotterdam 6I, I 47-9, I 56, I 89, 28 I

Russia I8, III, I6I

Second World War I4, 65, 238, 244, 256, 286, 288, 293, 295-6, 303, 305, 3 I 4n

Sharpeville Massacre 297-8

South African Party (SAP) 289

South African Republic - see Transvaal

Soweto riots $3 \mathrm{I}$

Spion Kop I98, 200-I

St. Helena I08, I I 8, I 30, I 74, 235-7

Stamverwantschap 20, 23-7, 29, 35, 37, $4 \mathrm{I}-2,46-8,53,56-7,59,63,73,76,80-$ I, 86, 90, I 5 5, I79, I 8 I, I 85 , I92, 2 I 2, 255, 282-3, 285, 292, 294, 296-30I, 303-6, 3 I In

Stellenbosch 29, 3I, 53, 85, 280-I

Suez II 4

Taalbeweging 24-5, 8I, 26I-3, 292-3

The Friend I 29, 259

The Hague 28, 46, 54, 57, 73, 76, I I 4 , I 6 , I I 9, I 44, I 47-9, I 53, I 56, I67, 2I 7, 272-3, 280-I, 294. 355 n, 368n

The Hague Peace Conference 57, I95, 205-7, 2 I I, 354n

Transvaal 9, II, I9-23, 27-8, 30, 36-9, 42-4, 46-56, 59-63, 67, 69, 7I-3, 75, 78-9, 82-4, 87-8, 9I 94-8, IO०, I05-I 2, I I 4-8, I 20-5, I30-3, I38, I43-6, I 4950, I 56-7, I65-7, I73-6, I79-82, I 8790, I97-8, 200, 2II-3, 2I 5-8, 223, 229, 232, 240-I, 245-6, 25 5, 262, 264-6, 269, 272-3, 275-82, 290-I, 297, 300, 3I $4 \mathrm{n}, 3$ I 8n, 322n, 323n, 344n, $369 \mathrm{n}$ Transvaal War I9, 22, 30, 35, 58, 65-6, 69, 7I, 75, 78, 82, 84, 87, I00, I 25, I 8 I, I 88 , I98, 282, 320 n

Uitlanders 47-9, 5 I-4, 95-9, I 82, I 89-90, 3 I $4 \mathrm{n}, 348 \mathrm{n}$ 
United States of America 47, 67, 80, I I 3 5 , I I 8, I 7 I, I 82 , I $88,280,328 \mathrm{n}$

Vereenigde Comités voor de noodlijdenden ten gevolge van den Zuid-Afrikaanschen oorlog $174-7$

Vereniging tot vereenvoudiging van onze schrijftaal 43-4, 85, 293
Zuid-Afrikaansch Museum (ZAM) 27580,307

Zuid-Afrikaansche Stichting Moederland 287 



